

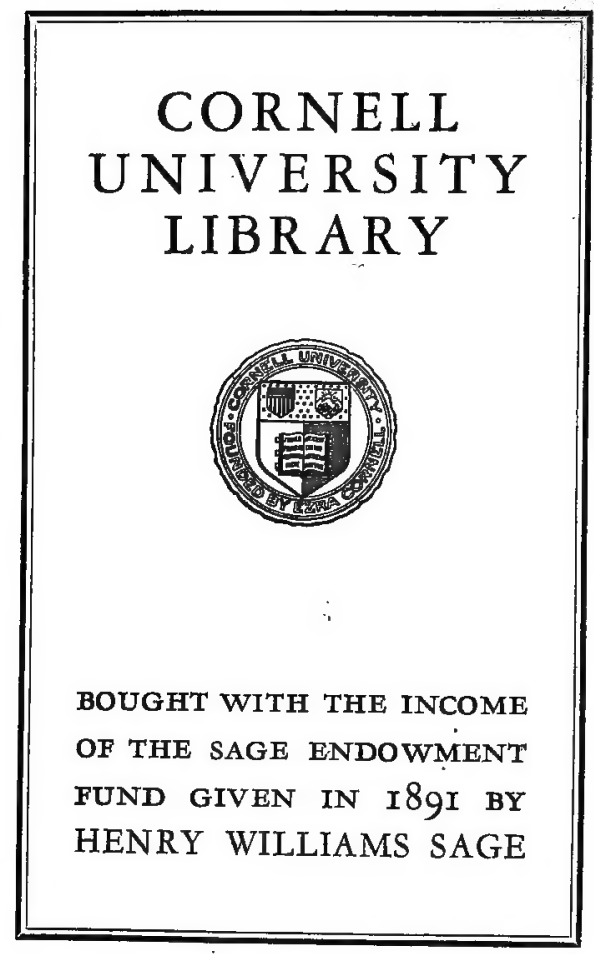




\section{QK 118 Cornell Universtly Library}

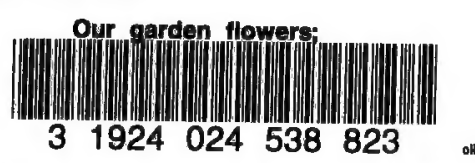




\section{Cornell University Library}

The original of this book is in the Cornell University Library.

There are no known copyright restrictions in the United States on the use of the text.

http://www.archive.org/details/cu31924024538823 


\section{OUR GARDEN FLOWERS}




\section{BOOKS BY HARRIET L. KEELER}

Published by CHARLeS SCRIbNeIr's sons

Our Garden Flowers. Cr. 8vo, . . net, $\$ 2.00$

Our Northern Shrubs. Cr. 8vo, - net, $\$ 2.00$

Our Native Trees. Cr. 8vo, . . . net, $\$ 2.00$

Each volume profusely illustraled 


\section{OUR GARDEN FLOWERS}

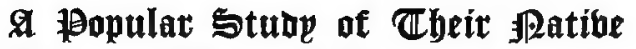
Zlands, Their 疋ite and Their Structural afteiliations

\section{By HARRIET L. KEELER AUTHOR OF "OUR NATIVE TREES" AND "OUR NORTHERN SHRUBS"}

WITH $9 O$ ILLUSTRATIONS FROM PHOTOGRAPHS AND 186 ILLUSTRATIONS FROM DRAWINGS

CHARLES SCRIBNER'S SONS NEW YORK :: : : : : : : : : $:$ iglo 


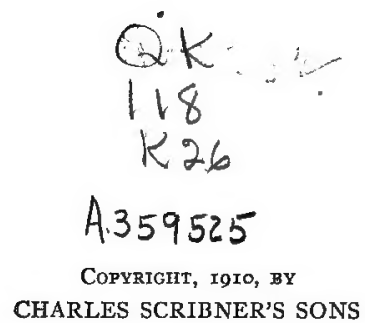

Published May, roro

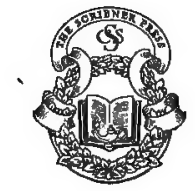


To

ADELIA A. F. JOHNSTON HER FRIEND DEDICATES THIS VOLUME 



\section{PREFACE}

THIS book is the outcome of a lifelong search for a volume with which one might make a little journey into the garden, and become acquainted with the dwellers therein; their native land, their life history, their structural affiliations.

Among the many species of a genus it has often been necessary to select but one for description. As a rule the choice has been either the typical form, or the one longest in cultivation, or the greatest favorite.

While it has been the aim to make the book a fairly complete study of all the annual and perennial flowering herbs commonly found in a hardy garden, it is by no means intended to be a catalogue.

The half-tones are from photographs, of which the larger number were made by Mr. Nathan R. Graves, of Rochester, New York.

The outline drawings, with the exception of the few that are marked, are the work of Miss Mary Keffer, of Lake Erie College, Painesville, Ohio. The following list names the books which have been especially helpful in the preparation of this volume:

"Cyclopedia of American Horticulture," L. H. Bailey; "Favorite Flowers of Garden and Greenhouse," Edward Step, F.L.S., and William Watson, F.R.H.S.; "The Flowering Plants of Great Britain," Anne Pratt; "Plantes Utiliores, or Illustrations of Useful Plants Employed in the Arts and Medicine," M. A. Burnett; "Manual of the Flora of the United States," M. L. Britton; Gray's "New Manual of Botany," seventh edition; Gray's "Field, Forest, and Garden Botany," revised edition. 


$$
\text { - }
$$

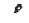




\section{O N T E N T S}

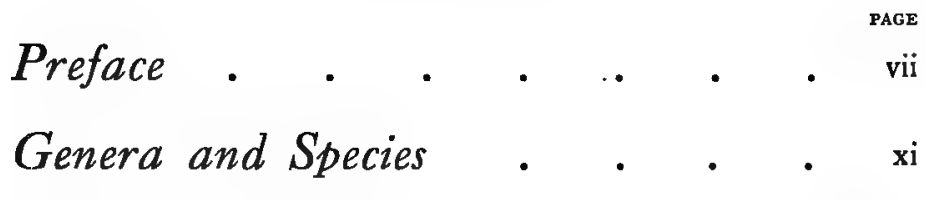
Illustrations . . . . • . . Descriptions of Garden Plants . . I Sweet Herbs . . . : . . 517 Glossary of Botanical Terms . . 533 Index . . . . . . . . 537 


$$
-
$$




\section{GENERA AND SPECIES}

NAJADACE $\Phi$.

Aponogeton distachyum

ARACE A

Richardia africana

Commelinaces

Tradescantia virginiana

Tradescantia fluminensis

Zebrina pendula

Commelina nudiflora

Pontederiaces .

Pontederia cordata

LILIACE AS

Lilium .

Lilium candidum

Lilium longiflorum var. $e x-$ imium

Lilium philadelphicum

Lilium elegans

Lilium speciosum

Lilium auratum

Lilium tigrinum

Lilium superbum

Lilium canadense

Tulipa Gesneriana

Tulipa suaveolens

Fritillaria meleagris

Fritillaria imperalis

Scilla sibirica

Chionodoxa lucilice
- Pondweed Family

PAGE

- Cape Pondweed .

3

Arum Family

- Calla Lily

- SPIDERWort Family

- Spiderwort . . 8

- Wandering Jew . . . I0

- Wandering Jew . . . Io

- Wandering Jew Io

Pickerel-Weed Family

- Pickerel-weed

I 2

- Liliy Family

Lily . . I4

- Madonna Lily . . . I6

Easter Lily I8

Wood Lily. $\quad 20$

- Upright Lily . . . 20

- Japanese Lily . . $\quad 22$

- Gold-banded Lily 24

- Tiger Lily . . 26

- Turk's Cap Lily 27

- Meadow Lily . 27

- Common Tulip . 29

- Fragrant Tulip 34

- Checkered Lily 34

Crown Imperial . . $\quad 35$

- Siberian Squill . . $\quad 36$

- Glory of the Snow . . 37 xi 
PAGE

LILIACEX-Continued

Ornithogalum umbellatum . Star of Bethlehem . $3^{8}$

Muscari botryoides . . Grape Hyacinth . . . $3^{8}$

Hyacinthus orientalis . . Hyacinth . . . . 40

Hyacinthus candicans . . Summer Hyacinth . . 42

Funkia subcordata . . Funkia . . . 43

Hemerocallis fulva . . Day Lily . . . . 45

Hemerocallis flava . . Lemon Lily . 46

Kniphofia aloides . . . Torch Lily . 46

Yucca filamentosa . . Yucca . 47

Allium cernuum . . Wild Onion . . . 50

Allium cepa . . . Common Onion . 50

Allium schoenoprasum . . Chives . . 52

Trillium grandiflorum . White Trillium . . 52

Asparagus officinalis . . Garden Asparagus 53

Asparagus Sprengeri . Ornamental Asparagus 54

Asparagus plumosus . . Ornamental Asparagus . 54

Asparagus medeoloides . . Smilax . . 54

Convallaria majalis $\quad$. Lily of the Valley 55

Eremurus robustus . . Eremurus . . $\quad{ }_{56}$

Paradisia liliastrum . . St. Bruno's Lily . . $\quad 5^{6}$

Bulbocodium vernum . . Woolly Bulb . 58

Colchicum autumnale . . Meadow Saffron . $\quad 58$

Tricyrtis hirta . . . Toad Lily . . . $\quad 58$

Dioscoreace $1 E$. . . Yam Family

Dioscorea divaricata Cinnamon Vine . . 59

Amarvilidace Aa .

AMARYLlis Family

Narcissus .

Narcissus . . . . 6 6

Narcissus pseudo-narcissus . Trumpet Daffodil . 62

Narcissus bulbucodium . Hoop-petticoat Daffodil 66

Narcissus incomparabilis . Superb Daffodil . 66

Narcissus poeticus . . Poet's Narcissus . 68

Narcissus tazetta alba . Paper White Narcissus . 69

Narcissus tazetta orientalis . Chinese Sacred Lily . . . 69

Narcissus tazetta . . . Polyanthus Narcissus . . 70

Narcissus jonquilla . . Jonquil . . . . 72

Galanthus nivalis . . $\quad$ Common Snowdrop . . 74

Galanthus Elwesii . . Larger Snowdrop . . 75

Leucojum vernum . . . Spring Snowflake . . 76

Polianthes tuberosa . . Tuberose . . . . 77 
IRIDACE $/$ A

Iris

Iris germanica

Iris pumila

Iris xiphium.

Iris xiphioides

Iris levigata

Gladiolus

¿rocus.

Crocus sativas

Ixia

Tigridia pavonia

Belamcanda chinensis

- Tritonia crocosmceflora

SCITAMinaCe

Canna hybrida

ORCHIDACE $A$

Cypripedium

URTICACE N .

Humulus lupulus.

Humulus japonicus

ARISTOLOCHIACE E

Aristolochia macrophylla

$\checkmark$ Polygonace

Polygonum Sieboldi

Polygonum sachalinense

Polygonum baldschuanicum

Polygonum orientale

Fagopyrum esculentum .

Rheum rhaponticum

Chenopodiacese

Beta vulgaris

Spinacia oleracea

Chenopodium botrys

Kochia scoparia

Boussingaultia baselloides

IRIS FAMILY

PAGE

Iris . . . . 79

- German Iris . . 80

Dwarf Iris . . . . 83

- Spanish Iris . . . $\quad . \quad 83$

- English Iris . . $\quad .84$

- Japanese Iris $\quad$. $\quad .84$

- Gladiolus . . . 86

- Spring Crocus . . . 89

- Saffron . . . . 9I

Ixia . . $\quad$. $\quad 9^{2}$

- Tiger Flower . . $\quad 9^{2}$

- Blackberry Lily . . 95

- Montbretia . . 96

\section{Banana Family}

- Canna

- Orchis Family

. Lady's Slipper

IOO

NetTle Family

Common Hop . . . $\quad \mathrm{IO}_{3}$

Japanese Hop . . 104

BIRTHWORT FAMILY

Dutchman's Pipe

I05

BUCKWHEAT FAMILY

Bushy Polygonum . I07

Bushy Polygonum . . I08

Twining Polygonum . . 108

Prince's Feather . . Iog

Buckwheat . I Io

Pie Plant . III

- Goosefoot Family

- Beet . . . . II3

Spinach . . . . II4

Feather Geranium . II5

Mock Cypress . II5

Madeira Vine . . II6 xiii 


\section{Amarantace \\ Amarantus caudatus \\ Amaranius gangeticus \\ Amaranius tricolor \\ Comphrena globosa \\ LCelosia cristata \\ Telanthera \\ Tresine Herbstii}

Amaranth Family

Prince's Feather

Love-Lies-Bleeding

Joseph's Coat

Globe Amaranth

Celosia

Alternanthera

Achyranthes

LYyctaginace As

Mirabilis jalapa

Abronia umbellata

Caryophyllace

Dianthus barbatus

Dianthus chinensis

Dianthus caryophyllus

Dianthus plumarius

Lychnis chalcedonica

Lychnis githago

Lychnis Flos-cuculi

Agrostemna coronaria

Silene armeria

Saponaria officinalis

Gypsophila paniculata

Corasinm tomentosum

Stellaria media

Stellaria Holostea.

Four-o Clock Family

Four-o'Clock

Abronia

- Pink Family

Sweet William

- 128

China Pink

- I30

Carnation .

I 32

Garden Pink

134

Maltese Cross

- $\quad 135$

Corn Cockle . . . 136

Ragged Robin . . $\quad 136$

Mullein Pink $\quad$ 1 36

Sweet William Catchfly $\quad{ }_{1} 3^{8}$

Bouncing Bet

I39

- Gypsophila . . . I40

Mouse Ear Chickweed . I4I

Chickweed . . . $\quad$ I42

- Easter Bell . . $\quad$ I44

\section{ROSACE $A$}

Potentilla canadensis

Rose Family

Potentilla argyrophylla

Geum triflorum

Geum chiloense

$\begin{array}{llll}\text { Cinquefoil . } & . & \text { I46 } \\ \text { Garden Potentilla } & \cdot & & \mathbf{1 4 6} \\ \text { Long-plumed Avens } & & \text {. } & \mathbf{1 4 7} \\ \text { Chilian Geum . } & . & \text {. } & \mathbf{1 4 7}\end{array}$

Portulacacen

Portubaca grandiflora

Portuláca oleracea

- Purstane Family

- Portulaca

I 48

- Purslane

NYMPHAACE

Nymphea odorata

Water LILy Family

Nelumbium indica

Nelumbium luteum

White Water Lily 
RanUnCUlaCER

PAGE

Paonia hybrid

Aquilegia vulgaris

Aquilegia canadensis

Aquilegia formosa.

Aquilegia carulea

Aquilegia chrysantha

Aquilegia glandulosa

Aquilegia Skinneri

Delphinium

Aconitum napellus

Clematis virginiana

Clematis viorna

Clematis Davidiana

Clematis paniculata

Clematis Jackmanni

$\checkmark$ Anemone coronaria

Anemone hortensis

Anemone japonica.

Anemone patens

Anemone nemorosa

Anemone pennsylvanica

Anemonella thalictroides

Trollius europoeus

Trollius asiaticus.

LRanunculus acris var. flore-

$$
\text { pleno }
$$

Thalictrum aquilegifolium

${ }^{\prime}$ Hepatica acutiloba

Adonis vernalis

Laltha palustris

Helleborus niger

Aigella damascena

\section{BERBERIDACE A}

Akebia quinata

Epimedium macranthum

Papaverace

Papaver somniferum

Papaver rhceas

Papaver nudicaule

Papaver alpinum

$\begin{array}{lll}\text { Double Buttercup } & \cdot & \text { I } 78 \\ \text { Thalictrum } & \cdot & \text { I } 79 \\ \text { Hepatica } & & \text { I } 79 \\ \text { Spring Adonis . } & & \text { I82 } \\ \text { Marsh Marigold } & & \text { I83 } \\ \text { Christmas Rose . } & & \text { I84 } \\ \text { Nigella } & & \text { I86 }\end{array}$

\section{Crowfoot FaMILY}

- Peony

I 55

Columbine . . . . I60

Red Columbine . . . I62

Western Columbine . . I I64

- Colorado Columbine . . 165

Golden Columbine . . . 166

- Siberian Columbine . . . I66

- Mexican Columbine . . 166

Larkspur . . . 167

- Monkshood . . . 168

- Wild Clematis . . . I 70

- Leather-leaf Clematis . I $7 \mathbf{r}$

- Bush Clematis . . . I I

- Japanese Clematis . . $\mathbf{I}^{2}$

Large-flowered Clematis I 74

Poppy Anemone . $\quad$ I 74

Garden Anemone I74

Japanese Anemone I75

- Pasque Flower . . . $\mathbf{1} 76$

- Wood Anemone I76

- Pennsylvania Anemone I76

- Rue Anemone . $\quad 176$

- Globe Flower . . . I77

Globe Flower . . . I 77

Double Buttercup . . $\quad$ I 78

Thalictrum . . . I79

Hepatica . . I79

183

I84

BARBERRY FAMILY

Akebia . $\quad$. $\quad$ I 88

- Large-flowered Barrenwort I89

- Poppy Family

- Common Poppy . . . Igo

Scarlet Poppy . . $\quad$ I93

Iceland Poppy . $\quad$. $\quad$. 194

Alpine Poppy . . . $\quad$ I95 
Papaverace 4 -Continued

Papaver orientale

Bocconia cordala.

Sanguinaria canadensis

Eschscholtzia californica

Chelidonium majus

Argemone platyceras

Romneya Coulteri .

Fumariace $x$

Dicentra spectabilis

Dicentra canadensis

Dicentra cucullaria

Dicentra eximia

Dicentra formosa.

Adlumia cirrhosa.

\section{CruCIFER}

Matthiola incana

Iberis umbellata

Iberis amara

Alyssum maritimum

Alyssum sexatile

Lunaria biennis

Hesperus matronalis

Brassica oleracea.

Brassica campestris

Brassica nigra

Brassica alba

Arabis alpina

Draba

Aubretia deltoidea

Cheiranthus cheiri

Nasiurtium officinale

Nasturtium armoracia Barbarea vulgaris.

RESEDACEAC

Reseda odorata

- Mrgnonette Family

Mignonette

SARRACENIACE 1 .

Sarracenia purpurea

- Pitcher Plant family

- Pitcher Plant

203

204

Dicentra . . . 206

Dicentra . . 206

Dicentra . . 208

Adlumia . . 208

- Mustard Family

- Stock

2 IO

Purple Candytuft _. 2I3

Bitter Candytuft . . 2I4

Sweet Alyssum . . 2I4

Yellow Alyssum . 2I5

Honesty . . 2I5

Sweet Rocket . 2I6

Wild Cabbage . 2I 7

- Field Turnip . 218

- Black Mustard . . 2 I9

- White Mustard 2 I9

- Rock Cress . . . 2I9

Whitlow Grass . 2I9

False Wall Cress . 219

Wall Flower . . . 2I9

Common Water Cress 220

- Horseradish . . 220

. Winter Cress . 220 xvi 
Crassulace

Sedum telephium

Sedum acre

Sedum spectabile

Sedum ternatum

Sempervivum tectorum

\section{SAXIFRAGACE}

Saxifraga virginiensis

Saxifraga crassifolia

Tiarella cordifolia

Heuchera sanguinea

\section{LEguminos AE}

Lathyrus odoratus

Lathyrus latifolius

Centrosema virginianum

Pisum sativum

Baptisia australis

Trifolium pratense

Trifolium repens.

Trifolium hybridum

Trifolium agrarium

Trifolium arvense

Trifolium incarnatum

Lespedeza Sieboldi

Lupinus polyphyllus

Melilotus alba

Coronilla varia

Phaseolus vulgaris

Dolichos lablab

Apios tuberosa

Ononis rotundifolia

Vicia oroboides

Pueraria Thunbergiana

Wistaria chinesis

Medicago sativa

Cassia floribunda.

Arachis hypogaa

\section{LINACE}

Linum usitatissimum

Linum perenne
PAGE

ORPINE FaMILY

227

228

228

228

230

Hen-and-Chickens

SAXIFRAge FAMILY

Early Saxifrage . . . 232

Thick-leaved Saxifrage 232

Tiarella . . . 233

- Heuchera . . . 233

Pea Family

Sweet Pea . . . 235

Everlasting Pea . . $\quad 23^{8}$

Butterfly Pea . . 239

Garden Pea . . 239

Baptisia . . 240

Red Clover : 242

White Clover . . 243

Alsike Clover . . 243

Hop Clover . . . 244

Rabbit-foot Clover . 244

Italian Clover . . 244

Lespedeza . • . . 244

Many-leaved Lupine . $\quad 246$

Sweet Clover . . . 247

Coronilla . . . . 248

Kidney Bean . . . 249

- Hyacinth Bean . $25^{\circ}$

Ground Nut . . 25I

- Rest Harrow . 252

- Pea-like Vetch . . . 252

- Kudzu Vine . . 252

- Wistaria . . . $25^{2}$

- Alfalfa . . . 254

- Cassia . . . . 254

. Peanut . . . . 254

Flax Family

Common Flax . . 256

Perennial Flax . . . 257 xvii 
OXALIDACE 2

Oxalis violacee

Oxalis acetosella

Oxalis, stricta
WOOD SORREL FAMILY

Violet Wood Sorrel . . 258

White Wood Sorrel . . 258

Sheep's Sorrel' . . . 258
Geraniace $x$

Pelargonium hortorum

Geranium maculatum

Geranium Robertianum .

Tropaolum majus.

Tropeolum peregrinum

RUTACE A

Ruta graveolens

Dictannus albus

Celastrace $3 \mathrm{~g}$

Celastrus scandens

Euonymus radicans

EUPHORBIACE

Euphorbia marginata

Euphorbia corollata

Euphorbia pulcherrima

Euphorbia heterophylla

Ricinus communis

Pachysandra procumbens
- Geranium Family

Garden Geranium

Wild Geranium

Herb Robert . . . 26I

Nasturtium . . . 262

Canary-bird Flower . . $\quad 265$

Rue Family

- Common Rue . . . 266

. Gas Plant . . . . 268

\section{- Staff Tree Family}

Climbing Bitter-sweet . . 269

Climbing Euonymus . . 269

- Spurge Family

- Snow-on-the-Mountain - 270

- White-flowering Spurge . 272

- Poinsettia . . . 273

Annual Poinsettia . $\quad$. 274

Castor-Bean . . $\quad 274$

Mountain Spurge . . 275

SAPINDACE 2 E

Cardiospermum halicacabum

SoApberry Famity

Balloon Vine . . . $\quad 276$

BALSAMINACE 疋 .

Impatiens balsamina

Touch-Me-Not Family

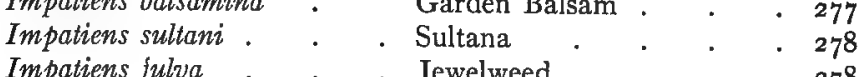

VITACE $\mathbb{E}$

Ampelopsis quinquefolia

Ampelopsis Veitchii

Vitis vulpina

Vitis labrusca

- Jewelweed . . . $\quad 278$

- Vine Family

- Virginia Creeper $レ$. 280 Boston Ivy . . . $\quad 28 \mathrm{I}$

- River-bank Grape . . 282 xviii

Northern Fox Grape . . $\quad 283$ 
Malvace $x$

Mallow Family

Althaa rosea.. . . Hollyhock. .

Althea officinalis . . . Marsh Mallow . . . 288

Hibiscus moscheutos . . Hibiscus . . . 288

Hibiscus trionum . . . Flower-of-an-Hour . 290

Hibiscus esculentus . . Gumbo . . . $29 \mathrm{I}$

Malva moschata . . . Musk Mallow . . . 292

Malva rotundifolia . . Common Mallow . . 292

Malva sylvestris . . . Tree Mallow . . . 293

Gossypium herbaceum . Cotton . . . . 293

Gossypium arboreum . Tree Cotton . . $\quad 293$

Lavatera trimestris . . Lavatera . . . $\quad 294$

Malope trifida . . . Malope . . . . 294

Callirrhe involucrata . $\quad$ Poppy Mallow . . 294

Ternstremiacese . . Tea Family

Actinidia . . . . Actinidia . . . 295

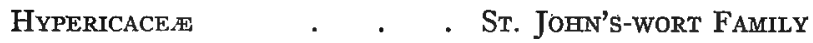

Hypericum moserianum . Gold Flower . . . 296

Cistacea . . . . . Rockrose Family

Helianthemum vulgare . Rockrose . . 298

VIOLACEA

Viola tricolor var. hybrida

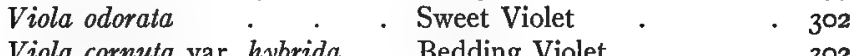

- Violet Family

Viola cucullata . . . Common Blue Violet $\quad$. 303

Passifloraces - . . . Passion Flower Family

Passiflora incarnata . . Passion Flower . . 306

Passiflora ccerula . . . Passion Flower . . 308

Loasace . . . . . LoAsa FAMily

Bartonia aurea . . . Bartonia . . . . 309

LyThrace. . . LOOSESTRIEE Family

Lythrum salicaria . . . Swamp Loosestrife . $3^{\text {IO }}$

Cuphea ignea . . Cigar Plant . . $.3^{\mathbf{I} 2}$ xix 
ONAGRACE $A$

Evening Primrose Family

Enothera biennis . . . Evening Primrose . . 3I4

Enothera fruticosa . . Sundrops . . . 3I5

Enothera amona . . Godetia . . . . 3I6

Fuchsia macrostemma

Epilobium angustifolium

Fuchsia . . . $3^{18}$

Gaura parvifolia. Clarkia elegans . . . Clarkia . . . 320

BORAGINACE $/ E$

Mertensia virginica

Myosotis palustris

Echium vulgare

Borago officinalis

Pulmonaria saccharata

Heliotropium peruvianum
UMBELLIFER E

Daucus carota

Pastinaca sativa

AEgopodium podograria

Eryngium amethystium

Plumbaginace

Statice latifolia

Armeria vulgaris
- Great Willow-herb $3^{18}$

Primulace ब

Primula variabilis var. polyanthus

- Polyanthus

Primula officinalis . . Cowslip

Mertensia

Viper's Bugloss

Common Borage

325

Bethlehem Sage .

326

- Heliotrope 326

Primula elatior

- Oxlip

Parsley Family

Wild Carrot

Parsnip

- Bishop's Weed

- Eryngium

Primula acaulis

Lysimachia vulgaris

Lysimachia quadrifolia

Lysimachia nummularia

Dodecatheon Meadia

- Primrose

Sea Lavender

. Thrift

- Lysimachia

Whorled Loosestrife

- Money

- Shooting Star

- 340

- 342

- 342

- 343

343

Gentianacex

Gentiana crinita

- Gentian Family

Fringed Gentian 
Vinca minor. . . . Vinca

Vinca major. . . . Larger Periwinkle . . 348

Vinca rosea . . . . Rose Vinca . . . 348

Nerium oleander . . . Oleander . . 350

Amsonia taberncemontana . Amsonia . . $35^{\circ}$

Apocynum androsamifolium . Dogbane . . 350

ASCLEPIDACE $/$ F

Asclepias tuberosa

Periploca graca

\section{Convolvulaces}

Ipomae hybrida

Ipomoea bona-nox .

Ipomea pandurata

Ipomea quamoclit

Ipomoea batatas

Convolvulus sepium

Convolvulus japonica

Convolvulus tricolor

Polemoniaces

Phlox paniculata

Phlox Drummondii

Phlox divaricata

Phlox subulata

Cobrea scandens

Gilia tricolor

Polemonium reptans

Polemonium ccruleum

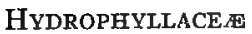

Nemophila insignis
Milkweed Family

Butterfly Weed

Convolvulus Family

Morning-Glory

Moon-Flower

- 356

Man-of-the-Earth

- 357

Cypress Vine . . . $35^{8}$

- Sweet-Potato . . . 358

Convolvulus . . 359

California Rose. . 360

Tricolored Convolvulus $\quad \cdot 3^{60}$

Phlox Family

- Perennial Phlox . . . 362

- Annual Phlox - 362

Wild Phlox 364

- Moss Pink . 364

. Cobœa . . . . 365

- Tricolored Gilia . . $\quad .368$

- Greek Valerian . . . 369

Blue Polemonium • 369

. Water-IEAF FamiLy

- Nemophila .

VERBENACE A

Vervain Family

Verbena hybrida . . . Verbena

Caryopteris mastacanthus

- Blue Spirea

Mint FamiLy

Salvia splendens . . . Salvia 


\section{LABIATA-Continued}

Monorda fistulosa

Physostegia virginiana

Coleus hybrida

Rosmarinus .

Lavendula vera

Nepeta glechoma

Lamium maculatum

Stachys lanata

\section{SOLANACE}

Petunia hybrida

Salpiglossis sinuata

Nicoliana alata

Datura fastuosa

Browallia demissa

Lycium vulgare .

Schizanthus pinnatus

Lycopersicum esculentum

Solanum tuberosum

Solanum dulcamara

Nierembergia

Physalis alkekengi

Capsicum annurm

Solanum melongena

Solanum pseudo-capsicum

SCROPHULARIACEIE

Antirrhinum majus

Antirrhinum maurandioides

Linaria vulgaris

Collinsia verna

Digitalis purpurea

Chelone obliqua

Torenia Fournieri.

Penstemon digitalis

Veronica longiflora

RUBIACE

Galium mollugo

Asperula orientalis

PAGE

Wild Bergamot . . $\quad 378$

Physostegia . . . 379

Garden Coleus . . $3^{80}$

Rosemary . . . . $3^{80}$

Sweet Lavender . . . . 38I

Ground Ivy $\quad \cdot \quad \cdot \quad \cdot 3^{82}$

Dead-Nettle $\quad \cdot \quad \cdot 3^{82}$

- Hedge-Nettle . . . $3^{82}$

Nightshade Fammy

Petunia . . . $3^{8} 3$

Salpiglossis . . . $3^{87}$

Nicotiana . . . . $\quad . \quad 388$

Datura . . . . 390

- Browallia . . . 392

- Matrimony Vine . . 393

Butterfly Flowers . $\quad 394$

. Tomato . . . . 394

Potato . . . . 397

$\begin{array}{lll}\text { Nightshade } \quad . \quad & 398\end{array}$

Cup-Flower . . . 399

Ground Cherry . . . 399

Red Pepper . 399

- Egg-Plant . . . 400

Jerusalem Cherry . . 400

- Figwort Family

Snapdragon . . . 401

Maurandia . . . 402

Toad-Flax . . 402

- Collinsia . . . 405

- Foxglove . . . 405

. Chelone . . . 409

Torenia . . 4Io

Penstemon . . . 4II

Veronica . . . . 4I 4

MADDER FAMtIY

Galium

415

Asperula . . . 446 xxii 
BIGNONIACE AE

Tecoma radicans

Incarvillea Delavayi

Calampelis

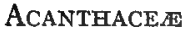

Thunbergia alata

Acanthus mollis

CAPrifoliace $A$

Lonicera japonica

Lonicera sempervirens

VALERIANACE 里

Valeriana oficinalis

Cenanthus ruber

\section{Cucurbitaces}

Cucurbita pepo, var. maxima .

Cucurbita pepo

Curcurbita pepo, var. ovifera

Cucumis sativus

Cucumis melo

Citrullus vulgaris

Echinocystis lobata
Bignonia Family

Trumpet Flower .

Incarvillea

Calampelis .

ACANThus Family

Thunbergia

420

$42 \mathrm{I}$

Honeysuckie Family

Honeysuckle

Trumpet Honeysuckle

VALERIAN Family

Valerian

Red Valerian

428

Gourd FaMILY

Hubbard Squash

Pumpkin

Gourd . . . $43 \mathrm{I}$

Cucumber . . . 432

Muskmelon . . . 433

Watermelon . . . 434

Wild Cucumber . . $\quad 435$

BeLlflower FaMily

Canterbury Bells . . 437

Campanula medium

Campanula rapunculoides

Campanula persicifolia.

Campanula carpatica

Campanula pyramidalis

Campanula rotundifolia

Platycodon grandiflorum

LOBELIACEA

Lobelia FaMiLy

Lobelia erinus

Blue Lobelia

- 446

Lobelia cardinalis

Cardinal-Flower

- 447

Lobelia syphilitica

Great Lobelia

- 448

DIPSACACE 雨

Scabiosa atropurpurea
- Teasel family

Sweet Scabious xxiii 
Composita

Composite Family

Helianthus annuus . . Common Sunflower

Helianthus debilis . . Small Sunflower

Helianthus decapetalus.

- Perennial Sunflower

Helianthus tuberosus

- Jerusalem Artichoke

Heliopsis laevis .

Heliopsis

460

Helenium autumnale

Helenium

$46 \mathrm{I}$

Rudbeckia laciniata

Rudbeckia

462

Echinacea purpurea

- Purple Cone Flower

Lepachys pinnata.

Lepachys

464

Achillea ptarmica.

- The Pearl .

465

Dahlia variabilis

Dahlia

Chrysanthemum coccinium

Chrysanthemum carinatum

Pyrethrum .

466

Chrysanthemum coronarium

Chrysanthemum balsamita

Summer Chrysanthemum

470

Garland Daisy

$47 \mathrm{I}$

Costmary

472

Chrysanthemum segetum

Chrysanthemum aureum

Corn Marigold

472

Golden Feather

472

Chrysanthemum frutescens

Marguerite .

473

Chrysanthemum uliginosum

Giant Daisy

473

Chrysanthemum leucanthemum

Ox-eye Daisy

473

Chrysanthemum

Hardy Chrysanthemum

474

Chrysanthemum parthenium

Feverfew

474

Yellow Chamomile 475

Anthemis tinctoria

Yellow Chamomile

- 476

Gaillardia

Gaillardia

477

Arctolis grandis

Arcto! is

Calendula officinalis

Marigold

478

Tagetes erecta

African Marigold

Tagetes patula

Coreopsis lanceolata

Coreopsis tinctoria

Callistephus chinensis

Aster

French Marigold

Coreopsis

Coreopsis

480

482

Bollonin asteroides

Emilia flammea

China Aster

484

484

Aster .

485

486

. . . . 488

Bellis perennis

Brachycome iberidifolia

Zinnia elegans

Tassel Flower

489

English Daisy . 490

Cosmos bipinnatus

Solidago

Swan River Daisy

$49 \mathrm{I}$

Zinnia

492

Cosmos

493

Golden-rod .

494

Cornflower.

496

Centaurea cyanus .

Sweet Sultan

499 xxiv

502 
Composite-Continued

PAGE

Cichorium intybus

Ageratum conyzoides

Helichrysum bractealum

Anaphalis margaritacece.

Ammobium alatum

Echinops exaltatus

Eupatorium purpureum

Eupatorium perjoliatum

Eupalorium ageratoides

Liairis

Doronicum

Artemisia abrotanum

Artemisia absinthium

Santolina chamacyparissus

Taneretum vulgare

- Chicory . . . . 504

Ageratum . . . : 506

- Golden Immortelle . . 507

Pearly Everlasting . 510

Winged Ammobium . $\quad 5^{\mathrm{II}}$

. Globe Thistle . . . $5^{\text {I2 }}$

- Joe Pye Weed . . . 5I3

. Boneset . . . . 5 513

- Eupatoriun . . . 5I3

Blazing Star . . . 5I4

. Leopard's Bane . . . 5 5I4

- Southernwood . . $5^{\mathrm{I} 4}$

Wormwood . . . $5^{14}$

. Lavender Cotton . . $5^{\mathrm{I} 6}$

- Tansy . . . $5^{\mathrm{I} 6}$

Sweet Herbs

Salvia offcinalis . . . Sage . . . . 520

Thymus vulgaris . . . Thyme . . . 521

Origanum marjorana . Sweet Marjoram . . $5^{22}$

Satureia hortensis . . . Summer Savory . . $\quad 5^{23}$

Ocimum basilicum . . . Sweet Basil . . . 524

Mentha peperita . . Peppermint . . . 524

Mentha viridis . . Spearmint . . . 525

Faniculum vulgare . Sweet Fennel . . . $5^{26}$

Anetham graveolens . Dill . . . . 529

Carum petroselinum . Parsley . . . . $53^{\mathrm{I}}$ 


\section{ILLUSTRATIONS}

PAGE

Garden Walk, . . . . . . 2

Cape Pondweed, Leaf and Flowers of

Calla Lily, Flowers of

Spiderwort, Flowering Stem of

Wandering Jew, Spray of . Io

Pickerel-weed, Leaf and Spike of . . . . . . . . .

Madonna Lily, Flowering Stems of

Easter Lily, Flower of

Upright Lily, Flower of

Japanese Lily, Flowering Stem of

Gold-banded Lily, Single Flower

Tiger Lily, Flowering Stem of

Meadow Lily, Flowers of . . 28

Tulips, Flowers of . . . $3^{\mathrm{T}}$

Checkered Lily, Flowers of, . 33

Crown Imperial, Flowering Stem of . . . . . . . 35

Scilla, Entire Plant of . $\quad \cdot 3^{6}$

Grape Hyacinth, Plants of $\quad 39$

Hyacinth, Plant of . . . 4I

Roman Hyacinth, Flowering Stem of . . . . . $4^{2}$

Funkia, Flowering Stems of - 44

Lemon Lily, Flower of . . - $4^{6}$

Torch Lily, Flower Spike of - 47

Yucca, Flowering Plant of . 49

Wild Onion, Umbel of . . . 50

White Trillium, Flowering Stems of . . . . . . 5I

Asparagus, Spray of . . . 54

Lily of the Valley, Flowering Plant of . . . . .

Eremurus, Flowering Plant of .

Cinnamon Vine, Leaves and Flowers of
Trumpet Daffodil, Flower of . 63

Superb Daffodil, Flowers of . 65

Hoop-petticoat Daffodil, Flower of . . . . . . . . 66

Poet's Narcissus, Flowers of $\quad 67$

Polyanthus Narcissus, Flowering Stems of . . . . . 7 I

Jonquil, Flowers and Leaves of 72

Snowdrops, Flowering Plants of 73

Spring Snowflake, Flowering Stems of . . . . 76

Tuberose, Flowers of . . 77

German Iris, Flower of 8I

Spanish Iris, Flower of . $\quad 84$

Japanese Iris, View of . 85

Gladiolus, Flowering Stems of 87

Spring Crocus, Divided Plant of 9o

Ixia, Flowering Stems of 93

Tigridia, Flower of . . 94

Blackberry Lily, Fruit of $\quad \bullet \quad 95$

Montbretia, Flowers and Leaf

of . . . . . . . 96

Canna, Flower of . . . . 98

Cypripedium, Flowering Stem of ror

Japanese Hop, Leaf of . . . I04

Dutchman's Pipe, Leaf and

Flowers of . . . . . . I05

Bushy Polygonum, Leaf and Flower of . . . . 108

Prince's Feather, Flowering Spikes of . . . 109

Buckwheat, Flowering Raceme of . . . . . . . . IIO

Feather Geranium, Leaf and Fruiting Panicle of . . . II5

Prince's Feather, Flowering Stem of . . . . . . . II8

Globe Amaranth, Flowering

Heads of . . . . . I 20 
Celosia, Flowering Plant of PACE Alternanthera, Leafy Stem of . i 22 Achyranthes, Leaves of . . . I23 Four-o'Clock, Flowering Stem of 126 Sweet William, Flowering Stems of . . . . . . . . . I 29

China Pinks, Flowering Stems of . . . . . . . . . I I I

Garden Pink, Flowering Stems of . . . . . . . . . I33

Scarlet Lightning, Flowering Stem of . . . . . ${ }^{1} 3^{6}$ Mullein Pink, Flower of . . I37 Sweet William Catchfly, Flowers of . . . . . . . . $\mathrm{I}_{3} 8$

Bouncing Bet, Flowers of . . I39 Gypsophila, Flowers of . . . I4I Cerastium, Flowering Stems of I 43 Portulaca, Flowering Stem of $\mathrm{I}_{4} 8$ Purslane, Leafy Stem of . . - I49 White Water-Lily, Flowers of . I5I Nelumbium, Leaf, Flower and Fruit of . . . . . . I54 Double Red Peony, Flower of . I57 Single White Peony, Flower of ${ }^{5} 59$ Columbine, Flowering Stems of I6I Red Columbine, Flowering Stems of . . . . . . $\mathrm{r}_{3}$ Golden Columbine, Flower of . I66 Larkspur, Flowers of . . . . I68 Monkshood, Flowers of . . . I69 Clematis, Flowers of . . . . I 7 I Clematis, Fruiting Spray of . . I 72 Jackman's Clematis, Flowers of $\mathrm{I}_{73}$ Japanese Anemone, Flower of . I75 Hepatica, Flowering Tuft of . I8I Christmas Rose, Flowers of . . I85 Nigella, Flower and Fruiting Capsule of . . . . . . 187 Akebia, Leaf and Flowers of . I88 Common Poppy, Flowers in variety

Scarlet Poppy, Flower of . . 193

Iceland Poppy, Capsule of . . I95

Oriental Poppy, Flower of . . Ig6

Plume Poppy, Leaf of . . . I97 Bloodroot, Leaf and Flower of I 99
California Poppy, Flowers of Prickly Poppy, Flower of . . 202 Bleeding Heart, Flowering Sprays of . . . . . . 205 Dicentra, Flower of . . . 206

Dicentra, Leaf and Flowering Stem of . . . . . 206

Squirrel Corn, Leaves and Flowering Stems of . . . 207

Dicentra, Flowering Stem of . 208 Adlumia, Leaves and Flowering

Stems of . . . . . . . 209

Stock, Flowering Stem of , . 211

Candytuft, Flowering Head of . 2I3

Sweet Alyssum, Flowering Raceme of . . . . . 2I5 Lunaria, Flower and Pod of . 216 Sweet Rocket, Flower of . . 2I 7 Wild Cabbage, Plant of . . 2I8 Mignonette, Flowering Stem of . 222 Pitcher Plant, Flowering Tuft of 225 Live-for-ever, Leaf of . . . 227 Stone Crop, Flowering Stem of 228 Sedum, Flowering Plant of . 229 Hen and Chickens, Rosette of . 230 Heuchera, Leaf and Flowering Stem of . . . . . 234 Sweet Pea, Flowers of . . . 236 Everlasting Pea, Flowering Raceme of . . . . . . 237 Garden Pea, Flowering Spray of . . . . . . . 240

Baptisia, Flowering Spray of . $24 \mathrm{r}$ Red Clover, Leaf of . . . . 242 White Clover, Head of . . . 243 Many Leaved Lupine, Flowering Stems of . . . . . . 245

Lespedeza, Leaf and Flowers of 246

Sweet Clover, Flowering Stems of . . . . . . . . 247 Coronilla, Leaf of . . . . 248

Kidney Bean, Leaf and Flowers of

Hyacinth Bean, Flowers and Pod of . . . . . . . .250 Kudzu Vine, Leaf of . . . . 252 Wistaria, Flowering Racemes of 253 
Climbing Bitter-sweet, Fruiting Spray of . . . . . . 269

Snow-on-the-Mountain, Flowering Stem of . . . . . $27 \mathrm{I}$

Snow-on-the-Mountain, Single Involucral Group of . . . 272 Castor-Bean, Leaf of . . . . 275 Balloon Vine, Leaf and Fruit of 276 Garden Balsam, Single Flower of . . . . . . . . 277 Jewelweed, Flower of . $\quad .278$ Jewelweed, Fruiting Capsule of . . . . . . . . . 279

Virginia Creeper, Leaf of . . 280 Boston Ivy, Leaves and Fruit of .

Hollyhock, Flowering Stems of . 286

Hollyhock Column of Anthers . 287

Hibiscus, Flowering Stem of . 289

Flower-of-an-Hour, Flower and Leaves of . . . . . . $29 \mathrm{I}$

Musk Mallow, Flower and Leaves of . . . . . . . 292

Actinidia, Leaf of . . . . . 295

Gold Flower, Flowering Stem of 296 Pansy, Flower of . . . 30r Blue Violets, Flowering Tuft of 305 Passion Flower, Flowering Spray of . . . . . . 307

Swamp Loosestrife, Flowering Stems of . . . . . . 3I I Cuphea, Flower and Leaves of . $3^{\text {r } 2}$ Evening Primrose, Flowering Stem of . . . . . 3I 3

Enothera, Single Flower of . - 3I5 Fuchsia, Flowering Spray of . 3I 7 Gaura, Flowering Stem of . . $3^{\text {I } 9}$ Clarkia, Flowering Stem of $\cdot 321$ Mertensia, Flowering Stems of . 323 Forget-me-not, Flowering Stem of . . . . . . . 324 Borage, Flowering Stem of $\cdot 325$

Wild Carrot, Leaves, Flowers, and Fruit of . . . . . 327 Bishop's Weed, Leaf of . . 330 Eryngium, Flower-head of . .332 Statice, Flowering Stem of . . 333 Thrift, Leaves and Flower-head of . . . . . . . 336 Polyanthus, Leaves and Flowering Stems of . . . . . 337 Cowslip, Flower of . $\quad .340$ Primrose, Flowering Plant of 34I Money, Flowering Stem of . $\quad 343$ Fringed Gentian, Flowers of . 346 Larger Periwinkle, Leaves of . 348 Rose Vinca, Flowering Stems of 349 Butterfly Weed, Single Flower of $35^{2}$ Morning-Glory, Flowers of $\quad 355$ Moon-Flower, Flower of . . 356 Cypress Vine, Leaves and Flower of . . . . 358 Hedge Bindweed, Leaf and Flower of . . . . . . . 359

Three-Colored Convolvulus, Flowers of . . . . 360 Perennial Phlox, Flowering Panicle of . . . . . . 363 Moss Pink, Flowering Stems of 365 Cobœea, Leaf and Flower of . . 366 Gilia, Flowering Stems of $\quad 3^{67}$ Polemonium, Single Flower of .369 Nemophila, Flower and Leaves of . . . . . . . . 37 I

Verbena, Flower Clusters of $\cdot 373$ Scarlet Salvia, Flowering Stems of . . . . . . 377

Fragrant Balm, Flower-head of 378 Physostegia, Flowering Stem of 379 Coleus, Leaf of . 380 Lavender, Leaves of . . $\quad 38 \mathrm{I}$ Ground Ivy, Leaves of . $\quad 3^{82}$ Petunia, Flowers in variety . $\quad 3^{85}$ Salpiglossis, Flower of . . 387 Nicotiana, Flower of . . $\quad 389$ Datura, Flowers of . . 39r Browallia, Flowering Stem of $39^{2}$ Matrimony Vine, Flowering Spray of . 
Butterfly Flower, Flowering Plant of ., . . . . 395

Tomato, Flowers of . . . 396

Potato, Flowers of . . . 397

Nighțshade, Flowers and Fruit of . . . . . . . 398

Maurandia, Leaves and Flower of . . . . . . . . . . 402

Snapdragon, Flowering Stems of 403 Toad-Flax, Flowering Spike of 404 Foxglove, Flowering Spike of . 407 Chelone, Flowering Stem of . 409 Torenia, Flowering Stem of 4I I

Penstemon, Flowering Stem of . 4I 3

Veronica, Flowering Spike of . 4I4 Galium, Flowering Spray of . 4I 5 Asperula, Flowering Stem of . $4 x 6$ Trumpet Flower, Flowering Spray of . . . . . . 4I7

Thunbergia, Flower of . . 420

Honeysuckle, Flowers of . . 422

Trumpet Honeysuckle, Flowering Spray of . . . . . 425

Common Valerian, Flowering Stems of . . . . . . 427 Hubbard Squash, Flower of . $43^{\circ}$ Cucumber, Flowering and Fruiting Stem of . . . . . 433

Wild Cucumber, Flowering Spray of . . . . . . 436

Creeping Bellflower, Flower of $43^{8}$

Canterbury. Bells, Flowering Stem of . . . . . . . 439

Narrow-leaved Bellflower, Flowering Stem of . . . . . 441

Harebell, Flowering Stems of . 442

Platycodon, Flower of . . . 444

Lobelia, Flowering Stem of . 446

Cardinal-Flower, Flower of $\quad$. 447

Great Lobelia, Flowering Stem of

Scabious, Flower-head of . 450 Sunflower, Flowers in Four Stages . . . . . . . 454

Great Sunflower, Flower-head of 455 Perennial Sunflower, Flowerheads of.
Helenium, Flowering Stem of . 462 Purple Cone Flower, Flowerhead of . . . . . 463 Lepachys, Flower-head of . . 464 White Tansy, Flowering Stem of 465 Achillea, Flowering Stems of . 467 Dahlia, Flowers in variety . $\quad 469$ Summer Chrysanthemum, Flower-head of. . . . . . . 471

Garland Daisy, Flower-head of 472 Golden Feather, Leaf and Flowers of . . . . . . . 473

Costmary, Flowering Stem of . 473 Feverfew, Flowers and Leaf of . 475 Golden Marguerite, Flower and Leaves of . . . . . 476

Arctotis, Flower-head and Leaf of . . . . . . 478

Gaillardia, Flowers in variety .479

Marigold, Flower-head of . $48 \mathrm{I}$

African Marigold, Flowers in variety . . . . . . 483

Coreopsis, Flower-head of . . 485

China Aster, Flowers of . . . 487

White Aster, Flowering Spray of . . . . . . . 488

Boltonia, Flower-head of . 489

Tassel Flower, Flowering Stem of . . . . . . . . 490

Swan River Daisy, Flower-head and Leaf of . . . . . 492 Zinnia, Flowers in variety . 495 Cosmos, Flower-head of . . 496 Golden-rod, Flowering Stems of 497 Centaurea, Flowers in variety . 50I Dusty Miller, Leaf of . . . 502 Sweet Sultan, Flower-head of . 503 Chicory, Flowering Stem of - 505 Golden Immortelle, Flowering Stems of . . . . . . . 509

Pearly Everlasting, Flowering Spray of . . . . . . 510

Winged Ammobium, Flowerheads of 5 II Globe Thistle, Flower-head of 5 I2 White Eupatorium, Flowering Stem of 
PAGE

Southernwood, Leaf of . . . $5^{\mathrm{I} 4}$

Lavender Cotton, Spray of . . $5^{\text {I }} 4$

Leopard's Bane, Flowering

Stems of . . . . . . 5I5

Sage, Leaves of . . . . 5I9

Thyme, Leafy Stem of . . . 520

Sweet Marjoram, Leafy Spray

of ... . . . . 521
Summer Savory, Flowering Stem

of . . . . . . . . 522

Sweet Basil, Flowering Stem

of . . . . . . . . 523

Spearmint, Leafy Stem of . $5^{25}$

Sweet Fennel, Flowering and

Fruiting Umbel of . $\quad .527$

Dill, Fruiting Umbel of . . . 529 

OUR GARDEN FLOWERS 


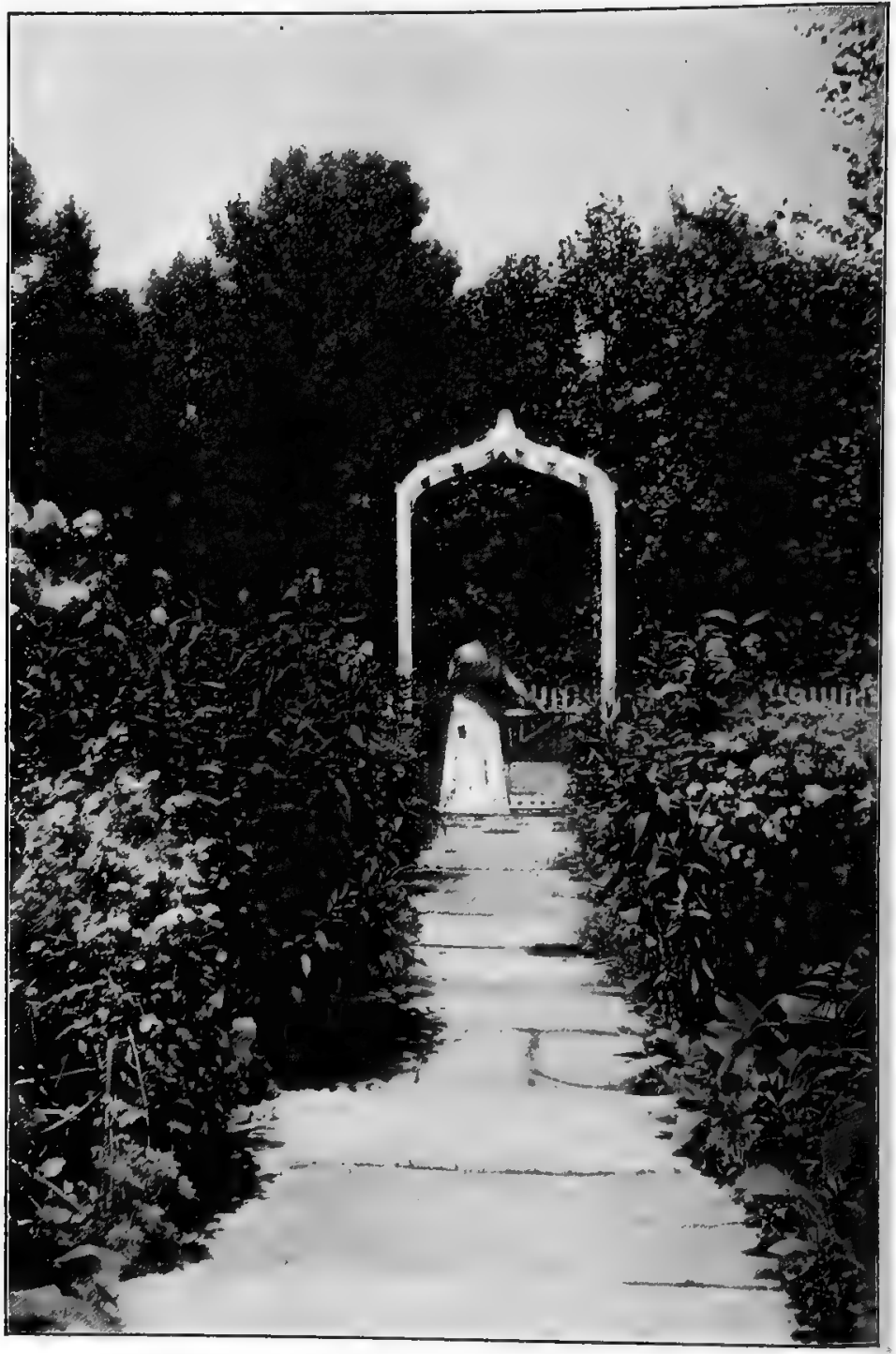

Garden Walk at the Country Home of Miss Sherwin, at Gates Mill, Ohio 


\section{NAJADÀCEAE-PONDWEED FAMILY}

\section{CAPE PONDWEED. WATER-HAWTHORN}

Aponogèton distáchyum. Potamogèton distáchyum.

Aponogeton, neighbor to water; in allusion to its habitat.

A hardy, aquatic plant with floating leaves; cultivated in watergardens. Native to the Cape of Good Hope.

Roots.-Tuberous.

Leaves.-Floating, oblong or lance-shaped, round-based, longpetioled.

Flowers.-Fragrant; white in effect; borne in fleshy, forked spikes, which consist of a double row of alternate, thick, white, wax-like bracts on a thick white axis. At first the entire inflorescence is enclosed in a tapering spathe which is forced off as the bracts develop.

Stamens.-Six to eighteen, with short filaments and reddish-brown anthers.

Carpels.-Four to six, with short style and simple stigma. Seeds four in each carpel.

This Pondweed, with its pretty floating leaves and curious flowers, is perfectly hardy in the water-gardens of northern Ohio. The usual fault found with it is that it spreads too rapidly, as the ripe seeds fall to the bottom of the pond and quickly germinate. Although the plant cannot compare in beauty with Nymphæa or Nelumbium, it has its personal merits and is worthy of cultivation.

The inflorescence first appears enclosed in a tapering spathe which is forced off as the white mass of bracts develop. When in full bloom the flowering axis and the bracts together make 
a white, waxen mass, in texture not unlike that of a tuberose and very fragrant. The bracts are alternate and each sustains and protects a little group of brown-anthered stamens, surrounding

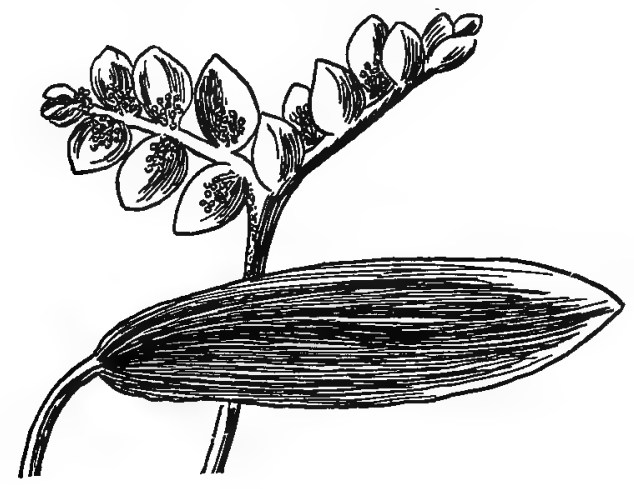

Cape Pondweed. Aponogèton disláchyum

a group of carpels. After fertilization of the flowers, the bracts become green and look like tufts of leaves among which the large, beaked carpels will be found.

This Pondweed was introduced into English water-gardens in 1788 , and the fragrance of the flowers gave it the common name of Water-Hawthorn. There is a variety known as $\mathrm{La}$ grangei with violet bracts and leaves violet beneath. 


\section{ARÀCE/E-ARUM FAMILY}

A peculiar inflorescence marks all the Arums. The flowers are borne on a terminal fleshy axis called a spadix, carefully wrapped about by an enfolding bract called a spathe. This spathe is usually large, sometimes beautiful, and always protective to the buds. The individual flowers consist of stamens, or of pistils, or of both, and frequently are absolutely destitute of calyx and corolla; sometimes these are present in the form of a few scales. The roots are tuberous. The most familiar example of the family in cultivation is the Calla Lily; the best-known wild. species are Jack-in-the-Pulpit and the Skunk Cabbage.

\section{CALLA LILY. LILY-OF-THE-NILE}

Richárdia africàna.

Richardia, in honor of L. C. Richard, a French botanist; I754-I821.

The familiar Calla of Easter decorations; grown at the North only in greenhouses, as a window plant, or partly submerged in aquariums. Southern Africa.

Root.-A thick rhizome, perennial.

Leaves.-Radical, variable; blade about twice as long as wide, cordatesagittate at base, cuspidate at apex; petioles long, stout, sheathing at the base.

Flowers.-Monœcious, both staminate and pistillate borne on a spadix at the summit of a scape, and wrapped about by a large white bract called a spathe; the pistillate flowers at the base of the spadix and the staminate above; there is neither calyx nor corolla.

The spathe is broad, spreading above, convolute at base around the slender cylindrical spadix, which is densely covered above with yellow stamens; below with ovaries, each imperfectly three-celled. 


\section{ARUM FAMILY}

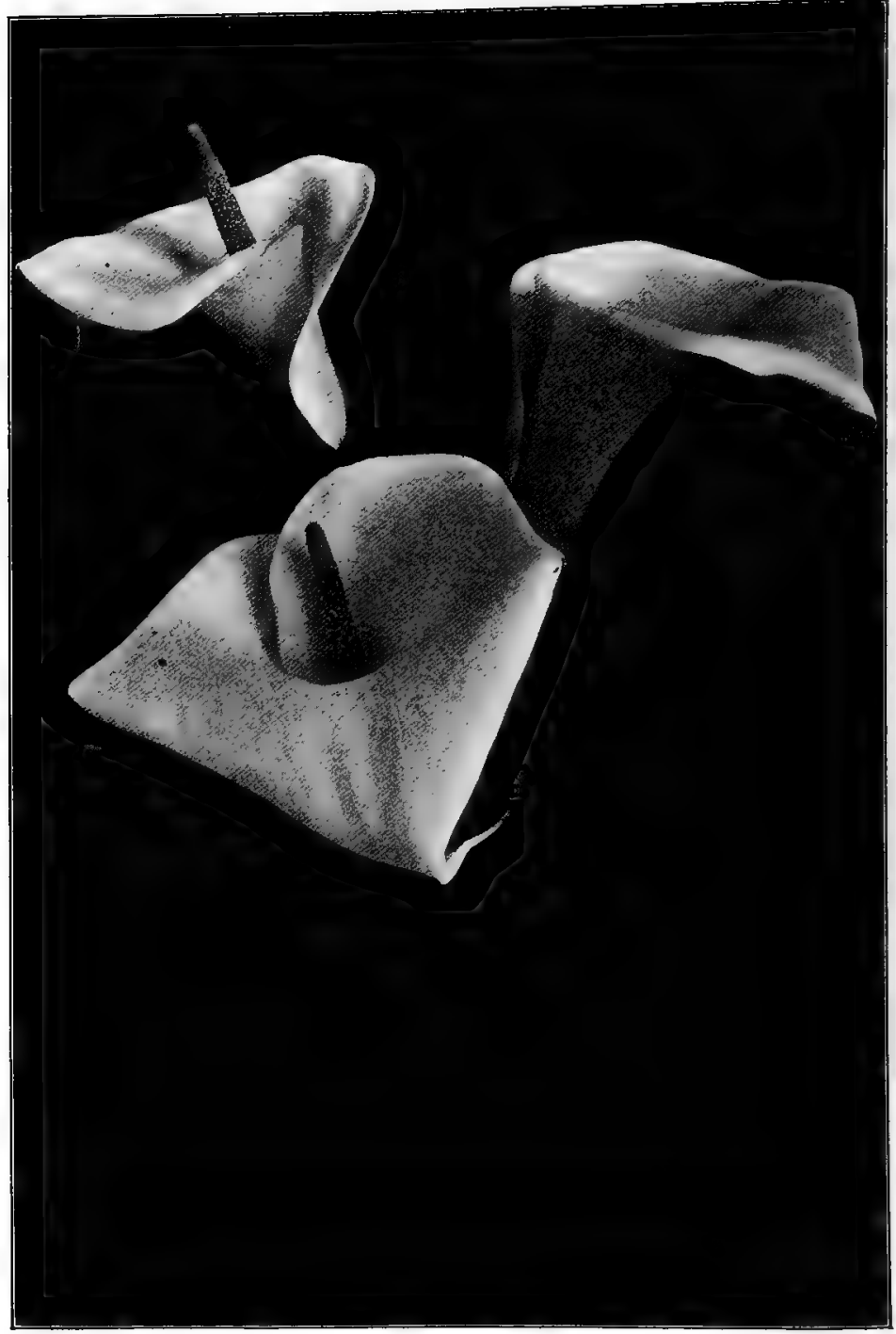

Calla Lily. Richardia africàna 
Richardia africana was introduced into England from the Cape of Good Hope in the year I73I, under the name of Calla Ethiopica, by which it is still known in many trade lists; though it has long been removed from the genus Calla.

The flowering column starts from the fleshy root, protected by the enrolling leaf or leaves, which it finally outstrips in height. As the spadix rises and matures, the spathe enlarges, flattens, and bends backward, becomes cream-white in color, but still wraps so close about its treasures that only the top of a little column suggests the wealth of stamens and pistils hidden within. Sports with double and triple spathes often occur. The species has varied into many forms, both standard and dwarf. 


\section{COMMELINÀCEA-SPIDERWORT FAMILY}

\section{SPIDERWORT}

Tradescântia virginiàna.

Named in honor of John Tradescant, gardener to Charles the First of England.

A native perennial, transferred to the garden. New York, Virginia, and westward. May-August.

Stem.-One to three feet tall, erect, leafy, mucilaginous.

Leaves.-Alternate, parallel-veined, lance-linear, keeled, ten to fourteen inches long, sheathing the stem at base.

Flowers.-Showy, violet-blue, rarely white; borne in many-flowered, terminal or axillary cymes; subtended by two leaf-like bracts; pedicels slender, villous.

Sepals.-Three; ovate, acute, or obtuse, villous.

Petals.-Three; orbicular, alternate with the sepals; blue, sometimes white.

Stamens.-Six, showy; filaments violet, bearded; anthers brilliant orange.

Ovary.-Oblong, three-celled; style thread-like; stigma capitate.

Capsule.-Three-celled, several-seeded.

The Spiderwort is rather an unusual type of flower. The blossoms are at the summit of what looks like an iris stem; usually two or three are open, but more drooping buds are clustered between long, blade-like bracts. The rich blue petals, the brilliant orange anthers set upon a cluster of blue bearded filaments, and the dark-green sepals and leaves, form a pleasing combination of color. The plants are robust, strong-growing, and form dense clumps. 


\section{SPIDERWORT}

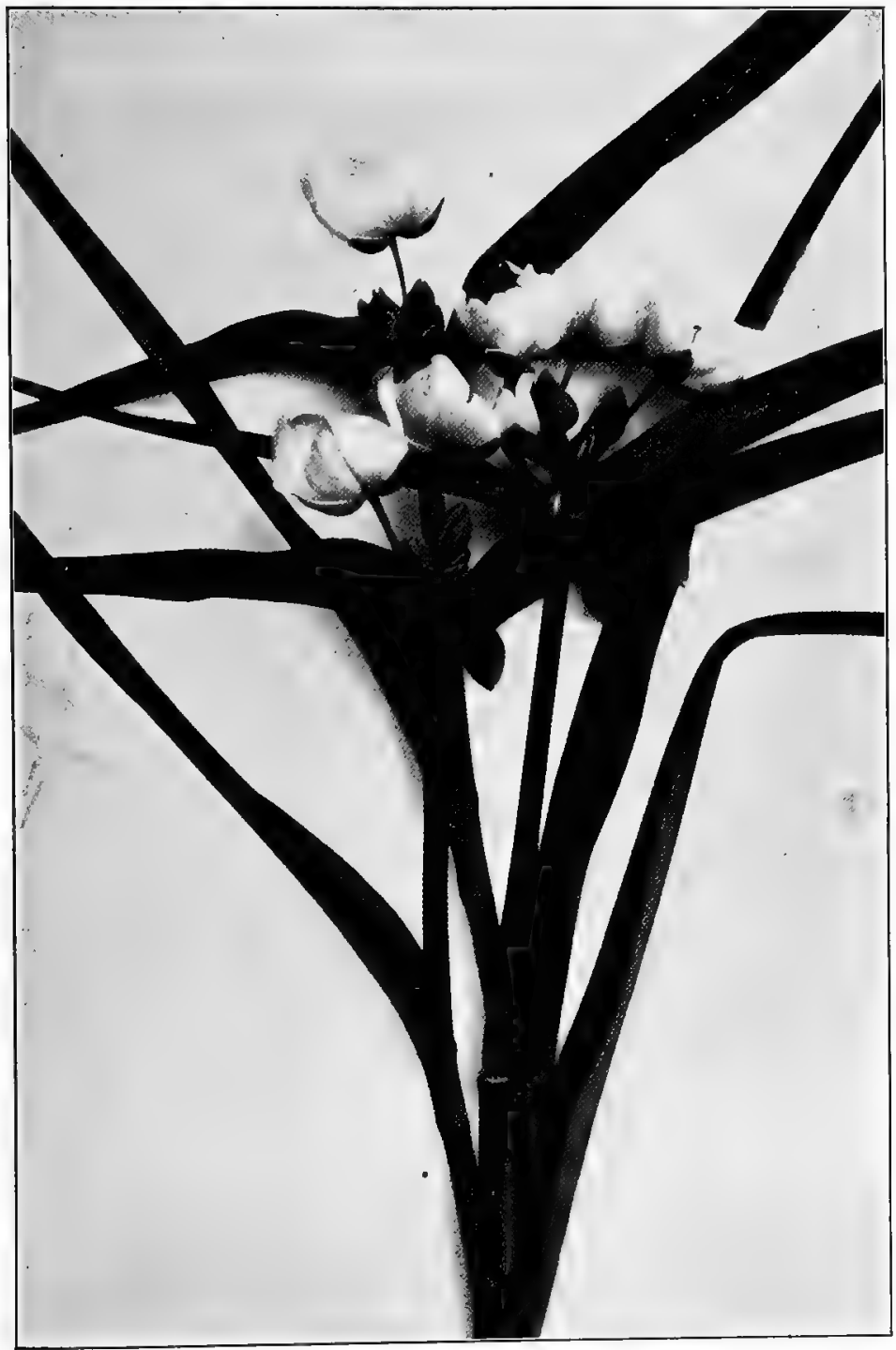

Spiderwort. Tradescántia virginiùna 


\section{WANDERING JEW}

Tradescántia fluminénsis. Zebrina péndula. Commelina nudifldra.

Perennials; often grown in water as house plants, noticeable for their shining, striped leaves. Spread by branching and rooting freely. Native to South America and Mexico.

Stem.-Prostrate, trailing, branching, rooting at the joints.

Leaves.-Sheathed at base, alternate, parallel-veined, oblong; green or purplish above, often variegated with two broad stripes of silverywhite.

Flowers. - White, rose-red, or blue; in terminal clusters, subtended by two leaf-like bracts.

Sepals.-Three, ovate, acute.

Petals.-Three, broad cvate; white, red, or blue.

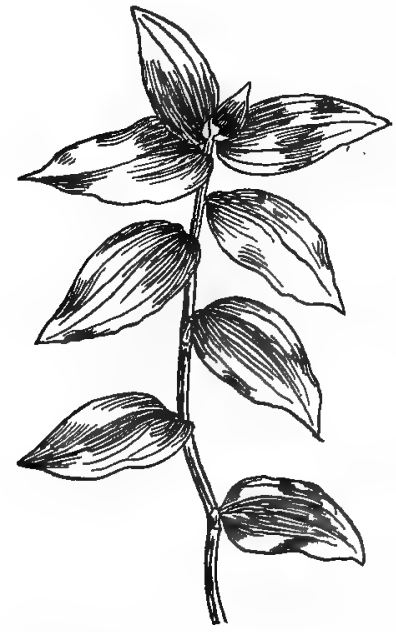

Wandering Jew. Commelina nudifidra

Stamens.-Six; filaments bearded; anthers conspicuous.

Ovary.-Oblong, three-celled; style thread-like; stigma capitate.

Capsule.-Three-celled, many-seeded.

Wandering Jew is the common name for three forms of Tradescantia, all alike in essential characteristics, though varying in minor points. They dwell principally in the dim light under greenhouse benches, yet often appear in hanging baskets. They are remarkably tenacious of life; a small branch put into water will root and grow indefinitely in the temperature of the ordinary living-room. The leaves of well-grown plants shine as if dipped in silver; when they have little light they are green, but when they have plenty of sunshine they become striped white or cream, and red-purple beneath. Both stem and leaves are succu- 
lent and the plant must have an abundance of moisture to do well.

Tradescantia fuminensis is tender; sheaths of the leaves hairy at the top and the flowers white. Zebrina pendula is also tender; the sheaths hairy at the top and the flowers rose-red. Commelina nudiflora is the hardy form; the sheaths are glabrous and the flowers blue. 


\section{PONTEDERIÀCE E-PICKEREL-WEED FAMILY}

A family of perennial bog plants having usually large thick leaves standing up well above the mud and water on long petioles. The flowers are perfect, more or less irregular, and borne upon a spadix that issues from a spathe which is soon outgrown. The familiar Pickerel-weed of shallow, clear-flowing, northern streams is the one species transferred from its wild home to the garden.

\section{PICKEREL-WEED}

Pontedèria cordàta.

Named in honor of Giulio Pontedera, professor of botany in Padua; I688-I757.

Stem.-Rather stout, two to three feet high, one-leaved, with several sheathing bract-like leaves at the base.

Leaves.-With many parallel veins, ovate, cordate-sagittate, the apex and the basal lobes obtuse; basal lobes often with long narrow appendages; radical leaves long-petioled.

Spadix and Inflorescence.-Glandular-pubescent.

Flowers.-Terminal, ephemeral, numerous, borne on a spadaceous spike; blue; trimorphous.

Perianth-Funnel-shaped, two-lipped, tube slightly curved; upper lip of three ovate lobes, the middle lobe longest; the lower lip of three linear spreading lobes.

Stamens.-Six, borne at unequal distances upon the perianth tube, three of them opposite the lower lip; the others opposite the upper lip. Ovary.-Three-celled, two cells abortive and empty, oblong, tapering into the style; stigma minutely toothed.

Fruit.-Enclosed in the thickened base of the perianth.

To one who, as a child, played and fished in northern streams the Pickerel-weed suggests long summer days, clear slow-flowing water, trout and pickerel hidden among the weeds of the brook- 
side or pond. The plant still stands in its ancient home, but of late years it has also come into the water-garden and made the acquaintance of civilization. It is an interesting creature, lifting

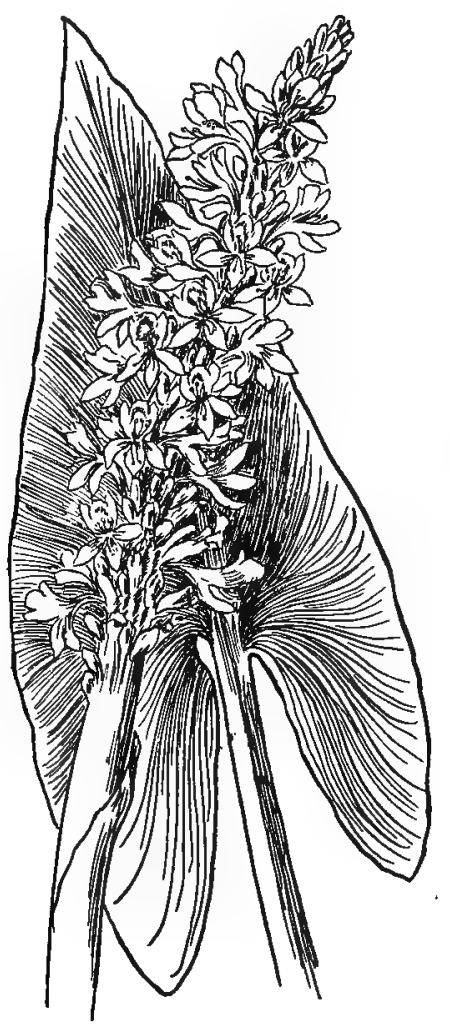

Pickerel-weed. Ponledèria cordàta

up above the water and the weeds one large, blunt arrowhead of a leaf on a stem crowned with a showy spike of bright-blue ephemeral blossoms-blue from tip to toe-perianth blue, filaments, anthers, and style, all blue--with but one tiny dash of yellow within each open cup.

The flowering season is long, beginning in June, and October is toward its close before the end comes. 


\section{LILIȦCEA-LILY FAMILY}

The Lily Family is one of the large botanical groups. In it the calyx and corolla so nearly resemble each other and are so often more or less united, that they are usually called by a single name-perianth; that is, floral envelope. This perianth.has six divisions. The stamens are six, one opposite each division of the perianth. The ovary is three-celled, always free from, and in position above, the base of the perianth. The fruit is a pod or berry; usually many-seeded.

The family includes the Lily, Tulip, Hyacinth, Squill, Funkia, and Yucca, together with other genera not so well known.

\section{LILY}

\section{Lilium.}

Lilium, an ancient Latin name of unknown meaning.

The genus Lilium is the type of the order Liliacea and contains about forty-five species of perennial bulbous plants mostly native to the north temperate zone. The larger part of our best garden species come to us either from western Asia or from Japan and China. None of the American species are especially successful in our gardens.

Leaves.-Alternate or in whorls, variable in shape, often bearing bulblets in the axils.

Flowers.-Funnel-form or bell-shaped, nodding or erect. The perianth is a combination of sepals and petals, three each; the sepaloids can be detected by their habit of overlapping the petaloids; there is often some slight difference in form; all are nectar-bearing.

Stamens.-Six, attached more or less to the base of the segments; filaments long and slender, bearing at their tips the swinging anthers heavy with pollen. 
Ovary.-Superior, that is, above the base of the perianth; threecelled; style long and slender; stigma club-shaped, three-lobed.

Fruit.-A three-celled, many-seeded capsule.

Lilies are not so extensively cultivated as their beauty would seem to warrant, and the explanation, doubtless, is that in several respects they are peculiar plants and require especial treatment. The bulbs differ materially from the bulbs of tulips or hyacinths, in that they are composed of many overlapping fleshy scales; that is, the bulb leaves are broken off, do not wrap round each other closely and make a compact mass, but are separate and loose. Hence, in a way, the heart of the Lily bulb is open to the air and is easily injured by careless exposure. Furthermore, the Lily needs a moist, cool root-run and that is one reason why it is well to plant it among shrubs.

In the case of most bulbs the fibrous roots start only from the base; this is plainly seen in any hyacinth forced in a glass. But when the Lily bulb becomes established it sends out roots from above as well as from below, and it is these roots that feed upon the surface soil and these are the ones that suffer most in heat and drought. Failure to understand this characteristic is at the bottom of much failure in Lily culture.

The books divide the Lilies into six groups or sub-genera; five of which have representatives among our familiar garden species; the sixth is a central Asian group, rarely cultivated in this country.

In the first stand the Madonna and Easter Lilies, marked by a funnel-shaped perianth, with oblanceolate segments which recurve only at the tip. The second finds a representative in our native Wood Lily, Lilium philadelphicum, whose upright cup takes in the sunshine unabashed. This group is marked by either single or umbellate flowers, the perianth erect and spreading; the segments recurved only in the extended flower but not revolute; the stamens diverging from a straight style. In the garden, Litium elegans is one of the best of this type.

The third group includes the well-known and highly prized Tiger Lily, as well as the two beautiful Japan Lilies, Lilium speciosum and Lilium auratum. It is marked by a funnel-form 
perianth whose segments finally spread or twist and become distinctly revolute; they are usually papillose within, and the stamens diverge from a curved style.

The fourth group is well defined by our native Turk's Cap, Lilium superbum, with its strongly nodding flowers, its very revolute perianth segments, and the stamens diverging from a curved style. The beautiful Meadow Lily, Lilium canadense, which in midsummer lights up our northern lowland meadows with its nodding bells, is our best example of the fifth group.

There are many species and more variants; yet, notwithstanding all the variations of size, color, inflorescence, leaves, and stems, the lily type of flower remains unchanged. A Lily is a Lily all the world over.

\section{WHITE LILY. MADONNA LILY.}

\section{Lîlium cándidum.}

Native of southern Europe and western Asia; long in cultivation.

Bulb.-Ovoid, large.

Stem.-Two to four feet high, erect, stiff.

Stem-leaves.-Scattered, sessile, acute, bract-like above.

Flowers.-Six to twenty-five in a raceme; pure-white, fragrant.

In the beauty of the lilies Christ was born across the sea.

-JULia WARd Howe.

The great white lily with his chalice of silver, the old lord of the garden, the only authentic prince whose nobility dates back to that of the gods themselves-the immemorial lily!

-MaETerinck.

Perhaps it is safe to say that this is the oldest and loveliest lily in cultivation; certainly for more than a thousand years it has wrought upon the imagination of the people of Europe as the flower of the Madonna. Its exquisite shape, its snowy petals, its delicate fragrance, have made it the symbol of beauty, purity, and love. In sacred pictures, Gabriel kneeling before the Virgin bears it in his hand; smiling angels chant in heavenly choirs 


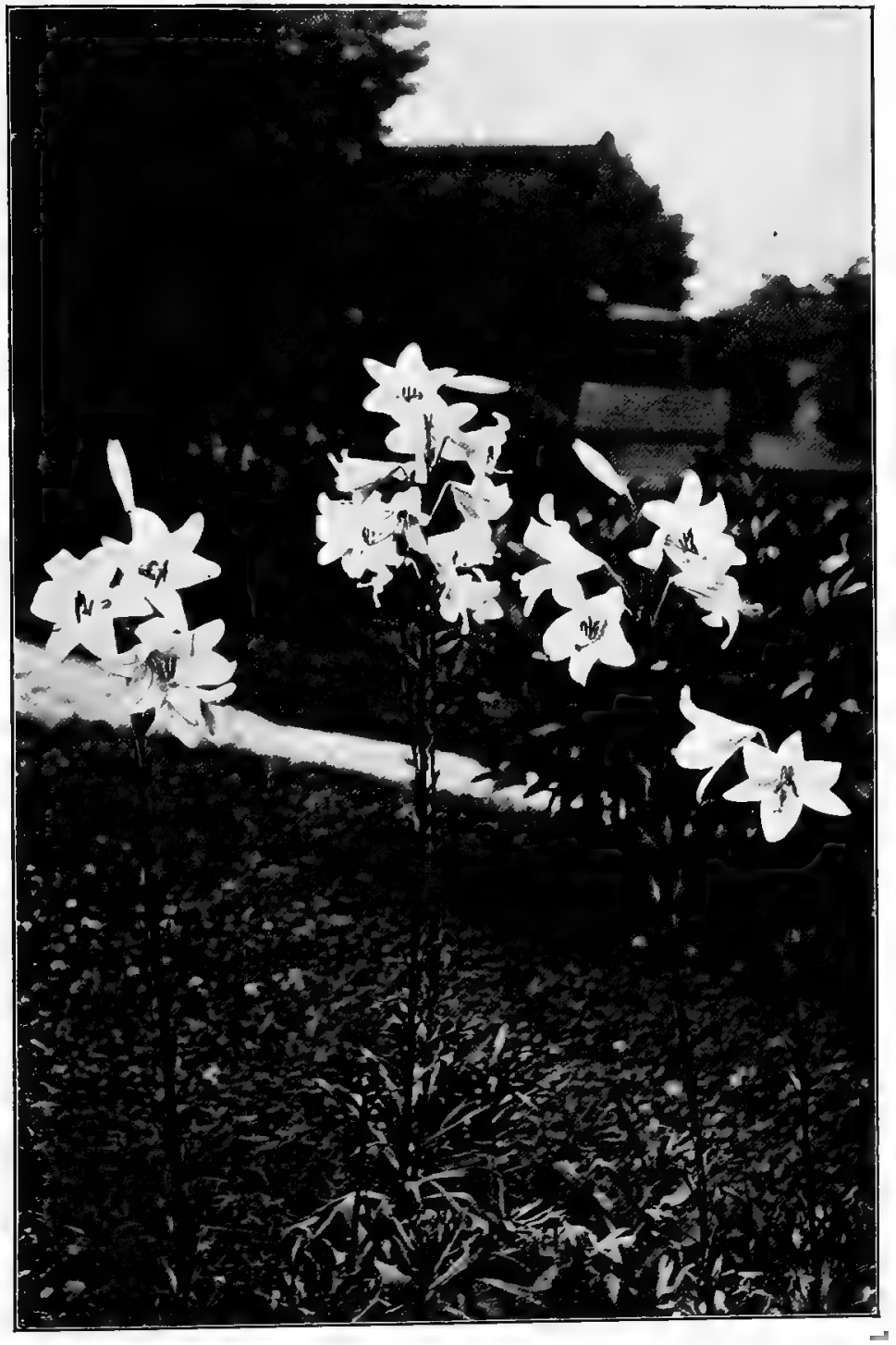

Madonna Lily. Lilium cándidum 


\section{LILY FAMILY}

amid its clustered bells, and no pictured saint but is ennobled by the presence of this matchless flower. With all these associations gathered about it, the plant was brought to this country to be our Easter Lily. But however the florist proposes, in the end the climate disposes. Outdoor bloom in April and May was obviously quite impossible and when forcing was attempted the plant proved wilful. Our best Madonna Lilies are now the outdoor product, blooming in June, thriving in any good soil and rejoicing in abundant light and air. The seçret of success in their culture is to let them alone after they are once well established.

\section{EASTER LILY. BERMUDA LILY}

Lilium longiflorum var. eximium.

Native to the temperate regions of Japan, China, and Formosa.

Bulb.-Globose.

Stem.-One to three feet high, erect.

Leaves.-Scattered, abundant.

Flowers. - Trumpet-shaped, nearly horizontal; fragrant; waxy-white; tube scarcely widened from base to middle.

Until the early eighties the Easter Lily of America was the Madonna, Lilium candidum, the well-known white-flowered species of southern Europe. But the Madonna Lily did not take kindly to forcing-florists could never be quite certain when their lilies would bloom - and to have a fine crop come into market one or two weeks after Easter sometimes spelled ruin to the grower. Hence the introduction to the trade by William $\mathbf{K}$. Harris, a Philadelphia florist, of the Bermuda Lily under the name Lilium Harrisii, was hailed with enthusiasm. The new species, though received by way of Bermuda, had long been known to botanists as a lily of China and Japan. This, however, was quite immaterial to the florist, the name was nothing, the native land was even less; here was a white lily that could be relied upon to come when called, and that was everything. 
The new species had larger flowers and more of them than the Madonna Lily; it was two months earlier, requiring only thirteen weeks for development under favorable conditions; and, best of all, it took kindly to forcing-house temperature. For a few years its vogue was tremendous, its position unrivalled. It adorned the pack of Santa Claus, it lay upon the altars of Easter, it wreathed the soldiers' monuments on Decoration Day. Thousands of bulbs were imported from Bermuda and from Japan. But the effort to comply with the demand for early bloom wrought destruction to the Bermuda crop; the bulbs were not allowed time to ripen and the entire crop became for a time seriously diseased. This, of course, was a passing condition.

Under the general title of Easter Lily there is now offered ${ }^{\circ}$ by the trade not only Lilium Harrisii, which is the Bermuda

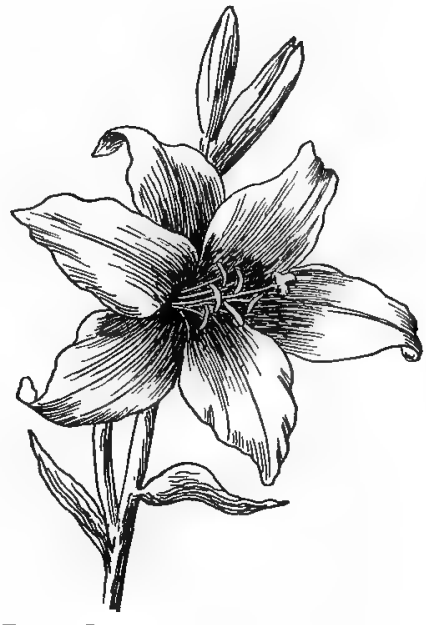

Easter Lily. Lilium longiflorum var. eximium variety, but Lilium longiflorum, the original type; also, a species from the Philippines.

When this lily is in the shops the flowers are usually mutilated; frequently not only the anthers but all the stamens are removed. There are two reasons for this: one, the abundant pollen which would soon be scattered over the inner surface of the flower and so mar its exquisite whiteness; the other, that if fertilization is prevented the life of the flower is extended; the florist knows that the flower lasts longer even if he does not know the reason why. There are those who will not buy mutilated lilies, but their number is small. 


\section{WOOD LILY. RED LILY}

\section{Lîlium philadélphicum.}

The only native lily of the North whose bells are not recurved. Prefers dry or sandy ground; and ranges from New England south to North Carolina, and west to the Mississippi.

Bulb.-Annual, rhizomatous, small, with few thick, brittle scales.

Stem.-Erect, leafy, one to three feet high.

Leaves.-Lanceolate or lance-linear, in whorls of five to eight.

Flowers.-One to three at the summit of the stem; opening upward; the six segments narrowing to a stem-like slenderness toward the base. Color varying from orange-scarlet to scarlet-orange and paler, more or less spotted with purple-brown on the inner part of the cup.

The Wood Lily is our native representative of the second subgenus of lilies, of which Lilium élegans and Lilium concolor are excellent garden forms.

One finds it on midsummer days a blaze of orange and scarlet amid the grass and weeds of upland meadows, or glowing like a lamp in the shadow of the hill forest. It is our one lily whose petals do not recurve, whose cup is open to the sun-lily to its heart's inmost core-nevertheless, it neither droops nor nods; it is erect, upright, unyielding.

\section{UPRIGHT LILY}

\section{Lîlium élegans.}

Bulb.-Perennial, ovoid.

Stem.-One to two feet high, stiff, erect, slightly cobwebby, or sometimes nearly glabrous.

Leaves.-Scattered or crowded, lanceolate, five to seven-nerved.

Flowers.-One to five, erect, spreading; segments oblong, spatulate, usually self-colored in yellow or orange-red, sometimes more or less dotted. June.

Lilium elegans is a Japanese lily much cultivated under a variety of forms and of names. In the type the flower is self-col- 


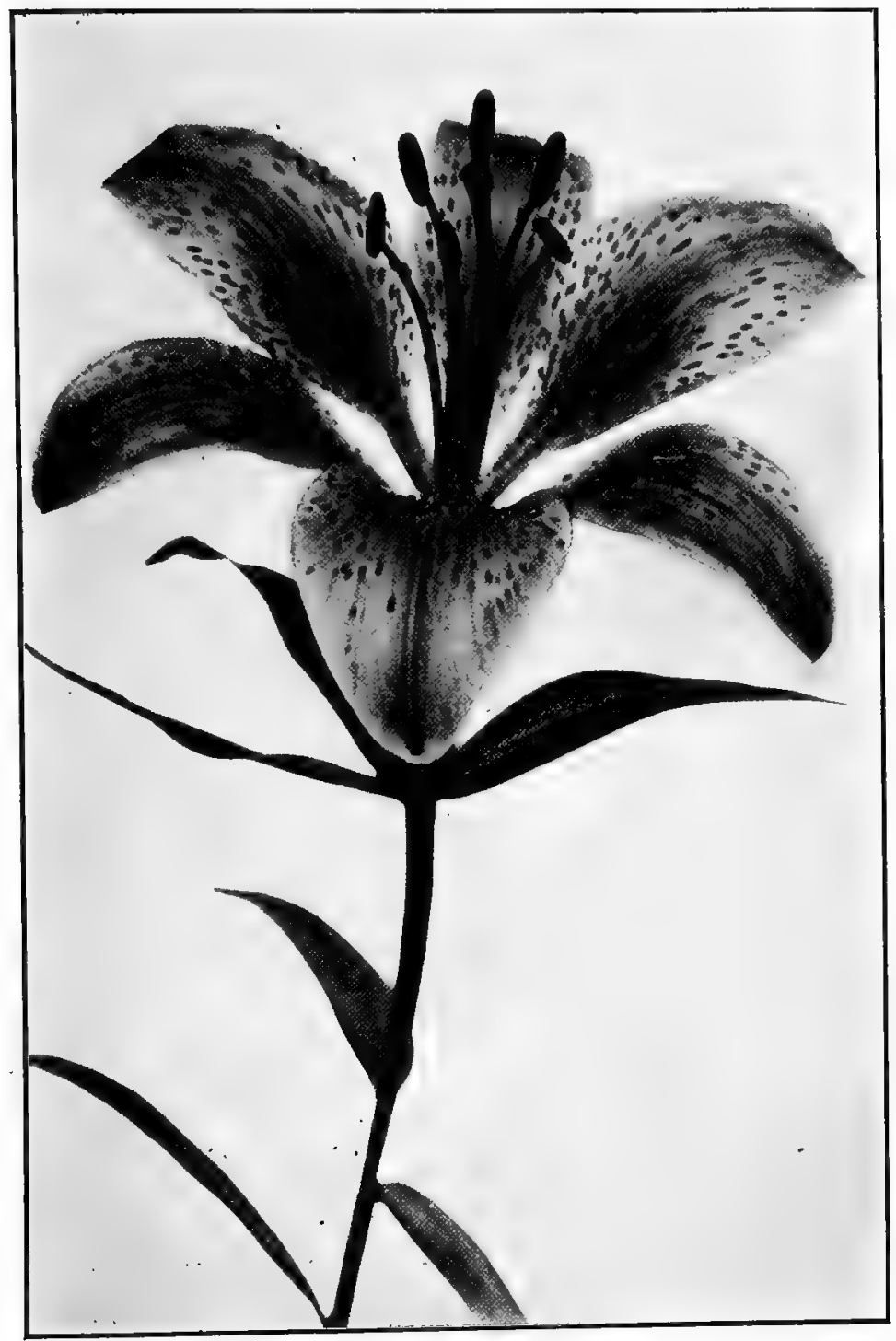

Upright Lily. Lilium élegans 
ored in a range of orange, yellow, and red, without spots; but in its hybrids and variants it appears more or less spotted. The one essential is the poise of the flower cup; the petals do not recurve, as the blossom opens they spread. The short, sturdy stem often bears five flowers all clustered at the summit.

\section{JAPANESE LILY. SHOWY LILY}

\section{Lilium specidsum.}

One of the most beautiful of the lilies of Japan, now appearing in many varieties.

Bulb.-Perennial, globose.

Stem.-One to three feet high, stiff.

Leaves.-Scattered, lance-ovate or oblong; five to seven-nerved; slightly petioled.

Flowers.-Fragrant; borne in panicled racemes; segments reflexed and somewhat twisted; white, suffused with pink, and spotted with red dots and warty projections inside.

Stamens.-Spreading; with large chocolate anthers.

Lilium speciosum with its varieties, rubrum and album, is a very satisfactory lily for the hardy garden. It is thrifty, its foliage graceful, the habit of the plant self-reliant, and the flowers charming in shape and beautiful in color. The florists' custom of mutilating lilies, depriving them of their stamens and sometimes of both stamens and pistils, so disfigures them that it is quite impossible to obtain a correct idea of their grace and beauty from specimens bought in the shops. To know a lily well one must grow it. The variety rubrum is considered more vigorous than the type, as well as more beautiful. 


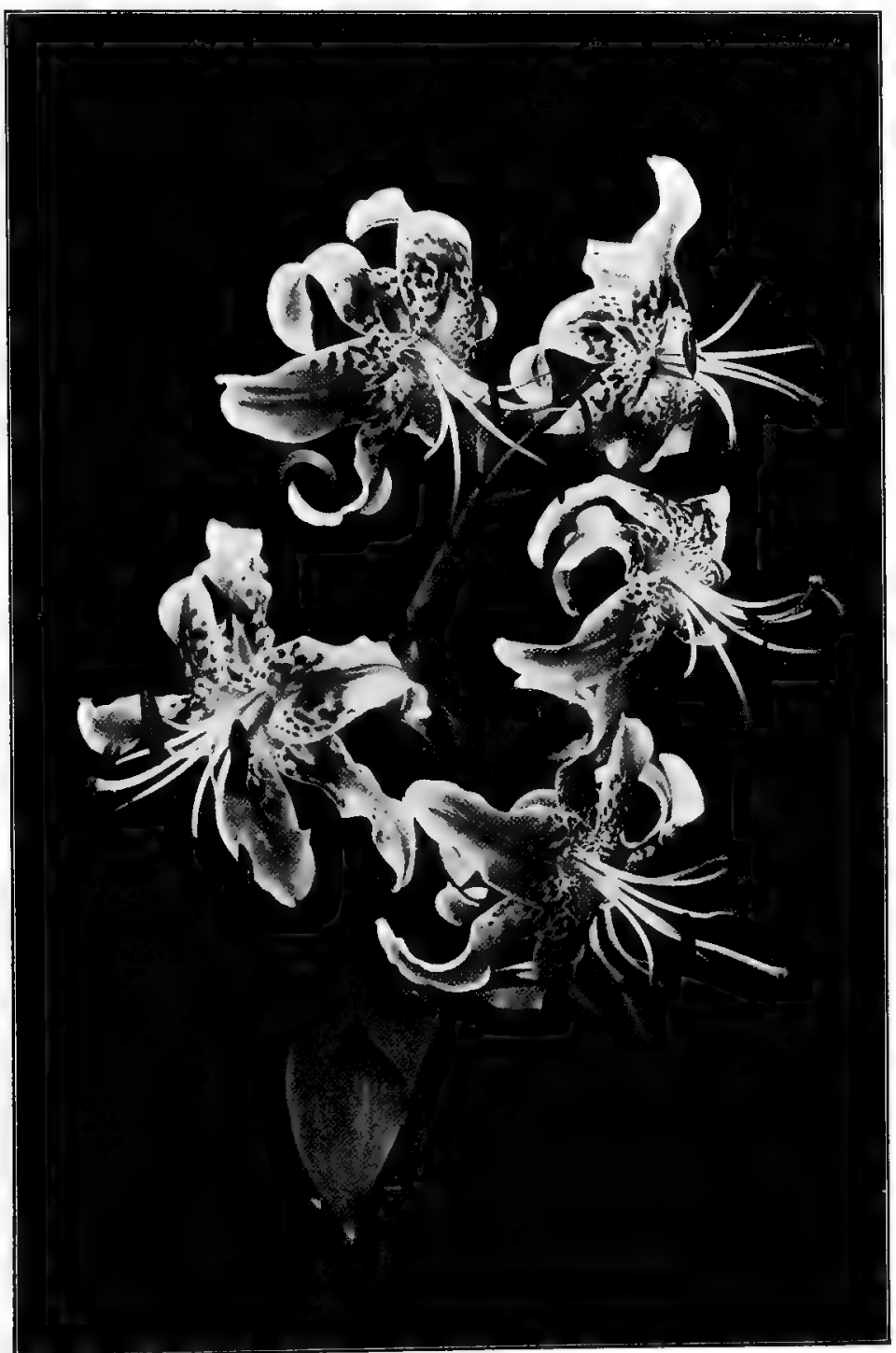

Japanese Lily. Lilium słeciòsum 


\section{LILY FAMILY}

\section{GOLD-BANDED LILY}

Lílium auràtum.

Native of Japan, brought into western cultivation in 1862 .

Bulb.-Perennial, globose.

Stem.-Two to four feet high.

Leaves.-Scattered, five-nerved.

Flowers.-In a short raceme, with bractiolate pedicels, spreading; segments reflexed and somewhat twisted, white, more or less marked

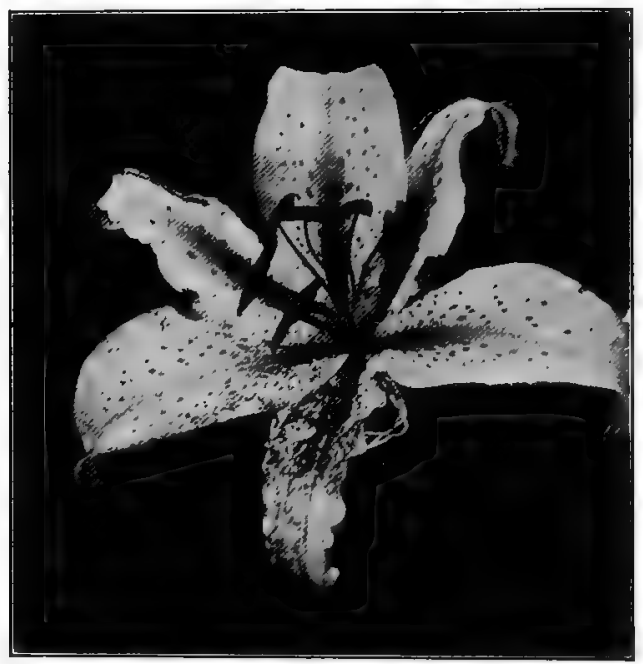

Gold-banded Lily. Liliım auràıum

with bands of yellow and spots of carmine or dull-red; at the base thickly studded with fleshy excrescences.

Stamens.-Long, with large chocolate anthers.

Style.-Long, with deep-red stigma.

There is in this splendid lily that has come to us out of the East, an air of distinction as if belonging to a caste apart. Unquestionably the most magnificent lily of the genus-superb, regal, incomparable-one may marshal all the adjectives and yet fall 
TIGER LILY

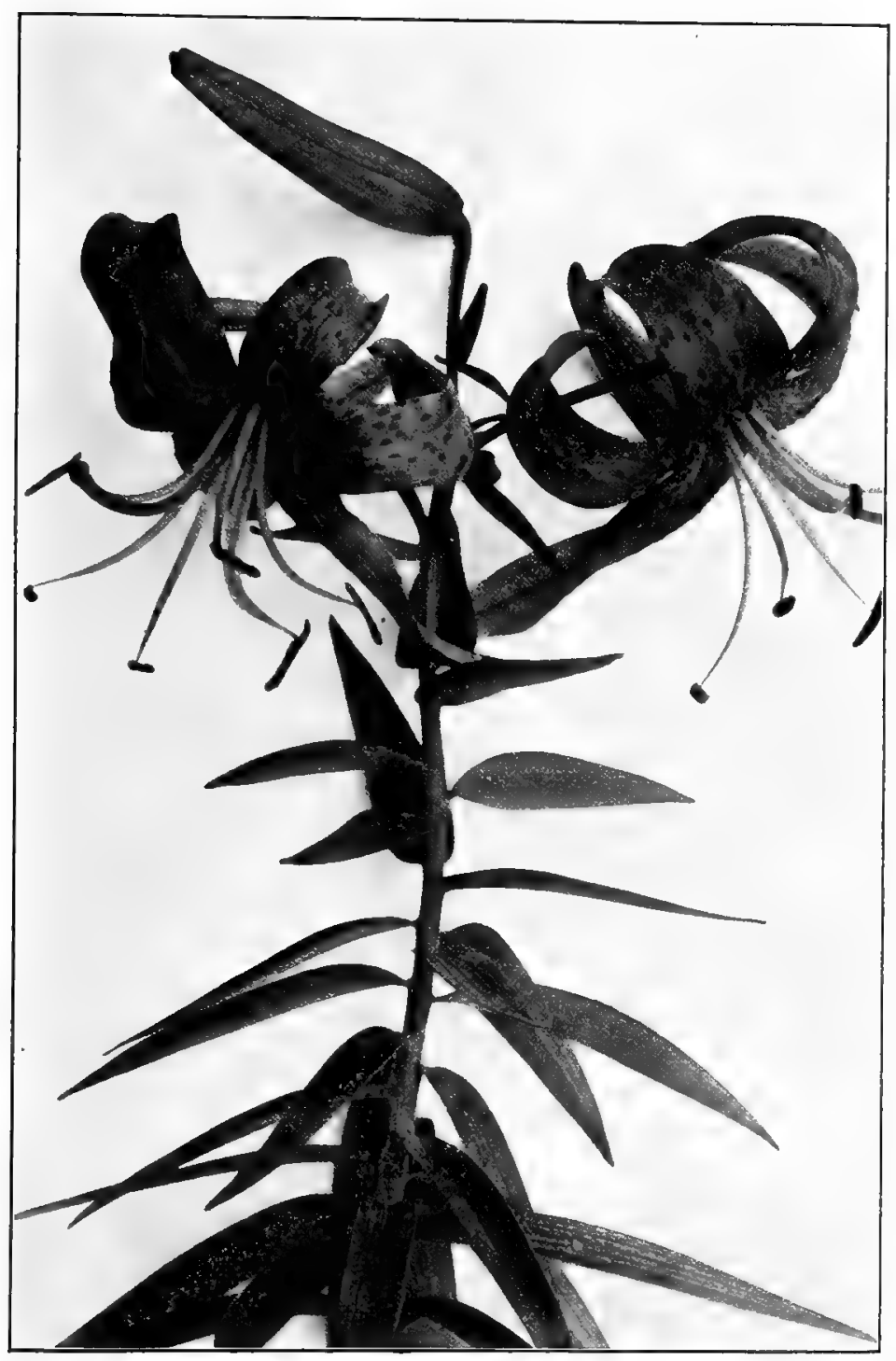

Tiger Lily. Lîlium tigrinum 
short of its royal perfection. Ten to twelve inches from tip to tip, its white petals thickly fretted with deep-red, and a gold band running lengthwise through each, with chocolate-colored anthers and a red-tipped pisti! to lend an added charm to the lily bell.

The plant is a true Oriental-difficult to grow-a little wilfuldoing well-doing ill-not as yet quite comprehended-possibly beyond the reach of the amateur-unwilling, as yet, to make its home in the West.

\section{TIGER LILY}

Lîlium tigrinum.

A thoroughly old-fashioned and very useful plant which lives and thrives from year to year in the open border, where it should be planted in masses. China and Japan.

Bulb.-Perennial, globose.

Stem.-Three to five feet high; greenish-purple or dark-brown.

Leaves.-Sessile, deep-green, scattered, lanceolate, five to sevennerved, the lower ones enlarging more at the apex.

Bulblets.-Appear in the axils of the upper leaves, adhering to the stem at first, finally falling off to produce new plants.

Flowers.-Large, three to ten or more in a wide, panicled raceme, nodding; segments recurved, bright red-orange, thickly dotted with large dark spots.

The Tiger Lily from eastern Asia was probably the first lily brought to this country, as the lists of old-time garden flowers always include it. The type has been improved, and a plant of great natural dignity and beauty, now under the guise of tigrinum spléndens, represents the older form. The plants are easily recognized by the little black bulblets in the axils of the leaves. 


\section{TURK'S CAP LILY}

\section{Lilium supêrbum.}

Our most vigorous and picturesque native lily; its habitat extends from Canada to Georgia and west to the Mississippi. Should be cultivated among shrubbery.

Bulb.-Large, rhizomatous.

Stem.-Three to six feet high; tall, erect.

Leaves.-Lanceolate, pointed; three to five-nérved; lower leaves whorled, upper more or less scattered.

Flowers.-Nodding; ten to forty in a pyramidal paniculate raceme; bright red-orange with numerous dark purple spots inside; segments lanceolate, acute, strongly recurved."

The Turk's Cap Lily is found rarely enough in its extended habitat to make the finding - certainly the first finding-an event. To come upon a slender leafy pillar crowned by a score of nodding lily bells in a fence corner whose possibilities you thought you knew absolutely, is like finding an alert ivory-billed woodpecker under the maples in your city lot, or a tired loon in your country barn-yard, or the Grass of Parnassus when you are out for Goldenrod, or a bright blue vrolet, in late November. All these things happen, and the day they happer is memorable.

The segments of the mature blossom are greatly recurved, the brown anthers swing free, and the half-nodding orange cup is freckled with brownish-purple spots. This is our best representative of the Martagon type of lily, and is worthy of cultivation. It should be planted among high shrubs and it will climb to light and sunshine.

\section{MEADOW LILY. WILD YELLOW LILY}

\section{Lîlium canadénse.}

The familiar, nodding lily of northern meadows. Its range extends from New Brunswick to Georgia and west to the Mississippi; prefers moist lowlands. June, July. 


\section{LILY FAMILY}

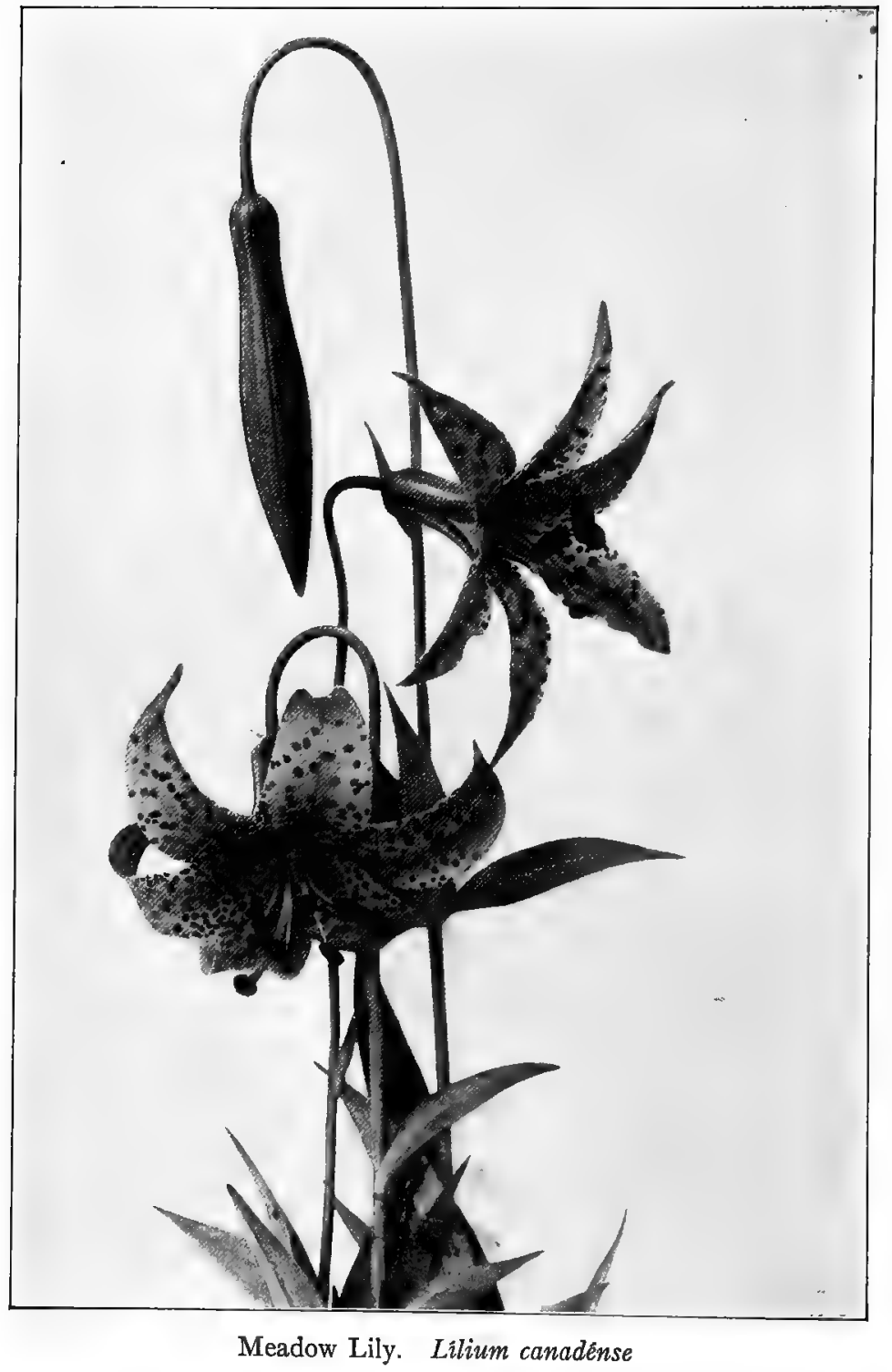


Bulbs.-Rhizomatous.

Stem.-Two to five feet high.

Leaves.-Lanceolate, three-nerved, margins and nerves rough, remotely whorled.

Flowers.-Few, on long peduncles, yellow or orange usually spotted with brown; the perianth segments recurved and spreading.

This is the common Lily of the North, abundant in alluvial meadows throughout its entire range. The stem ordinarily rises to the height of three feet and bears several whorls of brightgreen lanceolate leaves. At the summit it divides into several flower stems and each bears a delicate, pendulous bell, dull buffyellow or dull orange without, and orange or pale yellow within, freckled with purple brown spots. It fails of the glowing color of the Wood Lily, but it bears its blossoms with an incomparable grace and possesses a charm unsurpassed by any lily of the garden. It is our only native representative of the fifth sub-genus of lilies.

\section{COMMON TULIP}

\section{Tilipa Gesneriuma.}

Tulipa, derived from the Persian toliban, turban, which the inverted flower resembles. face.

Bulb.-Tunicated, the outer tunic often lairy or woolly on the inner

Leazes. - Linear or broad.

Flower-stem.-Three to thirty inches high, usually one-flowered.

Flowers,-Erect, rarely nodding; showy; sometimes fragrant.

Perianth"segments. - Six; stamens six, inserted on the torus.

Ovary.-Three-celled; stigmas three, sessile.

Pod.-Oblong; seeds many, flat.

Tulipase do carry so stately and delightful a form, and do abide so long in their bravery, that there is no Lady or Gentleman 'of any worth that is not caught with this delight.--"Paradisus Terrestris," PARkInson; I600.

The origin of the cultivated Tulip is lost in the mists of antiquity. The plant came into Europe by way of the Turk, the first seeds having been sent or brought to Vienna in I 554 by the Aus- 
trian ambassador to the Sultan of Turkey. After the first introduction the plants rapidly increased and were distributed very generally throughout Europe. A careful description as well as several drawings of the plant were published by Konrad von Gesner, a Swiss botanist, who saw it growing at Augsburg in I559. Linnæus in I753 simply grouped all the garden Tulips he knew under the name Tulipa Gesneriana in compliment to Gesner; but this name never represented a primitive form, it merely designated the Tulip as it then appeared in cultivation.

The wanderer made its way into. England as early as I599 and became the flower of fashion for a hundred years. Then a reaction came on and the "gaudy tulip" was relegated to cottage gardens. That sort of folly finally passed and the Tulip now stands simply upon its merits, which are great.

Holland was the producing centre for Tulips as early as I600, and the astonishing craze, known as "tulip mania," began in I634 and lasted four years. This was a speculative craze, extraordinary only in the object selected for speculation; but when I 3,000 florins were paid for a single Tulip bulb the government felt that it was high time to interfere, as indeed it was.

The garden varieties of Tulips are now so many and so varied that florists have been compelled to group them into classes, and so classified the bulbs are offered for sale by the trade. This grouping is explained by Edward Step, F.L.S., and William Watson, of Kew Gardens, as follows: "Primarily we may distinguish a division into Early and Late-flowering Tulips. The Early-flowering are divided into Singles and Doubles; but the classification of the Late-flowering is not nearly so simple. First, these are separated under the heads of Bizarres, Byblœmens, Roses, Darwins, and Parrots; second, they are divided into Feathered Bizarres, Flamed Bizarres, Feathered Byblœmens, Flamed Byblœmens, Feathered Roses, Flamed Roses. But where Tulips are raised from seed, there is an early stage in which the flowers are neither feathered nor flamed, but are of one uniform color. This first flowering takes place when the seedling plant is four or five years old, and its color may be white, yellow, purple, or red; 


\section{COMMON TULIP}

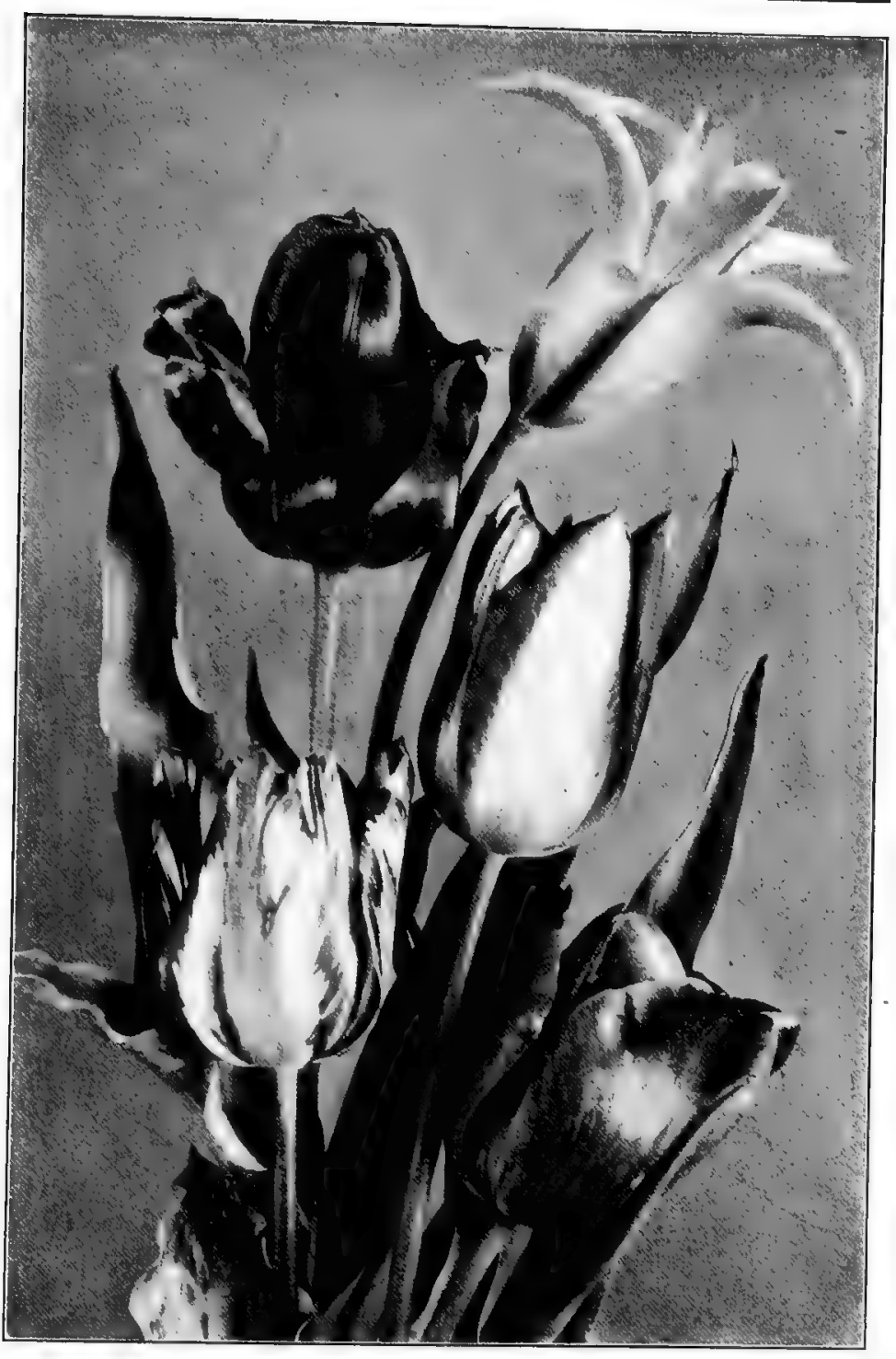

Tulip in variety. Tulipa Gesneridna 
it is now termed a Breeder. At some future flowering period -how many seasons later is quite uncertain -it may 'break' into central markings of another color, and these may be either flame-like or feather-like. It is now Rectified, and is placed in the Flamed or Feathered section of its class according to the character of this variegation.

"In Bizarres the ground color is either lemon or golden yellow and the base of the flower is of clear yellow. Above this clear base is laid the flame or feather marks of orange, scarlet, crimson, black, or brown. If the base is stained with a tinge of green, then, according to the rules, all its value as an exhibition plant is gone.

"Byblomens have a clear white ground and white base, above which the variegations are similarly laid in violet, purple, black, pale-lilac, lavender, and heliotrope.

"Roses also have a clear white base, and a white or rose ground above it, on which are laid flames or feathers of delicate pink, soft rose, glowing scarlet, scarlet-cerise, rose-pink, carmine-rose, or the deepest crimson.

"Darwins are really late-flowering Breeders, developed in England and differing from the Dutch Breeders in their numerous and striking shades of color, ranging from the lightest to the darkest, and in their long flower stalks.

"Parrots or Dragon Tulips have flowers brilliantly colored, of large size, and the edges of the segments deeply toothed and slashed."

Since it was the Turk who developed the Tulip, it is interesting to inquire what type of flower was most agreeable to him. We find that the Turkish form was one of pointed segments rather than rounded ones, and that the preferred colors were solid reds and yellows. All the variegation has been produced on European soil. The chief value of the Tulip lies in the masses of dazzling color which it can give to our yards, lawns, and parks, while vegetation as a whole is yet in the bud. No other plant can do this so well, and coming out of the Levant three hundred years ago it seems to have started upon a triumphal march around the world. 


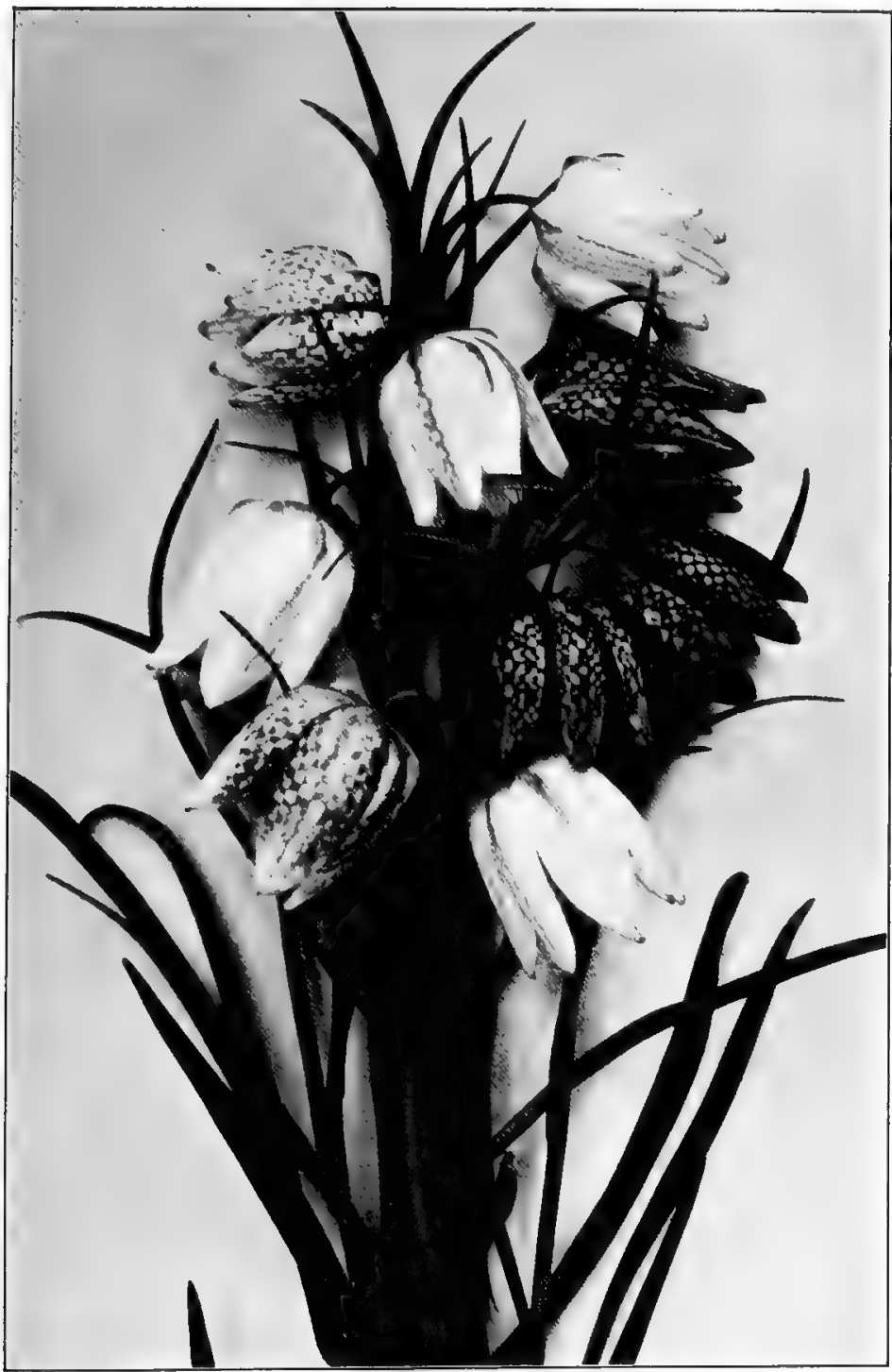

Checkered Lily. Fritillària meleàgris 


\section{LILY FAMILY}

The Fragrant Tulip, Tulipa suavèolens, was discovered growing wild in southern Europe about three hundred years ago. There is no proof that it is a primitive form, the probability is that it is an escape from gardens. As early as 1799 it was distinguished from other Tulips then known by the fragrance of the flowers, and the earliness of the bloom. From the first, there were among the Turkish Tulips some distinguished for fragrance, and this is one of the reasons for believing that Tulipa suaveolens is an escape rather than a primitive.

The class of Tulips known as Duc van Thol are usually regarded as descendants of this type. These have, however, become so hybridized that they cannot now be distinguished from the other forms.

Parrot Tulips became known toward the end of the seventeenth century. They were undoubtedly developed by the French, probably by selection, as a tendency toward serrate or cut edges may be observed among our present garden varieties.

\section{FRITILLARIA. CHECKERED LILY}

Fritillària meleàgris.

From Fritillus, commonly understood to be a checker-board.

Bulb.-Of few thick scales.

Leaves.--Slender.

Flowers.-Solitary, nodding, checkered in colors; mostly greenishwhite and purple.

Perianth.-Of six separate segments, each bearing a hollowed honey gland at the base.

Stamens.-Six, attached to the base of the segments.

Ovary.-Three-sided; style three-grooved; stigma three-lobed.

A widely distributed European plant, ranging from Great Britain to the Caucasus; producing large, pendulous, bell-shaped, solitary flowers, in light colors, checkered with green and purple, and borne on slender stems a foot high. They resemble lilies in having drooping flowers, but their anthers are fixed at the base, while those of lilies are versatile and free to swing. Several Fritillaries are in cultivation, but the common Snake's Head, 
or Checkered Lily, so-called from the curious tessellation of colors, is the most popular. This plant grows wild in moist English meadows and is reported as easy of growth.

Fritillaries have never been very extensively cultivated in this country.

\section{CROWN IMPERIAL}

Fritillària imperàlis.

One of the characteristic plants of old-fashioned gardens, but banished from modern ones because of its fetid odor. Native of Persia; introduced in to England before 1596. April, May.

Bulb.-Coated or scaly. Stem.-Two to three feet high.

Leaves.-Broad lanceolate, numerous, often whorled midway up the stem, which is also terminated by a tuft of leaves above the flowers.

Flowers.-In a whorl of nodding bells underneath the terminal leaves; yellow to crimson; segments six, not recurved, a honey gland at the base of each.

Stamens.-Six, attached to the base of the segments.

Style.-Long; stig ma three-lobed; pod six-angled.

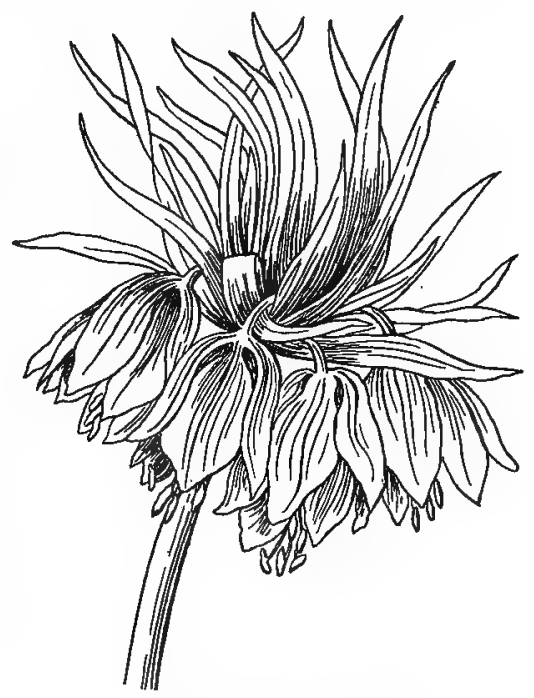

Crown Imperial. Frilillì̀ia imperàlis

The Crown Imperial, for its stately beautifulness deserveth the first place in this our garden of delight, to be here entreated of before all other lilies. The whole plant and every part thereof doe smell somewhat strong, as it were the savour of a foxe, yet is not unwholesome.

- "Paradisus Terrestris," Parkinson.

The Crown Imperial is a plant which has outlived its social consideration. Parkinsnn regarded it as the best of the lilies, but no one gives it that place to-day. In an age that asks for fragrance, 
it is distinctly ill-smelling; in an age of careless grace and lawless beauty, it is stiff and unyielding. But should the fashion in flowers drift back to stiff and stately forms, the Crown Imperial, as well as the Camellia, may regain its imperium.

\section{SCILLA. SIBERIAN SQUILL.}

Scilla sibirica.

Scilla is the old Greek name meaning, I injure; referring, it is supposed, to the poisonous bulbs.

Scillas form a group of early-flowering bulbous plants. One of the best is Scilla sibirica, native to Russia, Siberia, and Asia Minor. March.

Leaves.-Two to four, narrow, ascending, four to six inches long. Flowers.-Deep-blue in the type, borne on one to three-flowered

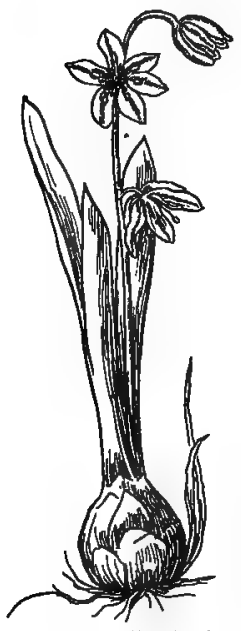

Scilla. Scilla sibirica scapes, horizontal or drooping.

Perianth.-Of six distinct segments.

Stamens.--Six with flattened filaments and oblong anthers.

Ovary.-Three-lobed; style slender, stigma minute.

Capsule.-Triangular, three-valved; seeds black.

Of this group of bright little flowers, Scilla sibirica has become a garden favorite. Its blue stars come early, usually in March, and they are wholly, delightfully, persistently blue. The perianth is about an inch across, pure blue, with a darker line in the middle of each petal; the stamens are blue; the style and stigma are blue; only the green ovary lies in the centre. It should be planted in mass, for only by numbers can the best effects be produced. A number of species are in cultivation; among the best are bifolia, which can be had in several colors; amèna, very hardy and robust; vêrna, a native of sea-shores, and autumnàlis, blooming in September. 


\section{CHIONODOXA. GLORY-OF-THE-SNOW}

\section{Chionodosxa lucilia.}

Chionodoxa, Greek, glory of the snow; referring to the early flowering.

A hardy little, bulbous plant, bearing a raceme of three to six blue flowers, shading to white in the centre; blooming in early spring. Native to the mountains of Asia Minor. Variable; having several garden forms.

Leaves.-Narrow, pointed, rising from a small bulb.

Flowers.-Blue and white, stalked on a short raceme; the tube shorter than the recurved spreading, acute segments.

Stamens.-Six; filaments dilated.

Ovary.-Three-celled, style short, stigma capitate.

The attractive name of this pretty plant refers to the fact that it flowers amid the melting snows of its mountain home. It dwells upon the heights of the Taurus range in Asia Minor, and was there discovered by the Swiss botanist, Boissier, at an elevation of 7,000 feet above the sea. It has been cultivated since I877.

The leaves are three to six inches long at the flowering period, strap-shaped, and surmounted by a slender raceme of three to six, sometimes more, intensely blue, six-starred flowers which fade to white in the centre and are fully an inch across when expanded. To get the best effects the plant should be massed; the bulbs planted an inch or two apart.

There are several Chionodoxas in cultivation, but luclice is regarded as the most satisfactory of them all. In color it runs into white, red, and pink forms.

Chionodoxa'sardensis has small, dark-blue flowers with no white eye. This genus is very closely allied to Scilla, but differs principally in having a short tube to the perianth; the two hybridize, and for garden effects are virtually the same. 


\section{LILY FAMILY}

\section{STAR-OF-BETHLEHEM}

\section{Ornithógalum umbellatum.}

An ancient whimsical name, meaning bird-milk.

The common Star-of-Bethlehem is the only representative of the genus Ornithogalum that is at all common in American gardens. It is a dwarf, hardy, bulbous plant, which bears umbels of green and white flowers in May. Mediterranean region.

Leaves.-Several, six to twelve inches long, narrow, deeply channelled, distinctly striped with white.

Flowers.-White, striped with green outside, twelve to twenty on a scape six inches high.

Perianth-Of six segments, spreading, with honey gland at base.

Stamens.-Six, filaments flattened.

Ovary.-Three-celled; style short, stigma three-angled.

Capsule.-Three-celled, many-seeded.

In the Star-of-Bethlehem the green and white of the leaf is curiously repeated in the white and green of the flower, which is a pretty six-pointed star, opening in sunshine.

\section{GRAPE HYACINTH}

\section{Muscàri botryoùdes.}

Muscari, from the musky scent of one flower of the species.

One of the early-flowering bulbous perennials of country gardens, escaping into lawns and fields. Europe. March, April.

Leaves.-Radical, linear.

Flowers. - Violet-blue to pure blue, borne in a dense raceme, on a naked scape four to six inches high.

Perianth-Globular, or urn-shaped, constricted at mouth; violetblue, white at the mouth, six-toothed.

Stamens.-Six; ovary three-celled, forming a triangular three-celled capsule.

These are hardy little bulbous plants from central Europe with very short dense racemes of small, nodding, globular flowers, and 
erect glaucous leaves. The plant is well suited for the wild part of the rockery; naturalizes readily at the edge of woods. Several species are in cultivation, but the one that everybody knows is Muscari botryoides, which means, "like a bunch of grapes." It belongs in every garden; its dainty flowers are a part of the wel-

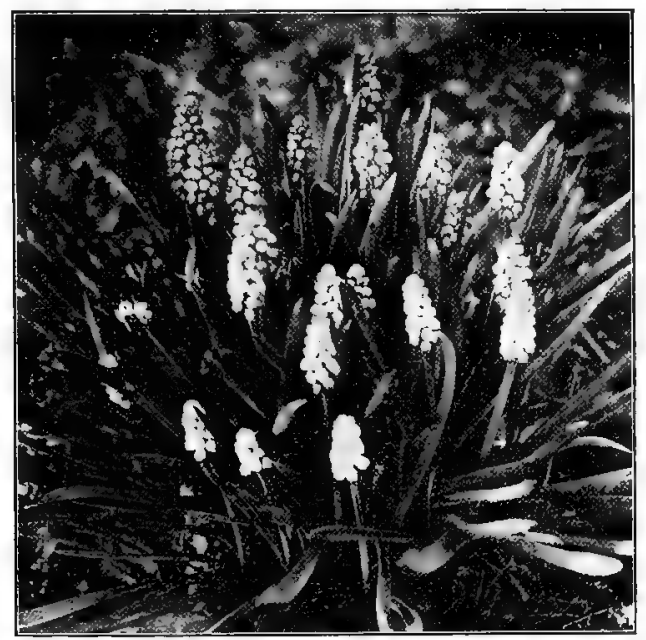

Grape Hyacinth. Muscàri bolryoìdes

come to spring. Personally, I do not care what color Grape Hyacinths are, so long as they are blue; but misguided gardeners sometimes cultivate varieties with white and with yellow or fleshcolored flowers-a mistake.

There is a species, Muscari commòsum, rather larger than our garden favorite, bearing violet-colored, oblong flowers; which has a variety, monstròsum, called Feathered Hyacinth. The inflorescence is a panicle mass of aborted, contorted, blue petalage; that the catalogues say is of "striking and handsome appearance." 


\section{HYACINTH}

Hyacínthus orientàlis.

A perennial, bulbous plant, cultivated from ancient times; native to Greece, Balkan peninsula, Asia Minor, and Syria. Extensively grown in Holland for export and consequently known as the Dutch Hyacinth.

Bulb.-Producing many long, fibrous roots.

Leaves.-Erect, radical, eight to twelve inches long.

Flowers.-Borne on a stout scape, in a dense raceme four to six inches long.

Perianth.-A bell-shaped tube, swollen at the base, with six recurved segments.

Stamens.-Six, inserted on the tube of the perianth; anthers pale yellow; pollen abundant. Often double in cultivation; color range includes blue, red, purple, lilac, yellow, and white.

And the Hyacinth purple and white and blue,

Which flung from its bells a sweet peal anew

Of music so delicate, soft, and intense,

It was felt like an odor within the sense.

一 Shelley.

The garden race of Hyacinths are at base Hyacinthus orientalis, a species native to western Asia and possibly south-eastern Europe. It is evident that the plant has been cultivated in the East from very ancient times; for it came into western Europe highly developed, early in the sixteenth century. It was then a plant of both single and double varieties with blue, purple, and white flowers. The other colors have arisen either as sports or from seedlings. The story goes that the first lilac variety appeared as a sport from a red-flowered bulb in the possession of a Dutch grower. He was so solicitous lest some misfortune should overtake his precious plant that he put the pot containing it into a bird-cage and hung it from the ceiling of his room. He was successful in its propagation and that bulb is regarded as the parent of the present lilac forms. To get some idea of the extent of the early culture of Hyacinths in Holland, one may note that the Gardener's Dictionary, by Philip Miller, published in I725, 


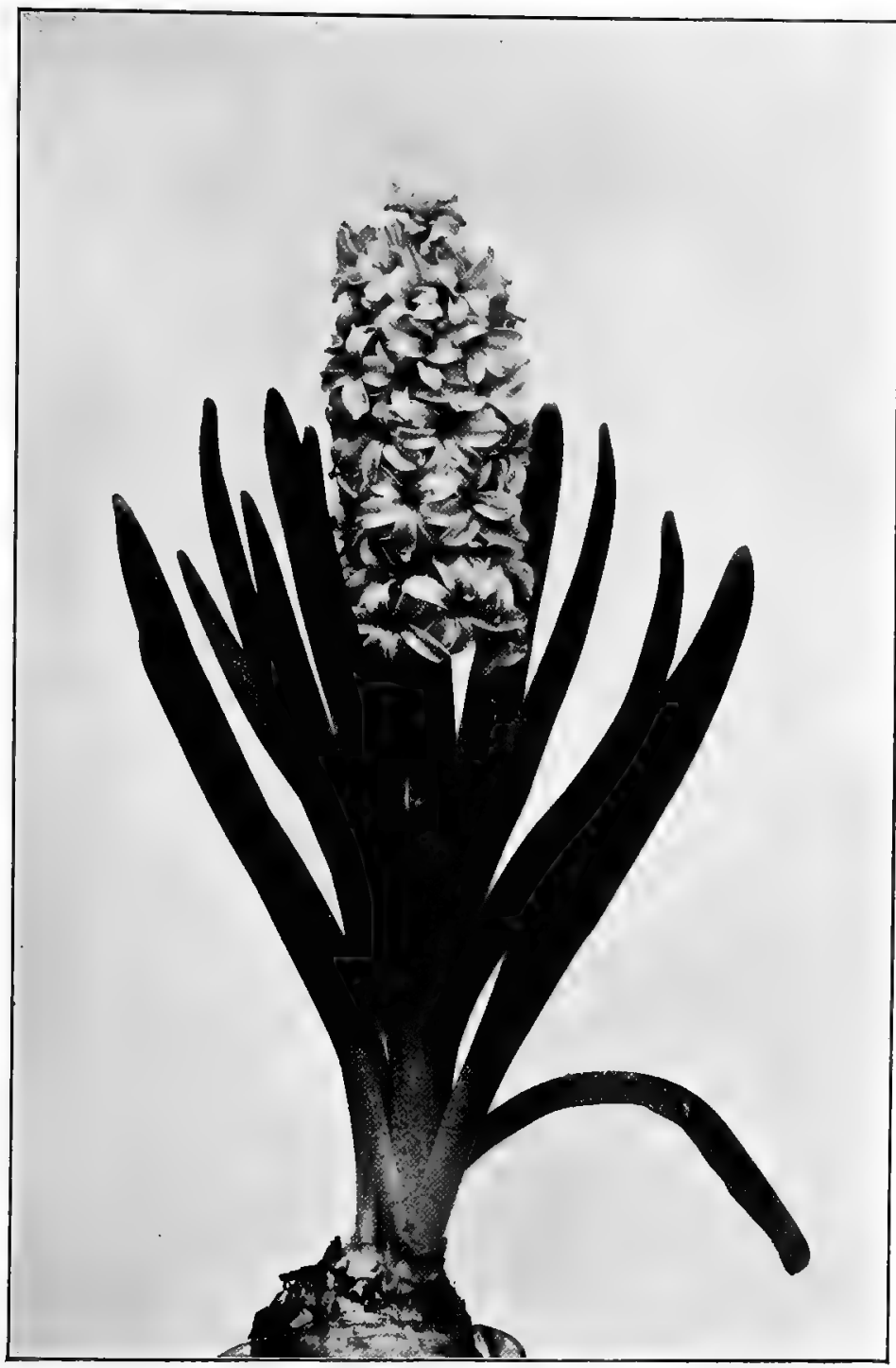

Hyacinth. Hyacinthus orientàlis 


\section{LILY FAMILY}

states' that about two thousand varieties were then under cultivation by the growers of Haarlem.

It seems as if the last word had been said respecting Hyacinths. To such perfection in form and color have the types attained that seldom is a seedling produced that equals the parent plant. The group is a remarkable example of a species having red, blue,

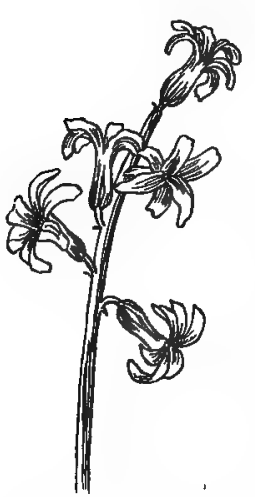

Roman Hyacinth, $H_{y d-}$ cinilhus orientdlis var. albuins white, and yellow varieties, though the yellow is more of a buff than a true gold:

There are other species of Hyacinths in cultivation besides orientalis, but they are not common nor especially desirable. There is, however, a variety, known as the Roman Hyacinth of the Dutch growers, Hyacinthus orientàlis var. albulus which is altogether charming and delightful. Instead of one strong dense raceme from each bulb, the Roman Hyacinth produces three or four smaller but more graceful ones. The bells are fewer, hang loosely upon the stem, and are the embodiment of grace and delicacy. The bulbs can be forced as easily as those of the type and in the open they bloom early.

Hyacinthus cándicans is a luxuriant, free-growing, summerflowering species, that sends up tall scapes four to five feet high, each bearing twenty to thirty large, white, nodding bells. The individual plant is fine; but Hyacinths, some way, seem to harmonize best with the spring-time's foliage and flowers, and these pretty waxen bells are not fortunately placed when surrounded by the blazing beauties of midsummer and early autumn.

Holland grows.Hyacinths for all the world. The soil and the climate of that country seem peculiarly suitable for bulb culture, which has been one of its leading industries for two hundred years. 


\section{FUNKIA. DAY IILY. PLANTAIN LILY}

Finkia subcordàta. Finkia grandiflòra.

Funkil, in honor of two men; one named Funke, r755-180r, and the other Funk, 1771-1839, both German naturalists.

The common Day Lily of old yards; a most excellent plant. Perennial; native of Japan. Summer.

Leaves.-With marked parallel veins, bright-green, large, broadly cordate, making clumps twelve to twenty inches high.

Flowers.-White, open, bell-shaped, borne in a short raceme, on a tall flowering stem; bracts prominent; fragrant.

Perianth.-White, long, bell-shaped, six-lobed; lobes more or less irregular, and not widely spreading.

Stamens.-Six; filaments thread-like, bent at the tip; anthers versatile.

Ovary.-Oblong; style slender, bent at tip.

Capsule--Oblong, angled, many-seeded. Seeds black, winged.

Funkia subcordata is the old favorite, and still holds its place as an attractive, ornamental, foliage plant; the great circular clumps of broad, shining, prominently veined leaves adorning many a yard. There are several species in cultivation; all are Japanese, all are very much alike, and all easily recognizable by the habit of forming clumps of radical leaves. While the inforescence is attractive and interesting, the real value of the plant lies in its foliage. The flowers are either white, blue, ilac, in the different species, of varying size, but all of the same type.

Funkia sicboldiana has leaves of bluish-green and blue or lilac Gowers. Funkia fortinei is very much the same, having smaller leaves and paler flowers.

Funkia ovdta is the common blue-flowered species, and Funkia lancifoliu, with narrower leaves and pale-lilac flowers, has two varieties whose leaves vary to white: albo-marginata has leaves edged with white, and undulata is a form with undulate, whitemargined leaves or with leaves conspicuously variegated and margined with pure white. This is a very pretty plant and much used for borders. 


\section{LILY FAMILY}

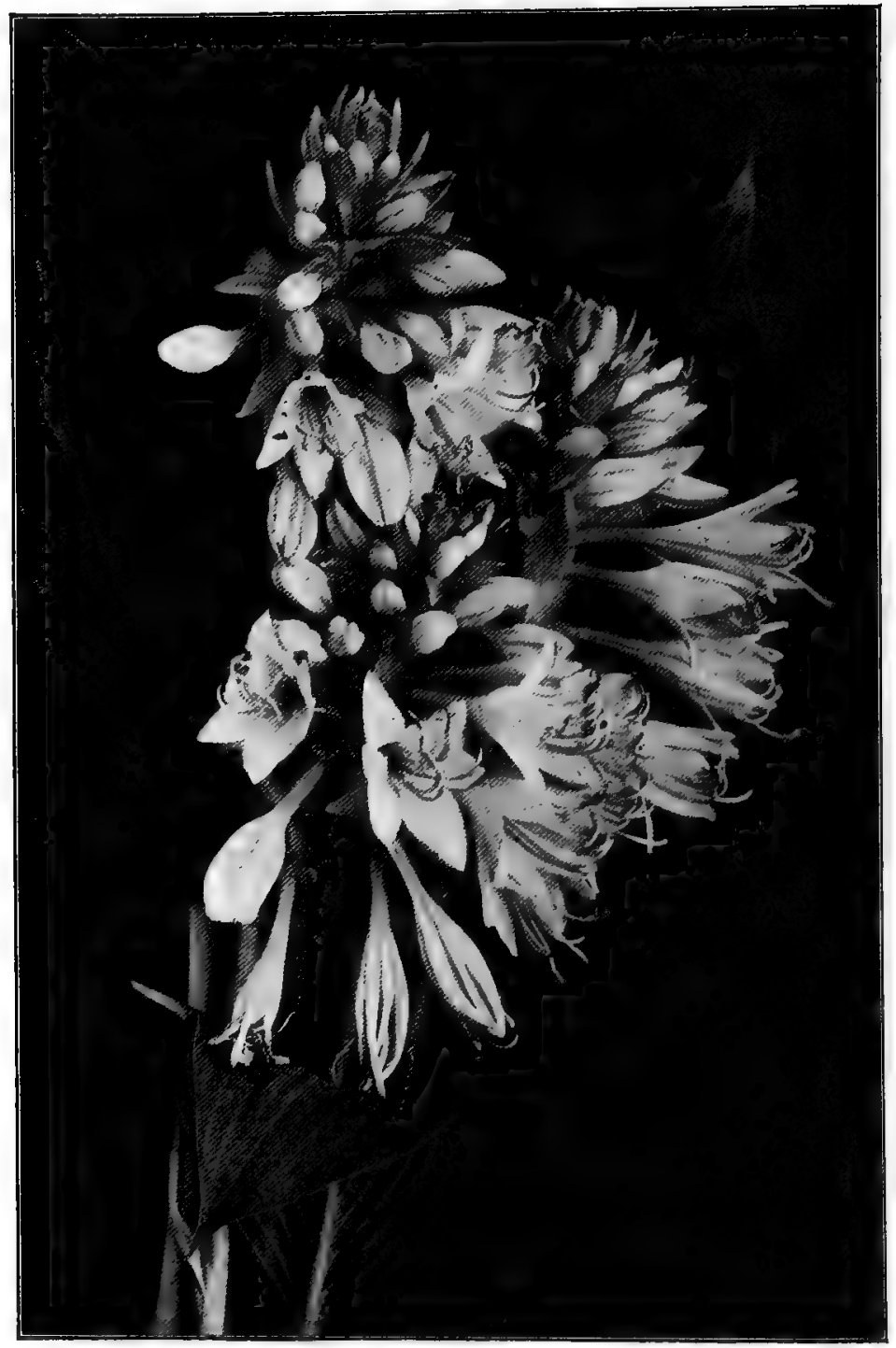

Day Lily. Fúnkia 


\section{DAY LILY}

\section{Hemerocallis fuilva.}

Hemerocallis, Greek, from hemera, day, and kallos, beauty-beautiful for a day.

A tall, robust, lily-like plant, which has escaped from cultivation and borders roadsides and streams, flourishes in meadows and on abandoned house sites. Native of Europe and Asia. Blooms from June to September.

Root.-Perennial, fleshy, fibrous.

Leaves.-Linear, keeled, eighteen to twenty-four inches long.

Flowers.-In loose corymbs of six to twelve at the summit of leafless scapes three to five feet high; tawny-orange, opening for a day.

Perianth-Funnel-shaped, lily-like, the short tube enclosing the ovary; the spreading limb six-parted; the sepaloid lobes narrower than the petaloid lobes.

Stamens.-Six inserted at the summit of the perianth tube; filaments long and slender; stigma club-shaped.

Capsule.-Three-celled, many-seeded.

This plant is not misnamed; its flowers are beautiful and live but for a day, yet as the succession is continuous the flowering period is extended. The books call the blossom tawny-orange, and as you look down into the cup you see a heart of dull yellow which deepens at the point where the segments curve and lightens again as the color runs to the tips. The result is dull orange on a base of yellow. The sepaloid segments are readily distinguished by shape as well as by position. The long orange filament bears anthers heavily loaded with pollen and the style is a slender yellow wand four inches long, extending far beyond the pollen zone. Evidently cross-fertilization is desired. What is to be done, however, must be done quickly, for opening under the stimulus of the rising sun the blossom dies with his departing rays; and the flower erst so lovely becomes a mass of decay on the parent stem. These tawny lovers of the sun live their own lives, freed both from the protection and the domination of man. They gather at the road- 


\section{LILY FAMILY}

side; you find them in the tangle with the milkweeds and the teasel; they border the meadows; they mass themselves in old dooryards; they are beautiful, wild, and free. Gardeners recommend them for planting among shrubbery, doubtless because of

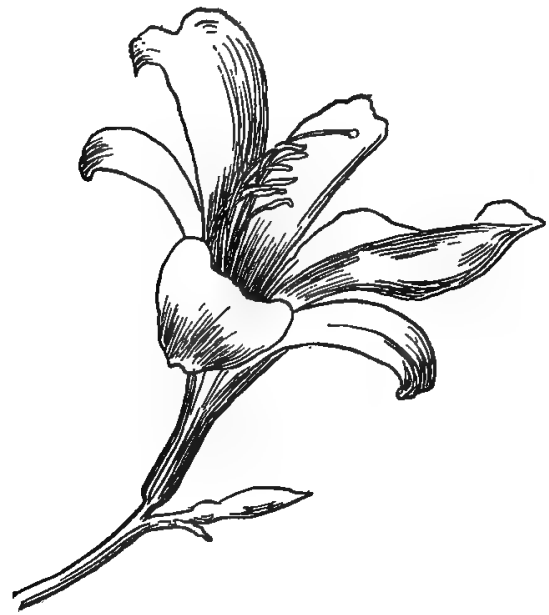

Lemon Lily. Hemerocallis flèva their ability to take care of themselves.

The Lem on Lily, Hemerocallis flava, is structurally the same as Hemerocallis fulva, but more delicate, with narrower leaves and clear, pale-yellow, fragrant flowers. One finds it a most satisfactory garden plant, on account of its beauty, its early bloom, and its ability to live without coddling. The race is hardy, and though this one has not as yet become a wanderer like its tawny blood-brother, it may any day leap the garden wall and attain freedom. The trade offers variants of both forms in singles and in doubles, and the two are the oldest cultivated representatives of the genus.

\section{TORCH LILY. KNIPHOFIA}

Kniphdfia aloides.

Kniphofia, named in honor of Prof. Kniphof, of Erfurt; I 704-1763.

A plant known in the trade as Tritoma, as well as Kniphofia. Native to southern Africa. September.

Root.-A rhizome with numerous thickish root-fibres.

Leaves.-Sword-shaped, two to three feet long, keeled, glaucous, scabrous on the margin, growing in a tuft. 
Flowers.- Red and yellow, borne in a many-flowered, terminal spike.

Perianth.-Cylindrical, an inch or more long, six-toothed.

Stamens.-Six, protruding.

Ovary.-Three-celled; style thread-like; stigma minute.

Capsule.-Three-celled, several-seeded.

Kniphofia is one of the most unique plants in general cultivation, and rejoices in several common names-Red-Hot-Poker, Flame Flower, Poker Plant, Torch Lily-all emphasizing the spectacular effect of its cylindrical spike of blazing blossoms, a veritable flame mixture of red and orange and yellow.

The genus is African, and although there are several species in cultivation, aloides with its hybrids and variants is the favorite.

The long, narrow, keeled leaves form a tuft from whose centre rise several scapes two to three feet high, each crowned by a spike four to eight inches long, of perhaps a hundred tubular, drooping flowers, glowing in fiery red and yellow.

The trade advertises many different varieties, but at heart they are all aloides.

\section{YUCCA. ADAM'S NEEDLE}

\section{Yúcca filamentòsa.}

$Y$ ucca, an Indian name without application to this flower; given by mistake.

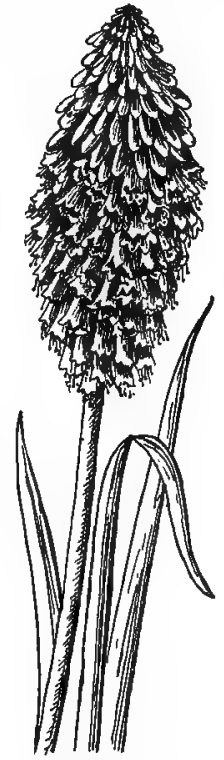

Torch Lily. Kniphófia aloides

The hardy species of Yucca which fruits in cultivation at the North. Native to the Southern States. June.

Leaves.-Borne upon a short trunk; evergreen, long, narrow, spinypointed; rather weak, somewhat concave, with slender, curly, marginal fibres.

Flower-Stem.-Three to four feet high, bearing a loose, long-stalked panicle of cream-white nodding bells.

Perianth.-Of six oval, acute, distinct segments; the three inner broader than the outer. 


\section{LILY FAMILY}

Stamens.-Six, shorter than the perianth.

Ovary.-Oblong; stigmas' three, sessile.

Capsule.-Oblong, three-lobed, many-seeded.

$Y u c c a$ is a genus comprising a few liliaceous plants native to the semi-arid portions of the United States and Mexico. A few species are hardy at the North; Yucca glauca, whose home is the Rocky Mountain region and the Western Plains, flowering early in June; and Yucca filamentosa, native to our Southern States, are the two most satisfactory in our Northern gardens.

The effect of a blooming bed of Yuccas, when properly placed, is particularly good; but the stiff tropical habit of the plant does not harmonize with softer vegetation.

If one would know the Yucca in its best estate, one must see its blooming panicles by moonlight, for it is the moon's own flower. The mass of nodding bells, comparatively dull and opaque by day, by moonlight are transfigured and fairly radiate a soft, silvery lustre impossible to describe.

One of the most extraordinary cases of the mutual dependence of an insect and a flower, says Campbell's "Text Book of Botany," is found in the species of Yucca known by the common name of Yucca filamentosa, native to the southern Atlantic States, and common in gardens. This species depends for its pollination upon a small nocturnal moth of the genus Pronuba. This moth deposits its eggs within the ovary of the Yucca, and the larvæ feed upon the young seeds. In order that the flower may be fertilized so that the ovules will develop into the seeds necessary to nourish the larvæ, the moth deliberately collects a quantity of pollen, which it pushes into the cavity at the apex of the stigma, thus insuring the fertilization of the ovules. In this species of Yucca it is absolutely necessary, in order that seeds may be formed, for the moth to do this, and if the insect is absent the flowers will all remain sterile. The larvæ of the Pronuba do not destroy all the seeds; a considerable number remain uninjured and mature in the ripe capsule. 


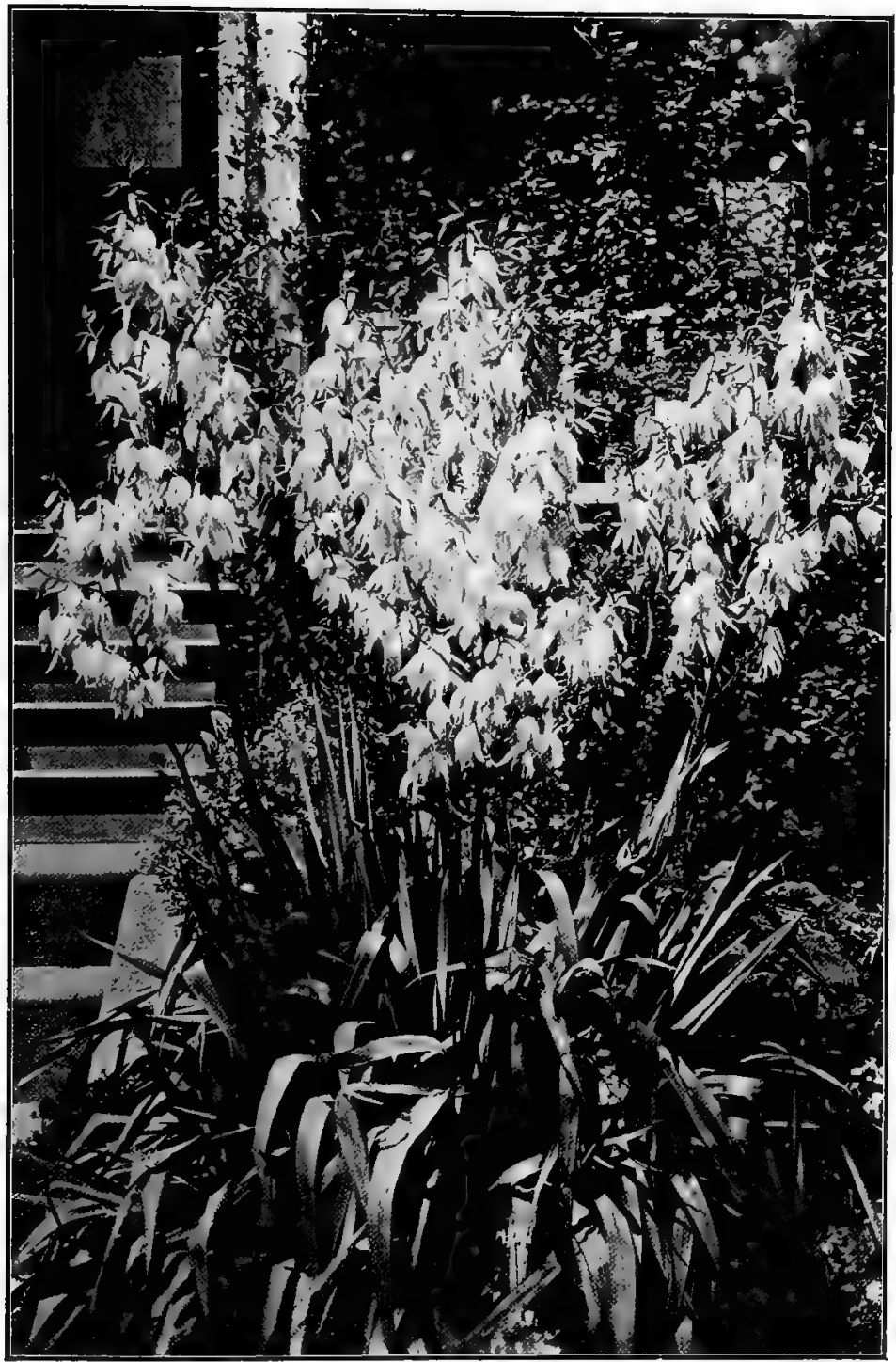

Yucca. Y úcca filamentòsa 


\section{WILD ONION. ALLIUM \\ Allium cérnuum.}

Allium, the ancient Latin name of the garlic.

Bulb.-Coated, onion-scented.

Leaves.-Linear, flattened, sharply keeled.

Scape.-Angular, nodding at the apex, bearing a loose or drooping, few to many-flowered umbel of pale pink or purple flowers, from a scarious spathe.

Perianth.-Of six segments, united only at the base.

Stamens.-Six; filaments slender, exserted.

Ovary.-Crested; style slender.

Capsule:-Crested; three-lobed.

The Alliums are a genus of strong-scented and pungent herbs; the leaves and stems arise from a coated bulb; and the flowers

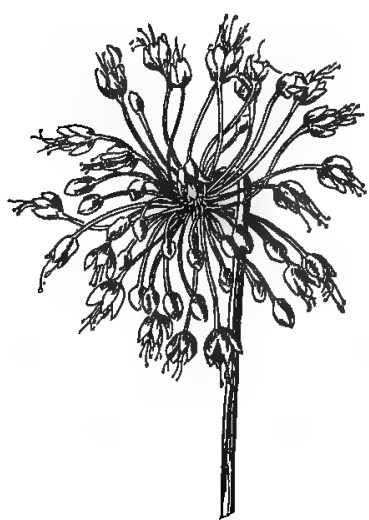

Wild Onion. . Allium cérnurm appear in a simple umbel, wrapped in the bud by a scarious spathe.

Allium cernuum is a native species often found in cultivation, and the flowering umbel at its best is very pretty, but there are so many better plants for the garden that it can never achieve much success. The Allium that is usually forced for the winter trade is Allium neapolitdnum, which produces a large umbel of white flowers.

The value of the genus is shown in the kitchen garden where, in some respects, it has no rival. It is difficult to imagine how the fine art of cooking would have developed without chives, leeks, and onions.

The Common Onion, Allium cepa, has been in cultivation so long that its native land is unknown, some supposing it to be India, others Egypt; in both it has been cultivated from remote antiquity. 


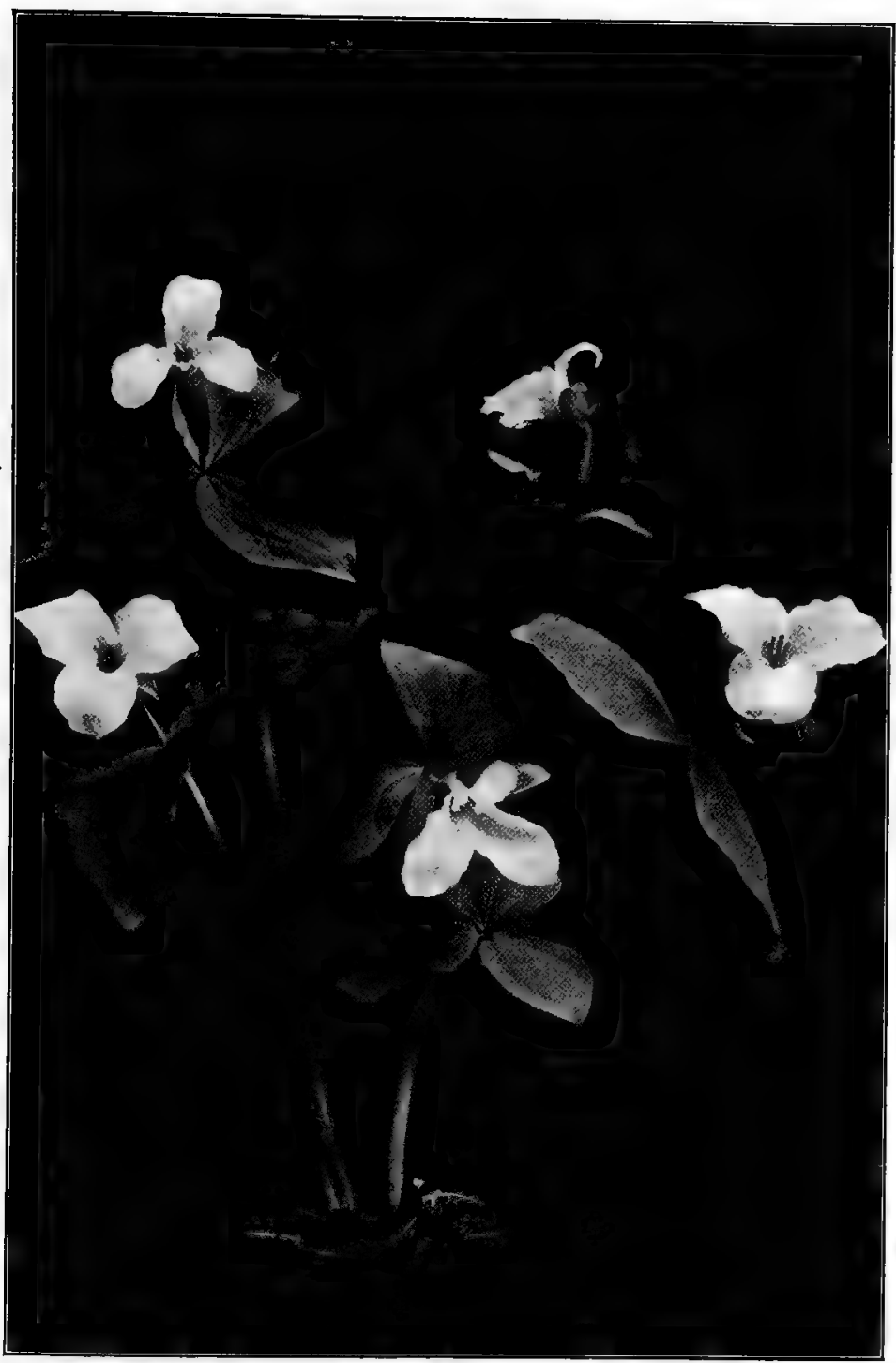

White Trillium. Trillium grandiflòrum 


\section{LILY FAMILY}

The onion is nutritious, rich in uncrystallizable sugar and a volatile, sulphurous oil which is present in all members of the genus. The bulb is biennial, the leaves hollow and tapering, the flowerstem also hollow and swelling at the middle. The flowers are borne in a large, globose, terminal umbel; the lobes of the perianth obtuse and hooded, not half so long as the stamens, which protrude and make the globe fuzzy.

Chives or Cives, Allium schcenoprasum, is a perennial plant whose leaves are used in seasoning soups, salads, and stews. It is also used as a perennial edging plant, well fitted for this use by its habit of growing in close little clumps; also, because it blooms freely in low, violet-colored heads. It rarely seeds in this country, but thrives in any good garden soil and may be cut liberally.

\section{WHITE TRILLIUM. WAKE ROBIN}

\section{Trillium grandiflòrum.}

Named from tres, three; all the parts being in threes.

The Great White Trillium of northern woods; a favorite wild flower now coming extensively into cultivation. Rich woods from Vermont and Quebec to North Carolina, Missouri, and Minnesota. Perennial, April, May.

Rootstock.-Short, tuber-like.

Stem.-Stout, simple, bearing at the summit a whorl of three ample leaves and one large flower.

Leaves.-Three, rhombic-ovate, more or less ribbed, net-veined, entire; acute or acuminate.

Flowers.-White, terminal, large, solitary.

Sepals.-Three, lanceolate, spreading, herbaceous, persistent.

Petals.-Three, white, sometimes changing with age to pale-rose.

Siamens.-Six; anthers linear on short filaments.

Ovary.-Three-celled; stigmas three, separate down to the ovary.

Fruit.-A berry, several-seeded.

Great White Trillium, Trillium grandiflorum, is one of the very finest of our native flowers. It loves the open woods and is planted 
abundantly where wild gardening is practised on any liberal scale. An open grove is often devoid of interest because there is nothing under the trees but grass; but such woodland can be transformed into a fairy land simply by keeping out the cattle and restoring the herbaceous growth. Nothing is better to accomplish this than to bring back the old flowers that have been driven out. Of these, in northern Ohio, Trillium grandiflorum is one of the best; and along with it, flourishing under similar conditions, should be Smilicina, Solomon's Seal, Bellwort, Mitella, Tiarella, Wild Phlox, and Adder's Tongue, together with all the little groundlings that will venture back as soon as conditions are safe.

\section{GARDEN ASPARAGUS}

Aspäragus officinàlis.

Asparagus, the ancient Greek name; the meaning obscure.

A perennial herb, cultivated for the edible young shoots which appear in early spring. Europe. May and June.

Stem.--Rising from thick and matted rootstocks, two to three feet high, succulent and simple with fleshy scales when young, becoming branched when old.

Leaves. - The narrow, thread-like, so-called leaves are really branchlets, acting as leaves, clustered in the axils of little scales which are the true leaves. These are well shown on the shoot.

Flowers.-Small, greenish-yellow, in the axils of the leafy branchlets.

Perianth.-Six-parted, spreading above.

Stamens.-Six; filaments thread-like; style short; stigma three-lobed. Berry spherical, red, three-celled; cells two-seeded.

The Garden Asparagus has been a table vegetable for more than two thousand years. Native to southern Europe and western Asia, it was well known both to the Greeks and to the Romans.

Structurally the plant is especially interesting, as it gives an example of small branchlets which appear and behave like leaves. The real leaves are scales which are much in evidence on the edible shoots and may be seen at the base of the leaf-like branchlets looking like stipules or bracts. 


\section{LILY FAMILY}

In May or June the inconspicuous flowers appear; later a wealth of green berries sits in the axils of the leaf-like branchlets; finally in late summer these berries become brilliant scarlet and the asparagus bed is fair to see.

Three species of Ornamental Asparagus are in cultivation, two

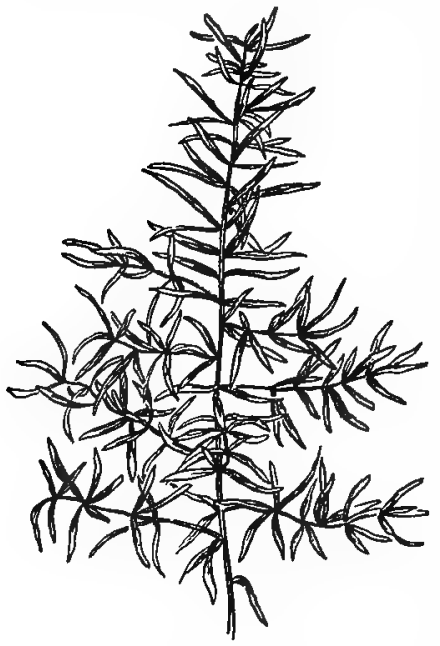

Ornamental Asparagus. Asparagus Spréngeri named Asparagus and one called Smilax.

Asparagus Spréngeri; native to Natal, South Africa, has long, slender, drooping branches; the so-called leaves narrow, flat, about an inch long, glossy green; the flowers white and small, sixparted in short racemes, slightly fragrant; the berry small and red. The plant is of easy culture and very popular for porch boxes and hanging baskets. Professor Bailey records that it was introduced to horticulture by Dammann and Co., Italy, and named for their collector, Herr Sprenger.

Asparagus plumdsus is the species with fine thread-like foliage; branches flattish and horizontal. This too is most popular for decoration, the sprays holding their shape and color for weeks. The varieties nàna and tenuissimus are preferred to the type.

The florist's Smilax, grown for decoration and sold by the string or by the yard, is also an asparagus, little as it approaches our idea of one-Asparagus medeoldides. It, too, is of South African origin. Its twining stem is slender, perfectly smooth, and its socalled leaves are an inch or more long, thick, glossy green on both sides, strong-nerved, and standing edge-wise to the stem. The flowers are small, white, solitary, fragrant; and the succeeding berries dark-green. 


\section{LILY OF THE VALLEY}

Convallària majàlis.

Convallaria, derived from convallis, a valley.

The well-known Lily of the Valley. Native to Europe, Asia, and America. A shade-loving plant. May.

Leaves.-Radical, rising from an upright rootstock or pip.

Flowers.-White, nodding, and in a short raceme, fragrant.

Perianth.-White, bell-like, six-toothed.

Stamens.-Six; ovary globose; style and stigma one.

Lilies of the Valley are forced into bloom and sold at so many seasons of the year that we are likely to lose sight of the fact that

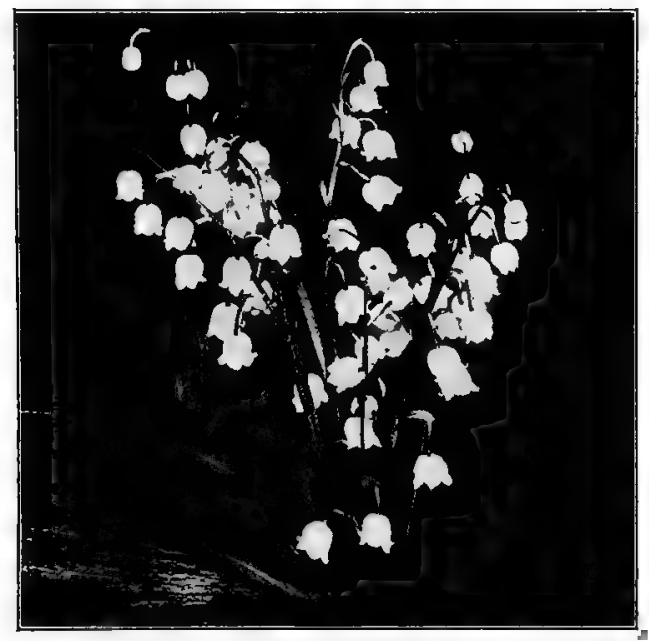

Lily of the Valley. Convallària majàlis

they are naturally flowers of May. Nothing is prettier than these delicate, fragrant bells nestling among their broad leaves in the garden-bed. There is always a demand for flowers growing in partial shade, and few plants are more satisfactory for this than Lilies of the Valley. The plants run wild in many old yards, in cemeteries, and along shady roadsides. 


\section{EREMURUS}

Erémurus robúshus.

Eremurus is a Greek name referring to the tall and striking appear ance of the plant in its desert home.

Roots.-Clusters of fleshy fibres.

Leaves.-Radical, in dense rosettes, linear, two feet long, glabrous, glaucous, roughish on the margin with minute recurved teeth.

Flower-stem.-Six to nine feet high, bearing a spike four feet long, of rosy six-pointed stars.

Flowers.--Spreading, bell-shaped; the six segments slightly united at the base.

Stamens.-Six; ovary three-celled; seeds one to four in each cell.

Eremurus is one of the most striking plants that a northern garden can produce. Native to the deserts of Turkestan, it has acquired the habit of putting forth tremendous energy for a short period and then resting for the remainder of the year. When spring growth begins there is an upheaval of the ground about the stem, the roots are so strong and so many. Large plants will produce annually a flower-stalk nine feet high, and four feet of this will be covered thick with starry blossoms. As this is a spike and it takes considerable time for the flowering impulse to reach the top, the blooming period lasts a month. Then the seeds mature, the stalk dies, the leaves disappear, and all is over until the next year. The plant needs plenty of water while flowering, but none afterward. As it developed in an alkali desert it is very grateful for wood ashes about its roots. Gardeners recommend a mulch of dry leaves for the winter. The plant is hardy, interesting, and effective.

Among other Liliacece in cultivation are the following varieties:

St. Bruno's Lily, Paradisea liliastrum, a species from southern Europe, which sends up from a tuft of flat, radical leaves a simple scape bearing, perhaps, twenty fragrant white bells tipped with green. 
EREMURUS

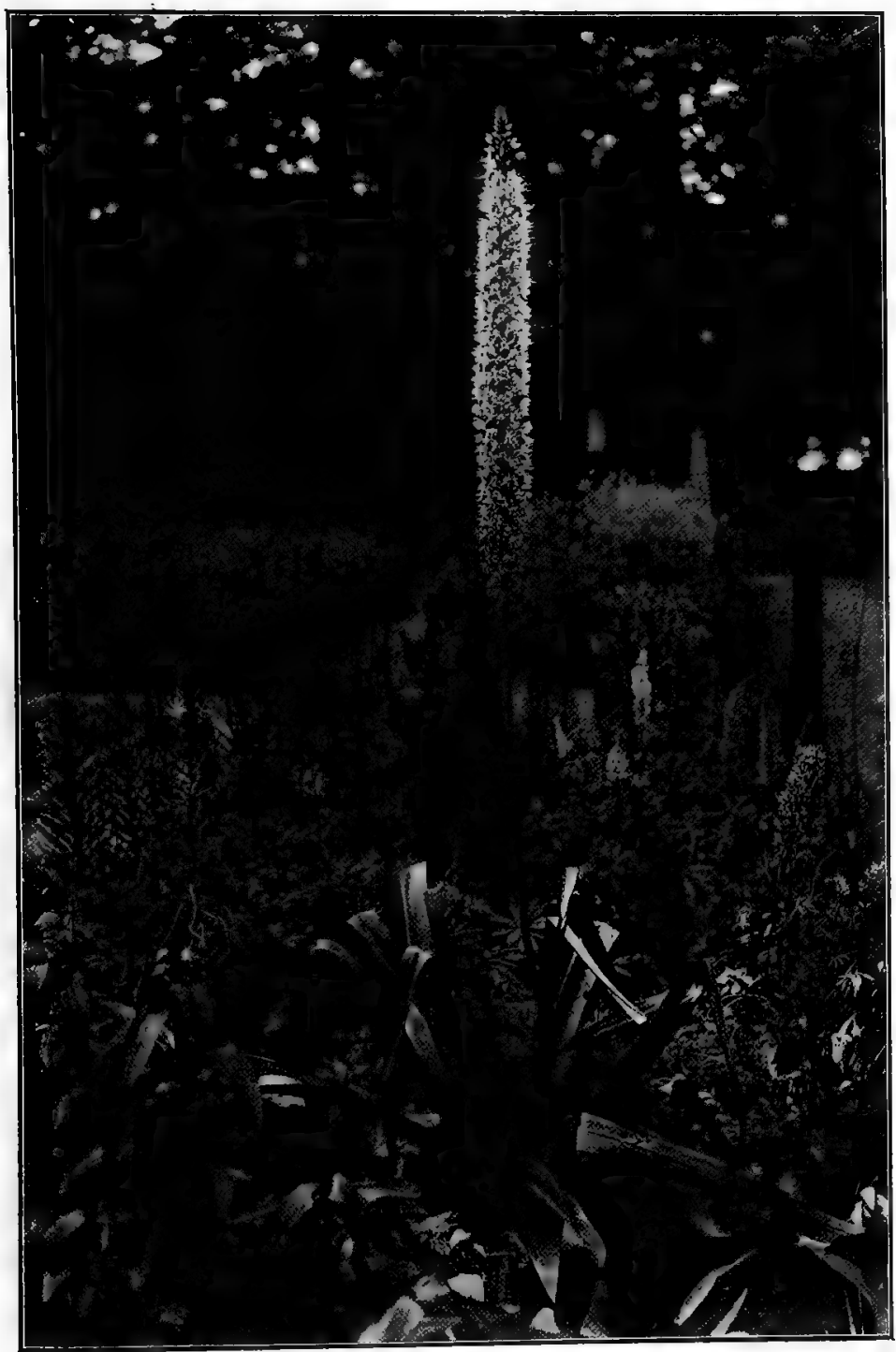

Erémurus. Eremurus robuistus 
Woolly Bulb, Bulbocodium vêrnum, that much resembles a. crocus, but is not so good a plant horticulturally. The flowers are rose-purple flecked with white, and bloom before the crocus. Is native to the Mediterranean region.

Meadow Saffron, Colchicum autumnàle, produces clusters of crocus-like flowers in August and September, after the coarse foliage has died, as it does in June. To most of us a crocus belongs to the spring; and we do not especially care for it in midsummer.

Japanese Toad Lily, Tricyrtis hirta, is an interesting plant, but recently introduced.' It grows to the height of eighteen inches, and in late September and in October produces a profusion of lily-like flowers, cream-white with purplish-brown spots. It needs a half-shaded location.

There are a number of native plants-Bellwort, Solomon's Seal, Smilicina, Dog's-tooth Violet, Camass, and Star Grass-all of which have garden value upon occasion, and all are offered by the trade. 


\section{DIOSCOREÀCEAE-YAM FAMILY}

\section{CINNAMON VINE}

Dioscorèa diva icàta.

Named for Dioscorides, a Greek writer on plants.

A perennial twining plant, with large farinaceous roots, bearing shining opposite leaves; cultivated as a cover vine. China, Japan, Philippines. August.

Stem.-Twining, making ten to thirty feet in a summer.

Leaves.-Opposite, smooth, shining, cordate or halbert-shaped, often bearing little bulblets in the axils.

Flowers, - Dicecious, white, small, in small racemose panicles in the axils of the leaves.

Perianth.-Six-parted.

Stamens.-Six; ovary three-celled; styles three.

Fruit.-A three-winged capsule; seeds winged.

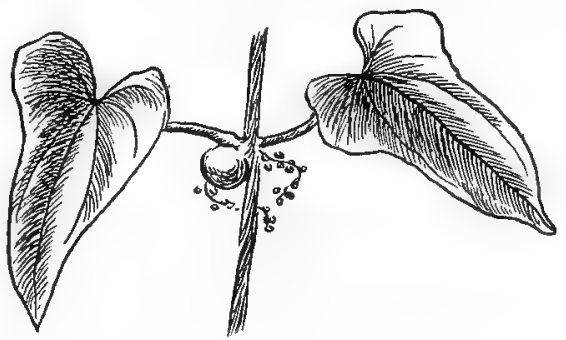

Cinnamon Vine. Dioscorèa divarìcàta

The Cinnamon Vine obtains its name from the fragrance of its flowers, which appear on well-established plants in August. The vine is really a variety of the yam, or Chinese potato, and although Asiatic, is fairly hardy in our climate. The large roots or yams are not produced until the second year of plants grown from bulblets.

The stems are quick-growing, and although the leaves are very pretty the internodes are so long that the foliage effect is scanty, which detracts from its value as a cover vine. In the axils of the leaves are little bulblets the size of peas, which will grow if planted. 


\section{AMARYLLIDÀCEAE-AMARYLLIS FAMILY}

Smooth perennial herbs, with bulbs or rootstocks; bearing flat, radical leaves that have no distinction between blade and petiole. The flowers are borne singly, or in clusters at the summit of a scape; at first, included in a membranous spathe. Perfect, usually regular; the calyx and corolla so united that no distinction is made between them; and the floral envelope is called a perianth. This is tubular, the border six-lobed or six-parted; it sits upon and is adnate to the ovary. There are six stamens. The ovary is three-celled; style slender. Fruit a three-celled capsule, many-seeded.

The Amaryllids are closely allied to the lilies. The chief difference between them lies in the position of the ovary. In the lilies the three-celled ovary lies within the flower cup; in all the Amaryllids the flower cup sits upon the ovary; that is, in botanical language, the ovary is inferior. Structurally, the difference is considerable; apparently, it is very little.

The family includes many species distinguished by the beauty of their flowers. They are herbaceous plants, or when, as in the genus Agdve, Century Plant, they form woody stems they have still the character of gigantic herbs rather than of shrubs. There are about four hundred known species in the Family, natives of tropical, sub-tropical and more sparingly of temperate regions-particularly abundant at the Cape of Good Hope. A few species only are European.

In general cultivation are the Daffodil, Poet's Narcissus, Polyanthus Narcissus, Jonquil, Snowdrop, Snowflake, and Tuberose. In addition to the hardy representatives of the family there are coming into the gardens species of Alstrameria and Crinum that can be cultivated out of doors with but slight protection. 


\section{NARCISSUS}

\section{Narcíssus.}

Leaves.-Produced from a coated bulb.

Scape.-Rising from the bulb, bearing one or more flowers, which at first are included in a membranous spathe.

Perianth.-Tube more or less cylindrical, with six equal, widely spreading divisions. A cup-shaped corona or crown is borne at the throat of the perianth. crown.

Stamens. - Six, inserted in the tube and not protruding beyond the

Ovary.-Three-angled; the thread-like style ends in a blunt stigma.

The Garden Narcissi are classified into three divisions according to the character of the corona, thus:

Group I.-Long-crowned. In this group the corona is as long or longer than the segments of the perianth. The Trumpet Daffodil, Narcissus pseudo-narcissus, with its varieties and hybrids, is the type of this group.

Group II.-Medium-crowned. In this the corona is one-half to three-fourths the length of the perianth segments. The Superb Narcissus, Narcissus incomparabilis, is the type.

Group III.-Short-crowned. In this the corona is very short. The Poet's Narcissus, Narcissus poeticus, and the Paper White Narcissus, are types of the group.

All the Narcissi have bulbs which are really dwarfed stems, surrounded by succulent leaves. These are underground treasurehouses, in which the material made by the leaves in the spring has been stored up and kept intact through summer heat and winter cold. From this bulb arise the leaves and flower stems of the new plant.

To the family characteristics of the Amaryllids the genus Narcissus adds one that is peculiarly and distinctively its own. The union of calyx and corolla is so complete that botanists make no effort to distinguish them, and call the floral envelope a perianth. This takes the form of a tube with a spreading six-parted border. At the very throat of this tube, at the point where the border divides into spreading segments, there develops a growth known 
botanically as a corona or crown. Sometimes, as in the Trumpet: Daffodil, it is long; -again, as in the Poet's Narcissus, it is short; but it is always more or less frilled and crumpled at the margin. Double flowers appear in many species; they, however, lack the grace of the single forms.

Baker, in his "Handbook of the Amaryllidacea," reduces the species of Narcissus to sixteen; other writers recognize more. But it seems to be good opinion that the Garden Narcissi, of which, all in all, there may be a thousand varieties, are, in the main, the hybrids and the variations of six species.

\section{TRUMPET DAFFODIL. DAFFODIL}

Narcíssus pseìdo-narcíssus.

The best-known daffodil of our gardens, the type of the long-crowned group. Exceedingly valuable. Native to south-western Europe and the Mediterranean region; naturalized in England; extensively grown in Holland for exportation; not long-lived in America.

$B u l b .-$ One and a half to two inches in diameter.

Leaves.-Glaucous, nearly flat, five or six to a scape.

Scape-Two-edged, about a foot-high, one-flowered.

Perianth.-Yellow; segments oblong, acute at apex.

Crown.-As long as the segments, an inch or more across; margin crisped and toothed.

The Trumpet Daffodil is such a favorite among us that one wishes it would naturalize here; but so far the common experience has seemed to prove that it will not, except possibly in a single form. Usually the plant struggles along in the open for a few years, and then, as a rule, succumbs to the unfavorable conditions of our climate. The secret of having fine daffodils is to replant continually with fresh bulbs, and as these are cheap it is no great hardship.

Under cultivation the Trumpet Daffodil takes on many variant forms; but in the type the perianth is yellow, the trumpet crown as long as the spreading segments, and the stamens are attached low in the tube. 


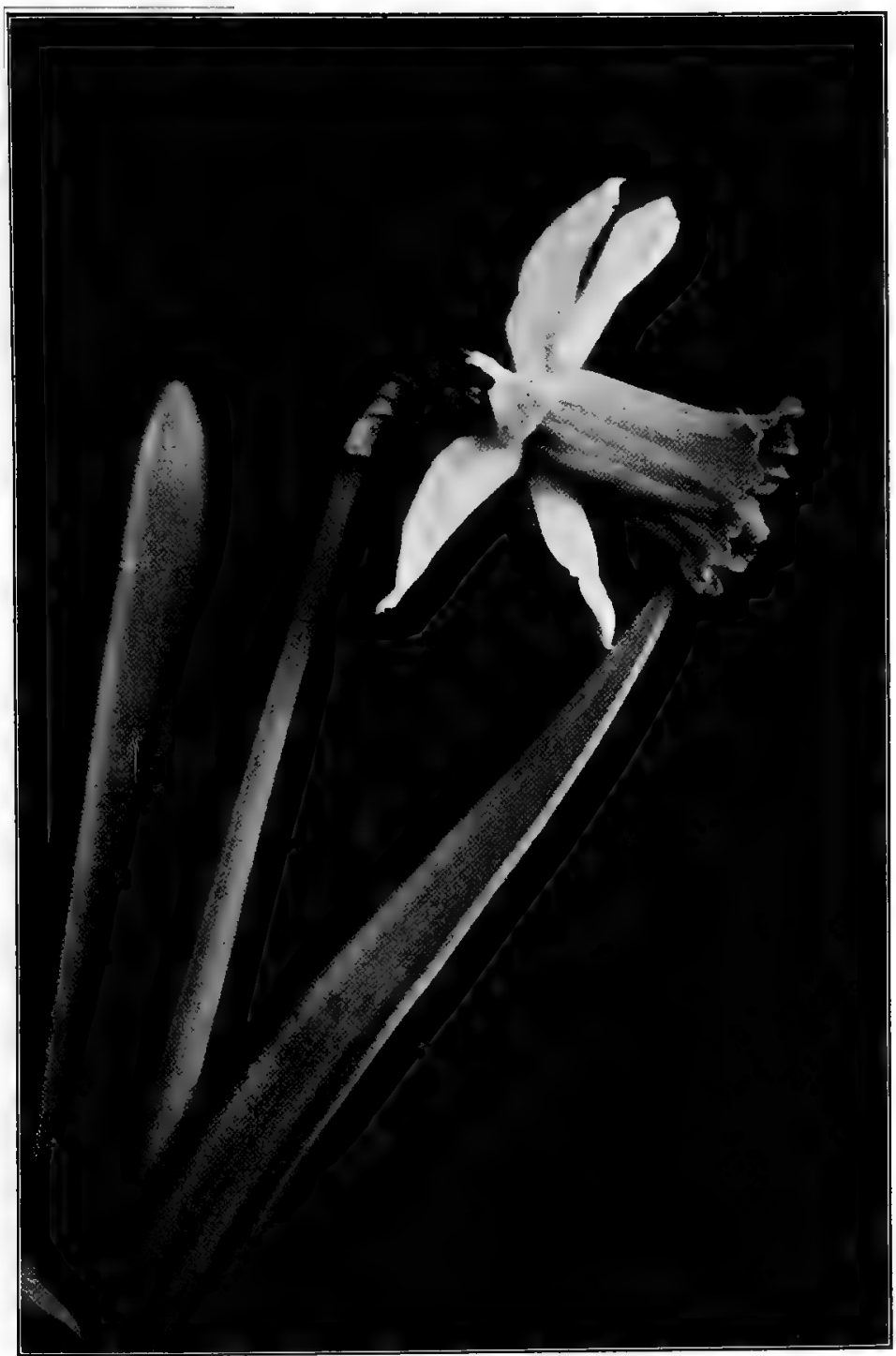

Trumpet Daffodil. Narcissus pseùdo-Narcíssus 


\section{AMARYLLIS FAMILY}

The flower has an exquisite grace, a kind of spiritual beauty, and about its golden and radiant head has gathered a halo fròm. the ages. It has touched the imagination and moved the hearts of the English people from most ancient times. The Anglo-Saxon name is music in itself, af-fa-dyl-le-with every vowel sounded. English children chant in English meadows to-day, as they did three hundred years ago:

Daffy-down-dilly, just come to town

With a yellow petticoat and a green gown.

Shakespeare knew the daffodils, .

That come before the swallow dares, and take

The winds of March with beauty.

And Milton wrote:

And daffodillies fill their cups with tears,

To strew the laureate hearse where Lycid lies.

Wordsworth gives the modern touch; when, wandering "lonely as a cloud," the daffodils

Stretched in never-ending line

Along the margin of a bay:

Ten thousand saw I, at a glance,

Tossing their heads in sprightly dance.

The waves beside them danced, but they

Outdid the sparkling waves in glee:

A poet could not but be gay,

In such a jocund company;

I gazed-and gazed—but little thought

What wealth the show to me had brought;

For oft, when on my couch I lie,

In vacant or in pensive mood,

They flash upon that inward eye

Which is the bliss of solitude,

And then my heart with pleasure fills,

And dances with the daffodils. 
SUPERB DAFFODIL

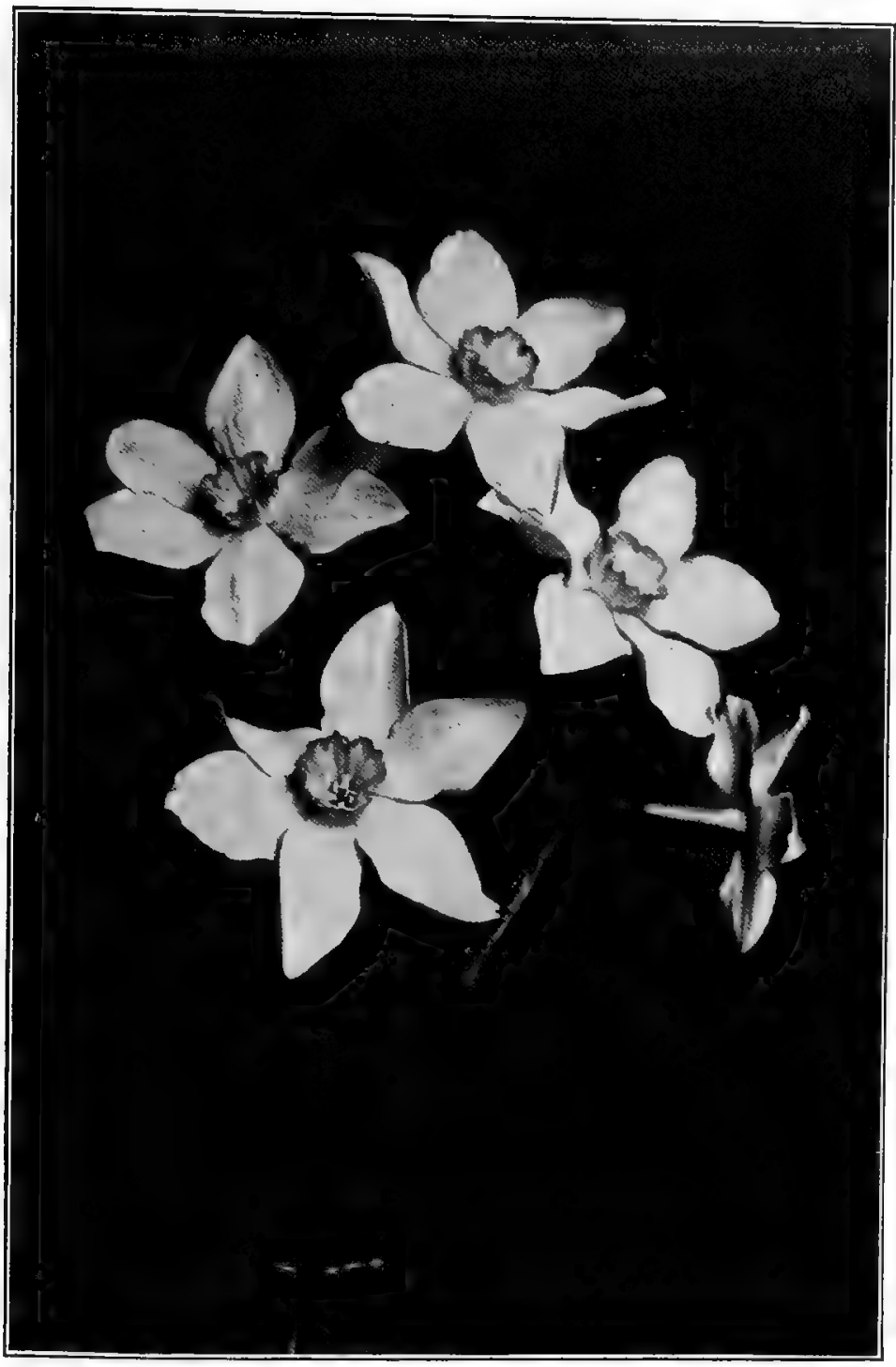

Superb Daffodil. Narcissus incomparabilis 
The variant forms fluctuate about the type; the corona enlarges or contracts, the gold deepens or pales, in a few varieties the flower becomes bicolored, in others it fades into pure white. Thus varying in detail, but true in essentials, the daffodils pass, a procession of loveliness, through the changing days of May.

Our best double form of the daffodil is named in the catalogues Van Sion. Curiously enough, it seems to be the strongest member of the species. The variety has been able to maintain.

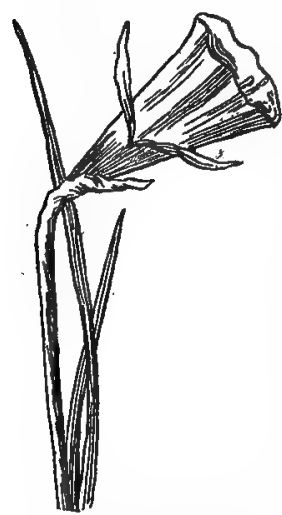

Hoop-Petticoat D a f fodi1. Narcissus bulbucddium itself in this country: for years and is the common daffodil of old-time gardens: "In the oldest form the corona disappears as a" separate body and supernumerary segments are present. The form now sought by gardeners is that in which the segments remain intact, and the trumpet fills with petaloids. This double daffodil has long been cultivated in England, where it is known as Narcissus telamònius plènus; it is, however, simply a variety of Narcissus pseudonarcissus.

Another attractive species of the longcrowned group offered by the trade is Narcissus bulbucddium, the Hoop-Petticoat Daffodil. This is rather a delicate plant in appearance, with a small bulb and slender leaves, of which there are three or four with each scape. The flower is solitary, bright-yellow in all its parts-the very prominent thin corona so extending the tube as to make the perianth funnel-shaped. The stamens are rather long and inserted at the base of the tube. The type is native to southern France and northern Africa; it blooms in April and * May and runs into many garden forms.

Typical of the medium-crowned group, resembling the Trumpet in general effect, yet different in detail, is the Superb Daffodil, Narcissus incomparabilis. A native of France and Spain, and :. recognized as a distinct species, many botanists believe it to be a hybrid, the result of a union between the Trumpet and the Pheas- 


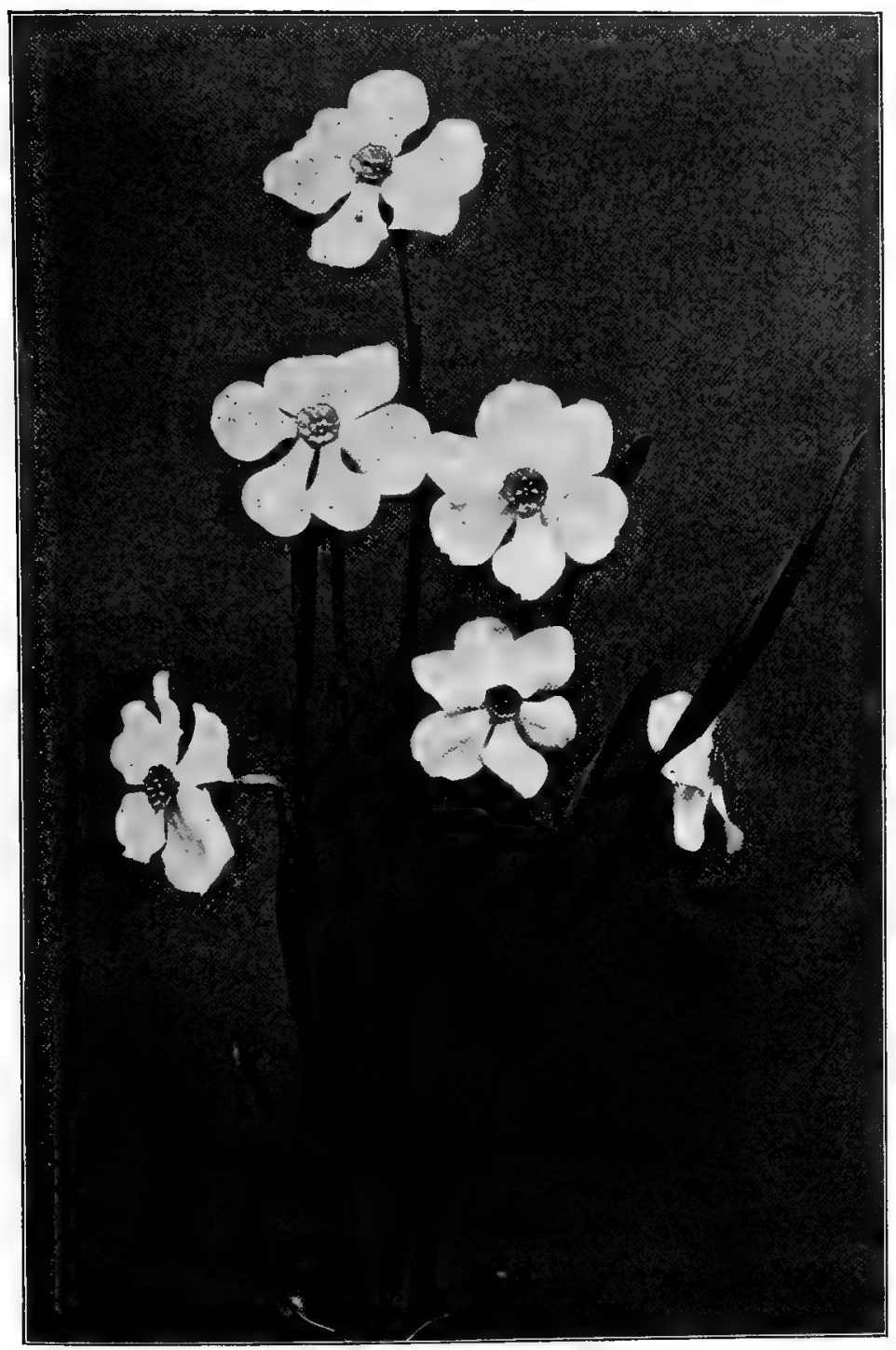

Poet's Narcissus. Narcissus poéticus 
ant's Eye, Narcissus poeticus. Botanically, it differs from the Trumpet in the shorter corona and the longer perianth tube, but resembles it in bulb, and leaf, and structure of the flower. Both the type and its variants are reputed hardy.

\section{POET'S NARCISSUS. PHEASANT'S EYE}

\section{Narcissus poéticus.}

Strong-growing species; sometimes a foot and a half high; the type of the short-crowned group. Native to France, Switzerland, and southern Europe. Naturalizes readily in this country. May.

Bulb.-About an inch thick.

Leaves.-Flat, somewhat glaucous.

Scape. - Two-edged, eight to twelve inches high.

Flowers.-Solitary, fragrant, wide open; the obovate segments white; the very short yellowish corona much crisped and red-edged. A double form is pure white.

Narcissus poeticus is in this country the most vigorous species of the genus. It naturalizes readily and may be grown successfully either in garden beds or scattered through the grass. Indeed the plant often does better in half-neglected places than in the wellkept border where it has richer soil and more consideration. It rather likes to be a weed. Should an old bed of poeticus fail to flower satisfactorily, the probable reason is that the bulbs have increased beyond the capacity of the bed, and that they are starving.

The name poeticus implies that this species is that of the classical writers of antiquity; but the ancients were so indefinite in their descriptions of plants and flowers that a satisfactory decision is impossible. The plant which replaced the youth who died from love of himself, Ovid says, was yellow; Virgil once calls it yellow, and a second time refers to it as purple; Dioscorides records it as purple. Narcissus poeticus is white, with a small yellow corona strikingly red-edged, so that there is in the flower both yellow and red. It is believed that the ancients often confounded red and purple, if, indeed, their purple was not our red. The identifica- 
tion is obviously imperfect. Pheasant's Eye of course refers to the yellow and red corona.

The plant has long been a favorite. The blooming period is normally the last of May, though earlier varieties have been developed. All the varieties are profuse bloomers, and most of them are hardy. In the double form the corona disappears entirely and the segments are greatly increased in number, thus making the flower pure white.

\section{POLYANTHUS NARCISSUS. PAPER WHITE NARCISSUS}

\section{Narcissus tazétta var. alba.}

Sturdy free-blooming plant, largely used for winter forcing; tolerant of the conditions of ordirary homes; asks only water and light to bloom in mass. Belongs to the short-crowned group.

Bulb.-Large, two inches in diameter.

Leaves.-One to two feet high.

Flowers.-Four to twelve in a cluster at the summit of a scape; segments white; corona white with crisped and crinkled margin.

Stamens.-Six; three near the throat, three lower in the tube.

Style.-Thread-like; stigma slightly cleft.

The Polyanthus Narcissi are best known to us in the varieties of Narctssus tazetta alba, the Paper White Narcissus, and Narcissus tazetta orientalis, the Chinese Sacred Lily. Both are extremely popular for winter bloom.

The flowers of the Paper White come out in clusters of four to thirteen. Each flower makes a broad angle with its stem. The perianth tube is about an inch long, pure white, though a little greenish where it joins the vividly green ovary. It broadens into six pure-white segments, three exterior and three interior. The flowers of well-grown and vigorous plants are from an inch to an inch and a half across. A beautiful tiny corona, crinkled and scalloped, sits upon the throat of the tube, and out of it look the yellow anthers of three stamens; the other three stamens are in seclusion lower down in the tube.

The Paper White can be forced in any ordinary living room. 
Given six or eight bulbs, planted in a dish sufficiently deep to allow coarse gravel or pebbles to be packed about them so as to hold them in place, the bulbs well supplied with water and kept in a dark, cool place until abundant roots are produced-this is all that is necessary for success. By the time that a heavy mat of roots has been formed, the leaves have started. At this stage the dish of bulbs should be brought into abundant light. It is best in steam-heated rooms to place the plants at the coldest window; they are lovers of cold, not of warmth, and too great heat blasts the buds; sixty to sixty-five degrees is a good temperature. Most living rooms are too warm for them; and unless a cold niche can be found the bloom may prove unsatisfactory. But with an agreeable temperature and plenty of sunlight the plants will bloom delightfully, filling the room with delicious fragrance. Nearly two weeks elapse between the appearance of the first and the last blossoms of an ordinary cluster, and as the clusters do not all come forth at the same time there is a long flowering period. Though the flower looks delicate, as a matter of fact the texture of the petals is almost leathery.

Narcissus tazelta, the primitive type from which the garden forms of clustered Narcissi are derived, is a species remarkable for its variability as well as for its geographical distribution. Its range extends from Portugal through southern Europe and northern Africa to Syria, Persia, Cashmere, India, on to China and Japan. It is very rare to find a tropical plant that so nearly encircles the globe. The Paper White in some respects well represents the type, yet the primitive blossom is white with a lemonyellow corona, and in this respect the Chinese Sacred Lily more nearly represents it.

Notwithstanding all that has been said about red and purple, since the matter is undecided one may be permitted to believe that this primitive form is the ancient Narcissus, the flower of Mohammed's devotion, "wondrously glittering," whose "sweet scent caused all the broad heavens above and all the earth to laugh, and the salt waves of the sea." 1 "Fed by heavenly dews

1"Homeric Hymn to Demeter." 


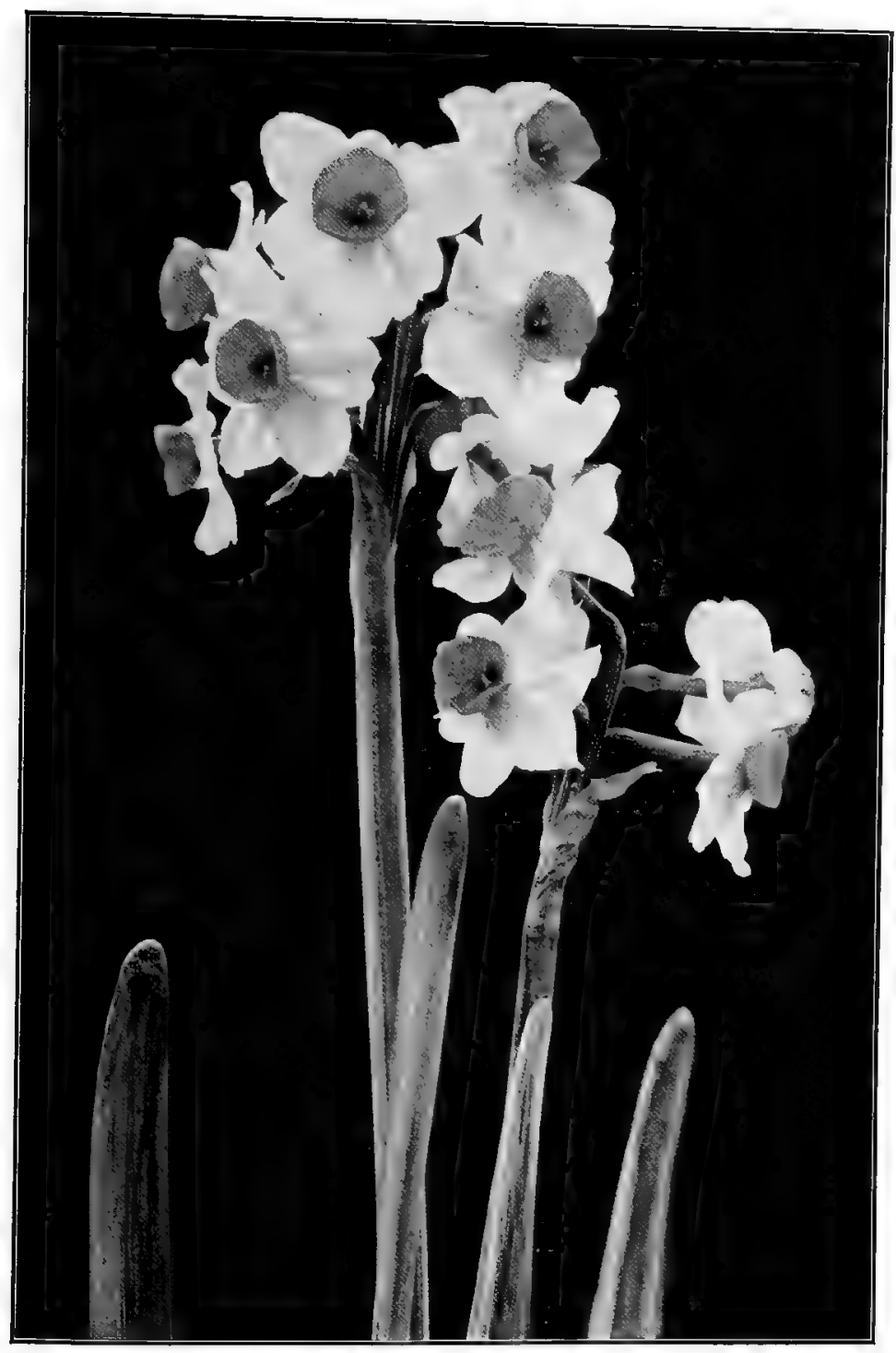

Polyanthus Narcissus. Narcissus tazêtia 
the narcissus blooms morn by morn with fair clusters, crown of the great goddesses of yore." 1

This Narcissus was not only the theme of the ancient poets; it was also a decorative flower, used largely in connection with

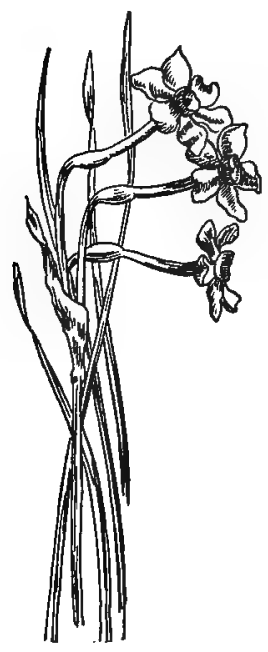

Jonquil. Narcissus jonquillla death and burial. That it was so used before the Christian era in the making of funeral wreaths is known from the actual evidence of specimens of the Narcissus tazetta flowers which after long entombment were unearthed in 1888 from an ancient cemetery at Hawara.

\section{JONQUIL \\ Narcíssus jonquilla.}

One of the Iong-cultivated species of Narcissus; quite hardy in the Middle West. Native to southern Europe and northern Africa.

Leaves.-Glossy, dark-green, very narrow, and rush-like.

Flowers.-Two to six on the stem; the tube greenish-yellow, slender, cylindrical, about an inch long; segments yellow, slender, obovate, scarcely overlapping; corona very short, crenate, the same color as the segments.

There has been a curious interchange of name between this species which is the real Jonquil, and the Trumpet Daffodil, which is often called Jonquil. It is, upon the whole, best to use the names as the books record them. The Jonquil leaves are rushlike, not flat; the flowers slender and delicate, in a cluster, pushing out from a common enclosing spathe. The plant is somewhat at a disadvantage in comparison with the Trumpet Daffodils, because of its very delicacy.

\footnotetext{
1 " Edipus at Colonus" -Sophocles.
} 
SNOWDROPS

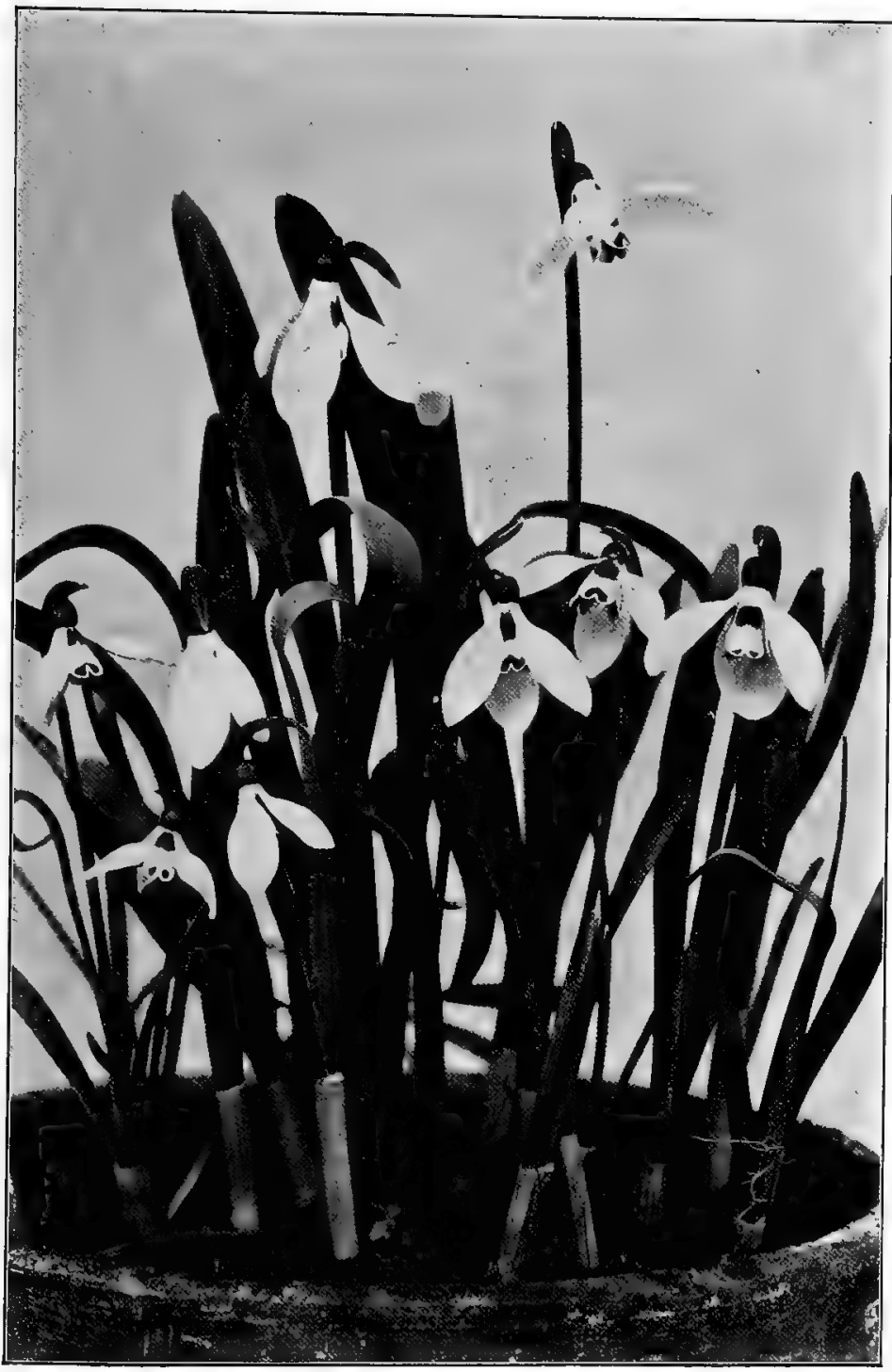

Snowdrops. Galanthus 


\section{COMMON SNOWDROP}

Galánthus nivàlis.

Greek, gala, milk; anthos, flower: the milk-white flower.

Galanthus is a genus of hardy bulbous plants, known as Snowdrops, of which nivalis is the type.

Bulb.-Small, coated.

Leaves.-Two to three from each bulb; six to nine inches high, bright-green, narrow, channelled.

Flowers.-Solitary, white, nodding; borne on a scape and rising from a spathe.

Perianth.-Of six segments; three outer and spreading; three inner smaller, marked with green, notched, apparently forming a tube.

These plants doe grow wild in Italie and the places adjacent; notwithstanding our London gardeners have taken possession of them manie years past.

-Gerard.

The Snowdrop is our only out-of-door flower that will bloom in midwinter. The wise and the efficient may count on the Christmas Rose, Hellêborus nìger, in December; but one may possess the Snowdrop's nodding flower in January, without being either very wise or extremely efficient. The eagerness of the little creature to bloom is both pathetic and enchanting. Any weather which will permit the chickweed to open its petals will also lure forth the white bells of the Snowdrop. In I906 the Snowdrop was in blossom in the gardens of Cleveland on January $2 \mathrm{r}$; the same was true in rgog. A few days, such as frequently occur in midwinter, warm enough to thaw the surface of the ground sufficiently so that the green leaves can push through, are all that is necessary. The little flower, so white, delicate, and spiritual that it seems to be snow organized into flower form, comes at once to the surface. We have no other that responds so quickly to the summons of the sun. Six inches of snow may next day cover these blossoms-that is only an incident in their career; their lover will dig them out, place them in water, give them a cool temperature that they may get their bearings, and after a night of coolness and 
retirement they will come into the morning sunshine fresh, hale, and hearty,--"the unflinching snowdrop."

The nodding flower looks as if it were made up of three concave white petals surrounding a greenish tube; but upon examination the tube proves to be itself made up of three separate parts, which are white, marked and blotched with green. The stamens are six, and consist of short green filaments with long-pointed, bright-yellow anthers, which discharge their pollen from the top.

The leaves come up with the flowers, attain their full growth later, and commonly die down in midsummer. A fine bed of Snowdrops is easily acquired; one needs only to plant the bulbs permanently in a sheltered place and let them alone. They will thrive, even on neglect.

The winter bloom, however, is only casual and incidental; the blossoming period in our northern climate is March or April, depending somewhat upon the season.

The books give southern Europe and northern Africa as the native home of the species. Although a child of the lowlands it possesses many Alpine characteristics which lead one to infer either that it was left behind in the retreat of the glacial ice, or that it has for some reason descended from the mountain heights into the valleys at their feet.

Whether the plant ever pushes its way up through the snow is doubtful, though the French name, Perce-neige, certainly suggests as much. The German name, Schnee-glocken, refers simply to the form of the flower. In England the little creature has long been known in cottage gardens as "the Fair Maid of February."

The species known as Galanthus Ellwesii, introduced into England from the mountains of Asia Minor in 1875 , is in some respects a better gardener's flower than Galanthus nivalis, though it blooms two weeks later. The flowers are larger, with slightly different markings. The gardeners have succeeded in producing double forms-woe worth the day! 


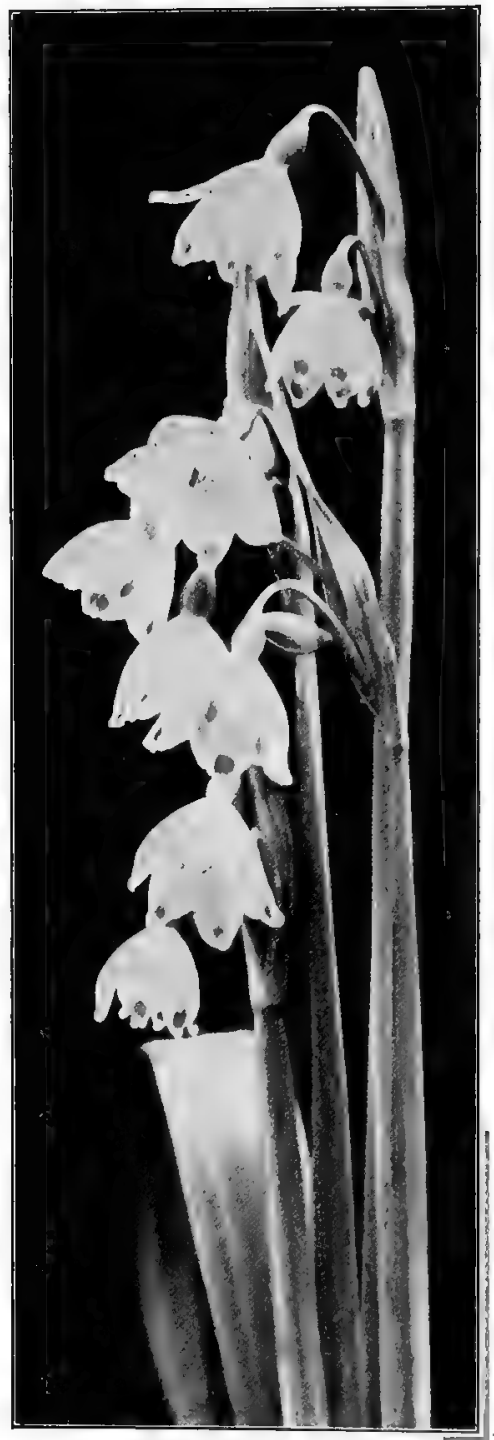

Spring Snowilake. Lewcdjum virnum

\section{SPRING SNOWFLAKE}

Leucdjum vérnum.

From the Greek, leukos white, and ion a violet.

Bulb.-Small.

Leaves.-Strap-shaped, six to nine inches long.

Scape--Six to twelve inches high, usually one-flowered.

Flowers.-Nodding.

Perianth.-Six-parted.

Segments. - Ovate, white tipped with green.

Perianth Tube. - None. Bloom in May.

Leucojum is a genus of hardy bulbous plants, natives of the Mediterranean region. The species chiefly cultivated in this country is the Spring Snowflake, Leucojum vernum. It has not the characteristic grace of the snowdrop, the stems being sturdier, the arch quite different in character; and the perianth segments all similar in size, form, and markings.

It bears at the tip of each snowy petal a spot of soft bright green, exquisite and precise, "a snowflake with green of living spring." 


\section{TUBEROSE}

\section{Poliânthes tuberòsa.}

Greek, polios white or brilliant, anthos flower.

Rootstock.-Tuberous.

Stem.-Two to three feet high with eight to twelve reduced leaves; basic leaves six to nine to a stem, linear.

Perianth.-White, waxen in texture; tube long, narrowly funtnelshaped, curved.

Segments.-Short, unequal.

Stamens. - Six inserted on the middle of the tube.

Ovary.-Three-celled, free at apex; stigmas three.

The Tuberose is a flower that may be said to have experienced in its many changes "the slings and arrows of outrageous fortune." Once borne upon the very crest of fashion, associated with the camellia in the most aristocratic period of that flower's social reign, it has so fallen that there are few to do it honor, either in house or garden. Two causes have contributed to bring about this change in its social status: its heavy odor and its funereal associations. Then, too, garden ideals have changed, and the stiff, clumsy stalk laden with stiff, heavy blossoms, does not and cannot harmonize with the tousled beauties whose sway is now unquestioned. As a matter of fact the double Tuberose never did harmonize with any other flower; it never was anything but a lump of cloying sweetness.

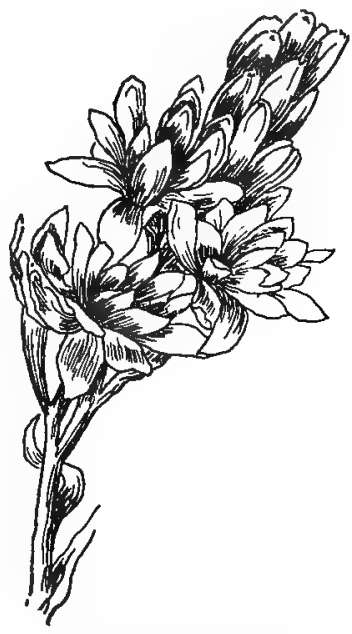

Tuberose. Polianthes tuberdsa

The English name of the plant gives us an interesting example of the ease with which a word may be turned from its real meaning and be made to express something quite different. To most of 
us Tuberose seems an appropriate name for a blossom tubular in form, which gives forth an odor that may perhaps be considered rose-like. But neither the tube nor the odor really had anything to do with the selection of a name. The word originally was an adjective: tu-ber-ose, meaning tuber-like in reference to the thickened rootstock. The plant was the Tuberose Polianthes, but in some way Polianthes was dropped and tu-ber-ose became Tuberose, and Tuberose it will probably remain. By any other name it doubtless would smell as sweet. 


\section{IRIDÀCE/E-IRIS FAMILY}

This is a family of brilliant coloring, consisting entirely of perennial herbs. The leaves arise from bulbs, corms, or rootstocks; are narrow for their length, and enfold each other in two ranks, as if astride; a position known technically as equitant.

The flowers are usually showy, perfect, either regular or irregular, each subtended by two bracts. The three petals and three petal-like sepals are convolute in the bud; the tube adnate to the three-celled ovary. The stamens are three, either distinct or monodelphous, alternate with the petals; anthers extrorse. Style single, usually three-cleft. Stigmas three, or six by the parting of the style-branches. Capsule three-celled, many-seeded.

The garden representatives of the family are Iris, Crocus, Tigridia, Ixia, Gladiolus, Blackberry Lily, and recently some forms of Blue-eyed Grass.

\section{IRIS. FLEUR-DE-LIS}

\section{Iris.}

Iris, the rainbow, anciently applied to this genus on account of its bright and varied colors.

About one hundred and seventy species of Iris are known to botanists. These are natives of the North Temperate zone, inhabiting Asia, Europe, and North America, with a few species in northern Africa. The Irises of Europe are in the main broadleaved species, which give way in Asia to many narrow-leaved forms of which there are representatives upon our Pacific slope. Spain and the Mediterranean regions of Africa are the home of the bulbous forms. 


\section{GERMAN IRIS}

\section{Iris germanica.}

Typical of many species in which the beard is confined to the midrib of the reflexed perianth segment. The German Irises of the garden are not simply varieties of Iris germanica, but hybrids of various species. They appear in endless variety, varying in stature, size, coloring, and time of flowering.

Root.-Of thickened creeping rootstocks, more or less tuberous.

Stem.-Erect, simple or branched, bearing flowers, solitary or panicled.

Leaves.-Ascending, equitant, parallel-veined, sword-shaped.

Flowers.-Perfect, proceeding from a somewhat papery spathe of two or more bracts.

Perianth.- - Of six-clawed segments united below into a tube, convolute in the bud. Segments in two rows; outer segments reflexed, bearded on the midrib; inner segments erect, overarching the centre of the flower, always narrowed to a distinct claw.

Stamens.-Three, inserted at the base of the outer segments; the oblong anthers on slender filaments, sheltered under the overarching, petal-like branches of the style and looking outward.

Ovary.-At the base of the flower, protected by the papery bracts, three-celled, many-seeded; style divided into three petal-like branches, which are bifid or crested at the lip; the stigmatic surface is a thin lip or plate under the parted apex.

Fruit.-A capsule, containing many shining seeds.

The Iris has been called the poor man's orchid; certainly few orchids have finer flowers than the best of the Irises, and in grace and dignity the Iris plant far outranks the orchid.

The structure of an Iris flower is extremely puzzling to an amateur because the parts are so grown together. Ovary, perianth, and style unite to transform the lower part of the blossom into a sort of stem, and the upper part of this stem sometimes becomes tubular before it divides; sometimes the division takes place directly. The perianth divides into six segments of which the outer or sepaloid ones have great beauty, both of form and color, becoming bearded and many-veined, broad and reflexed. The 


\section{GERMAN IRIS}

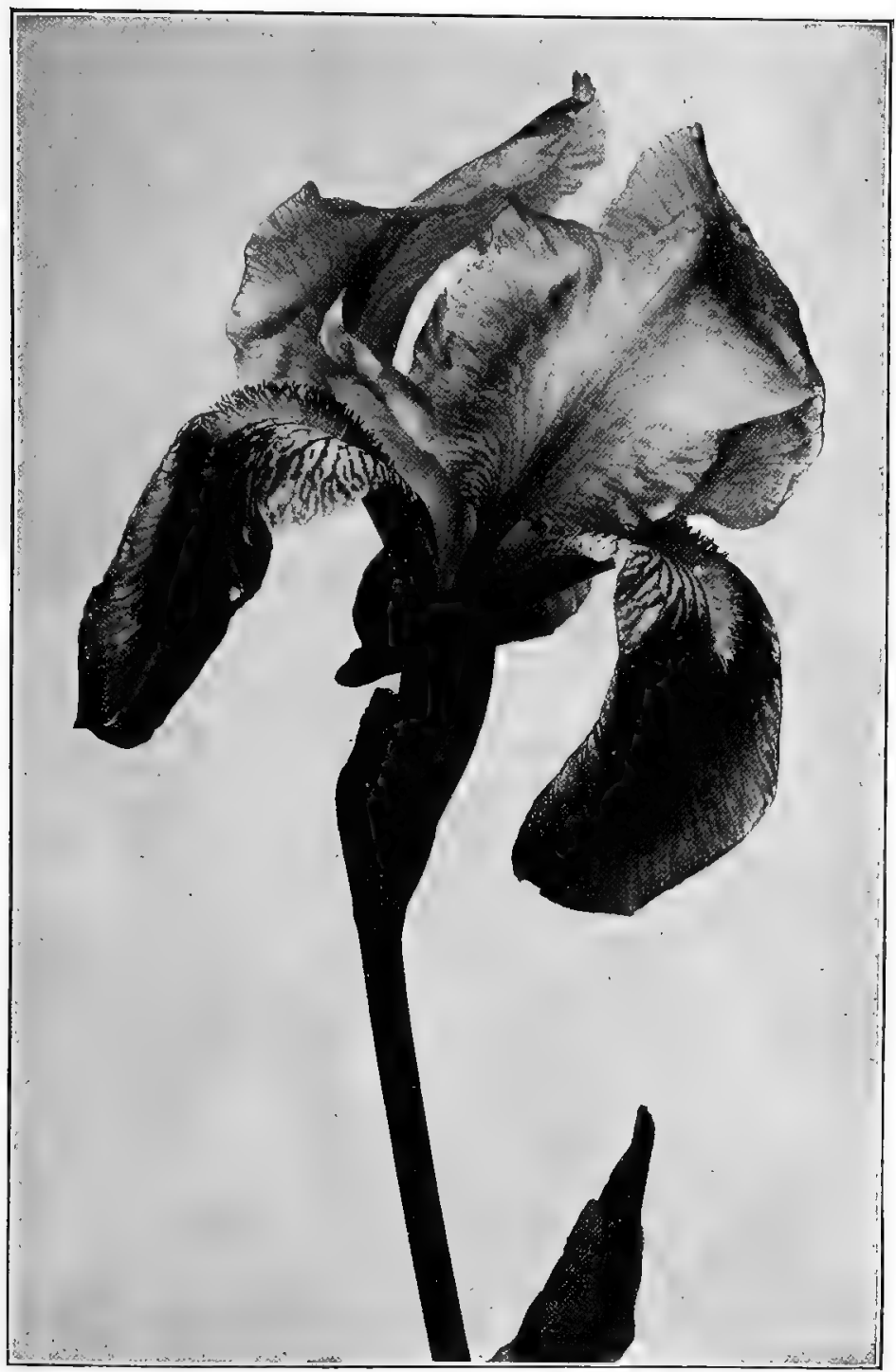

German Iris. Iris germanica 


\section{IRIS FAMILY}

gardener calls these the falls. The three inner or petaloid segments rise each on a claw, broaden, and overarch. These are the standards.

Looking directly into the flower the observer fails at first to 'discover either pistil or stamens; certainly the accustomed yellow heart is wanting. But pistil and stamens are both present, though one has taken an unusual form and the other is well hidden. The heart of the blossom which looks like three additional petals is the enlarged and glorified style, divided into three arms which separate and curve outward. The stigmatic surface is so small and so hidden that one rarely sees or knows that it is there. It is a thin edge under the divided crest and can be detected by its slightly shining surface or by the pollen which may chance to adhere to it. From the base of each of the outer perianth segments rises a stamen with short filament and large anther, usually of the same color as the blossom, and closely pressed against the overarching arm of the style. The pollen cells open outward.

This flower structure is admirably adapted for cross-fertilization by bees. In the first place, abundant nectar is poured forth from the inner surface of the lower part of the flower and the feast is made ready. The bee seeking the honey presses in below the arch of the style-arm, and must necessarily sweep off on her back some of the pollen from the anther, which is placed in exactly the right position for this result. The same bee upon entering another flower must necessarily leave some pollen on the stigmatic edge, which is placed so as to be most sure of sweeping it off. The arrangement is remarkably perfect and one expects the result which follows-all the Irises seed abundantly.

The German Irises of the catalogues are purely garden flowers - varieties, hybrids, sports-into whose composition have gone the strains of a score of primitives. Probably in the beginning Iris germanica was the basic plant, but it would be a wise Iris that could now recognize her own children. Yet, since the gardener's ideal has been solcly color and size, the structure of the flower has not been broken down nor the form of the leaf interfered with. Owing to the great diversity of origin the varieties have great 
diversity of color, ranging from pure white through many hues of mauve, blue, purple, yellow, bronze, and claret. Many are most exquisitely veined and marked.

The leaf is erect and without distinction of blade and petiole; the surfaces which stand right and left are alike. A careful examination shows that what appears to be a flat leaf-blade is in fact a leaf-blade folded lengthwise. Toward the tip the folding is complete and the lateral halves are blended, but nearer the base they are still more or less distinct and a crevice is there left in which are clasped the flower stem and the base of the sword-like leaf above it on the opposite side. That which answers to the under side of other leaves is here the outside. The clusters of leaves at the ground are arranged in what is termed an equitant manner; each leaf by its folding sits astride the leaf just above it.

Dwarf Garden Iris, Iris pimila, is a low species of the germanic type. The flowers are purple and violet and the entire plant not more than six inches high. Two native mountain species, both dwarf, are sometimes found in cultivation, Iris vêrna and Iris cristata.

\section{SPANISH IRIS}

\section{Iris xîphium.}

Long cultivated; native to North Africa, Corsica, and south of France. The type is violet and purple; the principal varieties are Iris lusitanica, in which the flowers are yellow, and Iris spectábilis, in which the habit is more robust and the flowers darker yellow touched with brown.

Rootstock.-Bulbous.

Leaves.-Slender, half-round, deeply channelled.

Stem.-One to two feet high; the spathe one or two flowered.

Perianth-tube.-Wanting; outer segments with an orbicular blade about an inch broad, much shorter than the fiddle-shaped haft, the whole two to two and a half inches long; inner segments oblong, clawed, a little more than half an inch broad.

Stamens.-Three.

Style-branches.-An inch or more long; crests large, quadrate. 


\section{IRIS FAMILY}

Early in June, just as the bloom of the German Irises is waning, the beauty and brilliancy of the genus passes on to another great garden group known as the Spanish Irises. Their color range is of marvellous beauty: white, blue, yellow, and brown in bewildering combinations. Three forms are in general cultivation; the

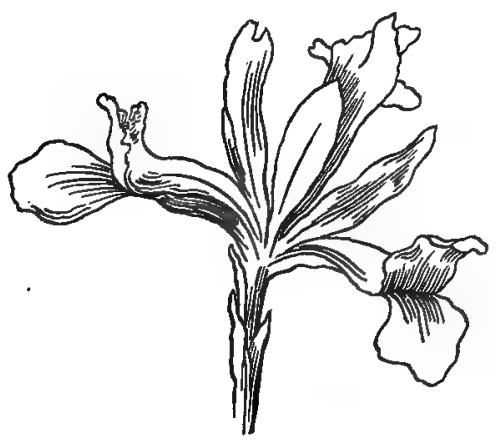

Spanish Iris. Iris xiphium most common that with narrow falls spreading laterally; the Portuguese, Iris lusitan ica, with relatively broad falls which rise slantingly; and the old form known as the Thunderbolt, Iris spectabilis, of bronzy flowers which are larger in all their parts than the type. The gardeners say that these Irises need a full supply of water in order to do well. The English Irises,

Iris xiphidides, closely follow the Spanish kinds and keep up a succession of attractive flowers. As is well known, they are not English at all, but Spanish, yet having come into Holland by way of England they received the name of their foster-land. The leaves are wider and the flowers larger than those of the Spanish types. This group has been cultivated for at least two hundred and fifty years.

\section{JAPANESE IRIS}

Iris levigàta. Iris Kömferi.

Native to eastern Siberia and Japan. Long cultivated by the Japanese in many varieties. June.

Root.-Rhizomous.

Leaves.-Thin, sword-shaped, one to two feet high.

Stem.-Taller than the leaves, obscurely angled, spathe two to three flowered. 
Perianth-tube.-Funnel-shaped; outer segments three inches long and three to five inches broad; inner segments narrowed and short.

Stamens.- Three, style-branches more than an inch long; crests large, deltoid.

The flowering of the Japanese group in late June closes the Iris season, though sometimes it runs on into July. In general appearance this group differs greatly from other Irises. The leaves are bright and grass-like; the stems considerably overtop the leaves and bear a single cluster of two or three flowers. The colors run mostly from white through violets and purples, though there are queer pinks and wonderful blue-grays; marvellous markings and veinings appear in bewildering confusion. The flowers seem lightly poised on their tall stems and the effect is in striking contrast with that of the German

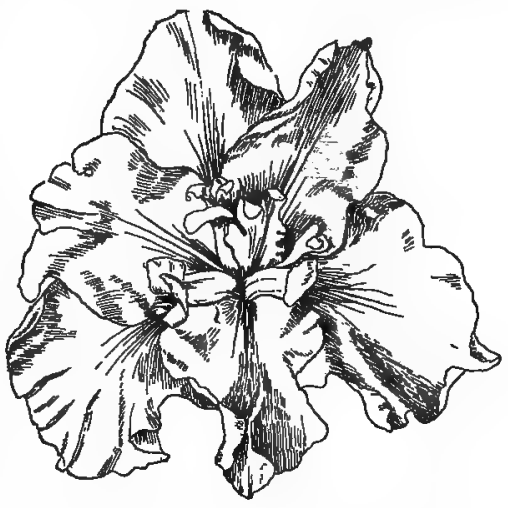

A View of Japanese Iris Looking Down upon the Flower

Irises. In form the flower differs from the common type. The falls are wide and flat, the standards narrow and short, and the result is that, to a certain extent, the blossom becomes salvershaped. Double forms appear, in place of three falls there are six, but this doubling seems not to lessen the grace of the flower.

Though all the Japanese Irises are referred to a single primitive, Iris lavigata, it is evident that the type was broken long ago by the Oriental gardeners and that a new species may be said to have been created. Excellent examples were sent to this country soon after the opening of the Japanese treaty ports, but they attracted little if any attention. The popularity of these Irises dates from very recent times. They are admirable garden plants, not at all particular about soil, but should have a good deal of moisture in order to do well. 


\section{GLADIOLUS}

\section{Gladiolus.}

Gladiolus, Latin, a dagger; in allusion to the shape of the leaves.

A genus of about one hundred and thirty species of perennial herbs, natives chiefly of the Cape and tropical Africa; only fifteen species being known in Europe and western Asia.

Roots.-Cormous.

Leaves.-Sword-shaped or linear.

Flowers.-Borne in a two-ranked spike on a tall scape.

Perianth-tube-Funnel-shaped, six-parted, somewhat two-lipped; tube short and segments unequal.

Stamens. - Three, inserted on the perianth-tube.

Ovary.-Oval, three-celled; style thread-like, with three-parted stigma.

Capsule.-Three-celled, containing many seeds.

Gladiolus as we know it to-day, is a triumph of the gardener's art. Its forebears are the native Gladioli that were brought into Europe from southern Africa about the middle of the eighteenth century. Some twelve different species were at first under cultivation by the Belgian, Dutch, and French growers. A fortunate crossing of two species, believed to be Gladiolus cardinalis and Gladiolus psittacinus, by the gardener of the Duke of Arenburg produced the hybrid known as Gladiolus gandavensis, the Ghent Gladiolus. The famous house of Van Houtte took up the plant and introduced it in $I 84 \mathrm{I}$ into the wider gardening world. Immediately the work of variation and hybridization began, with the result that there were established several distinct strains of great beauty and virility. To-day, the number of varieties is legion though botanically the genus is utterly confused. However, since the gardener's ideal has been large flowers, rich and varied colors, long full spikes, the structure of the blossom has not been materially interfered with. As the perianth segments open we find three stamens with long anthers standing together, near the middle upper segment. With them is the long style, but its stig- 


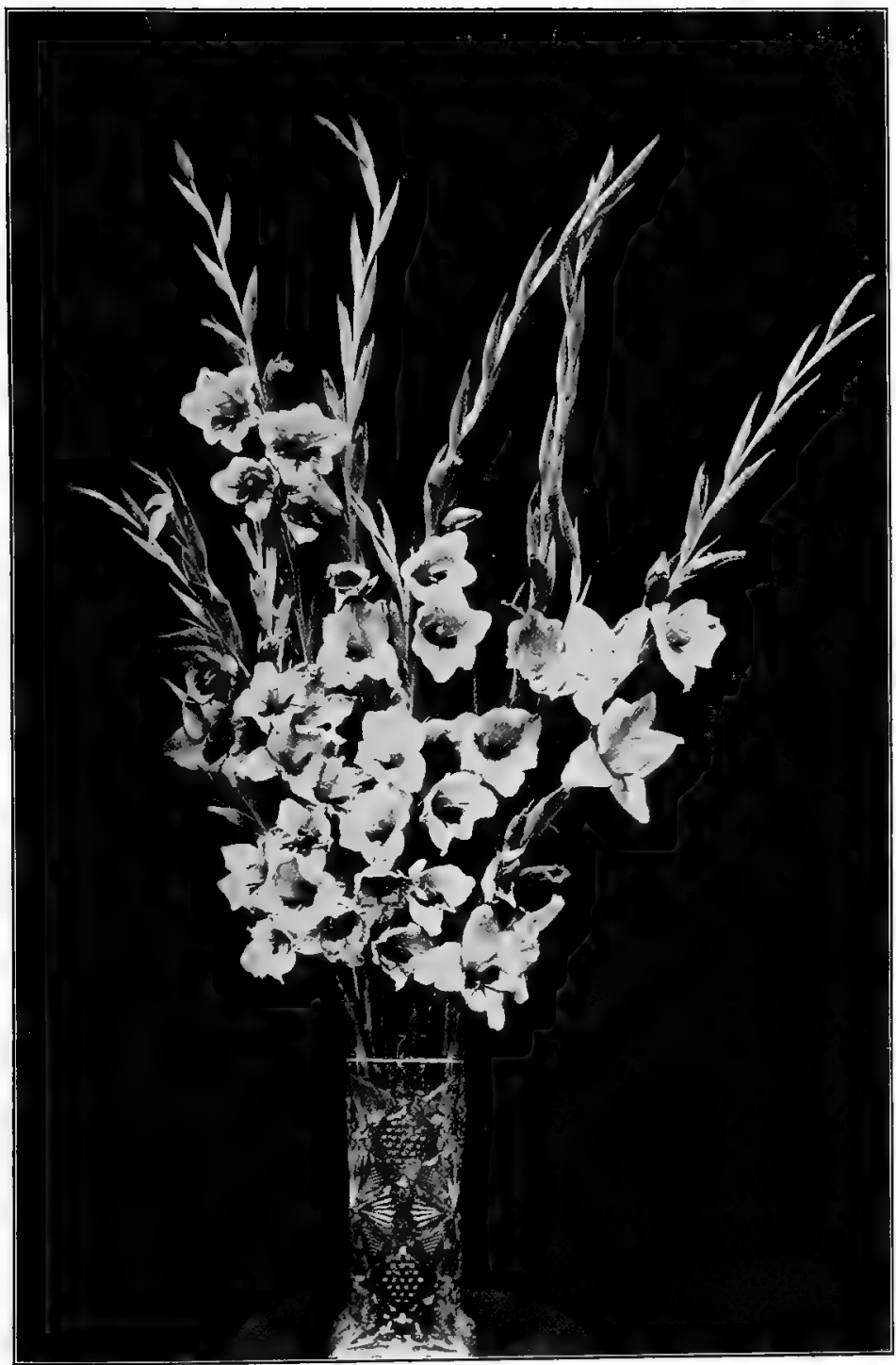

Gladiolus. Gladiolus 
mas do not become receptive until the anthers have matured and cast their pollen, thus insuring cross-fertilization. At the bottom of the tube is a full drop of limpid nectar. The existence of this nectar is so well known to the humming-birds that they will hover in flocks over the gladiolus beds, and it is quite possible to lure them from the garden to the piazza by means of the flowering stalks. It is well to fill some of the flowers fairly full of sweetened water so that the birds come to know that sweets are to be had; then quietly cut the stalks and remove them in full sight of the little fellows and in time they will pluck up courage and follow. As long as the supply of sweets holds out they are likely either to remain, or if they fly away, to return. Incidentally, one gets light upon humming-bird character. One day, the strongest of the flock decided to take possession of the piazza nectar supplycorner the market as it were-and perched upon the. back of a. chair kept watch and wait over his monopoly. The little wretch was strong enough to terrorize all his companions, and if the Deus ex machina had not finally interfered and set his grumpy majesty afloat, the rest of the flock would have had nothing. It was a complete dog-in-the-manger plan, and how so much selfishness, wrath, and wrangling could dwell in so exquisite a form was a wonder. The old adage, "Handsome is as handsome does," did not quite fit the conditions of that summer morning.

The ordinary color range includes all the chromatic changes possible upon the chord of red varying to white, but recently, purples have appeared from hybridization. If the gardeners choose, the blues will follow, for where nature gives a secondary color, it is quite possible to obtain from it by patience and effort both primaries. 


\section{SPRING CROCUS}

Cròcus.

Crocus, the ancient classical name for saffron.

Well-known horticultural group of early blooming plants; in their garden forms chiefly hybrids.

Crocus verrnus, native of southern Europe, is the parent of many of the cultivated lilac and white varieties. Crocus biftorus, also from southern Europe, produces the group known as the Scotch Crocus. Crocus moesiàcus or aurèus, ranging from Transylvania to Asia Minor, is the primitive of the Yellow Dutch Crocus. Crocus susianus, from Crimea, is the favorite yellow crocus known as the Cloth of Gold; it appears in variants and hybrids. Crocus versicolor, from the mountains of southern France, is the parent of the purplish-feather-veined crocuses so common in gardens. Crocus sativvas, from Asia Minor, is the common fall-blooming species and the source of the saffron of commerce. These are the parents of the common crocuses of the trade.

Corm.-Three-fourths to an inch in diameter.

Leaves.-Grass-like, rising directly from the corm, in some species two to four, in others four to eight, forming tufts or bundles; linear, edges usually reflexed and a central band of white.

Flowers.-Showy, in many colors, ranging through purples, lilacs, and yellows, to white, often feather-veined and striped.

Perianth.-Funnel-shaped and erect, with a very long tube and six nearly equal segments. Spathe one-flowered.

Stamens. - Three, inserted at the throat of the tube, shorter than the segments; filaments thread-like; anthers linear.

Ovary-Three-celled; style long, thread-like; style-branches entire at margin, or fimbriated, or forked.

Capsule.-Three-celled, often more than an inch long, seeds many.

The flaming crocus made the mountains glow. - - Homrr.

Our association of early spring with the Crocus and the daffodil is a memory acquired in gardens; for neither is native to American soil. To us of the North, spring comes in the soft, feathery, white bloom of the shad-bush, or the pale tints of the sturdy hepatica, or the blushing petals of the spring beauty. 
But to the Greek, whose oneness with nature is still the marvel of the ages, spring came in the cup of the Crocus, in the trumpets of narcissus and amaryllis. They to him showed "the first coming of the breath of a renewed herbage, and they are the

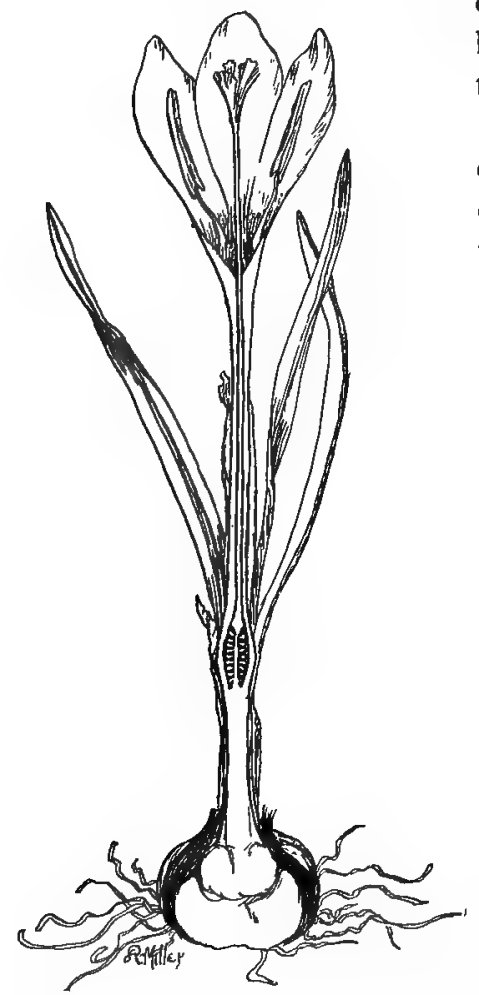

Crocus. Cròcus vérna. Half of Entire Plant only golden flowers that are to burn on the trees and float on the streams of paradise."

Instead of a bulb like the daffodil the Crocus, has a solid corm, which is a depressed and thickened stem. From this corm arise the grass-like leaves in a bundle, the outer series wrapping the inner and giving such support to each other that they really do duty as a stem. The flowers and leaves arrive in the upper world together and like the snowdrop arise early in the year. The flower will open while the snow and frost are still supreme; its own little spot must be warm, it matters not how much cold there is elsewhere.

However much the Crocuses are hybridized, the changes come chrefly in size and color; the structure of the flower, so far, has not been broken down. The blossom rises amid the leaves; and the long tube with six segments, three stamens, and long style, appears in every species. The stamens stand up against the style, the anthers open along their outer faces, and the stigmas arch slightly over them. The anthers mature first. As the flower gets older the stigmas bend apart and press down between the anthers in such a way that they 
dust themselves with pollen. The ovary is hidden away among the bases of the leaves and not until considerable growth has taken place is it brought up above-ground by the lengthening of the flower stalk. The Crocus bears seeds in midsummer, but few garden crocuses are propagated in this way; the life of the plant passes on by way of the corm rather than by the seed. At the base of each shoot, arising from an old corm, there will be formed, after the flowering period, a little corm, and as there are several leaf-bundles there will be an equal number of new corms clustered on the remains of the old one. These, of course, are nearer the surface than was the parent. If undisturbed, the corms of each succeeding year will be more crowded and less deeply buried, until at last they lie close together at the surface. This is the reason for the gardener's advice to lift the corms every two or three years.

The Crocus lends itself to a great variety of effects with its rich purples and yellows, its delicate mauves and whites. The flowers are beautiful anywhere, but especially upon the lawn in the grass, because having only insignificant leaves of their own they look the better for a background of green.

The cultivation of Crocus sativas is a very old industry. Its large orange stigmas contain a strong-scented volatile oil and a rich yellow dye. These stigmas and a portion of the style are gathered and dried and form the saffron of commerce. Five pounds of the fresh stigmas are said to yield one pound of the dried. Saffron was formerly of great repute in the materia med$i c a$, and still enjoys that reputation in Oriental countries, but is rarely prescribed elsewhere by the profession. The present supply comes chiefly from Persia. 


\section{IXIA}

Ixia.

Ixia, Greek, birdlime; in allusion to the sticky juice of some species.

South African plants introduced into England and Holland in the latter half of the eighteenth century. They have been crossed and improved by the Dutch growers with whom they are still a specialty.

Rootstock.-A corm.

Stem.-Unbranched.

Leaves.-Linear.

Flowers.-Salver-shaped, borne in spikes.

Perianth-tube-Cylindrical, with six, equal, spreading segments.

Stamens.-Three, inserted in the throat.

Ovary.-Terminating in a thread-like style with three, slender, recurved stigmas.

The Ixias are a horticultural group of early-blooming bulbous plants originally from the Cape of Good Hope. Silence of the catalogues as to the parentage of the many varieties shows clearly that the present garden forms are hybrids whose origin is not very well understood.

The flowers are borne in spikes and exhibit an exceptionally wide range of color: white, varied yellows, orange, lilac, rose, pink, crimson, varied purples, ruby-red, pale-blue, and even green. The flowers are either of solid color or appear with an eye.

\section{TIGRIDIA. TIGER FLOWER}

Tigridia pavònia.

Tigridia, tiger-like; referring to the peculiarly marked flowers.

A summer-blooming bulb; first sent from Mexico to Spain by Hernandez, physician to Philip II, because of supposed medicinal qualities; reached England in 1796.

Corm.-Ovoid, an inch and a half in diameter.

Leaves.-Lanceolate, about a foot high and an inch wide. 


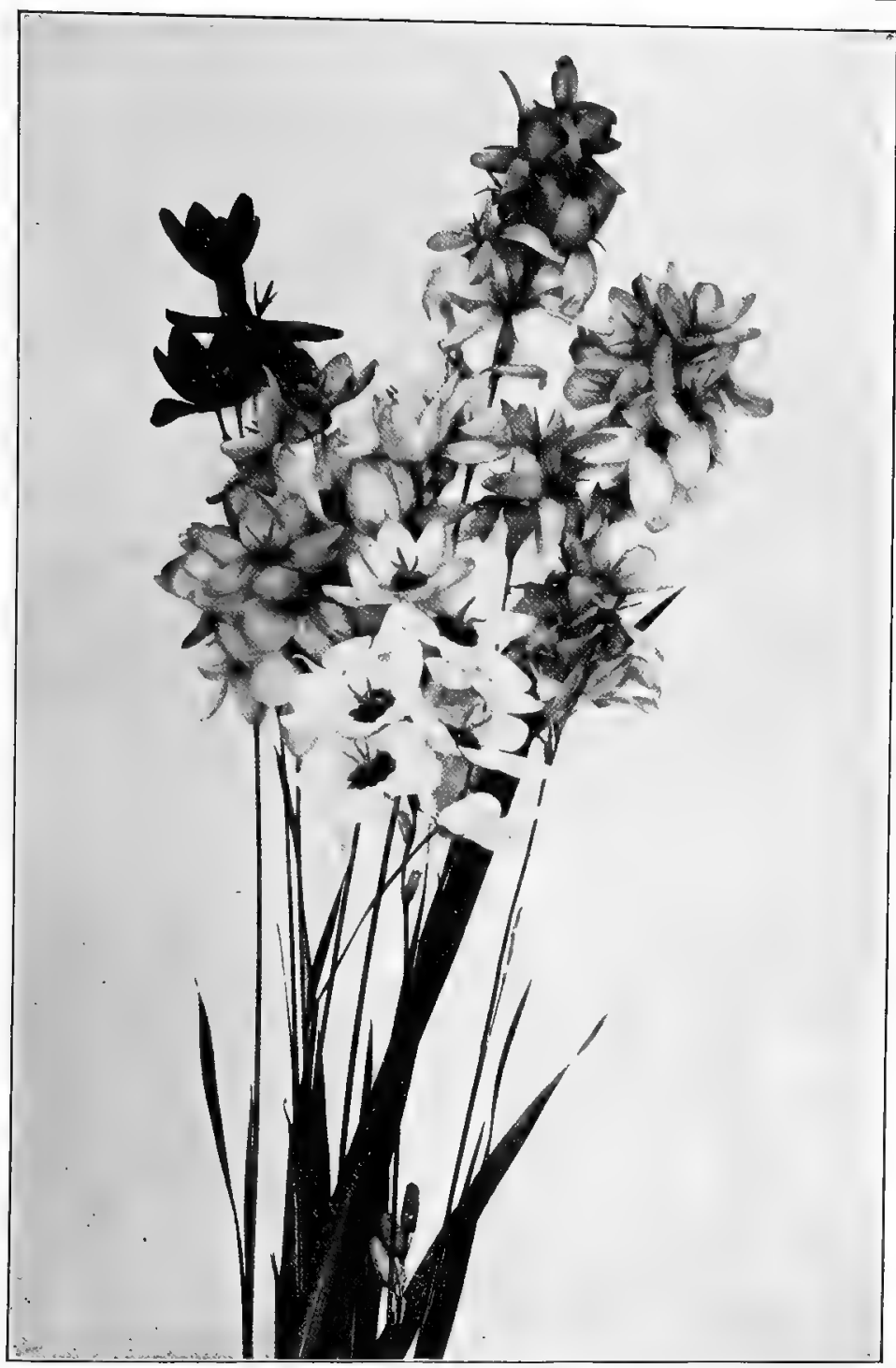

Ixia. Ixia 
Scape-Cylindrical, bearing two or more flowers at the summit.

Flowers.-About four inches across, borne from a long spathe.

Perianth.-Segments in two sets; dissimilar but grown together in a cup at the base, spreading at the top. Outer segments obovate, brilliantly colored and spotted; inner segments fiddle-shaped, smaller than the outer, also brilliantly colored and spotted.

Stamens.-Three, the filaments united into a long cylindrical tube which encloses the style.

Ovary.-Three-celled; style long, with three two-parted branches.

Tigridia pavonia has been in cultivation in the gardens of Europe for more than three hundred years. It is one of the ten-

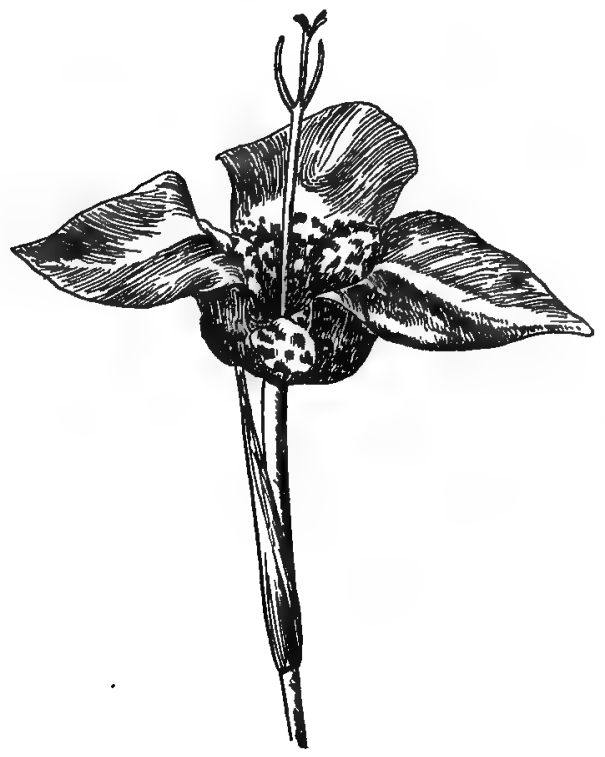

Tigridia. Tigridia pavonia der bulbous plants of Mexico which in order to flourish at the North require the same treatment that we give to gladiolus. Although a most unique and interesting plant, it cannot compare with gladiolus either in beauty or effectiveness, for its flowers are both solitary and fugitive. The color range of this fantastic flower is splendid, reaching the extreme hues of red, orange, and yellow in combinations so barbaric that the tiger and the peacock may well stand sponsors for its name. A child of the tropics, it rejoices and thrives under the heat of our summer sun.

In the genus there are some eight or ten species whose habitat ranges from Mexico to Peru and Chili; only one is found within 
the limits of the United States. Tigridia pavonia with its hybrids and variants is the species commonly cultivated. Destitute of fragrance, its value lies in its marvellous coloring.

\section{BLACKBERRY LILY}

Belamcânda chinénsis. Pardânthus sinénsis.

The only species in the genus; escaped from old gardens to roadsides and meadows. Native of China and Japan. June, July.

Rootstock.-A short, stoloniferous rhizome.

Stem.-Three to four feet high, erect, leafy.

Leaves.-Equitant, eight to eighteen inches long, about one inch broad.

Flowers.-In loose terminal corymb; orange, dotted with crimson and purple. The three sepaloid segments of the perianth a trifle longer than the three petaloid.

Stamens.-Three; style slender; stigma three-lobed.

Capsule.-More than an inch long; the three valves are reflexed and the black shining seeds cling to the central placenta in a way to suggest a blackberry.

One meets the Blackberry Lily by the roadside; rarely is it found within the garden gate. There are two reasons for this: the foliage though of the iris type adds nothing to the foliage effect of the garden, and the blossom though apparently a lily is a small lily, not more than two and a half inches across. These blossoms last but for a day; not more than two or three are in bloom

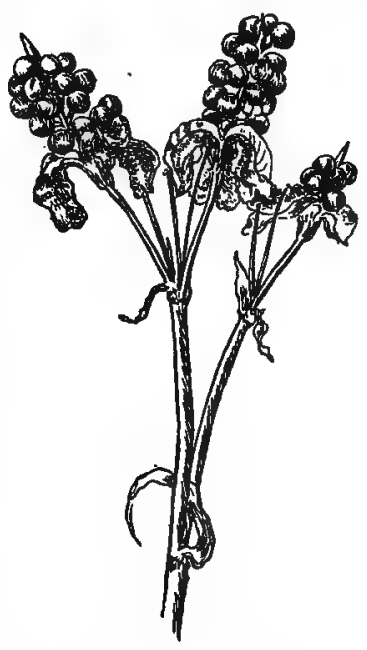

Fruit of the Blackberry Lily at one time on a single stem. The color is striking, orange dotted with red, darker in effect though of the same type as the tiger-lily. But the petals never achieve the curve which makes the tiger-lily so attractive; the flower is 


\section{IRIS FAMILY}

always a flat, six-pointed star. The common name is suggested by the ripened capsule; an enlarged central column comes up through the ovary, the outside covering falls away, the round

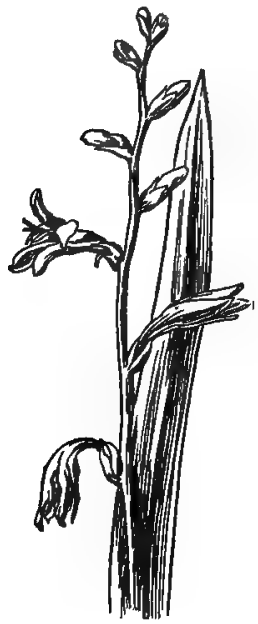

Montbretia. Tritónia crocosmatiora

black seeds cling fast to the column and form a clever imitation of a ripe and luscious blackberry.

\section{MONTBRETIA}

Montbrètia. Tritònia cracosmafldra.

Tritonia from Triton, a vane, alluding to the variable directions of the anthers in different species.

Root.-Bulbous.

Leaves.-Tall, stiff, narrow, abundant.

Flowers.-In spike-like racemes, orange-scarlet.

Perianth.-Lily-like, six-cleft.

This familiar Montbretia is a hybrid of two South African species and is regarded as the best of the garden forms. It is a hardy, summer-flowering bulb, to be treated like gladiolus, although it is said that it may be left out-of-doors for the winter, if given some protection. 


\section{SCITAMINÀCEA-BANANA FAMILY}

\section{CANNA. INDIAN SHOT}

Cânna hýbrida.

Name of Oriental origin and of no application, so far as known.

A stout, unbranched, large-leaved, tropical plant, with brilliant ornamental flowers and showy foliage. Of garden origin.

Stem.-Erect, simple, three to five feet high.

Leaves.-Large, oblong, acute.

Flowers.-Extremely irregular, large, brilliant red, yellow, or particolored, borne in a terminal raceme or panicle.

Calyx.-Of three oblong, pointed sepals, normally green, but in the highly bred varieties taking on the color of the corolla.

Corolla.-Of three narrow, pointed petals more or less rolled into a tube.

Stamens.-Represented by the apparent petals, five; two or three of which are much lengthened and broadened; another is narrowed and deflexed and forms the lip of the flower, and one, more or less coiled or rolled upon itself, bears the solitary one-celled anther, clinging rather precariously at one edge.

Ovary.-At the very base, small, green, covered with minute tubercles, three-celled, containing many ovules. Style is long, flattened, color of flower; the stigmatic surface extending about a quarter of an inch.

Capsule--Large, three-celled, many-seeded.

Cannas are favorites largely because they give such generous return for the care expended upon them. The higher kinds quickly make a leafy hedge, the lower will give a brilliant bed of color, and both will do the thing expected of them in a comparatively brief period. People ordinarily depend upon the nearest florist for their Cannas, and these come to hand well started in little pots; but the roots can be kept over winter as easily as those of the 
dahlia, and a plantation once established need not be lost. If one wishes fo make experiments, it is necessary only to sow the seeds, and the seedlings may be wonders.

The blossom is marvellously irregular. We are accustomed to double flowers like the rose and the water-lily. We know that

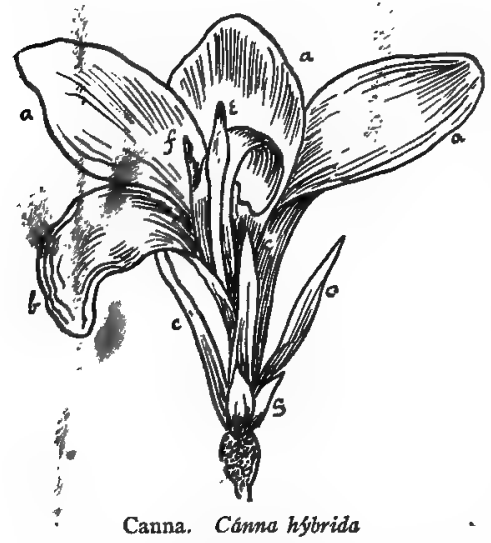

$a a a b$, petal-like bodies representing the stamens, called staminodia; $b$, is the staminodia that forms the lip of the flower; $f$, is the anther clingin" to the side of the fifth staminodia; $c$, is style; $c c c_{*}$ the petals; $s$, the calyx. now and then in a flower the corolla disappears and the calyx comes forth, brave in seeming and lovely of color, as in the larkspurs; but we are not quite prepared to have the filaments of the stamens broaden into apparent petals and produce the beauty and the glory of the flower, and yet this is precisely what the Canna does.

The history of the garden race is well known and few flowers have shown more remarkable development in recent years. At the present time the Crozy Cannas, so named from Crozy, of Lyons, France, who introduced the greater number of them, are most popular. This type is often called the French Dwarf, or the Flowering Canna, and is marked by a comparatively low stature and very large and showy flowers in many colors; whereas the Cannas of a few years ago were very tall plants, with small, late, dull-red, narrow flowers, and were grown exclusively for their foliage effects. How has this transformation come about? In the first place, it should be said that there are many species, and about half a dozen of these were well known to gardeners by 1800 . About 1830 they began to attract much attention from cultivators, and the original species were soon variously hybridized. Crossed seeds and seeds from the successive generations of hybrids introduced a host of new and variable forms. 
The first distinct fashion seems to have been for tall, lateflowering forms. In 1848, Annee, a cultivator in France, sowed seeds of Canna Nepalénsis, a tall Indian species, and there sprang up a race of plants which have since been known as Canna Annèi. It is probable that this Canna Nepalensis had become fertilized with other species growing ann Annee's collection, very likely with Canna glàuca, from tropical America. At any rate, this race of Cannas became popular and was to its time what the French Dwarfs are to the present day. The plants were freely introduced into parks, beginning about 1856 , but their use began to wane by 1870 , or before. Descendants of this type various crossed and modified are now frequently seen in parks and gardens.

The beginning of the modern race of dwarf, large-flowered plants was in 1863 , when one of the smaller-flowered Costa Rican species, Canna Warscewiczii, was crossed upon a large-flowered Peruvian species, Canna iridiftòra. The offspring of this union came to be called Canna Ehemanni. This hybrid has been again yariously crossed with other species and modified by cultivation and selection, until the present composite type is the result. Seeds give new varieties; and any seedling which is worth saving is thereafter multiplied by division of the root and the resulting plants are introduced to commerce.

Since new forms are so easily obtained, it is not surprising that our great florists so frequently place new varieties upon the market. But the characteristics of the race are well fixed and the plants fall into certain definite groups regardless of high-sounding names. In habit they are either standard or dwarf; the foliage is either green or bronze; the flowers are self-colored, spotted, blotched, or edged, all brilliant and all beautiful. 


\section{ORCHIDÀCEA-ORCHIS FAMILY}

Orchidaceæ are a group of perennial plants so organized as to be absolutely dependent upon insects for fertilization. Failing of insect help they cannot mature seeds. The flowers are always irregular and often fantastic in shape, on the plan of three. The perianth has three sepaloid divisions which are outer and three petaloid segments which are inner. One of the inner set differs more or less in form from the others and is called the lip. This lip is really the upper petal, but by a twist of the ovary it is commonly directed forward and downward. Before the lip is the column composed of one stamen, or of two stamens and a rudiment of a third, variously borne on the style, or thick, fleshy stigma. The fruit is a one-celled, three-valved capsule filled with innumerable minute seeds appearing like fine sawdust.

\section{CYPRIPEDIUM. LADY'S SLIPPER}

\section{Cypripèdium.}

Cypripedium, the Slipper of Venus.

Root.-Of many tufted fibres.

Leaves.-Large, many-nerved, and plaited, sheathing at the base.

Flowers. - Solitary or few, large and showy, the lip becoming a large infiated sac. Sepaloid segments spreading; all three distinct, or usually two united into one under the lip. Petaloid segments three; one becoming the large sac, the other two resembling the sepaloids, only narrower.

Column.-Declined; on each side a fertile stamen with its short filament bearing a two-celled anther. On the upper side is a dilated, triangular, thickish body which covers the summit of the style. ish.

Sligma.-Terminal, broad, obscurely three-lobed, moist and rough-

Pollen--Viscid, adhering to whatever touches it. 


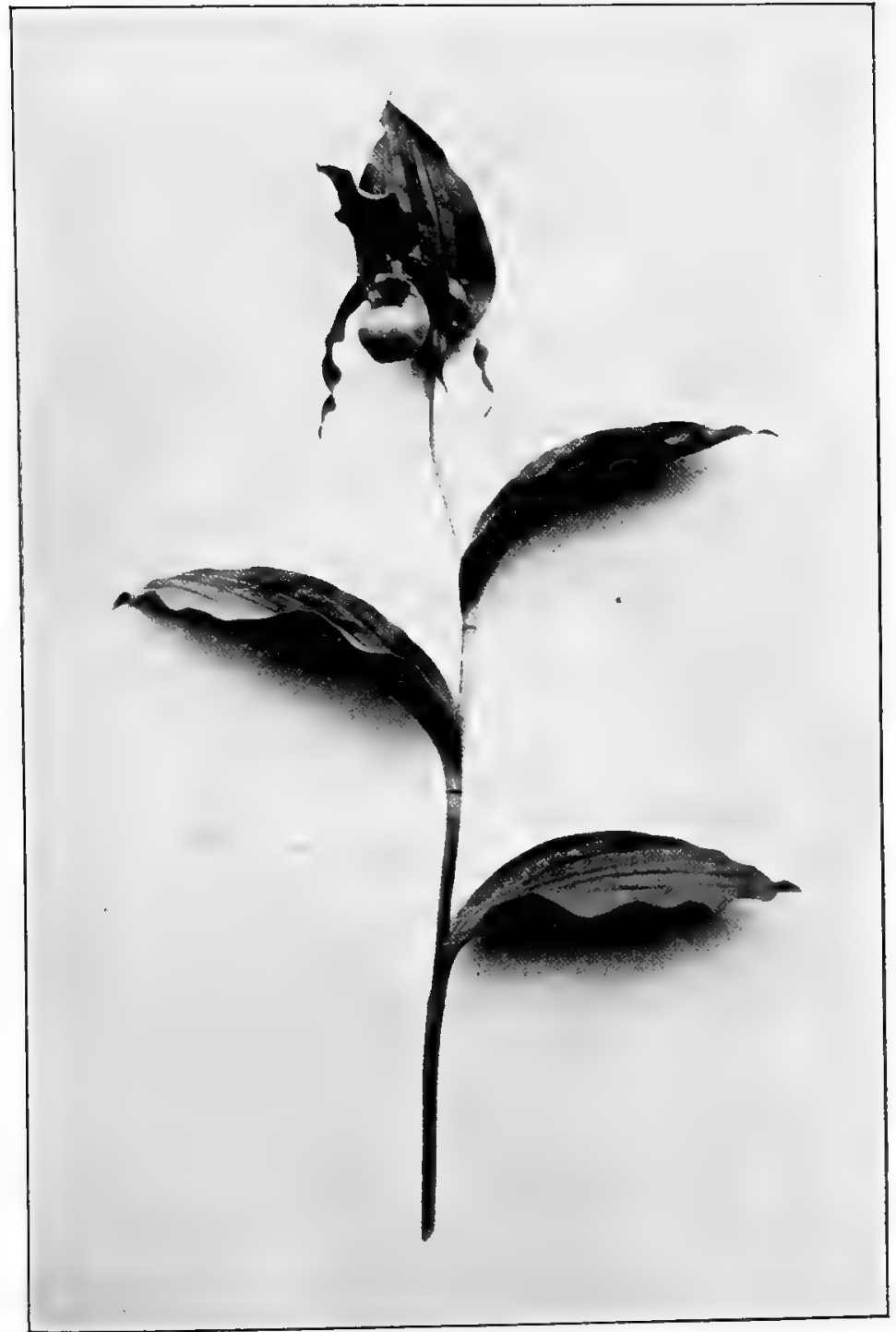

Lady's Slipper. Cypripèdium 


\section{ORCHIS FAMILY}

Six species of Cypripedium are found within our northern range, all beautiful. The plants love cold bogs and prefer peat soil; are often found in low, moist woods. The distinguishing characteristic which makes them noticeable is the sac into which one of the petals is transformed. The other two petals look like sepals, but this one becomes the whole flower to the ordinary observer. There are two species that will do well in the garden, Cypripedium acaùle and Cypripedium pubéscens. Cypripedium acaùle is a stemless species bearing its rose-purple Venus Slipper at the summit of a naked scape. Cypripedium pubéscens bears a very beautiful yellow blossom upon a downy, leafy stem. 


\section{URTICÀCEA-NETTLE FAMILY}

\section{COMMON HOP}

\section{Himulus lipulus.}

Humulus, a late Latin name of Teutonic origin.

A perennial, twining vine, native to Europe and North America; long cultivated for the hops, which are used in the brewing of beer. Native to river banks and thickets at the north.

Stems.-Growing twenty-five to thirty feet long in a single season; rough, hairy.

Leaves.-Opposite; ovate or-orbicular-ovate in general outline, palmately three-lobed, sometimes more, or the upper leaves not lobed; margins strongly dentate; petioles long.

Flowers.-Diœcious; staminate flowers with five erect stamens, and a five-parted calyx, in little, drooping, tassel-like racemes; pistillate flowers with an entire perianth closely investing the ovary, which bears two long stigmas. The flowers are in pairs under large overlapping bracts, these making a cone-like catkin.

Fruit.-Is the enlarged and mature pistillate catkin, oblong or ovoid, loose and papery; straw-yellow; often two inches or more long, glandular and fragrant. Seed is really an akene.

The Wild Hop is found trailing and climbing over the bushes and in the thickets of river banks at the north throughout three continents.

The fruit is a beautiful straw-yellow sort of catkin, called hop, abundantly sprinkled with yellow resinous grains which give it the bitterness and aroma that make it valuable in the manufacture of beer.

Pliny mentions this as one of the garden plants of the Romans, who, it appears, ate the young shoots as we eat asparagus. It is said this is still done in some parts of England. 
The Hop is essentially a field plant; yet it has a real value as a cover vine, because of its easy cultivation, luxuriant growth, and abundant foliage; and in September the great drooping bunches

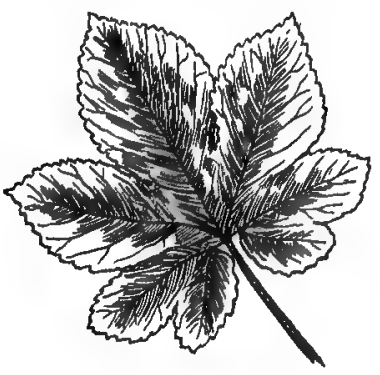

Japanese Hop. Himulus japónicus of mature catkins are very graceful and attractive.

Japanese Hop, Humulus japonicus, the species oftenest found in gardens, came to us in I886 and at once achieved a popularity that it has never lost. The leaves are usually five-lobed and often streaked and splashed with white. It is easy of cultivation, is a quick grower, and will make good vines from seed sown in the spring; but in autumn it lacks the charm of the hanging hops of Humulus lupulus, for its pistillate catkins do not enlarge in fruit. 


\section{ARISTOLOCHIÀCEA-BIRTHWORT FAMILY}

\section{PIPE VINE. DUTCHMAN'S PIPE}

Aristolòchia macrophỷlla. Aristolòchia sìpho.

Aristolochia is the ancient name; supposed to refer to medicinal properties.

A perennial, climbing, woody vine, found in rich woods from Pennsylvania to Minnesota and south to Georgia and Kansas; cultivated as a trellis and porch cover. May, June.

Stem.-Twining, nearly glabrous.

Leaves.-Alternate, brightgreen, large, heart-shaped, or reniform, margin entire, apex acute.

Flowers.-Solitary on long peduncles, brownish.

Calyx.-An inflated, curved, yellowish-green, veiny tube, enlarged a bove the ovary, con-

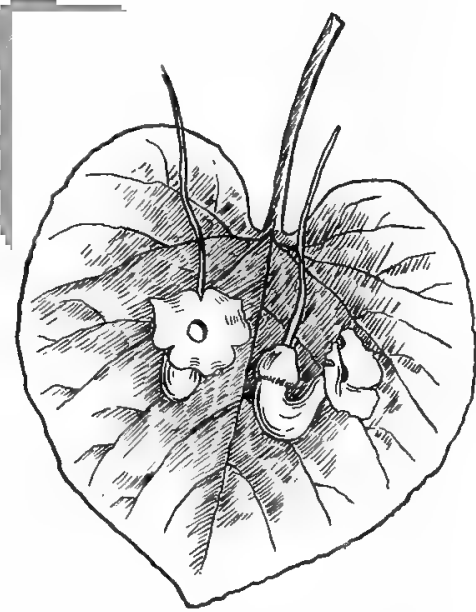

Pipe Vine. Aristolòchia macrophýlla tracted at the throat; the flat border brownish-purple and obscurely three-lobed.

Corolla.-Wanting.

Stamens.-Six anthers and no filaments, in united pairs under the three lobes of the short, thick stigma.

Fruit.-A many-seeded, six-lobed capsule.

This is one of our best hardy climbing vines for screen or shade, as its great leaves overlap each other and quickly form a leafy wall. In rich soil along the Alleghany Mountains and on the 


\section{BIRTHWORT FAMILY}

ranges farther south it clings to the trees and forms dense masses of foliage; the leaves sometimes more than a foot across.

The blossoms are borne on the old wood, usually solitary, but sometimes two or three together on long, slender petioles. Their color is produced by numberless tiny, brownish-purple dots and ridges upon a background of dull orange. The flower is not beautiful, but curious and interesting.

The genus Aristolochia is a large one, though there are but few species native within the limits of the United States. As a whole the genus is characterized by grotesque flowers with offensive odor, though the Dutchman's Pipe does not offend in this respect. 


\section{POLYGONÀGEÆ-BUCKWHEAT FAMILY}

Herbs with alternate entire leaves, and stipules in the form of sheaths above the swollen joints of the stem. The flowers are mostly perfect, with a more or less persistent calyx. The calyx is three to six cleft; corolla absent; stamens four to twelve inserted on the base of the calyx; ovary one-celled and bearing two or three styles or stigmas. The fruit usually an akene, compressed, angled, or winged.

The family includes the Buckwheat of commerce, the familiar Rhubarb, the Bushy Polygonums, and the Prince's Feather of the garden, together with sundry and divers well-established weeds, among them the Docks and the Smartweeds.

\section{BUSHY POLYGONUM}

\section{Polýgonum Sièboldi. Polýgonum cuspidàtum.}

An excellent representative of the perennial, bushy, high-growing polygonums; effective for bold effects and desirable for the flowering mass it produces in autumn. Appears in several hybrids. Japan.

Polygonum sachalinénse is a similar plant; more robust and likely to become a pest from its power to spread. Also from Japan.

Stem.-Stout, handsome, bushy, three to five feet high; dying to the ground in winter.

Leaves.-Short-oval to broad-ovate, truncate or slightly cordate at base, abruptly pointed, the strong side veinlets uniting in marginal loops. Sheaths short and flaring, deciduous.

Flowers.-Small, whitish in type, very numerous in slender-panicled racemes in the axils of the leaves.

Calyx. - White, four to five cleft.

Corolla.-Wanting.

Stamens.-Eight.

Ovary.-One-celled; style three-parted and fruit a triangular akene, surrounded by the white calyx. 
The Bushy Polygonum is interesting in that it plays the game of now you see it and now you do not. We expect that, of course, in the case of ordinary herbaceous perennials, but this Polygonum

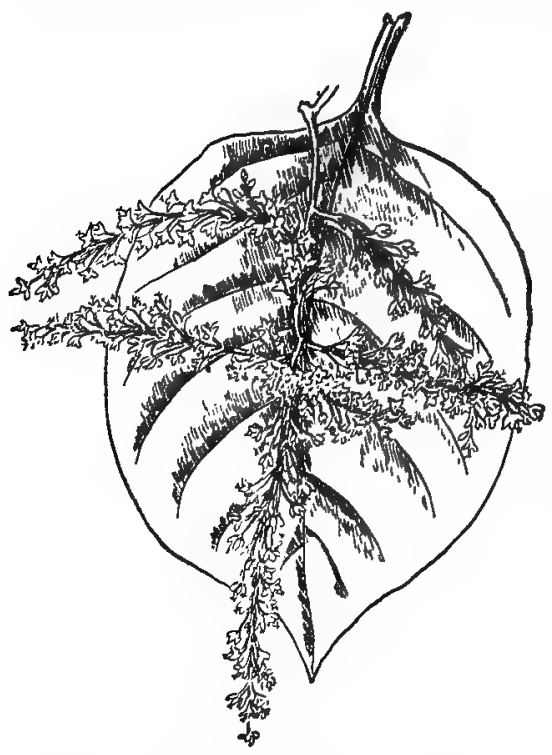

Bushy Polygonum. Polygonum cuspiddum so perfectly counterfeits a bush that it is a distinct surprise to discover in the spring that it is not a bush. But the place that knew it knows it again, for the root system is vigorous, the strong stems rise in numbers, curve gracefully outward, and in a short time the plant assumes the poise and character of a well-grown bush.

In late August or early September, from the axils of the leaves on the upper half of the stem appear panicled racemes of small flowers which transform the bushy top into a cloudy mass of white or pink which lasts until snow flies. Then flower and stem die together and the bush disappears only to be renewed the coming year.

The flower holds its color because the color resides in the calyx, and the calyx persists in order to protect the fruit.

Polygonum sachalinense, very much like Sieboldi, but larger and more vigorous, has been rather generally distributed but has proved itself too much of a weed; indeed, one should think twice, possibly thrice, before planting any Bushy Polygonum within the garden enclosure.

A twining woody Polygonum, Polygonum baldschuanicum, is recommended as an interesting and showy climber which blooms profusely in late summer. 


\section{PRINCE'S FEATHER}

\section{Polýgonum orientàle.}

Polygonum, Greek for many-kneed; from the swollen joints of the stem.

A tall-growing, branching annual, perhaps the best garden representative of the polygonums. Sparingly escaped into waste grounds; native to India. Summer.

Stem.-Three to four feet high, hairy, branching above, bearing long, slender, nodding spikes of bright rose-pink flowers.

Leaves.-Alternate, large, ovate, or oblong, entire, pointed, distinctly petioled; with stipules in the form of sheaths above the swollen joints of the stem.

Flowers.- Rose-pink or flesh-color, in close cylindrical spikes arranged in open panicles.

Calyx.-Deep-rose, four to five parted, persistent.

Corolla.-Wanting.

Stamens.-Seven, exserted.

Ovary.-Flat, one-celled; style twocleft.

Fruit.-A lenticular shining akene, surrounded by the rose-colored calyx.

The Polygonums, known chiefly by two weeds - the Knot-Grass and the Smartweed-have few representatives in the garden. The one

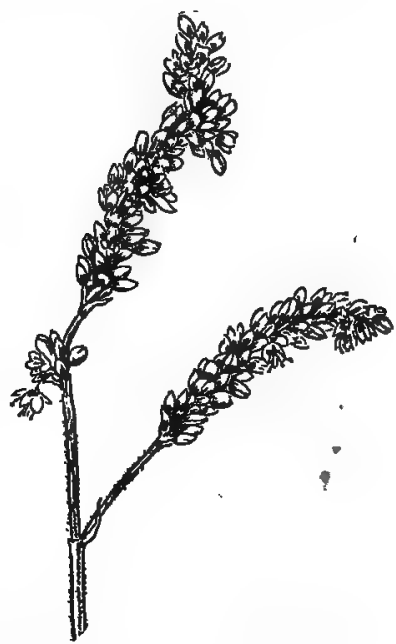

Prince's Feather. Polýgonum orientale to which least exception can be made is Prince's Feather, an inmate of old-time gardens and often self-sown in the new, but rarely planted there. It is of the same type as our native species, particularly Polygonum pennsylvanicum, but taller, with rosier flowers in longer spikes. There are so many better flowers, it does not seem worth while to give garden space to so ineffective a plant, as it neither 
masses well nor has it individual dignity, for however graceful a single nodding spike may be, it is distinctly at a disadvantage in any garden grouping.

\section{BUCKWHEAT}

\section{Fagopỳrum esculéntum.}

Fagopyrum notes the resemblance of the grain to the beechnut.

A tender, annual, grain plant. Produces a particularly fragrant honey, dark in color. Native to central Siberia and Manchuria. Sown late in summer.

Stem.-Erect, branching, slightly hairy.

Leaves.-Alternate, triangular, heart-shaped, inclining to halberdshaped or arrow-shaped, on long petioles; margins slightly ruffled, apex acute or acuminate.

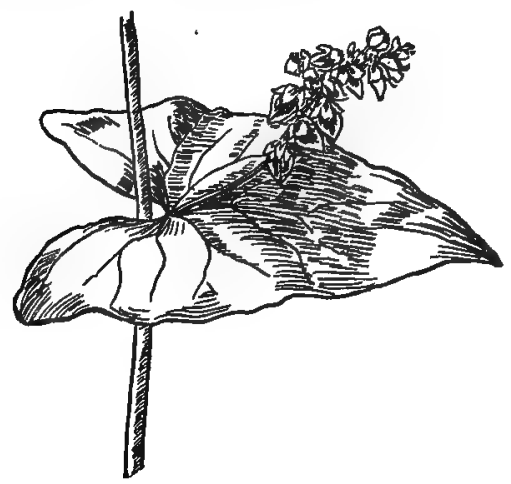

Buckwheat. Fagopýrum esculenium
Sheaths.-Semi-cylindrical.

Flowers.-White, in corymbose panicles, terminal and axillary.

Calyx,-Five white, petallike sepals, closing when still white around the triangular akene.

Corolla.-Wanting.

Stamens.-Eight, inserted at the base of the calyx and alternating with as many small honey glands.

Ovary. - Triangular, with three stigmas.

Fruit.-A triangular akene white until full-grown.

The Buckwheat field is an elysium for bees. Each little white, spreading blossom has a honey heart, as the bees well know, and Buckwheat honey is always part of the hive's resources.

Soon after the flower opens, the ovary develops into a great white, triangular, baby akene, which grows plump and still stays white, embraced by the white arms of the calyx. Finally, when 
the seed begins to mature, the calyx browns and the stems take on a strain of crimson and scarlet. When the seed is fully ripe it contains an excellent farina which is a substitute for that of cereals. Buckwheat is one of the farmer's late crops; it will grow in poor soils, requires little care, and ripens quickly.

\section{PIE-PLANT, RHUBARB}

\section{Rhèum rhapónticum.}

$R h a$, the Greek name fo: the species, was the ancient name of the Volga River; the first recorded specimens of the plant were procured from the banks of the Volga.

A strong perennial with thick, clustered roots, grown very generally throughout the United States for the succulent, acid petioles of the radical leaves which are used in early spring for pies and sauces. Native to northern and western Asia. Several garden varieties are in cultivation. May, June.

Root.--Tuberous, large, reddish-brown.

Flowering stem.-Three to five feet high, hollow, bearing large, terminal, racemose flower panicles which burst out from large white bracts; each leaf has a stipular sheath.

Radical leaves.-Very large, cordate-ovate, undulate or entire, acute at apex, glabrous and shining above, pubescent on the veins beneath, twelve to twenty-four inches long.

Petioles.-Four to ten inches long, large, semi-cylindric, fleshy, loaded with a pleasant acid juice.

Flowers.-Small, whitish, borne in tall, leafy, densely flowered panicles; the pedicles jointed below the middle.

Perianth.-Six-parted, greenish with white margins, spreading.

Stamens.-Six or nine.

Ovary.-Three-angled and bearing three styles.

Fruit.-An akene, with three-winged angles.

De Candolle named our Pie-plant the Rhubarb-from-Pontus; its native land, however, is not limited to Pontus, but includes Siberia as well as western Asia.

Like the celery; the Rhubarb is cultivated for its leaf stalks; both leaf and root are worthless; it is the large, juicy, suc- 


\section{PIE-PLANT}

culent petiole, heavy with malic and citric acid, that has culinary value.

The Rhubarb of the materia medica is the root of one or more species of Rheum growing in China. This first came into Europe by way of Turkey, then through Russia, and it is now exported directly from China. Rheum palmàtum, a species with palmately lobed leaves, is believed to produce the larger part of the world's supply. 


\section{CHENOPODIÀCEA-GOOSEFOOT FAMILY}

The Chenopods are a family of homely, weed-like herbs, more or less succulent, with alternate leaves and minute, usually greenish flowers. The calyx is persistent, three to five lobed or cleft; corolla absent; stamens usually as many as the lobes of the corolla; ovary one-celled; styles and stigmas two to five. The fruit is an akene or utricle. The family includes several potherbs such as Beet and Spinach; a group of aromatic Goosefoots sometimes found in gardens; Kochia, a plant but recently in general cultivation; also, the well-known Madeira Vine is referred to this family.

\section{BEET}

Bèta vulgùris.

Beta, Celtic from bett, red; the ancient name.

The Garden Beet of cultivation, the original form of which grows on the coasts of southern Europe, reaching as far north as the Straits of Dover.

Root.-Biennial, fleshy, terete, tapering downward, red or yellow.

Leaves.-Radical, large, greenish-purple, ovate-oblong; petioles four to eight inches long, succulent, channelled.

Flower stem.-Two to four feet high, leafy, paniculately branching, bearing dense, sessile, axillary clusters, interruptedly spicate. base.

Calyx._Urn-shaped, three-bracted, five-cleft; finally hardened at

Corolla.-Wanting.

Stamens.-Five.

Style.-Short; stigmas two.

Fruit.-An akene.

The Goosefoot family is chiefly known to us by a few vilesmelling weeds abounding in waste places; but it includes one 
plant of great economic value, Beta vulgaris, the Garden Beet. Native to the Mediterranean region and cultivated from Roman times, this species has been developed along three lines-as a root-vegetable, a leaf-vegetable, as well as a foliage plant.

The root-vegetable varieties cultivated in our gardens constitute our table Beets. Their color and form vary from dark bloodred to pink and white and from turnip-shaped to long-tapering forms. As a vegetable, the Garden Beet is boiled, pickled, used as a salad, and the tops cooked for "greens" in the same way that spinach is cooked.

Mangel-wurzel is a coarse form used for cattle-feeding, having large tops and often very large roots. The Sugar Beet is simply a form of the common Beet in which the percentage of sugar has been largely increased by cultivation and selection.

The strain of Beta vulgaris which is grown as a leaf-vegetable is generally known as Chard, or Swiss Chard. It has large tops, broad leaf-blades, and succulent leaf-stems.

The foliage varieties of Beets are grown for their ornamental value, and are used for bedding and for borders where strong and heavy effects are desired. The large leaves of the several varieties are richly marked with different shades of red, orange, white, and intermediate tints.

\section{SPINACH. SPINAGE}

\section{Spinàcia oleràcea.}

Spinach, bearing a spine; referring to the projection on the fruiting calyx of one species.

The common potherb of the garden. Native to south-western Asia; now widely cultivated. Annual.

Leaves.-Radical, soft, fleshy, triangular, eaten for "greens."

Flower stem.-Branching, two to three feet high, bearing axillary clusters of small flowers. Fruit an akene.

The cultivated forms of Spinach have developed large, radical leaves, and the shape of the leaf varies away from the tri- 
angular type. It is a cool-season plant and is in the market spring and fall; the summer leaves are tough. In summer its place is often taken by the New Zealand Spinach, which is a warm-weather plant; it, however, is not related to the ordinary Spinach, but is a Tetragonia, belonging to the Ficoidea.

\section{JERUSALEM OAK. FEATHER -GERANIUM}

\section{Chenopòdium bòtrys.}

St.om.-Low, spreading, clammy, pubescent, sweet-scented.

Leaves.-Sinuate-pinnatifid, slenderpetioled.

Flowers.-M in ute, abundant in loosely corymbed racemes; sweetscented.

Calyx.-Five-cleft; ovary and utricle depressed.

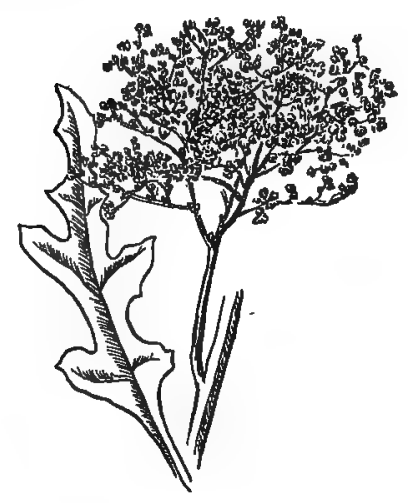

Feather Geranium is extremely Feather Geranium. Chenopòdium bòtrys aromatic-stem, leaves, flower, and fruit all heavy with fragrance. The plant is spreading, half-prostrate; is weedy in habit and not often found in modern gardens.

\section{MOCK CYPRESS. MEXICAN FIRE PLANT}

\section{Kòchia scopària.}

Kochia, in honor of Dr. Koch, professor of botany at Erlangen, I77 I-1849.

Stem.-Two to three feet high, erect, much branched; branches slender, standing close to the main stem.

Leaves.-Alternate, narrow, one to three inches long.

Flowers.-Numerous, inconspicuous, green, more or less clustered in the axils of the leaves.

Perianth.-Orbicular, five-lobed.

Stamens.-Five; stigmas two to three. 
The Mock Cypress is a little chenopod growing usually about two feet high and curiously resembling a small, closely sheared evergreen; the foliage being a pale bright-green until September, when the entire plant-stem, leaves, fruit-becomes a mass of deep crimson. The minute flowers are borne in the axils of the leaves and are followed by small, angular akenes. The plant is largely used for dwarf hedges or to emphasize a garden path; it passes with the summer but makes its exit in a blaze of glory. The name Mexican Fire Plant, which was first given it, is a misnomer, as the plant is not Mexican nor even American, but is native to southern Europe and western Asia.

The Madeira Vine, Boussingaùltia baselloides, is a rapid-growing vine prized for porches and arbors. The roots are stored in the winter and planted out after danger from frost is past. The stem will often reach twenty feet in a season, and in late summer bears numerous racemes of small white flowers of delicious fragrance. It is a plant of easy culture, native to Ecuador. 


\section{AMARANTÀGEA-AMARANTH FAMILY}

The Amaranths' are a group of plants, chiefly herbs and largely weeds, whose inconspicuous flowers are provided with dry, crowded, and persistent bracts which, in the cultivated species, are brilliantly colored. The flowers are always destitute of a corolla and frequently without a calyx.

Among the well-known garden species are Love-Lies-Bleeding, Prince's Feather, Celosia, and Globe Amaranth, together with the familiar bedding species, Telenthera and Iresine. The Pigweed of waste places belongs to this family.

\section{THE RED AMARANTHS}

Amarantus caudàtus. Amarántus Gangèticus. Amaràntus trícolor.

Amarantus, Greek for unfading.

Leaves.-Alternate; mostly long-petioled.

Flowers.-Monœcious or polygamous, in axillary or terminal spiked clusters. Three dry bracts at each flower.

Calyx.-Five or three erect sepals.

Corolla.-Wanting.

Stamens.-Five, sometimes three.

Ovary.-One-celled, stigmas two or three; fruit a utricle, pointed at apex, opening transversely, the upper part falling off as a lid, discharging the seed.

As has been said, "the Amaranth is a fact and a fancy. It is the flower of immortality, the flower of love, the flower of fame, and, the flower that accompanies Hope until she is swallowed by Despair. Amarantus is the unfading flower, amar, giving the adjective to the noun. By a confusion common in the history of 


\section{PRINCE'S FEATHER}

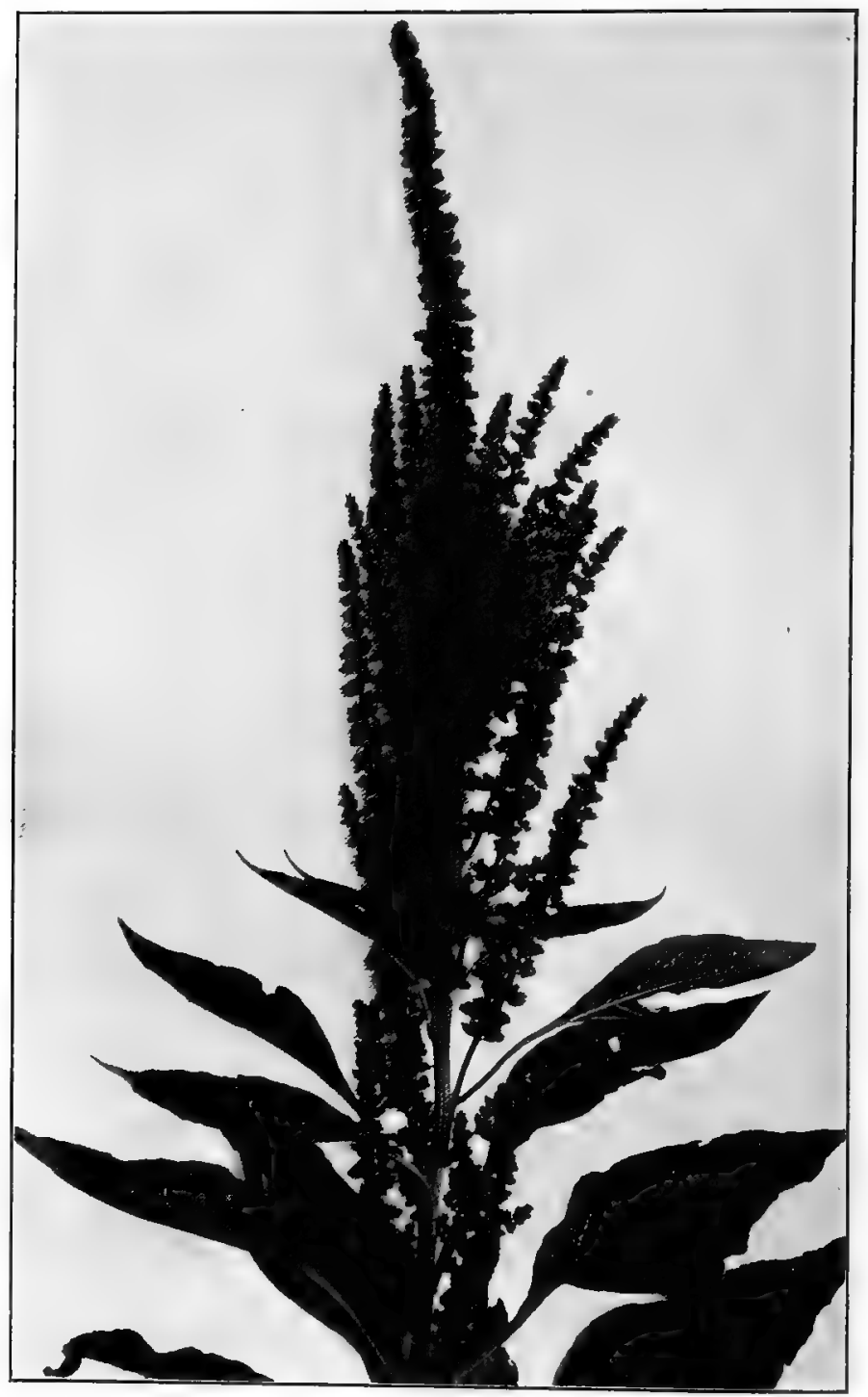

Prince's Feather. Amarantus candàtus 
words, amar has been considered amor and the unfading flower becomes the flower of love."

All the Amaranths are coarse annuals, most of them undesirable weeds, but a few Asiatic species whose persistent bracts are red and not brown have been welcomed to the garden.

Love-Lies-Bleeding, Amarantus Gangeticus, bears tall red spikes more or less branching but blunt, thick, and lumpy. The central spike is longer than the others and drooping.

Prince's Feather, Amarantus candatus, is similar, but with upright instead of pendent inflorescence, a somewhat coarser plant; Joseph's Coat, Amarantus tricolor, has foliage marked with red, violet, or yellow, and its stems and stalks are red. It, as well as Love-Lies-Bleeding, is a variety of Amarantus Gangeticus, which also is grown by the Chinese in America as a potherb.

\section{BACHELOR'S BUTTON. GLOBE AMARANTH}

\section{Gomphrèna globòsa.}

Gomphrena, a corrupted ancient name for a species of amaranth; referring to the highly colored foliage of some species.

An annual, bearing terminal, globular flower-heads, whose persistent, colored bracts give them the character of everlasting flowers. India. July, October.

Stem.-Twelve to eighteen inches high.

Leaves.-Elliptic to obovate, acute, downy.

Flower-heads.-Globose, about an inch in diameter; bracts persistent, concave, keeled, purple in the type, hiding the true flowers.

Calyx.-Five-parted, packed in woolly hairs.

Stamens.-Five, filaments united to form a tube within which is the one-celled ovary.

Fruit.-A one-seeded utricle.

The Globe Amaranth was introduced into England from India in $\mathrm{I}_{7} \mathrm{I} 4$ and has, from the first, enjoyed considerable popularity. The flower-heads are spherical, an inch or more in diameter. The persistent bracts are very brilliantly colored, and if the heads 
are gathered before quite mature, and dried in the shade, they become everlasting flowers.

The garden race produces, in addition to the primitive purple, white, golden-yellow, brownish-yellow, and pink flowers.

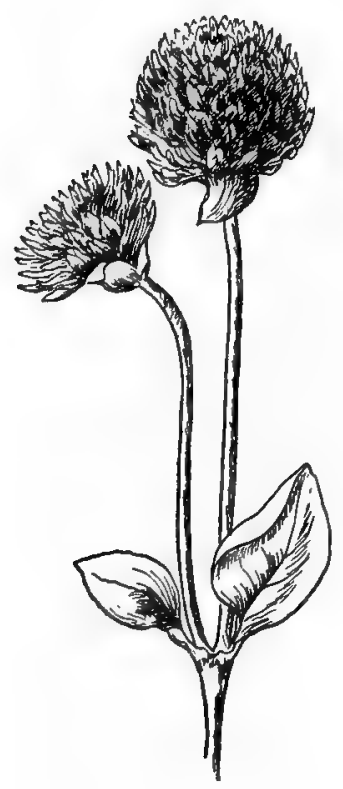

Globe Amaranth. Gomphrina globòsa

Gomphrena globosa var. nàna is a dwarf, not half the height of the type, but forming a little bush with dark-red flower-heads.

Two other species are in cultivation and appear both in type and as hybrid: Gomphrena perénnis, a perennial from South America; and Gomphrena pulchélla, from Brazil.

The Globe Amaranth is also known as Bachelor's Button, though two other entirely distinct plants, Centaurea cyanus and Ranunculus acris, have the same popular name.

\section{CELOSIA. COCKSCOMB}

Celòsia cristàta.

Celosia, Greek, dried or burnt; referring to the dry, scarious bracts.

Leaves.-Alternate, usually long-petioled. Flowers.-Borne in crowded spikes, each minute blossom with its shining, brilliant bracts. In cultivation these spikes are often changed into crests corrugated and frilled at the edge like a cock's comb.

Calyx.-Five spreading segments, subtended by three bracts.

Stamens.-Five, united at their base to form a cup.

Fruit.-Utricle, the upper part falling off as a lid.

The Celosia is one of the old plants in cultivation, the earliest English record of it standing, "from Asia, I 570." The primitive form was characterized by erect, pyramidal, plumy panicles. The garden form which appears in the illustration is a monstros- 
CELOSIA

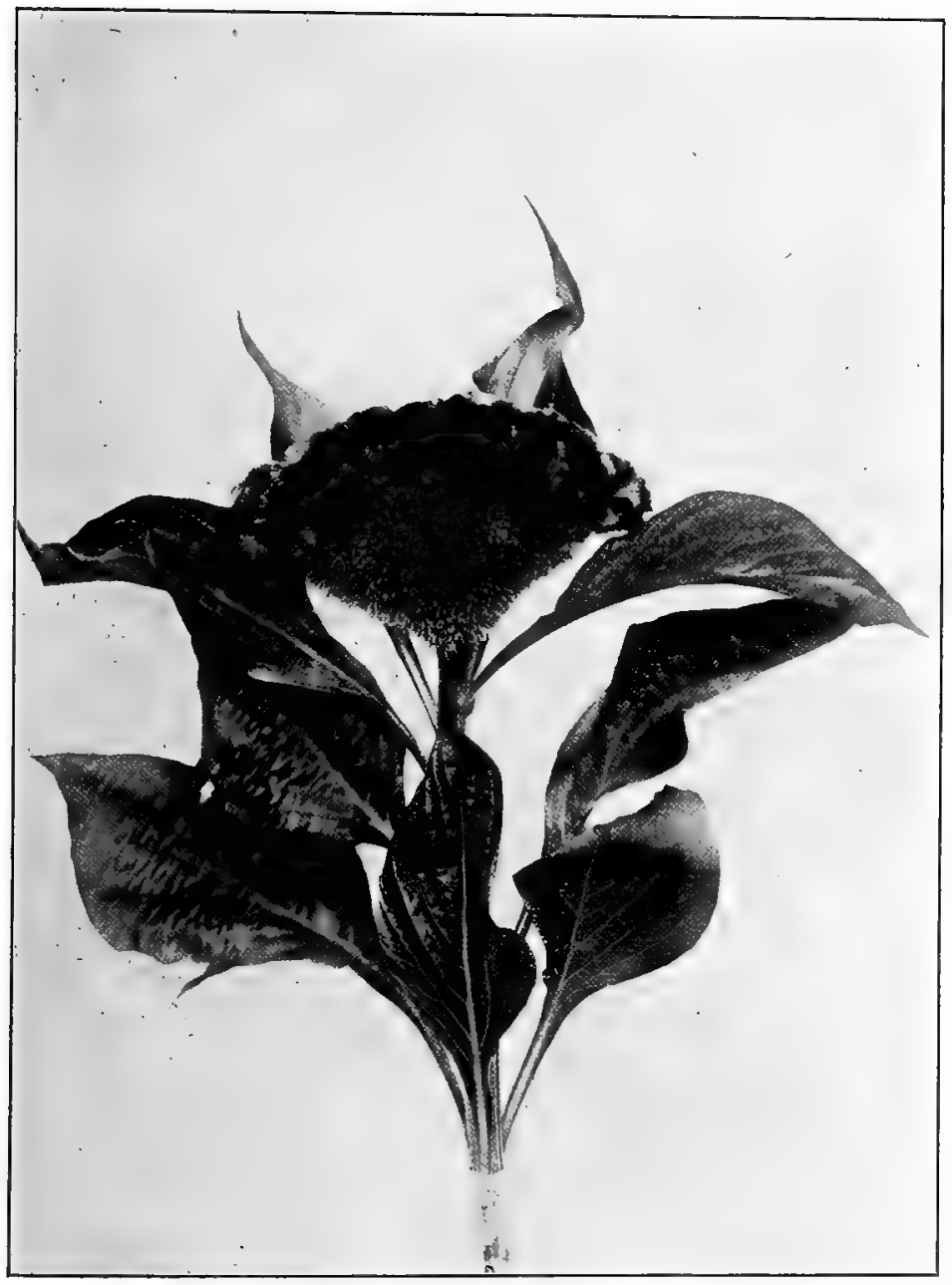

Celosia. Celòsia cristàta var. monstrata 
ity in which the stems and plumes have become laterally joined, with a partial suppression of their upward growth-the botanists call this change fasciation.

The primitive form has always remained in cultivation and very airy, graceful, beautiful varieties are now offered by florists, which are a welcome addition to the flowers of October.

The color variations range through reds and yellows. The brilliant coloring is due to a vast number of small bracts intermingled with the flowers. These persist unchanged from the opening of the perianth to the maturing of the seeds; thus making a long blooming season and giving value to the plant.

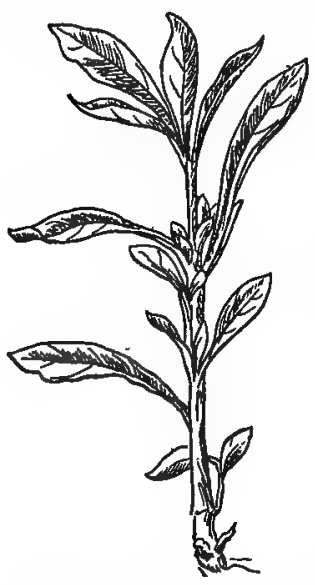

Alternanthera. Telanihera

\section{ALTERNANTHERA}

Telanthèra.

Telanthera, Greek for complete anthers.

Leaves.-Opposite, small, variable in shape, inclined to be obovate.

Flowers.-Small, perfect, in small axillary clusters.

Calyx.-Five-parted, the divisions unequal.

Corolla.-Wanting.

Stamens.-Five, anther-bearing, alternating with five sterile filaments of the same length; all united into a short tube.

These low-growing Brazilian weeds have a very definite value to gardeners, as they rank among the stock plants for the foundation work in carpet-bedding. They are amaranths, and, like most of the family, the flower is small and consists principally of bracts and stamens. Their value lies not in their flowers, but in their firm little leaves; and three species of Alternanthera, which are distinguished by the color of their leaves and the height of the plant, are recorded as in cultivation. No doubt considerable hybridization has occurred among them, but in any case the gardeners divide the present race into two definite groups: in the 
leaves of one the yellow-greens predominate, in those of the other the copper-reds. In addition they display orange, red, purple, green, bronze, pink, and brown in bewildering confusion. The colors blend in an exquisite harmony, subdued yet effective. If one must have carpet-beds, these little Brazilian weeds can do yeoman duty toward making them.

\section{IRESINE. ACHYRANTHES}

\section{Iresine Hérbstii.}

Iresine, the Greek name for a harvest garland wound in wool; in allusion to the woolly appearance of the stems of some species.

A foliage plant brought into England from southern Brazil in I864, by Mr. Herbst, of Kew Gardens. Several horticultural varieties have been developed.

Stem.-Red or yellow, twelve to eighteen inches high.

Leaves.-Opposite, variable, broadly ovate or orbicular, acute or obtuse or notched at the apex; purple-red of varied tints, with prominent veins; or green with yellow veins.

Flowers. - Small, perfect or imperfect, greenish-white, in axillary or terminal panicles.

Perianth.-Five-parted.

Stamens.-Five; stigmas two or three.

Fruit.-A little utricle.

The Iresines are a group of South American plants of brilliant foliage that are supplanting coleus in beds and borders, because they are quite as effective, considerably hardier, and bear the shears as well. The chief objection to coleus as a border

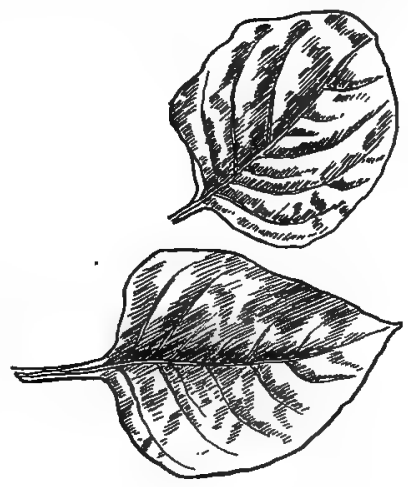

Achyranthes. Iresìne Hérbsizii plant is its extreme sensitiveness to cold; after a light frost its stems stand leafless, but Iresine will bear about as much cold as the geraniums. It appears in two colors, a deep blood-red and a greenish-yellow, of course with variations of each. 


\section{AMARANTH FAMILY}

These plants, when first introduced and imperfectly understood, were called Achyranthes, which they continue to bear as a garden name. They possess the two great virtues of bedding plants: they bear well both sun and shears, and are easy of propagation. 


\title{
NYCTAGINÀCEÆE-FOUR-O'CLOCK FAMILY
}

\author{
FOUR-O'CLOCK. MARVEL OF PERU \\ Mirábilis jaläpa.
}

Originally called admirabilis, admirable, which word Linnæus shortened.

A night-blooming perennial, usually treated as an annual; frequently used to form temporary hedges. South America. Summer.

Root.-Large and fleshy, often tuberous.

Stem.-Erect, bushy.

Leaves.-Opposite, heart-shaped at base, apex acute, margin entire. Flowers.-Funnel-shaped, borne in terminal clusters, each flower lasting for a night.

Involucre.-Looks like a calyx, five-cleft.

Calyx.-Looks like a corolla, funnel-shaped, border five-lobed, red, pink, white, yellow, variegated.

Corolla.-Wanting.

Stamens.-Five, exserted; filaments long and slender.

Ovary.-Globose; style long, slender, protruding; stigma capitate. Stigmas and anthers take on the color of the calyx to a marked degree.

Capsule.-Oblong-conical, containing one large angular seed.

To the botanist the Four-o'clock is a flower of "make believe." What looks like corolla is really calyx, what passes for calyx is really involucre, and the corolla-like calyx is red, pink, yellow, white, or variegated, as it happens, for flowers of two or more colors are frequently upon the same branch. The blossoms begin to open late in the afternoon, remain open all night, and close under the full sun of the morning. On cloudy days they stay open considerably longer. The life of a blossom is a single night; it does not reopen, having once closed. It calls to the 
dwellers of the night and fills the air with fragrance to guide them to its stores of nectar.

Ordinarily treated as an annual, the Four-o'clock is really a perennial, and forms large tuberous roots not unlike those of

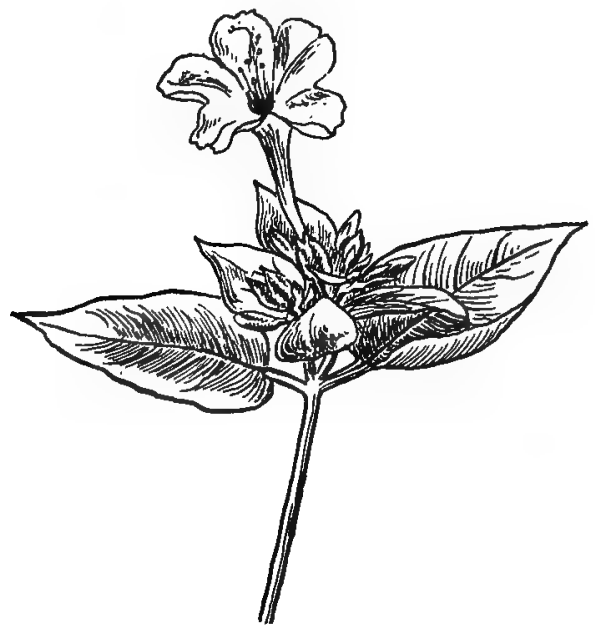

Four-o'clock. Mirábilis jalápa

the dahlia, which if stored with the dahlias and planted at the same time in the spring will produce stronger plants and better flowers than can be had from seed. The habit is bushy, and a row of plants will readily develop into a hedge which will do duty until frost comes. There are dwarf and compact varieties, also forms with variegated foliage; all will thrive in any good garden soil.

\section{ABRONIA. SAND VERBENA \\ Abrónia umbellàta. \\ Abronia, Greek, meaning graceful.}

A slender, prostrate herb of the western coast; sometimes cultivated. California. Summer.

Siem.-Prostrate, branching, jointed, tumid at the joints.

Leaves.-Opposite, ovate-oblong, thick, entire. 
Flowers.-Pink, small, in an umbel-like head, surrounded by an involucre of about five bracts.

Calyx.--Salver-shaped, looks like a corolla; border five-lobed; open by day.

Corolla.-None.

Stamens.-Five, inserted on the calyx tube; style included.

Ovary.-One-celled, containing one ovule and forming a seed-like fruit.

Abronia is a genus of about fifteen species, all native to western North America. Like the four-o'clock, the flower has no corolla, but its calyx looks like one. The leaves are opposite and at every node one leaf is larger than the other.

Abronia umbellata is a common plant along the California coast, often making masses of deep-pink on the beach. 


\section{CARYOPHYLLÀCEA-PINK FAMILY}

\section{SWEET WILLIAM. BUNCH PINK}

Dianthus barbdtus.

One of the oldest garden flowers. Its range extends from China to Russia and southward as far as the Pyrenees. Perennial. Summer.

Stems.-Tufted, glabrous, erect, swollen at the joints, ten to eighteen inches high.

Leaves.-Lanceolate or ovate, opposite.

Flowers.-Borne at the top of the stem in a flat, dense cyme; varying in color through all the reds to white. base.

Calyx.-Tubular, five-toothed, with several awl-shaped bracts at

Petals.-Five; claw long and slender; border spreading, notched and toothed.

Stamens.-Ten, exserted, maturing before the stigma.

Ovary.-Oblong, one-celled, stipulate; styles two.

Capsule.-Cylindrical, opening by four or five short teeth at the summit; seeds compressed.

Sweet Williams are worthy the respect of the Greatest Ladies who are Lovers of Flowers. -Old English Hrrbal.

Sweet William is a name of Dianthus barbatus used by the earliest English writers on gardens; furthermore, they tell us that the narrow-leaved varieties of the species were called Sweet Johns and the broad ones Sweet Williams, but who the honored John and William may be, not one of them deigns to tell; possibly they did not know, certainly we do not.

Gerard, in 1586 , says that he can find no explanation for either name, and utterly repudiates the existence of any St. William 


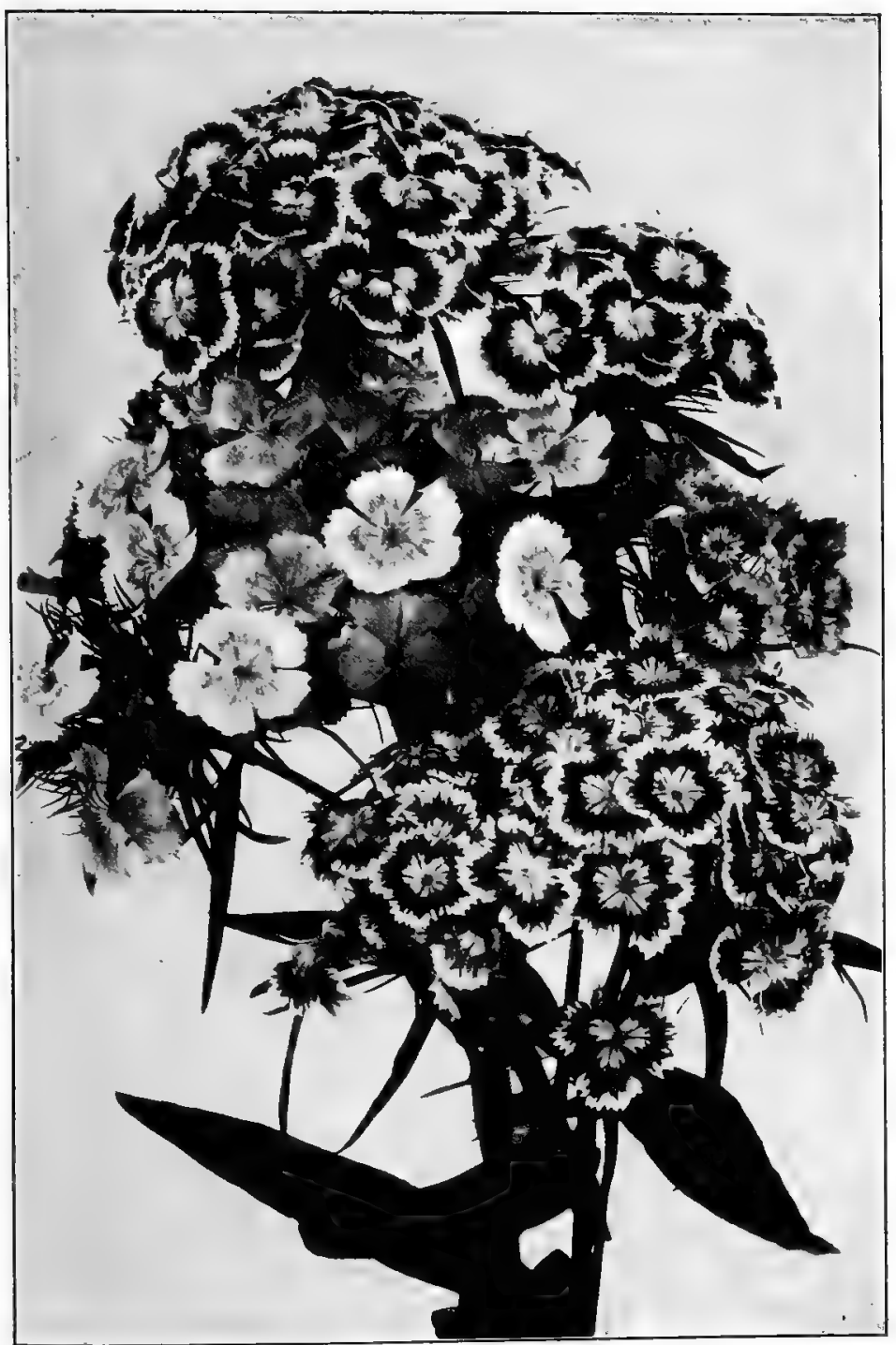

Sweet William. Diánthus barbàtus 
to whom the flower was dedicated. The matter so rested until recently, when an English writer suggested that as the plant came into England from France, it brought its French name, Fillet, with it. In accordance with the genius of the Anglo-Saxon race, that name could soon degenerate into Willy, which might, in time, be improved into William. The sweetness and beauty of the flower would do the rest. This explanation is ingenious, illuminating, and satisfactory, so far as Sweet William is concerned, but it does not seem to do anything for Sweet John, and he is part of the problem.

A flowering of Sweet Williams of the modern type is a very gorgeous affair. The color scheme ranges from purest white to darkest red, with infinite variety of tint and combination. The texture of the darker petals is velvefy, and probably no tint or shade of red is unattainatble in the corolla. Usually a bunch of blossoms is homogeneous in color and markings, but sometimes one will contain a number of flowers with varied markings and different colors. Double forms occur, but as in the case of the double geranium the result is simply a mass of color which might as well be made of strings or ribbons; all the quaint beauty and individuality of the blossom is gone-there remains only a blur of color. The books call the plant a perennial-amateur gardeners believe it to be biennial-in any case it is inclined to commit suicide by choking out its own life. The tufts should be divided frequently and seedlings should often be reset.

As cut flowers Sweet Williams are manifestly impossible; they adorn the garden but not the house.

\section{CHINA PINK. INDIAN PINK}

Diânthus chinénsis.

Perennial, but best treated as a biennial. Native to China and Japan, and introduced into Europe by a French missionary early in the eighteenth century. Blooms from July to the end of the season. 


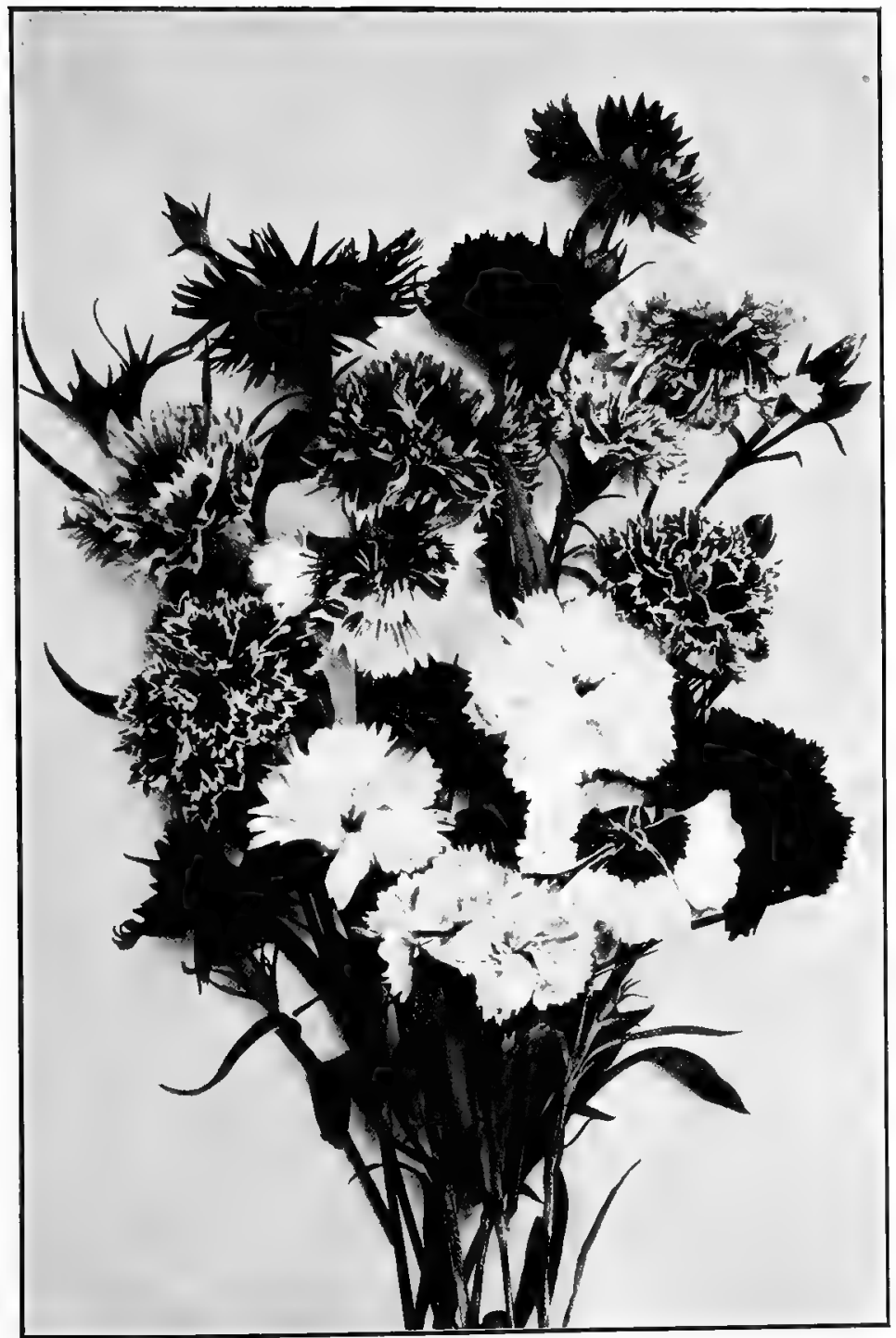

China Pink in variety. Diâthus chinénsis 


\section{PINK FAMILY}

Stem.-Erect, branched, angled, and more or less grooved, swollen at the joints.

- Leaves.-Opposite, linear, lanceolate.

Flowers.-Terminal, solitary, variable in size, color, and markings.

Calyx.-Tubular, five-toothed, with linear bracts at base.

Petals.-Five, long-clawed; border spreading, deeply notched and toothed, showing the hues of red in great variety.

Stamens.-Ten, maturing before the stigmas.

Ovary.-Oblong; styles three.

Capsule.-Opening at the summit.

The China Pink is a very beautiful flower whose value is enhanced because of its extended blooming period; beginning in early summer, it continues until snow flies. All the wild bizarre markings which characterize the genus may be found in any well-grown plantation of China Pinks. The color range is anything as long as it is red. The flower lacks the fragrance that we associate with pinks and to that extent is disappointing. The petals are deeply toothed and in some varieties almost fimbriate. Numerous garden forms exist; one of the best of these is Dianthus chinensis var. Héddewigi, which is annual, producing both single and double forms of many colors and strange markings.

\section{CaRnation. CLOVE PINK}

Dianthus caryophÿllus.

The primitive of the carnations of commerce. Native to the Mediterranean region.

Stem.-One to three feet high, glabrous, almost woody below, joints swollen.

Leaves.-Long, linear, glaucous.

Flowers.-On long stems, in the type flesh-colored, fragrant.

Calyx.-Five-toothed; bracts short and broad.

Petals.-Five to many, long-clawed; border dentate.

Stamens.--Ten; styles two.

The primitive of the modern Carnation grows wild in the Mediterranean region, where it is a perennial plant of erect, branching 


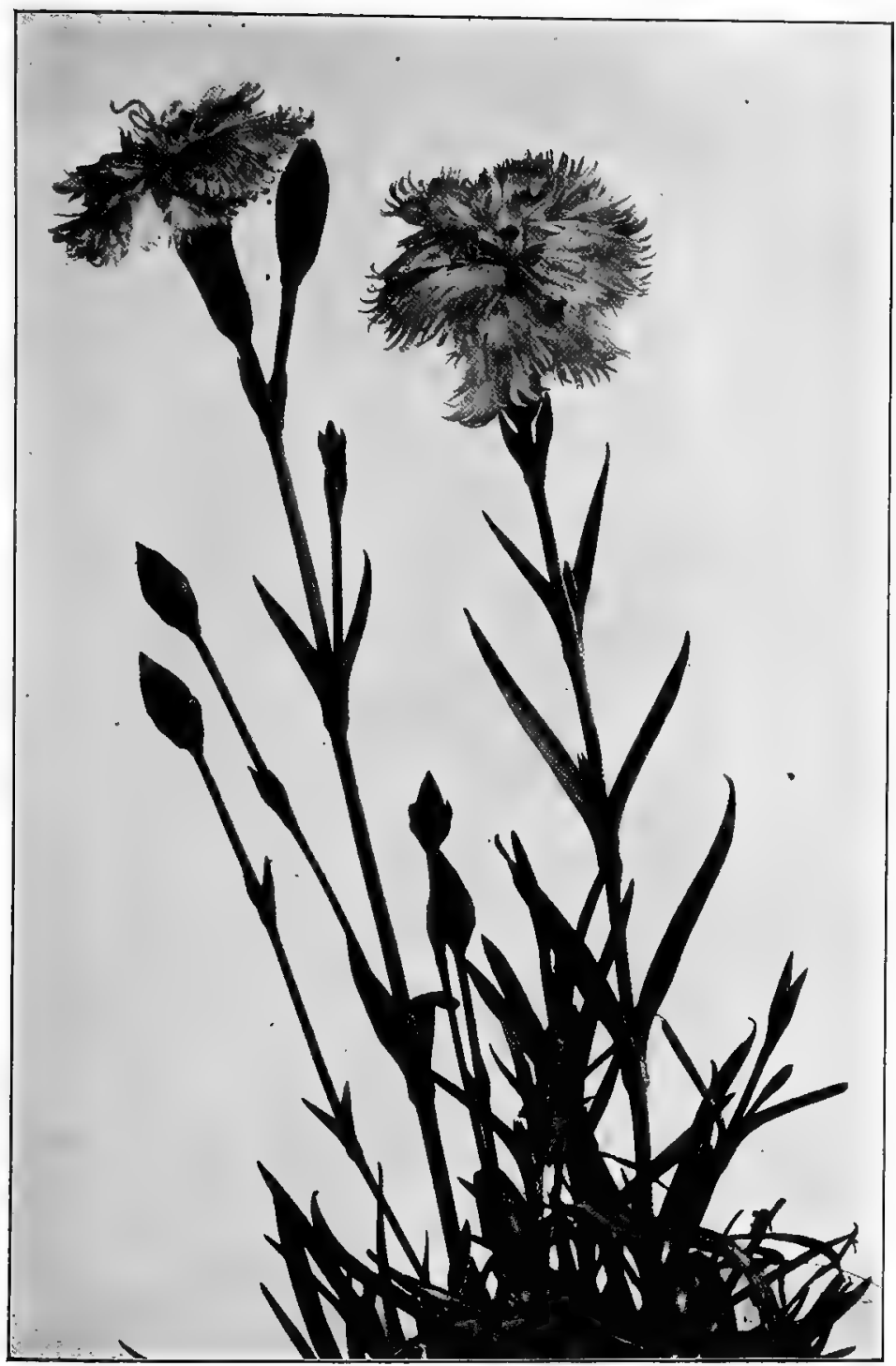

Garden Pink, Dianthus plumàrius 
habit, long cylindrical calyx, and single flesh-colored flowers, with a delightful clove-like fragrance. The plant seems not unlike its companions, though in one important respect it differs greatly; it has in its make-up a genius-if one may say so-for variation. This species has been cultivated for centuries and the forms under which it has appeared number thousands; for its cultivation and its variation began in the Roman era. The primitive as well as the best of its variants are characterized by a delicious fragrance which gave it originally the English name of Clove Pink. Sops-in-Wine and Gilliflower were also early names; the one emphasizes the aromatic character of the plant, as used to improve the flavor of wine; the other denotes the time of flowering.

The species has divided into many garden races, one of which -the Perpetual Bloomer, our greenhouse variety-is chiefly cultivated in this country under many varying forms of size, color, and habit. This group originated in France but has been developed in America.

The race of Hardy Carnations that are such favorites in English gardens have gained little foothold here; in part, maybe, because they are overshadowed by the florist's flower and in part because they are not adapted to our climate.

\section{GARDEN PINK. GRASS PINK. PHEASANT'S EYE}

Dianthus plumàrius.

A low tufted plant ,with narrow graỳ-green foliage; hardy; much used in old gardens as edging for beds; double form common. Ranges from Austria to Siberia. June. ।

Stems.-Six to twelve inches high, swollen at the joints.

Leaves.-Opposite, grass-like, glaucous, gray-green.

Flowers.-Pink and white, variegated, single and double, fragrant.

Calyx.-Tubular, five-toothed; tube likely to break down so as to spill the petals; bracts short, broad.

Petals.-Five to many, long-clawed; border spreading, deeply fringed.

Stamens.-Ten.

Ovary.-Cylindrical; styles two.

Capsule.-Opening by four or five short teeth at the summit. 
This old edging Pink rejoices in many common names: Grass Pink, Scotch Pink, Pheasant's Eye, Feathered Pink. A long row in full bloom, with its gray-green foliage and pale-pink blossoms heavy with fragrance, is an acquisition to any garden. This species possesses to a marked degree the family fault of the genus; that is, the calyx is rarely strong enough to hold the petal-claws in place, but breaks down on one side so that the petals "spill" out. This gives an untidy and dishevelled look to the blossom. The garden forms vary from single to full double and from white to variegated pink.

\section{MALTESE CROSS. LONDON PRIDE}

\section{Lýchnis chalcedónica.}

Lychnis, lamp, of Greek derivation; referring to the brilliancy of many of the flowers of the genus.

A perennial herb, native to Russia, which has long been in cultivation.

Stems. - Simple, two to three feet high, usually hairy.

Leaves.-Oblong or cordate-lanceolate, clasping upper ones often narrow and pointing.

Flowers.-Scarlet to brick-red, borne in dense terminal cymes, or spreading heads.

Calyx.-Narrow, ribbed, five-toothed.

Petals.-Five, long-clawed; limb obcordate, notched, spreading, with a two-cleft scale or pair of teeth at the base of the blade.

Stamens.-Ten.

Ovary.-One-celled; styles five.

Alice Morse Earle writes most sympathetically of this wellknown plant as follows: "A great favorite in the old garden was the splendid scarlet Lychnis to which in New England is given the name of London Pride. There are two varieties-one has five petals with squared ends and is called, from the shape of the expanded flower, the Maltese Cross; the other, called Scarlet Lightning, has five deeply nicked petals. It is a flower 


\section{PINK FAMILY}

of Midsummer Eve and magic power, and, I think, must have some connection with the Crusaders, being called by Gerard "floure of Jerusalem and floure of Candy."

Professor Bailey thinks the plant originally came from Japan; evidently it has been so long in cultivation that its origin is lost.

A lover of the sun, it glows in the border on a hot summer day with an air of contentment and satisfaction, and often rises head

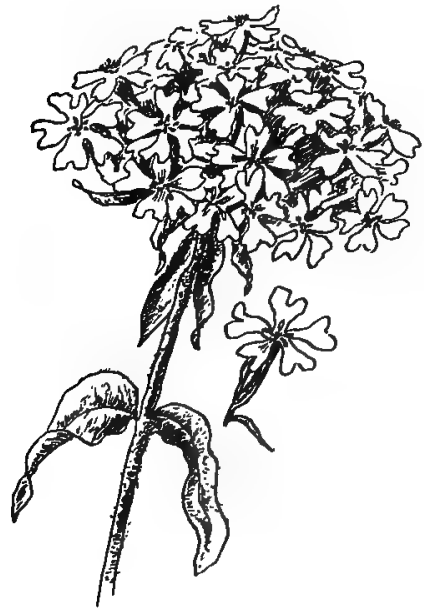

Scarlet Lightning. Lýchnis chalcedônica and shoulders above its neighbors. The typical color is scarlet or brick-red, but there are varieties with rose-colored, fleshcolored, and white blossoms, also with double flowers.

Corn Cockles, Lychnis githào, a tall, hairy plant with showy crimson flowers resembling those of the Mullein Pink, is a bad weed in the wheat fields of Europe; its seeds are acrid and unwholesome.

Ragged Robin, Lychnis Floscùculi var. pleníssima, is a very pretty species much grown for spring edgings, as it blooms abundantly in May. The petals are deeply cut, the flower clusters lax, and the flowering stem rises from a tuft of lanceolate leaves. Lychnis còla-rdsa is another favorite form, producing rather small, bright, rose-red flowers.

\section{MULLEIN PINK. ROSE CAMPION}

\section{Lýchnis coronària. Agrostêmna coronària.}

A perennial herb, readily recognized by its hoary foliage, forked style of growth, and splendid solitary flowers. Native to southern Europe. Long in cultivation. July, August. 
Stem.-Two to three feet high, jointed and forked, covered with white woolly hairs.

Leaves.--Opposite, oblong or oblong-spatulate tapering to a more or less clasping base.

Flowers.-Rose-crimson or white, borne singly on the ends of the branches.

Calyx.-Cylindrical, five-ribbed, five-toothed; teeth short and slender.

Petals.-Five, long-clawed, crimson, velvety, each bearing two small appendages at the base of the border.

Stamens.--Not more than ten; anthers coming up to the opening of the throat.

Ovary.-One-celled; styles five, sometimes four.

Pod.-Opening at the top, many-seeded.

The Mullein Pink in bloom is an effect in gray and crimson. The gray, produced by an immense number of soft, white, woolly hairs clinging to stems and leaf surfaces, has a beautiful greenish undertone, and above the gray foliage, crowning and completing it, are the flowers of vivid crimson, making a glowing mass of color unsurpassed in richness of tint by any occupant of the garden. There are three forms of this plant in cultivation: the single red, the single white, and the double red. Gerard records that they were growing "plentifully in most gardens." $\mathrm{He}$ speaks of the soft leaves as being "fit to make candle weekes," and refers to the brightness of the flowers as suggesting the names by

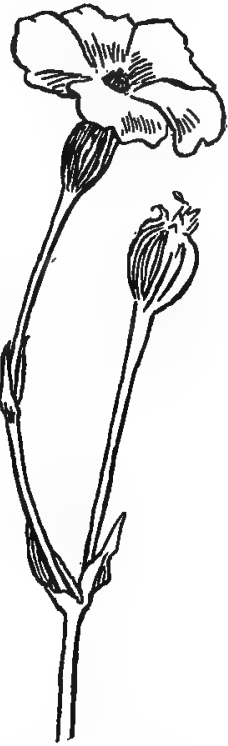

Mullein Pink. Lýchnis coronatria which it appears they were then known, as the "gardner's delight" or "gardner's eie." The plant was known also as the Rose of May and the Rose of Heaven. These titles seem to us rather extravagant, but the superb color of the flowers warrants a good deal of enthusiasm, and those early gardeners knew nothing of our modern wonders.

The spread of the flower frequently reaches an inch and a half and in the velvet-crimson of its petals are darker lines leading to 
the throat. Each petal has two tiny appendages at the point where the blade narrows to the claw, and the ten together make a minute corona which evidently guards the stamens until the pollen is mature.

\section{SWEET WILLIAM CATCHFLY}

Silène armèria.

Silene, Greek; referring to the sticky exudation on stem and calyx of several species, by which insects are often caught.

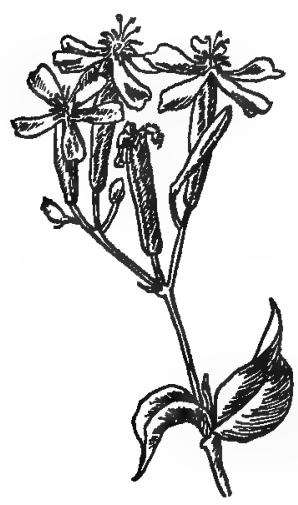

Sweet William Catchfly. Sillene armeria

Stem.-Twelve to eighteen inches high.

Leaves.-Opposite, ovate.

Flowers. - Pink or white, in manyflowered terminal and axillary flat-topped panicles.

Calyx.-Cylindrical, five-toothed.

Petals.-Five, long-clawed; each blade with two appendages at its base.

Stamens.-Ten.

Ovary.-One-celled; styles three; seeds many.

This is the Catchlly of old gardens, which still persists as an inheritance of the past, but has little to support it in competition with the flowers of the present. Though long in cultivation it is still weedy.

The species now chiefly offered by the trade is Silene péndula var. compacta, which is a dwarf upright form of a trailing primitive. It grows two or three inches high, forms cushion-mats a foot in diameter, and blooms profusely in early spring. 


\section{BOUNCING BET. LADY BETTY}

Saponàri officinàlis.

Saponaria, soapwort; because the mucilaginous juices of stem and root will make a lather in water.

An escape from early gardens now found by roadsides, railroad tracks, and in neglected fields throughout the North as far as the foot-hills of the Rockies; spreads by underground stolons. Central Europe. June, until snow falls.

Stem.-One to two feet high, glabrous, swollen at the joints.

Leaves.-Opposite, ovate, entire, acute.

Flowers.-Clustered, rose, pale-pink, single or double.

Calyx.-Cylindrical, five-toothed; readily cutting down at one side.

Petals.-Five or more, long-clawed, border spreading, with small crown, pink.

Stamens.-Ten.

Ovary.-Slender, oblong; styles two, long, coiled at apex; seeds many.

Curiously enough there is a small group of plants that are united not by botanical affiliations but by social status. Two well-known members of this outlawed group are Saponaria officinalis, commonly known as Bouncing Bet, and Linària vulgàris, Common Toadflax. Both, originally of the garden, are today outcasts; both in their primitive forms bear flowers of great beauty. It is clear that their vitality has wrought their social

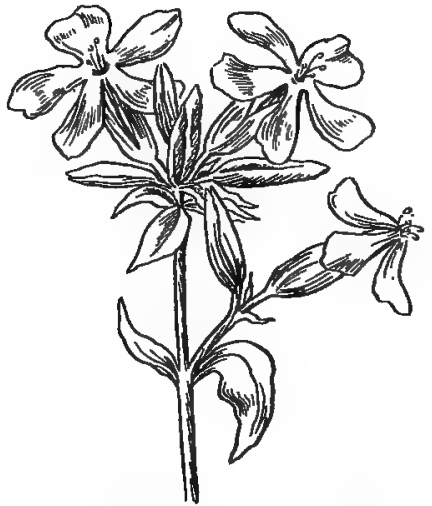

Bouncing Bet. Saponària officinàlis ruin. In a way the garden enclosure spells aristocratic seclusion, and when these two became rampant democrats, if not anarchists, when it was discovered that no fence could limit their activities or check their advance, they were discarded; and now as va- 
grants they wander along the highways and comfort the waste places, but the garden knows them no more. They are a joy by the roadside to the eye that can see and, as is not surprising, objects of contempt to the unseeing.

There are indications, however, that Lady Betty will ere long come to her own, neither "despised nor misprized." Landscape architects are beginning to appreciate her value as one who can be relied upon to do what is expected, and even gardeners are comprehending that a cared-for clump of Saponaria is a thing of beauty.

Lady Betty bears a blossom of exquisite rose-pink when first she opens her petals to the light, but pink is an unstable color in flower tissues and soon fades. However, as the bloom is clustered, the color ranges from rose to flesh. The great fault of the calyx is its weakness; - it is not strong enough to hold fast against the pressure of the petals, and cuts down one side, permitting the petals to fall out. This is the fault of many primitive pinks; the strong calyx is the result of cultivation and selection. Notwithstanding her neglected condition, the plant has developed several clearly defined forms: one with fimbriated petals and another full double, both extremely beautiful. The deeper-colored double form is sold by the florists under the horticultural name of Saponaria caucásica.

\section{GYPSOPHILA. BABY'S BREATH}

Gypsóphila paniculàta.

Gypssphila, Greek, loving gypsum; because it prefers calcareous soil.

A perennial, but succeeding best when treated as an annual; beautiful in itself but chiefly cultivated because of its ability to enhance the beauty of other flowers. Southern Europe and western Asia. June to September.

Stem.-Smooth, erect, one to three feet high, branching; the branches repeatedly forking, finally bearing at the ultimate divisions very delicate white flowers about three-sixteenths of an inch across. 
Leaves.-Opposite, lance-linear, entire.

Calyx.-Bell-shaped, five-cleft, minute.

Petals.-Five with slender claws, border notched.

Stamens.-Ten; filaments and anthers white.

Ovary.-One-celled; styles two.

Pod.-Four-valved; many-seeded.

A shimmer of white, a greenish mist, a veil-this is Gypsophila at its best. The chief characteristic of the plant is its lightness and delicacy; the stems stand upright, divide and subdivide, and then divide again, and when in bloom are covered with a mass of minute white flowers of the pink type. These flowering sprays when combined with coarser and more brilliant blossoms soften the effect, transform crudity into sweetness and light, and even enhance beauty by throwing a veil over loveliness itself. When grown for this purpose the large and the double blossoms offered by the trade should be carefully

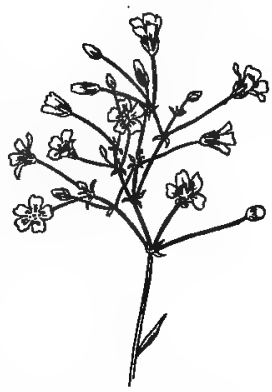

Gypsophila, Gypsôphila paniculàıa avoided; the smaller and more abundant flowers produce the more desirable and effective results.

Several other species are in cultivation; the best of these are Gypsophila acutifolia, a strong-growing plant with large panicles of small white flowers, and Gypsophila cerastoides, an Asiatic species whose small white flowers are veined with red.

\section{MOUSE-EAR CHICKWEED}

\section{Cerâstium tomentòsum}

Cerastium, Greek, a horn; alluding to the shape of the seed-vessels.

A low plant of weak, spreading stems and used for edgings because of its silvery foliage. Europe.

Slem.-Low, creeping; shoots spreading; all crowded with oblong or spatulate, white, woolly leaves making dense silvery mats.

Flowers.-White, on forking peduncles six inches high. 
Sepals.-Five, shorter than the petals.

Petals.-Five, deeply cleft so as to look like ten.

Ovary.-One-celled; styles five.

Capsule.-Cylindrical, opening at the top by ten teeth.

Cerastium tomentosum is valuable both as a foliage and as a flowering plant. In bloom its white flowers fairly overwhelm the leaves; later the leaves are as desirable as the flowers, they are so white and velvety. The blossom shows distinctly the chickweed characteristic of divided petal; apparently there are ten petals, but really only five, for each petal is cleft so deep that it looks like two.

\section{COMMON CHICKWEED}

Stellària mèdia.

Stellaria, Latin, a star; referring to the shape of the flower.

Annual, spreading, much-branched, procumbent. Naturalized from Europe. Grows everywhere and blooms all the time; is cultivated in the suburbs of Paris for canary-birds.

Stem. $\rightarrow$ Procumbent, weak, and spreading.

Leaves.-Ovate, or oblong, the lower on hairy petioles.

Flowers.-Small, white, borne on loose terminal cymes, also solitary in the axils; the peduncles lengthen after the flower fades.

Calyx.-Star-like, pale-green, pubescent.

Sepals.-Five, ovate, longer than the petals.

Petals.-Five, deeply two-cleft so that apparently there are ten; shorter than the sepals.

Stamens.-Vary in number from two to ten.

Ovary.-One-celled; styles three to five; seeds many.

The Chickweed is everywhere: along the garden walk, among the flowers, by the side of the house, in every neglected corner. The plant is rather pleasant to look upon, and in Novémber, after the first frosts, when the vegetable garden is a scene of desolation, the soft green carpet of the Chickweed -so covers unsightly places that one almost pardons it for being a weed; it is so soft, so green, so thriving, so hopeful in the very breath of coming winter. 


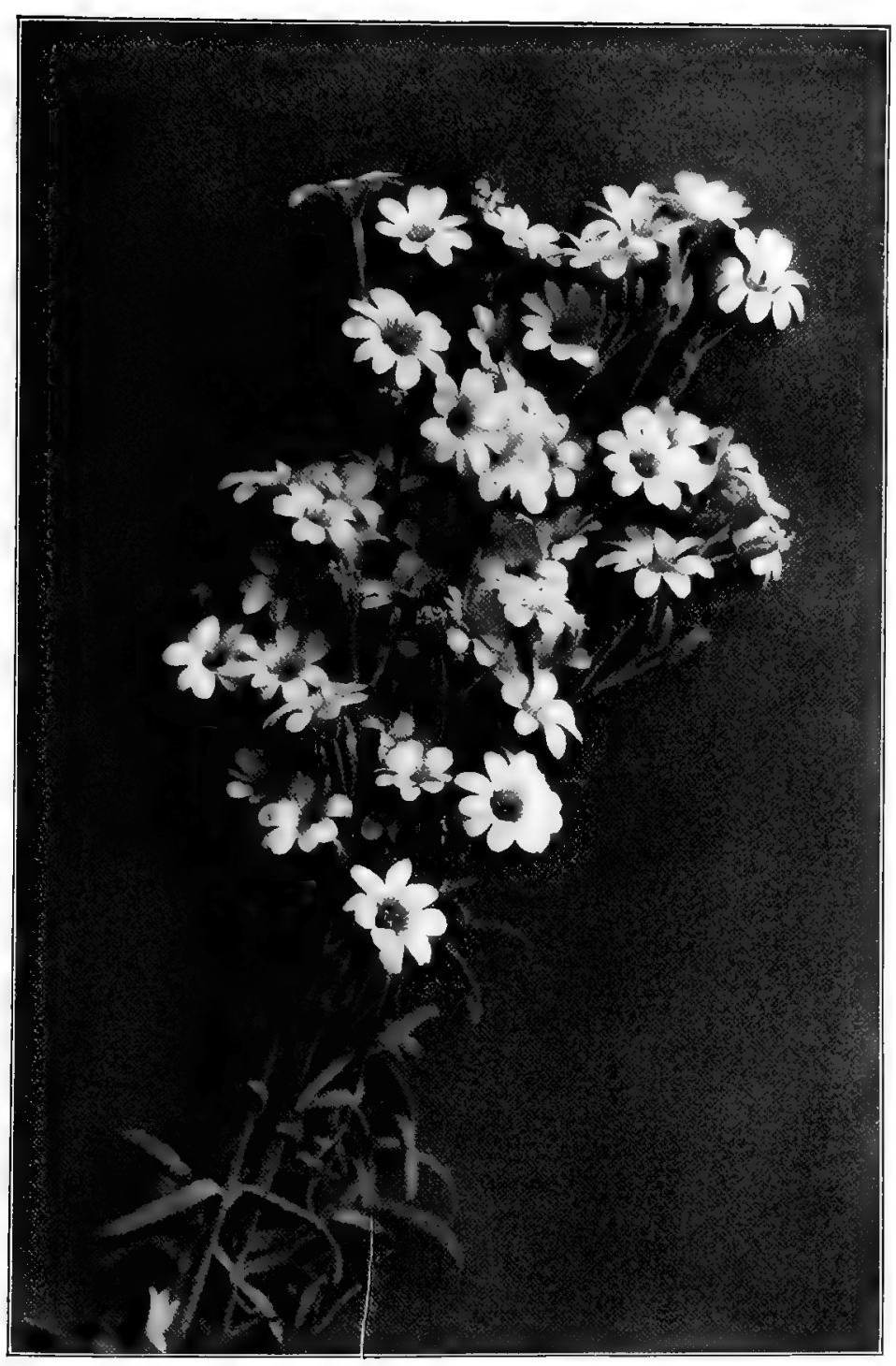

Cerastium. Cerastium tomentòsum 
The blossom is very small and through a glass extremely pretty. The five sepals form a very perfect star; the petals are curiously two-cleft, making five look like ten; these are rounded at the apex and shorter than the sepals. The stamens are a variable number; when things are going well with the plant there are sure to be five and maybe more, but in late autumn or early winter the pinched little blossom may be able to afford only two.

The Chickweed is our one plant hardy enough to live and blossom throughout a Northern winter. Probably it could not do this anywhere in New England; but on the southern shore of Lake Erie, during those winters that not infrequently occur when no ice is gathered from the lake, it grows and blossoms all winter long in protected places. Its only possible companion is the dandelion and it is hardier than the dandelion.

Most plants have one device for self-preservation; the Chickweed has two. After the blossom fades the flower stem lengthens and droops, thus giving the ripening capsule the protection of the leaves and body of the plant against frost. Also, the blossom is capable of self-fertilization, for it will mature seeds after all insect life has disappeared and its winter buds scarcely open. Its production of seed-that test of successful plant life-is so sure that the plant is found in almost every place where civilized man has been. A very striking story to illustrate this is told by Sir J. D. Hooker, who says: "Upon one occasion, landing on a small uninhabited island nearly at the Antipodes, the first evidence I met with of its having been previously visited by man was the English Chickweed, and this I traced to a mound that marked the grave of a British sailor which was covered with the plant, doubtless the offspring of seed that had adhered to the spade or mattock with which the grave had been dug."

Easter Bell, Stellaria Holostea, is a Chickweed often found in rock gardens and is really desirable for dry banks where grass will not grow. It is a perennial with erect stems six to twelve inches high, from a creeping rootstock. The leaves are gray-green, sessile, lanceolate, one to three inches long. Flowers are abundant, white, terminal, and each of the five petals is cut half down 
to the base. The flower is three-fourths of an inch across. Native to Europe and Asia.

Stellaria graminea is another European species planted in rock gardens, but smaller in leaf and flower than Holostea.

A variety, aurea, called Golden Stitchwort, is sometimes grown for carpet-bedding. 


\section{ROSÀCEA-ROSE FAMILY}

\section{POTENTILla. CINQUEFOIL. FIVE FINGER}

Potentâlla canadénsis.

Potentilla, a diminutive from potens, powerful; originally applied because of the reputed medicinal powers of one species.

Stem--Ascending or procumbent at length, often rooting at the tip, spreading, flowering from the node above the second internode.

Leaves.-Three-foliate, but apparently five-foliate by the parting of the lateral leaflets.

Leaflets.-Serrate, somewhat hairy.

Flowers.-Bright-yellow, resembling in shape small strawberry blossoms; solitary.

Calyx.-Flat, five-cleft, with a bract at each sinus.

Petals.-Five, roundish, yellow.

Stamens.-Many,

Carpels.-Many; styles thread-like.

Akenes.-Many, forming a head, on a hairy receptacle.

The little perennial Cinquefoil smiles in one's face from the meadow path or the roadside in May. The flower looks like a small strawberry blossom, only yellow. In fact there is very little difference, structurally, between the Potentilla and the strawberry flower, but practically there is a great deal, for one produces a strawberry and the other does not. Our little plant is so common that its garden value lies in its willingness to render good service in the rock garden.

There are several other native Potentillas valuable in a similar way. The garden forms of the genus are somewhat trailing, rather tender herbs with strawberry foliage and double buttercuplike flowers of varied colors blooming more or less profusely all 
summer. Originally produced by the union of Potentilla argyrophýlla and Potentilla napalensis two Himalayan species, they have now developed into a race of great beauty but, unfortunately, are not quite hardy enough to be happy in our Northern climate. The variations they display on the chord of red and orange are simply marvellous.

\section{LONG-PLUMED AVENS. GEUM}

\section{Gèum triflòrum.}

Geum is a plant name used by Pliny.

A perennial herb found principally in limestone regions, noticeable for its showy head of plumed akenes, when in fruit. From Labrador to Ontario and westward through the United States.

Stem.-Low, softly hairy.

Root-leaves.-Interruptedly pinnate; leaflets numerous and crowded, oblong-wedge-form, deeply cut-toothed.

Flowers.-Three or more on long peduncles.

Calyx.-Campanulate, five-cleft.

Petals.-Five, oblong, purplish.

Stamens.-Many.

Carpels.-Many; styles long, strongly plumose, and feathery in fruit.

The Long-Plumed Avens is an exceedingly pretty but rare plant of Northern range. The clustered akenes feathered with long silvery hairs are more noticeable than the flowers.

This species belongs to the same type as Geum chiloense, the best of the cultivated forms, which is a favorite in rock gardens because of its double blossoms and brilliant colors. The heads of these fruiting carpels also bear long and plumy styles. The plant comes from Chili. 


\section{PORTULACÀCE E-PURSLANE FAMILY}

\section{PORTULACA}

\section{Portuláca grandifiòra.}

Name of Latin origin and uncertain history.

A prostrate or ascending plant, six to ten inches high, thriving in the hottest exposure and producing beds of brilliant flowers. Brazil and southward.

Stem.-Fleshy, terete, trailing or ascending, hairy at the joints, ruddy in color.

Leaves.-Scattered or somewhat clustered, fleshy, terete.

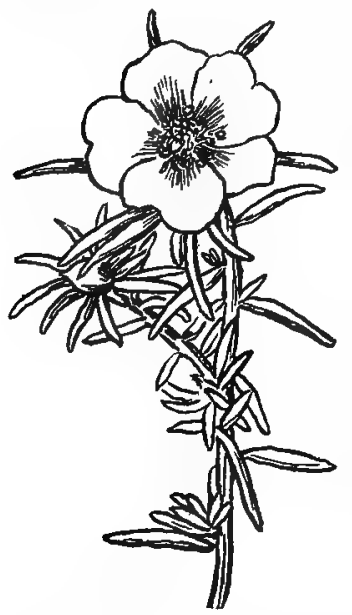

Portulaca. Portulaca grandifiora

Flower.-A cup formed of five overlapping petals borne at the summit of the stem and subtended by a cluster of leaves; one and a half to two inches across.

Petals.-Five, heart-shaped, brilliantly colored.

Sepals.-Two, united at the base.

Stamens.-Many; filaments of varying lengths, frequently taking on the color of the petals.

Ovary.-One-celled; style three to several-parted, extending considerably beyond the stamens.

Capsule.-Opening bv a lid: seeds small, many.

Portulaca is a lovable little creature, living in the sand and the sun. When the day is gray the flowers furl close to disappearance, but when the warm sunshine beats full upon them "a myriad of little fleshy arms stretch out, each holding a colored bowl to catch the sunbeams."

The plant is native to the hot plains of southern Brazil and was 
described in the Botanical Magazize of 1829 . Since that time it has been in general cultivation and has varied into many garden forms. The present color range varies from pure-white to yellow, orange, rose, scarlet, crimson, and deep-red. Double forms are common but not desirable. A bed will often perpetuate itself, and in some places the plant persists about old gardens. It is tender to frost and the seed should be sown late, as, like the corn and the cucumber, a warm root-run is essential.

The seed-vessel is interesting in structure; the lower part of the ovary unites with the bottom of the calyx, and the result is that when the capsule is mature the upper part comes off, as if it were a lid, and discloses a tiny dish of fruit.

Purslane, Portulaca oleràcea, is the "Pusley" hated of gardeners and of amateurs.

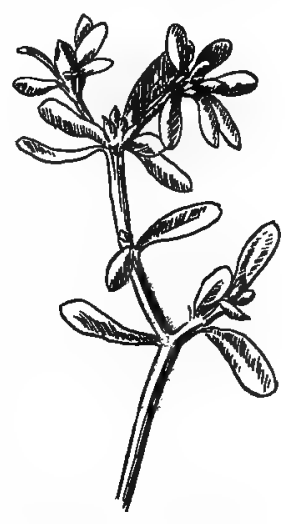

Purslane. Portulàca oleràcea A common trailing weed in sandy soil, it remains true to its gens and thrives in the fiercest sun. The leaves are small, obovate, very obtuse, very thick, dull-green or reddish. The smooth prostrate stems go out in all directions from the root crown, the thick leaves lie upon the ground or rise a few inches, and in the hot sun of midsummer noonday it opens a few small, pale-yellow flowers very close to the stem. These ripen many seeds. This "Pusley" is sometimes eaten as greens, but there are French upright forms that are much better and are cultivated as food plants. 


\section{NYMPHÆÀCEÆ-WATER-LILY FAMILY}

\section{WHITE WATER-LILY}

\section{Nymphaca odoràta. Castàlia odoràta.}

Nymphoea, dedicated to the water nymphs. Castalia, a fountain on Mount Parnassus, sacred to Apollo and the Muses.

This is the white, sweet-scented Water-Lily of the North, found in the still or slow-flowing water of lakes and ponds; it varies into a form with pink flowers. June to September.

Another species, Nymphaa tuberòsa, is associated with it in Western waters. Both are the primitives of many hybrid forms.

Rootstocks.-Long, prostrate, often as thick as one's arm; which send up floating leaves and large flowers.

Leaves.-Floating, rounded, with a narrow cleft reaching nearly or quite to the petiole; margin inrolled in the bud. Under side of leaf reddish, hairy; upper side smooth, green; margin entire.

Petiole.-Long, hollow, strong.

Flowers.-Floating, large, white, fragrant.

Sepals.-Four.

Petals.-Many, in several rows, inserted on the ovary, passing gradually into stamens.

Stamens.-Many, the outer rows with petaloid filaments and short anthers; the inner rows with linear filaments and elongated anthers.

Ovary.-Globular, many-celled; around a little knob at the top the numerous stigmas radiate as in a poppy-head, ending in long and narrow incurved lobes.

Fruit.-The many-seeded ovary enlarged, covered by the persistent bases of the petals. Each ripe seed is in a little arillus, or bag, open at the top. The fruit ripens under water. 


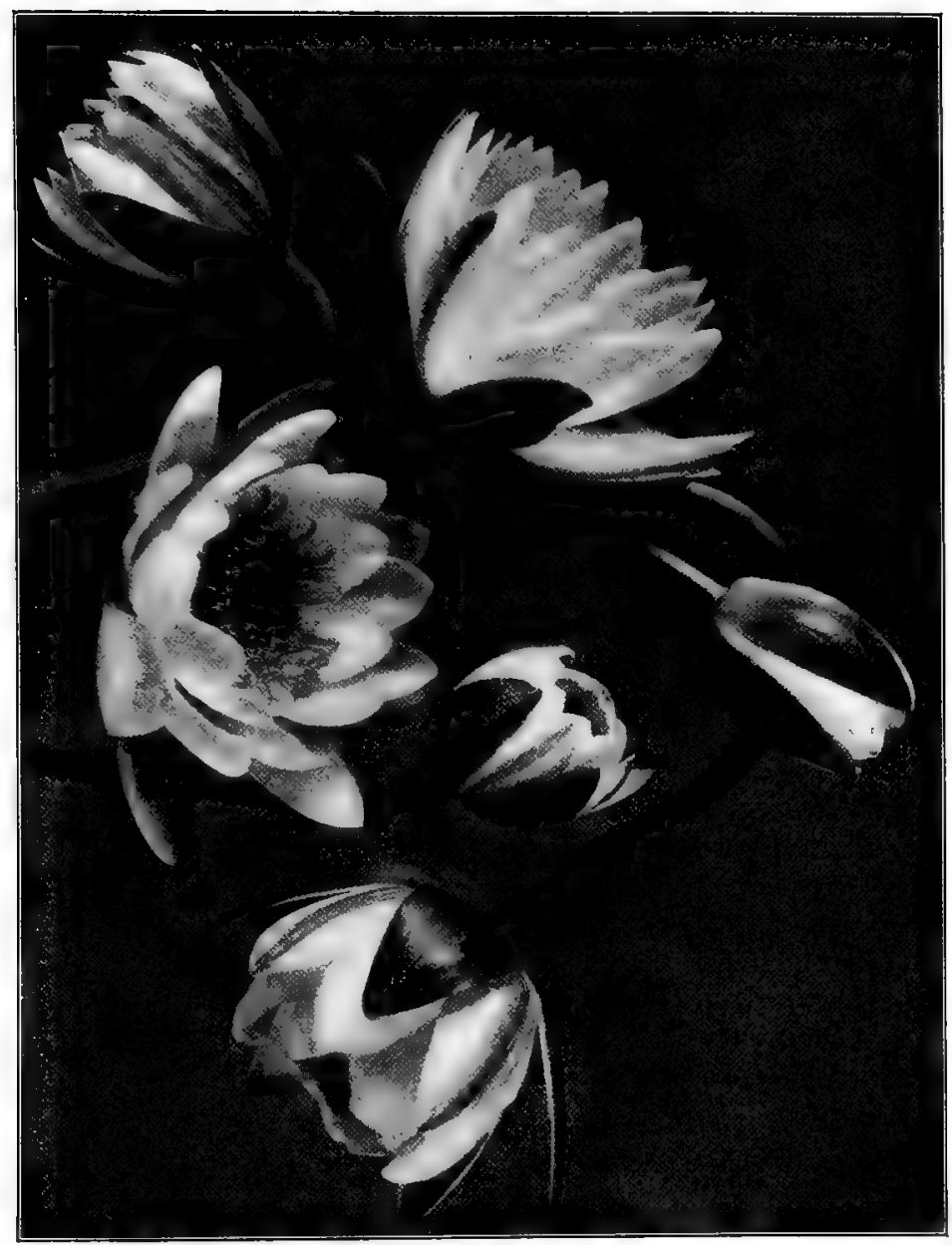

White Water-Lily. Nymphàa odoràta 
From the reek of the pond the lily

Has risen in raiment white,

A spirit of air and water,

A form of incarnate light.

Yet, except for the rooted stem

That steadies her diadem;

Except for the earth she is nourished by,

Could the soul of the lily have climbed to the sky?

- Lucy Larcom.

Very generally throughout the Northern States in certain elect places, where the under soil is rich, the water smooth and not deep, preferably the borders of lakes and the slack water of rivers, this water nymph finds her home. The great leaves have floated since May; in early June the buds began to appear, making their way to the surface on petioles adjusted to the water's depth; and at length when summer days are long and warm, the buds open and the many-petalled cups of snow appear, so perfect in form, so delicate in texture, so spotless, so fragrant, that one stands charmed by their exquisite beauty.

Every radiant floating cup is an anchored boat that rises and falls with the undulating flow of the water. The petioles-strong, hollow tubes-are equipped to bear the stress and pull of mud and wave and they hold their own bravely. The life of the blossom is about three days, opening in the morning and closing at night. Afterward the petiole begins to curve and coil and finally pulls the seed-pod with the remnants of the petals beneath the water, where it ripens, dropping the seeds on the water floor.

In our present water-gardens are assembled Nymphæas from all parts of the world, varying in size from the enormous Victoria règia of the Amazon to the tiny odorata minor of the gardens. In color they run through a wondrous scale of white, cream, yellow, pink, lavender, blue, scarlet, and crimson. They appear -both in types and in hybrids, but always and ever, great or small, tender or hardy, blooming by day or blooming by night, they possess a share of the same incomparable grace and exquisite beauty of our own delightful Water-Lily, Nymphoea odorata. 


\section{NELUMBIUM. SACRED BEAN. EGYPTIAN LOTUS}

Nelümbium indica. Nelümbium speciòsam.

Nelumbo is the Ceylonese name of the East Indian species.

Aquatic perennial, half-hardy, one of the best of large pond plants. China, Japan.

Rhizomes.-Thick, usually tuber-bearing.

Leaves.-Circular, peltate, borne on stout, erect petioles, usually high above the water.

Flowers.-Large, pink, five to eight inches across, solitary on tall stout stems.

Sepals.-Several, passing into petals.

Petals.-Pink, in several rows.

Stamens.-Many, on broad, short filaments.

Pistils.-Many, each sunken in the obconical and nearly flat-topped receptacle, the embedded fruits looking like nuts in separate open cells. When ripe they resemble acorns.

Nelumbo, or as it is more commonly called, Nelumbium, is one of the best of the large pond plants and should be grown in association with the Nymphæas. It is known in the trade as Egyptian Lotus, but the real Egyptian Lotus was a water-lily, Nymphoea ccrùlea. However, that matters little and, furthermore, Nelumbium was and perhaps still is sacred in India. At any rate, it is a very interesting plant and produces very beautiful pink flowers of the water-lily type about six inches in diameter; and in the centre of the flower, surrounded by rows of yellow stamens, is a curious top-shaped body whose flat upper surface is apparently studded with tiny green acorns. These apparent acorns are the ovaries; the little knob at the top of each is its stigma; the big fleshy top is the receptacle which envelops and protects them.

Our first Nelumbiums came to us from Kew Gardens, where they had been cultivated for many years, but now fresh importations come directly from Japan.

Water Chinquapin, Nelumbium liteum, is the American representative of the genus, called locally Giant Water-Lily, and found 
abundantly in a few chosen places; among these the marshes of Sandusky Bay, on the southern shore of Lake Erie, are well known. The species is most abundant along the line of the Great Lakes and is believed to. have been disseminated by the Indians.

The blossom is large, eight to ten inches across, the sepals are yellow-green, and the petals change from the greenish-yellow

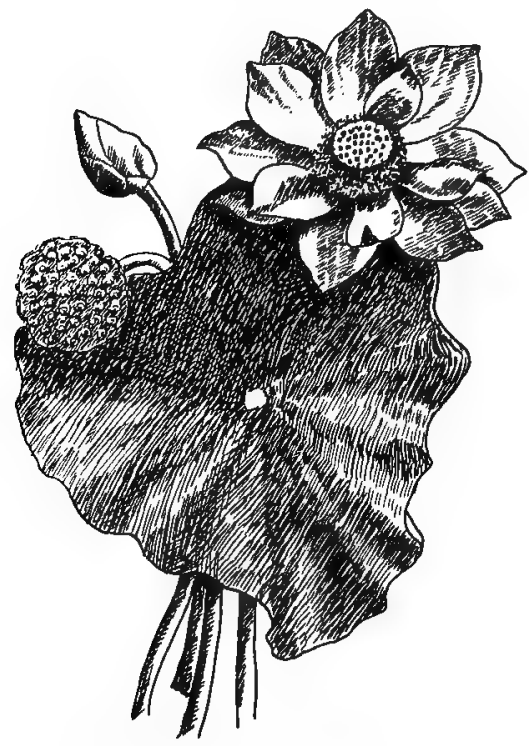

Nelumbium. Nelambium indica

of the outer row to the deep-cream of the inner rows. Each topshaped receptacle bears usually more than a dozen ripened nuts. The wild ducks know the home of Nelumbium and eagerly seek the acorns-the meat is very rich.

Unlike the water-lilies, the blossoms and leaves of Nelumbium stand well out of the water; the fruit ripens at the summit of an upright stem; and when the receptacle dries the nuts shake out of their little cases into the water beneath. 


\section{RANUNCULÀCEA-CROWFOOT FAMILY}

The plants of this group are principally herbs with an acrid watery juice; not distinguished by any one or two particular marks, but on the whole indicated by having numerous stamens, usually more than one pistil; all the parts of the flower distinct and all inserted on the receptacle. The calyx is often colored like a corolla, when the latter is wanting.

The principal garden representatives are Peony; Clematis, Larkspur, Monkshood, Columbine, Anemone, Hepatica, Adonis, Buttercup, Trollius, Hellebore, Nigella, and Thalictrum.

\section{PEONY}

\section{Parònia hýbrida.}

Paonia is the ancient Greek name of the genus accepted by the Romans and by us. The Chinese name, Hoa Ouang, signifies the King of Flowers. The German Gichtrose means gouty rose. The Spaniards call it the Rose of the Mountain. Moutan is the Chinese for the woody species. Paconia is referred by Pliny to Pæon, the physician, who healed Pluto of the wound inflicted by Hercules. A less poetical explanation is that the word is derived from Pæonia, a mountainous country of Macedonia where some of the species grow wild.

A garden race of magnificent blooming perennials whose primitive forms have been in cultivation in Asia and in Europe for thousands of years. May, June.

Root.-Fleshy; thickens to form upright rootstocks.

Stem.-Stout, two to three feet high.

Flowers.-Large, solitary, ranging from deep-red to pure-white, both single and double. 
Sepals.-Unequal, concave.

Petals.-Five to many.

Carpels.-Two to five, borne on a fleshy disk; stigma recurved.

Fruit-follicles.-Opening when ripe; seeds large.

It is well known that the magnificent Peonies which adorn our lawns in May and June are the products of the gardener's art. Into the making of these Peonies three species have largely entered: Pronia officindlis, Paonia albifolia, and Pconia mouttans.

Pconia officinals, the Red Peony, is the form that, so far as we know, was first cultivated. It is native to southern Europe and south-western Asia, and we may believe that it bloomed in the temple gardens of Tiryns and Mycenæ.

Man coming out of barbarism cultivates flowering plants because of the medicinal properties they are supposed to possess, not because of their beauty; and color of flower or shape of leaf is believed to give the hint of virtues which the plant possesses.

What, then, more natural than the belief that this great crimson flower possessed virtues for the healing of wounds. The elder Pliny, writing about $70 \mathrm{~A}$. D., after referring to the virtues of Moly, the plant which protected Ulysses from the wiles of Circe; to those of Dodecatheon, sacred to the twelve gods, a plant which has been identified with the primrose, goes on to say: "The plant known as Pæonia is most ancient of them all. It still retains the name of him who was the first to discover it. This plant is a preservative against the illusions practised by the Fauni in sleep (nightmare). It is generally recommended to take it up at night; for if the woodpecker of Mars should perceive a person doing so it will immediately attack his eyes in defence of the plant."

This ancient belief in the medicinal virtues of the Peony long continued. During the Middle Ages it was supposed to drive away evil spirits, to avert tempests, and to protect houses simply by growing near them. In England, in comparatively recent times, children wore necklaces of beads which were made of dried portions of the roots, in order to aid dentition and prevent convulsions. 
DOUBLE RED PEONY

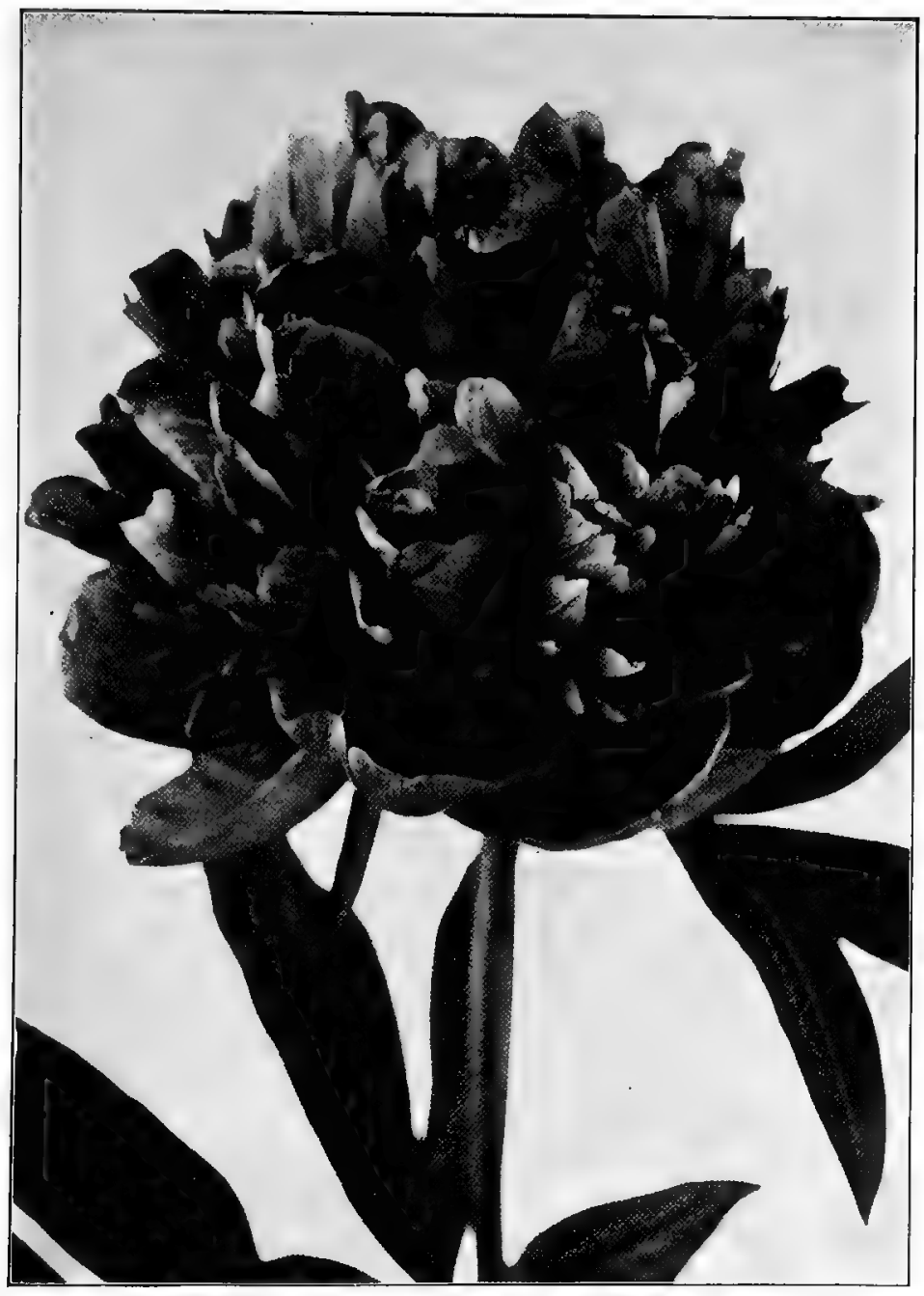

Double Red Peony. Prònia officinalis 
The first Peony cultivated in New England and the Middle States was the Double Red, which is still a favorite. It is not altogether clear where this form developed, but it seems to have been brought to Antwerp in the latter part of the fifteenth century and from there very generally distributed. Probably, it was brought to Manhattan by the Dutch; certain it is that for a long time the only Peony of American gardens was the Red Peony.

Peonra albifolia, the White-Flowered Peony is a plant of the Northlands, credited in the books to Siberia.

It is difficult to be absolutely certain of the typical form of a plant which has long been in cultivation, but what is believed to be the original form is eight to ten petalled, pure-white, delightfully fragrant, four to five inches in diameter, rather cup-shaped and in the centre is a cluster of bright-yellow stamens. By crossing the different varieties of Pconia officinalis with Pceonia albifora, the race of double Peonies ranging from pure-white to deep-crimson was produced. 'In the development of the varieties of to-day another strain has contributed; this is the Moutan or Tree Peony of China and Japan, the only woody Peony of the world.

The first of the Moutans were brought into England in 1789 ; others soon followed. They came in many forms and of varied colors; for these were by no means Peonies in the raw, they had behind them more than a thousand years of such cultivation as only Japanese gardeners know how to give. Some of them had been double so long that they had forgotten how to be single. Others were in single form; one of these the so-called "poppyflowered," white with a purple spot at the base of each petal is believed to be the original wild form, but no one really knows. Their color range swept from pure-white and flesh through a marvellous group of salmon-pinks to a lemon-yellow and an intense tawny-red.

As a result of hybridization and selection there has been produced the present garden race, which, counting those in Europe and this country, numbers something over a thousand named varieties. 
SINGLE WHITE PEONY

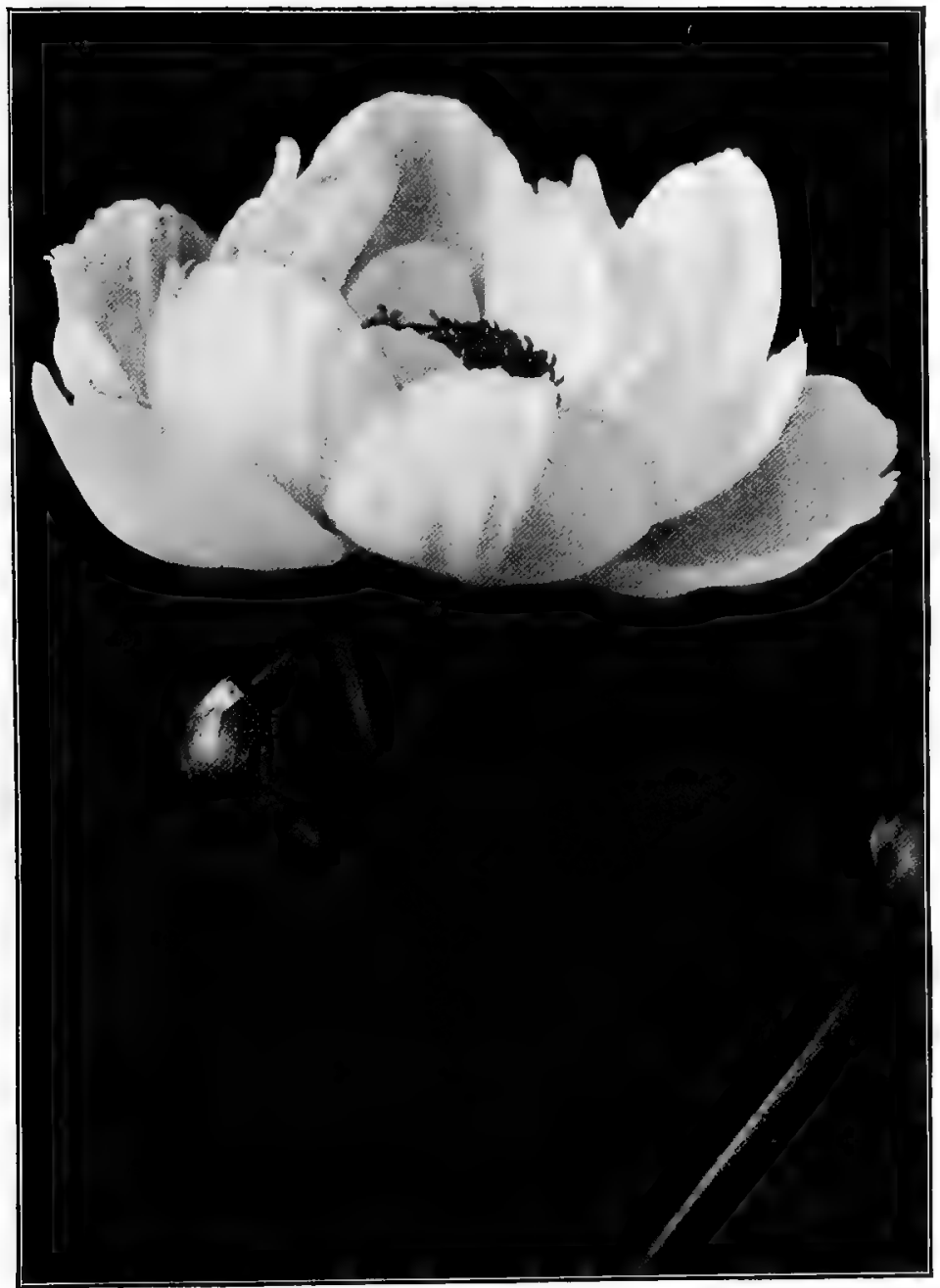

Single White Peony, Paònia albifolia 
The Peony is said to be a gross feeder, but when one realizes the amount of plant energy required to bring to maturity such a wealth of magnificent bloom, this is not surprising. We cannot drive an engine unless we give it fuel, nor can we expect fine flowers unless we give the plant the means to produce them, and only a plant capable of assimilating large quantities of food could produce them.

\section{COLUMBINE}

Aquilègia vulgàris.

Aquilegia from aquilegus, water-drawer; not from aquila, eagle.

A hardy perennial, native to Europe and northern Asia, long naturalized in America. Summer.

Stem.-Branching, one and a half to two feet high, many-flowered.

Leaves.-Radical, or alternate on the stem; twice or thrice palmately compound, the divisions in threes; leaflets roundish and abtusely lobed.

Flowers.-Showy, nodding, borne in loose panicles, blue, pink, or white.

Sepals.-Five, equal, owate, spreading,petal-like.

Petals. - Five, all alike, attached by the margin of a dilated mouth and prolonged baci $-a$ rd into a hollow spur, the knob at the end filled with nectar.

Slamens.-Many, on filaments, which vary in length.

Pistil.-Five distinct carpels, each with a slender style and a minute stigmatic surface at the summit.

Fruit.-Five, many-seeded follicles; seeds small.

The flowering of the Columbine Commendable, as Skelton called it four hundred years ago, marks the beginning of summer. The reign of the bulbs is over-

"The wind flower and the violet they perished long ago,"-

the petals of the early roses are falling; the elder blossoms show white along the fence rows, and the season waxes to its prime.

A wild flower of English fields, the Columbine was early transferred into English gardens and has held its place securely there for at least five hundred years. Its seeds were among the treasures 


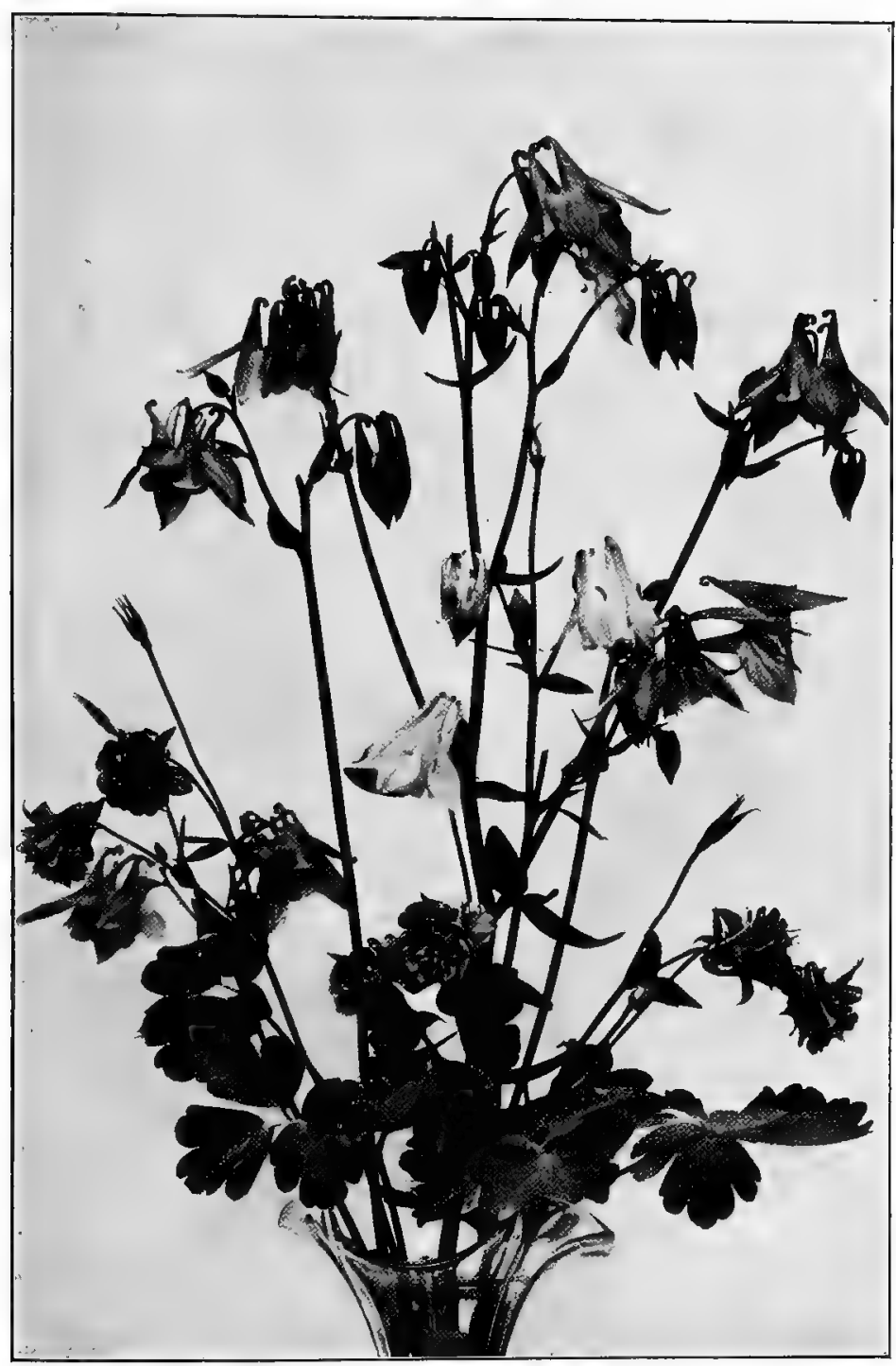

Columbine. Aquilègia vulgàris 
borne over sea to the new world, and it early bloomed in Pilgrim gardens. This primitive stock still persists in cultivation, so vigorous and so virile as to challenge successfully the later arrivals and the newer favorites.

The flower of the Columbine is a unique and interesting form. The sepals look like petals and the petals are veritable horns of plenty, filled with nectar at the closed end for the swarms of bees which gather: about. The sweets are produced by the blossoms on a generous scale and to a Columbine bed in full bloom the bees come, big and little, noisy and silent-all giddy with the feast. There is no use trying to drive them away for they will not go. Clumsy bumblebees with tongues long enough to reach the honey by the open door, wise honey-bees who have learned to take the short road to the nectar by biting through the spur, quiet brown bees, little green carpenters-all are there, "vehement, voluble, velvety," in a glorious riot of happiness and honey.

The doubling occurs chiefly with the petals; the sepals as a rule hold true to the five. But the petals sometimes double in number, becoming ten spurs in place of five, and each spur becomes a nest of spurs like a set of Chinese cups, though the innermost are frequently imperfect.

The colors are not always desirable. Dark opaque-blues smoky-purples, muddy-pinks abound, although pale-blues, exquisite-lavenders, and pure-whites also abound. In any group of Aquilegia vulgaris white should be abundant; it is the one effectual peacemaker.

\section{RED COLUMBINE}

Aquilègia canadénsis.

The common, perennial Red Columbine, often called Honeysuckle. Growing in ledges of rocks throughout the North. May, June.

Stem.-One to two feet high.

Leaves.-Radical or alternate on the flower stem; twice or thrice palmately compound, the divisions in threes, leaflets roundish.

Flowers.-Showy, nodding, red and yellow, borne at the end of branching stems. 


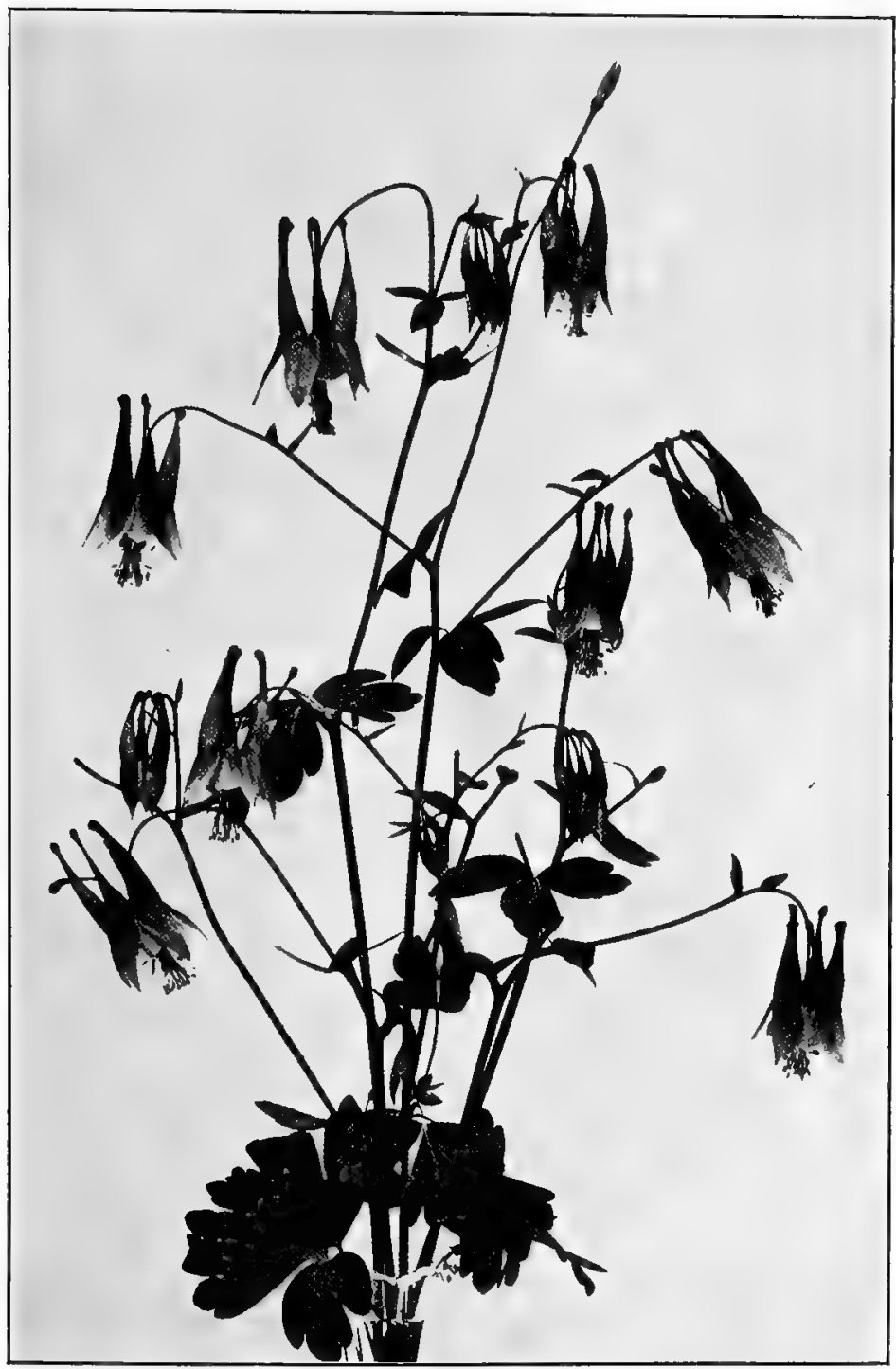

Red Columbine. Aquilègia canadénsis 
Sepals.-Five, petal-like, similar, red tinged with yellow.

Petals.-Five between the sepals, each consisting of a spur and an open border; spurs red, border yellow.

Stamens.-Many on the receptacle; filaments of varying lengths.

Pistil.-Five distinct carpels, each with a slender style, minute stigmatic surface at summit.

Fruit.-Five many-seeded carpels; seeds small.

The Red Columbine is the native Aquilegia of New England and the Middle States. Its chosen home is among the rocks, and one often sees it in early spring clinging to a cleft, the stems dancing with the wind and the flowers aflame against the gray ledges. A wild creature, it submits to civilization if it must, but loses something of its rare grace thereby. It is better in the rock garden or the wild-flower section than along the garden walk. The wilfulness of the untamed is in its blood, and it yields its body but not its spirit to the fetters of the gardener. The stalks send out their lateral branches at a wide angle, and these divide again; this makes the flowers unmanageable when cut and emphasizes the fact that they never should be forced to do household duty. Their rôle is the simple life out-of-doors.

In order to obtain the plants it is best to gather the ripe seeds in July and sow them so that the seedlings are well established before winter. Such plants will bloom the next year.

\section{WESTERN COLUMBINE}

Aquilègia canadénsis var. formòsa. Aquilègia formòsa.

Plant of the habit of the Red Columbine, though it prefers low, moist situations. Found from Sitka to California and east to the Rockies. Appears in our gardens as a primitive and in hybrids. May to August.

Stems and leaves.-Like those of Aquilegia canadensis.

Flowers.-Red and yellow.

Sepals.-Longer than the spurs; spurs rather spreading.

Stamens and pistil,-Like the type. 
This Western Columbine seems to be the Red Columbine of the East that has suffered a mountain change; or what is more probable the two are brothers, only one has been developed in the East and the other in the West. The Eastern form loves the rocks, the Western makes the valleys gay. The Western bears more gold in its petals; they are usually edged as well as lined with yellow. Its spurs and petal limbs are comparatively short, but the sepals are large, and the many stamens and long, slender styles protrude like golden tassels from each flower. The foliage is very abundant, dark-green above and pale and whitish underneath.

\section{COLORADO COLUMBINE}

\section{Aquilègia ccerùlea.}

The State flower of Colorado, native to the low $\sim r$ mountain regions from Montana to Mexico. April to July.

Stem.-One to two and a half feet high, finely pubescent above, bearing loose panicles of flowers.

Leaves.-Radical or alternate on the stem, twice or thrice palmately compound, leaflets three-lobed.

Flowers.-Two inches across, blue and white.

Sepals.-Often blue, oblong, obtuse.

Petals.-With long slender spurs, rather straight but curving outward, white dashed with blue, and small knobs at the end.

Stamens.-Many, protruding.

Pistil.-Of several carpels; styles long and slender.

Fruit.-Several follicles, pubescent; seeds many.

It would be interesting to know what personal experiences antedated the vote of the members of the State Legislature of Colorado which made Aquilegia carulea the State flower. For Colorado was first a trapper's land, next a miner's State, and this beautiful plant in bloom must have been associated with many a toilsome climb and many a weary day. One finds it on the flanks of the high mountains. 


\section{GOLDEN COLUMBINE}

Aquilègia chrysântha.

Native to Arizona and New Mexico; appearing in our gardens both as primitive and in hybrids. May to August.

Stem.-Three to four feet high.

Leaves.-Twice or thrice palmately compound.

Flowers.-Abundant on the stem, golden-yellow with paler tints, two to three inches across.

Sepals.-Pale-yellow, often with a claret tint spreading horizontally. Petals.-Deep-yellow; spur about two inches long, slender, rather straight, divergent.

Stamens.-Many.

Carpels.-Several; follicles glabrous; seeds many.

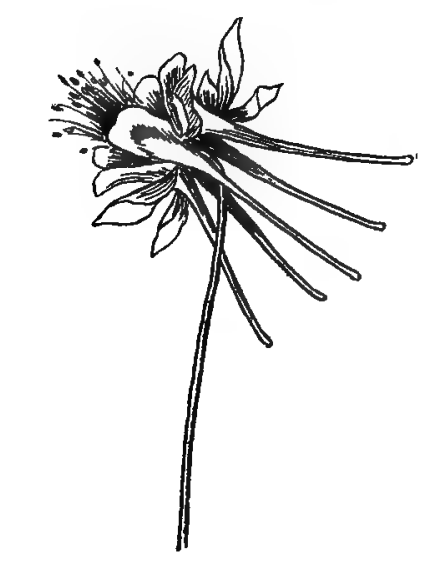

- Golden Columbine. Aquiègia
chrysantha

As a bright effective flower this golden blossom, poised delicately in air as if in upward flight, is certainly not surpassed by any other inmate of the garden.

There are several Siberian Columbines in cultivation, which have added much to the beauty of the garden group both as primitives and hybrids. They are characterized by lilac-blue flowers, both light and dark, large sepals, short blunt spurs considerably incurved, and included stamens. Aquilegia glandulòsa, Aquilegia Sibérica, and Aquilegia oxysépala are the best known.

Among other Columbines may be noted Aquilegia Skinneri, an interesting species from the mountains of northern Mexico, bearing flowers with green sepals, greenish-orange petal limbs and bright-red spurs. All these are probably perennials when at home but do better in the garden when treated as biennials. 
All the Aquilegice hybridize readily; indeed, the problem of the growers is to keep the seeds true, for the insects hybridize them and it is almost impossible to prevent it. Therefore buyers should be charitable if the purchased seeds do not always come true to name.

\section{DELPHINIUM. LARKSPUR}

\section{Delphinium.}

Delphinium, Greek, a dolphin; from the shape of the flower.

The garden race of Delphiniums are hybrids; annual or perennial herbs.

Stem.-Erect, simple or branched.

Leaves.-Alternate, petioled, palmately divided.

Flowers.-Borne in showy racemes or panicles, each flower starting from the axil of a slender bract.

Calyx.-Five petal-like sepals, grown together, the upper one produced as a long spur behind.

Petals.-Two to four; the two upper with spurs which lie within the spur of the sepab; the lateral ones when present small and spurless.

Stamens.-Many.

Pistil.-One in the annual forms; three in the perennials; forming many-seeded pods.

Our garden Delphiniums are hybrids and may be divided into two well-marked groups: the annuals and the perennials. The annuals are largely descended from Delphinium Ajàcis.

Most of the highly bred Delphiniums are the result of crossing Delphinium elatum, the old continental form, with Delphinium formosum, which brings in the pale-blues, and with Delphinium grandiflòrum, which gives size. Scarlet flowers indicate a strain of -Californian blood.

Delphiniums double so easily, hybridize so readily, respond to environment so quickly that the genesis of any hybrid can only be established by record. The gardener's ideal has been the fullflowered spike with a goodly range of colors on the chord of blue. Other colors seem by-products; we think of Larkspur as blue. 
Some of these blues are pale as the sky, some pure-cobalt, others indigo, and still others are a strange broken blue, gorgeous and intense, yet impure, glittering on the surface as if it were strewn

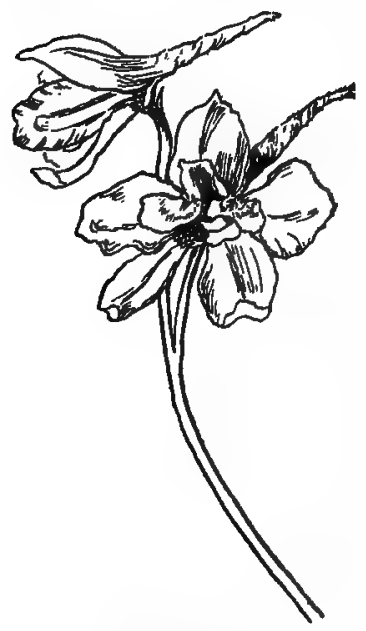

Delphinium. Delphinium with broken glass, and sometimes darkened into red. The centre of a Larkspur is often grotesque, the hairy petals suggest a bee at the heart of the flower, and the flower itself looks like a little creature poised for flight. In structure the garden race has changed very little from the primitive type, though that type has wandered far from the simplicity of the buttercup which names the Ranunculacee. Whatever path of evolution the Larkspur has trod, it is very clear that the goal at which it has arrived is crossfertilization by means of the bee. At some time along the path the calyx took on the duties of the corolla, became highly colored, developed a spur while at the same time the corolla lessened both in size and in importance. The stamens mature before the pistil and are so placed that the bee cannot get at the honey without covering her head with pollen which she then bears to another flower. The stigma of any blossom is not in evidence until the anthers have passed.

\section{MONKSHOOD. ACONITE}

\section{Aconttum napéllus.}

A hardy, erect perennial, with poisonous juices; bearing flowers of singular shape; formerly much used in borders. Native to central Europe. July and August.

Root.-Tuberous, turnip-shaped.

Stem.-Tall, erect, three to six feet high.

Leaves.-Alternate, deeply cut. 
Flowers.-Dark, violet-blue, borne in a terminal raceme, each flower subtended by two small bracts.

Sepals.-Five; upper sepal a hood which shuts down over the two lateral sepals and over the two hammer-like petals; the two lower sepals are small and pointed.

Stamens.-Many, the filaments cohering into a short tube.

Pistils.-Three to five, developing into many-seeded follicles.

Stigmas.-Not receptive until after the anthers mature.

The monkshood of stately growth, Betsy called Dumbledore's Delight, and was not aware that the plant, in whose cowl-shaped flowers that busy and best-natured of all insects appears to revel, is the deadly aconite of which she read in poetry. - "The Doctor," Southey.

This is a beautiful stately plant found in old gardens but not much favored in new ones; for its acrid juices are exceedingly poisonous and consequently it has been banished.

From the root is obtained the aconite of the materia medica.

The root is harmful only when eaten, and people do not as a rule eat the roots of their flowering plants; but there

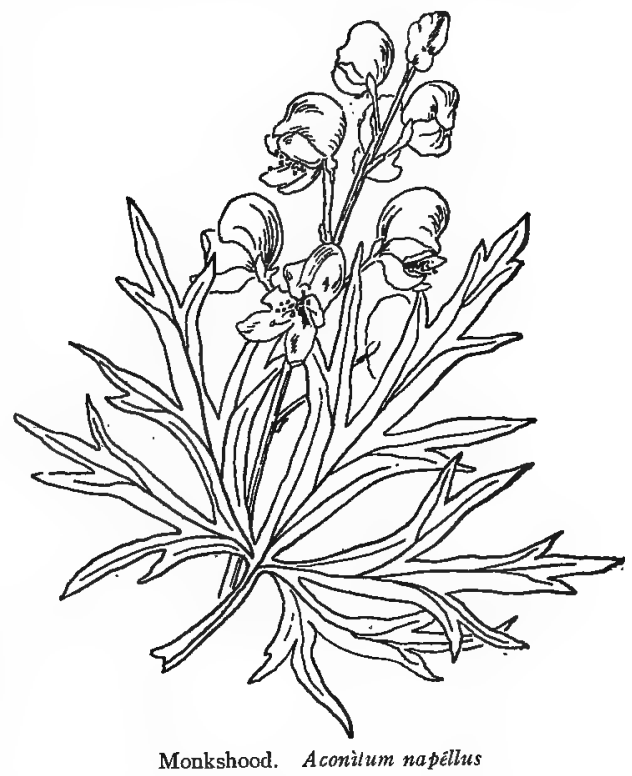
is just enough uncertainty about it to make owners of gardens nervous when children visit them. The general appearance of leaf and flower stalk resembles the larkspur-tall, cylindrical in effect, crowned with a crowded raceme of blue or violet flowers.

The blossom, like that of the larkspur and the columbine, has 
wandered far from the buttercup type. The upper sepal has become not a spur but a hood, and under this hood are two petals whose shape to us is more like two hammers with long handles than anything else; but to our forefathers it seems to have suggested in some curious way two hidden monks-whence the ancient name, Monkshood. Usually these two strange petals represent the entire corolla, but sometimes there are three more which look like little stamens without any anthers.

\section{WILD CLEMATIS}

\section{Clèmatis virginiàna.}

Clematis, the Greek name of a climbing plant.

The well-known Clematis of Northern fields, wildwood tangles, and river banks, climbing over rocks and shrubs. Perennial. July, August.

Stem.-Woody, climbing, smooth.

Leaves.-Opposite, trifoliate; leaflets ovate, acute, cut or lobed, heart-shaped at base; the stem climbing by means of the leaf-stalk.

Flowers. - White, borne in full-panicled clusters from the axils of the leaves; diocious or polygamo-dioecious.

Calyx.-Four petal-like sepals, white, thin.

Corolla.-Wanting.

Stamens.-Many in the staminate flowers; wanting or imperfect in the pistillate.

Carpels.-Many in the polygamo-diøcious and pistillate flowers; wanting in the staminate.

As the carpels ripen the styles lengthen into conspicuous feathery tails.

The Wild Clematis is the graceful queen of our Northern roadsides, trailing over rocks and fences, swinging its drooping sprays in charming abandon from the tops of shrubs and the low branches of trees. It may generally be found throughout the North, blooming in midsummer wherever there is a thicket of bushes in the open protected from cattle.

The roots need the coolness and moisture which the thicket gives, and the stems, woody but weak, require support, so the plant shoulders its way up to the sunlight. 
The Clematis stem does not twine, it puts forth no tendrils; the leaf petioles do the work; they take a sort of sailor's knot about outlying branches and twigs, and in this way the stem rises little by little until, having reached the top, it spreads out its panicles of white stars to the sunlight and rejoices in its success.

The flowers are of two kinds, pistillate and staminate, borne usually on different plants, sometimes on the same. The staminate flowers have white plumy stamens, those in the very centre pale-yellow, while the pistillate flowers have a bunch of carpels giving them a green centre. Frequently the pistillate flowers have stamens as well, but these are often sterile, made of filaments only-no anthers.

After fertilization the styles do not fall off-on the contrary they begin to grow and

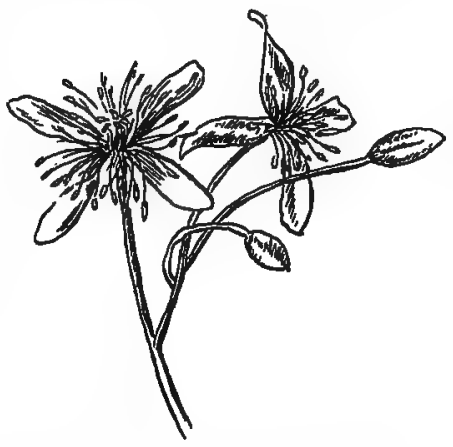

'Staminate Flowers of Clematis become long, hairy tails to the seed-vessel beneath. Finally the plant covers itself with these plumy, silvery-white bunches, and becomes more noticeable even than when in flower.

This long, trailing vine so adorned is the trophy of our autumn walks, and we bring it home with the pods of the milkweed and the autumn leaves. The species is worthy of cultivation as a fence cover and to give wildwood effects; it is not as good a porch plant as Clematis paniculata, and its flowers àre not as fragrant as Clematis flammula.

Leather-Leaf Clematis, Clematis viórna, is a climbing vine with pinnately compound leaves, and curious thick, leathery flowers, reddish-purple. Its seeds bear the characteristic feathery styles and the stem climbs by its leaf-stalks after the family fashion.

The plant is of Southern and South-western habitat and is cultivated rather as an object of interest than for any horticultural value. 
David's Clematis, Clematis Davididna, is the only Bush Clematis at present known. The blossoms are brilliant-blue and the plant is interesting, but as a shrub it has little value, since it is hardly strong enough to stand without support. Native to Japan.

\section{JAPANESE CLEMATIS}

Clématis paniculdta.

A hardy, vigorous, climbing perennial from northern Japan and China, bearing abundant clusters of small white flowers. Popular because of its adaptability as a porch plant. August, September.

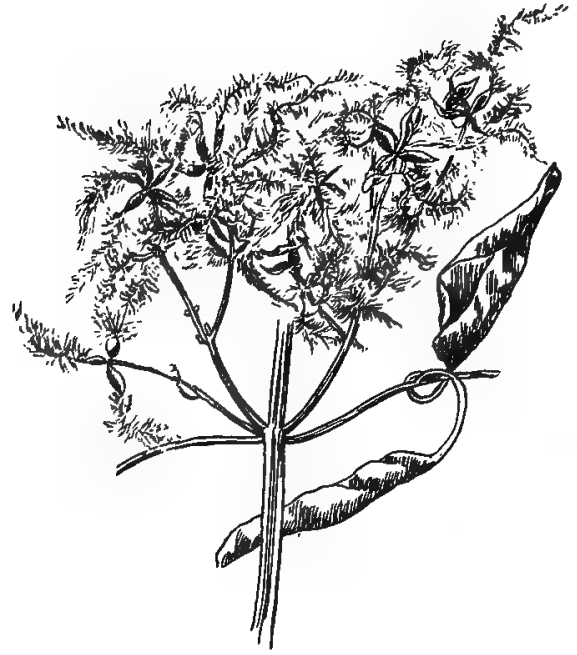

Plumy Seeds of Japanese Clematis. Clémalis paniculda

Stem. - Climbing by petioles, growing ten to twenty feet in a single summer.

Leaves. - Opposite, pinnately compound; leaflets three to five, longpetioled, ovate-cordate, entire; in some forms the leaflets are lobed.

Flowers. - White, in large axillary and terminal panicles.

Sepals.-Four, white.

Pelals.-Wanting.

Stamens.-Many.

Pistils.-Many, longtailed and silvery in fruit.

Clematis paniculata was introduced into the United States from Japan in the early seventies and immediately achieved great popularity as a porch climber for several excellent reasons. Unlike our native Clematis virginiana, the root will bear a sunny exposure. The growth is vigorous, the bloom abundant, and, furthermore, this bloom appears in September. It is pleasant in the wane of the year to find a plant bursting 
JACKMAN'S CLEMATIS

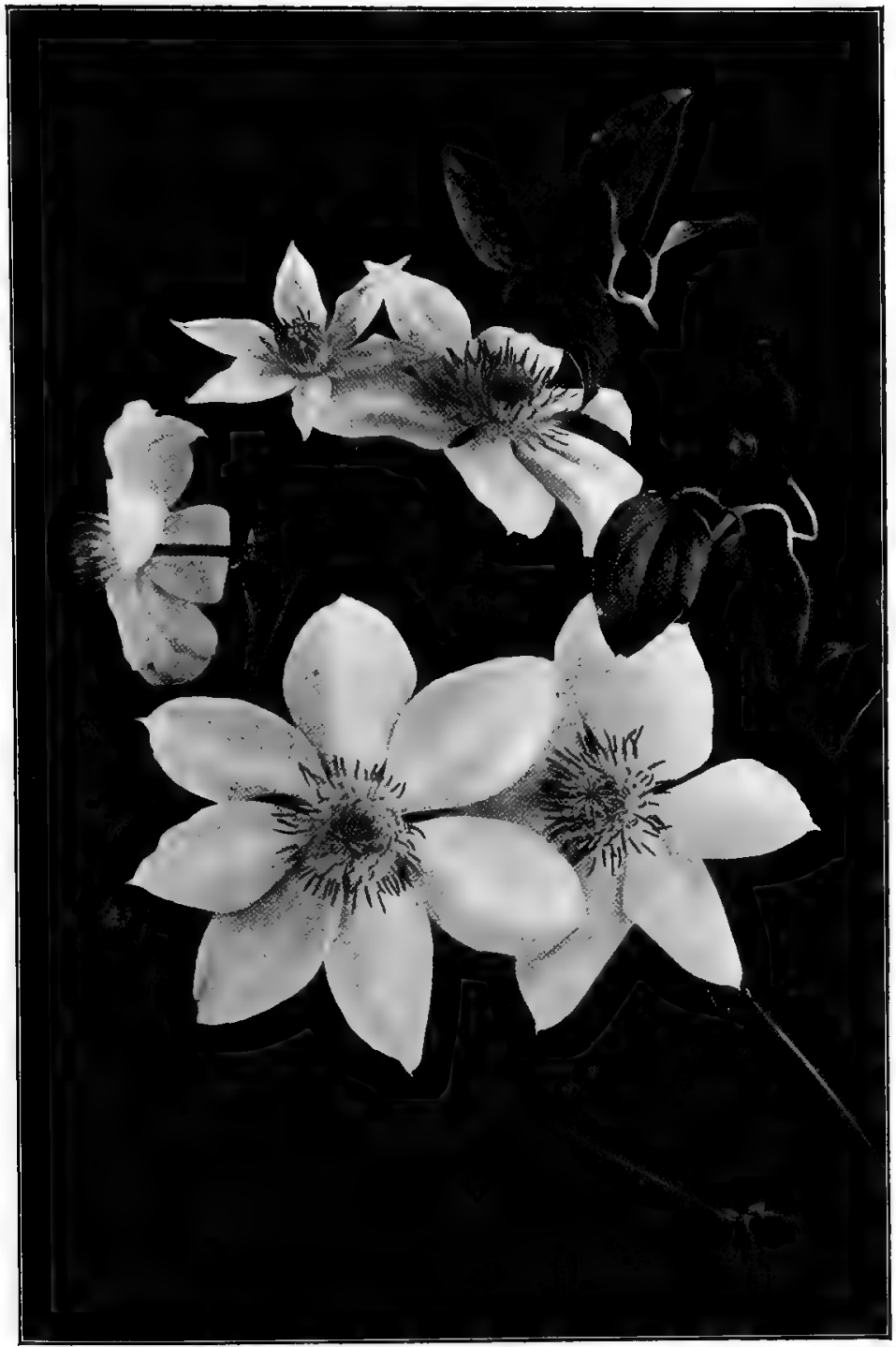

Jackman's Clematis. Clématis Jackmánni 


\section{CROWFOOT FAMILY}

into such sheets of white blossoms with no distinction of location and no especial regard to sun or shade. Its virtues are so many that the florists' catalogues become positively enthusiastic.

\section{LARGE-FLOWERED CLEMATIS}

\section{Clématis Jackmanni. Clématis Hénryi, etc.}

All the Large-Flowered Clematis are hybrids taking either the name of the producer or one that he gives. Jackman's Clematis was named by Mr. Jackman, an English florist, and is believed to be a hybrid of Clematis viticélla, a hardy European species with blue or purple flowers two to three inches across, and Clematis languindsa, a Chinese species, with white or purplish flowers three to four inches across.

All the large-flowered forms offered by the trade, under whatever name they may appear, are probably either hybrids or variants of these two species, with perhaps a strain of Clematis caruilea, also a Japanese species.

The entire group is beautiful and worthy of all that is said in their favor. It must be remembered, however, in planting them, that the vines are valued principally for their bloom, and if abundant foliage is desired other forms must be associated with them.

\section{ANEMONES}

Anémone coronària. Anémone hortênsis. Anémone japónica.

Two of the well-known garden Anemones bloom in the spring; one, Japonica, is an autumn bloomer.

Poppy Anemone, Anemone coronaria, is one of the spring bloomers whose home" is southern Europe. The roots are tuberous, the stems about eighteen inches high, the leaves ternately compound, and the poppy-like flowers range through reds and blues as well as white. The blossom, like all the Anemones, is made of colored sepals; the corolla is always absent; the stamens are many and the carpels many. May.

Garden Anemone, Anemone hortensis, is very like the Poppy Anemone, possibly not quite so large. The flowers are red, rose-purple, 
or white, single, an inch and a half across. In the type there is a distinct eye of a second color in the centre of the flower. Southern Europe. May.

Japanese Anemone, Anemone japonica, is native to China and Japan. It blooms late in the season. Its roots are fleshy and its stem branching, the leaves ternate and the flowers either white or rose, two to three inches across. Sepals of one to three whorls; corolla wanting; stamens many; the carpels make a little green ball in the centre of the blossom.

Although America has beautiful native Anemones, those of the garden are aliens; two from southern Europe bloom with the tulips and the daffodils; one from Japan keeps company with the dahlia and the cosmos.

The early Anemones require essentially the same treatment as tulips and are usually classed with bulbous plants. They have held an honored place in

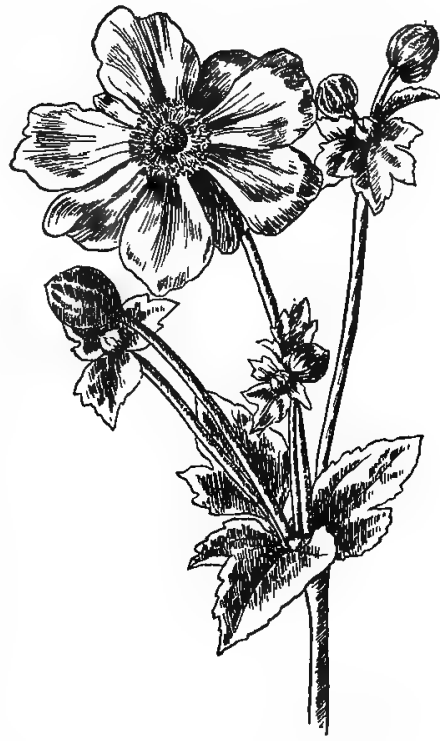

Japanese Anemone. Animone japónica English gardens for three hundred years, Anemone coronaria coming from the Levant in I596 and Anemone hortensis following in 1597 .

The Japanese Anemones were brought into England in 1844. They are excellent general utility plants; they bloom in shade, they flourish in full sunshine, they are happy and contented at the margins of streams and lakes. The color of the type is rose-red, but the white variety seems to be the present favorite although a silvery-pink is much in evidence.

A white Japanese Anemone is really a flower of exquisite beauty. The silvery star has a spread of two to three inches and in the 
centre is a green ball which under a glass becomes a mass of styles and stigmas. Surrounding this green ball is a fringe of stamens with short white filaments and bright-yellow anthers. To add to their charm, these wholly adorable blossoms have the late-flowering habit; the autumnal equinox comes and goes, but the Anemones bloom on, careless of threatening skies or pinching cold.

Two additional Anemones are offered by the trade but not much cultivated-Anemone ranunculoides, a European species with the general habit and appearance of our Anemone nemorosa, but with bright-yellow flowers; and the Pasque Flower, Anemone pulsalilla, a species of northern Europe, long cultivated for its large violet flowers, its silky carpels, and its delicate, finely divided foliage.

There are several native Anemones which are worthy of cultivation. One of the best is the American Pasque Flower, Anemone patens, var. Nuttalliàna, which bears an exquisite blossom, six or more sepalled, an inch and a half across, white with a dash of lavender outside. The stem is silky and there are many-fingered leaves in reserve after the blossom falls. It is at home on the prairies of the West and North-west and blooms in April.

The Wood Anemone, Anemone nemorosa, common in our Northern woodlands, bears a very pretty, solitary white blossom on a slender stem about six inches high, which sways with the passing breeze. It holds its head well above its leaves, though it hangs down in discouraged fashion at night or during cloudy weather. - Blooms in April and May.

The Pennsylvania Anemone, Anemone pennsylvànica, is a species found in shaded woods and open meadows, blooming in midsummer The flowers are white, the plant sturdy and robust and comes into the garden willingly.

Windflower as a name for Anemone is an inheritance from Pliny, who gravely states that the plant never blooms but when the wind blows upon it.

Rue Anemone, Anemonélla thalictroides, although technically not an Anemone, horticulturally may be considered one. It is a 
charming little plant, five to eight inches high, bearing the leaves of the meadow rue and a cluster of three to five long-stemmed Anemone blossoms. Will make beds of easiest culture. Blooms in April and is altogether lovely.

This plant seems to be a link between two well-defined species -Anemone and Thalictrum. The little beauty consequently has never been permitted to possess a name in peace but has been tossed from Anemone to Thalictrum and back again; then to Syndésmon and now Anemonella. The crux of the matter lies in some little tuberous roots possessed by the plant.

\section{GLOBE FLOWER. TROLLIUS}

Tróllius europìues.

Trollius, from old German troll, a globe or something round; in allusion to the shape of the flower.

A perennial herb native to northern Europe, growing naturally in marshy places. April, May.

Stem.-Erect, one to two feet high, often branching.

Leaves.-Palmately five-parted; lobes cleft and toothed.

Flowers.-Terminal, lemon-yellow, globular, solitary or in twos.

Calyx.-Of petal-like sepals ten to fifteen in number.

Petals.-Small, spatulate; often longer than the stamens, with a nectar-bearing pit at the base.

Stamens.-Many.

Carpels.-Many, which develop a head of follicles.

Trollius looks like a big, sleepy buttercup which refuses to open, but, as a matter of fact, differs very considerably from the buttercup. Its apparent petals are really sepals; it true petals are small, narrow, nectar-bearing bodies surrounding the stamens. The flower has a real globe shape and appears as if semidouble.

Trollius asiaticus has a more open flower than Trollius europaus and in color ranges from deep-orange to red. The gardeners are seeking to open all the blossoms in the cultivated forms; in this 
they will no doubt-be successful, and having succeeded the distinctive charm of the flower will be destroyed. We shall have one more big buttercup, but no longer the graceful, winning, sleepy, Globe Flower.

\section{DOUBLE BUTTERCUP}

Ranünculus àcris var. flòre-plèno.

Ranunculus, from Rana, little frog; because many of the species live in swamps with the frogs.

A full, double-flowered variety of the common field Buttercup long in cultivation. One of the old-fashioned flowers.

Siem.-Erect, two to three feet high, branching.

Leaves.-Much divided, juices watery, acrid.

Flowers.-Terminal, bright-yellow.

Sepals.-Five, green.

Petals.-Five in the type, many and crowded in the garden form.

Stamens and pistils.-Wanting in the double form.

The common Buttercup of neglected fields and roadsides came to us from England. The plant is a weed, pure and simple, taking the food and the moisture of the soil without return. Its acrid juices make it immune from grazing animals, so that it increases without stint in pasture-lands.

The origin of the double form is not well understood, but it seems to be among the first double flowers cultivated in English gardens. The multiplying petals are curiously symmetrical, both in form and arrangement, producing golden globes, which win interest if not admiration because of their prim regularity. They are often called Bachelor's Buttons; a name given to Centaurea cyanus.

The Bulbous Buttercup, Ranunculus bulbdsa, has a double form; also Ranunculus rèpens. No doubt any Buttercup could be made to double. 
Very graceful, pretty-flowered perennial with finely decompound foliage. Europe and northern Asia. May, July.

Stem.-Large, hollow, one to three feet high, glaucous.

Leaves.-Alternate; once or twice three to five parted; leaflets stalked or nearly sessile, roundish, slightly lobed or obscurely toothed.

Flowers.-In a corymbose panicle; dicecious.

Sepals.-White, deciduous.

Petals.- -Wanting.

Stamens.-Purple or white, many.

Carpels.-Three-angled, winged, one-seeded.

Thalictrum is valued for the feathery heads of flowers which contrast well with the handsome stems and leaves. The flowers are abundant, crowded, and without petals. They lose their sepals early and then become simply a-mass of slender stamens exceedingly attractive and pretty. Thalictrum polyganum, the Tall Meadow Rue of Northern lowlands, is worthy of a place in the garden. It grows three to five feet high and produces masses of white feathery bloom. Early Meadow Rue, Thalictrum dioicum, shows its tasselled fringe of tawny gold by the woodland paths in April.

\section{HEPATICA. LIVERWORT}

Hepática tríloba. Hepática acutiloba.

Hepatica, liver; referring to the shape of the leaf.

A perennial herb native to the open woods of the northern parts of America, Europe, and Asia. Forms tufts, blooms in the forest before the leaves of the trees come out. March, April.

Scapes.-Four to six inches high, downy.

Leaves.-Long-petioled, thick, evergreen, three-lobed, reniform.

Flowers.-Blue, lavender, white, pale-pink, borne solitary on erect scape; with three involucral leaves a quarter or an eighth of an inch below the blossoms looking like a calyx. 
Corolla.-Wanting.

Sepals.-Petal-like, five to eight, oblong, obtuse.

Stamens.-Many.

Carpels.-Many, one-celled, one-ovuled.

Akenes.-Short-beaked, hairy.

I, country-born and bred, know where to find

Some blooms that make the season suit the mind,

$\mathrm{An}^{\prime}$ ' seem to metch the doubtin' bluebird's notes,-

Half vent'rin' liverworts in furry coats.

- "The Biglow Papers," Lowell.

This is the first spring flower of the fields that people ordinarily see. The skunk cabbage is indeed earlier, but it is coarse, illsmelling, and little known; while the Hepatica is delicate, beautiful, and everywhere recognized. The blossoms appear in warm, sheltered places the last of March and are abundant in sunny ravines and hollows in early April. They precede the new leaves by some weeks, the rusty old ones being obliged to do duty as foliage while the plant is in bloom. The buds and new leaves are very fuzzy, with long silky hairs, which disappear later in the season. The flowers vary in color from pale-blue to pure-white, shading to lavender and soft-pink, and the flower stems come out of the ground in little tufts; one root frequently producing ten to thirty individuals.

The blossom is wonderfully sturdy. It opens at the regulation time, and though afterward the winds blow, the frost comes, or April snow falls thick and fast, it is all one to the little creature, for the tinted sepals then close about the stamens and pistils, the three-leaved involucre enfolds them all, each tiny blossom bows its head to the storm and waits till the clouds roll by. Cradled in the arms of arctic snows for innumerable ages, the plant has acquired a hardiness out of all proportion to its apparent delicacy.

A group of blossoms that are to-day closed tight in patient endurance of wind and snow will to-morrow stand open-eyed in the sunshine. The strength of the North is in their tissues; the endurance of the North marks their vitality. 
The names Hepatica and Liverwort hark back to the age of the simpler, and echo the doctrine of signatures. In mediæval medical practice, it was believed that every disease could be cured by some plant; moreover, that this plant was indicated by a real or fancied resemblance between a given part and the organ diseased. As the leaf of the Hepatica is three-lobed, it suggested the liver; hence the plant was considered a specific for diséases of that organ.

A group of Hepaticas is an acquisition to any'lawn, and may be easily acquired.

Plant the roots about the trunk or under the shade of a deciduous tree, preferably the maple. These roots are lovers of shade, leaf-mould, moisture, and non-interference. The last cannot be emphasized too much. Let the bed alone. Let the autumn leaves sift down upon and over it, making a protecting blanket. Never permit them to be raked away. Remember the Hepatica is a nursling of

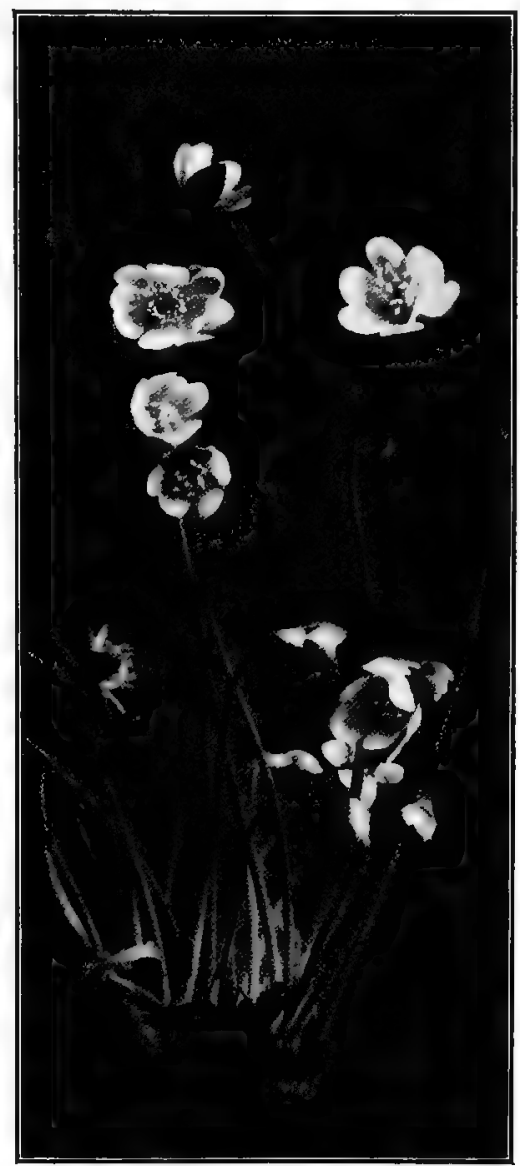

Hepatica. Hepática aculíloba ' the forest.

Two species grow side by side in our Northern States, Hepatica triloba, sometimes called the Round-leafed Hepatica because 
the leaf-lobes are rounded; and Hepatica acutiloba, so called because the leaf-lobes are pointed. The first is more abundant in the Eastern States, the second is the prevailing form in Ohio and westward; in other respects the two are one.

\section{SPRING ADONIS}

Addnis vernális.

Adonis, named in honor of the lover of Venus, who, after his death, was changed into a flower.

A perennial, cultivated for its showy, early yellow flowers. Native of Italy.

Stem.-Simple, one foot high.

Leaves.-Finely cut, produced in whorls on the stem; lower leaves scale-like.

Flowers.-Large yellow, solitary, terminal.

Sepals.-Five.

Pelals.-Ten to fifteen, lanceolate, slightly toothed.

Stamens.-Many.

Carpels.-Many.

Fruit.-An akene.

Introduced into England from southern Europe two hundred and fifty years ago, the Spring Adonis has remained a favorite there to the present time. In this country it has never had the recognition that perhaps it deserves. The flowers are like large anemones, two or three inches across, and the finely cut leaves are produced in whorls about the stem.

The annual species in cultivation are Pheasant's Eye, Adonis astivalis, bearing crimson flowers with yellow centres, and Flos Adonis, Adonis autumnalis, bearing small crimson flowers with dark centres. 


\section{COWSLIP. MARSH MARIGOLD. CALTHA.}

\section{Câltha paluistris.}

\section{Caltha, an ancient name of the marigold.}

A stout succulent herb, with hollow stems and glossy yellow flowers; found in marshy ground and along slow-flowing streams; from Newfoundland to South Carolina and west as far as Nebraska. April, May.

Siem.-One to two feet high, furrowed, hollow.

Basal Leaves.-On long, broad petioles, cordate or reniform, entire or crenate.

Flowers.-Golden-yellow, shining, two and a half inches across, borne in loose terminal clusters.

Sepals.-Five to nine, petal-like, imbricated in bud.

Petals.-None.

Stamens.-Many, filaments and anthers bright-yellow.

Pistils.-Five to ten, in a head, ripening into many-seeded pods.

And the marsh marigold shines like fire in fields and copses gray.

-Tennyson.

Caltha palustris is not a Marigold and still less is it a Cowslip, but both names designate it. The Indian name, Onondaga, "it blooms in the swamps," is best of all, if we could only make up our minds to use it. The English species has the pretty name Kingcup, but though celebrated in English verse, this seems never to have come over-seas to us.

In the Marsh Marigold we find sepals of the glossy brilliant yellow which usually distinguishes buttercups; the true petals have disappeared. The brilliant blossoms in early spring follow the line of the watercourses or adorn the swamps with flecks of flame.

The genus, Caltha, is of northern habitat and numbers about ten species, of which seven are native to North America; of these seven, two encircle the globe.

Transferred to the garden our wild Caltha will do well if given a moist location, and like all the Ranunculacea will double if desired. In late summer the leaves become very large. 


\section{CHRISTMAS ROSE}

Helléborus niger.

An ancient name of unknown meaning.

A stemless, evergreen perennial; often blooming in the open air at Christmas, in the climate of New Jersey and Ohio.

Rootslock.-Short, thick, black.

Flower Stem.-Simple or once branched.

Leaves.-Radical, evergreen, leathery, irregularly lobed; petiole five to seven inches long.

Flowers.-Large, white, sometimes flushed with purple; of leathery texture, two to three inches across.

Calyx.-Five petal-like sepals.

Corolla.-Five small, tubular petals.

Stamens.-Many.

Pistil.-Six to eight carpels, forming many-seeded capsules.

Christmas Rose, or Black Hellebore, as it is called from the color of its root, is a perennial plant growing spontaneously on the rocky and wooded mountains of many parts of Europe, especially the southern Alps and the Apennines. Cultivated in our gardens as an ornamental plant and in mild seasons blooming from December to March with very slight protection, it has gained the name of Christmas Rose. In northern Ohio on the lake shore, in those open winters that are not infrequent, it blooms without protection throughout December. In a cold frame it will bloom all winter unless zero weather intervenes. Any weather which will permit the lowly chickweed to open its corollas to the midday sun will bring forth the Christmas Rose. The large, irregularly lobed leaves spring directly from the rootstock on long, smooth, cylindrical petioles, which are sometimes dotted with red. The beauty of the blossom is due to the enlarged sepalsthere are indeed petals, rows of them, but they are curiously turned into two-lipped tubes producing nectar. The stigmas mature before the anthers. 


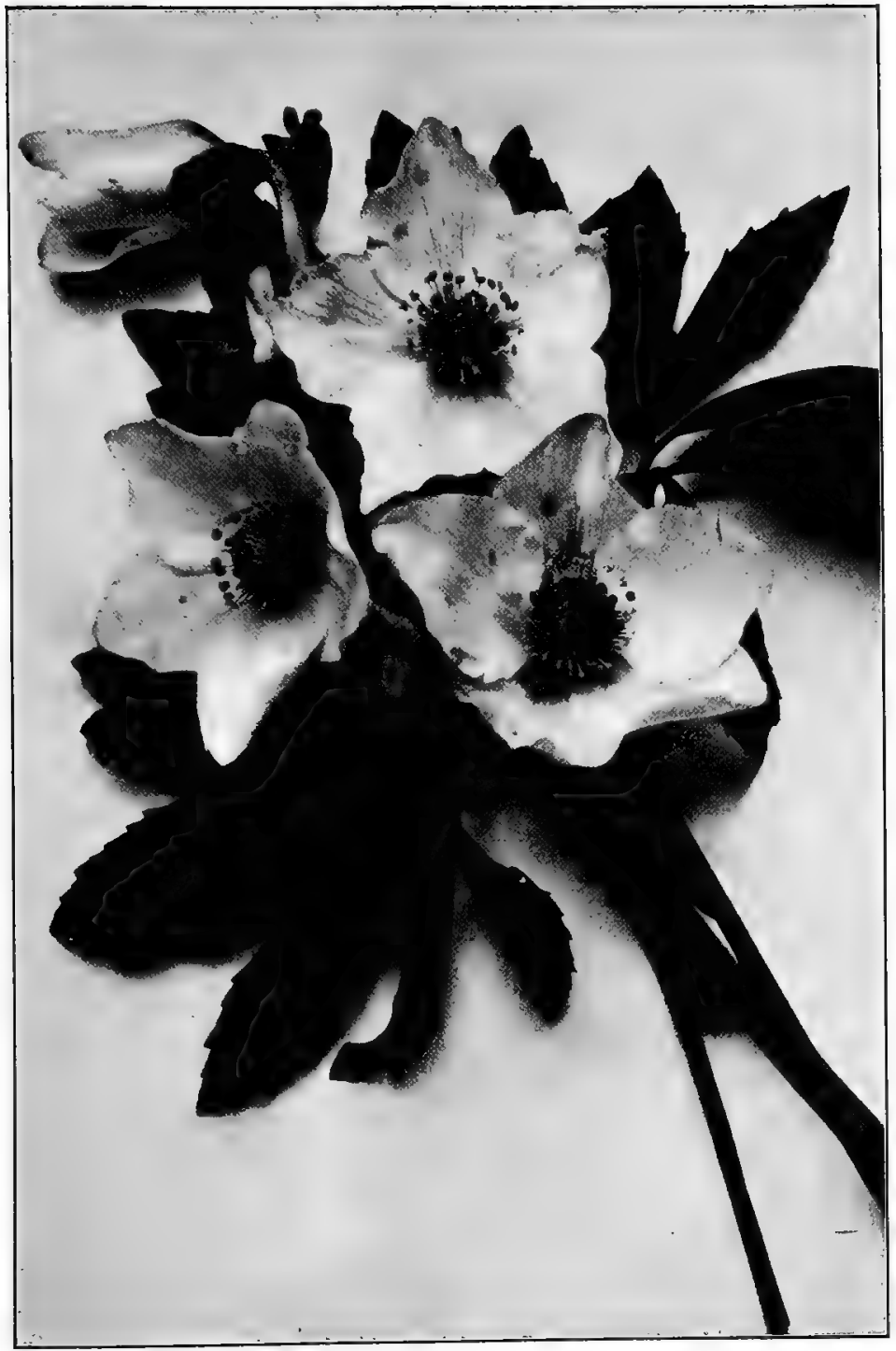

Christmas Rose. Helléborus niger 
Of the genus Helleborus eight species are known and most of them have been cultivated. Beside Helleborus niger, Helleborus viridis is common. The insect powder in common use is made from the stems and leaves of a plant called White Hellebore, but it belongs to an entirely different genus and is known as Verdtrum album.

\section{NIGELLA. LOVE-IN-A-MIST}

Nigélla damascèna.

N.igella, diminutive of niger, black; referring to the color of the $\therefore$ seeds."

A hardy annual from the Mediterranean regions. June to September.

Stem.-Erect, one to two feet high.

Leaves.-Alternate, finely divided, bright-green.

Flowers.-Showy, pale-blue or white, terminal on the branches, surrounded by a finely divided involucre. Calyx of five sepals colored like the petals.

Corolla.-Five petals with hollow claws, notched or two-lobed, often double.

Stamens.-Many, inserted on the receptacle.

Pistil.-Five ovaries united below; which matures into a five-celled, inflated pod in which the lining of the cells separates from the outer part. Seeds black, shining, spicy.

Nigella is a flower of unusual appearance, a radiant star, blue or white, that sits enveloped in a green mist. Like so many of the ranunculi, the sepals and petals are the same in color and in the double forms are fairly indistinguishable. Technically, the envelopment of finely dissected leaves is involucre; in the double forms this involucre sometimes becomes entangled with the petals.

The full rich stamens with anthers of warmer color than the petals and the green pistils standing out in bold relief from the centre give a certain touch of definiteness to the flower which it otherwise would lack. The five petaloid sepals betray their nature and their race by the delicate veining of faint-green lines; and the definite points in whicl they terminate make the blossom a five-pointed star. The single varieties possess a distinction I86 
of appearance wanting to the double forms. Too often, double flowers show simply a mass of petalage which is poor compensation for the individuality which is obliterated. A faint delicate perfume of anise lingers about the flower.

The genus Nigella is credited in the books with sixteen species, all European or Asiatic, of which three have been cultivated. Besides our own Love-in-a-mist, there is in Europe the Spanish Nigella, Nigella hispania, similar to it though larger and a somewhat coarser plant; both have been in English gardens over three hundred years. The third species is Nigella sativa, which had a career as a prized inmate of the herb gardens of the sixteenth century. It was brought into England from Egypt in 1548 , its seeds being in request as a spice or seasoning. This species seems to have been cultivated in the East for ages; indeed, the plant has been identified as the "fitches," whose seeds

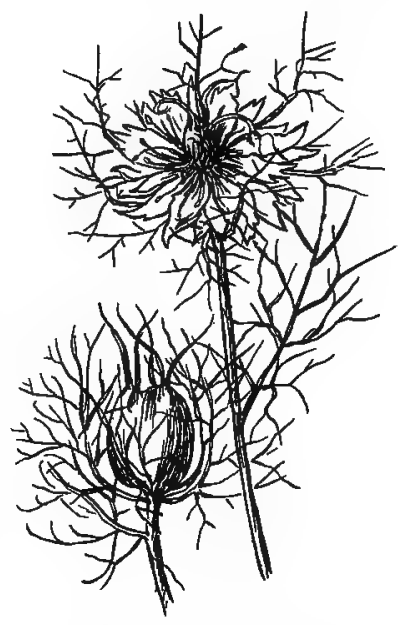

Nigella. Nigélla damascèna are "beaten out with a staff," as stated in Isaiah xxviii. The Egyptian fellaheen still cultivate the plant for the sake of these seeds, which they scatter over their bread before baking, using them as caraway and poppy seeds are used in Europe.

The gardener's advice is that the seed should be sown in the open border, in good soil, any time after the middle of March, and the seedlings thinned to a distance of about eight inches. They seldom do well if transplanted. 


\section{BERBERIDÀCE王-BARBERRY FAMILY}

\section{AKEBIA}

Akèbia quinàla.

Akebia is the Japanese name.

An ornamental climbing shrub, free from attacks of insects and especially adapted for places in which a dense screen is not wanted. China, Japan. April, May.

Stem-Climbing, twelve to fifteen feet long.

Leaves.-Long-petioled, palmately five-fingered; leafiets oval or oblong-ovate, one to two inches long.

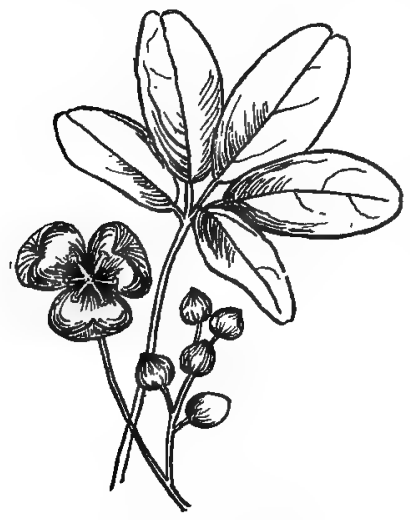

Akebia. Akèbia quindıa

Flowers.-Fragrant, diocious; the pistillate purplish-brown, about an inch across; the staminate smaller, rosy-purple.

Sepals.-Three; stamens five.

Fruit.-An oblong berry, three inches long, purple with glaucous bloom.

Akelsia makes a good permanent covering for porch pillars, clinging to a surface almost as closely as ampelopsis. Its vigorous growth begins early in the spring and its five-fingered leaves are of a type not common with us.

The inconspicuous flowers appear in April and become more abundant as the vine gets older; of the two kinds the pistillate are considerably the larger.

Akebia fruits but rarely in this country. The fruit technically is a berry; it is large, four to six inches long, somewhat suggest- 
ing a pawpaw; in color dark-purple, mottled with blue and covered with a glaucous bloom. Within is a layer of thin, dry flesh about a whitish pulpy mass in which great numbers of black seeds are embedded; the taste is insipid.

The long, slender, pliable shoots are used in Japan as we use willow, for the manufacture of baskets, trays, and even hats. No enemies have as yet appeared in this country, either insects or fungi.

\section{LARGE-FLOWERED BARRENWORT}

\section{Epimèdium macränthum.}

The ancient name dating from Dioscorides; given, perhaps, because the plant grew in Media.

Stems.-Both erect and creeping underground.

Leaves.--Thrice ternate; leaflets cordate-ovate, unequal at the base, sharply toothed; petioles with conspicuous hairs.

Flowers.-Odd-looking, long-spurred, starry; in terminal panicles.

Sepals.-Eight, in two sets; outer set sometimes bright-red, remaining after the larger and showier parts of the flower have fallen; inner sepals ovate-lanceolate, violet. Petals four, in the form of spurs, an inch long, white; nectar-bearing.

Stamens.-Four.

Ovary.-One-valved; style single; capsule opening by a valve on the back; several-seeded.

The genus Epimedium contains a number of perennial herbs which are characterized as among the daintiest and most interesting plants that can be grown in the hardy border.

The Great-Flowered Barrenwort is reported "as distinct, complicated, and fascinating as many of the rare, tender, and costly orchids." What adds to the interest is that the sepals take on petaloid forms and colors, the petals become spurs for the production of nectar, and the whole is brilliantly colored. The plant is native to Japan and has been in cultivation long enough to develop several garden varieties. 


\section{PAPAVERÀCEA-POPPY FAMILY}

Papaveracea is a group of herbs with regular flowers; a calyx of two sepals which fall as the blossom opens; petals four to ten; stamens many; the fruit a many-seeded capsule. The juice is usually milky or colored and either narcotic or acrid.

The principal garden representatives are Poppy, Plume Poppy, California Poppy, Bloodroot, and Prickly Poppies.

\section{COMMON POPPY. OPIUM POPPY}

\section{Papaver somniferum.}

Papaver is the ancient name of unknown meaning.

Oldest of cultivated poppies, containing the opium-producing variety. Annual.

Stem.-Three to four feet high, robust, glaucus and glabrous; juice milky.

Leaves.-Oblong, unequally toothed at base, or deeply cut. Flower stems long and flower buds nodding.

Flowers.-Naturally single, but in cultivation double as well; the color range extensive and varied.

Sepals.-Two, which drop as the flower opens.

Petals.-Four, orbiculate; or many.

Stamens.-Many:

Ovary.-An ovoid, or obovate, or glandular capsule, covered with a disk in which the stigmatic lobes are embedded; these radiate from the centre. When ripe the capsule opens under the lid at the top by transverse pores between the placentæ; the openings are very small. Seeds many and small.

Being of many variable colours and of great beautie, although of an evill smell, our gentlewomen doe call them Jone Silver-pin. -Gerard. 


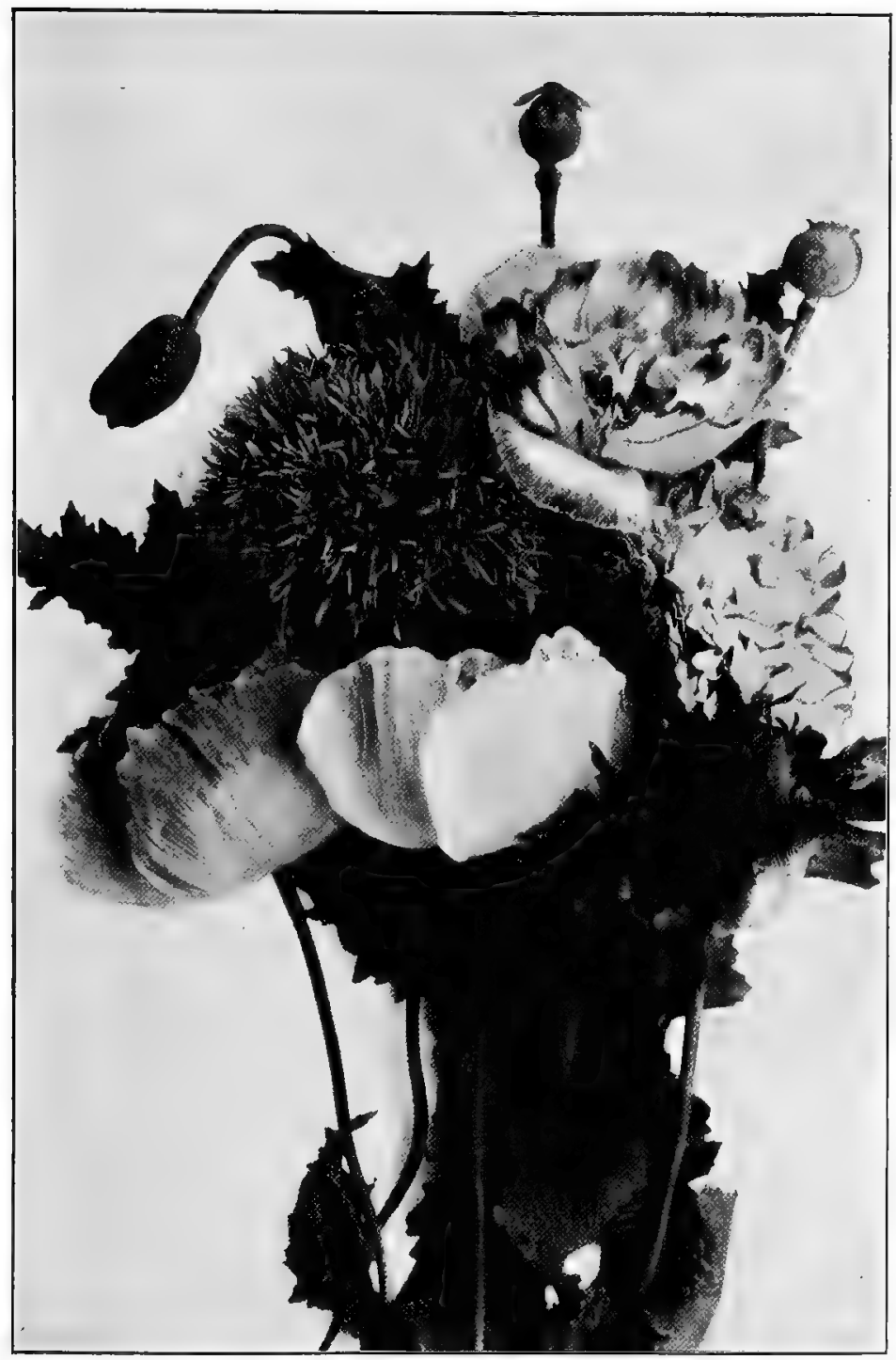

Poppy in variety. Papáver somniferum 


\section{POPPY FAMILY}

The Sleep-Bearing Poppy is the best known of its race and the most variable. As it now appears it is, of course, a hybrid, marked with the strains of many forebears, which show in the infinite variations of color, size, and form; yet, notwithstanding all vagaries, at base the prepotent primitive persists.

There is something marvellously fine about the Poppy. Its robust health, the nodding grace of the buds, the airy poise of the fully opened flower, the silky tissue of the petals, and the bold riot of color which "against the light or with the light is a flame and warms the wind."

The chief objection to the Poppy is the shortness of the flowering season, and the death of the plant immediately after; thus leaving its place in the garden bare in midsummer. A wonderful burst of color for two or three weeks and all is over! This gives a problem that has to be met by all who grow poppies.

The Poppy doubled under cultivation long ago, and has developed along two main types, known as the peony-flowered and the carnation-flowered. The carnation-flowered have fringed petals, the peony-flowered have not. Many different strains of each type are in the market, and there is probably no limit to the number of varieties that may be produced.

A variety of Papaver somniferum grown extensively in Persia, India, and China produces the opium of commerce. This is the milky juice which issues from shallow cuts made in the young capsules, thickens and darkens as it exudes, and becomes crude opium. Opium can be made wherever the Poppy will grow, but cheap labor makes it profitable in the East.

The seeds have no narcotic properties and are sold for bird food under the name of maw seed. In the East a valuable oil is obtained from them.

Papaver is a genus of about fifty species, mostly natives of the Mediterranean region. One species is reported from South Africa, one from Australia, and there is one in California. Curiously enough the California Poppy of the gardens is not a true Papaver, but an allied genus. 


\section{SCARLET POPPY. CORN POPPY}

\section{Papàver rhèas.}

Rheas, an ancient classical name for Corn Poppy.

The annual scarlet Poppy of the wheat fields of Great Britain and the Continent. Parent of the French Poppies and of the Shirley strain.

Stem.-Bristly, two feet high.

Leaves.-Yellow-green, bristly, pinnately parted.

Flowers.-Scarlet with a black eye, two of the petals smaller than the other two; in cultivation every color of the opium poppy has been reproduced, but the flowers are always smaller.

Ovary.-Ovoid or obovate; stigmatic rays eight to ten.

All silk and flame, a scarlet cup seen among the wild grass far away like a burning coal fallen from Heaven's altars. You cannot have a more complete, a more stainless type of flower absolute-inside and outside-all flower!

-RUSKIN.

Rhaas is the Poppy of English literature. Native or naturalized to Great Britain and the Continent, particularly enjoying a limestone soil, it has become the weed of the wheat fields and the occupant of waste and neglected places. In Germany the blue cornflower disputes possession of the wheat fields, but even there the Poppy fairly well holds its own. The question has been raised whether it would ever become a weed in this country, but horticulturists think not; we grow it with some difficulty in our gardens.

Upon this primitive stock the French gardeners worked, breaking down the original color and producing a strain

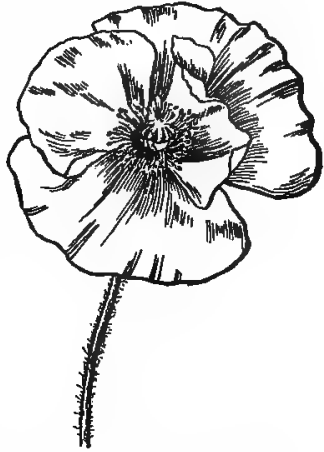

Scarlet Poppy. Papdver rhàas var. Shirley which was considered the best garden form until I886 when the Shirley Poppies appeared. 
These were the work of the Rev. W. Wilks, secretary of the Royal Horticultural Society, who gives the following account of the development of these poppies in "The Garden," vol. LVII.

He says: "In I880 I noticed in a waste corner of my garden, abutting on the fields, a patch of the common, wild, field poppy Papaver rhaas, one solitary flower of which had a very narrow edge of white. This one flower I marked, and saved the seed of it alone. Next year, out of perhaps two hundred plants, I had four or five on which all the flowers were edged. The best of these were marked and the seed saved, and so on for several years, the flowers all the while getting a larger infusion of white to tone down the red, until they arrived at quite pale-pink, and one plant absolutely pure-white. I then set myself to change the black central portions of the flowers from black to yellow or white, and at last fixed a strain with petals varying in color from the brightest scarlet to pure-white, with all shades of pink between and all varieties of flakes and edged flowers also, but all having yellow or white stamens and a white base."

The marked characteristics of Shirley Poppies are four: They are always single, always have a white base, stamens are yellow or white, and there is never the smailest particle of black about them. Double Poppies and Poppies with black centres are beautiful, but they are not of the Shirley strain. It is the absence of black blood that gives the Shirleys their wonderfully light, silken, papery texture.

\section{ICELAND POPPY}

\section{Papàver nudicaùle.}

Stem.-Slender, leafless.

Leaves - Radical, rough-hairy, obovate in outline, deeply pinnatifid, growing in tufts.

Flowers.-Yellow or orange, solitary; on a hairy scape, six to twelve inches high.

Sepals.-Two, which drop as the flower opens.

Capsule.-Long, slender, hairy. 
The Iceland Poppy is a widely distributed, arctic, perennial species which is found in America as far south as the peaks of the Rockies in Colorado. It is naturally variable and readily doubles. The primitive is yellow, but hybrids now appear in colors varying from yellow through orange to scarlet and rose-pink.

The flowers are airy and wind-blown cups swaying on stems slender as grass and-one more virtue to their credit-they are useful for cutting. For this, however, they should be picked when in bud.

The flowering season will be lengthened if the seed pods are not permitted to mature, and as they are northern plants they should be grown where the hot south-western sun will not strike them.

Closely allied to this species is Papaver Alpinum, typically a fragrant white-flowered perennial of the

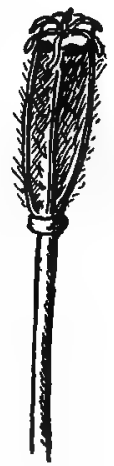

Capsule of Iceland Poppy European Alps; of dwarf habit. It is not very easily grown.

\section{ORIENTAL POPPY}

\section{Papduer orientàle.}

A magnificent perennial Poppy, a native of Persia and Asia Minor; introduced into England from Armenia in I 7 I4. May, June.

Stem.-Stout, leafy, crowned with the flower.

Leaves.-Hispid, pinnately parted or cut; lobes oblong-lanceolate, serrate.

Flowers.-Terminal, with a spread of six to eight inches; in the type scarlet with a black eye.

Sepals.-Three, which drop as the flower opens.

Stamens.-Many, dark-purple.

Capsule.-Large, obovate with flat disk; stigmatic rays eleven to fifteen.

The Oriental Poppy is the most superb and barbaric representative of the wonderful Papaver family. The blood of all the Poppies runs rich and red; all in the sunshine are incarnate color, but of them all the Oriental bears the palm. 
Best of all, this gay and gallant creature blooms in the spring, bearing onward from the rows of daffodils and beds of tulips the warm glow of color.

In May great flower stalks rise from a tuft of leaves, crowned with heavy buds that increase in size, till some morning the thick,

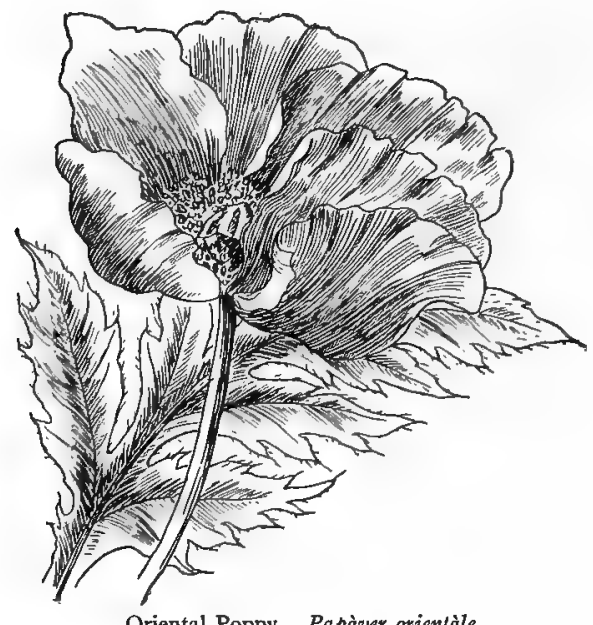

Oriental Poppy. Papàver orientàle hairy calyx breaks, and the great scarlet petals shake themselves free.

The great petals are splashed near the base with broad, irregular spots of black-purple. Dominating the flower, covered and crowned with purple rays softened with lilac, stands the seed pod an inch high and more than an inch across. Around this splendid central globe are the stamens, row upon row, circle within circle bearing anthers of a splendid duskypurple, each held upon a slender filament of deeper-purple.

Although in the type the flower is scarlet, a considerable class of hybrids has been produced which extend the color range through red to orange and from salmon to pale-pink. When once the color of a primitive is broken, one cannot predict what changes may occur. All the variants are beautiful, but they do not transcend the type.

The plant is perfectly hardy, rarely fails to blossom generously, and will flourish with little care. 


\section{PLUME POPPY. BOCCONIA}

Boccònia cordàta.

Named for Bocconi, an Italian botanist.

A tall perennial with leafy stems and cordate, orbicular, lobed leaves; bearing long terminal panicles of white flowers in summer. In general appearance very unlike a Poppy. Midsummer. China.

Stem.-Simple, erect, six to eight feet high, leafy.

Leaves.-Alternate, orbicular,' cordate, lobed, pale-green above, silvery beneath.

Flowers.-Cream-white or pale-rose, small, borne in plume-like panicles.

Calyx.-Two oblong sepals, a quarter of an inch long.

Stamens.-Many.

Ovary.-One-celled.

Stigma-Two-lobed.

Capsule.-Many-seeded.

The Plume Poppy is as much unlike our idea of a Poppy as can well be. In the first place, the stem is very tall; in the second, it bears a plumy panicle of many small flowers, not one of which ever had any corolla, whose sepals did duty while the flowers were in bud, but departed immediately the buds opened, so that each flower consists principally of a group of slender diverging stamens. These are crowded and so form a feathery mass.

In many respects the plant is disappointing. It seems better adapted for a distant view than for close relations along the garden walk.

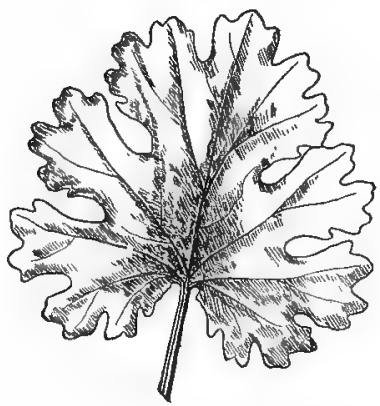

Leaf of Plume Poppy. Boccònia corddta Doubtless, it can be utilized successfully in lawn or park planting, where its gray foliage would add a touch of desired color.

The root suckers freely and when well established is hard to eradicate. 


\section{BLOODROOT}

Sanguindria canadénsis.

Sanguinaria, from the color of the juice.

A low perennial, with thick, prostrate rootstocks, sending up in earliest spring a one-flowered, naked scape protected by a palmately lobed leaf rolled around it. The entire plant is surcharged with redorange acrid juice. Grows in open woods from Nova Scotia to Manitoba and south to Florida, Arkansas, and Nebraska. April and May.

Rootstock.-Horizontal, thick; juice red.

Leaves.-Basal, palmately veined and lobed, cordate or reniform, five to twelve inches across.

Sepals.-Two, that drop as the flower opens.

Petals.-Eight to twelve, white, oblong, arranged in two or three rows, early deciduous.

Stamens.-Many, considerably shorter than the petals; filaments thread-like; anthers linear.

Ovary.-Oblong, one-celled; stigma grooved.

Capsule.-Oblong, narrow; seeds smooth, crested.

Bloodroots whose rolled-up leaves if you oncurl,

Each on 'em's cradle to a baby pearl.

—"Biglow Papers," Lowell.

From the terminal buds of the thickened underground stems of the Bloodroot there arises in very early spring a flower-stalk bearing, as a rule, a single blossom. For a time both stalk and opening bud are enveloped and protected by a closely rolled leaf, but this gives way finally and discloses a starry flower of snowy whiteness with a heart of gold. When in full bloom the petals fall so easily that it will hardly bear transportation, for with a touch the stem stands naked.

Like all the poppies, the calyx falls when the bud opens, and the full-blown flower has none.

The bloody name of Sanguinaria is due to the acrid red-orange juice with which the entire plant is surcharged, and which flows freely when rootstock, leaf-stalk, or flower stem is broken. 


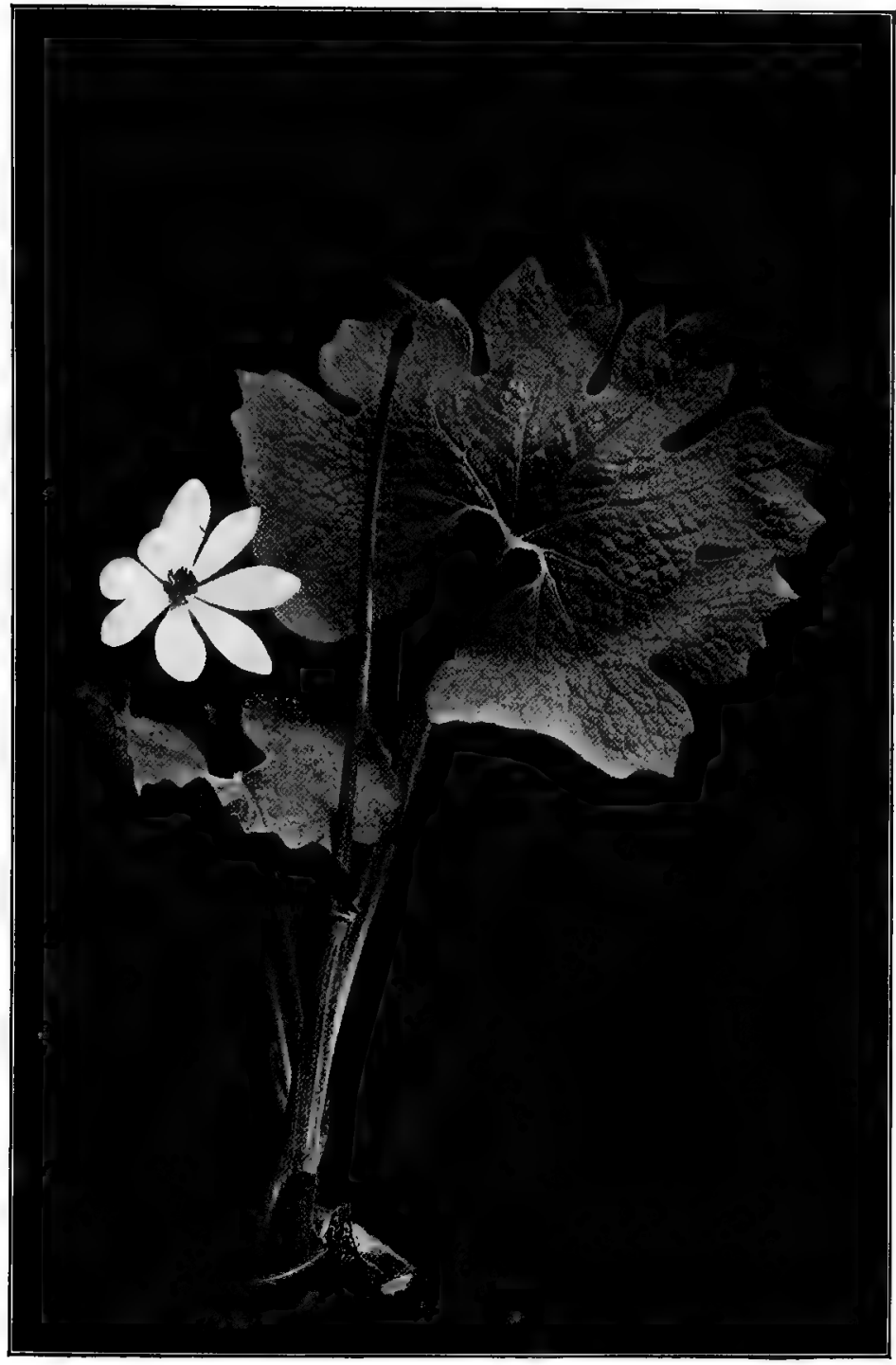

Bloodroot. Sanguinària canadênsis 
Bloodroot is easily cultivated, blooms with the hepaticas, and makes a beautiful plant for the garden, open woods, lawn, or park. Late in the season the leaves increase very much in size.

\section{CALIFORNIA POPPY. COPA-DE-ORO}

\section{Eschschòltzia califórnica.}

Eschscholtzia, in honor of Eschscholz, the surgeon on the Rurik and friend of Chamisso, who named the plant Copa-de-oro, Cups of gold.

A perennial herb, best treated as an annual, now appearing in many colors.

Stem.-Twelve to eighteen inches high and branching.

Leaves.-Alternate, finely dissected, gray-green, glaucous.

Flowers.-Two or three inches across, usually orange and yellow, but ranging from that to white. Top of the peduncle enlarged into a cupshaped disk, upon the upper inner surface of which are borne the calyx, corolla, and stamens.

Calyx.-A pointed green cap of two sepals falling early.

Petals.-Four.

Stamens.-Many; filaments short; anthers long.

Ovary.-One-celled; style short; stigmas three to six, unequal.

Capsule-Cylindrical, ten-nerved, two or three inches long.

The early Spanish explorers sailing back and forth along the Californian coast noted the flame of the poppies upon the hillsides coming down to the sea, and called the coast the Land of Fire, "sacred to San Pascual," they said, "since his altar-cloth is spread upon all its hills." Later, when the Russian expedition of 18 I5, under Kotzebue, sailed northward exploring the coast, the countless millions of golden cups again won the notice and admiration of the visitors, and Chamisso, the naturalist of the expedition, in reporting the plant, gave it the name of the surgeon of the expedition, Eschscholz, and Eschscholtzia it remains. The name seems unfortunate, as it is one that will never be spoken trippingly on an English tongue, though really more appalling to 
sight than to sound. : California Poppy rightly belongs to another plant, Papaver californica, but is pre-empted by this one.

At home Eschscholtzia is perennial, but our Eastern climate transforms it into an annual. The color range includes yellow, orange, rose, carmine, and scarlet, but the glowing orange is after all the most satisfactory. Satellites of the sun, the beautiful blossoms will not unfurl their flaming petals save to his direct rays, hence they are early to bed and late to rise. The flowers open for two, sometimes three, consecutive days. In one particular, Eschscholtzia differs from all other genera of the poppy family. Two sepals are the family allowance, and these though enclosing the bud are thrust apart by the opening petals and fall to the ground as soon as the corolla is mature. In our California

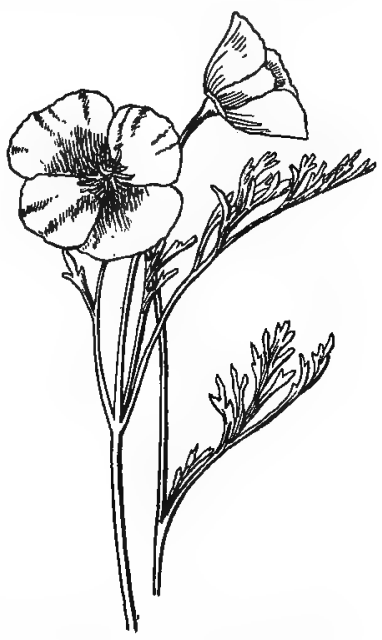

California Poppy, Eschschblzzia califórnica

Poppy, however, the sepals are too closely united to be driven asunder by the petals, and consequently the calyx is simply lifted up and off as if it were an extinguisher or a dunce cap, and the glowing flower smiles open to the sky.

There are many forms of Eschscholtzia and of late the original Eschscholtzia californica has been divided into a number of new species, which are, however, difficult of determination.

The following species of Papaveracee have been cultivated, but have now given place to more desirable forms:

Celandine, Chelidònium màjus, owes its ancient Greek name to the fact that its flowers appeared with the coming of the swallows. 
The little yellow blossom is often referred to in English poetry, but its charm is that of the wild flower, the plant being scarcely worthy of a place in the garden.

Prickly Poppies, Argêmone platycèras and Argémone mexicàna, have both been tried in our gardens. The blossoms are like large

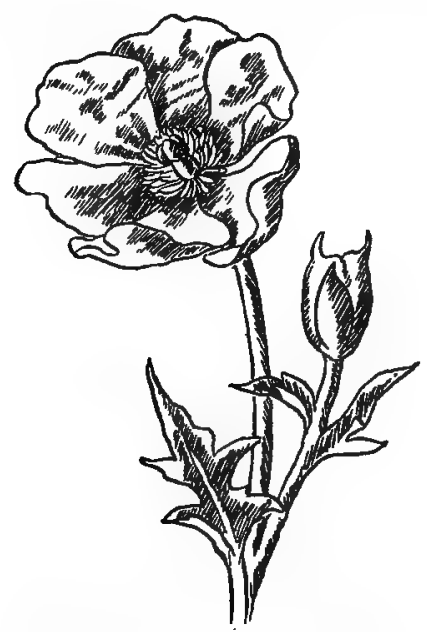

Prickly Poppy. Argémone mexicàne

single poppies and in themselves attractive, but the plants are coarse and produce abundant, sticky, yellow juice which pours out from every wound of the stem.

These are very effective on the mesas of Colorado or the dry plains of the South-west, but when transferred to the garden they do not readily harmonize with their surroundings. They might be used for broad effects in color as their gray foliage is striking.

Matilija Poppy, Romneya Coilleri, a shrub poppy of Southern California, nearly herbaceous at the East, produces magnificent flowers four to six inches across, but is not sufficiently hardy for successful cultivation at the North. 


\section{FUMARIÀCE E-FUMITORY FAMILY}

Delicate smooth herbs with watery juice, compound dissected leaves, and irregular flowers. The two sepals are small and scalelike. The corolla consists of four petals in two pairs; the outer with spreading tips, and one or both of them spurred or saccate at the base; the inner pair narrower and their callous-crested tips united over the stigma. The stamens are in two sets of three each, placed opposite the larger petals; their filaments often united; the middle anther of each set two-celled, the lateral ones one-celled. Pod one-celled, one or several-seeded. Several native species are in cultivation, but the best-known garden representative of the family is Bleeding Heart, an Asiatic species.

\section{BLEEDING HEART}

\section{Dicéntra spectábilis.}

Dicentra, Greek from dis, and kentron, two-spurred; originally misprinted Diclytra and then supposed to be Dielytra.

An ornamental spring-blooming perennial, native to Japan, northern China, and Siberia; sent into England in 1846 by Robert Fortune.

Stem.-One to two feet high, branching.

Leaves.-Compound in threes, divisions rather broad, suggesting peony leaves.

Flowers.-Irregular, heart-shaped, rose-colored, borne in simple, secund, drooping racemes, four to eight inches long.

Calyx.-Reduced to two small scales, often disappearing.

Corolla.-Cordate at base, four-petalled; petals in two pairs, connivent, slightly coherent; outer pair rose-colored with flaring tips; inner pair protruding, white, spoon-shaped, winged at the back and easily breaking into two parts, closing over the anthers and stigma at the apex of the flower. 
Stamens.-Six in two sets; filaments of each set more or less grown togethere, curved to conform to the shape of the outer petals; all the anthers tightly pressed together and around the stigma at the union of the tips of the inner petals.

Ovary.-Long, slender; style slender.

Capsule.-Several-seeded.

Although Linnæus possessed dried specimens of Bleeding Heart, the first living plant seen in Europe was sent by Robert Fortune to the London Horticultural Society in 1846 , and bloomed on their grounds in May, 1847 . Going to China, in 1842 , as a representative of the society, Mr. Fortune selected and sent home many plants; among them Bleeding Heart, Weigela, and the Chusan Daisy, the parent of the present Pompon Chrysanthemum.

Dicentra spectabilis has certainly proved an acquisition to our garden flora, its beauty is of such rare and unusual type. The long drooping sprays of pendent rose-colored hearts are certainly unique among floral forms.

The plant, too, is hardy and, best of all, an early bloomer. The blooming spray has little value as a cut flower, but it adorns the garden walk wondrously. The gardeners have meddled very little with the plant except to feed it generously and it remains a primitive. It can be forced, but this is scarcely worth while.

\section{DICENTRA. SQUIRREL CORN}

\section{Dicêntra canadênsis.}

Root.-Fibrous, with subterranean shoots bearing scattered tubers, resembling yellow peas.

Leaves.-Gray-green, radical, with slender petioles, ternately compound and dissected; lobes linear.

Flowers.-Four to ten on a slender scape, odd shaped, white tinged with rose, slightly fragrant.

Calyx.-Two small and scale-like sepals.

Corolla.-Heart-shaped; spurs very short and rounded; the four petals in two pairs; the crest of the inner petals conspicuous, projecting. 
BLEEDING HEART

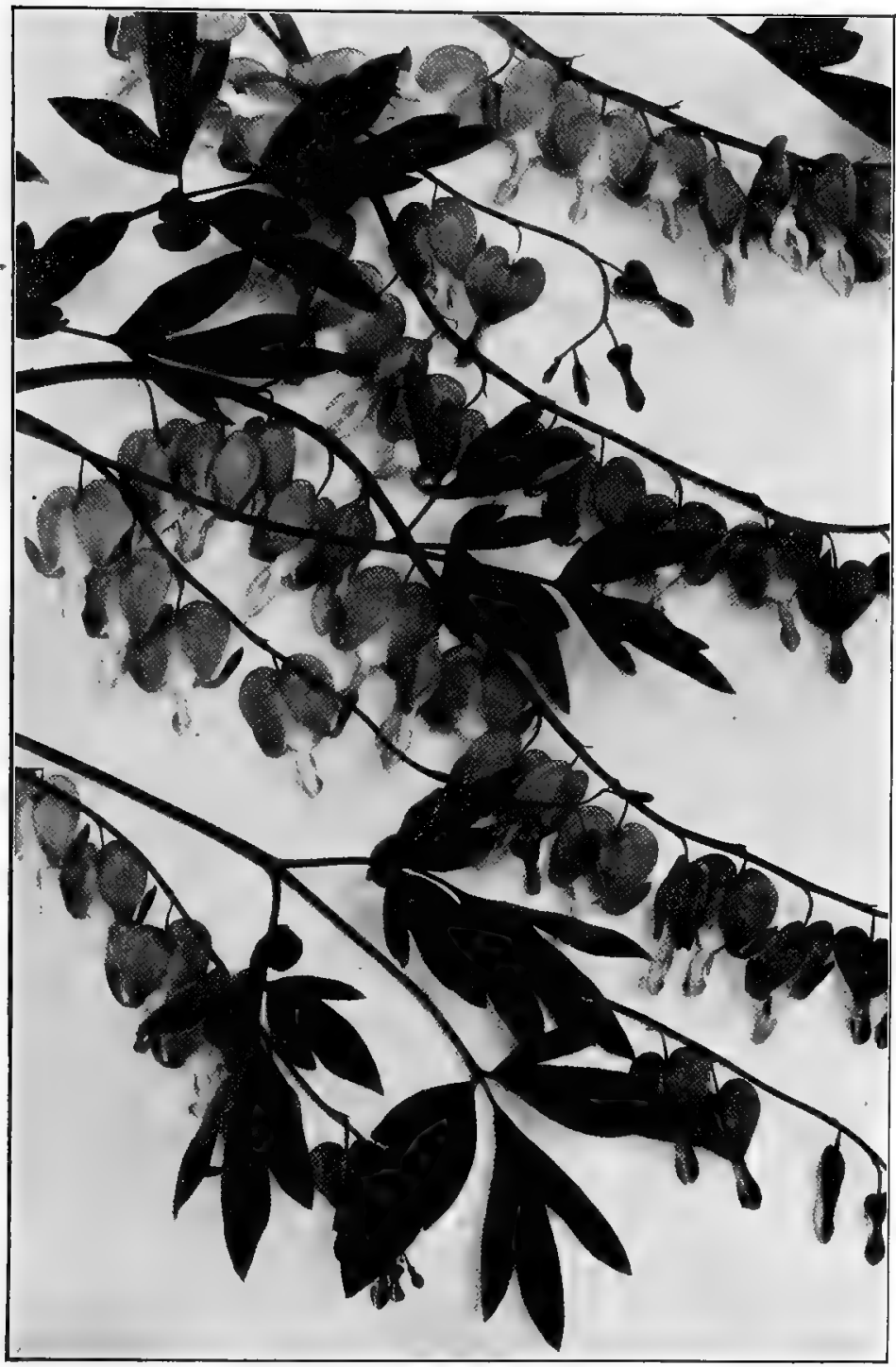

Bleeding Heart. Dicéntra spectábilis 
Stamens.-In two sets of three each, slightly united by their filaments. Ovary.--One-celled; style slender; stigma two-crested.

Pod.-Ten to twenty-seeded.

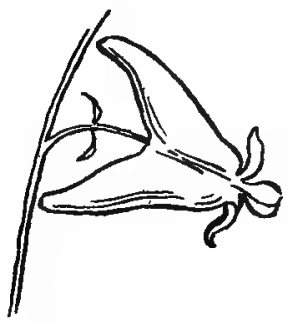

Flower of Dicéntra cucullària slightly enlarged

The two Dicentras, canadensis and cucullaria, are the Dromios of the wild woodthey appear, "not one without the other." As a rule one species is most abundant in a given locality, but the other is to be found near by in lesser numbers. The foliage of both is the same grayish-green, dainty and delicate; the flowers alike in general form, differing only in slight detail; the general effect of the plants charming to a degree. They can easily be distinguished by root and by flower. The roots of cucullaria are a collection of small, solid tubers enclosed in a common scaly sheath; that of canadensis round, scattered, yellow tubers, the size of peas. The flower of cucullaria has a corolla with two divergent spurs longer than the pedicel; the crest of the inner petals" minute. The flower of canadensis is merely heartshaped, the spurs very short and rounded, the crest of the inner petals conspicuously projecting. The flowers of cucullaria are white tipped with cream, those of canadensis white tinged sometimes with rose, more or less fragrant. Both succeed in cultivation.

Two other native Dicentras are

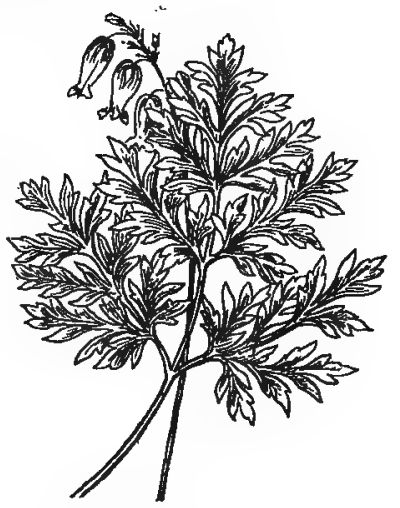

Dicéntra eximia in cultivation which very greatly resemble each other, and concerning which the books give confused reports.

Dicentra eximia is a rare species of the Alleghanies found in New York and southward as far as Georgia. Its leaves are simi- 


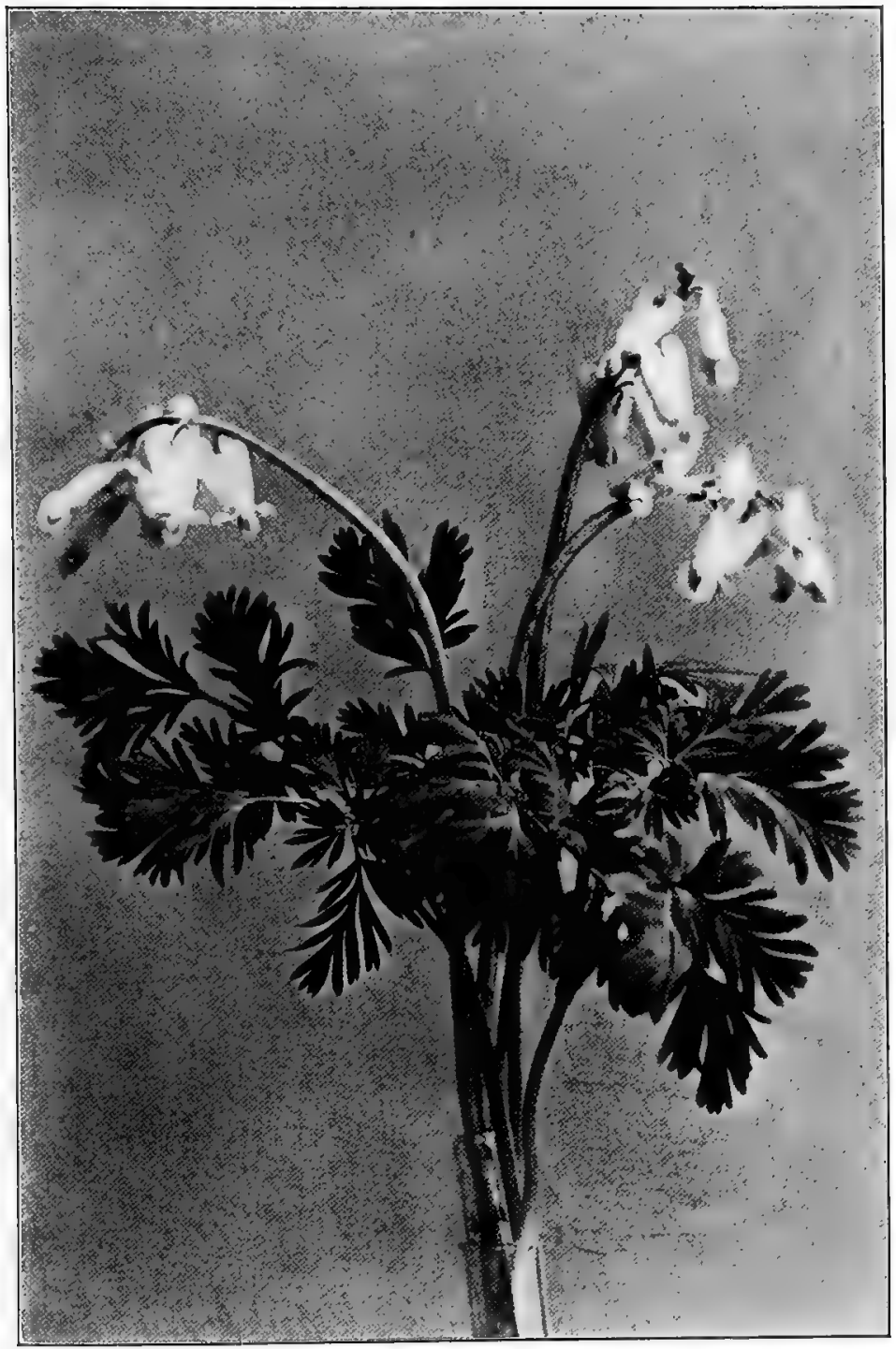

Squirrel Corn. Dicéntra canadénsis 
lar in type to those of canadensis, but coarser. The subterranean shoots are scaly. The flowers are borne in compound

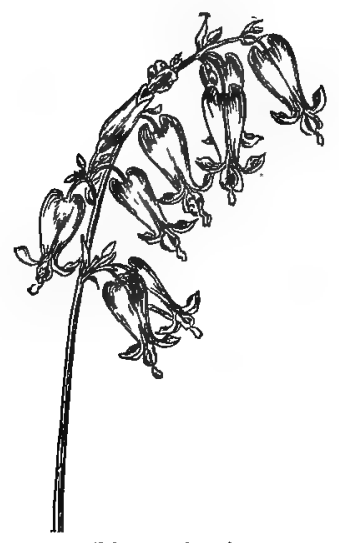

Dicénlra formòsa racemes, are rose-pink, the corolla oblong, heart-shaped at base, the crest of the inner petals projecting. Blooms throughout the summer.

Dicentra formosa is a plant of northern California and is the species oftenest named in the florists' lists. Its leaves are similar to those of canadensis but coarser. The flowers are borne in compound racemes, rose-pink, the corolla oblong, heart-shaped at base, the crest of the inner petals scarcely protruding. To an amateur it would seem that the two are simply an Eastern and a Western form of the same species. It is evident that the species are confused by the trade, which certainly is not surprising.

\section{ADLUMIA. CLIMBING FUMITORY. ALLEGHANY VINE}

Adlùmia cirrhòsa.

Named for John Adlum, one of the first horticulturists in this country.

A delicate vine found in low, shady grounds, and climbing over bushes to a height of eight or ten feet by means of the slender young leaf stalks. Sometimes cultivated. Summer. Biennial.

Stem.-Weak, slender, delicate, climbing.

Leaves.-Very compound, delicate, pale-green, with climbing leaf stalks.

Flowers.-In loose clusters of three to six, flesh-colored or pink.

Sepals.-Two, scale-like. long.

Petals,-United into one slender heart-shaped body about an inch 
Stamens.-Six in two sets at the summit; grown together in a tube below, which is adherent to the corolla.

Ovary.-Oblong; stigma, two-crested; seeds, not crested.

The Alleghany Vine is a delicate creature, native to the Appalachian range, found in low, rich ground climbing and trailing over

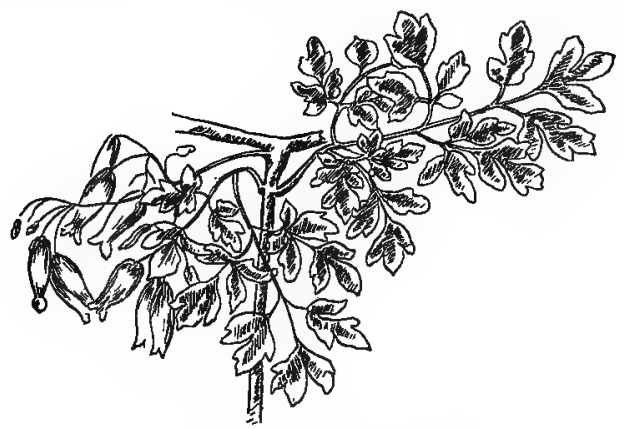

Adlumia. Adlimia cirrhòsa

bushes which give support to its weakling stems. It climbs like the clematis by means of its prehensile leaf stalks. The foliage is misty, pale-green, extremely delicate, and the vine hangs fairy festoons of beautiful foliage and exquisite pale-pink blossoms from branch to branch in its leafy covert. Its garden value taken by itself is slight, but in association with stronger vines as a sort of veil and a bit of lighter color it produces admirable effects. 


\section{CRUCIFERÆ-MUSTARD FAMILY}

The Crucifers are not martyrs, as their name might imply; on the contrary, they constitute a most vigorous and highly organized floral group, thoroughly equipped to succeed in the struggle for life. They have developed and applied two important principles: the first, to make one stem do duty for many flowers; the second, to permit no blossom at the tip of the flowering stem, so ending its upward growth. Each flower has four sepals, and four petals arranged in the form of a Greek cross, whence the name, Crucifere. The stamens are six, four long and two short. The pistil is two-celled and in fruit forms a pod whose sides split off from the central plate, leaving the seeds free to fall; this technically is called a silique.

The family is made up principally of herbs with watery, pungent juice, alternate leaves, and flowers either in racemes or corymbs.

\section{STOCK. GILLIFLOWER}

Matthìola incàna.

Matthiola, in honor of Dr. Matthiol, an Italian botanist; 1500-1577.

Biennial or perennial, but best treated as an annual; becoming woody at base. Native to the Mediterranean region.

Stem.-Stiff, cylindrical, erect, branching,

Leaves.-Alternate, oblong, entire, obtuse, tapering to a petiole.

Flowers.-Single or double, borne in short terminal racemes which lengthen during the flowering period; colors range from white through rose, crimson, purple, and parti-colored, fragrant.

Calyx.-Two lateral sepals slightly saccate; other two narrow, with. out sacs.

Petals.-With long claws and wide-spreading border.

Siliques.-Three to four inches long, erect; seeds broad, winged. 


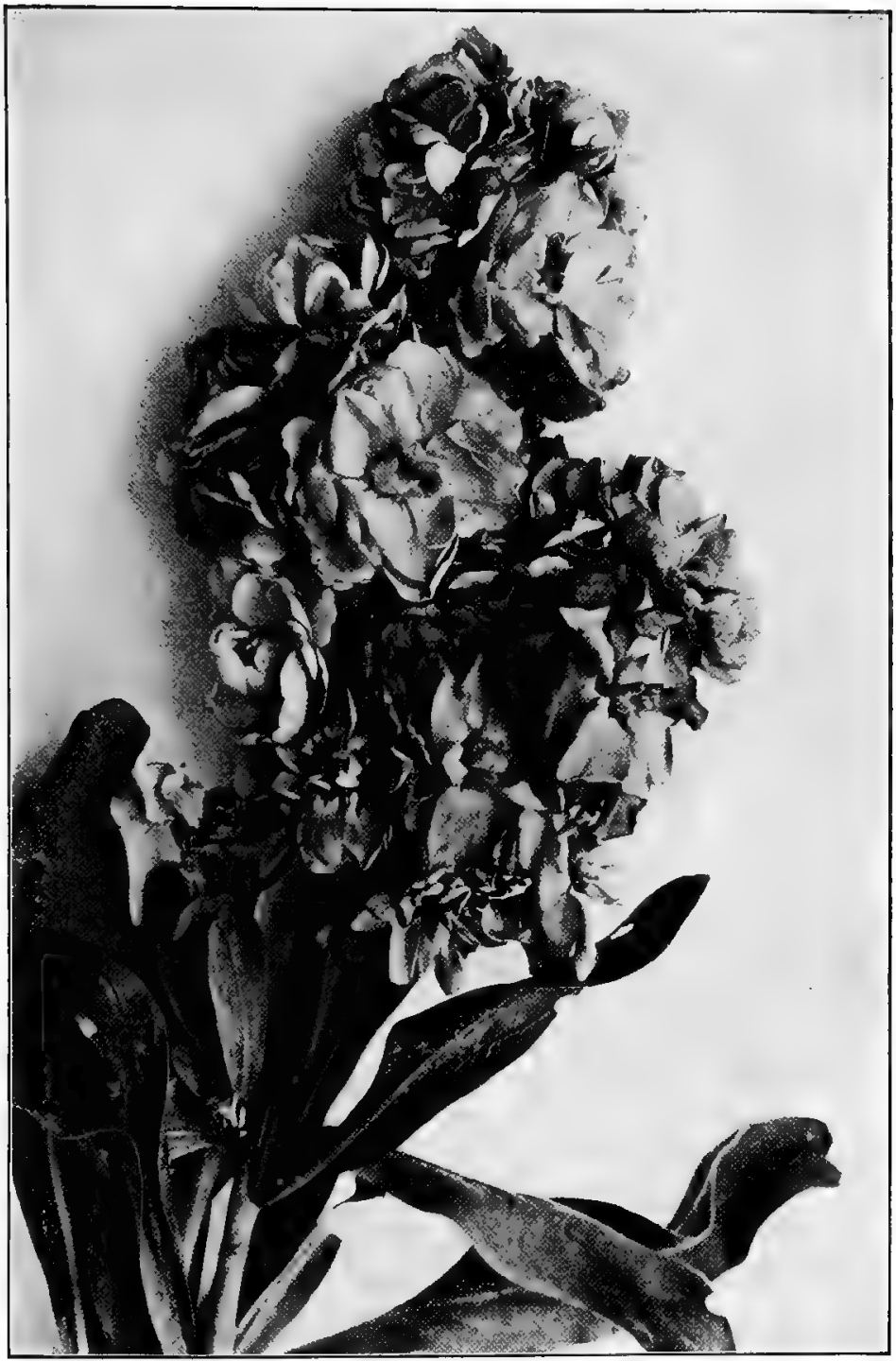

Stock. Matthiola incàna 
Stocks are divided into two groups: the autumn-flowering Queen or Brompton Stocks, and summer-blooming Ten Weeks, or Intermediate Stocks.

These are sometimes referred to two species, Matthiola incana and Matthiola annua, but it is probable that they are garden forms of one polymorphous species; certainly they cannot now be distinguished by any definite botanical characters.

The double-flowered varieties, known as Ten Weeks, are among the most pleasing of garden annuals. They come quickly into bloom, are delightfully fragrant, and linger long in autumn. If early bloom is desired the plants should be started in cold frames. The garden name emphasizes the fact that from the time of sowing to the time of flowering is about ten weeks. The autumnblooming stocks are biennials.

It is interesting to know that the seed of both groups comes to us from Germany, principally from Erfurt and Quedlinburg, where plants are especially grown for seed which will produce double flowers. Obtaining these is a very careful and delicate process. In the beds are both single and double-flowering plants. In the doubles the stamens and pistils are either partially or entirely aborted.

The beds require an enormous quantity of water which must be given under most careful conditions. After the plants have been in bloom for some time, the double-flowering specimens are cut out and the beds continue to be carefully watered until the seedpods which form on the single plants show indications of ripening, which is in October. The plants are then pulled and tied into bundles which are hung up in dry sheds until November or December, during which time the seed fully matures in the pod. Finally, the stalks are taken down, the seed-pods picked and sorted. Curiously enough the pods indicate by their shape and size whether the seeds will produce a high percentage of double flowers the - following year, and the selection is made with great care. The seeds that go on the market are greatly improved by the removal of the "wild pods" which contain the single seeds. The pods are shelled by hand, the work being done by women and children. 
So we may add the Double Stocks that hlow. llong the garden path to the already long list ont things "made. in Germany."

\section{PURPLE CANDYTUFT}

Ibèris umbellàta.

Iberis from Iberia, the ancient name of Spain where the genus is abundant.

A showy, branching annual of easy cultivation; common in gardens.

Stem.-Branching, about a foot high.

Leaves.-Lanceolate, acuminate, lower ones serrate, upper entire.

Flowers.--In flat-topped clusters, pink or pale-purple; four-petaled; petals clawed, irregular, two much larger than the other two.

Sepals.-Saccate; six stamens, four long and two short; siliques much compressed, winged, one-seeded.

Candy or Candia is the old English name for the island of Crete, from which seeds were brought into England some three hundred years ago that produced the plant we know as the Purple Candytuft. It is recorded by Gerard, I 587, that he received

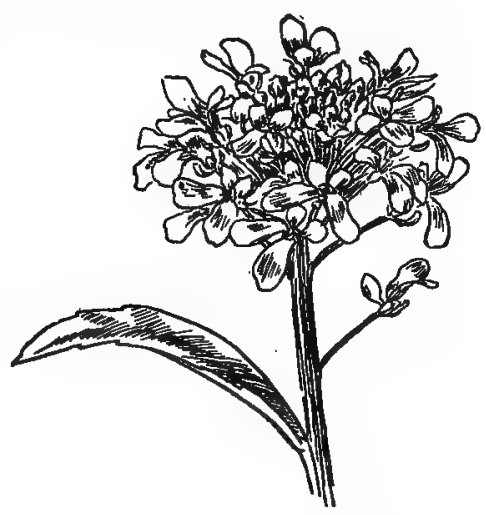

Bitter Candytuft. Ibèris amdra seeds of the Candy-mustard which produced in his garden flowers that were "sometimes blue, often purple, sometimes flesh-colored and seldom white."

As a rule the crucifers have petals alike in form and size, but. one of the generic peculiarities of Candytuft is that the petals are not of the same size, two being considerably larger than the other two. The flowers in the centre of the cluster are smaller than those at the circumference. This is the common annual Candy- 
tuft with colored flowers, the colors being more numerous and better fixed than in any other species, and a well-grown blooming bed gives wonderful variations in tone of rose-purple melting through pinks and flesh into white as one little head stands close to another.

The Bitter Candytuft, Iberis amàra, is the white annual species generally grown in gardens. This is a small plant six to twelve inches high with erect branching stems. The flowers are white, sometimes purplish, borne in a cluster which begins as a corymb and ends as a raceme. In general effect the flowers differ very little from those of Iberis umbellata and the species appears both in variants and hybrids.

The Evergreen Candytuft, Iberis semperrvirens, a native of Crete, is a delightful little creature that spreads its shrubby stems in a thick mat over the ground and blooms in early April in company with the Moss Pink, Phlox subulata. The two make most beautiful borders or smiling beds of early flowers. This is the most robust of the perennial species.

\section{SWEET ALYSSUM}

\section{Alýssum maritimum.}

Alyssum, Greek, of unknown signification.

A low, spreading annual, much used for borders, and bearing an abundance of white flowers during the entire summer.

Stem.-Bushy, low, spreading.

Leaves.-Alternate, linear, or lanceolate, tapering at the base.

Flowers.-Crucifers; sometimes double, small, white, fragrant; borne in racemes which elongate as the flowers mature.

Siliques.-Tiny pointed spheres, containing one or two seeds.

Sweet Alyssum bears all the marks of its gens. The stem is four-angled; the juice is biting; the leaves are alternate; the inflorescence begins as a corymb and ends as a raceme; the corolla is a cross. If one looks down upon and into the Alyssum flower- 
cluster, the reason why the flowering period continues all summer becomes apparent. In that cluster are a great number of buds in all stages of development and all these buds are produced from the side of the stem. The growing point at the centre never produces a flower, consequently as the lower and outer flowers mature and ripen seeds this growing point lengthens and produces more buds; this life goes on until frost comes or the vitality of the plant is exhausted. Indeed, Sweet Alyssum is one of the last annuals to surrender at the approach of winter; its white sprays can usually be found at Thanksgiving and often much later. The double form is desirable, as this emphasizes the white flowers.

Yellow Alyssum, Alyssum sexátile, or Golden Tuft, has long been a favorite. It is a perennial of spreading habit, and forms a mat six inches high which in early spring is covered with an abundance of golden-yellow flowers, in loose panicles, which last two or three weeks.

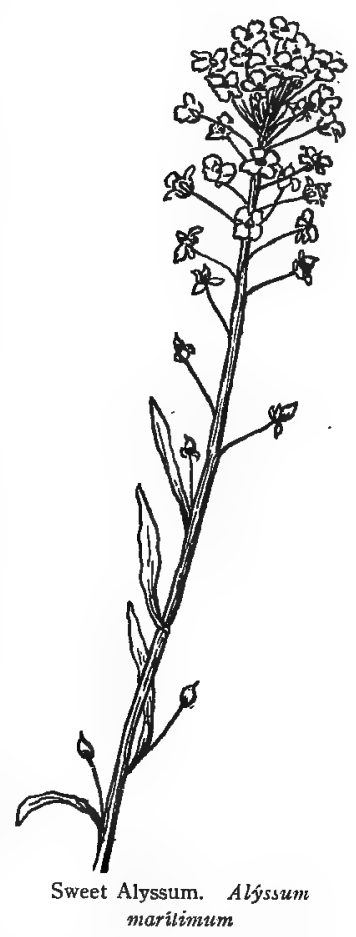

It thrives best in a sunny position in sandy soil, and is used as a border plant; is also common in rock work.

\section{LUNARIA. HONESTY}

\section{Lunària biènnis.}

Lunaria, Latin, lunit the moon, from the shape and color of the disk-like partition of the seed-vessel.

An erect, hardy biennial, native of northern Europe; long cultivated for its flat pods, which are used in winter bouquets of dried plants. Summer. 


\section{MUSTARD FAMILY}

Stem.-Two feet high, bushy.

Leaves.-Large, coarse, heart-shaped, toothed.

Flowers.-Regular crucifers, in terminal and axillary racemes, pinkpurple.

Silique.-Broadly oval, flattened parallel to the partitions; when ripe the outside valves fall away and leave the thin, persistent, silvery partition with seeds clinging to it; seeds flat, winged.

The characteristic of Lunaria which gives it garden value is the extraordinary degree to which the seed-vessel is compressed. It

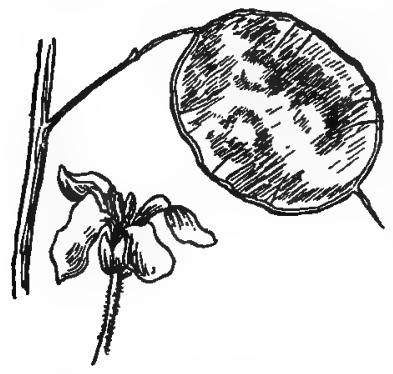

Silique and Flower of Lunaria varies between oval and orbicular in outline, and when the valves drop off the seeds remain attached to a thin pearly membrane from which they soon slip away. This thin, translucent partition-disk has given the plant the name Moneywort, though it is commonly called Honesty.

The plant as a whole is large and coarse, its flowers ordinary but its curious flat seed-vessels, called the "Pope's money," have long been prized for winter bouquets, and it holds a record in English gardens of more than three hundred years.

\section{SWEET ROCKET. DAME'S VIOLET \\ Hésperis matroñàlis.}

Hesperis, evening, of Greek derivation; because the flowers of some species are more fragrant in the evening.

A vigorous, hardy, herbaceous perennial, forming clumps two to three feet high; branched from the base and covered with showy, terminal, loose spikes of four-petaled flowers resembling stocks. Native to Europe and northern Asia. May, June.

Stem.-Branching at base, two to three feet high, hispid-pubescent; forming clumps.

Leaves.-Alternate, ovate-lanceolate, three to four inches long, toothed. 2 I6 
Flowers.-White, lilac, pink, or purple crucifers borne on loosely flowered terminal racemes, fragrant at night with the odor of violets.

Siliques.-Long, slender, contracted between the seeds.

Hesperis matronalis has been long in cultivation. Its native land is southern Europe and we:stern Asia, but it has escaped from gardens and grows wild in many parts of England. The early English gardeners record that its fragrance was such that ladies were fond of

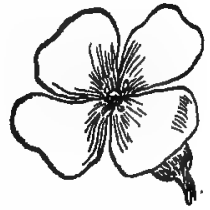

Flower of Sweet Rocket. Life size having it in their apartments; hence the name Dame's Violet. The colors range from white, through lilac and pink to purple. The flower doubles readily and the double forms are popular; in general appearance it resembles the stocks.

\section{SEA CABBAGE. WILD CABBAGE}

Brássica oleràcea.

Brassica, the Latin name of the cabbage.

A biennial plant growing wild on the sea-cliffs of western and southern Europe; the original stock from which has sprung all forms of cabbages, cauliflowers, Brussels sprouts, and kales.

Root.-Tough and woody, habit of plant diffuse.

Leaves.-Large, thick, deeply lobed; in various tints of green, flushed with red, more or less glaucous.

Flowering stem.-Tall and branching; flowers yellow.

Siliques.--Long, pointed.

We possess in the Wild Cabbage a most interesting example of the existence of a primitive side by side with the developed and cultivated forms. As a rule our domestic plants have varied so far from their wild forebears, both in time and in environment, that the search for the original is a hopeless quest; it has either disappeared or is so different as not to be recognized.

Anne Pratt, in "The Flowering Plants of Great Britain," says: "Few plants are more conspicuous on the sea-cliffs of England than this cabbage; from May till the end of summer it is one of 
the loveliest ornaments of the cliffs. Much of it is verdant when all around is fading; and dark, purplish, red-tinted leaves mingle with those which are green, and with others which are of deepest yellow, and when the hoar-frost spangles them they seem enriched with glittering diamonds.

"The leaves have a salt and bitter flavor, but repeated washings will fit this cabbage for use, and when boiled it is a good vegetable.

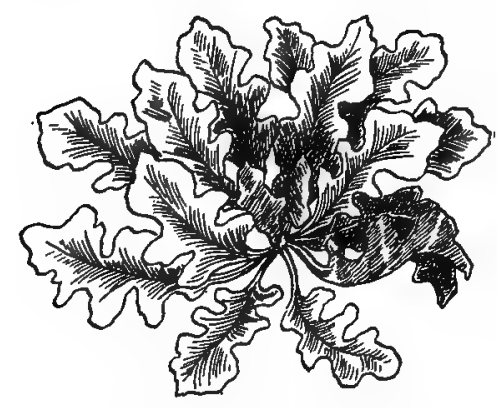

Wild Cabbage. Brássica oleràcea

Boys occasionally gather it from the cliff and carry it into the town for sale, but it does not seem to be much used in the neighborhood either by rich or poor.

"This Sea Cabbage, small as it is, with its few scattered leaves is important as having been the origin of all the giant and small cabbages, both white and red, of savoys and Brussels sprouts, and delicate cauliflowers and broccoli, and all the varieties of greens which the gardener raises with so much care. None who looked at it as it grew on the cliff would have believed that culture could have wrought such changes; but from earliest days it has received cultivation.

"We know that the ancients had a curled cabbage; they, therefore, probably, dined sometimes on broccoli. Our cauliflower was brought from the Levant into Italy about the sixteenth century, and gradually found its way into England.

"The Wild Cabbage grows on the sea cliffs of several parts of the shores of Europe and other wild cabbages grow on more distant shores. The cabbage plant, too, is a frequent object of culture in the East. Mr. Fortune, in his 'Wanderings in China,' says that one of the cabbage tribe, Brassica chinensis, is extensively cultivated in the province of Chekiang and also in Kiangse."

Field Turnip, Brassica campéstris, has been cultivated, since Roman times, for its fleshy roots. The flowering stem is about 
two feet tall, much branched, the flower a yellow crucifer and the silique from one to two inches long. The plant is biennial.

Black Mustard, Brassica nigra, and White Mustard, Brassica $a l b a$, are the mustards of commerce. The seeds germinate so rapidly that it has been extravagantly said that a salad might be grown while the joint of meat was roasting. Both species are common in fields throughout Europe. The powdered seeds are used as a condiment because of a fixed and very acrid oil which they contain. The seeds of White Mustard are considered more delicate than those of Black.

Other species of Crucifera in cultivation are:

Rock Cress, Arabis alpina, one of the earliest and prettiest of spring-blooming plants; growing in tufts which are covered with terminal flat-topped clusters of pure-white crucifer flowers soon after snow disappears. It is a perennial of easy culture, and thrives even in poor soil, but requires plenty of sun. Native to the mountains of Europe.

Arabis albida is also a favorite and its flowers are a little larger than those of alpina.

Whitlow Grass, Dràba, is a genus of spring-blooming plants admirably adapted for the alpine garden. Its flowers are small crucifers, white, yellow, or purple, and the leaves grow in dense little rosettes. When grown in mass the plants are effective.

False Wall Cress, Aubrètia deltoídea, is a favorite plant for rock work and edging. It is a perennial evergreen trailer with spatulate or deltoid leaves, producing violet or purple crucifer flowers in early spring. Many variants from the type are in cultivation. Native to western Asia and southern Europe.

Wall Flower, Cheiranthus cheiri, is not hardy in New England and the idea prevails that it is not hardy elsewhere. As a matter of fact it bears the winter well on the shore of Lake Erie in northern Ohio, and is regarded as one of the best of early blooming plants. Its color range runs through. all the yellows to orange-brown. With us it lives in the garden only, but in Europe it "sings among the ruined walls and covers with light the grieving stones." 
Toothwort and Bitter Cress, Dentària and Cardámine, are native genera of very attractive little plants blooming in early spring and would undoubtedly have their representatives in the garden were these not so abundant in the fields. They are allied to the Cuckoo Flower and the Lady-smocks of English fields and English literature. The plants repay cultivation.

Common Water Cress, Nasturtium officinàle, the well-known garnishing and salad plant is a hardy aquatic perennial which grows in pure running water and has a delightful peppery taste.

I linger round my shingly bars,

I loiter round my cresses.

—"The Brook."-Tennyson.

The stems are spreading and take root at the lower nodes. The leaves are pinnate; leaflets three to eleven, roundish or oblong. Flowers are small white crucifers, rather abundant, appearing in June. It is interesting to note that the Latin name of this plant has become the English name of Tropeolum. -

Horseradish, Nasturtium armoràcia, is a hardy perennial whose grated roots so often appear upon our dining-tables. Naturalized from Europe and found growing in moist situations, it is reported from New York State as a troublesome weed.

The root is perennial, fleshy, whitish externally, pure-white within, cylindrical, and when bruised emits a volatile oil of strong pungent odor and hot, biting taste, which gives the plant its antiscorbutic value. The root-leaves are very large, coarse, oblong, crenate, more or less heart-shaped; those of the stem lanceolate. The flowers are white crucifers, about half an inch across, borne on an ascending, terminal'raceme., The silique is globular, but the plant seldom fruits in this country.

The Herb of St. Barbara, or Winter Cress, Barbarèa vulgàris, sometimes called Yellow Rocket, is the tufted mustard, whose blossoms brighten the moist places of meadows and the banks of neglected runlets in early May. For nearly a month a golden glow is diffused about the place where this plant abides. A single root crown will produce perhaps, a dozen sturdy stems a foot high, 
each bearing a showy panicled spike of brilliant yellow flowers. The lower leaves are lyrate, the terminal lobe round; the lateral lobes in one to four pairs; the upper leaves obovate, cut-toothed at the base. Apparently introduced, but really indigenous from Lake Superior, northward and westward. It is biennial, which is always an objection to a cultivated plant; but it is capable of producing admirable color effects in mass.

Great Spider Plant, Cleome pringens, is a robust, strong-scented annual, producing tall spikes of rose-pink flowers, with six long, purple, antennæ-like stamens and four clawed petals, the whole giving a certain spidery aspect to the flower. The plant is weedy in looks and also in its ability to take possession of a garden. It is not a crucifer but belongs to the closely allied family of Capparidàcea. 


\section{RESEDÀCEA-MIGNONETTE FAMILY}

\section{MIGNONETTE}

Reseda odoràta.

Reseda, Latin, to calm; from supposed sedative properties.

Well-known garden favorite, treated as an annual; with inconspicuous flowers of delightful fragrance. Northern Africa and Asia Minor.

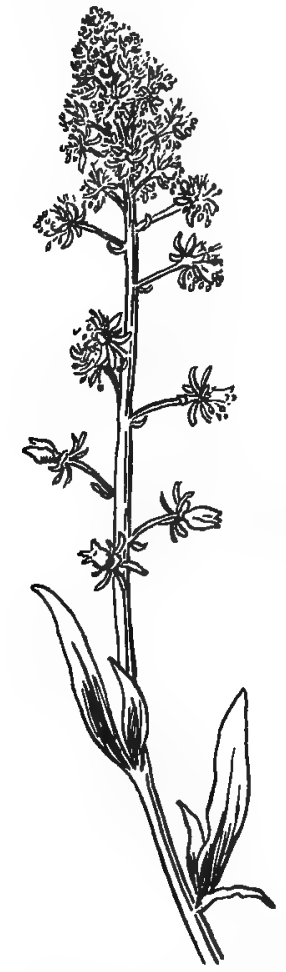

Mignonette. Reseda odordıa

Stem.-Upright, finally more or less decumbent, branching.

Leaves.-Alternate, variable, spatulate, or ovate, mostly entire, sometimes notched or three-lobed, apex obtuse.

Flowers.-Small, irregular, in spicate racemes that become loose and open with age.

Sepals.-Four to seven, usually six, spreading.

Petals.-Four to seven, attached beneath the ovary; the upper cut into a number of segments like white fringe.

Stamens. - Ten to forty, borne on a one-sided disk; anthers large, dull, reddish-orange, conspicuous, giving the color to the flower. Disk broad, appears between the petals and the stamens, dilated at the upper side of the flower into a yellowish plate, secreting honey at the back.

Ovary.-Sessile, one-celled.

Stigmas.-Three.

Capsule.-One-celled, three-horned, opening before the seeds are mature.

A blooming stem of Mignonette consists principally of green sepals, white fringe, reddish anthers, and fragrance. The white fringe is the petals, the reddish anthers give the color, and in the fragrance lies the value of the flower. 
Reseda odorata is a plentiful weed in northern Africa and particularly Egypt, whence it came into Italy and from that centre was distributed over Europe. In I742 it was introduced into England from France where it had become a great favorite and had received the common name which it now bears-Mignonette, "Little Darling."

With us the plant is an annual, but in the sub-tropical countries where it is at home it becomes a perennial.

The gardener's ideal of Mignonette has been a plant with as large a spike as possible. The color and form of the flower and the habit of the plant has been secondary to size and abundance of spikes, consequently the blossom itself has varied little from that of the wild plant; only the anthers, in size and color, have shown change.

Enlarging the spikes has not always improved the odor; in some cases this has been transformed into something unpleasant, in others totally destroyed, in others strengthened.

Take it all in all, the old garden form, with its light, sweet, pleasant fragrance, holds its own fairly among the fifty improved varieties offered by the trade.

Mignonette is a late bloomer; may be found along the garden walk long after the tender plants are destroyed. In order to have satisfactory late blooming, sow the seeds the last of July. 


\title{
SARRACENIÀCEA-PITCHER PLANT FAMILY
}

\author{
PITCHER PLANT. HUNTSMAN'S CUP
}

Sarracènia purpìrea.

Named in honor of Dr. Sarracin, a botanist of Quebec.

A curious and interesting plant growing in peat-bogs throughout the North, remarkable because of its peculiar trumpet-shaped leaves. Perennial. May, June.

Leaves.-Tufted, yellowish-green with red-purple veining, hollow, pitcher-shaped, curved, winged, with an erect hood at the top and at the base narrowing to a petiole. Four to ten inches long, usually half filled with water and the fragments of insects. Glabrous except the inner side of the hood and the inner surface of the pitcher, which are clothed with hairs pointing downward.

Scape.-One-flowered, twelve to fourteen inches high.

Flowers.-Nodding, solitary, reddish-purple and yellowish-green.

Sepals.-Five, with three bractlets at base, colored, persistent.

Petals.-Five, fiddle-shaped, arched over the greenish-yellow style.

Stamens.-Many.

Ovary.-Five-celled, globose, crowned with a short style which is expanded at the summit into a very broad and petal-like five-angled, five-rayed, umbrella-shaped body; the five delicate rays terminating under the angles in as many little hooked stigmas.

Capsule.-Five-celled, many seeded.

The extraordinary character of the leaves of Sarracenia purpurea invests the plant with a peculiar interest. These are long, ascending, trumpet-shaped cups lined with hairs pointing downward, apparently arranged with sinister intent. The descent to Avernus is easy, but woe-betide the luckless fly that gets to the bottom, for there is no possible return. The sticky exudation weighs his feet, the bristling hairs impede his upward progress, 


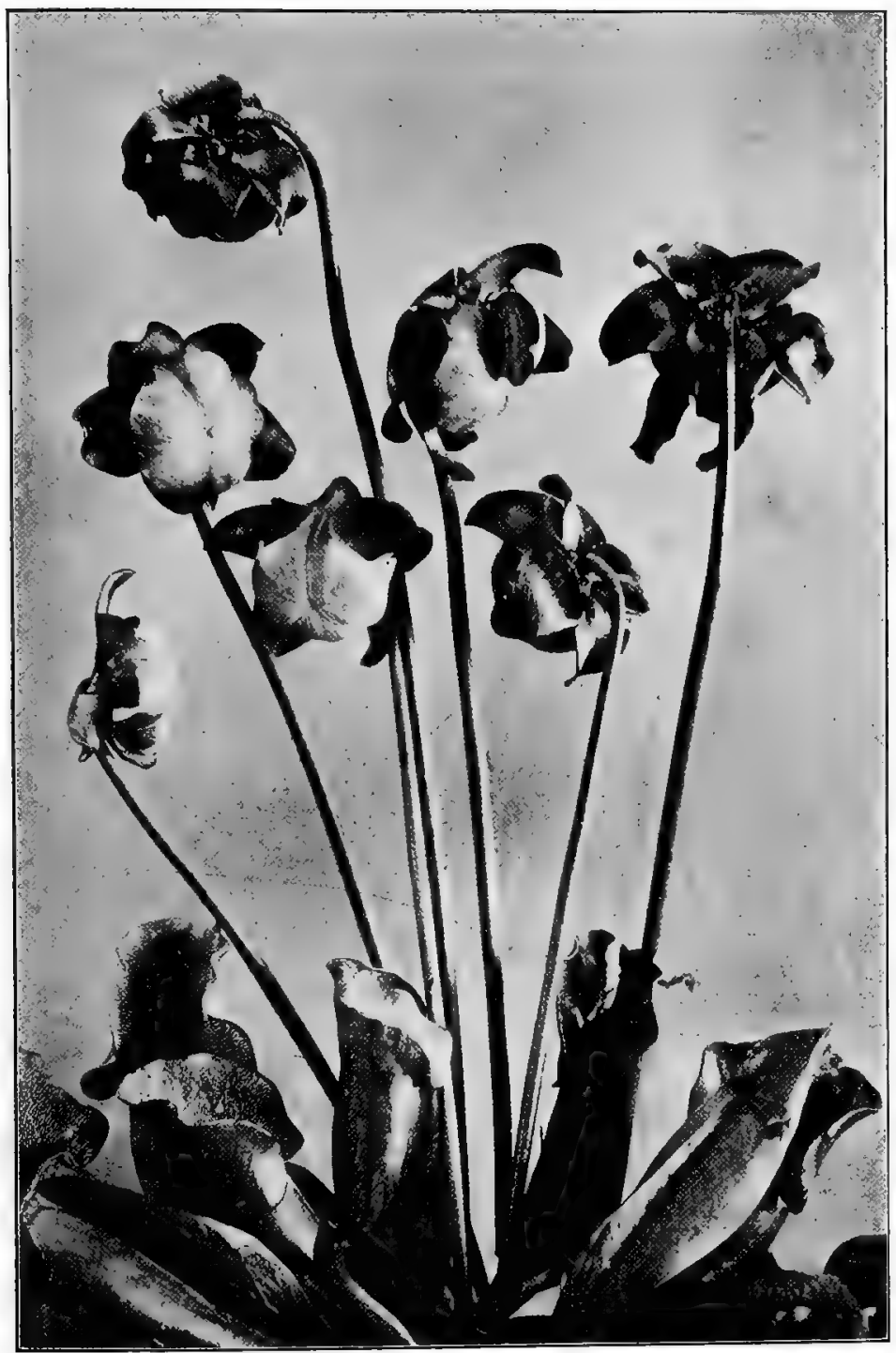

Pitcher Plant. Sarracènia purpirrea 


\section{PITCHER PLANT FAMILY}

and in time he dies. It is believed that the plant feeds upon his juices; in short, that we have here a curious monster-a plant that catches insects and feeds upon them. There are several. Southern species but this is the only one native to the North. It is easily transferred from its wild home to the bank of the water-garden and is an interesting acquisition. 


\section{CRASSULÀCEÆ-ORPINE FAMILY}

\section{LIVE-FOR-EVER. GARDEN ORPINE}

Sèdum teléphium.

Sedum, from sedeo, to sit; because many of the species grow upon rocks.

A survivor of early gardens, now rarely cultivated, but found on abandoned farms, and by the way-sides in New England and the Middle West. June-September.

Stem.-Stout, erect, leafy, one to two feet high.

Leaves.-Scattered, smooth, fleshy, wavy-toothed, pale-green.

Flowers.-Small, pinkish-purple, in a terminal compound cyme; its parts varying from four to five, usually five.

Sepals.-Five, ovate, acute.

Petals.-Five, twice as long as the sepals.

Stamens.-Ten; alternate ones adhering to the base of each petal.

Pistils.-Five, tipped with a short style; ripening to follicles.

Country children know the Live-for-ever because the under skin of its fleshy leaves can be loosened by childish fingers and the leaf then blown up like a bladder. The plant blooms but sparingly; indeed, many people suppose it

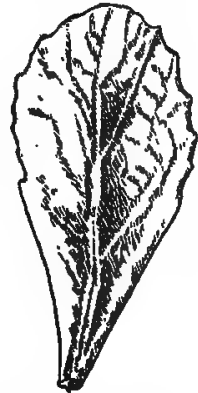

Leaf of Live-for-ever never blooms at all; it spreads by rooting at the nodes. It is very tenacious of life, and though long since discarded from the garden list, has lived in odd corners and by the roadside in apparent contentment. All comes, the proverb says, to one who waits, and the waiting Live-for-ever is welcomed back to-day to the rock garden where its merits are appreciated and its place assured. 
The genus Sedum numbers about one hundred and fifty species, of which thirty are within the limits of the United States. Any rock garden can successfully use the wild Sedums of its locality; all the species are good cover plants, and many bloom abundantly.

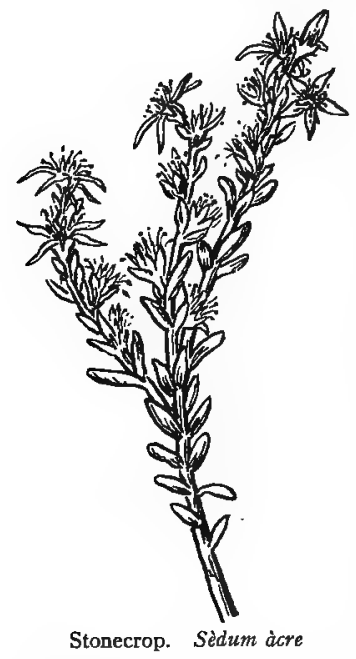

Stonecrop. Sèdum àcre

Of cultivated Sedums, probably Sedum àcre, Stonecrop, Wall Pepper, Love Entangle, is the species most commonly used. It is native to England and well known to the people, as its three names testify. The barren stems are creeping and branched, two or three inches long; the leaves small, crowded; the flowers yellow, starry, half an inch across in forked cymes. Much used for edging and carpeting, as it will thrive in poor soil. There is a variety that in spring shows yellow leaves; these usually change to green in midsummer.

Sedum stoloniferum, from Asia Minor, makes an admirable ground cover three to four inches thick, brightened by clusters of rosepink flowers. The fleshy leaves at first seem whorled, but as the stem lengthens they become alternate.

Showy Sedum, Sedum spectàbile, is a favorite both for its foliage and its flowers, which vary from rose to purple. It varies greatly in habit, foliage, and inflorescence; blooms in September or later, and is believed to be a native of Japan.

Sedum ternàtum, a species found in rocky woods from New England to the Mississippi, does very well in the rock garden. The leaves are flat; the lower whorled in threes, wedge-obovate; the upper scattered, oblong. The cynie is threespiked, leafy, and the petals white. It is a typical example of the genus.

There is a group of succulent herbs with thick and fleshy leaves which are used with the Sedums as bedding plants. They appear 


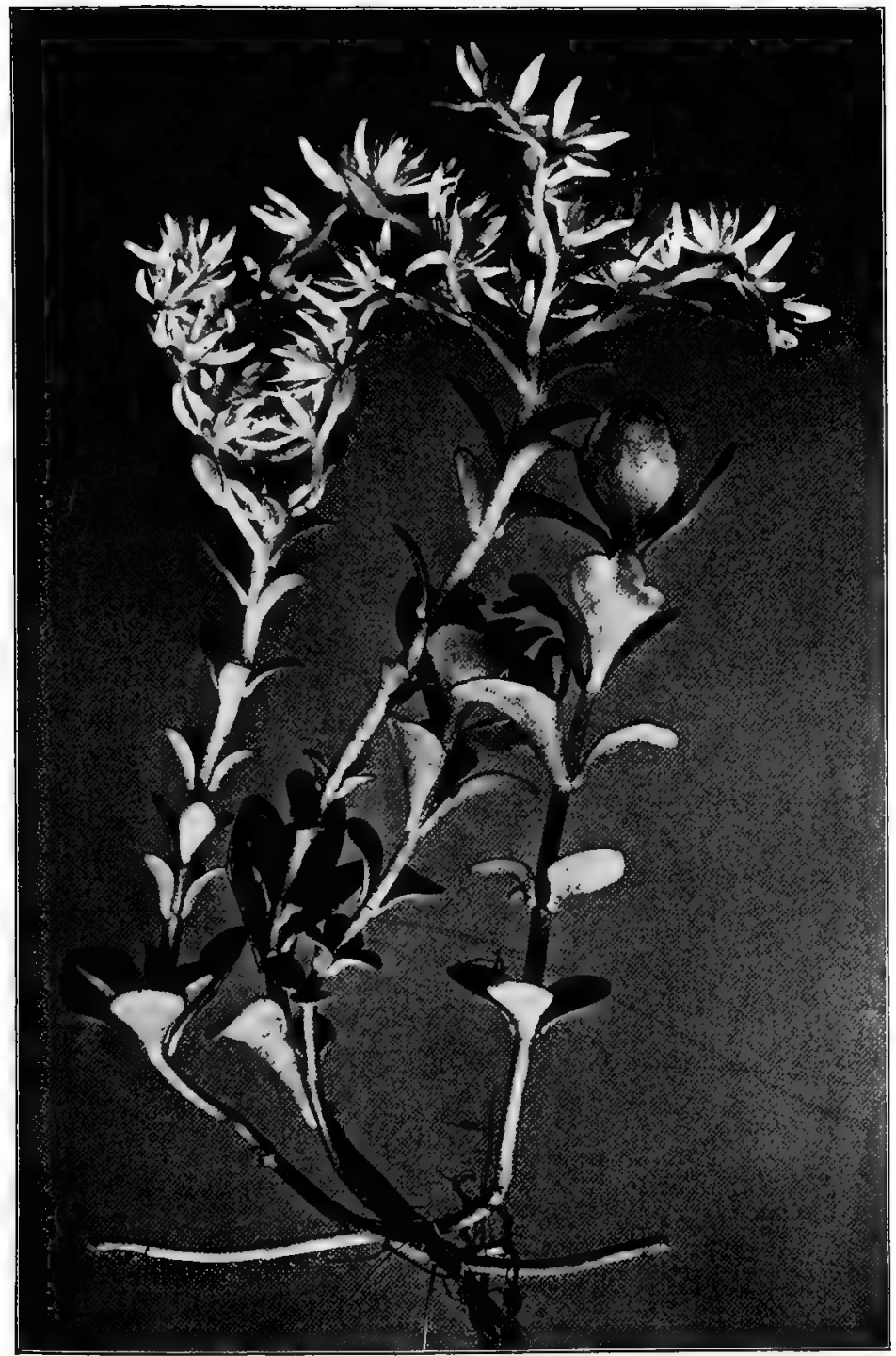

Sedum. Sødum ternàtum 
in the catalogues as Echeveria. The generic difference between them and Sedum lies in the union of the petals which in Sedum are distinct. The best-known species is secunda glauca, a variety with blue-green leaves.

\section{HOUSELEEK. HEN-AND-CHICKENS}

Sempervivum tectòrum.

Sempervivum, always living; because of the vitality of the plant.

This is one of the common species largely used for carpet-bedding. The plant appears as a rosette of thickened leaves and propagates by offsets and short runners.

Leaves.-Thick, short, oval, or obovate, smooth except the margins, mucronate; sixty to eighty in a single rosette.

Flowering stems.- Six to nine inches high, leafy.

Flowers.-Borne in panicles; pale-yellow or dull-purple.

Flower parts.-Sepals, petals, stamens, and pistils normally twelve, but varying six to twelve.

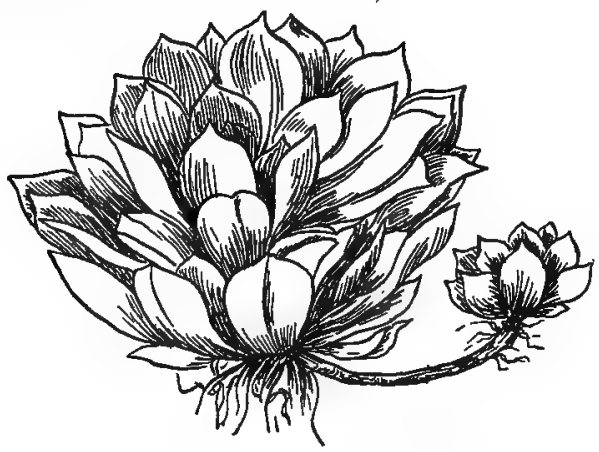

Houseleek. Sempervivum tecldrum

The Houseleek is so called because in Europe this variety is found growing on the thatched roofs of houses. It also has the name Hen-and-Chickens, which is popularly given to many representatives of the genus because the plants increase by little rosettes that are sent out from the parent plant. The genus numbers about forty species whose family resemblance is so marked that 
Hen-and-Chickens fits them all. They are mountain plants of Europe and Asia, accustomed to cling to rocks, to bear drought, to cover sandy, rocky hill-sides, in fact, to grow anywhere that Providence pleases. The many species vary in size of rosettes, color of leaves, character of flowers, and are perennial whenever the latitude permits. A beautiful display of these plants can be seen in the botanical garden of Harvard University. Among the many types is a curious group called Cobweb Houseleeks, so named because the little rosettes are covered with a veil of fine fleecy threads suggesting a spider's web. 


\section{SAXIFRAGÀCEAE-SAXIFRAGE FAMILY}

\section{EARLY SAXIFRAGE}

Saxîfraga virginiénsis.

Saxifraga, from saxum, rock and frangere, to break; many species rooting in the clefts of rocks.

One of the early wild flowers of the North, growing on exposed rocks and dry hill-sides. Perennial. April, June.

Acaulescent leaves.-In a basal rosette; obovate, narrowed into a broad petiole, crenate-toothed, thickish.

Flowers.-Dull-white, borne on a naked scape, in clustered loosely panicled cymes.

Calyx.-Five-cleft.

Petals.-Five, imbricated in the bud.

Stamens.-Ten.

Ovary.-Two-celled; styles two.

Capsule.-Two almost separate follicles.

This little rock breaker is attractive because it presents itself so early in the year; in northern Ohio it is one of the few April flowers that must be sought on dry hill-sides, not in moist woods. All the Saxifrages have been trained in the hard school of dry or rocky homes; many of them are arctic plants. As a result there are not many representatives in cultivation, and those that are inhabit the rock garden rather than the border. Probably the best of these is the Thick-Leaved Saxifrage, Saxifraga crassifdlia, a Siberian plant, which is a strong-growing species; the tufts of large thick leaves rise from a stout rootstock. The leaves are dotted with many small, punctate glands at the surface; the petiole is sheathed at the base and the plant is stemless. The scape rises a foot or more and bears numerous lilac or pale-purple flowers on 
the inclined or drooping branches of a panicle. The plant should have half shade and in winter needs some slight protection.

Tiarella, False Mitrewort, Tiarella cordifolia, is a low little herb whose feathery spikes of white flowers appearing in mass from great beds in the open woodland is one of the pleasant sights of early spring in the region of the Great Lakes. The leaves fairly carpet the forest floor and suggest maple leaves, though rough and hairy. The pretty name, Tiarella, little turban, refers to the form of the seed-vessel which is cleft like a tiara. The plant is excellent for either rock garden or wild border. Mitella diphyllla, Bishop's Cap, is a more delicate plant though very similar. Its little blossoms are so cut and fringed and spread that they look like snow crystals, and each is about the size of one.

\section{HEUCHERA. CRIMSON BELLS}

Herichera sangüinea.

Heuchera, in honor of Johann von. Heucher, Professor of Botany at Wittenberg; I677-r 747 .

A plant recently introduced from New Mexico and Arizona.

Root.-Acrid and astringent.

Leaves.-Radical, forming a cluster rather close to the ground; orbicular, cordate, crenate.

Flower scape.-Downy, about two feet high, bearing a one-sided, panicled raceme.

Calyx.-A crimson, five-lobed, drooping bell.

Petals.-Five, minute, borne on the calyx-bell, alternate with its lobes. Stamens.-Five, inserted on the calyx-bell.

Ovary.-One-celled.

Heuchera sanguinea, like so many of the saxifrages, grows in tufts, forming a cluster of radical leaves from whose centre rises several scapes, each bearing a racemose panicle of small, deep-red bells. Although red is the typical color, the bells vary in the cultivated forms from red to white. This little Heuchera bell is 
most interesting, for it is a case where the duty of attracting insects has fallen upon the calyx. The red bell is all calyx; the corolla is represented by five tiny points to be looked for between

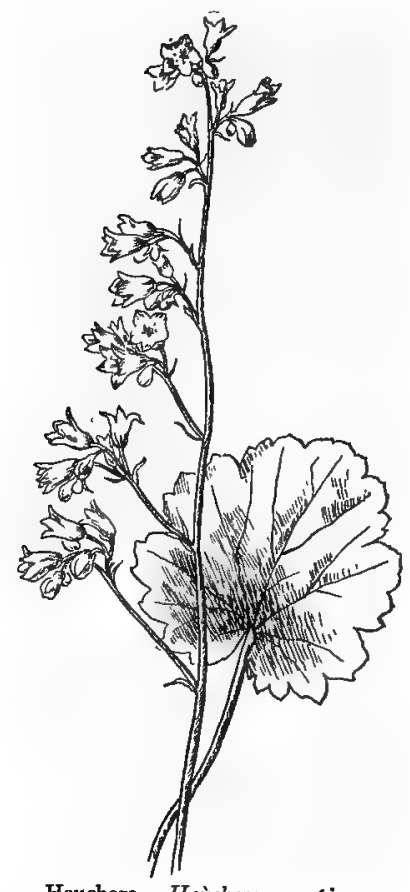

Heuchera. Heùchera sangáineo

- and a little below the lobes of the bell. So insignificant has the corolla become that some species of Heuchera dispense with it altogether.

The astringency of the root juices gives the common name Alum Root to the genus. 


\section{LEGUMINÒSE-PEA FAMILY}

The Pea Family is distinguished by a peculiar blossom which is characteristic of the greater number of the species. It is called papilionaceous and consists of five petals; the upper or odd petal, called the standard, being larger than the others and enclosing them in the bud; this usually turns backward or spreads. The two side petals are called wings and are exterior to the two lower which grow together more or less closely and form the keel, which usually encloses the stamens and pistil. Stamens ten, very rarely five; inserted with the corolla; sometimes all grown. together by their filaments, forming a tube; usually nine grow together and one is separate. Ovary one-celled, often long and slender, with a short style and simple stigma. The ovary develops into a pod of which the pea and bean are good examples.

\section{SWEET PEA}

\section{Lathyrus odoràtus var. hýbrida.}

Lathyrus, ancient Greek name, of obscuré meaning.

A favorite annual, universally grown because of the beauty and fragrance of the flowers.

Stem.-Rough, hairy, winged, tendril-climbing.

Leaves.-Equally pinnate, ending in a tendril or a point; leaflets ovate or oblong; stipules lanceolate.

Peduncles.-Two to four flowered, long.

Flowers.-Papilionaceous, fragrant, blue, red, purple, pink, and white.

Calyx.-Five-parted

Standard.-Large, roundish, notched; wings falcate-obovate or oblong; keel shorter than the wings, incurved, obtuse. 
Stamens.-Diadelphous, nine and one, or monodelphous below.

Style.-Curved, usually twisted, flattened, hairy along the inner side.

Pod.-One to two inches long.

The native land of the present garden race of Sweet Peas is divided between Sicily and far-away Ceylon. The white variety is native to Sicily; the famous old-time pink-and-white species,

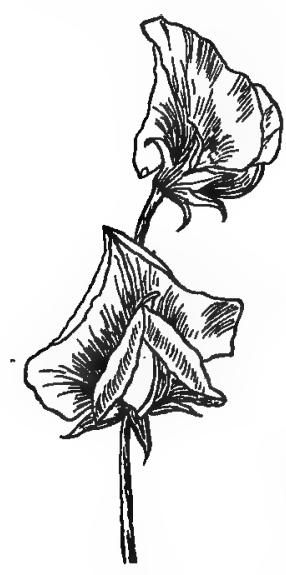

Sweet Pea. Lalhyrus odoràtus known as Painted Lady, is credited to Ceylon; thence, likewise, came the original red out of which all the crimson-scarlet sorts have been produced.

Father Franciscus Cupani, a devout Italian monk and enthusiastic botanist, is believed to have been, in 1699 , the first cultivator of the Sweet Pea, and he is known to have sent its seeds to England and elsewhere. By I730 Sweet Pea seeds were an article of commerce, and in 1793 a London seed catalogue listed five varieties of the flower: black, purple, scarlet, white, and Painted Lady. A few additional varieties were added to the number from time to time, but it was not until 1876 that the great improvement was made which placed the Sweet Pea in the royal group of garden flowers. This development was due to the skill of Henry Eckford, of Shropshire, England, a specialist, who in 1876 began work upon the plant as it then existed. Working patiently by means of crossfertilization and selection, he succeeded in obtaining new colors and larger flowers. His success was especially recognized by the Royal Horticultural Society, and by 1898 he had put out about seventy-five varieties of wonderful colors and remarkable size. Florists on the Continent and also other florists in England took up the task. About 1890 an interest in Sweet Peas appeared in America, especially aroused by the size and color of these new English strains. A demand for seed led to the suc- 
EVERLASTING PEA

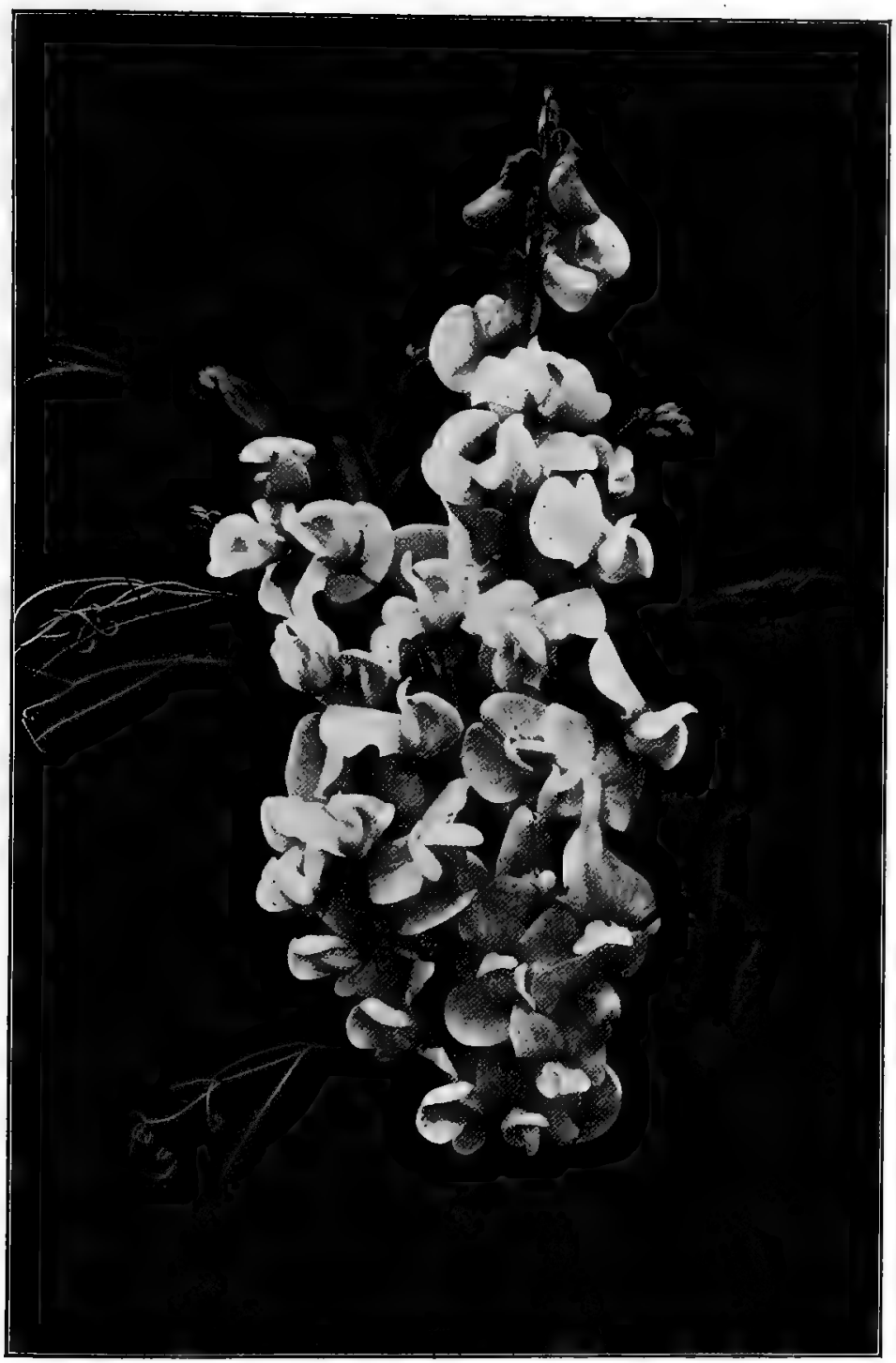

Everlasting Pea. Lâthyrus latifolius 
cessful experiment of growing it in California. The demand has increased until now practically the world's supply is produced by the California seed-growers, and amounts to hundreds of tons annually. Such an enormous growth of plants naturally led to the production of new sorts; the number of named varieties is now legion.

The first Dwarf Sweet Pea, a sport, was discovered in a California field in 1893 , and since that time the dwarfs appear in all the colors of the standard. In this form the plant makes a mat of low foliage; the blossoms are of the usual size but the stems are short.

Fortunately no encouragement has been given by the public to a double Sweet Pea.. The large single form is the approved type as it is certainly the most graceful. The aim of the florist is to obtain two to four large flowers on a single long stem.

Many flowers clearly force cross-fertilization; the Sweet Pea blossom, on the other hand, shows itself independent and self-fertilizing. The keel is a sac containing the stamens and pistil and in a healthy blossom the latter is rarely exposed. So jealously does each blossom fertilize itself that it sheds its pollen when half open and the sac at the upper end draws snugly up around the anthers pressing them closely about the stigma.

Everlasting Pea, Lathyrus latifolius, is the common perennial pea, native to the woods of Europe and one of the hardiest and most easily cultivated species, thriving in almost any location. It succeeds in shade and grows rapidly, but is impatient of removal owing to the size and length of its roots. The stem is winged and tendril-climbing and the leaflets ovate. It produces a full raceme of beautiful rose and white blossoms and the pod is four to five inches long. 


\section{BUTTERFLY PEA}

Centrosèma virginiànum var. grandiflòrum.

Centrosema, Greek, with spurred standard.

Stem.-Twining, two to six feet high.

Leaves.-Pinnately compound; leaflets three to seven.

Flowers.-Papilionaceous, one to four in the axils of the leaves, showy, violet-purple.

Standard.-Spurred on the back; keel broad; style bearded at the apex.

Pod.-Straight, four to five inches long.

The Butterfly Pea naturally grows in sandy woods, southward, and was introduced to cultivation many years ago, but, neglected, dropped out of sight. It now reappears in the variety grandiflorum, and is highly recommended as a hardy and desirable perennial vine, blooming the first season from seed. There is a white variety.

\section{GARDEN PEA}

\section{Pìsum satìuum.}

Pisum, derived from piso, to beat; referring to the manner of separating the seeds from the pods or grinding them into flour.

The common Pea of our markets, glabrous and glaucous, tendrilclimbing. Annual. Native of Asia.

Stem.-Weak, climbing by leaf-tendrils.

Leaves. - Compound, of one to three pairs of leaflets, the leaf ending in a tendril or point; stipules large and leafy; leaflets oval or ovate.

Flowers.-Papilionaceous, white, few, on axillary peduncles.

Calyx.-Oblique at base; the lobes more or less leafy.

Standard.-Obovate or orbicular; wings adhering to the keel.

Style.-Mostly rigid, widened above, bearded down the inner margin.

Pods.-Oblong; seeds globular, five to ten in a pod.

The Garden Pea has been modified by cultivation into several well-marked races and many varieties. With one exception all 
are cultivated for the delicious seeds which they produce; there is, however, a variety whose pods are edible when green.

The cultivation of

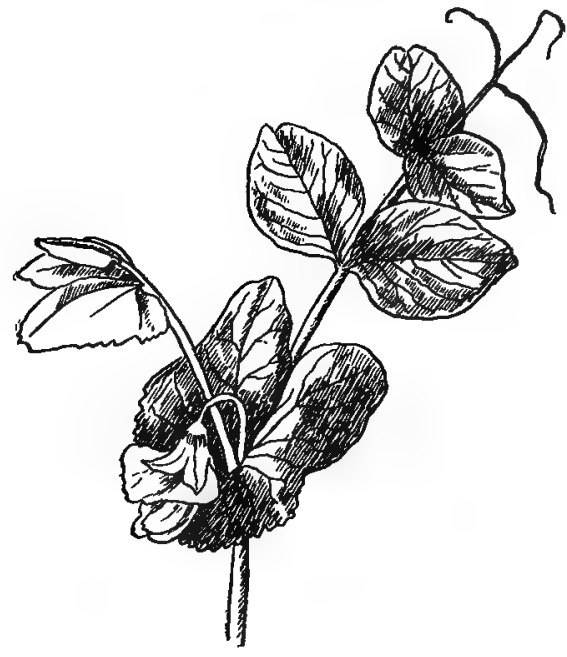

Garden Pea. Pisum sativwm the Pea, like that of the bean, was one of the industries of prehistoric man, yet both its native land and its primitive form are in doubt. Having now become part of the food of all civilized communities, there is no limit to the forms that may be produced by selection and variation.

The Field Pea, Pisum arvénse, differs from the Garden Pea

in being less delicate to the taste. The flowers are red and but one on a flower stalk. The plant is raised in Europe largely as food for cattle and horses.

\section{BAPTISIA. BLUE FALSE INDIgo}

Baptisio australis.

Baptisia, Greek bapto, to dip or dye; in reference to the coloring matter in some species.

A hardy perennial producing beautiful, loose, terminal racemes of papilionaceous flowers. In rich, alluvial soil from Pennsylvania, west and south. June.

Stem.-Stout, erect, branching, two to five feet high.

Leaves.-Three-foliate; leaflets oblanceolate or obovate; stipules lanceolate, persistent. 
BAPTISIA

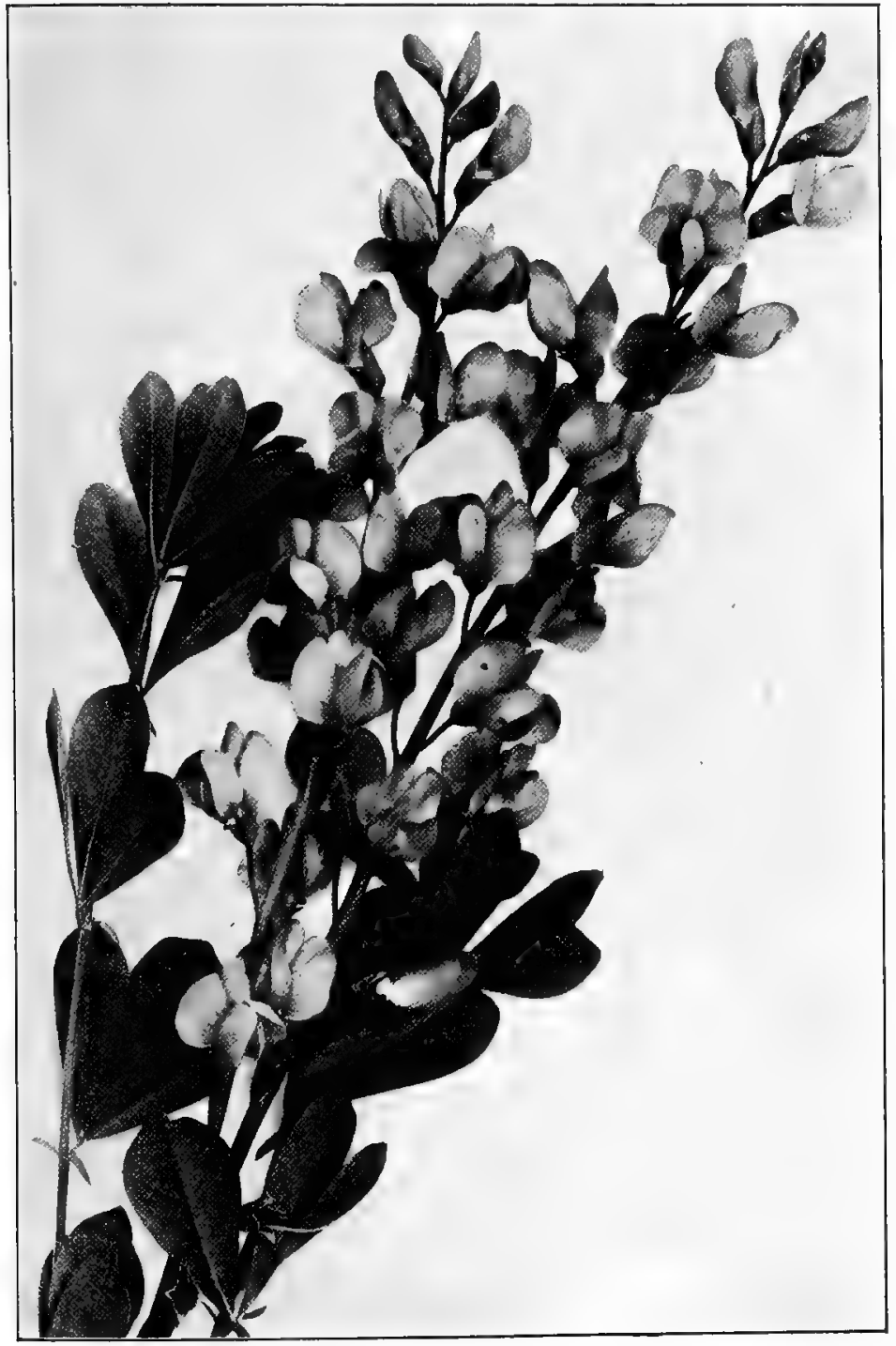

Baptisia. Baptisia australis 
Flowers.-Papilionaceous, blue, in long terminal racemes.

Stamens.-Ten, distinct.

Pod.-Oblong, stalked.

The Blue False Indigo, ornamental both in flower and foliage, is a strong species, abundant along the Ohio River and southward. It grows naturally in alluvial, sandy soil which is often submerged by an overflowing stream, and when transferred to the garden should be given a moist location. With some reason it is regarded * as a shy bloomer. There are many native Baptisias, but this is considered the best for cultivation.

\section{CLOVER}

\section{Trifolium.}

Named from tres, three, and folium, leaf.

Tufted or diffuse and creeping herbs, cultivated for their economic vilue.

Leaves.-Palmately trifoliate.

Stipules.-United to the petioles.

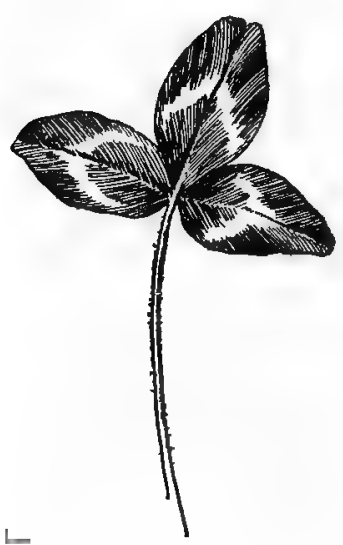

Leaf of Red Clover. Trildium pralense

Flowers.-Papilionaceous; all the petals -standard, wings, and keel-more or less united at the base; borne in dense heads or spikes.

Calyx.-Five-toothed.

Stamens.-Ten, diadelphous.

Pods.-Small, one to six seeded.

The Clover group are not garden plants, but they are beautiful in themselves, admirable for decoration in country houses, and, moreover, an individual plant of any of the species isolated and treated as an honored inmate of the garden will by its size and beauty astonish its protector.

The tufts of Red Clover, Trifolium praténse, are usually found wherever grass grows. The leaflets are oval, ovate, or oblong, bluish-green and conspicuously marked 
with a lighter-green triangle. The apex is obtuse and sometimes a little notched. Two stipules, more or less grown together sheathe the base of every leaf-stalk. The globular flower heads range in color through deep and pale rose-pink, sometimes are almost white. The tiny florets yield plentiful nectar which is mainly the property of the bumblebees.

White Clover, Trifolium repens, is a permanent resident of the roadside and seeks to be of the lawn. The slender stems, rooting at the nodes, creep and spread, are quick to have and strong to hold. The leaves are longpetioled; the leaflets much smaller than those of the Red Clover, ovate, obovate, or obcordate, obtuse at apex or notched, and frequently marked with a little pale triangle. At night the two lateral leaflets come forward and meet, the middle leaflet bends over, and the leaf holds this position until morning.

The heads stand up on long slender stems,

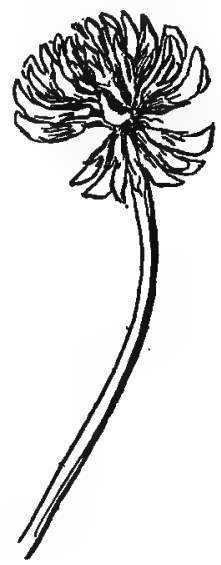

Head of White Clover. Trifolium rèpens well above the leaves, and as each tiny floret matures it becomes brown and reflexed. Thus by a glance it is possible to tell exactly the age of a White Clover head. The nectar is extremely delicate; belongs chiefly to the honey-bee, and White Clover honey commands the highest price in the market.

White Clover is one of the claimants to the name Shamrock. The plant was certainly brought to this country from Europe; it is also believed to be native here.

Alsike, or Alsatian Clover, Trifolium hýbridum, is somewhat similar to the White Clover, but a larger plant with a stout, branching stem. The finely serrate leaflets are ovate or obovate, but not obcordate, though sometimes slightly notched at apex. The flower heads resemble those of White Clover but are larger, in color varying from soft-pink to pinkish-cream and white; are exceedingly beautiful, fragrant, and rich in honey. The florets darken and turn downward as they grow old. 


\section{PEA FAMILY}

The two yellow Hop Clovers, common in fields and along roadsides, Trifolium agràrium and Trifolium procuimbens, are both of European origin. The flower heads are pale golden-yellow; the florets when withered turn brown so that the head looks like a small dried hop. The leaves are trifoliate but are not very much like the leaves of the other clovers.

Rabbit-Foot Clover, Trifolium arvénse, with gray-pink, hairy heads soft as silk, adorns the waste places in poor soil; old fields, and worn-out pastures. It grows in mass and forms large beds. The flower heads are cylindrical, very hairy, the corolla greenishwhite, the calyx tip pinkish, and the abundance of pale hairs give the gray effect.

Crimson or Italian Clover, Trifolium incarnàtum, is used as a cover plant in orchards. The erect stem is one to two feet high, the leaflets obovate, the stipules broad with leafy tips, the flowers crimson, scarlet, rarely cream, in long terminal heads.

\section{LESPEDEZA}

Lespedèza Sièboldi. Desmòdium penduliftòrum.

Lespedeza, in honor of Lespedez, a Spanish governor of Florida, who aided the botanist Michaux.

A hardy perennial herb throwing up strong, wiry shoots each year from the crown. Japan. September, October.

Stem.-Reddish or brown, hairy, two to four feet high; in summer looking like a bush.

Leaves.-Dull-green, pinnately trifoliate; leaflets elliptic-oblong, pointed.

Flowers.-Papilionaceous, half an inch long, rose-purple, drooping, in numerous long racemes which at the top of the plant are panicled.

Pod.-Small, pubescent, one-seeded.

The American Lespedezas are a group of weedy plants with inconspicuous, pea-shaped flowers, neither ornamental nor economically valuable. They are often found along the roadside, in thickets and tangles, in company with their friends and relations the Desdemoniums or Stick-tights. 


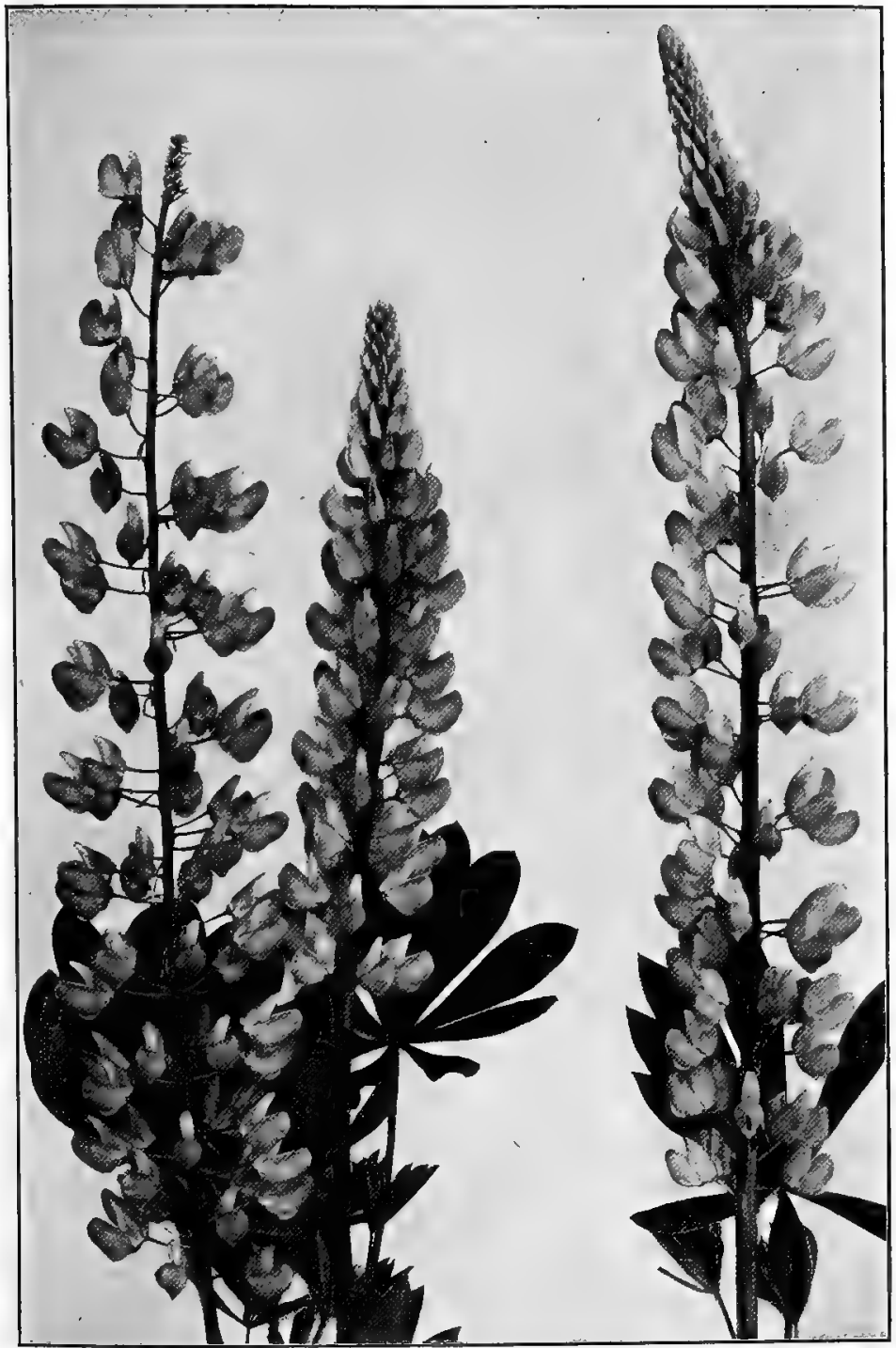

Many-leaved Lupine. Lupinus polyphýllus. 
The only members of the genus in cultivation are a few Oriental species, of which the most valuable is Lespedeza striàta, the Japan clover, now naturalized in the South and regarded as a good hay and pasture plant. The best of the ornamental species is Lespedeza Sieboldi, which in the spring sends up strong, wiry shoots that in time become thickly leaved, take on the aspect of a bush,

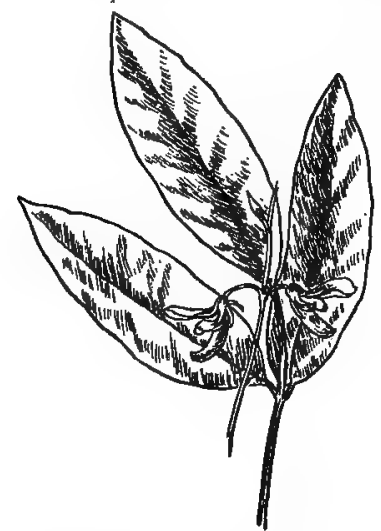

Lespedeza. Lespedèza sieboldi and in September and October are covered with a wealth of rose-purple blossoms. Lespedeza bicolor, also from Japan, is a slender, hardy shrub which is sometimes cultivated.

Lepedeza japonicum with. white flowers may be.a botanical variety of Sieboldi but seems to be horticulturally distinct.

\section{MANY-LEAVED LUPINE}

Lupinus polyphýllus.

Lupinus, from lupus, wolf, because these plants were supposed to destroy the fertility of the soil.

Stem.-Erect, three to five feet high.

Leaves.-Many, radical, long-petioled, digitate; leaflets five to twelve oblanceolate.

Flowers.-Papilionaceous, showy, blue, in terminal racemes.

Calyx.-Two-lipped and toothed; sides of standard reflexed; wings united at apex and enclosing the keel; keel scythe-shaped, pointed.

Stamens.-Monodelphous; anthers of two forms.

Ovary.--Sessile, style incurved, pod flattened.

This is the principal hardy perennial species of the gardens. Above a handsome clump of satiny, many-fingered leaves rises a long spike of bluish-purple, pea-shaped flowers in June and July.

Wild Lupine, Lupinus perénnis, is a native Lupine bearing spikes of pale-blue and violet flowers above a tuft of beautiful palmate leaves. Commonly there are about eight leaflets, though sometimes seven and rarely eleven. The plant grows luxuriantly 
on poor soil which makes it a desirable acquisition. All the Lupines are of similar appearance; they have palmately compound leaves and showy flowers in terminal spikes or racemes. Of the one hundred known species, seventy are North American, mainly west of the Rocky Mountains.

\section{SWEET CLOVER. WHITE MELILOT}

\section{Melilotus alba.}

Melilotus, Greek, from mell, honey, and lotus, some leguminous plant.

Biennial, growing along roadsides and in waste places, naturalized from Europe. Cultivated under the name of Bokhara Clover. Flowers all summer.

Stem.-Erect or ascending, three to six feet high; hard to break.

Leaves. - Alternate, pinnately three-foliate; leaflets oblong or slightly oblanceolate, finely serrate, notched or rounded at apex.

Flowers.-White, papilionaceous, borne in slender racemes two to six inches long; racemes often one-sided.

Pod.-Ovoid, wrinkled, one to two seeded.

From many points of view Sweet Clover is a weed; it no longer adorns the garden, but - lives on the roadside and loiters along the railroad track. The bees love its tiny blossoms heavy with nectar, and they never forsake them so long as there is enough daylight left for wanderers safely to wing their way homeward. The plant once had a

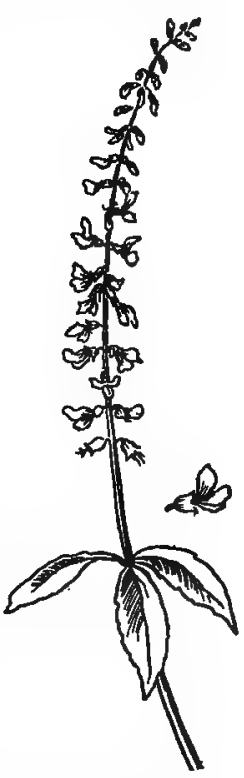

Sweet Clover. Melilòlus alba place among sweet herbs because its leaves are fragrant in drying.

It has been cultivated under the name of Bokhara Clover, but is reported poor among forage plants owing to the woody character of its stems. Sweet Clover in mass is beautiful, especially 
when it covers with leaf and flower neglected places; the long sprays are very decorative as cut flowers.

Yellow Melilot, Melilotus officinalis, resembles the White Melilot, and appears with it. The chief difference is the color of the blossom, though in some quarters officinalis blooms later.

Indian Melilot, Melilotus indica, has appeared at the Pacific seaports, having been introduced in ballast. Blossoms are yellow and small.

\section{CORONILLA}

Coronilla vària.

Coronilla, little crown.

Stem.-Straggling, creeping, and climbing.

Leaves.-Odd-pinnate; leaflets eleven to twenty-five, oblong or obovate, obtuse and mucronate at apex.

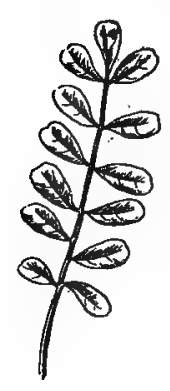

Coronilla. Corontlla vària

Flowers.-Papilionaceous, pink and white, or pale purple, borne in umbels that look like little heads.

Petals.-Clawed; standard nearly orbicular; wings obliquely obovate; keel incurved, beaked.

Stamens.-Diadelphous, nine and one; anthers all alike; pod jointed

Few perennial plants flower for so long a time as this pretty legume, which displays an array of pink and white balls upon the surface of a matted bed of pale-green leaves. This is the only member of the genus in this country; it came hither, evidently, as a vagrant, for it is rarely seen except on roadsides and in waste places in New England and the Middle States. It is recommended for the carpeting of ledges. 


\section{COMMON KIDNEY BEAN}

Phasèolus vulgàriss.

Phaseolus, the ancient name of the Kidney Bean.

This is believed to be the original of most of the cultivated Beans of our market with the exception of the Lima Bean. Good opinion refers the plant to South American origin. Annual.

Stem.-Short and erect, or long and twining.

Leaves.-Trifoliate; leaflets ovate.

Flowers.-Papilionaceous, in loose racemes on stout peduncles; the white flowers have a dark, silky spot in the middle of the two lateral petals; other petals entirely white.

Calyx.-With two bracts at base, somewhat two-lipped.

Keel.-Beaked and, together with stamens and style, spirally twisted.

Pod.-Many-seeded; seeds kidneyshaped, varying greatly in color and markings.

Our present Garden Bean is believed to be of American origin and of comparatively recent cultivation, although it is clear that several other species of Bean have been cultivated in the East from most ancient times. This, however, is regarded so highly that it is now well distributed over the world and has, in the main,

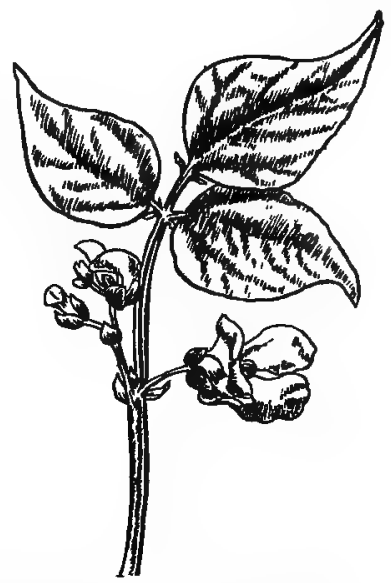

Kidney Bean. Phasèolus vulgàris supplanted other Beans.

The food value of the Bean, of whatever species, has long been recognized, and modern research has referred this value to the nitrogen which it contains. For years, the standing question has been, "Where and how did you get it?" for Beans growing upon soils meagre in nitrogen were themselves rich in nitrogen. It is now known that the entire leguminous family, cspecially Beans and allied species, harbor on their roots colonies of bacteria which have the power of transforming the free nitrogen of the air, which 
the plant cannot use, into nitrous acid, which the plant can use, and which in some form it stores up in its seeds.

Phaseolus lunatus var. macrocarpus is the Lima Bean of our

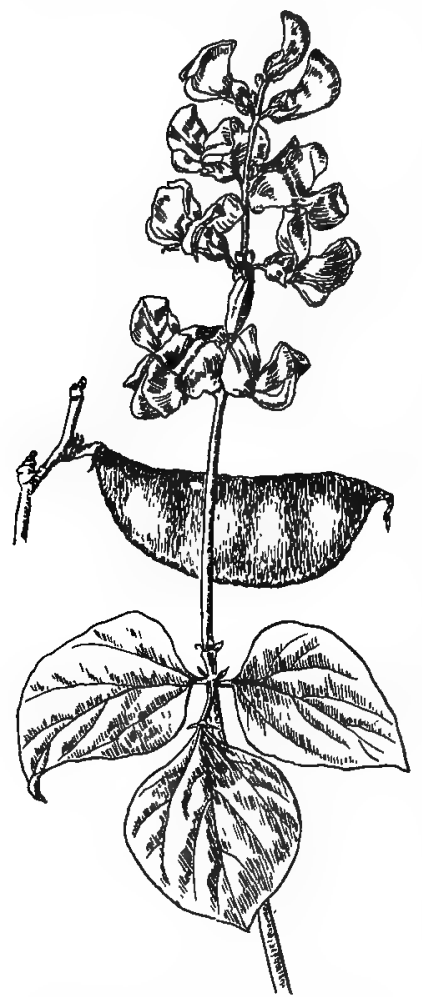

Hyacinth Bean. Dólichos lablab gardens, characterized by its robust growth, late ripening, large pods, and large, flat seeds. Several forms are in cultivation, all good. In the tropics the plant is perennial.

\section{HYACINTH BEAN}

Dólichos láblab.

Cultivated here as an ornamental climbing bean, but in the tropics the seeds are eaten. Annual.

Stem.-Twining, often ten to twenty feet.

Leaves.-Trifoliate; leaflets broadovate, rounded at base, pointed at apex.

Flowers.-Papilionaceous, purple, violet, or white, rather large, in a long, erect raceme; standard rounded, spreading; keel narrow and bent inward at a right angle, but not coiling.

Style,-Bearded under the terminal stigma.

Pods.-Thick, flat, broadly oblong, conspicuously tipped with style.

Seeds.-Tawny with a white scar.

De Candolle believes that Dolichos lablab was the ancient bean of India, but not of Egypt. In fact, what particular bean the ancients ate is a problem to those who care about the matter. We, however, regard the plant solely for its beautiful flowers which are very showy both in the violet-purple and the white varieties. The clusters of seed pods are a lasting ornament, as they turn a rich dark-purple and keep the color until killed by the frost. 


\section{GROUND NUT. WILD BEAN. APIOS \\ Ápios tuberdsa.}

Apios, Greek, from apsin, a pear; alluding to the shape of the tubers.

A climbing and twining perennial, found in low, moist ground from New Brunswick to Florida, and westward. Frequently associated with Clematis virginiana, the two flourishing under similar conditions. July, August.

Root.-Has underground shoots which produce strings of edible tubers one to two inches long.

Stem.-Slender, four to eight feet long, climbing and twining over bushes; juice milky.

Leaves.-Pinnately compound; leaflets five to seven; rarely three, ovate or ovate-lanceolate, acute at apex, rounded at base, margin entire.

Flowers.-Papilionaceous, brownish-red, or chocolate-brown, paler without than within, fragrant, borne in dense, short, axillary racemes which are sometimes branched.

Calyx.-Small,' campanulate, somewhat two-lipped.

Standard.-Very broad, slightly turned out and back at the sides; wings obliquely obovate, adherent to the keel which is long, incurved, scythe-shaped.

Stamens.-Diadelphous, nine and one.

Ovary.-Nearly sessile; style slender, ovules many.

Pod:-Linear, compressed, many-seeded.

Apios is a wild vine of extensive habitat, but rarely found in cultivated grounds. Its flowers are perhaps more interesting than beautiful; in form they are papilionaceous; their peculiarity lies in their color. The books describe them as brownish or chocolate-red, but words convey but little idea of the dull, deep, lurid hue of the inner part of the banner and wings, or the curious red, dusted with gray, of the exterior.

The crowded racemes are borne in the axils of the leaves and are from two to four inches long. So fragrant are they that one often finds the plant in a wildwood tangle by its odor alone. The foliage is loose and comparatively open. Like Clematis virginiana, Apios requires moist ground, loves to have its roots cool and 
shaded, but seeks the fullest sunlight for leaf and flower. Evidently the plant develops tubers at the expense of seeds, for the pod frequently does not form, and when formed often fails to reach maturity. In cultivation the plant will cover a fence or trellis in comparatively short time.

Other leguminous species in cultivation are:

Rest Harrow, Ononis rotundifolia, an attractive shrubby plant from the Mediterranean region about a foot high; the leaves are

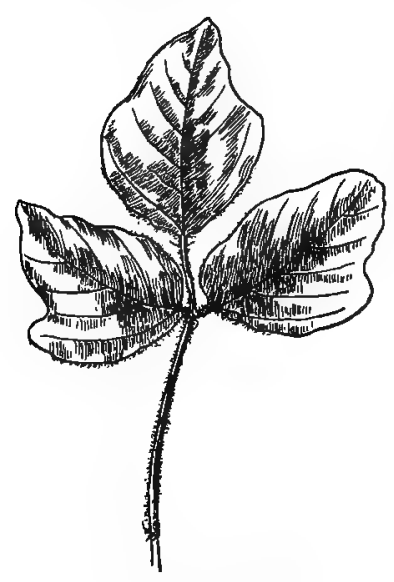

Kudzu Vine. Puerária

Thunbergidna. trifoliate and the pea-like blossoms, white and rose, appear in clusters of two and three. It is recommended for the rough part of rock gardens.

Pea-Like Vetch, Vicia oroboides, is a Siberian plant two to three feet high which produces̊ dense clusters of violet pea-like flowers. Will do well on poor soils.

Little Vetch, Orobus cêrnus, is also recommended as a hardy, early bloomer.

The Kudzu Vine, Pueraria Thunbergiana, is one of the most rampant growers ever introduced into our gardens, and it is well to think twice before planting it. Native to central and southern Japan as well as central China, it finds the climate of eastern America congenial.

The plant is a woody climber with large, dark-green threefoliate leaves, and bearing short, compact racemes of violetcolored pea-shaped flowers, followed by brown, hairy pods. It rarely blooms in New England and the stems die down throughout the North. Although earlier introduced the vine came into special notice at the Chicago Exposition, as the Japanese there 
WISTARIA

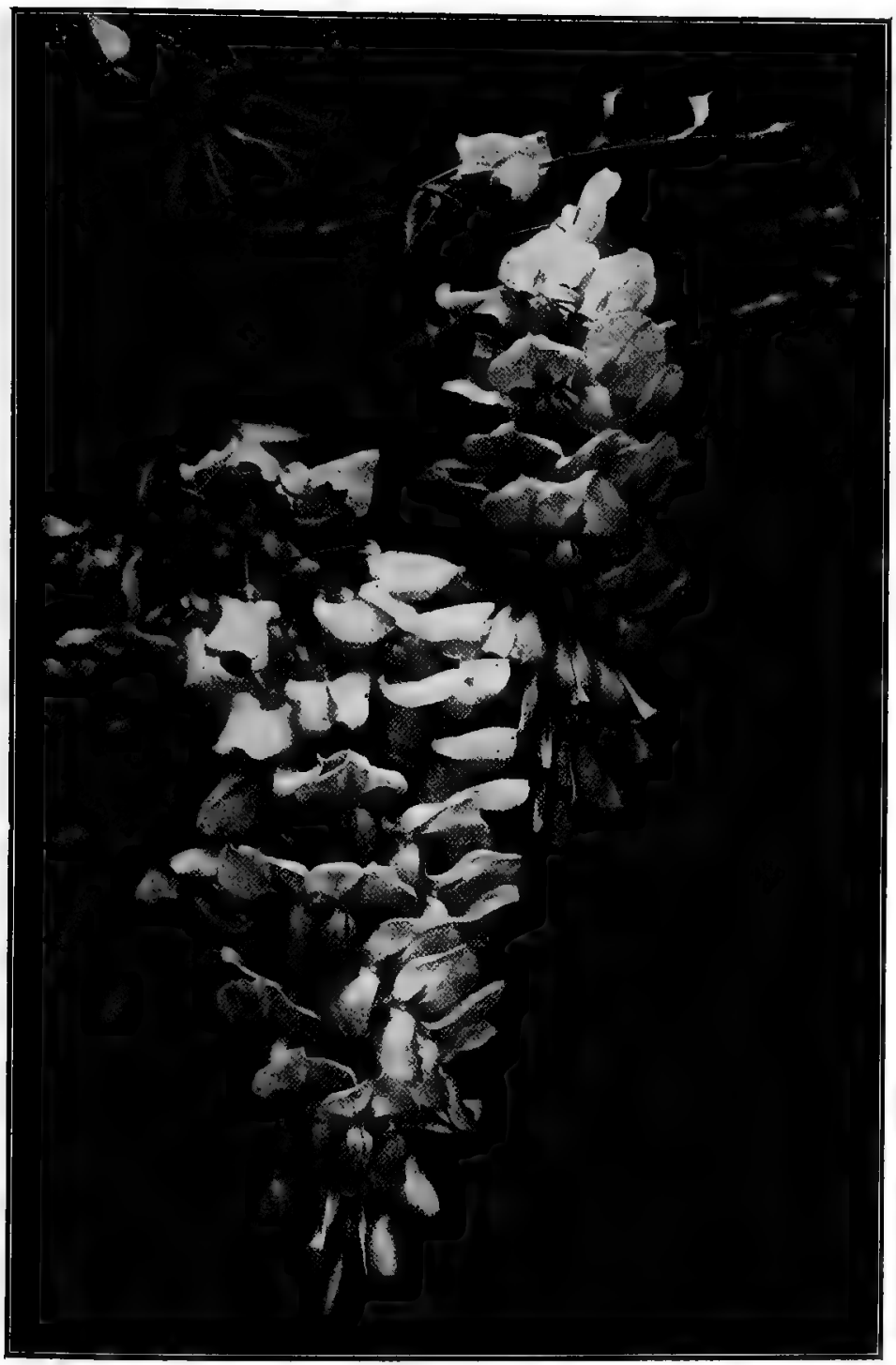

Wistaria. Wistària chinénsis 
used it wherever a quick-growing vine was needed in their landscape gardening. To us Kudzu is merely an ornamental plant, but in Japan its roots are used for food; from the bast a thread is made; while the dried leaves and stems are food for cattle.

Wistaria, Wistària chinensis, one of the best and commonest of hardy climbers, is a strong grower, long-lived and healthy. The foliage is pinnate and not sufficiently dense to afford a perfect screen, but is airy and graceful. The flowers appear in long, drooping racemes of purplish pea-shaped blossoms. These rac-

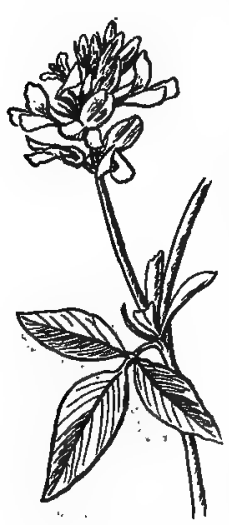

Alfalfa. Medic̀̀go saliva emes are often a foot in length.

The Chinese Wistaria was introduced into England in 1816, and in 1840 there was a specimen recorded with branches attaining a hundred feet on each side of the main stem and another covering nearly a thousand square feet of wall space.

The Wistaria used by the Japanese, which figures so largely in their decorations, is $W^{\prime}$ istaria multífuga, which with us is often called sinénsis; its clusters sometimes attain the length of three or four feet. This is not regarded as sufficiently hardy to become a favorite.

The Soy Bean, Glycine hispida, and the Cow Pea, Vigna sinensis, both Chinese plants, are widely grown as forage plants.

Alfalfa, Medicàgo sativa, is the deep-rooted forage plant of Europe so extensively grown in the arid regions of the United States. It grows about two feet high, bears pinnate leaves and small racemes of small, violet-purple, clover-shaped flowèrs.

Cassia, Cassia floribuinda, is a free-flowering plant with large orange-yellow flowers. It can be wintered in a dormant condition in a cellar or similar place where not exposed to severe frost, and planted in the spring. It will bloom throughout the summer and fall, producing the most dazzling effects by its profuse and brilliant bloom.

The Peanut or Goober, Aràchis hypogàa; from South America, 
produces the familiar nut-like pods whose oily seeds, when roasted, are the peanuts of children's devotion.

The leaves are pinnate, the flowers, papilionaceous, yellow, the banner veined with red. After blooming, the flowering stem grows longer, bends toward the earth, and fairly thrusts the pod underground to ripen. In cultivation this process is assisted and earth is heaped up about the stems.

The Peanut is cultivated all over the world where the climate permits, but probably is of the greatest economic value in Africa. It was long supposed that hypogea was the only species, but several others have recently been discovered in Brazil. 


\section{LINACEÆ-FLAX FAMILY}

\section{FLAX}

\section{Linum.}

The genus Linum is credited in the books with about eighty species, which fall into two groups, annual and perennial, and all possess certain family characteristics. All have herbaceous, subwoody stems, alternate leaves, flowers made on the plan of five: five sepals, five petals, five stamens, and a five-celled ovary which sometimes becomes ten-celled. The fruit is a globular capsule and the seeds are compressed.

Common Flax, Linum usitatísimum, the most useful, is indeed worthy of its specific name. Its native land no man knows; evidently it has clothed the world in linen since the dawn of civilization. Its use ante-dated the founding of Babylon, its fibres are among the remains of the lake-dwellings of Switzerland. Herodotus described it; Pliny extolled it.

This most useful plant is an annual herb, its smooth, slender stem growing to the height of two to three feet. The leaves are lance-linear, acute, an inch and a half long. The bright-blue flowers are borne at the summit of the stem on slender pedicels in a loose cluster.

The one thing which makes this apparently insignificant plant of such transcendent value to the world is that the stem produces a cortical fibre just strong enough and not too strong to make a thread which can be woven into cloth. Undoubtedly prehistoric man made the discovery, for historic man has been using it all his recorded life.

The seeds contain a fixed emollient oil which is very drying, hence used by painters. 
Flowering Flax, Linum grandifiorum, is an annual of erect, branching, leafy habit about two feet high. The flowers vary in tints and shades of red, are very bright and shining, and are

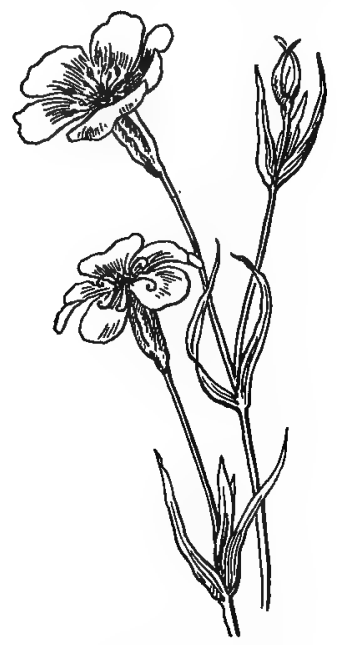

Flowering Flax.

Linum grandiflorum

borne in considerable number on slender pedicels at the summit of the stems. The plant makes a very satisfactory blooming bed, but the individual flowers fall quickly.

Perennial Flax, Linum perénne, is a hardy summer-blooming species with rather small, blue, sometimes white flowers. In these the styles and stamens are of different lengths in different flowers, a condition which is believed to have to do with cross-fertilization. 


\section{OXALIDÀGEA-WOOD SORREL FAMILY}

\section{WOOD SORREL}

\section{Óxalis.}

Oxalis, Greek, sour, from the acid juice.

Oxalis is a genus largely of tropical and sub-tropical plants, and although there are many species native to the North, none of the cultivated species are hardy in our gardens.

Plant-Annual or perennial, often with rootstocks or scaly bulbs, the sap sour.

Leaves.-PaImately three-foliate in our species; leaflets obcordate.

Flowers.-White, pink, purple, or yellow.

Sepals.-Five.

Petals.-Five.

Stamens.-Ten, five longer and five shorter, all anther-bearing.

Ovary.-Five-celled; styles five, separate; stigmas terminal.

Fruit.-A capsule.

Violet Wood Sorrel, Oxalis violàcea, is native to the Middle and Southern States; has rather fleshy, glabrous leaves and roseviolet flowers in simple umbels. Is used in rock work but is transient and hardly desirable.

- White Wood Sorrel, Oxalis acetosélla, lives in the open woods; has solitary flowers, white, veined with deep-pink, on scapes six inches high. Has a world-wide habitat, as it is found in America, Europe, Asia, and northern Africa.

Our best-known representative of the genus is the delicate little plant that lives about our house yards and gardens and by the edge of cultivated fields, Oxalis stricta, often called by country people Sheep's Sorrel. 


\section{GERANIACEA-GERANIUM FAMILY}

\section{GARDEN GERANIUM. PELARGONIUM}

Pelargdnium hortòrum.

Pelargonium, because the fruit is long and slender like a stork's bill.

The genus Pelargonium includes the race of garden Geraniums. Tender to frost. Summer.

Stem.-Shrubby or fleshy, in the erect forms becoming a leafy bush.

Leaves.-Variable, usually scented, pleasantly or otherwise.

Flowers.-Usually borne in terminal corymb, in color varying through reds to white.

Sepals.-Five, acute, hairy.

Petals.-Five, the two on the upper side differing from the rest more or less in size and shape.

Stamens.-Usually seven anthers; filaments often ten.

Ovary.-Five-celled; style one; stigmas five.

Fruit.-Consists of five one-seeded carpels, each with a long tail by which it is attached to the style.

The commonly cultivated forms of Pelargoniums are all descendants of South African plants and can be grouped into four general horticultural classes: Fish Geraniums, Ivy-Leaved Geraniums, Rose Geraniums, and Pelargoniums.

The Fish, Horseshoe, Zonal-the bedding types-are known to gardeners as Geraniums and in their present hybrid forms have been named by Professor Bailey Pelargonium hortorum. These are believed to be in the main descendants of two species: Pelargonium zonàle, characterized by the horseshoe mark on the leaves, 
a strong fishy odor, and rather narrow petals, and Pelargonium inquinas, which is without the zonal mark, has velvety foliage and broader and more rounded petals. In both the colors range from scarlet and crimson to white. The present garden race was fairly well established in England by the end of the eighteenth century, but its vogue as a bedding plant and the great development of the double forms are of comparatively recent date, probably since $\mathrm{I} 860$.

The Ivy-Leaved Geraniums are the descendants of Pelargonium peltàtum, a plant of weak, trailing, zigzag stems, thick, shining, angular leaves, and flowers in loose umbels. The plant is a favorite for window-boxes and hanging-baskets, where overhanging foliage is desired.

The Rose Geraniums are of several varieties, the best-known and most desirable are marked by the rose-like fragrance of the much-divided leaves. In the trade are forms known as apple, nutmeg, lemon, and others, all differentiated by the fragrance of the foliage. They are used principally as border plants.

The fancy type is known to gardeners as Pelargoniums or Lady Washington Geraniums. The American climate is very trying to these plants, and in order to do well they need more care than the amateur ordinarily has to give. They are very beautiful but, as a rule, whoever buys them buys disappointment.

The botanical characters of the genus Pelargonium are a fiveparted calyx; five petals, mostly obovate, comprising two upper and three lower; really ten stamens but three or more of them sterile filaments; a style dividing into five stigmas and the fruit a group of carpels.

The botanical difference between the real Geraniums which the cultivated Geraniums are not, and the Pelargoniums which the cultivated Geraniums really are, lies chiefly in two points: In most cases the flowers of Geranium are regular but those of Pelargonium are irregular, the two upper petals differing from the under in size, shape, and often in coloring. The most constant difference between the genera is the presence in Pelargonium of a spur ex- 
tending from the base of the upper sepal which is not noticed by the casual observer because it is grown to the footstalk. In many of the cultivated forms it seems virtually to have disappeared.

\section{WILD GERANIUM. CRANESBILL}

\section{Gerànium maculàtum.}

Geranium, Greek, geranos, a crane; alluding to the long beak of the fivecarpelled fruit.

A native perennial Geranium found on the border of woodlands, with five-lobed green leaves blotched with paler green and delicate pink blossoms two inches across. Common throughout the North. May, June.

Stem.-Erect, branching, hairy.

Leaves.-Palmately parted into five to seven wedge-shaped divisions cut and cleft at the end, sometimes whitish-blotched, rough, hairy.

Flowers.-In terminal or axilary loose clusters, pale magenta-pink, an inch or more across; pedicels one to three flowered.

Sepals.-Five, acute, awned.

Petals.-Five, pale magenta-pink, veined, beard on the claw.

Stamens.-Ten, the five inner ones the longer, each with a honey gland at its base.

Ovary.-Five united carpels; styles united; stigmas, five, recurved.

Fruit.-Separating from axis into five akenes and uplifted on the curving styles.

This native Geranium is worthy a place in the wild border if not by the garden walk. The opening corolla is a deep magentapink, but becomes paler with age. Cranesbill is a popular translation of Geranium which is derived from a Greek word meaning crane and which was given to the plant because of the resemblance of the fruit, with its prolonged beak, to the bill of a crane.

Herb Robert, Geranium Robertiànum, is a handsome plant adventive from Europe. There is always more or less red about both leaves and stems. The flowers are small, rose-pink with 
darker lines, and while the cranesbill seed-vessel clearly marks the family affiliations, it sends its seeds away a little more strenuously than the other species of the genus. It loves to live on rocks and bask in sunshine.

Edward Step, in "Romance of Wild Flowers," explains the name Robert as an example of interchange of meaning. He says the redness of the plant caused the country people to give it the name Robwort, that is, Redwort, and in course of time the $w$ disappeared in pronunciation, leaving it Rob'ort, to puzzle a later generation who spelled it Robert and wondered if ever the plant had been dedicated to a St. Robert. Linnæus regarded this Robert as a personal name and gave it a Latin termination by which the plant will doubtless always be known.

\section{NASTURTIUM}

\section{Tropceolum màjus. var. hýbrida.}

Tropaolum, Greek, a trophy; the foliage of the common sort suggesting a group of shields. Nasturtium is the Latin name of Water Cress.

Tender South American plants bearing very irregular and unsymmetrical flowers; often climbing by their long leaf-stalks; and filled with a watery juice of pungent odor and aromatic taste. Small Nasturtium, Tropaolum minus, is similar to Tropaolum majus, but smaller; petals with a bristle-like point.

Stem.--Either climbing or decumbent.

Leaves.-Circular, peltate.

Flowers.--Irregular, spurred, yellow and orange.

Calyx. - Five sepals, united at the base, and on the upper side of the flower extended into a long, descending spur.

Corolla.-Five petals; the two upper more or less different from the others and inserted at the mouth of the spur; the three lower clawed and more or less fringed at the base.

Stamens.-Eight, unequal; filaments usually turned downward and curving. 
Ovary.-Three lobes surrounding the base of a single style; in fruit becoming three thick and fleshy closed carpels, each containing a single seed.

Three hundred years ago, when the free-booting ships of England were sailing the uncharted seas, one danger and one alone brought fear to the heart of a Drake or a Raleigh-the dread of scurvy among his crew. Consequently plants possessing antiscorbutic properties were eagerly sought in every newfound land. Among such plants was the Small Nasturtium, Tropaolum minus, introduced into English gardens from Peru by way of Spain and France before 1596 , and cultivated for a hundred years because of the high value placed upon its seeds, which were pickled when full-grown but yet green. Owing to the pungent and aromatic juices of the plant it obtained the common name of Indian Cress. The leaves and flowers were used in making salads, and the plant was a denizen of the kitchen garden. About a hundred years after the arrival of the first Nas-

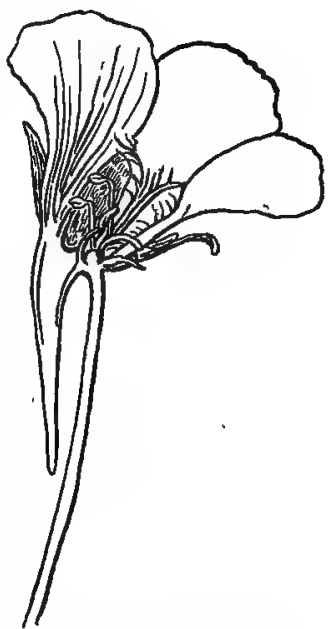

Half of a Nasturtium Flower. turtium came the second, Tropaolum majus, whether to join its smaller brother in domestic service the books do not tell, but the event proves that even if it came to drudge it has remained to reign. For the garden race of Nasturtiums is at base Tropaolum majus, modified by cultivation and selection, and possibly hybridized with one or more allied species. The plant is unique in habit, in foliage, and in flower. The circular leaves, each borne upon its stem like a shield on the arm of a soldier, standing close together or slightly overlapping, really make a leafy roof which keeps cool and shaded and dewy a space six inches above the surface either of soil or wall. Out of this shaded retreat the flowers emerge on slender stems, looking forth with a 


\section{GERANIUM FAMILY}

sidewise glance and a charming poise. As the summer waxes to its prime the entire bed becomes a blaze of blossoms which fairly radiate sunlight from their golden cups. The plant climbs the fences or trails along the ground, but wherever it is it craves light and sunshine.

The individual flower is in itself most interesting. The calyx is colored as the corolla only in lower tones. Its five sepals are fairly grown together and the three upper unite to form a long slender spur which is a storehouse of nectar. Upon the calyx and between its points grow the petals; the two upper directly attached, the three lower growing on long fringed claws. There are various markings seen as one looks into the heart of the flower, and all point down into the spur. No wandering bee should mistake the directions; they are there conclusive, unmistakable. No ants need apply; the petal fringe is a discourager of ant industry. There are normally eight stamens, and these do not mature at the same time, but discharge their pollen one after another. As the stigma is not receptive until the home pollen is fairly exhausted, the plan considerably lengthens the life of each flower, for as a rule the petals continue the honey call to the bee until the stigma is fertilized, or failing that until the vitality is exhausted.

After fertilization both calyx and corolla wither; the flower stem begins to curve, sometimes makes two or three turns so as to draw the fruit down into the cool retreat under the leaves that it may not be harmed by the sunshine.

Nasturtium behaves as if it were a mountain plant in its native land. It craves light and heat, thrives best on a thin soil and in a dry, warm location. At the same time it bears a very considerable degree of cold. Its leaves change their poise when night comes so as not to radiate heat.

Tropaolum Lobbiànum is a species from Columbia with blossoms of the normal type, red to nearly' red-black. This species has enriched the present garden race so that a group of Nasturtium blossoms now gives a marvellous scheme of color-yellows to orange, orange to red and red-browns-all radiant with im- 
prisoned sunlight; a combination that words can only suggest, not describe.

Canary-Bird Flower, Tropaolum peregrinum, unlike its blood brothers who climb when they feel like it, always climbs. The leaves are five-lobed, not very abundant, and the petals of the blossom are considerably cut and slashed. The plant certainly is interesting. 


\section{RUTÀCEA-RUE FAMILY}

\section{COMMON RUE}

Rùta gravèolens.

Ruta, the ancient name of the plant; meaning unknown.

A strong-scented, hardy perennial once cultivated but now found only as an escape. Native to the Mediterranean regions of Europe and western Asia. Juices acrid. July, August.

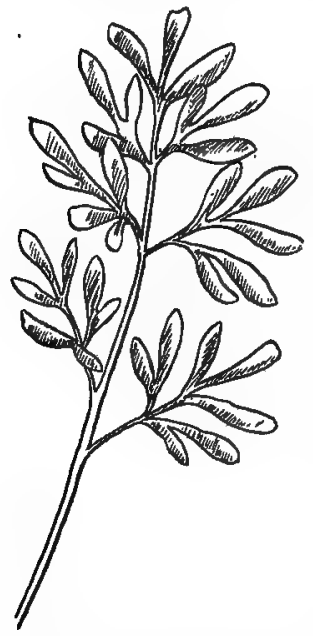

Common Rue. Riula gravèilens

Stem.-Slightly woody at the base, two to three feet high, leafy, bushy.

Leaves. - Alternate, pinnatelydecompound; gray-green, dotted with small, transparent glands resembling punctures, containing an acrid, bitter, aromatic oil.

Leaflets.-Oblong or obovate, entire, the terminal one often the broader.

Flowers.-In few-flowered corymbs, greenish-yellow, parts spreading, produced all summer.

Calyx.-Four or five sepals.

Corolla.-Four or five yellow petals, curved and arching at the apex.

Stamens.-Eight to ten, twice as many as the petals.

Ovary.-Four to five lobed, four to five celled.

Seeds.-Several.

This plant is filled with acrid juice which contains a volatile oil that is a powerful stimulant and in large doses acts as a narcotic poison. At one time the stems were employed to sprinkle holy water in the ceremonies of the Catholic Church, which is, perhaps, the explanation of Ophelia's saying, "We may call it herb of grace o' Sundays." 


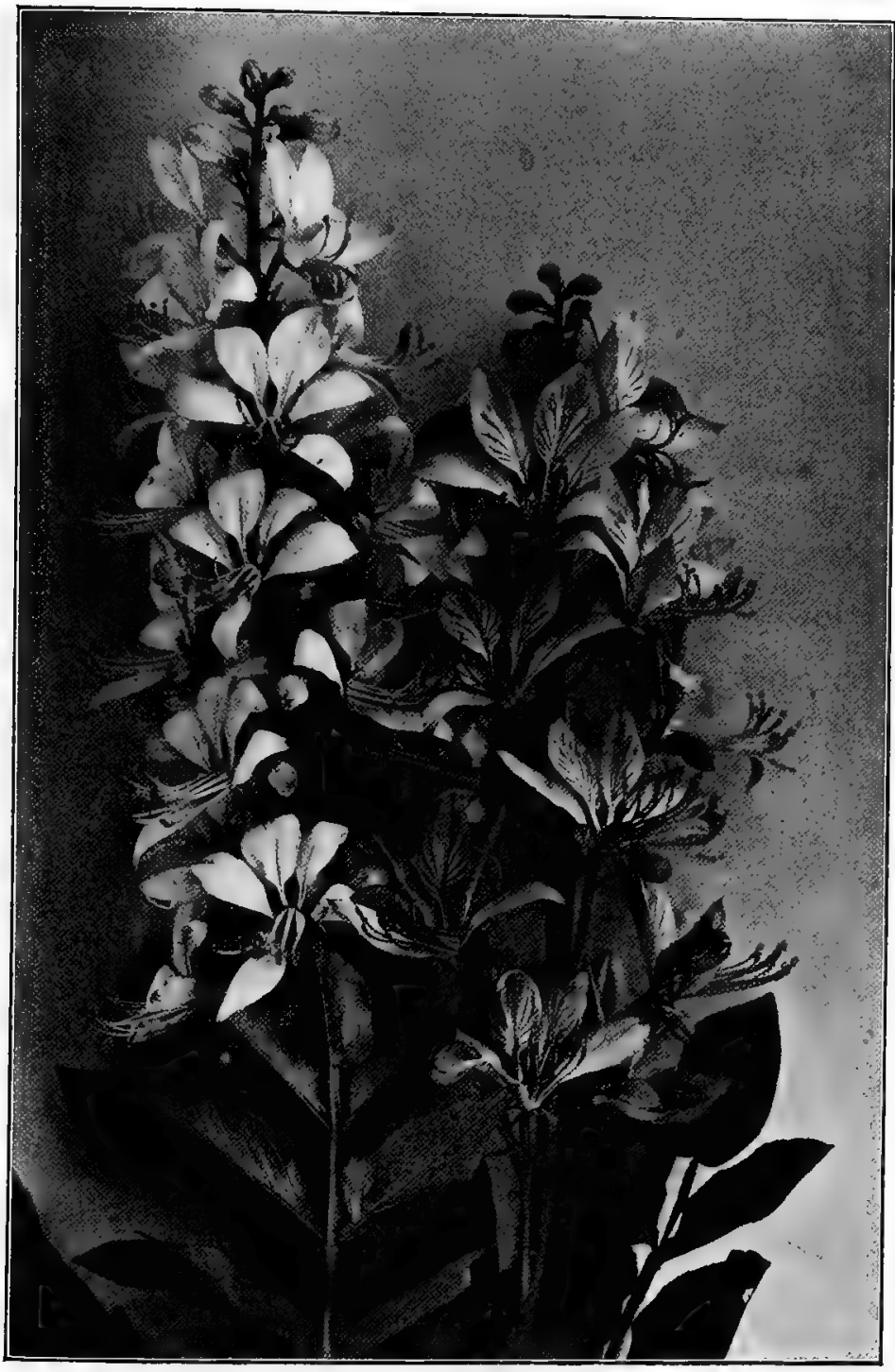

Dictamnus.' Dictamnus albus 
Here, in this place

I'll set a bank of rue, sour herb of grace;

Rue, even for ruth, here shortly shall be seen,

In the remembrance of a weeping queen.

- "Richard II," Act III, Sc. 4, Shakespeare.

Among the ancients Rue was in great repute as an amulet; in mediæval times it was a common witch's drug; later it had a place in the materia medica. To-day it is simply a coarse, disagreeable herb, interesting because of the associations that gather about it, of itself worthless and unattractive.

\section{DICTAMNUS. GAS PLANT. DITTANY}

\section{Dictamnus albus.}

An old Greek name, supposed to indicate foliage like the ash.

A garden favorite of long standing, with glossy, leathery leaves, having strong smell of lemon. Southern Europe to northern Asia. Summer.

Stems.-Three feet high, forming clumps.

Leaves.-Alternate, odd-pinnate; leaflets nine to thirteen, ovateserrulate, dotted with oil glands.

Flowers.-White or pale purple, pencilled with darker lines, fragrant, borne in long, showy, terminal racemes.

Sepals.-Five.

Petals.-Five, long and lanceolate on short claws, the lower declining, the others ascending. lar.

Stamens.-Ten; filaments long, declining and curved, partly glandu-

Ovary.-A little elevated, deeply five-lobed; styles five; in fruit the ovary separates and becomes five, flattened, two to three-seeded pods.

Dictamnus was a great favorite in old gardens because of its fine clumps of glossy, dark-green, aromatic leaves which make it a very effective plant throughout the entire season. Flowers and flower stems are covered with glandular hairs which secrete a volatile oil so abundantly that at the height of the flowering season and when the fruit is forming the plant ignites for a moment at the burning of a match. 


\section{CELASTRÀCEA-STAFF TREE FAMILY \\ CLIMBING BITTER-SWEET}

Celästrus scandens.

Celastrus, an ancient Greek name for some evergreen.

Twining shrub, common along streams and in thickets, from Maine to Manitoba and southward. June.

Stem.-Climbing to twenty feet or more.

Leaves.-Alternate, ovate-oblong, finely serrate, pointed.

Flowers.--Small, greenish-white, polygamo-diocious in axillary or terminal racemes.

Sepals.-Small, five-cleft.

Petals.-Five, stamens five; both inserted on the margin of a cup-shaped disk which lines the base of the calyx.

Ovary.-Two to four-lobed; two to fourcelled; style thick; stigma lobed.

Capsule.-Orange-yellow, dehiscent by two to four valves, each containing one or two seeds enclosed in a fleshy scarlet aril.

Climbing Bitter-sweet is a very vigorous twining shrub, leafy in summer and. Climbing Bitter-sweet. Celásirus in autumn, ripening a mass of beautiful,

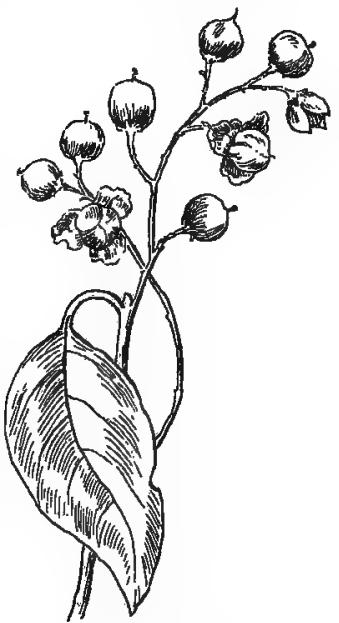
berry-like fruit, orange and crimson, which remains upon the branches well into the winter.

Euonymus radicans is a Japanese climbing shrub of the Staff Tree Family. The climate of northern Ohio seems not particularly favorable to its development; it lives, but does not thrive; at the south it flourishes apace. 


\title{
EUPHORBIÀCE $/$-SPURGE FAMILY
}

\author{
SNOW-ON-THE-MOUNTAIN
}

Euphórbia marginàta.

Euphorbia, said by Pliny to be named in honor of Euphorbus, the physician of King Juba; possibly from the Greek word for fat.

A very handsome annual, cultivated because of the beautiful whitemargined leaves and bracts that crown the stem and surround the inconspicuous flowers. Native to Ohio and westward. July and August.

Stem.-Erect, stout, two to three feet high, covered with white, woolly hairs and topped by a three-rayed umbel of whitish flowers and leafy bracts; juice milky, acrid.

Leaves.-Except the whorl subtending the umbel, scattered, ovate to oblong or obovate, two and a half to three inches long, entire.

Leaf-bracts.-Subtending the involucral groups, large, white-margined, clustered, conspicuous.

Involucre--Green, bell-shaped, bearing four or more green glands, each with a white, petal-like appendage.

Flowers.-Moncecious; both staminate and pistillate destitute of calyx as well as corolla, and together contained in a bell-shaped involucre which imitates a calyx.

Stamens.-Four to several, each regarded as a separate flower; each is possessed of a tiny, white, thread-like bract; all are enclosed in the involucral bell.

Ovary.-Three-lobed and three-celled, rises from the centre of the involucre on a long curved pedicel; styles three, each two-cleft; stigmas six.

Fruit.-When ripe bursts into three separate carpels each having one seed.

This is one of the most interesting plants in cultivation, because its floral structure is so unusual. The slender, pale-green stems are about three feet high, each one bearing at its summit a flat cluster of white-margined leaves, the whole being from four to six inches across. Upon examination each cluster resolves itself 


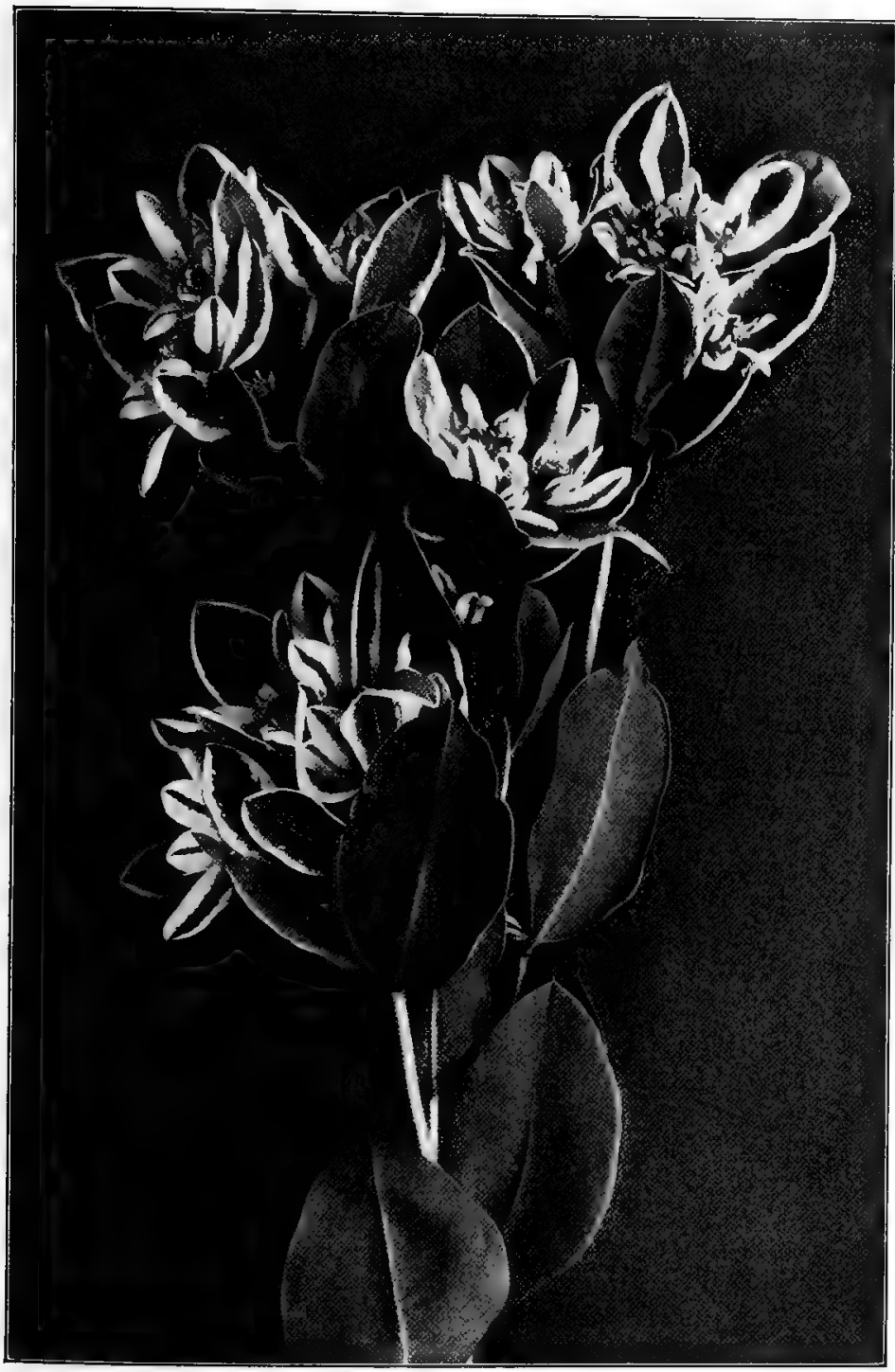

Snow-on-the-Mountain. Euphórbia marginàta 
into at least three smaller clusters of white-margined leaves, these surrounding a group of inconspicuous white flowers. The books call this inflorescence a three-rayed umbel; often there are several of these at the top of the stem. At the point where the three umbel rays come together rises an erect

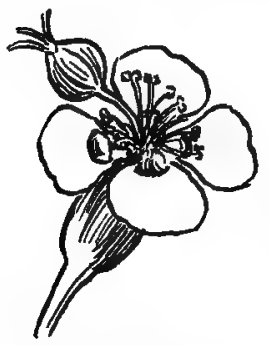

Involucral Group of Flowers; enlarged.

Euphdrbia marginàa stem about an inch high bearing a single flower group quite destitute of leafy bracts.

The involucral group looks like a four or five petaled white corolla with four or more stamens. A minute green cup is attached at the base of each apparent petal and the stamens come out from among a cluster of greenish-white threads. These represent bracts and each stamen is regarded as a distinct and separate flower.

There is one pistillate flower in the centre of each involucral group; this, likewise, is regarded as a distinct and separate individual.

It is rather curious that a plant native to the dry plains of the West should in cultivation obtain the name of Snow-on-theMountain.

\section{WHITE-FLOWERING SPURGE}

\section{Euphórbia corollàta.}

A native Spurge, sparingly found in gardens, whose involucre cups bear five conspicuous appendages imitating a five-cleft corolla. Grows in gravelly and sandy soil from Massachusetts west and south. Perennial by a long, stout rootstock. May-October.

Stem.-Erect, two to three feet high, diffusely branching; juice milky.

Leaves.-Scattered, whorled or opposite, ovate, oblong to lanceolate, varying greatly in size.

Flowers.-White, each group closely imitating a perfect flower, but really consisting of a single ovary on a long stem; three-celled and threeseeded, crowned with three styles; and several staminate flowers consisting each of a single stamen. Pistil and stamens are surrounded by a cup-shaped involucre with five lobes each bearing a white appendage. 
This pretty, white-flowered, forking creature is a puzzle for amateurs. Its flower cup is such a perfect corolla, its tiny stamens look so natural and law-abiding, the pistil is so evidently in place that the flower has a tendency to deceive even the elect botanist, until the long, thread-like stem that carries the ovary is noted and the puzzle is solved. The infloresence is abundant and borne in loose-flowered umbels, but the milky juice of the stem is an objection, for the garden value of the plant lies in its cut flowers, which, like those of Gypsophila and Galium, are at their best only in combination with others.

If one wishes to study the curiously abnormal inflorescence of the Euphorbias, it is only necessary to pick up the little, halfprostrate, forking mat that lies in the sand by the roadsides or creeps over the edge of the garden walk and spreads out over the pathway. By July the little creeping thing will have flowers in the axil of nearly every leaf, whose tiny globular seed-vessels on stems protruding out from the minute reddish flower will show the family characteristics. For this is Euphorbia maculàta, the Spotted Spurge, a citizen of the world. Its leaves are small, oblong, or ovate, obtuse, slightly serrate, oblique at base, and on red, hairy stems are themselves blotched with red. On the sands of the sea-shore or of the Great Lakes one may study Euphorbia polygonifolia, a very similar plant.

\section{POINSETTIA}

\section{Euphôrbia pulchêrrima.}

The most brilliant of the Euphorbias. At the North, grown in-doors and used in Christmas decorations. Native to moist, shaded places of tropical America.

Stem.-Woody, two to six feet high.

Leaves.-Ovate-elliptical or lanceolate; entire, sinuate-toothed or lobed; lower leaves green; upper leaves and leaf-like bracts brilliant vermilion-red.

Flowers. -Euphorbia type, in a loose cyme; involucres greenish with one large yellow gland. 


\section{SPURGE FAMILY}

Poinsettia, is the most gorgeous and tropical of all the redflowered plants grown for Christmas decoration. The true flowers are the inconspicuous yellow dots in the centre of the glowing rosette of leaf-like bracts and leaves at the summit of the stem, but nobody cares about those; it is the red leaves that call forth our admiration.

The plant is tropical and at home it glows in the shaded gloom of a swampy jungle. At the North it must be grown in the greenhouse; in Florida it romps at will in the gardens and lawns. The gardeners have developed varieties with white and with yellow bracts; also have succeeded in increasing the bracts and enlarging the leaves of the type. The plants were first introduced to horticulture by Dr. Poinsett, of Charleston, S. C., about 1833 . and their garden name is in his honor.

Annual Poinsettia, Euphorbia heterophyllla, grows two to three feet high, bears variable leaves, the upper ones bright-red, and can be grown in sunny places. Native to our Southern States, and blooms from July to September.

\section{CASTOR-BEAN}

\section{Ricinus comminis.}

Ricinus notes the resemblance of the seed to certain insects. ical.

A tree-like herb, common in cultivation as a decorative plant. Trop-

Stem-Bright-green to dark-red, three to fifteen feet in the United States, thirty to forty in the tropics.

Leaves.-Large, alternate, peltate, palmate, seven to many lobed; lobes serrate.

Flowers.-Monœcious, without petals or disk; in terminal and apparently lateral racemes; the fertile above, the staminate below.

Calyx.-Five-parted.

Stamens.-Very numerous, with repeatedly branching filaments.

Styles.-Three, united at base, each two-cleft, red.

Capsule.-Large, three-lobed with three large seeds 
The Castor-Bean is a tall, stately annual, extensively grown as a decorative plant. Its native land is unknown, probably India or Africa; but it is now naturalized in all tropical lands. Oil

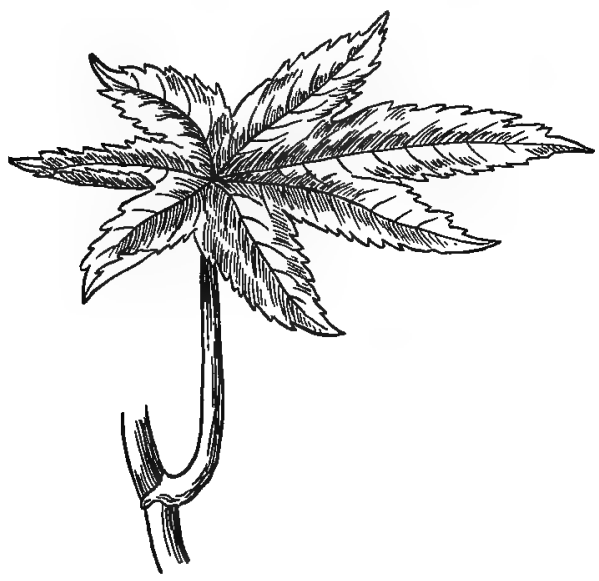

Castor-Bean. Rícinus commintis

obtained from the seeds is the castor-oil used in medicine and the arts. The species has varied into many horticultural varieties.

The genus Pachysaindra, Mountain Spurge, appears in two species, one procumbens, native to the Southern States, and the other terminalis, from Japan. The Japanese species is a true evergreen with thick, glossy foliage forming a dense mat, making a very desirable cover plant. The flowers are inconspicuous but rich in nectar and appear very early. The plant is desirable only for its foliage. 


\section{SAPINDȦCE E-SOAPBERRY FAMILY}

\section{BALLOON VINE. LOVE-IN-A-PUFF}

\section{Cardiospérmum Halicácabum.}

Cardiospermum, Greek, heart-seed; from the white, hèart-shaped spot on the round black seed.

A rapid-growing, annuả climber, doing best in a warm situation; with small white flowers, and seed-vessels that look like tiny balloons.

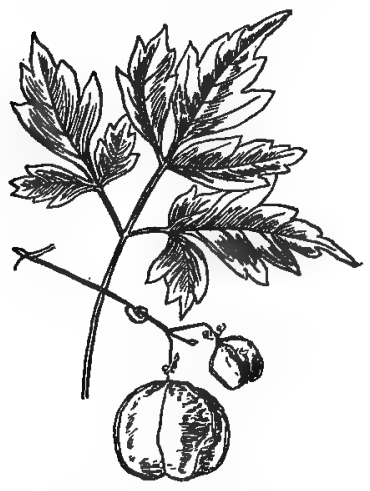

Balloon Vine. Cardiospérmum Halicácabum

Native to the South-western States and Mexico. Summer.

Stem.--Grooved, climbing by hooklike tendrils in the flower cluster.

Leaves.-Alternate, twice ternate, coarsely serrate.

Flowers. - Small, white, in fewflowered axillary clusters.

Sepals.-Four, the inner pair larger.

Petals.-Four, each with an appendage on the inner face; disk enlarged into two glands, one before each lower petal.

Stamens.-Eight, filaments of varying length.

Ovary.-Triangular, three-celled, one ovule in each cell.

Pod.-Bladdery, inflated, three-lobed with winged ridges, containing one to three bony seeds the size of small peas, each with a heart-shaped aril adherent to the base.

The inflated pod of the Balloon Vine is an inch or more in diameter. As the round black seeds are each marked with a white heart, in accordance with the old idea of signatures, they have long been considered efficacious medicine for heart diseases. 


\section{BALSAMINÀCEA-TOUGH-ME-NOT FAMILY}

\section{GARDEN BALSAM}

Impàtiens balsamina.

Impatiens, named from the sudden bursting of the pod when touched.

An erect, half-succulent annual, long since introduced from India and now widely cultivated for its showy flowers.

Stem.-Erect, low, leafy.

Leaves.-Lanceolate, crowded, the lower opposite.

Flowers.-Clustered in the axils of the leaves on very short stalks.

Sepals.- Similarly colored and not easily distinguished, one of the sepals, of which there seem to be three, long-spurred.

Petals.-Apparently three.

Stamens.-Five, anthers cohering.

Ovary.-Five-celled; stigma fivetoothed.

Capsule--Explosive, of five united carpels with very thin partitions; when ripe a pinch or concussion will cause the valves to separate and contract, throwing the seeds with considerable force.

The Common Balsam is a bloodbrother of the Impatiens of our

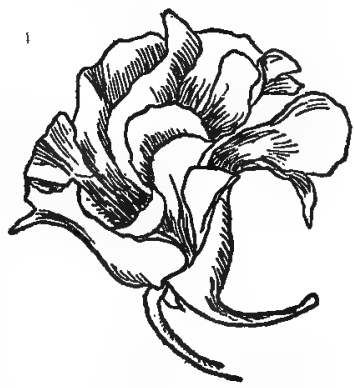

Balsam. Impàtiens balsamina shaded ravines and cool brook-sides.

It was brought from India into England before 1596 , became at once a favorite, and has since been developed into many garden forms. The flowers of the type were single and rose-red, but under cultivation very double blossoms have been produced, ranging in color through white to various reds and yellows. The full-double blossoms are known as the camellia-flowered 
varieties. The individual flowers are very beautiful, but they cling so close to the stem and are so overshadowed by the leaves that their value is greatly lessened.

Impatiens suitàni, often simply called Sultana, is a well-known house plant of succulent brittle stems, bright-green shining leaves,

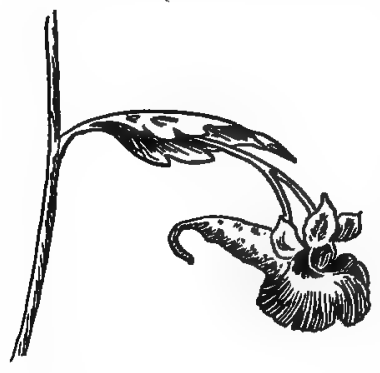

Jewelweed. Impditiens fulvo bearing in the primitive form beautiful crimson blossoms. Hybrids and sports have given colors from pink to purple and a white variety exists. The front view of the flowers suggests by its outline a pansy, but its structure is by no means pansylike. There are three sepals, two very small and green, the third with a larger blade than the others and a long slender spur. This spur seems so inconsequent and irrelevant that it never ceases to be a wonder. The petals are five and their arrangement suggests the pansy.

This child of the tropics finds the warm, moist atmosphere of the country kitchen most agreeable, and thrives there beyond measure. It possesses, moreover, the great house-plant virtue, it increases by cuttings which root readily, consequently no neighbor who wishes a plant need go without one.

The two Jewelweeds or Touch-me-nots, Impatiens fuilva and Impatiens pallida, the Tawny and the Pale, are among our most beautiful native plants. Lovers of shade, growing in great numbers in moist places and along mountain watercourses, they often possess and hold, without a rival, really large tracts. The translucent stems, with leaves which under water look silvery, bear a flower of such peculiar shape as to attract attention from the most casual observer. Its shape suggests a cornucopia with a curved and attenuated base and a frilled border. Sepals and petals have become virtually indistinguishable in respect to color. The flower is credited with three sepals, two lateral ones small and green, the third saccate and spurred, a veritable horn of 
plenty. The petals are five, or they may be regarded as three with two of them two-cleft. Stamens are five and the fruit is quite as interesting as the flower, an oblong capsule that grows irritable as it becomes mature, when a slight pressure will make

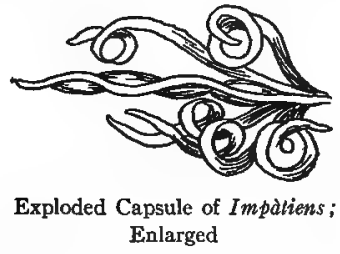

it explode and send the enclosed seeds flying. The technical explanation of the matter is that the capsule breaks up into five spiral coiled valves, expelling the seeds.

The Tawny Touch-me-not is somewhat variable in color, sometimes deeply freckled with red-brown over a deeply goldenyellow ground, other times much paler. The plant also produces cleistogamous flowers late in the season. 


\section{VITÀCEA-VINE FAMILY}

\section{WOODBINE. VIRGINIA CREEPER}

mpelópsis quinquefolia. Psédera quinquefolia.

Ampelopsis, Greek, like the vine.

The familiar creeping and trailing vine extensively cultivated, and common in its wild state in open woods and thickets, on rich low ground. Ranges from Maine to the Dakotas and southward. Summer.

Stem.-Climbing high by means of disk-bearing tendrils and ærial rootlets; bark with lenticels: pith white.

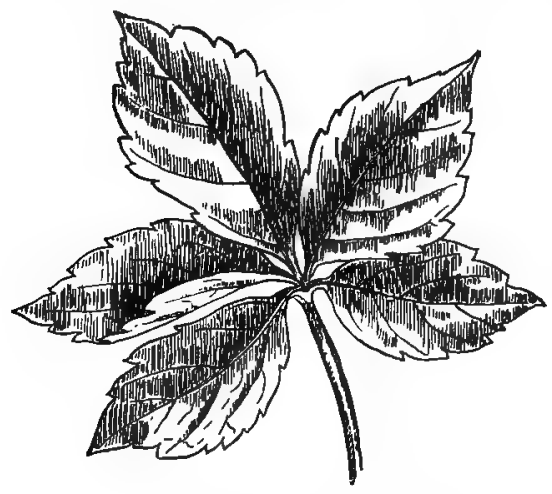

Woodbine. Ampelopsis quinquefolia

Leaves.-Alternate, digitately compound; leaflets five, elliptic or oblongovate, coarsely serrate.

Flowers.-Small, greenish, perfect or diœcious, borne in loose cymes.

Calyx.-Minute. ing.

Petals.-Five, spread-

Stamens.-Five.

Ovary.-Globose; style short.

Berry.-Dark-purple with a blue bloom, size of small pea, two to three seeded.

Ampelopsis quinquefolia and Ampelopsis Veitchii are the two favorite wall-covering vines of the North. Veitchii interprets the whole duty of a vine as the duty to climb, to hold fast and cling tight, and so it does, virtually sheathing the wall in a leafy armor. 
But quinquefolia has, apparently, a different view; with one arm clinging to a porch pillar or a perpendicular wall it waves another out toward the world at large. Itsatendrils sway with every zephyr and nod with every breeze. It is the more picturesque of the two as it clambers over the veranda or billows along the fence, but each has its own vital and all-sufficing charm, so that one may be happy with either.

The autumnal tints are bewitching and bewildering, a confusion of rich scarlet and crimson, changing somewhat earlier than the Japanese Ivy.

\section{BOSTON IVY. JAPANESE IVY} Ampelópsis Vêitchiz.

A hardy and useful climber, clinging firmly and covering walls densely; introduced from Japan.

Stem.-Climbing high by means

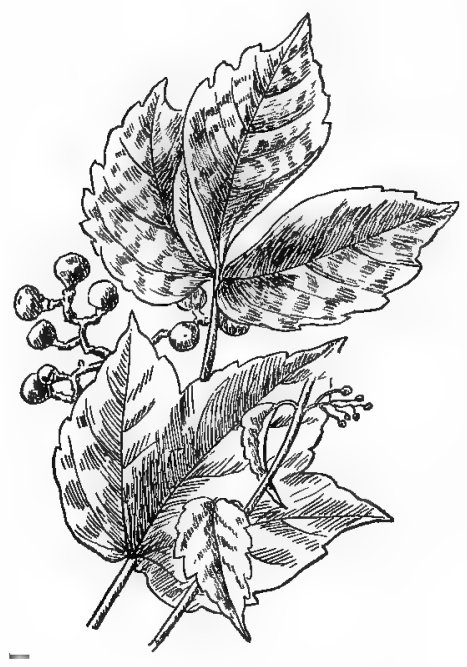

Boston Ivy. Ampelôpsis Vêitchii of short and disk-bearing tendrils.

Leaves.-Three-lobed or three-foliate; coarsely and remotely dentate, shining, glabrous on both sides.

Flowers.-Perfect, greenish, small, borne in short-stalked racemes.

Calyx.-Minute.

Petals.-Five.

Stamens.-Five.

Ovary.-Globose; style short.

Fruit--One to four-seeded berry, dark-purple with a blue bloom; size of pea.

The Japanese Ivy was brought from Japan about fifty years ago as a conservatory plant. It was soon discovered to be sufficiently hardy to withstand the Boston climate, and to-day it surpasses all other vines for covering brick and stone walls. It 
thrives in all locations and is remarkably vigorous in large cities, where it grows to a great height, clinging to bricks and stone and mortar in positions where no other vine so exposed to the power of the wind could survive.

The close double carpet of green, the broad, wax-like, shining leaves which in the fall change to scarlet and crimson, unite to make this the most desirable of all our climbers. Its tendrils adhere best to unpainted surfaces and it needs no support of any kind. Very young plants are tender in winter, but a slight protection for a year or two will establish them permanently in the soil, from which time their growth is rapid.

\section{RIVER-BANK GRAPE. FROST GRAPE}

Vitis vulpina.

$V$ itis, the ancient name of the vine.

The River-bank is the commonest grape of the Northern States west of New England; abundant along streams; frequently destroys shrubs and low trees. Variable in the flavor and maturity of the fruit.

Stem.-Vigorous, tall-climbing, with bright-green foliage; young shoots normally glabrous; stipules large; tendrils forked and coiling; nodes solid.

Leaves.-Thin, medium to large, cordate-ovate with a broad sinus at base; sometimes three-lobed; deeply and irregularly cut; apex prominently acute; generally glabrous, but veins and their angles often pubescent.

Flowers.-Small, greenish, diœcious, or polygamo-diœcious, borne in compound racemes.

Calyx.-Minute, five-lobed.

Petals.-Five, cohering at the tips and falling without expanding.

Stamens.-Five, alternating with nectiferous glands; stamens of fertile flowers curved; of sterile flowers erect.

Ovary.-Globular, two-celled; style short.

Berries.-Small, less than half an inch in diameter; purple-black with a heavy blue bloom, sour, generally ripening late; seeds rather small and distinctly pyriform.

The River-bank Grape is well known to all who live in the Middle West, for it festoons the thickets on the river banks, where 
it often takes entire possession of a tree. When transferred to the farm-house enclosures it throws a green mantle of beauty over unsightly places, and makes in all respects an admirable general utility vine.

The berries are small-less than half an inch in diameterpurple-black with a heavy blue bloom, sour and somewhat astringent, ripening late. The species sometimes hybridizes with labrúsca.

\section{NORTHERN FOX GRAPE}

Vitis labruisca.

One of the common wild grapes of the North and the parent of the Concord and other cultivated varieties. Found in thickets on moist grcund in New England, eastern New Yórk, and southward to Georgia and Tennessee. Blooms in May and June and fruits in August and September.

Stem.-Woody, climbing by tendrils, with watery and acid juice; bark loose and shreddy; young shoots very cottony; nodes solid, interrupting the pith; tendrils forked.

Leaves.-Alternate, rusty-brown, woolly beneath, rounded, heartshaped, palmately veined, varying from merely dentate to deeply lobed with rounded sinuses; opposite each leaf is a tendril or a flower cluster.

Flowers.-Greenish, small, diœcious or polygamo-diœcious, borne in a compact cluster.

Calyx.-Minute, obscurely five-toothed.

Petals.-Five, coherent in a cap and falling without expanding.

Stamens.-Five, alternate with five nectar-bearing disks.

Ovary.-Globular; style short.

Berries.-Few, two-thirds of an inch in diameter, purplish-black with bluish bloom, tough skin and musky flavor; seeds pyriform.

The Northern Fox Grape is the common wild grape of New England and eastern New York, and has a well-merited claim upon our attention as the parent of the Isabella, Concord, and Catawba-in fact, of most of the American cultivated grapes. The vine is strong, robust, climbing high in thickets and on trees; the young shoots are tawny with much scurfy down; the leaves are large and thick and broadly cordate-ovate; they vary con- 


\section{VINE FAMILY}

siderably as to lobes and margin but underneath are densely covered with a tawny, dun-colored, or red-brown tomentum. This characteristic persists in many of the cultivated varieties. The blossoms are both fertile and sterile upon the same plant; the corolla never opens, the small greenish petals grow together at the tip and fall without separating. The perfume of the blooming grape is subtle and delicious as all who have grapevines know. The fruiting raceme is short, carrying less than twenty berries in the wild type; the berries, large and nearly spherical, ranging from purple-black, the common color, to redbrown and amber-green; variable in taste, but mostly sweetish, musky, and sometimes slightly astringent. 


\section{MALVÀCEA-MALLOW FAMILY}

Herbs or shrubs with alternate, palmately veined leaves. The flowers are regular; sepals five and petals five. The filaments of the numerous stamens form a tube connected with the base of the petals; and this tube bears, either at its summit or along its sides, kidney-shaped, one-celled anthers. The styles, five or more, push out at the top of this tube. Pistils are several, either uniting in a ring or forming a several-celled pod. A whorl of bractlets either separate or grown together, called an involucre, surrounds the calyx. All members of the family are more or less mucilaginous. Its best-known garden representatives are Hollyhock and Hibiscus, its plant of greatest economic value is Cotton.

\section{HOLLYHOCK}

\section{Althèa ròsea.}

Althca, to heal, of Greek derivation; some of the species having been used medicinally.

An old-time garden favorite; a plant of vigorous growth, noble aspect, and ornamental character. Both biennial and perennial. The Levant.

Stem.-Tall, simple, hairy, bearing the flowers on short peduncles.

Leaves.-Rough, rounded, heart-shaped, angled, or five to seven lobed, palmately veined.

Flowers.-Large, rose, red, purple, white or yellow, single or double, borne in a spike. bracts.

Calyx.-Five-pointed, hairy, re-enforced by an involucre of six to nine

Corolla.-Single flowers of five large petals, wedge-shaped, convolute in bud. 
Stamens.-Many, filaments connected with the base of the petals and united into a tube; anthers kidney-shaped, one-celled.

Styles.-Many, slender, concealed at first within the corolla tube.

Ovaries.-Many, united in a ring, separating at maturity.

The Hollyhock puts into capitals the essential characters of the Mallow Family, and by carefully studying this flower it is possible to get the structure of the mallows so clearly in mind that whether
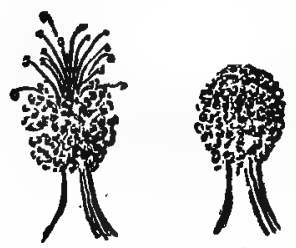

Tubes of Hollyhock Stamens big or little they are readily understood. The five-pointed velvety calyx is re-enforced by an involucre which looks like an extra calyx, and together they form the outer green cup in which the larger cup of the corolla sits. In the opening buds the great petals are rolled and twisted, then carefully and tightly tucked in at the end. The slender filaments of the stamens unite and form a tube which encloses and, in the opening flower, conceals a cylindrical bunch of thread-like styles.

By the time the petals have freed themselves of all their tucks and wrinkles the anthers are mature, the pollen is falling, and the nectar flows freely at the base of the staminate column; the feast is ready. The guests arrive duly, for the bees always know when the Hollyhocks are in bloom. After the anthers have matured the long slender styles push out at the top of the stamen tube frequently extending half an inch or more beyond and curving over. At this time the petals are full of life, the nectar continues to flow, and the bee comes again bringing pollen from some younger flower. After fertilization the petals become flaccid, twist and drop, while the blooming impulse passes on to the buds above.

The life of a Hollyhock blossom continues from three to five days, and usually from five to nine blossoms in different stages of bloom adorn each well-grown stalk.

The Hollyhock is the Holy Mallow, brought into western Europe, it is believed, by the Crusaders. The original color was rose, but selection and hybridization have produced a garden race whose 


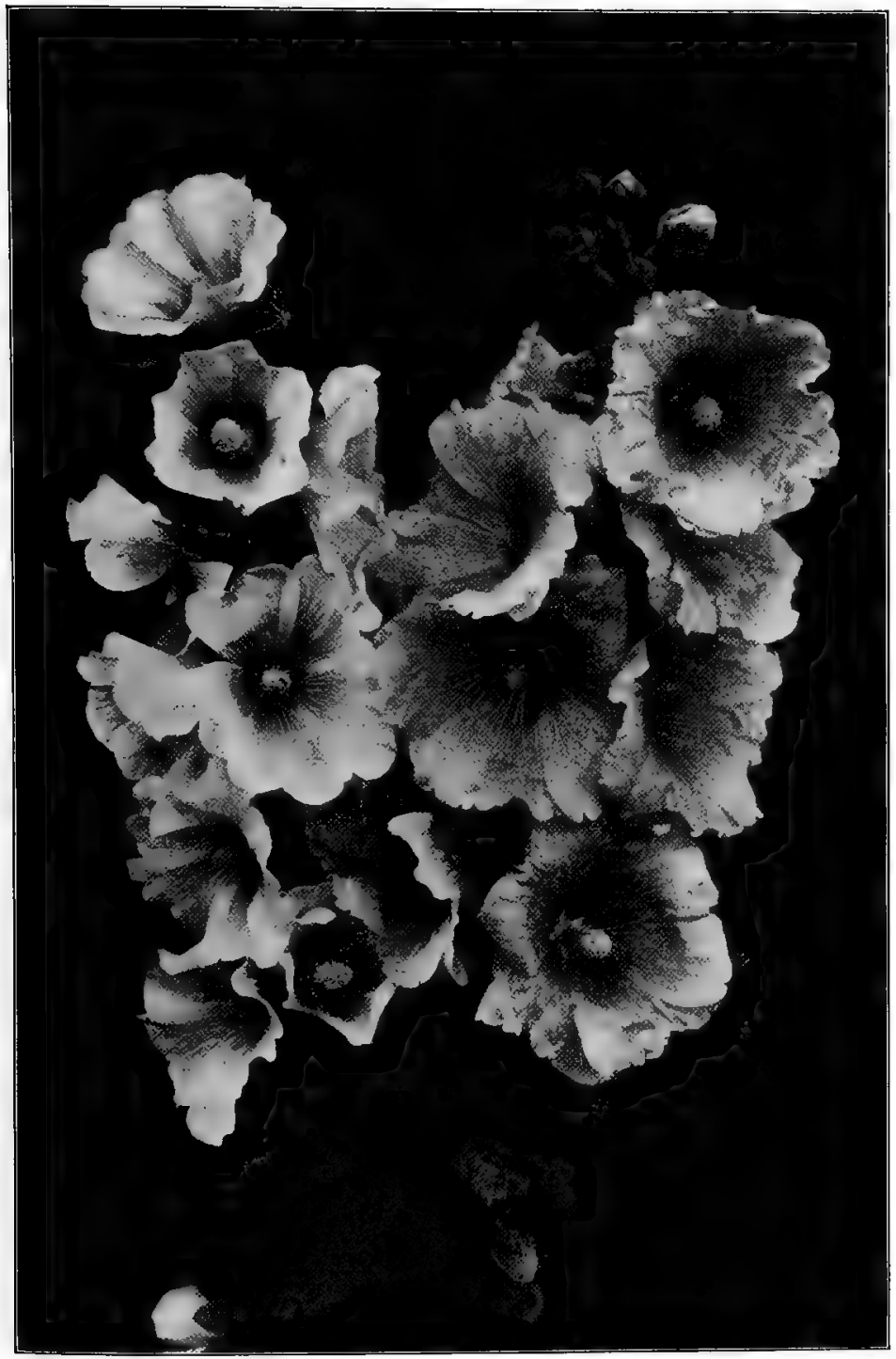

Hollyhock. Althèa ròsea 
colors range through a wide series of reds and yellows melting into white. The double forms are popular, but the singles hold their own because of their individuality and real beauty. A group of well-grown Hollyhocks in bloom is worth going far to see and the time has been when they were easy of cultivation, but of late years the plants have fallen victims to a parasitical fungus, Piccinia malvacearum, which has discouraged and disheártened growers.

\section{MARSH MALLOW}

Althèa officinàlis.

An erect perennial, naturalized from Europe in the salt marshes of the Atlantic coast from Massachusetts to New Jersey. August, September.

Stem.-Two to four feet high, branching.

Leaves.-Velvety-downy, alternate, ovate, toothed, sometimes threelobed.

Flowers.-Mallow-like pale crimson-pink and veined.

Calyx.-Surrounded by an involucre of six to nine bracts.

The name Marsh Mallow, frequently applied to the Swamp Rose Mallow, properly belongs to this species. Naturalized from Europe, it has found a home on our Eastern sea-coast and in midsummer beautifies the marshes from Cape Cod to Cape May. Its hollyhock flowers are a pale crimson-pink borne in small terminal clusters or at the leaf axils. The thick, mucilaginous root is used in the making of confectionery.

\section{SWAMP ROSE MALLOW. HIBISCUS}

Hibíscus moschèutos. Hibiscus paluistris.

Hibiscus is an anciènt name of obscure origin.

A tall perennial sending up strong, leafy canes each year which bear at their summit large hollyhock-like flowers. Found in marshes along the coast from Massachusetts to Florida and in interior marshes west to Michigan. 


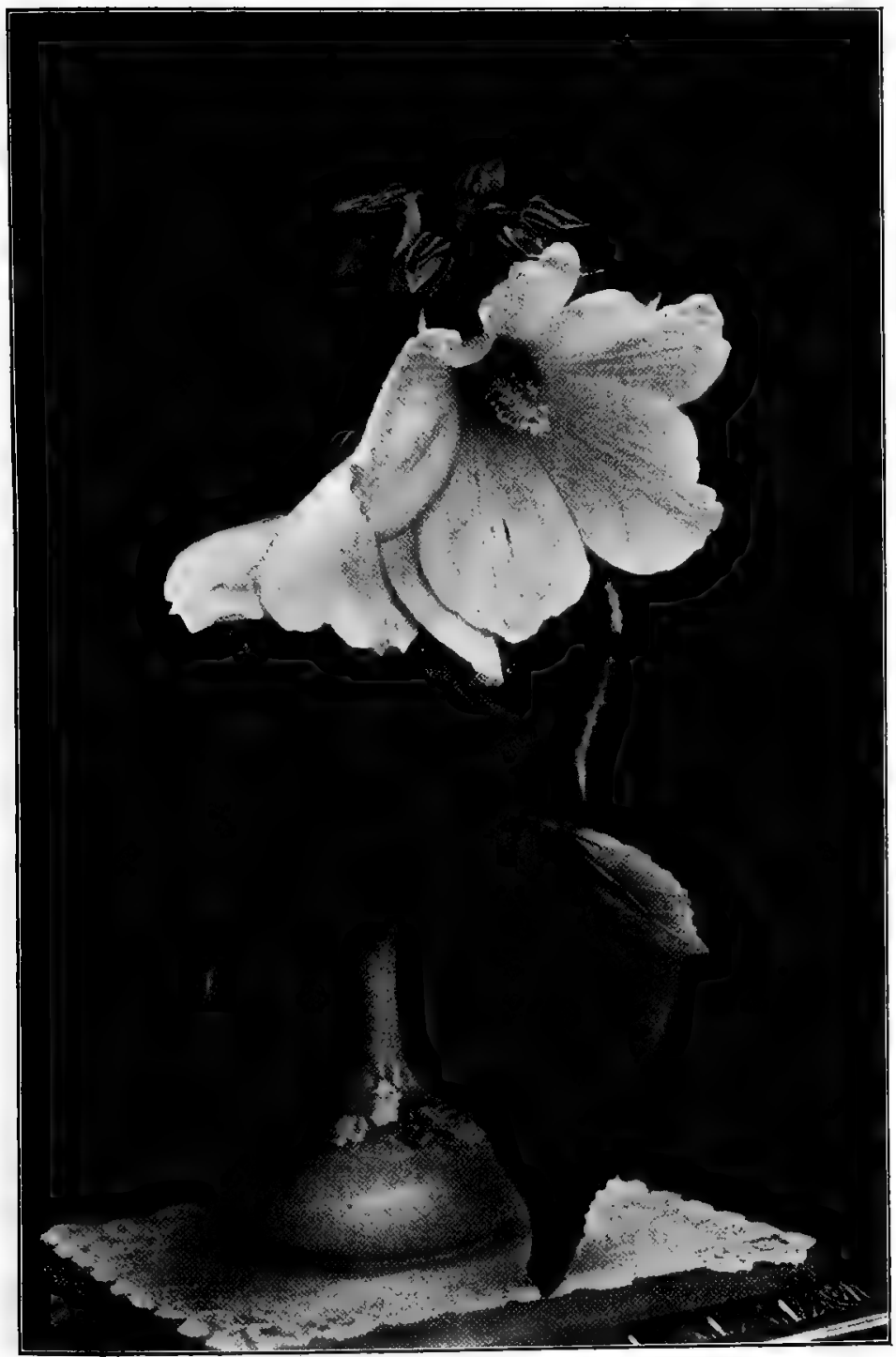

Crimson Eye. Hibiscus moscheittos 
Stem. - Three to five feet high, leafy, hairy.

Leaves.-Alternate, large, ovate, sometimes slightly three-lobed, crenate-toothed, with soft hairs beneath, petioled.

Flowiers.-Mallow type and showy on one-flowered peduncles, four. to six inches across, rose or white, with or without a crimson eye.

Calyx.-Five-cleft with an involucre of ten linear bractlets; not inflated in fruit.

Corolla.-Five obovate petals, ranging in color through rose to white.

Stamens.-United in a long column, bearing anthers for much of its length.

Styles.-United, bearing in full view above the stamen column five capitate stigmas.

Capsule.-Smooth, five-celled, sub-globose.

Seeds.-Several or many in each cell.

The flower of Hibiscus moscheutos greatly resembles a hollyhock; it is, in fact, quite as showy, but there are not so many individuals on the stem and the scale of color is not so varied. The blossom may always be known as Hibiscus in distinction from hollyhock by the five thread-like styles which protrude from the column of stamens, each bearing at the end a little stigmatic ball. This is characteristic of the genus.

At home these magnificent flowers appear among sedges and cat-tails, but, like so many others, the plant when transferred to the garden finds a congenial home.

A variety called Crimson Eye, a clear white with crimson centre, was found in a swamp in New Jersey and introduced to the trade in 1894 .

\section{TRAILING HOLLYHOCK. FLOWER-OF-AN-HOUR}

\section{Hibiscus triònum.}

A low annual appearing in gardens, but rarely cultivated, blooming only in sunshine. Native to southern Europe and northern Africa. Midsummer.

Stem.-Erect or decumbent, leafy, hairy, one to two feet high.

Leaves.-Alternate, lobed or three-parted, downy.

Flowers,-Mallow-shaped, solitary, in axils of the leaves, pale-yellow with a dark-reddish centre, open only in direct sunshine. 
Calyx.-Bell-shaped, nerved, winged, five-cleft, surrounded by an involucre of several linear, hairy bractlets; in fruit the calyx becomes inflated and bladdery.

Corolla.-Five petals connected at the base, pale-yellow with a maroon eye.

Stamens.- United into a reddish tube, with anthers along its length; anthers kidney-shaped, yellow; styles united in a tube; stigmas, five, red, protruding beyond the tube of stamens.

Pod.-Five-celled, enclosed in a bladdery husk.

Flower-of-an-Hour seems to belong to no man's land; perhaps one might say that it appears sooner or later in every garden, but is rarely welcomed and in fact usually uprooted. Native to the lands bordering the desert, the blossoms seem to translate into form the burning heat of the noonday sun, and

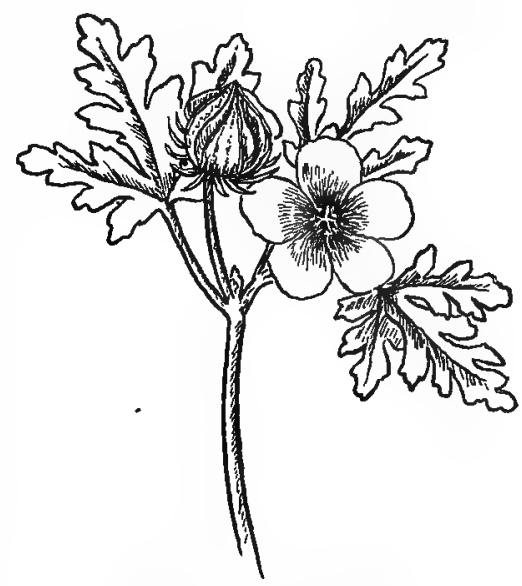

Flower-of-an-Hour. Hibśscus triònum when the sun's direct rays are withdrawn, even temporarily, the corolla closes. Consequently the flower is either a hope or a disappointment, according as one looks at it in the morning or in the afternoon, for once closed it never opens again.

Gumbo, Hibiscus esculentus, is a mallow of the vegetable garden. The mucilaginous properties of the family, in this species, are especially stored in the pod, which is three to four inches long and, when green, is commonly used to thicken soups. The leaves are five-lobed, rounded, and cordate; the flowers mallows of greenish-yellow with a dark eye. 


\section{MUSK MALLOW}

Málva moschàta.

Latin alteration of a Greek word meaning soft or emollient.

One of the prettiest of our garden escapes; sometimes cultivated but oftener found by the roadside where it seems at home. Perennial. Summer.

Stem.-One to two feet high, hairy.

Leaves.-Alternate, three to five parted, divisions once or twice cut into slender linear lobes, faintly scented with musk.

Flowers.- Of mallow type, pale-rose or white, flat, about two inches

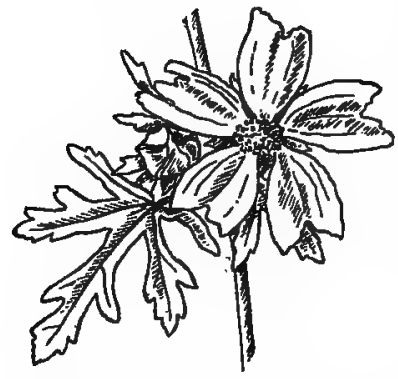

Musk Mallow. Málva moschäta across, in terminal and axillary clusters. Sepals. - Five, involucre of three bracts.

Petals.-Five, obcordate, united at the base.

Stamens.-United in a long column, bearing anthers.

Carpels.-United in a single whorl; styles many.

Long ago the Musk Mallow, with its pretty flowers and delicate odor of musk, scaled the garden wall, made itself at home upon the roadside and in waste places, and in consequence lost caste. Therefore, it is now rarely seen in garden enclosures, except in the wild border.

\section{COMMON MALLOW. CHEESES}

Málva rolundifolia.

An exceedingly common weed in cultivated grounds. The stems, procumbent and trailing, rise from a strong deep root, and bear very ornamental round leaves with five shallow lobes irregularly toothed. The flowers are the mallow shape, small, palelavender with darker veins, each petal notched. The popular 
name, Cheeses, refers to the disk-like form of the seed receptacle which, while green, is eaten by children.

Tree Mallow, Malva sylvestris, is a common biennial with an erect branching stem and bushy habit; naturalized from Europe. The leaves are five to seven lobed and the flowers pale crimsonpink, each petal with about four veins of deeper color. The flowers are borne in small clusters at the leaf angles. Once cultivated, it is now found chiefly on roadsides and in waste places.

\section{COTTON}

\section{Gossỹpium herbàceum.}

It may be a matter of interest to note the botanical affiliations of this most valuable economic plant. Cotton is an annual mallow, bearing a blossom pale-yellow with a dark eye. Its fruit is a capsule containing seeds with a spongy testa covered with woolly hairs called cotton.

The Cotton plant of cultivation is of doubtful origin, but the ancient species of Asiatic plantations and the one now cultivated in Europe and the United States is referred to Gossypium herbaceum, which is only a way of saying that it is an herbaceous cotton. The genus is not well understood and authors differ as to the number of wild Cottons in existence, but there are certainly several.

Gossypium arboreum is a Tree Cotton believed to be native to Egypt, concerning which Pliny makes the following interesting statement:

"The upper part of Egypt toward Arabia produces a shrub which some call gossipion and others xylon, whence the name xylina given to the threads obtained from it. It is low growing and bears a fruit like the bearded nut, and from the interior of this is taken a wool for weaving. None is comparable to this in suftness and whiteness." He adds, "The cloth made from it is used by preference for the dress of the Egyptian priests."

It is to be expected, in view of the increasing scientific interest 
of the South in agriculture, that in the near future the Cotton plant will be greatly improved and better strains developed.

Other species of Malvacee in cultivation are:

Lavâtera triméstris, a recent introduction from Spain, an annual Mallow with heart-shaped leaves and large rosy flowers. If the seeds are sown in May the flowers will appear in June and continue until September. The stem is bushy and reaches the height of two feet. The plant is named in honor of the brothers Lavater, Swiss naturalists.

Málope trifida, a native of Spain and northern Africa, which grows three feet high. It bears handsome mallow flowers, redveined with purple or darker-red. There is a white variety cultivated as Malope grandifira.

Poppy Mallow, Callirrhoë involucrd̀ta, is a distinctly Western plant of trailing habit, bearing continuously, from early summer until fall, large, showy, crimson, purple, or cherry-red flowers. The leaves are palmately five to seven parted. Perennial. 


\section{TERNSTRCMIÀCE/E-TEA FAMILY}

Actinidia.

Aktin, ray; referring to the radiate styles.

Stem.-Climbing, woody.

Leaves.-Deciduous, alternate, long-petioled, serrate.

Flowers.-Solitary or in corymbs, polygamous, white, cup-shaped, half to three-fourths of an inch across.

Sepals and petals.-Both five.

Stamens.-Many; stigmas, many.

Fruit.-A many-seeded berry, edible.

The genus Actinidia, woody climbers of the Himalayas and eastern Asia, is represented in our gardens by two Japanese species. The largest and strongest is Actinidia arguita, now fairly well established, which grows with great vigor and rapidity. Its leaves are elliptical, four to five inches long; its fruit about the size of a cherry and highly esteemed in Japan.

Actinidia polýgama is a more slender plant than arguta, with elliptical, slightly serrate,

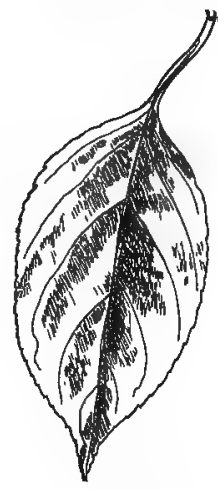

Actinidia. Actinidia polýgama long-petioled leaves three to four inches long. Professor Sargent, writing from Japan, says of it: "Its stems form great tangles, sometimes twenty feet or more across and fifteen feet high. The most remarkable thing about this plant is that in summer the leaves toward the ends of the branches become pale-yellow, either over their entire surface or only above the middle, not because they are drying up or ripening, but apparently from an insufficient supply of chlorophyll. The effect that the plants produce at this time is curious and interesting, and when seen from a distance they look like huge bushes covered with pale-yellow flowers."

The plant's attraction for cats is also very curious; beds of seedlings must be protected or cats will destroy them. 


\section{HYPERICÀCEA-ST. JOHN'S-WORT FAMILY}

\section{GOLD FLOWER}

Hypéricum moseriànum.

A hybrid sub-shrub raised by Moser, of France; valuable for its brilliant-yellow flowers. Not altogether hardy.

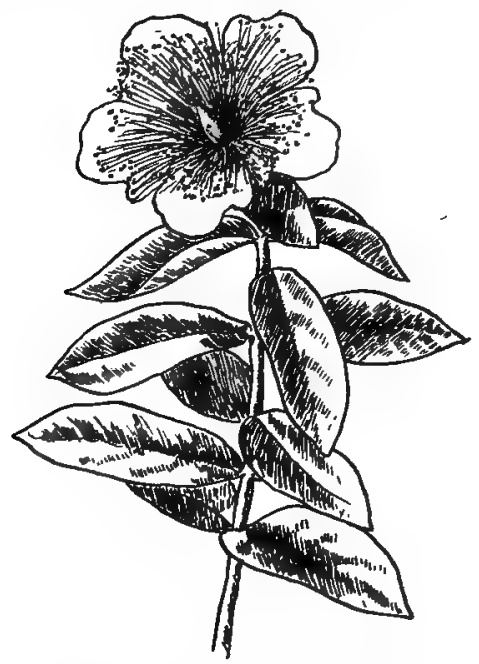

Gold Flower. Hypéricum moseriànum

Stem.-Woody, two feet high, erect, with the tips of the branches slightly pendulous.

Leaves.-Opposite, ovate-oblong, dark-green above, pale beneath.

Flowers.-Large golden-yellow cups, two inches in diameter.

Sepals.-Five, leafy, oblong.

Petals.--Five, broad, rounded, brilliant-yellow. 
Stamens.-Many, in tufted clusters, with yellow filaments and reddish anthers.

Ovary.-Five-lobed; styles and stigmas five.

Capsule.-Many-seeded.

Hypericum moserianum is the product of the union of Hypericum patulum, a tall evergreen shrub from Japan, and Hypericum calycinum, a dwarf evergreen from the western shore of the British Isles, though found elsewhere. It greatly resembles the latter, which, because of the size of its flowers, has the popular name of Terrestrial Sun. The parental name would not be inappropriate for the offspring, as its slender leafy stems are crowned with very gorgeous golden-yellow cups made still more effective by their wealth of yellow stamens and reddish anthers. This wealth of stamens is the endowment and the charm of the entire St. John'swort race.

It is believed that in the ancient Druidical worship some use was made of the golden blossom of St. John's-wort, probably to symbolize the sun; certain it is that both in England and in Germany the country people were formerly in the habit of gathering the local species on Midsummer Day and hanging it about their houses as protection against witchcraft and evil spirits. Midsummer Day is sacred to St. John the Apostle, and the plant most sought on that day became St. John's flower. 


\title{
CISTÀ'CEAE-ROCKROSE FAMILY
}

\author{
ROCKROSE
}

Helianthemum vulgàre.

Helianthemum, Greek, the flower opening in the sunshine.

Siem.-Low, procumbent, forming mats.

Leaves.-Evergreen, linear-lanceolate.

Flowers.-Mostly yellow, in terminal clusters.

Sepals.-Five; two exterior resembling bracts.

Petals.-Five, crumpled in the bud, soon falling.

Stamens.-Many; style one.

Seeds.-Many.

A very pretty, low-growing evergreen which forms broad clumps that during the flowering-season are quite hidden by the mass of bloom. Especially good for rock work. A Eurasian plant, long cultivated, running into many forms and offered by the trade under many specific names. It is the best Rockrose in cultivation.

A native species, Helianthemum canadénsis, a sturdy little plant, equal to living under hard conditions, is sometimes found in northern rock gardens, bearing the two names of Frostweed and of Sun Rose. It, too, forms a mat of spreading stems, and bears two kinds of flowers, both yellow: some with showy corolla and many stamens, others small and clustered along the stem, with inconspictuous corolla and few stamens.

It is rather interesting that the same plant should have the name of Sun Rose and Frostweed. But the blossoms open best under the direct rays of the sun, and the cracked bark of the spreading stems holds the moisture which freezes into ice crystals at the root. The two characteristics have suggested names that seemingly oppose each other. 


\section{VIOLÄCEÆ-VIOLET FAMILY}

Herbs with an irregular, one-spurred or gibbous corolla of five petals, five stamens whose anthers grow together over the pistil, and a one-celled, three-valved pod. Sepals five, persistent. Petals imbricated in the bud. Stamens with their filaments continued beyond the anther cells. Style usually club-shaped with the simple stigma turned to one side.

\section{PANSY}

Vìla trícolor var. hýbrida.

Viola is the ancient Latin name. Pansy, from French pensée, meaning thought.

The garden representative of Viola tricolor, developed to enormous size and to a marvellous variety of color and markings. Flowering through spring and summer.

Leaves.-Roundish, often oval, the lowest heart-shaped; stipules lyrate, pinnatifid, leaf-like.

Sepals. - Five, persistent, eared at base.

Petals.-Five, unequal; the lower one with a spur at base.

Stamens.-Five, short; the broad, flat filaments cohering around the pistil.

Ovary.-One-celled; style club-shaped; stigma one-sided.

Capsule.-One-celled; three-valved; many-seeded.

The Pansy has long been known in gardens, and, although its origin is more or less in doubt, the probability is that it has descended from Viola tricolor, native to the cooler parts of Europe. This violet in nearly normal form is still grown in gardens. Its flowers are small but interesting because of their variability in 
color. They usually have three colors, mostly blue and purple, white or yellow, but in different varieties one of the colors strongly predominates.

Gerard, writing in 1587 , pictures the Heart's-ease or Viola tricolor with small, violet-like flowers, the petals standing apart from each other. Of the Upright Heart's-ease he says: "The stalks are weake and tender, whereupon grow flowers in form and figure like the violet and for the most part of the same bignesse, of three sundry colors, whereof it tooke the syrname Tricolor, that is to say, purple, yellow and white or blew; by reason of the beauty and braverie of which colours they are very pleasing to the eye, for smel they have little or none at all. The seed is contained in small knaps of the bignesse of a Tare, which come forth after the floures be fallen, and do open of themselves when the seeds be ripe. The root is nothing else but, as it were, a bundle of threddy things."

Shakespeare has immortalized the Pansy in the speech of Ophelia:

There's rosemary, that's for remembrance; pray you, love, remember: and there is pansies, that's for thoughts. - "Hamlet," Act IV, Sc. 2.

And again, in "Midsummer Night's Dream," Oberon sends Puck to gather the flower:

Yet marked I where the bolt of Cupid fell:

It fell upon a little western flower,

Before milk-white, now purple with love's wound,

And maidens call it love-in-idleness. -Act II, Sc. 1.

That this flower early won the hearts of the English people is evidenced by the many caressing names it possesses:-Heart'sease, Love-in-Idleness, Pansy, Violet, Cuddle-Me-to-You, ThreeFaces-Under-a-Hood, Herb-Trinity, Johnny-Jump-Up.

The first improved Pansies appeared in England, whose cool, moist climate is well adapted to their growth, and for many years the English types were the best in the world. In the middle seventies three French specialists, Bugnot, Cassier, and Trimardeau, devoted themselves to the development of the Pansy and the results were a revelation to horticulturists. They produced the race 
that is sold in our markets to-day. Such sizes, such combinations of colors, such weirdness of expression in quaint faces painted upon the petals were never known before. The colors now run a marvellous range: pure-white, pure-yellow deepening to orange and darkening to brown, as well as a bewildering variety of blues and purples and violets. The lowest note is a rich and velvety shade that we speak of as black, but there is no black in flowers.

Our garden treatment of the Pansy leaves much to be desired. We set out beds of blooming plants in April and for a short time they are dreams of beauty; the plants are then either taken up or allowed to deteriorate and slowly to perish. The theory seems to be that as our summers are hot and may be dry, no Pansy bed can survive, so the little

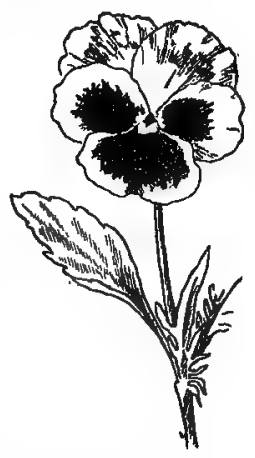

Garden Pansy beauties are permitted to die or are killed outright. But with proper selection of location a Pansy bed will be a pleasure all summer long. The place must be shaded, given the morning sun, but sheltered from that of noonday and afternoon; the lea of a tree or a building is good, and frequent sprinklings are needed to keep the foliage moist. A clay well enriched will grow the largest flowers, but any good garden soil will do. These should be continually picked otherwise the bed deteriorates.

The Pansy is the flower for all. It is cheap, it is hardy, it is beautiful; and its beauty is of an unusual and personal kind. The bright, cheerful, wistful, or roguish faces look up at you with so much apparent intelligence that it is hard to believe it is all a pathetic fallacy and there is nothing there. 


\section{SWEET VIOLET. ENGLISH VIOLET}

Vìola odoràta.

The parent of the florist's violets; widely distributed over Europe, Africa, and Asia.

Rootstock:-Short, producing stolons.

Stems.-Tufted, somewhat pubescent.

Leaves.-Radical, cordate-ovate to reniform, obtusely serrate; stipules glandular.

Flowers.-Blue running into white and reddish-purple, fragrant.

Sepals.-Five, eared.

Petals.-Five, unequal; spur nearly straight and obtuse.

Stamens.-Five.

Violets dim,

But sweeter than the lids of Juno's eyes

Or Cytherea's breath.

—"Winter's Tale," Act IV, Sc. 3, SHakespeare.

The primitive of the Sweet Violet of commerce is a variable species indigenous to three continents, Europe, Asia, and Africa.

The delicious fragrance of the flower has caused the plant to be cultivated and developed until many sorts bearing both single and double flowers have been derived. But English poets speaking of the Violet mean the simple, single, blue, wild form.

\section{HORNED VIOLET. BEDDING VIOLET.}

Viola cornùta var. hýbrida.

A tufted perennial plant, with diffuse stems whose hybrid forms are the Bedding Violet of the florists. Pyrenees. Entire summer.

Stems.-Tufted, diffuse, ascending.

Leaves.-Cordate-ovate, acuminate, obtusely serrate.

Stipules.-Large and deeply cut.

Flowers.-In type, lilac-blue; hybrids pansy-colored.

Spur.-Half the length of petals, pointed.

Sepals.-Awl-shaped.

Petals.-Five, unequal.

Stamens.-Five. 
The hybrid Bedding Violets look like small pansies and blossom profusely the entire summer, if in a reasonably shaded location.

They are believed to be the product of crossing Viola cornuta a mountain violet of the Pyrenees, with a variety of Viola tricolor, the common wild violet of Europe. Though long valued in England, they have but recently become favorites here.

\section{COMMON BLUE VIOLET}

Vìola cucullàta.

The commonest of our native violets; familiar on roadsides and in fields. In addition to the usual blossoms it also produces cleistogamous flowers.

Rootslocks.-Fleshy and thickened; stemless.

Leaves-_Radical, long-petioled, heart-shaped with a broad sinus, the sides rolled inward when young, obtusely serrate.

Flowers.-Irregular, deep or pale violet, blue, rarely white, solitary on scapes.

Sepals. - Five, exterided into ears at the base.

Petals.-Five, unequal, the lower spurred at the base.

Stamens.-Five, closely surrounding the ovary, slightly cohering, the two lower bearing spurs which project into the spur of the corolla.

Ovary.-One-celled.

Capsule.--One-celled, three-valved, many-seeded.

The violet blooms with every spring,

With every spring the breezes blow,

And once again the robins sing

A song more sweet than June can know.

So with the violet comes desire

For something else than common gain

The glow of more than earthly fire,

The sting of more than actual pain.

A blossom of returning light

An April flower of sun and dew;

The earth and sky, the day and night

Are melted in her depth of blue.

-Dora Read Goodale. 
There are many Violets in our woods and fields-all beautiful-but the one best known and best loved is the Common Blue, which sometimes covers hollows and hillocks in such purple crowds that

\section{One might guess}

A storm of blossoms had fallen there

And covered the ground with a sweet excess.

One broad distinction between species of Violets lies in the fact that some are stemless, that is, both the leaves and the flowers apparently spring directly from the ground, while others have stems upon which the leaves and flowers are borne. Blue Violet is one of the stemless species.

Possibly more than one observer has noted that no matter how abundant may be the blue blossoms-they may fairly carpet the earth-there is no corresponding production of seed. When one comes to think of it, there are never very many seeds on the Blue Violets; and thereon hangs a curious botanical tale. For it appears that this profusion of blue blossoms is largely for show and not for use, and that when the plant really wants to mature some seeds, it puts forth under the leaves and next to the ground some floviers which never open nor develop petals but are fertilized in the bud and are exceedingly fruitful. These are produced throughout the entire summer and are known as cleistogamous flowers-that is, fertilized in the bud.

The Violet is mentioned both by Homer and by Virgil. It was dear to the Athenians who deemed themselves most complimented when called violet-crowned. Ion was its Greek name, and Shakespeare, referring to Ophelia, alludes to the old tradition which said that this flower was raised from the body of Io by the agency of Diana.

Lay her i' the earth, And from her fair and unpolluted flesh

May violets spring!

"Hamlet," Act V, Sc. ..

Every garden is the better for a bank of Blue Violets, and they can be had simply by going to the fields for them. 


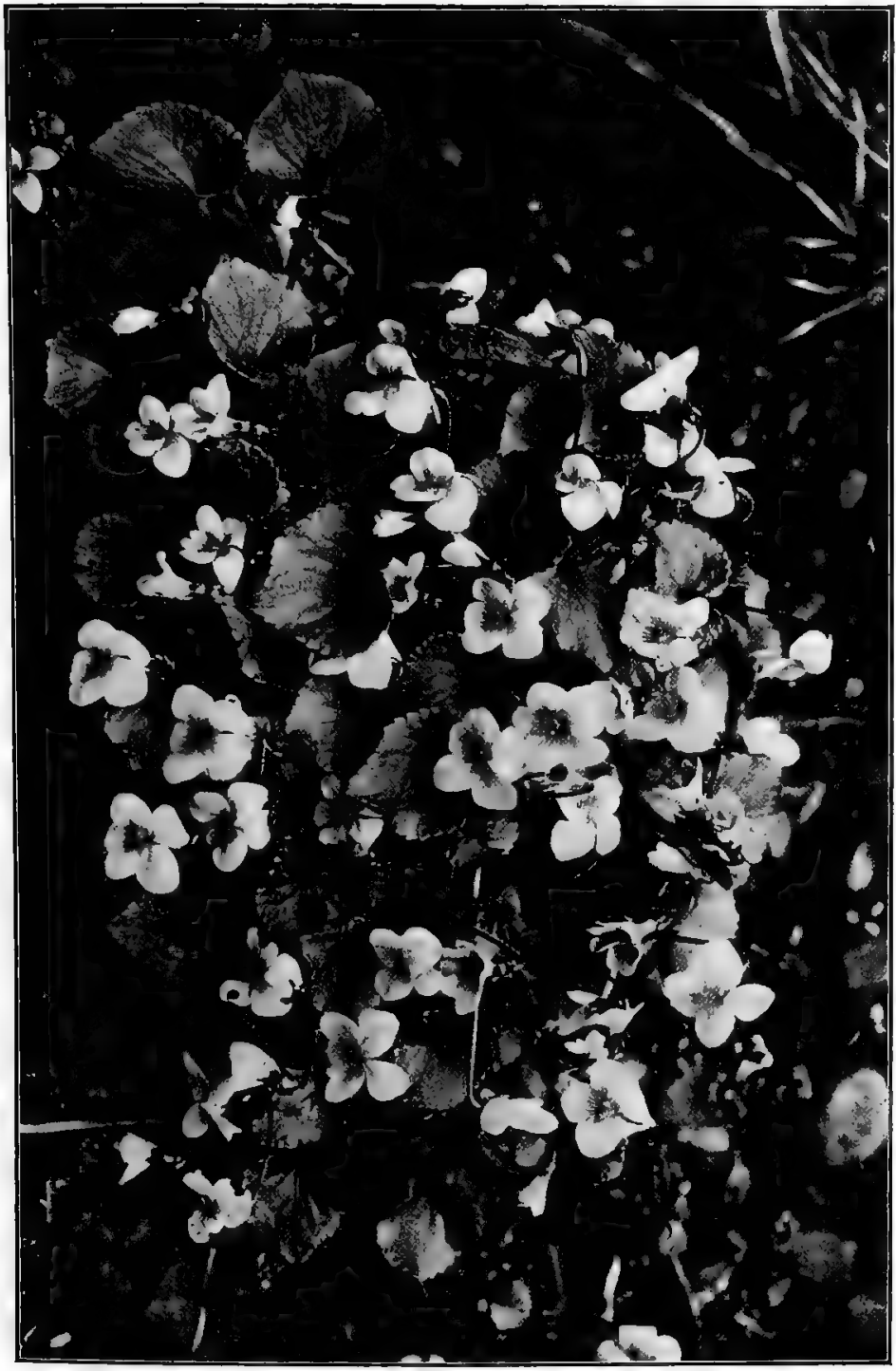

Common Blue Violet. Vìla cucullàta 


\section{PASSIFLORÀCEA-PASSION FLOWER FAMILY}

\section{PASSION FLOWER. MAY POP \\ Passifldra incarnàta.}

A strong vine which is a troublesome weed in the cotton fields of the South; but at the North makes a fine cover for arbors and verandas. Roots will survive the winter as far North as Baltimore, and even farther. From Virginia, south and west.

Stem.-Trailing or climbing by axillary tendrils.

Leaves.-Alternate, three-lobed, cordate-ovate in outline, serrate; petioles bearing two glands near the top.

Flowers:-Axillary and solitary, about two inches across, white with a light purple corona banded at its centre. Usually three bracts beneath the flower.

Calyx.-With short tube and five divisions, which are colored inside like the petals.

Petals.-Five, borne on the throat of the calyx; within them a con spicuous crown of numerous rays, forming a fringe about as long as the petals.

Stamens.-Five; anthers versatile; filaments united in a tube, sheathing and adhering more or less to the long stalk which supports the onecelled ovary; styles three; stigmas capitate.

Fruit.-An oblong berry, about two inches long; yellow when ripe.

The name of this flower throws an interesting light upon the methods of the early Catholic missionaries in their efforts to make clear and to fix their teachings upon the minds of the simple aborigines among whom they labored.

The blossom is large and striking in appearance, it has three long styles terminating in small heads, five stamens whose anthers are attached at the middle, a very prominent corona, five sepals and five petals very much alike. In their cloistered gardens the 
PASSION FLOWER

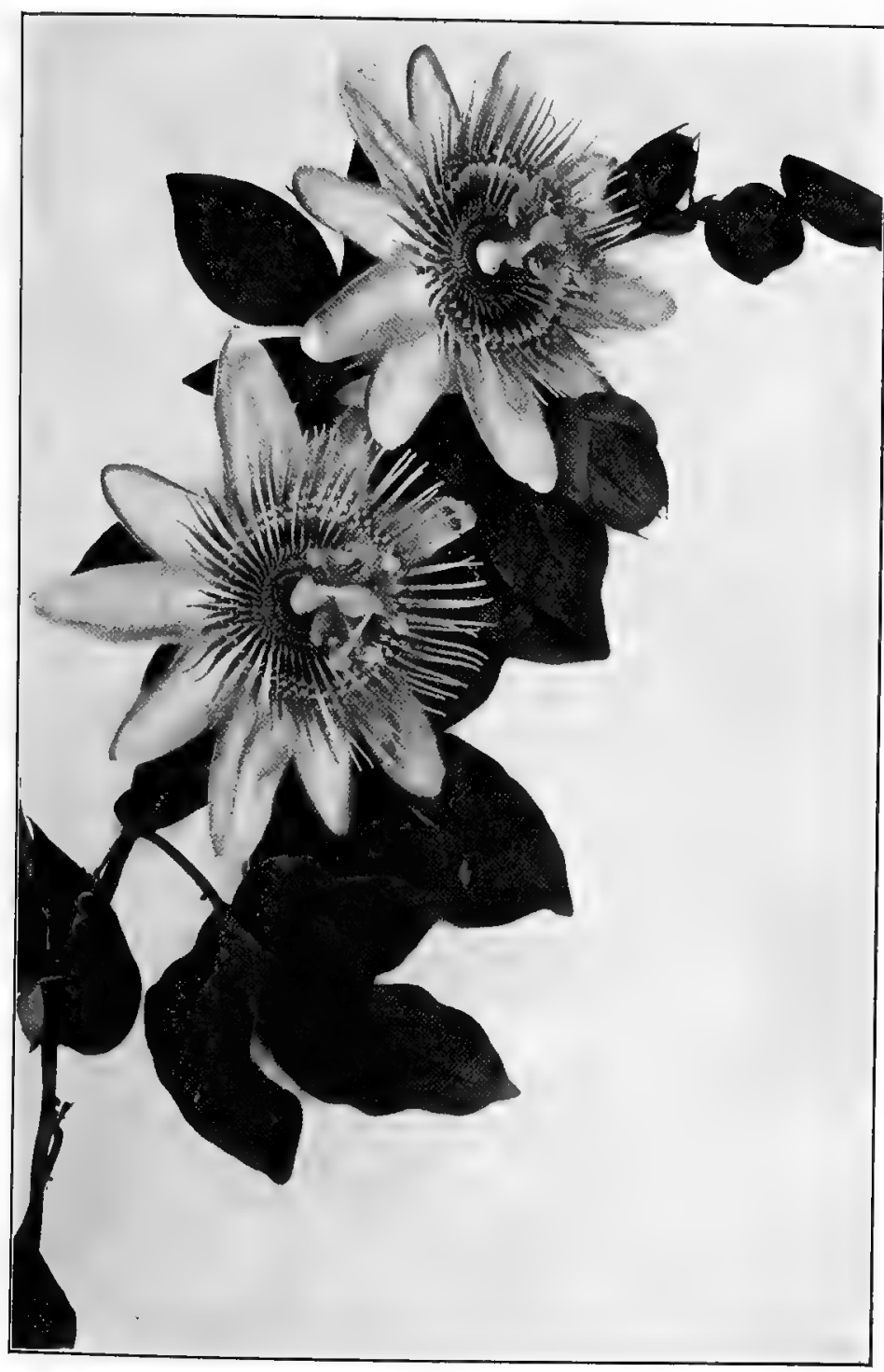

Passion Flower. Passiflora incarnàta 
monks meditated upon the wonderful plants that surrounded them and, quick to take advantage of every opportunity, they saw that these floral organs might be used as convenient symbols of the crucifixion; so they utilized the blossom in their teachings and named it the Flower of the Passion. The styles were the three nails; the stamens the hammers that drove them in, or, as others put it, the anthers are the five wounds, the corona is either the crown of thorns or the rays of glory. As the floral leaves were but ten and these were the apostles, the matter had to be explained; only ten were present, Judas and Peter were absent, the one having betrayed and the other denied his Master. The palmate leaves were the hands of the persecutors and the clinging tendrils the scourges.

The efforts of those simple earnest souls to teach their wild pupils have been commemorated for all time in the name Passion Flower. This is the only contribution of the Western world to the symbolical flowers of Christendom, and these star-like blossoms have taken a worthy place beside the mystical Roses and Trefoils of ecclesiastical decoration.

The genus Passiflora is in the main tropical American. Our weed of the cotton fields is typical of all the species; it is also the most Northern, if we except a small flowering plant of Pennsylvania.

The Passion Flower of the greenhouses is Passiflora carula with its hybrids and variants. This species is Brazilian and is reported hardy as far North as Washington; it will grow readily from seed and is a pleasant summer flower. 


\title{
LOASÀCEA-LOASA FAMILY
}

\author{
BARTONIA. BLAZING STAR \\ Bartonia aurèa. Mentzêlia Lindleyi.
}

Stem.-One to three feet high, stout, branched and straggling; gray with pubescence.

Leares.-Alternate, two to three inches long, coarsely toothed; with rough pubescence.

Flowers.- Solitary on short branches, about two and a half inches across, bright-yellow, fragrant in the evening, diurnal.

Calyx tube.-Cylindrical; five-cleft, persistent.

Petals.-Five, broadly obovate, spreading, inserted on the throat of the calyx, convolute in the bud.

Stamens.-Many, inserted with the petals on the throat of the calyx. Ovary.-One-celled; styles three, more or less united; stigmas minute.

Capsule--One-celled; opening at the summit.

Seeds.-Flat.

The Loasacee are a family of rough, thistle-like plants native to our Western plains and mountains. One species, Bartonia aurea, is found sometimes in the garden but is not very generally known.

There are, however, two night-blooming species of Mentzelia that should be in cultivation. They are wonderful plants; by day rough and thistle-like, unprepossessing and undesirable; but when the sun goes down the buds awaken, open, transform themselves into fluffy masses; the thistle sticks bloom like Aaron's rod, while a delicate fragrance fills the air. Some day these wild Mentzelias will be cultivated for evening decoration. 


\section{LYTHRÀCEA-LOOSESTRIFE FAMILY}

\section{SWAMP LOOSESTRIFE}

Lythrum salicària.

Lythrum, Greek for blood; application obscure.

A perennial species naturalized from Europe and largely used for planting about the border of ponds and in low, wet places. Variety rosèum is the garden form. Midsummer.

\section{Rootstock.-Creeping.}

Stem.-Erect, three to five feet high, crowned with spikes of many bright, crimson-pink flowers.

Leaves.-Lanceolate, heart-shaped at base, opposite or whorled in threes.

Flowers.-Crimson-pink, small, crowded in bracted half-whorls on a wand-like spike at the summit of the stem; honey-bearing.

Calyx-iube.-Ribbed, with five to six teeth and as many intermediate minute processes.

Petals.-Five to seven, oblong, slightly twisted, borne on the throat of the calyx.

Stamens.-Ten to twelve on the throat of the calyx; filaments vary ing in length, really trimorphous.

Ovary.-Two-celled; style one; stigma capitate.

Capsule.-Many-seeded.

The Purple Loosestrife came to us from Europe and has become naturalized along the Hudson River and, here and there, in New England. It loves to grow in masses on low, marshy land, and is a favorite for water-side planting.

At the summit of the wand-like stem, in the axils of leafy bracts, are groups of bright pink-purple flowers, whose narrow, slightly twisted petals give the stalks a rosy, fringed appearance. The flowers present an interesting example of trimorphous stamens 


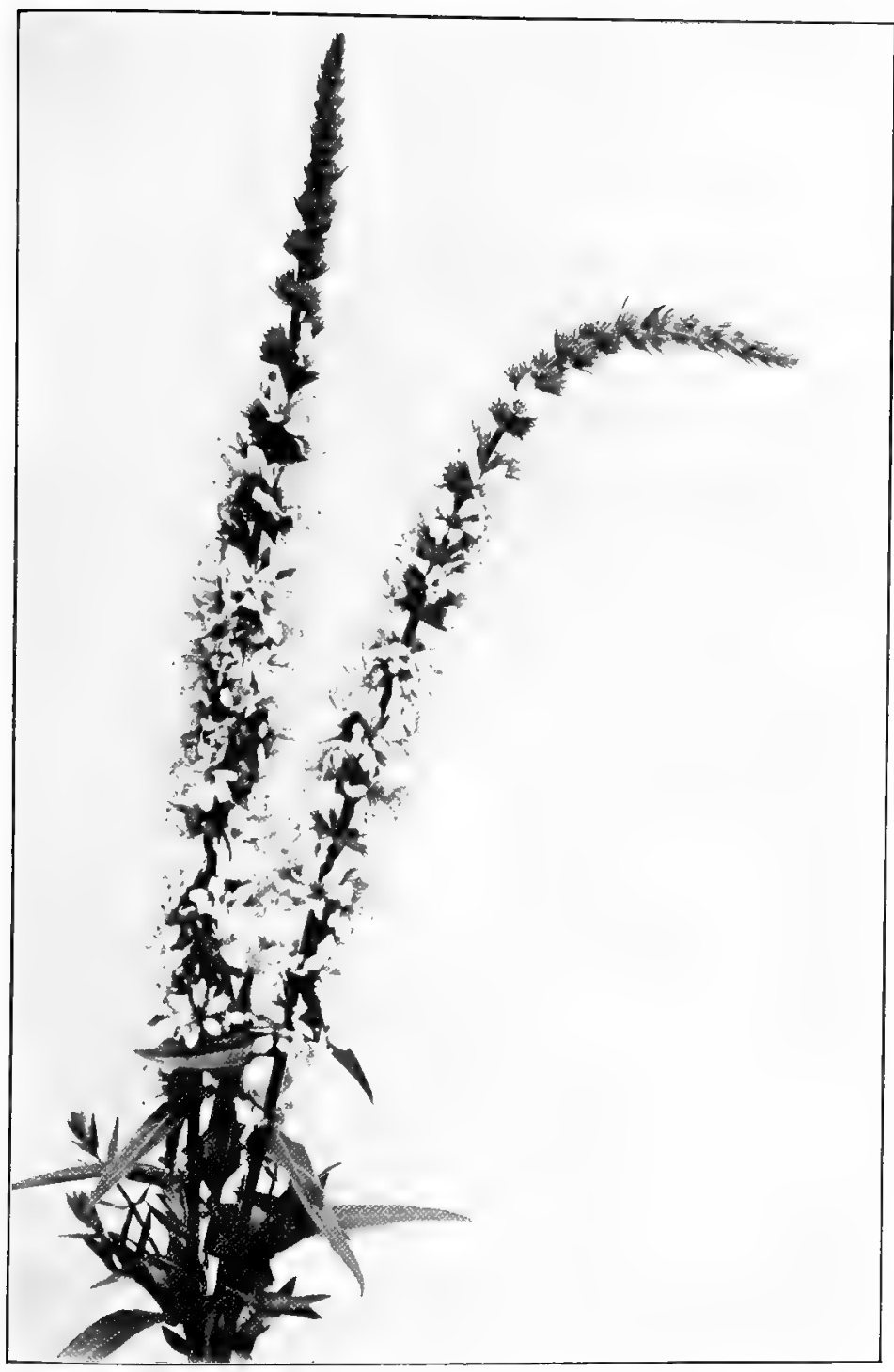

Swamp Loosestrife. Lýthrum salicària 
and style; that is, on different plants in the same group three different forms of flowers will be found, the variations being in the length of the styles and stamens, and relating, it is believed, to their cross-fertilization by insects.

\section{CUPHEA. CIGAR PLANT}

Cùphea ìnea. Cùphea platycêntra.

Cuphea, Greek for curved; from the shape of the calyx.

A delicate perennial, with glossy, dark-green leaves and small tubular flowers, cultivated in greenhouse and for borders. Mexico.

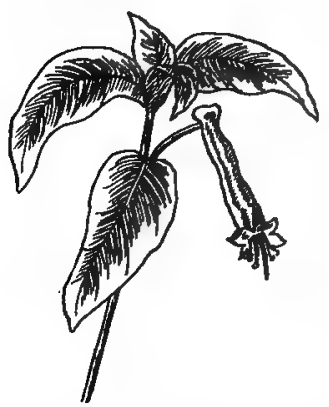

Cuphea. Cùphea ignea

Stem.-Eight to twelve inches high.

Leaves.-Opposite, glossy, ovate or lanceolate, acute.

Flowers.-Small, bright vermilion tubes about an inch long, solitary in the axils of the leaves.

Calyx.-Narrow and tubular, about an inch long, with a short, blunt spur at base; the narrow border and minute teeth dark violet, edged on the upper with white.

Corolla.--None.

Stamens.-Eleven or twelve unequal.

Ovary.-Flat, two-celled, one smaller than the other.

Pod.-Enclosed in the calyx.

The little Mexican, though tender to frost, makes an excellent border plant, as it supports a continuous bloom. The bright scarlet tubular flowers tipped with a ring of black and white have suggested the common name Cigar Plant. Other species are in cultivation, but this is the old-time favorite. 


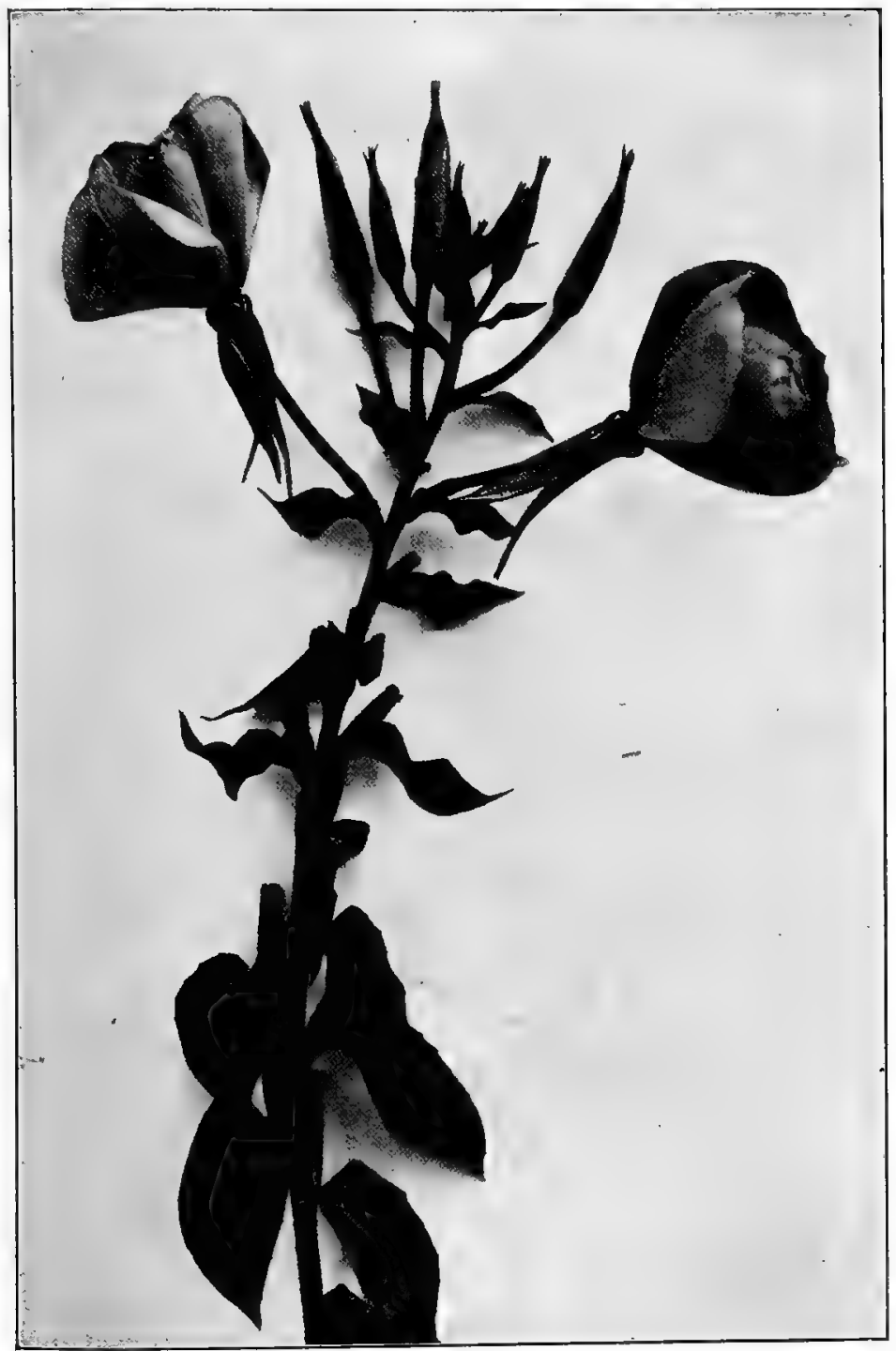

Evening Primrose. Enothèra biênnis grandiflòra 


\title{
ONAGRÀCEÆ-EVENING PRIMROSE FAMILY
}

\author{
EVENING PRIMROSE \\ Enothèra biênnis. Ónagra biénnis.
}

Enothera, a Greek name of obscure application.

Wild in open grounds, often in the Middle West taking possession of neglected tracts in the cities. The large-flowered forms are cultivated, especially the variety grandiflora. Common throughout the United States east of the Rocky Mountains. Midsummer. high.

Stem.-Erect, stout, leafy, more or less branching, two to five feet

Leaves.-Lanceolate to oblong, acute or acuminate, sessile; the lower petioled, repand-denticulate, two to six inches long.

Flowers.-Yellow, borne in a terminal, leafy, bracted spike, opening suddenly in evening twilight and fading away when bright sunshine comes.

Calyx-tube.-One to two inches long, prolonged beyond the ovary; border four-lobed; lobes valvate in bud, tips contiguous, turn back quickly as the corolla opens.

Petals.-Yellow, four, convolute in bud, unroll quickly as the sepals turn back.

Stamens.-Eight; anthers linear; pollen grains cobwebby.

Ovary.-Four-celled; style long, slender; stigma four-lobed.

Capsule.-Oblong, four-celled, many-seeded.

It is worth while to stand in the dim and dewy twilight and see the blossom of the Evening Primrose burst its bonds. All day the life within the long pointed bud has been restless, the petals have been slowly unrolling and steadily pushing against the green walls of their prison-house, and as the sun sinks they are ready to free themselves, only held in leash by the tips of the sepals, 
which cling together. Finally, the supreme moment arrives, the sepal tips are forced to give way, and the corolla, a pure clear yellow, surrounded by an atmosphere of perfume, looks out into the darkening twilight, fresh, fragrant, exquisite-to endure for a night. The pollen in cobwebby masses was freed from the anthers before the flower opened and is carried away by the honey-loving moths. As the flower opens the anthers lean away from the style, showing that self-fertilization is no part of nature's plan here.

We call the Evening Primrose a weed. It is a weed; and in late midsummer at midday, a coarse, dishevelled, unhappy-looking object; but in its youth and its strength it is not unhappy, it is splendid.

\section{SUNDROPS}

\section{Enothèra fruticòsa. Kneiffia fruticosa}

This is the common perennial Sundrop of northern fields and well worthy a place in the garden. Variety Youngii is the horticultural form.

Stem.-Erect, more or less branching, one to three feet high, leafy.

Leaves.-Reddish and hairy ovate to narrow lanceolate, usually acute, mostly sessile.

Flowers.-Brilliant yellow, two inches across, showy, borne in a lengthening cluster with linear bracts, opening in bright sunshine.

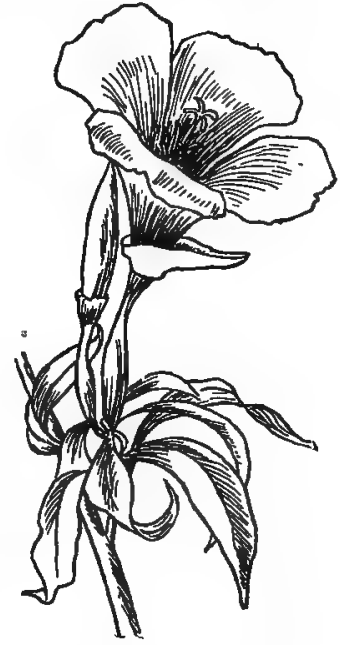

Garden Form of Enothèra

Calyx-tube.-Long and slender, enlarging at the top, four-lobed.

Petals.-Four, bright yellow, opening in direct sunshine, obcordate, convolute.

Stamens.-Eight; anthers versatile; style slender; stigma capitate. Capsules.-Oblong, four-angled; seeds many.

These yellow-flowered diurnal primroses called Sundrops appear in cultivation in many variable forms. The brilliant yellow flowers, standing erect, and open in the sunlight, are worthy of 
their common name, for in their native fields they look like flecks of sunshine.

Enothera fruticosa covers a very extensive range; is tolerant of many soils and different locations but needs sunlight. The variety Youngii, the form most commonly cultivated, is a little better than the type.

\section{GODETIA}

\section{CEnothèra amæ̀na.}

This is the common well-known Godetia much given to dwarf forms. It ranges the Pacific coast from Vancouver southward.

Stem.-Erect, slender, one to two feet high.

Leaves.-Narrow, lanceolate or oblong, nearly entire.

Flowers. - White, rose, or lilac, scattered on leafy branches; an inch and a half across, of brilliant satin lustre.

Calyx-tube.-Short, four-lobed.

Petals.-Four.

Stamens.-Eight.

Capsules.-Four-sided, not winged.

The Godetias are very showy garden annuals, native to the Pacific coast.

\section{FUCHSIA}

Fùchsia macrostémma.

Named in honor of Fuchs, an early German botanist.

This is believed to be the basic primitive of our garden race of Fuchsia hybrids.

Stem.-Erect, woody, branching.

Leaves.-Opposite, ovate, dentate, thick, shining.

Flowers.- Hanging on slender peduncles in terminal racemes and in the axils of the leaves, red, pink, purple, and white in combination.

Calyx.-Highly colored, tubular or funnel-shaped; border split into four spreading lobes.

Petals.-Four, usually of color different from that of calyx, obovate, retuse, convolute around the base of the projecting filaments and style.

Stamens.-Eight; filaments long, slender. 
FUCHSIA

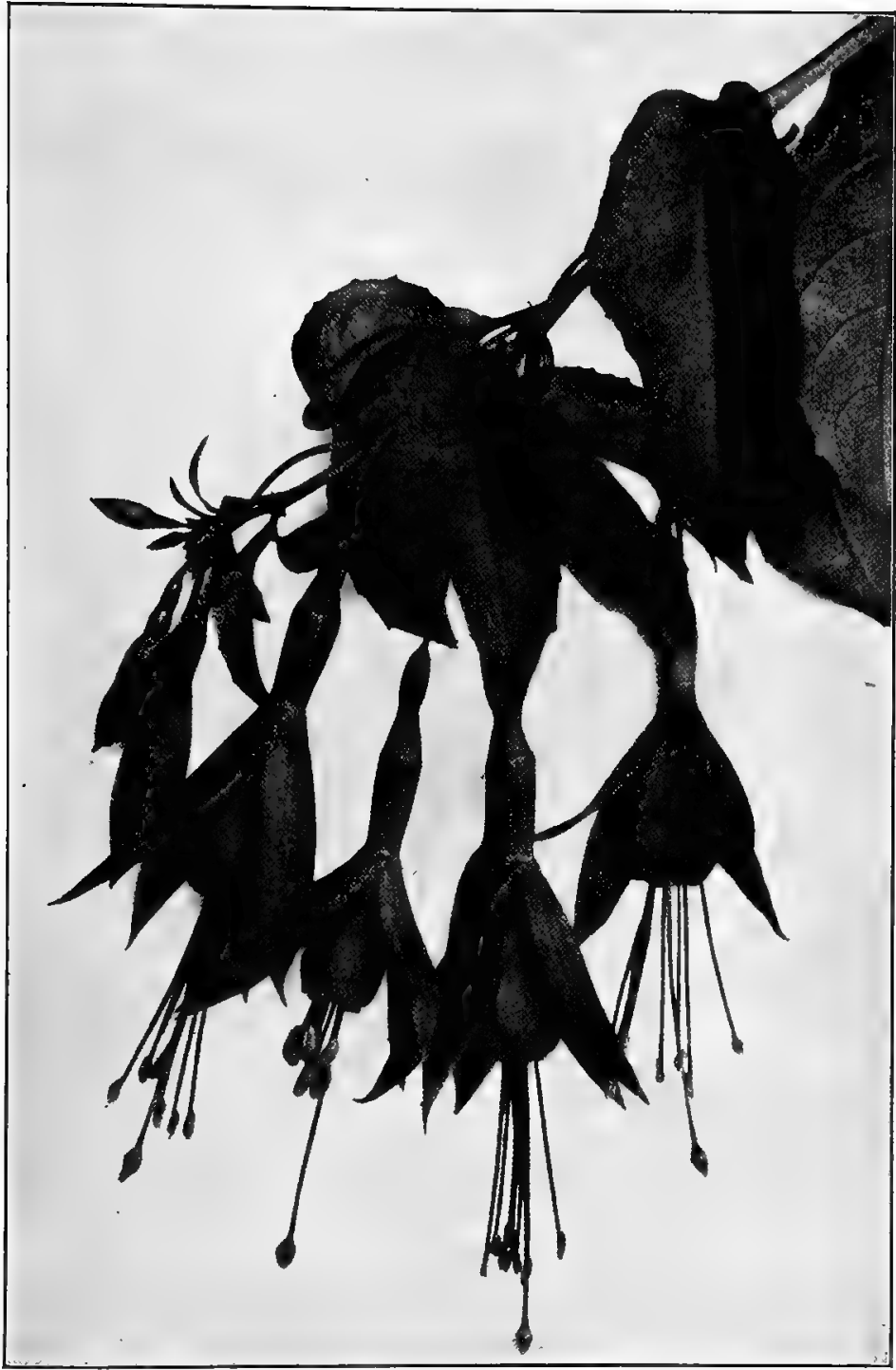

Fuchsia 
Ovary.-Oblong; style longer than stamens, slender with capitate stigma.

Fruit-A red, pulpy, four-celled berry.

The Fuchsia was first discovered by Father Plumier, a missionary in South America, who named it in honor of Fuchs, a German botanist, and published the name in 1703, calling his new flower Fuchsia triphylla.

The popular introduction of the genus came about in an entirely different way. The story goes that in the year 1788 a sailor lad who had returned from South America brought with him to London a growing plant which he gave to his mother. This was placed upon the window-sill and carefully tended. At length it flowered and attracted the attention of a nurseryman, Mr. James Lee, who chanced to pass that way. Impressed by the beauty of the flower, as well as the unusual form and habit of the plant, he succeeded in purchasing it. He struck cuttings as rapidly as possible, and as soon as his stock was sufficiently large put it upon the market, realizing, it is said, f,300 upon his investment. This plant is believed to have been Fuchsia coccinea, now regarded as a variety of Fuchsia macrostemma.

The Fuchsia does well on the Pacific coast, especially in San Francisco. There it develops into a. sturdy, compact little bush, two to five feet high, dripping blossoms at the axil of every leaf.

\section{GREAT WILLOW-HERB. FIRE-WEED}

\section{Epilobium angustifolium.}

Epilobium, Greek, upon a pod; referring to the flower placed upon a long ovary.

A tall perennial with ruddy stem and willow-like leaves. Common on newly cleared woodland, especially where the ground has been burned over. Europe, Asia, America, north and north-west.

Stem.-SIender, erect, two to four feet high.

Leaves.-Alternate, narrow, lanceolate, nearly entire.

Flowers.-Magenta-pink, rarely white, in a terminal showy spike, each blossom set upon the summit of a long slender ovary. 
Caly:-tube.-Long, slender, four-lobed.

Petals.-Four, convolute in bud.

Stamens.-Eight, deflexed.

Ovary.-Four-celled, with long, slender style and a four-lobed stigma.

Pod.-Long, slender, opening lengthwise to distribute many silky tufted seeds.

Tall and graceful and willowy, climbing the hillsides, wandering along the fences, taking possession of burnt tracts-citizen of the world-this is the Willow-weed. The Greeks called it Epilobium, sitting on the long pod; the English, Willow-herb because of its leaves, and Fire-Weed because it loves the ashes of burned tracts. On the continent of Europe it is known as Rose Bay and French Willow. Entering America by way of the Atlantic coast in colonial days, it crossed the White Horse Pass with the railroad and has recently been reported from the banks of the Yukon.

Epilobium has value among shrubbery, to brighten the midsummer green, but it is possessed of indefatigable runners, and the silky-winged seeds seek homes anywhere and everywhere. One should think twice before planting Epilobium, it is so efficient in planting itself.

\section{GAURA}

Gaìra parvifolia.

Gaura, Greck for superb; certainly here misnomer.

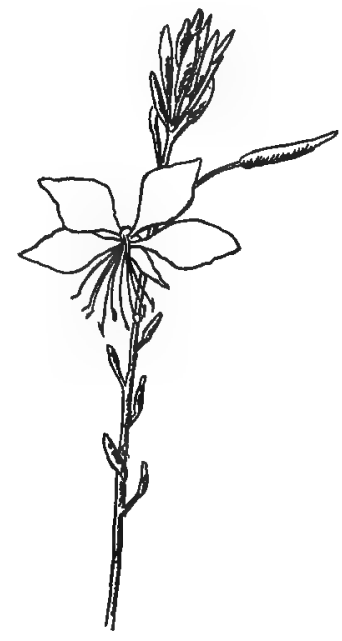

Gaura. Gaùra parvildia

Stem.-Long, slender, lengthening as the season advances.

Leaves. - Alternate, dentate or sinnate or entire.

Flowers.-White or rose, in long racemes.

Calyx.-Tubular with four reflexed lobes.

Petals.-Four, almost triangular in shape. 
Stamens.-Eight, exserted, with a small appendage at the base of each filament.

Ovary.-Four-angled; styles thread-like; stigma four-lobed.

Capsule.-One to four-seeded.

Gauras though long cultivated in England possess but little garden value, as the bloom ascends the stem too slowly to make them in any sense showy plants. What value they have is shown when planted among shrubs or in the mixed border.

\section{CLARKIA}

Clârkia élegans. Clärkia pulchêlla.

Named in honor of Captain Willian B. Clark, companion of Lewis;

the two were explorers of the Rocky Mountain region.

Clarkia elegans. Stem.- One to three feet high, reddish and glaucous, somewhat branched.

Leaves.-Alternate, broad-ovate to linear.

Flowers.-Purple or rose-color running into white; in cultivation very double.

Calyx.-Tubular.

Petals.-Four, clawed, with spreading border.

Stamens.-Eight, alternate ones shorter.

Stigmas.-Four.

Pod.-Four-celled.

Annual. Native to western North America.

Clarkia pulchella. Stem.-Tufted, branching, twelve to eighteen inches high.

Leaves.-Alternate, linear.

Flowers.-Terminal, forming a curiously lobed, four-armed cross, lilac running into white varieties.

Calyx, - Of four narrow sepals partly grown together; after the flower blooms the sepals recurve.

Pelals.-Four, clawed, border three-lobed.

Stamens.-Eight, alternate ones shorter.

Stigmas.-Four.

Pod.-Four-celled.

Annual. Native to western North America. 
Both Clarkias are common in cultivation. Clarkia elegans appears only in its double forms, which consist of loose rosettes of delicate colors, composed apparently of formless petaloids. Ob-

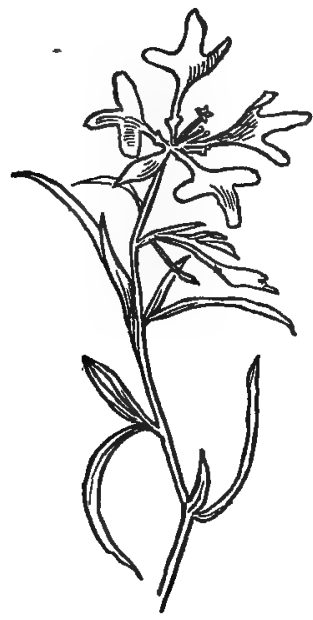

Clarkia. Cläkia pulchêlla

servation proves, however, that even in doubling there is a tendency toward the primitive type of petal.

Clarkia pulchella usually appears in its single form, which is far more beautiful than any double of it could be. Each petal is three-lobed and as there are but four and they spread at right angles to each other, the result is a curiously ornamental Greek cross which would be spoiled by any doubling.

Both Clarkias are hardy annual plants of easy cultivation. Will grow in full sun or in partial shade. 


\section{BORAGINÀCE $Æ-B O R A G E$ FAMILY}

\section{MERTEITSIA. VIRGINIAN COWSLIP. BLUEBELLS}

\section{Merténsia virginica.}

Named in honor of Franz Karl Mertens, a German botanist.

A well-known perennial herb, growing in alluvial soil from New York, west and south. Is one of the favorite, early, spring flowers of the Middle West. April, May.

Stem.-Smooth, leafy, one to two feet high.

Leaves.-Alternate, obovate, entire; the lower, large, rounded, and long-petioled; veins conspicuous.

Flowers.-Slender trumpet-shaped bells about an inch long; at first red-purple, later bright-blue, on slender pedicels in loose, raceme-like clusters.

Calyx.-Short, five-cleft.

Corolla-tube.-Cylindric; border bell-like; throat open and naked; red-purple in bud, blue when mature.

Stamens.-Five, inserted on the corolla-tube; filaments protruding.

Ovary.-Four-cleft; style arising from the centre.

Fruit.-Four rough akenes.

Mertensia virginica has three common names, Virginia Cowslip, Bluebells, Smooth Lungwort.

In a family noted for hairy stems and rough leaves Mertensia is conspicuously smooth, and its foliage tender. The blossoms in early spring are especially attractive because their color varies from red-purple to brilliant blue, and the plants naturally growing in clumps and the flowers in clusters, so that massed effects are easily obtained. 
MERTENSIA

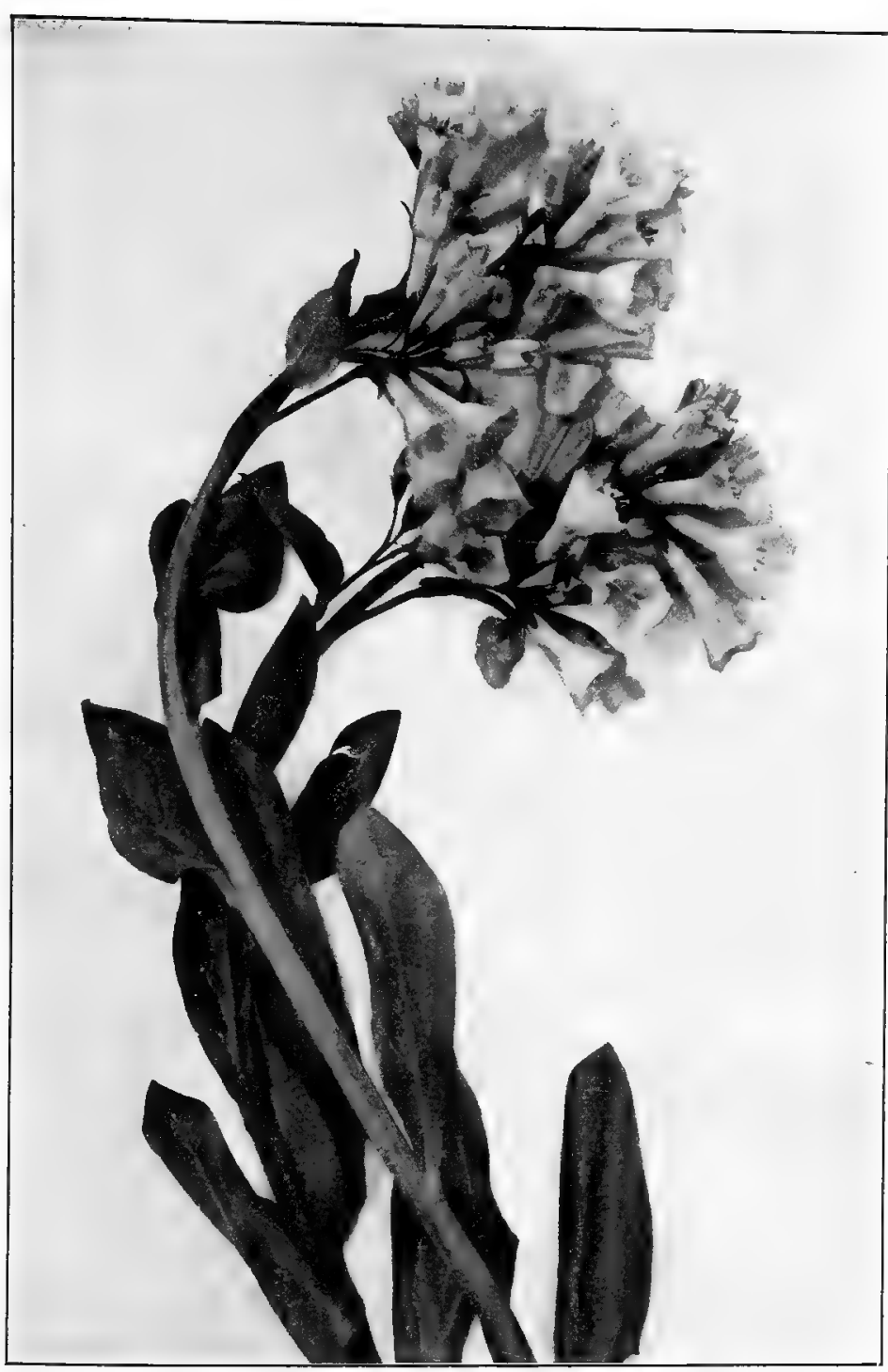

Mertensia. Mertënsia virginica 


\section{FORGET-ME-NOT}

\section{Myosdtis palustris.}

Myosotis, Greek, mouse-ear; from the short soft leaves of some species.

The primitive of many garden forms; native to both Europe and Asia. Perennial. May-July.

Stem.-Decumbent, loosely branched, growing from a creeping base. Leaves,-Alternate, lanceolate, or lance-oblong, pubescent, entire. Flowers.-Small, pale-blue with a yellow eye, borne in a loose raceme

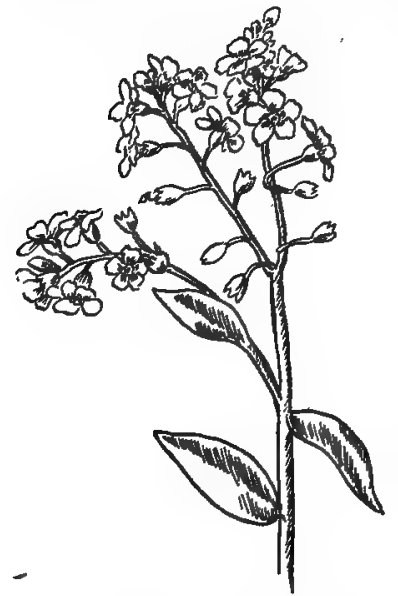

Garden Form of Forget-me-not curled at the end, and straightening as the flowers expand.

Calyx.-Five-cleft, remaining open in fruit; hairs of calyx straight.

Corolla.-Salver-shaped; lobes five, rounded, with appendages at the throat.

Stamens.-Five; ovary of five almost separate lobes, forming in fruit four nutlets; style thread-like.

It is very difficult for a man or a flower to live up to a fixed reputation, and our pretty Forget-me-not has virtually an impossible task to reach the requirements of the sentimental literature concerning it. The plant, apart from the literature, has a very real and natural charm; is pretty when banked by the side of a pond or a runlet, and gives an abundant and continuous bloom through all the summer days.

Various garden forms have been developed, some with flowers larger than the type; others with stems more erect; Myosotis arvénsis, the Field Forget-me-not, is an erect plant six to eighteen inches high, with flowers usually blue, though sometimes white. 
We have several native Forget-me-nots that may well be transferred to the garden, as they will grow on dry lands and also in the open.

Other species of Boraginace are:

The Viper's Bugloss, Echium vulgàre, which is a beautiful, bold, bad weed that no gardener should harbor, much less plant, despite the marvellous brilliancy of the broken metallic tints of blue and

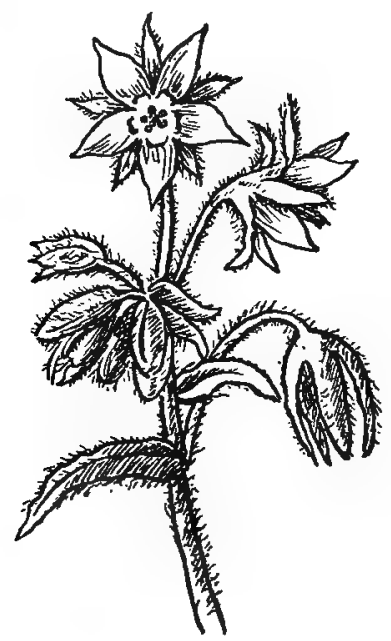

Common Borage. Borago officinalis

purple which its flowers display. It is biennial and for that reason can be easily dealt with, and kept within bounds.

Common Borage, Boràgo officinalis, is one of the plants that Pliny praised. It was supposed to exhilarate the spirits and drive away melancholy.

\section{I, Borage, \\ Give courage,}

expresses the long-lived belief, which has but recently disappeared. The plant is spreading, beset with sharp whitish bris- 
tles, and bears very handsome starry flowers, violet-blue with dark anthers.

Bethlehem Sage, Pulmondria saccharàta, is a noticeable plant because its large green leaves are curiously dotted with white spots. One can readily understand why the ancient simplers prescribed it for diseased lungs. The inflorescence is not unlike that of Mertensia and shows the same change of purple into blue.

Heliotrope, Heliotropium perivianum, is a well-known greenhouse and bedding plant. Native of Peru, it is naturally a lover of warmth and sunshine and only in such positions will do well. Its inflorescence is the best example among our familiar plants of the racemose type called by botanists scorpoid; the tip of the raceme curls itself up like the tail of a scorpion. 


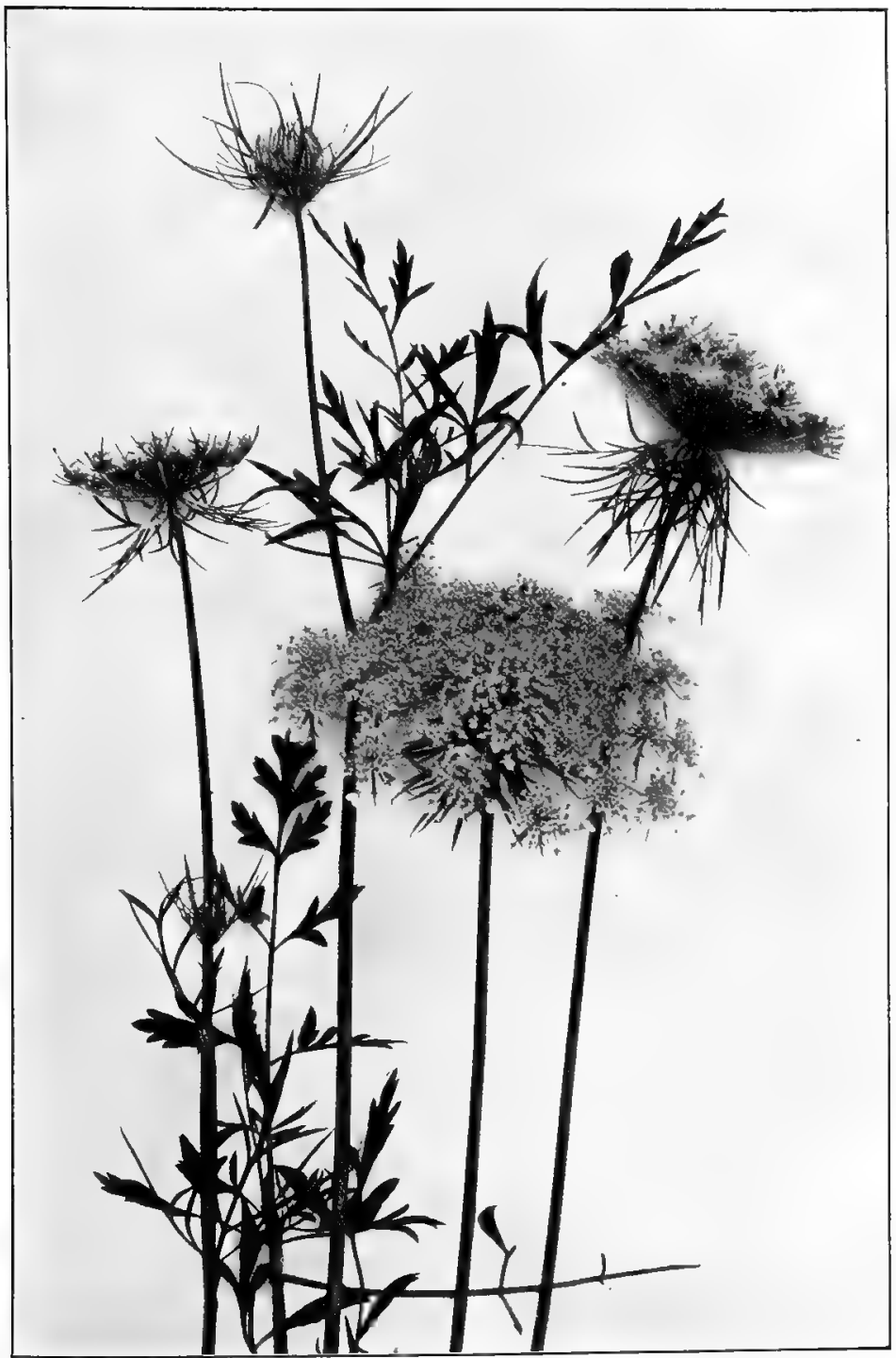

Wild Carrot. Daùcus caròta 


\section{UMBELLIFERA-PARSLEY FAMILY}

A family of herbs whose flowers have so marked a resemblance that the species are chiefly distinguished by the form of the fruit, and the oil tubes in the seeds.

The flowers are small; made on the plan of five; the calyx adherent to the ovary. There are five minute calyx teeth or none, five petals, five stamens, a two-celled ovary, and two styles. The dry fruit usually splits into two seed-like akenes. The flowers are usually borne in compound umbels; the circle of bracts often present at the base of the large umbel is the involucre. The stems are usually hollow, the leaves alternate, commonly compound or decompound. Eryngium is an exception to the type, having flowers in heads instead of umbels.

Carrot, Celery, Parsnip, and several Sweet Herbs belong to this family.

\section{WILD CARROT. QUEEN ANNE'S LACE \\ Daùcus cardta.}

Daucus, the ancient Greek name of the carrot. Meaning obscure.

The Wild Carrot, often called Queen Anne's Lace, is believed to be the reversion of the cultivated carrot to a weed. Biennial. Europe. Midsummer.

Stem.-Hollow, two to three feet high, hairy, branching. Leaves.-Tripinnate, yellowish-green; segments linear, pointed.

Flowers.-Small, white, borne in double compound umbels; outer florets the largest; in the centre of the umbel one dark maroon floret.

Fruit.-Short, splits in two when ripe; prickles in rows on the ribs.

Two herbs, weeds by every count, without one redeeming trait from the farmer's stand-point, with not one justification when 
brought into court, bear flowers of such surpassing beauty that they may easily challenge the petted darlings of our gardens and greenhouses. Flouted they live, despised they flourish, and only because they are in the wrong place do the Dandelion and the Wild Carrot fail of the appreciation that, if beauty only were to be considered, is their due.

The many tiny florets of the carrot umbel are disposed in a radiating pattern as fine as lace; in the centre of the cluster is one deep maroon floret, a single point of color surrounded by whiteness.

The umbel from its first showing of white is a full week coming to maturity; as the florets open it is concave, in its prime more or less convex; fading it becomes concave again, and finally the ripening seeds are protected by infolding arms that make, indeed, a bird's nest, which is one of the country names for the plant.

Nevertheless, this lovely creature is a weed, and will take possession of great tracts in defiance of the farmer, but, as it is a biennial, it can easily be extirpated, and its existence in cultivated land indicts the farmer.

Daucus carota var. sativa, the Garden Carrot, was certainly cultivated in Holland three hundred years ago. Whether it is simply carota improved or whether it is really another species seems difficult to determine, and the doctors disagree.

\section{PARSNIP}

\section{Pastinàca satìva.}

Pastus, food, from the use made of its roots.

The garden Parsnip, native to southern Europe, western Asia, India, and Siam. Biennial. July-September.

Root.-Biennial, fusiform, large and esculent.

Leaves.-Radical, yellowish-green, pinnately dissected; leaflets incisely dentate, the terminal one three-lobed.

Flower-stem.-Three to five feet high, rather stout, furrowed and branching. Umbels nearly level on the top. 
Petals.-Yellow, broad-lanceolate, with the apex somewhat rolled in. Fruit. Thin, or flatly compressed, with a broad margin.

In the wild state the roots of the Parsnip are aromatic, mucilaginous, sweet but slightly acrid. Cultivation has greatly modified this acridity and increased both the size and the fleshiness of the root. Growers allow their Parsnips to remain in the ground

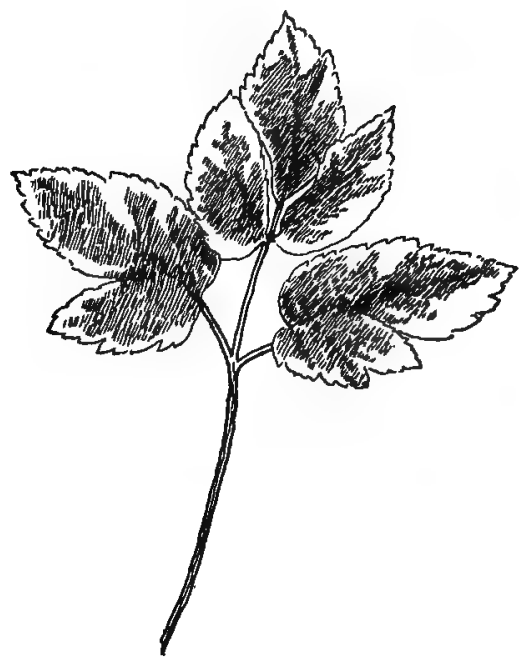

Bishop's Weed. LEgopddium podogrdria

during the winter, as frost is considered to improve their quality rather than injure it. The plant readily sows its own seeds and consequently is often found out of bounds.

\section{BISHOP'S WEED. GOUT WEED}

IFgopddium podogrària var. variegàtum.

Asopodium, cgo, goat, and podium, a little foot; without definite application to this plant.

A common foliage plant, green and white, which spreads quickly by creeping rootstocks. Europe. May-July. 
Leaves.-Radical, green with.white margin, three-foliate; leaflets ovate, serrate.

Flowers.-Cream-white, in rather large bractless umbels.

Calyx-teeth.-Obsolete.

Fruit.-Ovate, glabrous, destitute of oil cells.

This well-known foliage plant is easily established, but difficult to uproot when established. The leaves stand on rather long petioles, so that the pretty green and white border that it makes is about six inches high. Each leaflet has a green centre and a creamwhite margin and holds these colors under all vicissitudes of fortune.

The plant is so tolerant of conditions that in Europe it is considered a weed, but it has not become such in this country.

\section{SEA HOLLY. BLUE THISTLE. STAR THISTLE. ERYNGIUM Eryngium amethystium.}

An ancient name of uncertain meaning.

A plant with the aspect of a thistle, but blue in stem, leaf, and flower. Native to the southern Alps. Summer.

Stems.-Rigid, steel-blue or purplish.

Leaves.-Stiff and spiny.

Flower-heads.-Both terminal and axillary, surrounded by an involucre of long spiny bracts.

Flowers.-Blue, in heads, not umbels; a pointed bract under each flower.

Calyx.-Five awl-shaped teeth.

Petals.-Five, blue; styles two; fruit top-shaped.

The Sea Hollies, or Eryngiums are a curious and interesting group which have varied so far from their forbears that their nearest relations can scarcely claim an acquaintance. Their entire physical structure is a challenge; they out-thistle the thistles; their swords are never sheathed; they sleep on their arms. Nevertheless, they are not thistles at all, but belong to the unarmed race of Umbellifera-blood brothers to the carrot and the parsnip. 
Sea Holly is a misnomer. One species, Eryngium maritimum, growing on English beaches, attracted attention, and since its

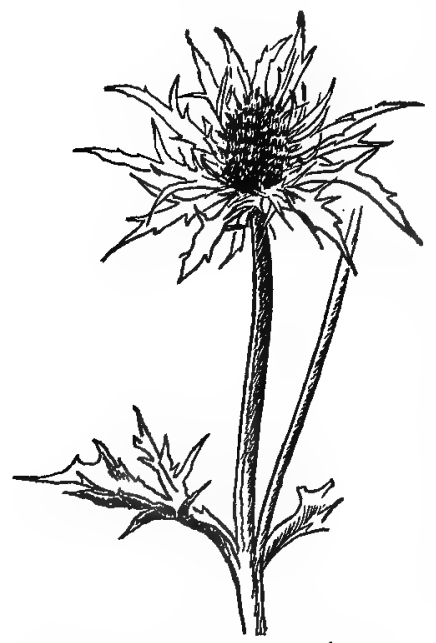

Amethystine Eryngium. Erýngium amelkýstium leaves were spiny, was named Sea Holly. This name became, in time, fixed upon the genus.

Blue Thistle is not much better, as the plant is not a thistle and but a small section of the genus is blue. Star Thistle is more appropriate, but Eryngium is best of all, for it at least does not mislead, since nobody knows what it means.

The cultivated members of the group are principally mountain species, natives of the high Alps, the Pyrenees, and the Spanish Sierras.

The determining factor which has brought them from their wild homes into the garden is the wonderful tide of blue color which surges up and through and over the plant, so that not only flower and bracts, but stems and leaves are blue.

Amethystine Eryngium, Eryngium amethystium, which was brought from the southern Alps into England fully two hundred years ago, is the species longest in cultivation. The plant has never achieved popularity because its extreme rigidity and metallic lustre produce so marked a contrast to softer types of vegetation as to be irreconcilable within the narrow limits of a garden. It must, however, have value in any large scheme of landscape coloring.

The Eryngiums are good inhabitants of poor sandy soils, for the stout roots go down straight and deep and enable their owners to withstand drought.

Of the several species in cultivation, Eryngium Bowgdi, a dwarf form, is bushy and well set up and might be valuable as a border plant. 


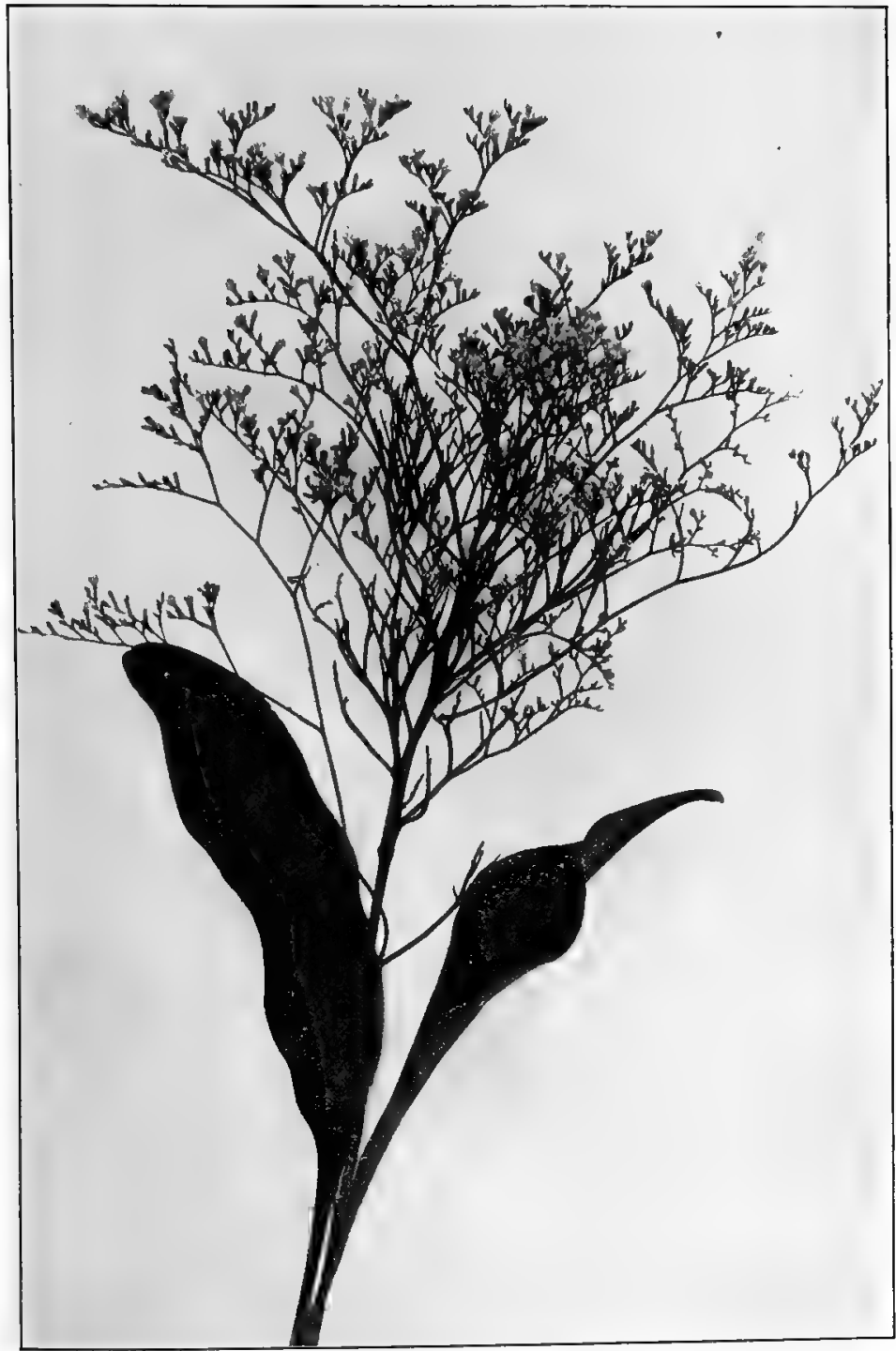

Statice. Státice latifolia 


\title{
PLUMBAGINACEA-LEADWORT FAMILY
}

\author{
STATICE. SEA LAVENDER
}

Státice latifdlia.

Statice, a Greek name without obvious meaning as applied to this plant.

A perennial herb with radical leaves and branching scapes, bearing many small flowers. Native of southern Russia. June, July.

Leaves.-Radical, seven to eight inches long; oblong-elliptic, obtuse, tapering into the leaf-stalk.

Flowers.-Small, violet, borne one-sided on the branches of corymbosepanicled, naked, flowering stems.

Calyx.-Two or three-bracted, pale, funnel-form, dry and persistent.

Corolla.-Violet, of five petals, nearly or quite distinct.

Stamens.-Five, attached to the petals.

Ovary.-Ovoid, one-celled; stigmas five.

Fruit.-A small utricle.

The garden Sea Lavenders are a group of seaside perennials which have been brought under cultivation. One of the best is Statice latifolia, a species native to southern Russia, which has long been in English gardens. The radical leaves cluster about the base of the naked flowering stem, which bears at its summit a much-branched, flat-topped panicle, and upon the upper side of each little branchlet sits a row of pale-violet flowers in a surrounding of gray-green. The color effect is produced by the number of flowers.

The garden value of the plant lies in its cut flowers, in their misty indeterminateness, which enables them to combine and harmonize other blooms, serving in this way as a sort of veil and enhancing the beauty of others without lessening their own. 
Gypsophila and Galium serve a similar purpose, perhaps more effectively because they are white. Several species of Statice are offered by the trade-all good. Statice incàna, from the swamps of southern Europe, is the species that, dried, is found among florist supplies.

We also have a charming native Statice, common everywhere along our Atlantic coast from Labrador to Florida, known as Marsh Rosemary, Statice caroliniànum. In later botanies it becomes Limònium caroliniànum. The little creature stands with its feet wet at high tide; a number of obovate leaves cluster at the base of the flowering stem, which rises twelve or eighteen inches. At the summit the stem divides and subdivides and divides again to bear a shimmer of gray-green and pale-violet so dim and misty that one can almost think it the outward expression of the spray of the salt sea.

\section{THRIFT. SEA PINK}

Armèria vulgàris.

One of a group of low, free-blooming perennials valuable as border plants. Native of sea-cliffs and mountains. Europe. Summer to early autumn.

Stems.-Tufted, six inches high.

Leaves.-Radical, thick, narrow, in dense clusters forming masses of grass-like foliage.

Flowers.-Many, borne in round heads surrounded by an involucre of bracts, on clean, long, wiry stems.

Calyx.-Funnel-shaped, dry and translucent.

Corolla.-Pink, of five petals, joined together by their bases.

Stamens.-Five, borne on the base of the petals.

Ovary.-Ovoid; stigmas, five.

Fruit.-A small utricle.

The Thrifts are sea-cliff and mountain plants, naturally choosing rocky homes, and consequently look well in the rock garden. Their low habit and tufted foliage make them good edging plants, but for some reason they are not greatly used in this country. 


\section{LEADWORT FAMILY}

The flowers are separately stalked, but clustered in dense hemispherical heads, surrounded by an involucre of bracts whose bases are continued as a translucent tube some distance down the scape.

Armeria vulgaris, the most common form in cultivation, makes broad tufts of dark-green, linear foliage and bears its purplishlilac flowers in loose heads, on stems averaging six inches high.

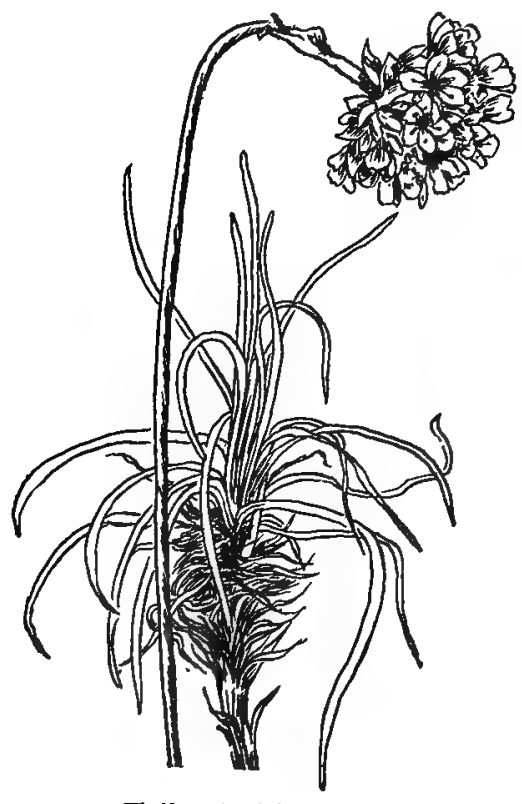

Thrift. Armeria vulgdris

The name Thrift apparently was given by some one who marked how the plant growing on the scantiest soil possessed that virtue which made good use of small things.

Shrubby Plumbago, Plumbàgo capênsis, is a tender South African climbing shrub, which is often turned out from the greenhouses in late spring to bloom in the garden until frost comes. The inflorescence in flower and cluster suggests phlox, but the color is a soft azure blue. 


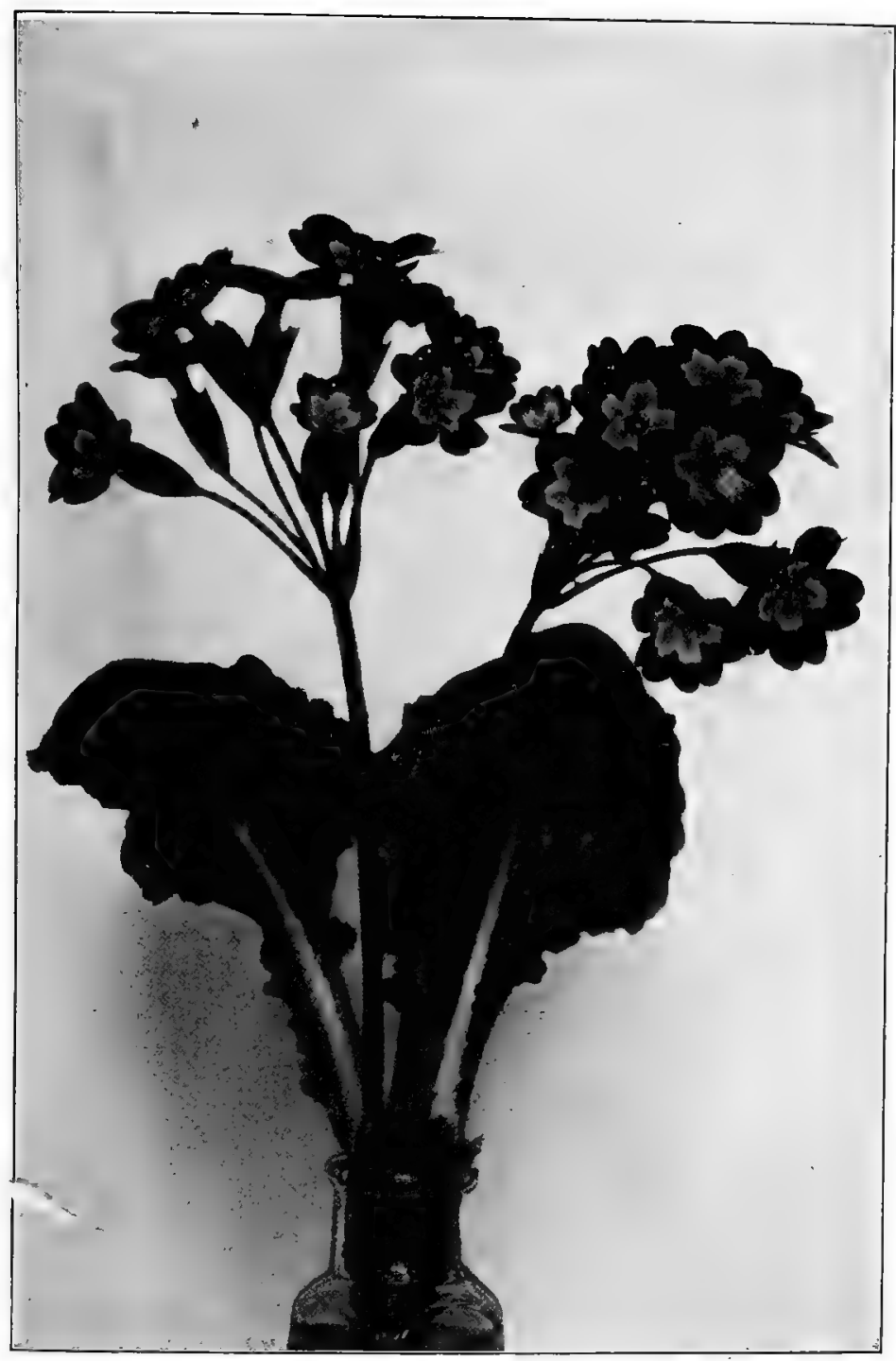

Polyanthus. Primula variàbilis var. polyanthus 


\section{PRIMULÀCEA-PRIMROSE FAMILY}

\section{POLYANTHUS}

Primula variàbilis, var. polyâthus.

Primula, Latin, primus; because of the early flowering of many of the species.

A low, stemless perennial, with radical leaves and scape-borne flowers; blooming in early spring. One of the best of the hardy European primroses, and believed to be of garden origin.

Leaves.-Radical, wrinkled, enlarging after the flowering period.

Flowers.-Red or red and yellow, borne on scapes, five to six inches high.

Calyx.-Long, slightly inflated tube, five-toothed.

Corolla.--Salver-shaped, with five spreading lobes, each lobe notched.

Siamens.-Five, inserted on the corolla tube.

Ovary.-Ovoid, one-celled; style thread-like bearing a capitate stigma.

In our northern 'gardens two types of hardy primroses are cultivated: Polyanthus and Common Primrose. Of the two, Polyanthus is in some respects the more desirable, as it seems to bear our climate a little better than the other. If the plant is given a moist location where it is slightly shaded from the midday sun, it will flourish and blossom from year to year. Its bright blossoms look very cheerful along the garden walk early in May, companioned by the moss pink and the hardy candytuft. During the blooming period the flowers quite overtop the leaves, hic by the middle of June the leaves become six or eight inches high and three to four broad.

The flowers of the type are principally yellow, or red with a yellow eye. There is a form with one corolla inside the other, known as Hose-in-Hose. 


\section{COWSLIP}

\section{Primula officinàlis. Primula vèris.}

This is the true Cowslip; a stemless, perennial plant, native to northern and central Europe; long in cultivation. April, May.

Leaves.-Radical, soft-pubescent, oval or oblong, margin denticulate or erose; petiole winged.

Flowers.-Drooping, bright-yellow, borne in an umbel, on a scape six to twelve inches high.

Calyx.-A loose tube, five-toothed.

Corolla.-Funnel-shaped, the lobes concave, forming a shallow cup about three-fourths of an inch across.

Stamens.-Five, inserted on the corolla-tube.

Ovary.-Ovoid; style slender; stigma capitate.

Where the bee sucks there suck I;

In the cowslip's bell I lie,-

There I couch: when owls do cry,

On the bat's back I do fly

After Summer, merrily.

—"Tempest," Act v, Sc. I, Shakespeare.

With cowslips wan that hang the pensive head.

—"Lycidas," Milton.

Of the five primroses native to England this obtains the common name of Cowslip and as such appears in English poetry The corolla is funnel-shaped and so makes a bell; while the corollas of the other species are salver-shaped and even Ariel would find it difficult to couch therein. Moreover, this is probably the flower that was suggested to the New England colonists by Caltha palustris, so that they named it Cowslip.

This form rarely appears in American gardens; in fact all the "hardy primulas find difficulty in withstanding our summer heat and sunshine without protection, and often that does not avail.

Primula elatior, Oxlip, is very like officinalis, but with larger flowers and is a taller plant. Native to the northern and mountainous parts of Europe. 
The genus Primula numbers about one hundred and forty species, all northern and many alpine. A great many are culti-

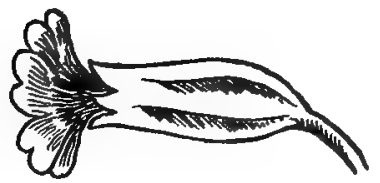

Cowslip. Primula officindlis vated in Europe that are never seen here. Ten or twelve species are credited in the books to the colder parts of North America, but all our cultivated species are of European or Asiatic origin.

Of greenhouse plants the Chinese Primrose, Primula sinénsis; the Japanese Primrose, Primula Japonica; and the Baby Primrose, Primula Forbesi, are favorites. The Japanese Primrose is reported as hardy.

Primula obcónica, from China, has become a popular winterblooming plant. The varieties grandifldra and fimbriata are most desirable.

\section{PRIMROSE}

Primula vulgàris. Prímula acaùlis.

A common English wild flower, early transferred to the garden and there transformed into many varieties. A stemless perennial with radical leaves. April, May.

Leaves.-Tufted, wrinkled, enlarging after the flowering period.

Flowers.-An inch across, pale-yellow, on separate footstalks as long as the leaves.

Calyx.-Tubular, not inflated, five-toothed.

Corolla.-Salver-shaped, border spreading, five-lobed.

Stamens.-Five, inserted on the corolla-tube.

Ovary.-Ovoid; style slender; stigma capitate.

Capsule.-One-celled; many-seeded.

This is the Common Primrose of the garden. The scape is suppressed in this species and the footstalks appear as scapes, so that the flowers are apparently solitary. The garden varieties are now not only yellow but white, lilac, and pale-purple. Bloom- 


\section{PRIMROSE}

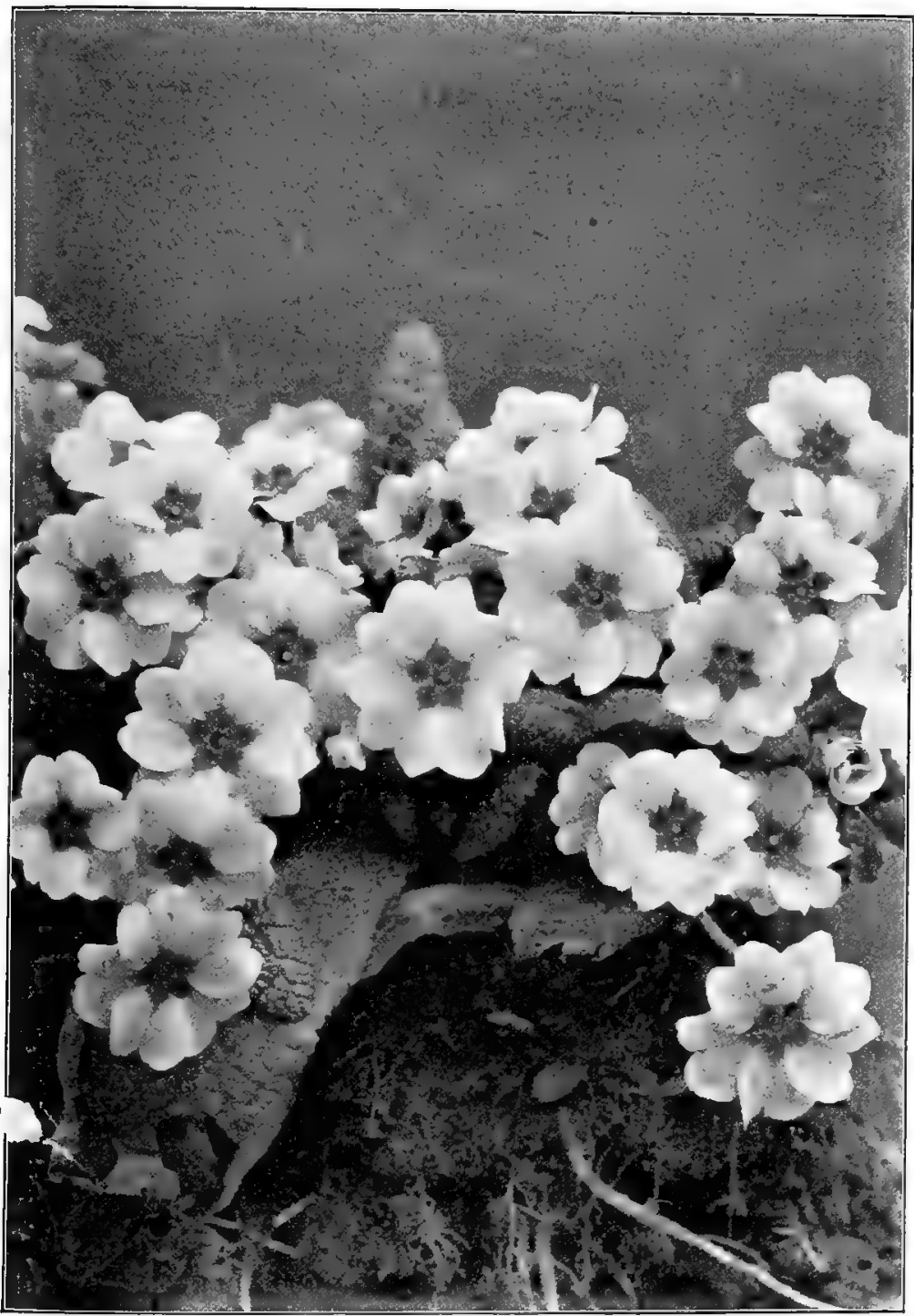

Primrose. Primula acaùlis 
ing abundantly in English fields it appears continually in English poetry from,

The primrose path that leads to the eternal bonfire, of Shakespeare, and,

The rathe primrose that forsaken dies,

of Milton, to the characterization of Peter Bell, by Wordsworth:

A primrose by the river's brim

A yellow primrose was to him, And it was nothing more.

\section{LYSIMACHIA. GOLDEN LOOSESTRIFE}

Lysimàchia vulgàris.

Supposed to be named in honor of King Lysimachus.

An old-time garden plant no longer prized, but found in fields and along roadsides in New England and the Middle States. Naturalized from Europe. Perennial. June to August.

Stem.--Erect, two to three feet high, branched above, downy.

Leaves.-Verticillate, three or four in a whorl, ovate-lanceolate, acute at both ends.

Flowers.-Yellow, borne in ample terminal, leafy panicles.

Calyx.-Five-parted, often red-margined.

Corolla.-Rotate, five-lobed.

Stamens.-Five, inserted on corolla.

Ovary.-One-celled; style and stigma one.

Capsule.-Many-seeded.

This old-time flower has given place to later comers, but as one sees it now and then in a New England yard, or a clump in full flower standing by the roadside, the effect is good. However it is weedy-perhaps all the Lysimachice are weedy.

The Whorled Loosestrife, Lysimachia quadrifolia, native to any soil in the eastern United States, is sometimes transferred to 
the garden. The flowers are yellow, fivepointed, with a dark eye, borne in the axils of the upper leaves.

Money, Creeping Charlie, Lysimachia nummulària, the well-known trailing plant, has now run wild. The stem creeps, the small round leaves are opposite, and the pretty yellow flowers are solitary on short peduncles. Where vigor is especially desired in a cover-plant, Money is extremely useful, for it is a rampant grower and will romp all over the place. It crowds out the grass when it gets an opportunity, is, however, always green, carpets the earth amply, and possesses many virtues of its own.

A Japanese Lysimachia, Lysimachia clethroides, with white flowers, has lately been introduced and is highly recommended both

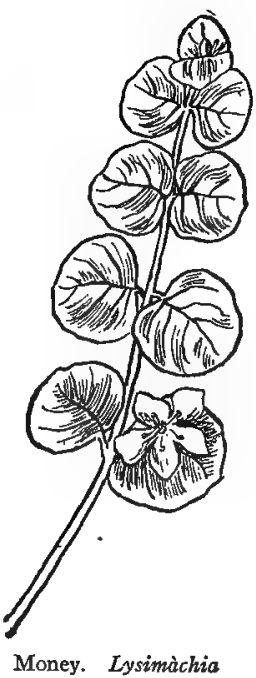
nummuld̀ria for a border plant and also as producing flowers for cutting.

\section{AMERICAN COWSLIP. SHOOTING STAR}

\section{Dodecàtheon Meàdia.}

Dodecatheon, Greek, the twelve gods; name given by Pliny to the primrose, which was believed to be under the care of the superior deities.

A beautiful wild flower extremely variable, developed into garden forms by the French florists. Tolerant of many locations, moist hillsides, cliffs, open woods, and prairies; ranges from Pennsylvania to the Dakotas and south to the Gulf. Perennial. Summer.

Leaves.-Radical, oblong or spatulate, rising in a cluster from the root.

Flowers.-Rose or white, borne in an umbel at the summit of a simple naked scape.

Calyx.-Deeply five-cleft, the divisions lanceolate. 
Corolla.-With short tube, thickened throat, five-parted, reflexed border; the divisions long and narrow.

Stamens.-Five, exserted; filaments short, anthers long, narrow, growing together in a slender cone, yellow tinted with purple at the base.

Ovary.-One-celled; style and stigma one.

Capsule.-Many-seeded.

Shooting Star appears as a rosette of oblong, deep-green leaves, from which rises a simple stem bearing a cluster of nodding, pointed flowers. The blossoms suggest a small cyclamen. The stamens come together in a point and seem to be shooting ahead, while the petals stream behind, thus giving the flower a frightened look. As a wildling its flowers are rose or white, but the garden forms vary the rose to lilac and purple, usually with a yellow circle at the mouth of the corolla. The garden forms are hybrids of Dodecatheon Meadia and Dodecatheon Jéffery, of the Rocky Mountains. 


\section{GENTIANÀCEÆ-GENTIAN FAMILY}

\section{FRINGED GENTIAN}

Gentiàna crinita.

An old name, from Gentius, king of Illyria.

One of the most beautiful of native plants, growing in moist woods and meadows, from Quebec to Minnesota and Georgia to Iowa. Biennial. September, October.

Stem.-One to two feet high, leafy; branches erect.

Basal and lower leaves obovate, obtuse; the upper opposite, lanceolate, sessile with a rounded or sub-cordate base, acute, entire; one and a half to three inches long.

Flowers.-Violet-blue, several, on long peduncles at the summit of the stem.

Calyx.-Tubular, four-lobed and four-angled; lobes acute and imbricate in . bud.

Corolla.-Narrow, bell-shaped, about two inches long, white below and violet-blue above, deeply four-parted; lobes obovate, fringed, convolute in bud.

Stamens.-Four, inserted on the tube of the corolla; filaments white, dilated; anthers extrorse, pale-yellow.

Ovary.-Spindle-shaped, an inch long, flattened; stigma square, twolobed.

Capsule.-Many-seeded.

To the exquisite beauty of the Fringed Gentian has been added the charm of elusiveness, of a certain wilfulness of growth in its wild haunts: "It was here-it was there--where is it now?"

Two wild flowers, separated by the entire flowering season-the trailing arbutus, a veritable incarnation of the spring, and the Fringed Gentian, the attendant of the dying year-hold a unique place in our affections. No others that I know, not even the blue violet, has so touched the emotions and moved the imagination of our people. One dares to invite the busiest man of affairs forth 
to seek arbutus or find Fringed Gentian, and although he probably does not go, he wishes that he could.

'Tis not what man does which exalts him, but what man would do! - "Saul," Robert Browning.

The poets have paid their tribute to the charm and beauty of these blossoms, and the "Mayflower," of Whittier, and the

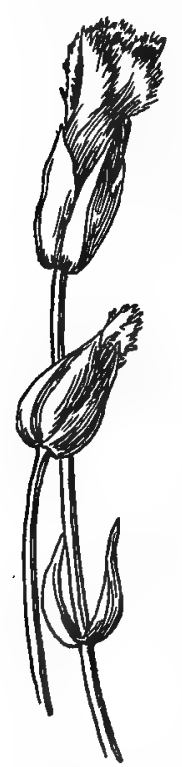

Fringed Gentian. Gentidna crinila "Fringed Gentian," of Bryant, will live because of the flowers; and the flowers, perhaps, will be better known because of the poems.

The color of the Fringed Gentian blossom has been the subject of considerable discussion apropos of Bryant's poem. The first stanza speaks of it as

Colored with the heaven's own blue,

and the fourth as

Blue-blue-as if that sky let fall

A flower from its cerulean wall.

Mr. Matthews, on the other hand, is very sure that "the color varies from pale to deep violetblue, with occasionally a ruddy tinge, but never with a suspicion of true blue, though lines of a deeper blue-violet appear on the outer surface of the corolla." He says what is undoubtedly true that the subtle charm lies in the delicate misty quality of the color.

Another interesting species that is sometimes transferred to the wild border is the Closed Gentian, Gentiana Andrewsii, which is remarkable for its cylindrical closed corolla. Nature's plan here is evidently self-fertilization. The color of the blossoms is a broken intense violet-blue and the flowers are in clusters either terminal or whorled in the axils of the leaves. This is the most common Gentian of Ohio.

To the Gentian Family also belongs the exquisite Sea Pinks, Sabbatia stellaris and Sabbatia gracilis, common on salt meadows along the coast from Maine to Florida. 


\section{APOGYNÀGEA-DOGBANE FAMILY}

\section{VINCA. PERIWINKLE. TRAILING MYRTLE}

Vinca minor.

Vinca, corrupted from pervinca, Pliny's name for periwinkle.

A trailing evergreen perennial, common in country gardens, cemeteries, and shady places. Many horticultural varieties, some with variegated foliage. Native to Europe. April, May.

Stem.-Trailing and creeping, rooting at nodes; only the short flowering stems ascending.

Leaves.-Opposite, evergreen, shining, ovate or oblong-ovate.

Flowers.-Solitary in the axils of the leaves, blue or white, salvershaped.

Calyx.-Tubular, five-toothed.

Corolla.-Pale-blue or white, salver-shaped, border five-lobed-lobes almost wedge-shaped, convolute in bud; throat angled and thickened.

Stamens.-Five, inserted on the upper part or middle of the tube; filaments short; anthers bearded at the tip.

Ovary.-Two carpels; style long, slender, supports a cup in which is the stigma.

Follicles.-Slender, many-seeded.

This is the first out-of-door flower in many country gardens where bulbs have no place; and its lovely blue flowers among the clean glossy leaves is a welcome sight of the early spring. Country people know the plant chiefly as Myrtle and Periwinkle; in city parks and gardens it covers the ground as Vinca; Pliny knew it in Roman times as Pervinca. Why the French call it Flowerof-Mystery is by no means clear; but the reason of the English name, Joy-of-the-Ground, is apparent to any one. 
The value of the plant lies chiefly in its hardy nature and trailing growth; so closely do the sterile, creeping stems cling to the ground that the ancients named them serpents.

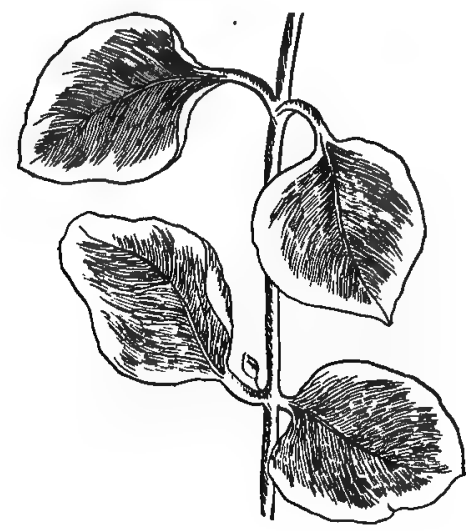

Larger Periwinkle. Vinca mdjor

Half-shaded locations suit it best; poor, stony soil makes a welcome home and though seeding rarely, the plant loses little, if anything, thereby, as the trailing stems root freely at every joint.

Larger Periwinkle, Vinca màjor, is larger in all its parts than minor, and not quite so hardy. It roots only at the tips of its sterile stems. A variegated form of it is seen trailing from nearly every veranda box in the country, as it has the merit of withstanding considerable neglect.

\section{MADAGASCAR PERIWINKLE. ROSE VINCA}

Vinca ròsea.

A tender, erect, ever-blooming plant, somewhat shrubby and used for summer bedding. West Indies and Florida.

Stem.-Erect, twelve to eighteen inches high.

Leaves.-Opposite, oblong, narrowed at base, thick, shining.

Flowers.-Rose, white, with or without a pink eye, salver-shaped, borne at the summit of the stem. 
ROSE VINCA

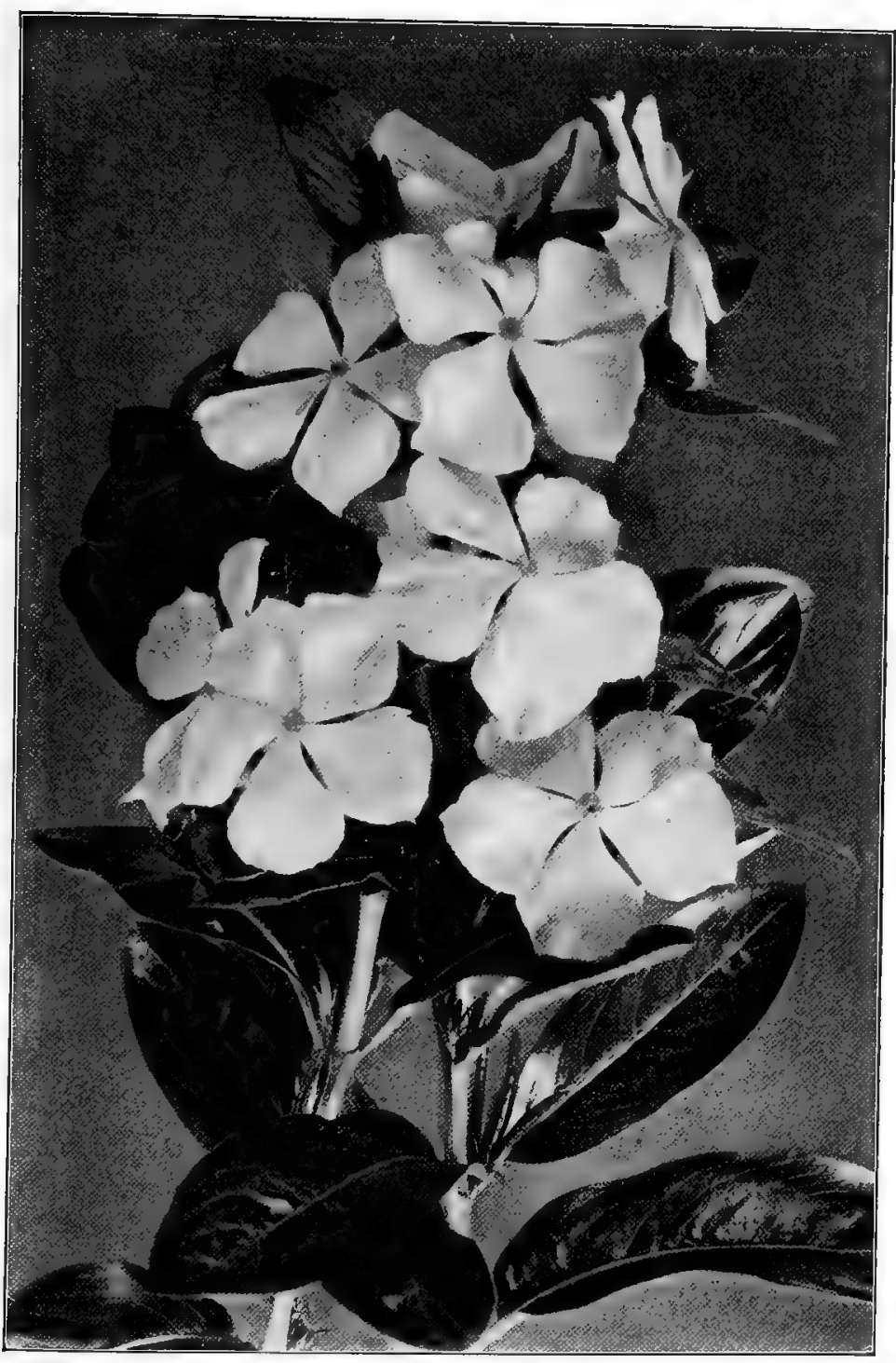

Rose Vinca. Vinca Ròsea 
Calyx.-Five-lobed.

Corolla-tube.-Slender, orifice small; border five-lobed; lobes obovate, not overlapping.

Stamens.-Five inserted on corolla-tube.

Ovary.-Two capsules; style one; stigma one.

Pods.-Short.

The Rose Vinca is a plant of erect growth which is used chiefly for summer bedding, as the plants bloom continuously from the time they are set out until frost. They are used largely in parks and public grounds in the same way as geraniums.

Other spectes of Apocynacea are:

Oleander, Nèrium oleander, of familiar house culture. The flowers are showy, borne in terminal cymes, either deep-rose or white, single or double. The plant came from the Levant.

Amsònia tabernamontana, a southern perennial, is grown in the hardy border mostly with shrubbery. The leaves are willow-like, the flowers small bluish bells in terminal panicles. The foliage holds late.

The two Dogbanes, Apócynum androsamifolium, Common Dogbane, an inmate of thickets, with its pretty, tiny, bell-corolla with revolute lobes, cream-white marked with pink lines within; and Common Indian Hemp, which loves wet banks of streams, and bears flowers more crowded and erect, are well worthy of a place in the wild garden. 


\section{ASCLEPIDÀCE/E-MILKWEED FAMILY}

\section{BUTTERFLY WEED. ORANGE MILKWEED}

Asclépias tuberòsa.

The most brilliant of our native Milkweeds; with tuberous roots; found in dry fields.

Stem.-One to two feet high, hairy, leafy; milky juice scanty or wanting.

Leaves.-Alternate, sessile, lance-oblong, thick, margins slightly reflexed.

Flowers.-Bright-orange, in many-flowered terminal clusters.

Calyx.-Five-parted, segments acute, turned backward.

Corolla.-Deeply five-cleft, the segments turned backward. Above them an erect five-parted crown, each part called a hood, with a tooth on either side and an incurved horn projecting from within.

Stamens.-Five, inserted on the corolla, short, stout, united by their filaments into a tube; anthers broad, united and covering the fleshy mass of the two united stigmas, terminating in a large sticky five-angled disk. The anthers are tipped with a winged membrane and the pollen coheres as a waxy pear-shaped mass.

Ovaries.-Two, forming follicles in fruit.

Seeds.-Many.

The flowers of the Milkweed are difficult for an amateur to understand because of the abnormal development of a horned and hooded crown which becomes the most prominent part of the blossom and quite overshadows the corolla. This crown is composed of five little cups like minute cornucopias surrounding a central column. These are the nectaries containing the sweets so attractive to insects; as one will readily understand who watches a bumble-bee as he follows the circle thrusting his long black tongue deep into each little horn. It is evident that the flower counts upon one or more of the bee's legs getting caught in an anther 
crevice and in extricating itself to carry along a pollen mass to be deposited on another blossom.

The Milkweed has become so highly specialized for cross-fertilization that although each flower-cluster may number fifty

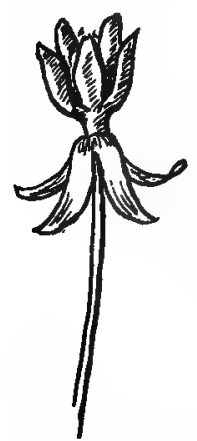

Flower of Butterfly Weed; Enlarged blossoms, more or less, it is rare that more than three to five are fertilized so as to produce fruit. The plant makes up for the small number of pods by the enormous number of seeds in each pod. Moreover, each seed possesses an admirable parachute attachment which wafts it away on the wings of the wind, "east of the sun and west of the moon," to the happy land where it finds a home.

The genus Asclepias is credited in the books with eighty-five species, mostly natives of America; of these but two have so far recommended themselves for domestication, and they are rather wildlings brought in upon occasion than to the manner born. The first is the Butterfly Weed, in color a vivid orange-a flame amid the green-and the other Asclepias incarnata, which adorns. swampy places and may well have a place in the tangle that it glorifies.

The Silk Vine, Periploca graeca, is a twining shrub from the Mediterranean region which, upon occasion, can climb as high as forty feet. The leaves are oblong-lanceolate, dark-green and shining, from two to four inches long. The brownish-purple flowers are of the milkweed type and borne in loose cymes. The fruit consists of follicles filled with many small, winged seeds. 


\section{CONVOLVULȦCEA-CONVOLVULUS}

FAMILY

Chiefly twining or trailing herbs, often with milky juice; alternate leaves, and regular flowers with their parts in fives. The calyx has five sepals imbricated in the bud; the corolla is fivelobed, the lobes convolute or twisted in the bud. Stamens five, inserted low down on the tube of the corolla, alternate with its lobes. Fruit is a capsule, two to four-celled. In cultivation are Morning-glory, Cypress Vine, Moon-flower, Great Bindweed, and Sweet-potato.

\section{MORNING-GLORY}

Ipomàa hýbrida.

The garden race of Morning-glories are hybrids developed chiefly from Ipomoea purpùrea and I pomcea hederàcea, both South American species. A heart-shaped leaf indicates the purpurea strain predominant; a three-lobed leaf indicates hederacea.

- Stem--Twining from left to right, hairy, six to twelve feet high.

Leaves.-Alternate, heart-shaped and entire, or three-lobed.

Flowers.-Funnel-shaped, color range extending from violet and redpurples to pure-white, variously striped and spotted. Peduncles three to five-flowered.

Calyx.-Five-parted, densely hairy below.

Corolla.-Funnel-shaped, one and a half to two inches across.

Stamens.-Five.

Ovary.-Three-celled; style and stigma one.

Capsule.-Three-celled; cells one-seeded.

The Morning-glory is undoubtedly somewhat of a rascal when given too free a hand in the garden. Possessed of tremendous vitality it will scurry up a string or a pole at an astonishing rate 
of speed, and when a temporary leafy screen is desired few vines will do the work as effectually and in so short a time.' The leaves are large, the internodes short, and the cover excellent. After the stem reaches the top of its support it usually looks about for something else to conquer and often doubles upon itself or embraces its neighbors. The stem must be provided with something to twine about or it will provide this for itself, and when the Morning-glory does its own providing it stops at nothing. It will overwhelm the rarest rose-bush, climb up the stalk of the finest perennial, or ruthlessly choke out the life of the most valuable plant in the garden. Hence, it must be kept within bounds or kept not at all.

Yet there is something so attractive in the poise of those airy bells that come out of the deep of the night, wet with the dews of the morning; so exquisite are the translucent depths of those perfect cups that, personally, I never see one without a thrill of pleasure, and under the spell of their delicate and ethereal beauty, I pardon something to the spirit of liberty.

The blossom of the Morning-glory does not bear direct sunshine, but, if it were desired, this characteristic could be greatly modified. There are always some vines whose flowers outlive their neighbors, and careful selection would in time prevail.

The Japanese grow the Morning-glory with devotion and have developed their native Morning-glory (or is it Chinese ?) to a point of marvellous variety and perfection. Wonderful tales are told by travellers of "a whole city full" of people going out with the dawn into suburban gardens to see the Morning-glories in bloom.

A flower that can be seen at its best only about sunrise, it is safe to say, will never be a favorite with the American people, and the Morning-glory vine, despite all its virtues, will probably remain as it now is, a utility plant loved by the few, outlawed by others, tolerated by the many. 
MORNING-GLORY

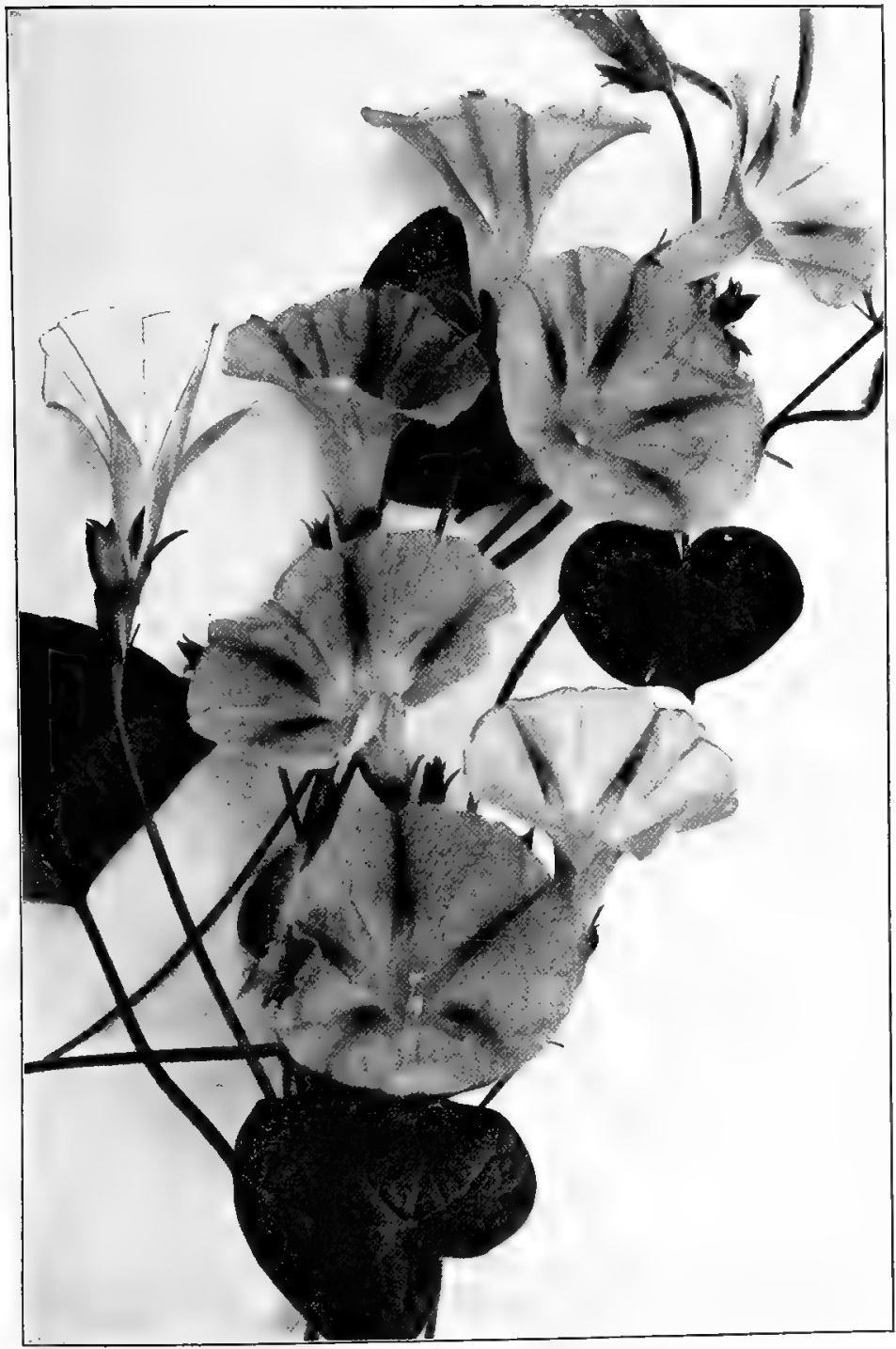

Morning-glory. Ipomàa hýbrida 


\section{MOON-FLOWER}

Ipomòa bòna-nox.

The familiar, night-blooming, white-flowered member of the Morningglory group. Variable. South America.

Stem.-Twining, often making twenty feet in a summer, smooth, often beset with soft projections.

Leaves.-Alternate, large, heart-shaped or angled.

Flowers.-White, with greenish lines, four inches across; opening late in the afternoon and remaining open until the direct rays of sunlight strike them; fragrant.

Peduncles.-One to four-flowered.

Calyx.-Five sepals.

Corolla.-Salver-shaped; tube three to four inches long; border three to four inches across, white, with five greenish lines radiating from the throat to the circumference; convolute in bud.

Stamens.-Five, just appearing at the throat.

Ovary.-Two-celled; style long, exserted; stigma two-lobed.

Capsule.-Two-celled; cells one-seeded.

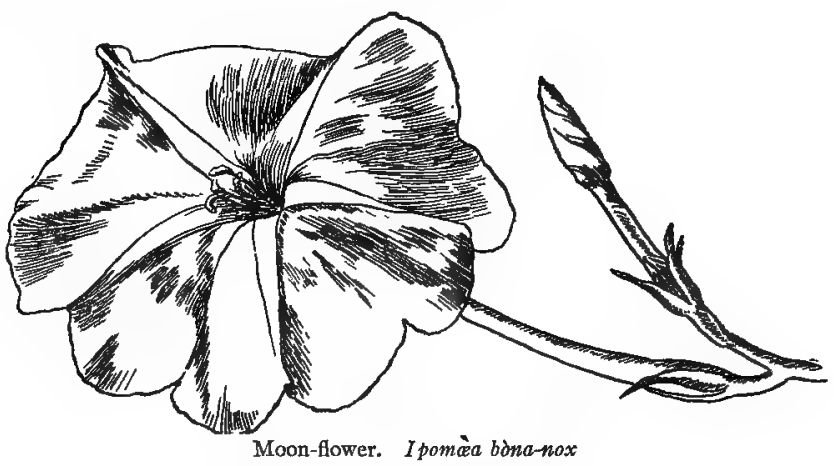

The Moon-flower is an admirable screen, porch, or wall vine, for the leaves are large and abundant. The flowers begin to open about sundown, and do not close until the next morning is well on toward noon. Being an Ipomeea it, of course, shares the family characteristics, twines from left to right, and crowds its neighbors, 
so that really it should be given the field when once placed. The seeds should be cut or filed before planting; the outer covering is so strong that, without this help, fully one-half will not germinate.

\section{MAN-OF-THE-EARTH: WILD POTATO VINE}

Ipomèa panduràta.

Regarded by farmers as a dangerous weed, but producing very beautiful white Morning-glory flowers. Perennial. Sandy fields and banks from Connecticut to Illinois and southward.

Root.-Huge, often weighs ten to twenty pounds.

Stem.-Long and stout, trailing, sometimes twining.

Leaves.-Heart-shaped, pointed, sometimes fiddle-shaped.

Flowers.-Large funnel-form, white with purple at the base; peduncles one to five-flowered.

Sepals.-Five, smooth, ovate-oblong, very obtuse.

Corolla.-Open, funnel-form, three inches long, white with deep purple eye.

Stamens.-Five, inserted on corolla tube.

Ovary.-Two-celled; style and stigma one.

Capsule.-Two-celled; cells two-seeded.

A vine that can achieve a massive root weighing twenty pounds demands respectful treatment, for if it once becomes established in a garden, it will probably remain. One should certainly think twice before planting Man-of-the-earth. The blossom is the beautiful cup of the Morning-glory, white with a purple eye, open all day long, drinking in the sunshine. On a sandy bank where little else will grow it is an acquisition. 


\section{CYPRESS VINE}

\section{I pomìa quamoclit.}

An annual twining vine with feathery foliage and small, bright-red flowers. Native of tropical America. Summer.

Stem.-Twining, reaches fifteen to twenty feet.

Leaves.-Pinnately parted into slender almost thread-like divisions.

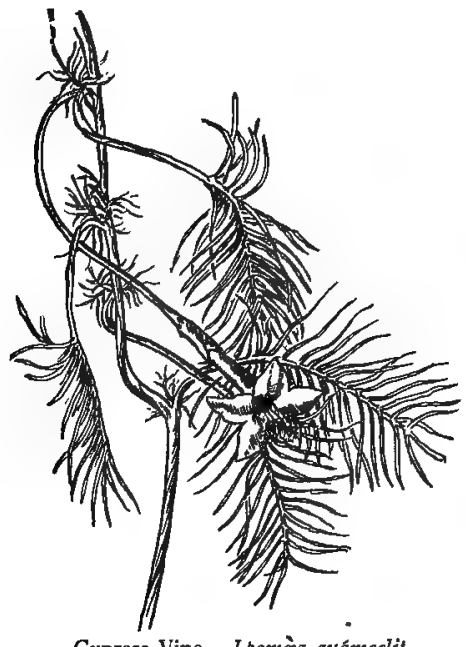

Cypress Vine. Ipomàa quámociit

Flowers.-Bright-red, diurnal, small for the genus; peduncles one to six-flowered.

Calyx.-Five-lobed.

Corolla.-An inch to an inch and a half long, scarlet; the tube narrowly funnel-form, inflated above; the border nearly flat, five-lobed.

Stamens.-Five, exserted; stigma capitate.

Capsule-Ovoid, four-celled; cells one-seeded.

The delicate feathery foliage of the Cypress Vine makes a beautiful background for the little scarlet flowers that stand out so clearly against it. The vine is a good strong grower and will do well in partial shade. There is a white variety.

\section{SWEET-POTATO}

\section{Ipomàa batàtas.}

The Sweet-potato of the market is a trailing vine of the Morning-glory group that produces an edible root. The origin of the present cultivated form is unknown, but believed to be a product of tropical America. We know certainly that it was cultivated by the aborigines when America was discovered, but its wild form has never yet been found. 
The branches root at the joints and the edible tubers grow close together under the crown and, unlike the common potato, they do not bear definite eyes. The commercial varieties that are carefully cultivated rarely bloom; the strength of the plant goes to the root. The blossom, when it does appear, is a purple funnelshaped bell opening by day and rarely producing seed. The leaves vary greatly in form and in size.

\section{CONVOLVULUS. HEDGE BINDWEED}

Convólvulus sèpium.

From the Latin convolvo, roll around or twine; referring to the habit of the plant.

A wild, climbing plant, common in low grounds; often planted to adorn walls and fences. Spreads by running rootstocks; variable; double-flowered in gardens.

Stem.-Twining freely, sometimes also trailing.

Leaves.-Triangular, and halberd-shaped, or arrow-shaped, with the lobes at base obliquely truncate; often somewhat toothed or sinuate-lobed.

Flowers.-White or pale-rose, one and a half to two inches long. Peduncles fourangled.

Calyx.-Enclosed in two large, leafy bracts; sepals five.

Corolla.-Bell funnel-form; white with pink lines or pale-rose; border obscurely five-lobed.

Stamens.-Five, inserted on the tube of the corolla.

Ovary.-Two-celled; style one; stigma two-lobed.

Capsule.-Two-celled; cells two-seeded.

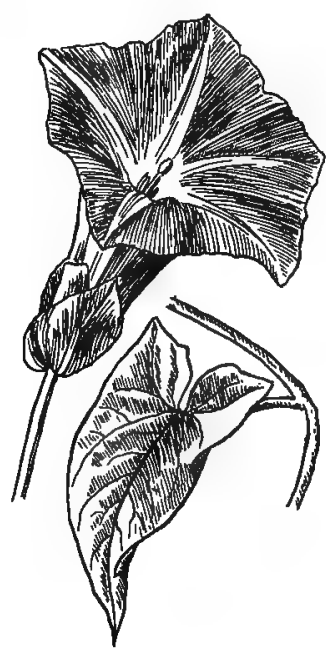

Convolvulus. Convólvulus sèpirum

The Convolvulus is also known as the Bindweed, and there is something decidedly sinister in the name of Bindweed, for it characterizes the evil power of the plant. The strong twining 
stem grips tight, and when it seizes something weaker than itself, the weaker suffers. The vine covers a fence or trails over a wall beautifully, when controlled is an admirable servant, but one should never forget that it is a rambler at the root.

California Rose, Convolvulus japonica, appears in our gardens principally in its double form. It is perennial, hardy, vigorous, often making twenty feet in a summer. The leaves are variable, hastate or ovate, with angular or rounded lobes at the base. The flowers are bright-pink, and the narrow wavy petals irregularly arranged make a very pretty rose-like effect. Like Convolvulus sepium it will bear watching, as it will wander far and is inclined to smother other plants when it has a chance.

\section{THREE-COLORED CONVOLVULUS}

Convolvulus trícolor.

An annual from southern Europe, one of the best of the hardy Convolvuli; blooms continually throughout the summer and remains open during entire day.

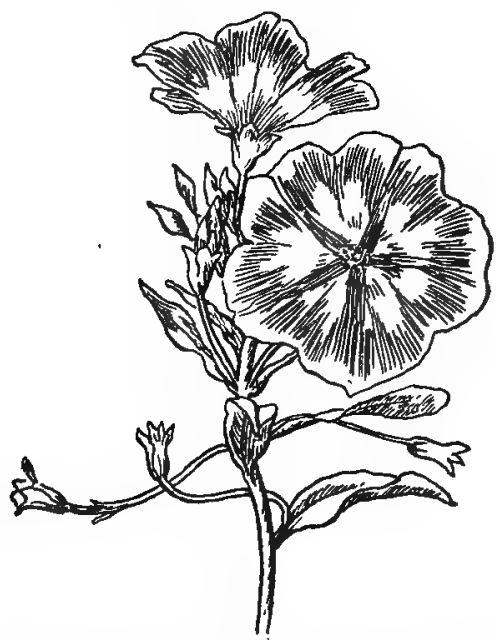

Three-colored Convolvulus. Convólvulus trícolor 360 
Stem.-Trailing and ascending; rises from twelve to eighteen inches, angular, hairy, branching.

Leaves.-Linear-oblong, or obovate, rather coarse.

Flowers.-Large and showy, loosely cymose, three-colored, blue, white, and yellow.

Calyx.-Hairy, five-lobed; lobes pointed.

Corolla.-Funnel-shaped, one and a half to two inches across; border blue with white throat, the tube yellow.

Stamens.-Five, of varying heights, inserted on corolla-tube.

Ovary.-Four-celled; style thread-like; stigma two-parted.

Convolvulus tricolor gets its name from its colors; blue edge, white middle, pale-yellow at the throat, is the regulation coloring, the blue extending in lines through the white, almost meeting the yellow. Any plant that will bloom continually through August is a prize. 


\section{POLEMONIÀCEA-PHLOX FAMILY}

\section{PERENIIAL PHLOX}

Phlox paniculàta.

Phlox, Greek, flame; anciently applied to Lychnis and transferred to these plants.

A perennial, bearing very showy flowers, growing in clumps and found in woods and thickets from Pennsylvania, south and west. Common in gardens. Summer.

Stem.-Stout, simple, two to four feet high.

Leaves.-Opposite and sessile, oblong-lanceolate, or ovate-lanceolate, pointed, tapering at base, heart-shaped at base, entire.

Flowers.-In ample panicles, somewhat pyramidal, pink-purple, varying to white.

Calyx.-Tubular, angular, five-lobed.

Corolla.-Salver-shaped with a long tube and a spreading five-lobed border.

Stamens.-Five, included, and unequally inserted in the corolla-tube.

Ovary.-Three-celled; style slender; stigma three-cleft.

Capsule.-Three-celled, several-seeded.

The race of Garden Phloxes has been developed from the wild species of our own fields and constitutes one of the most brilliant flower groups in cultivation.

Phlox paniculata has undoubtedly been the basic form, modified more or less by Phlox maculàta, and Phlox Drummondii, both native to the United States. In some forms the terminal panicles have become a foot long and densely filled with flowers. The colors range the chord of red, from carmine to crimson, from purple to pink, from coral to salmon; light-eyed, dark-eyed, or noeyed at all; and a plantation in full bloom is a dazzling sight. 


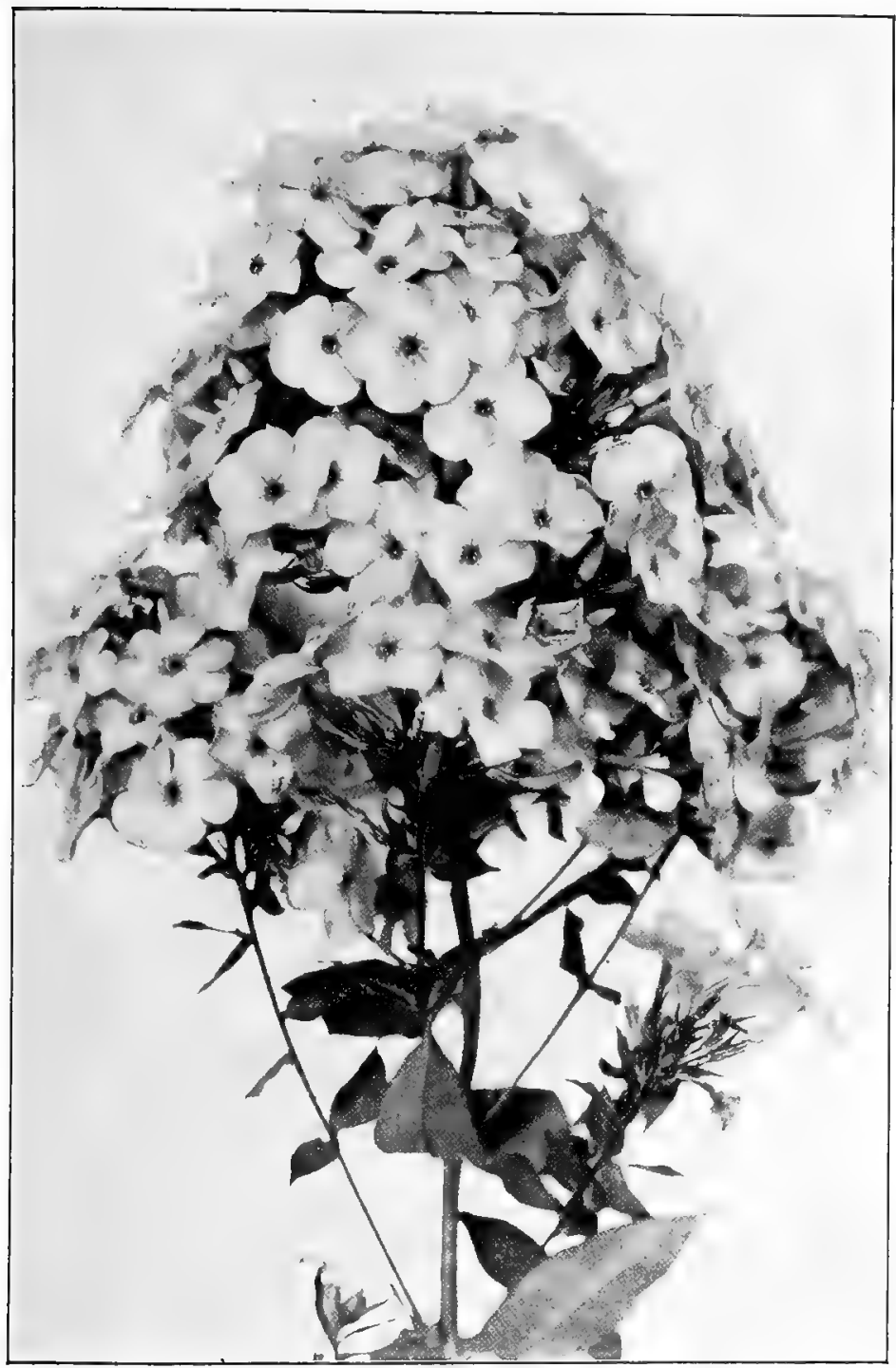

Perennial Phlox. Phlox paniculàta. 


\section{PHLOX FAMILY}

The plant naturally grows in tufts and should be allowed room to develop; it also is well to divide the old clumps, taking especial care of the young shoots on the outside.

Perennial Phloxes usually bloom in early summer, but if the tips of the shoots are pinched out once or twice the bloom may be greatly delayed and fine bloom obtained even in October.

The Annual Phloxes are derivatives of Phlox Drummondii, of Texas, a native species which has been so modified by domestication that the garden varieties are numbered by scores. In color they are the same as the perennial forms. The collector, Drummond, sent the seeds of this Phlox from Texas to England in I835, and it was named in his honor. A horticultural form called Star Phlox has been developed, more curious than beautiful.

The Wild Phlox of our northern spring is Phlox divaricata, which bears a loose, corymbose panicle of attractive flowers which vary in color from pale-lilac to nearly white. Like all the Phloxes the corolla is salver-shaped; this word referring to the ancient salver whose handle was a tube extending below the tray, rather than to our modern form. It is very pretty in masses, but its color is not decided enough to be effective alone and its loose clusters look a little ragged.

\section{GROUND PINK. MOSS PINK}

Phlox subulata.

A perennial of tufted or matted stems, extremely variable, prized for its abundant flowers in early spring. Native to Pennsylvania and ranges south and west. May.

Stem.-Tufted or matted, much branched and very leafy, more or less procumbent.

Leaves.-Crowded, narrow, linear, very sharp and usually stiff, ciliate.

Flowers.-Profuse, in small clusters, about an inch across, pink, pale-blue, white, sometimes eyed; standing two to six inches above the ground.

Calyx.-Tubular, five-lobed.

Corolla.-Salver-shaped, five-lobed; lobes notched or entire. 
Stamens.-Five, inserted on the corolla-tube.

Ovary.-Three-celled; style slender; stigma three-cleft.

Capsule.-Three-celled, several-seeded.

The Moss Pink sets the garden ablaze with brilliant bloom, and lights up the desolation of early May. The depressed stems with their little sharppointed leaves make dense mats of moss-like foliage, and when in flower these mats are transformed into a mass of rose-purple, pink, or white, so perfectly does the bloom hide the foliage. Rocky hillsides and river banks are its natural home, but any light soil will serve. Pretty as it is, its blood brother, the Creeping Phlox, Phlox réptans, of more southern range, surpasses it in size and brilliancy of flowers. The two are very similar in general

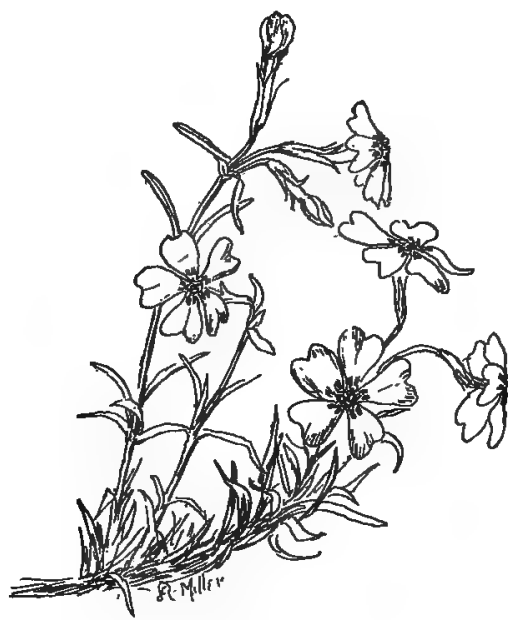

Moss Pink. Phlox subulàıa appearance, but the stems of this one grow a little taller and the flowers are a little larger. The blooming period, however, is somewhat later, which is a handicap, for the charm of the Moss Pink is its smiling entry into early spring.

\section{COBCEA}

Cobæ̀a scaindens.

Named for Father Cobo, a Spanish Jesuit of the seventeenth century; naturalist, and resident of Mexico for many years.

A smooth, tall, much-branching climber, valuable as a quick-growing vine. At home a perennial, but here treated as an annual. Mexico. August, September. 
Stem.-Making twenty feet in a single summer; climbing by compound tendrils at the apex of the pinnate leaves.

Leaves.-Alternate, pinnately compound; leaflets two to three pairs, oval, more or less eared; terminal leaflet often represented by a tendril.

Flowers.-Bell-shaped, an inch and a half across, green at first, finally pale violet or greenish-purple with protruding style and stamens.

Calyx.-Large, persistent, leafy, five-lobed.

Corolla.-Large, bell-shaped, with spreading five-lobed border.

Stamens.-Five, protruding, inserted on the corolla-tube and all in. clining to one side.

Ovary.-Obovoid; style long, slender, declinate; stigma three-cleft.

Cobæa is one of the most valuable of quick-growing vines. It does not climb as the trumpet vine or the Virginia creeper, by

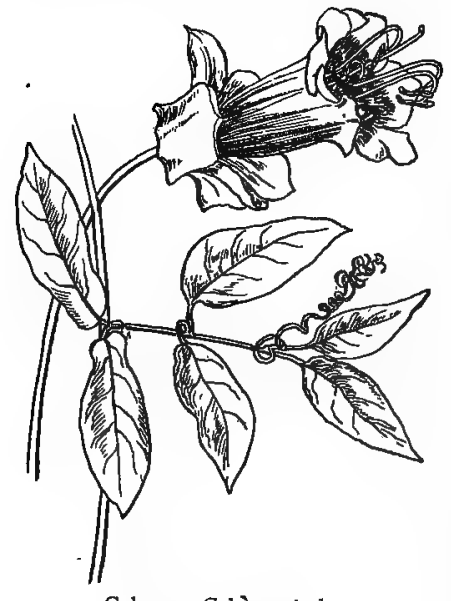

Cobcea. Cob̀̀a seándens means of aerial rootlets, but at the apex of its pinnate leaves are tendrils that catch quick and hold fast. The foliage growth is loose, irregular, and uncertain in direction, but easily controlled. The plant likes sunny locations, yet will grow in partial shade. The flowers are large, slightly iregular bells, two inches or more long and an inch and a half across.

The tendrils of Coboa scandens are forked and end in delicate branchlets, each bearing a minute double hook at its tip. The tendrils are flexible, a breath of wind sways them about, and the little hooks will catch hold of any slight irregularity, and, afterward, the tendril curls around and makes the attachment permanent.

A very interesting movement of spiral contraction occurs in tendrils after they have caught an object. At first they are straight, with the exception of the extreme tip which is firmly curled around 


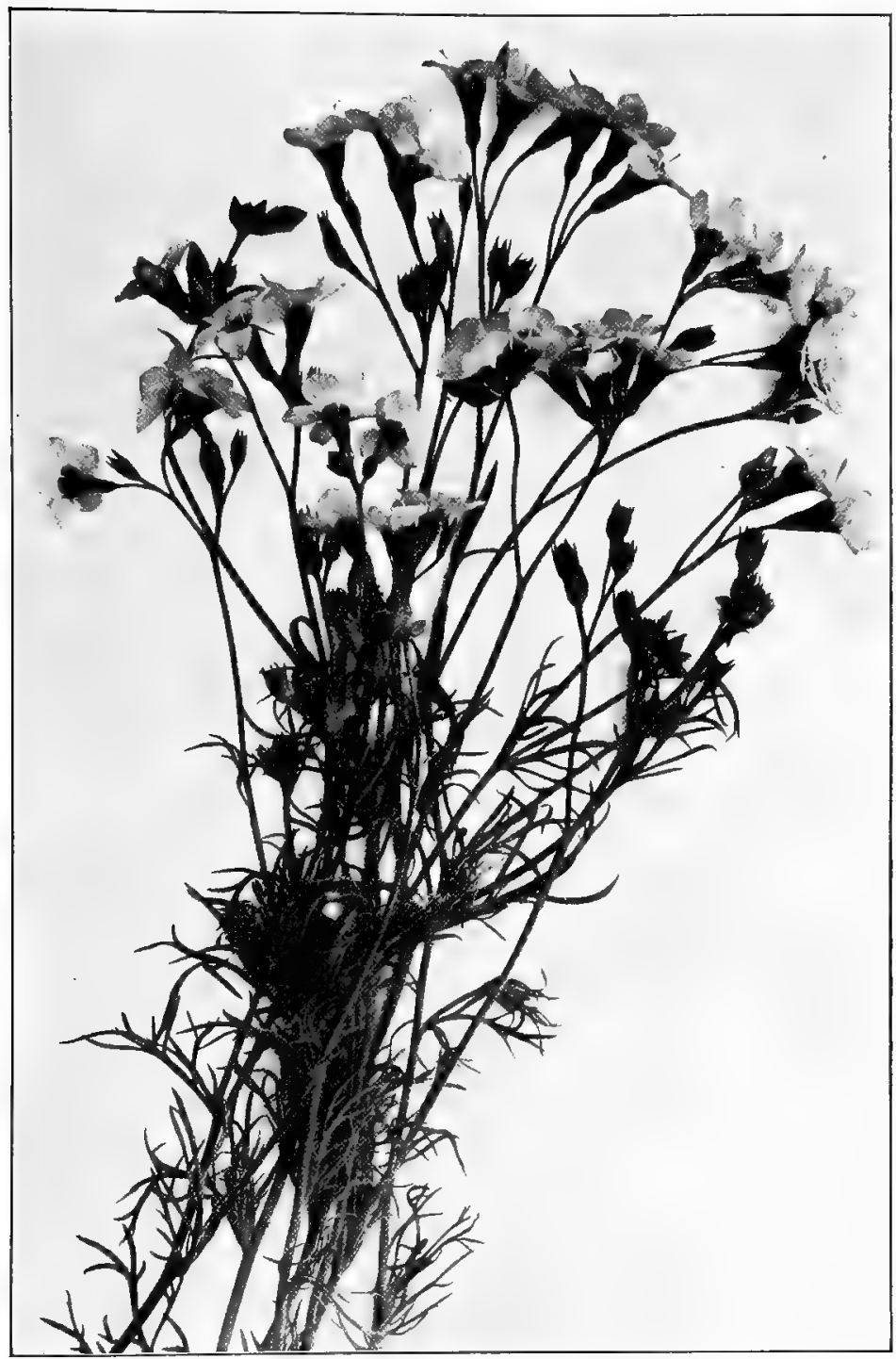

Gilia. Gília trícolor 
the object. Soon, however, the tendril body begins to contract and ultimately assumes the corkscrew-like form so commonly seen; this contraction drags the stem nearer to the point of attachment. A second use, and perhaps the most important, of this contracted tendril is that it acts as a spiral spring and becomes a yielding instead of an unyielding body; and thus enables a plant to weather a gale which might otherwise tear it from its support. After the tendril has taken hold of a support, spiral coils can be made in it only by the middle part turning, and this will cause the coils to be turned one-half in one direction and one-half in the other.

\section{TRICOLORED GILIA}

\section{Gilia trîcolor.}

Gilia, in honor of Philip Gil, a Spanish botanist.

A native of western California, found in gardens and sparingly escaped. Annual. Midsummer.

Stem.-Slender, branching, about a foot high.

Leaves.-Alternate, scattered, two or three times pinnately dissected into short linear divisions.

Flowers.-Lilac-purple, panicled at the end of the branches.

Calyx.-Tubular, five-lobed; lobes imbricated in the bud.

Corolla.-Short, funnel-form, with yellow tube, lilac-purple or whitish Iobes, deep violet-purple throat; lobes convolute in bud.

Stamens.-Five, inserted on tube of corolla.

Ovary.-Three-celled; style slender; stigma three-cleft.

The Gilias are Western flowers; seventy-five species are recorded and these are especially abundant in the Rocky Mountain region; indeed they are with you at every turn as you climb the mountain paths. The flowers are often showy and beautiful, and some of them resemble phloxes.

Gilia tricolor is especially abundant in western California. The corollas are a delicate lilac, blending into white toward the centre. Mrs. Parsons reports that the children are so won by the fresh and winsome blossoms that they call them bird's-eyes. 


\section{POLEMONIUM. GREEK VALERIAN}

\section{Polemdnium réptans.}

A smooth perennial with weak stems and alternate pinnate leaves, found in moist lands from New York to Minnesota and southward. May.

Stem.-Weak and spreading, but not creeping as the name suggests; six to twelve inches high.

Leaves.-Alternate, pinnately compound; leaflets five to fifteen, ovate-lanceolate, entire.

Flowers.-Pale blue-violet, rarely white; in loose few-flowered clusters. Calyx.-Bell-shaped, five-lobed.

Corolla.-Open bell-shaped, five-lobed, lobes rounded.

Stamens.-Five, inserted equally on the corolla-tube, declined, hairy at base, not protruding beyond the corolla.

Ovary.-Three-celled; style slender; stigma three-cleft.

Capsule.-Three-celled.

This wild Polemonium is a very charming plant and throughout the Middle West is frequently found in gardens. The commonly cultivated Polemonium, however, is another species, corilleum, of more robust habit and more abundant bloom. Both flower in May and adorn equally the border or the rock-garden.

Polemonium coerileum, the Blue Polemonium, is a plant of northern range and credited in the books to three continents, Europe, Asia, and America. Certainly, it has long been

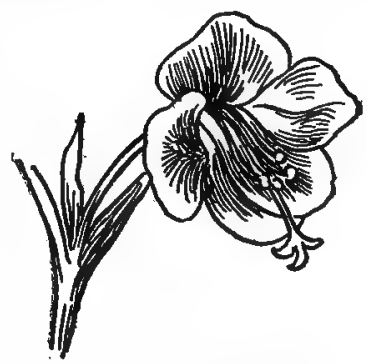

Blue Polemonium, Polemònium ccerùleum cultivated in English gardens and came to us over sea instead of from our own fields.

Polemonium himile, or Polemonium Richardsoni, as it appears in trade catalogues, is an Alpine species, a low plant, bearing in July a profusion of pale-blue bell-shaped flowers with golden anthers. It is highly recommended for the rock-garden. 


\section{PHLOX FAMILY}

This entire floral group seems to have acquired a choice collection of misfitting and foolish names. To begin with, Polemonium is referred in the books to the Greek polemos, war, a name utterly without significance. Our pretty wildling is called reptans, creeping; a thing it never does. The Blue Polemonium rejoices in the two names of Jacob's-ladder and Charity; and the genus itself is known in the botanies as the Greek Valerian. Few groups have suffered so severely at the hands of their friends. 


\section{HYDROPHYLLÀGEAE-WATER-LEAF FAMILY}

\section{NEMOPHILA}

\section{Nemóphila insígnis.}

Nemophila, Greek, lover-of-the-grove; referring to the habitat of some species. bent.

Leaves.-Pinnately parted into seven to nine segments, which are sometimes lobed.

Flowers.-Blue, white, or lilac, about an inch across; solitary and long-petioled.

Calyx.-Five-parted, with a reflexed appendage in $\mathrm{each}$ sinus.

Corolla.-Open bell-shaped, five-lobed with scaly appendages on the inside of the throat.

Stamens.-Five.

Ovary.-One-celled; style two-cleft; seeds few.

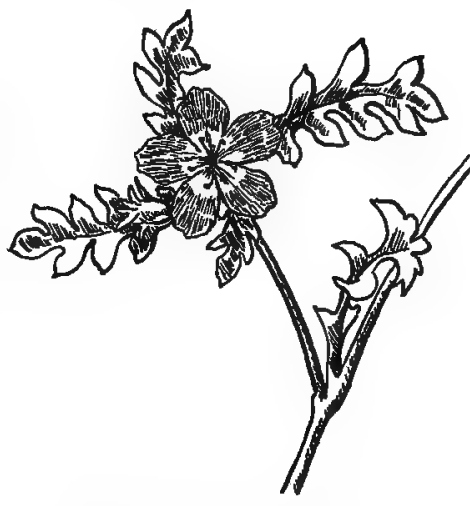

Nemophila. Nemóphila insîgnis

Nemophila is a pretty, compact little herb, excellent for borders and possessed of a charming name, Lover-of-the-grove. Insignis and Nemophila Menziesii, both California plants, are the two in common cultivation and both have varied into several garden forms. 


\section{VERBENÀCE E-VERVAIN FAMILY}

\section{VERBENA}

Verbèna hýbrida.

Verbena, ancient Latin name of the European vervain.

Siems.-Erect or decumbent, variable.

Leaves.-Opposite, variable.

Flowers.- In many colors, borne in corymbose clusters.

Calyx.-Tubular, five-toothed.

Corolla.-Salver-shaped; tube straight or incurved, hairy at the throat; border somewhat two-lipped; five-lobed, each lobe notched.

Stamens.-Four, in two pairs.

Ovary.-Four-celled; fruit four, ribbed nutlets.

The hybrid Verbenas are a garden race containing the strains of so many primitives that it is impossible to classify them according to their botanical derivation. They are the descendants of four or five Brazilian Verbenas, which have been crossed and hybridized to the utter destruction of all specific lines. The distinctions now made are purely horticultural and rest chiefly upon color and habit.

The growers class their Verbenas as selfs, eyed, and striped, in respect to color; and standard, or dwarf, in respect to habit.

The primitive forms of Verbena were introduced into England in the middle thirties of the nineteenth century. One seems to have borne scarlet flowers, another rose-purple, another palepurple, and a fourth white. From the first all were extremely variable, and by 1839 the florists had obtained "several excellent varieties." By 1840 they began to be cultivated in America and for a time were very popular plants. The smile of fickle fortune 


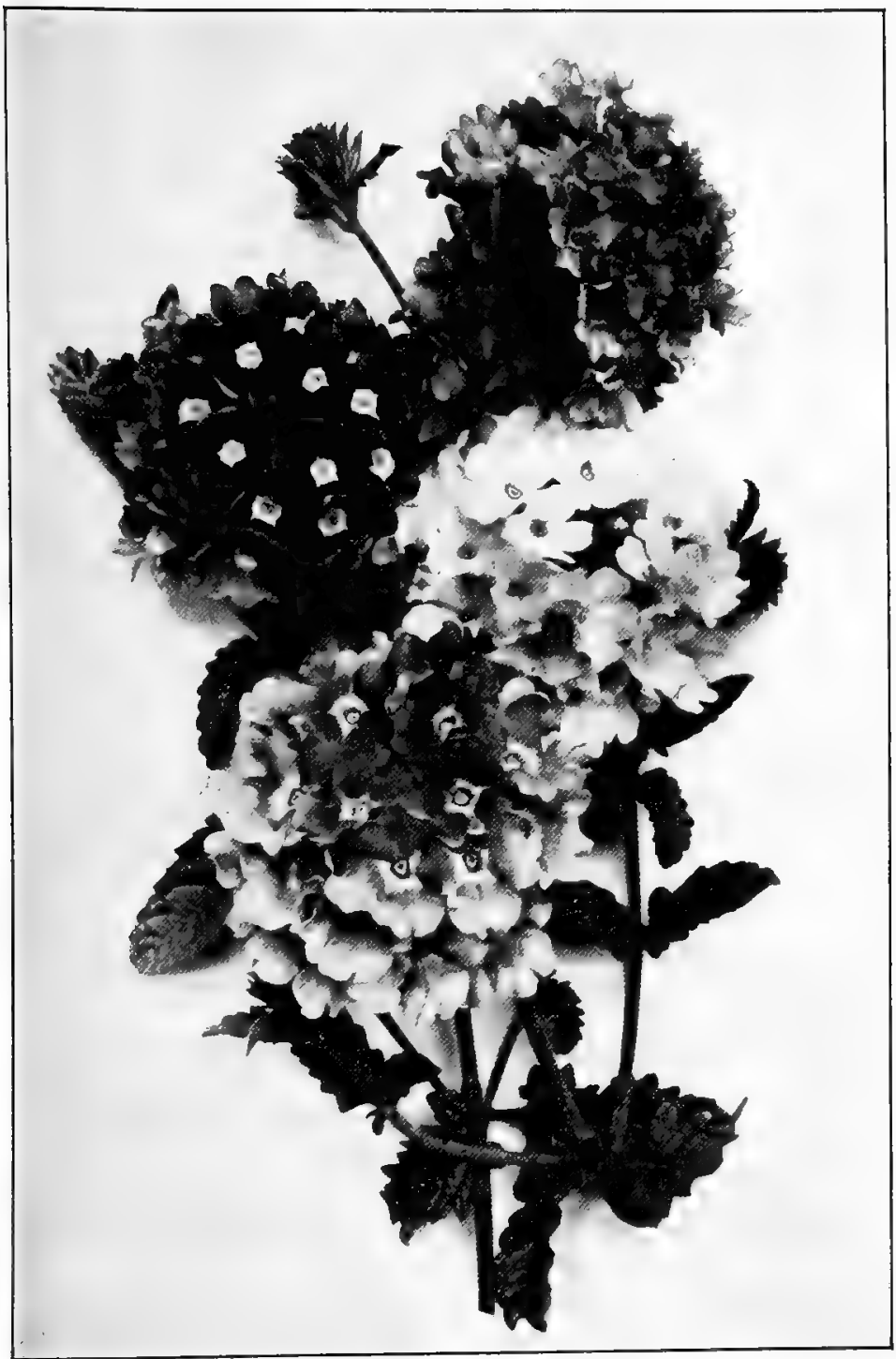

Verbena. Verbèna hýbrida 
faded, however, and since 1870 the Verbena has been judged upon its merits alone. These are by no means wanting, but better bedding plants than Verbenas are now to be had. The colors range along the lines of white, red, and purple.

The blossom has a two-lipped corolla, although that fact is not very apparent. The greenish-white tube swells out and becomes a little oblique at the throat and throws three lobes together above and two below. The throat is bordered with soft hairs which close over and protect the stamens and pistil. It is interesting to note in a cluster of Verbena flowers the attitude of these self-same hairs. As fertilization is accomplished by small insects, flies, etc., when the stamens or pistil are ready, the hairs are erect and the way to the nectar at the base lies open; but if not ready, or if the pistil has been fertilized, the hairs bend over and block the way.

\section{BLUE SPIR止A}

\section{Caryopteris mastacanthus.}

Caryopteris, Greek for nut and wing; referring to the form of the seed vessels.

Stems.-Woody, one to four feet high, springing up from perennial roots.

Leaves.-Opposite, ovate or oblong, coarsely serrate, pubescent above, tomentose beneath.

Flowers.-Blue, violet, or white in axillary cymes.

Calyx.-Five-toothed.

Corolla.-Five-lobed, one segment larger and fringed.

Stamens.-Four, exserted.

Style and stigma one; fruit separating into four somewhat winged nutlets.

Caryopteris is a recent arrival in our gardens and is valuable because of its late blooming season. It produces compact bushes about two feet high, bearing along the stems opposite clusters of feathery flowers. Both foliage and flowers are fragrant. The young shoots springing up from the roots will flower profusely the same season, as will plants produced from spring-sown seed. To do well they require well-drained, sandy soil and sunny location. Native of China and Japan. 


\section{LABIAT $/$ E-MINT FAMILY}

The Mints are chiefly herbs with square stems, opposite aromatic leaves, and a more or less two-lipped corolla. Calyx persistent, five-cleft; corolla two-lipped; stamens four in two pairs; ovary deeply four-lobed, forming in fruit four little seed-like nutlets or akenes which surround the base of the single style, in the bottom of the persistent calyx; stigmas two-lobed. The inflorescence is axillary, usually in cymose clusters running into terminal racemes or spikes. Foliage mostly dotted with small glands containing a volatile oil, upon which depends the warmth and aroma of the plants of the well-known family.

\section{SALVIA. SCARLET SAGE}

\section{Sálvia spléndens.}

Salvia, to keep safe or healthy; referring to the medicinal properties of the Common Sage.

Cultivated for ornament; introduced from Brazil, there a perennial, but here an annual. July until frost.

Stems.-Erect and branching, two to three feet high.

Leaves.-Opposite, acute and acuminate.

Flowers.-Scarlet, tubular, borne in a loose terminal spike, four to six inches long; making a whorl of blossoms, from two to six flowers in a whorl.

Calyx.-Scarlet, swollen, two-lipped, with soft, short, scarlet hairs.

Corolla.-Scarlet, long, lax, somewhat swollen tube, almost fugacious; two-lipped, the long undivided upper lip covering and protecting the stamens and the style; lower lip three-lobed.

Stamens.-Two, inserted on the-corolla-tube, each bearing a halfanther at the end of a long, slender connective; the other half of the connective sterile. lets.

Ovary.-Four-parted; stigma divided. Ovary ripens into four nut- 
The Scarlet Sage is one of the most brilliant red-flowered plants in cultivation. The mass of color of a well-grown bed defies description; it is magnificent, and it is barbaric. To that wondrous flame of scarlet the top of the flower stem, the bracts, the calyx, the corolla, all contribute. The vivid color strikes the eye as the sound of a trumpet rings upon the ear, insistent, high-keyed, pervading.

The structure of the individual flower is interesting. Open a corolla in full bloom and you will find two crescent-shaped anthers together with the two-lobed stigma at the very apex of the upper lip. Extending downward is a thread-like body which seems to serve no purpose. This red thread, three-fourths of an inch long, is a lengthened connective which should normally bear at its end the other cell of the anther but does not. In ordinary flowers the connective is merely a linear extension of the filaments and barely separates the two anther cells. But in all the Salvias the anther cells are forced a very considerable distance apart, and in this case one cell of each anther is missing.

The Blue Salvia, Salvia pàtens, bears a blossom which is as vividly blue as that of Salvia splendens is scarlet. It, too, is perennial where the climate permits. Native to the mountains of Mexico it does not seem to thrive very well in our gardens.

\section{OSWEGO TEA. FRAGRANT BALM. BEE BALM}

\section{Monárda didyma.}

Monarda, after Nicholas Monardes, a Spaniard who published in

I57 $\mathrm{r}$ a book containing the earliest picture of an American plant.

A strong-growing, attractive, native perennial, bearing deep-red flowers; sparingly transferred to gardens. Suitable for the wild border or thickets; grows in clumps. Summer.

Stem.-Three to four feet high, four-angled, rough-hairy.

Leaves.-Oblong, or lance-ovate with roundish base, serrate, petioled, fragrant.

Flowers.-Two-lipped, deep-red, borne in terminal or whorled heads.

Calyx.-Tubular, elongated, many-nerved, five-toothed. 


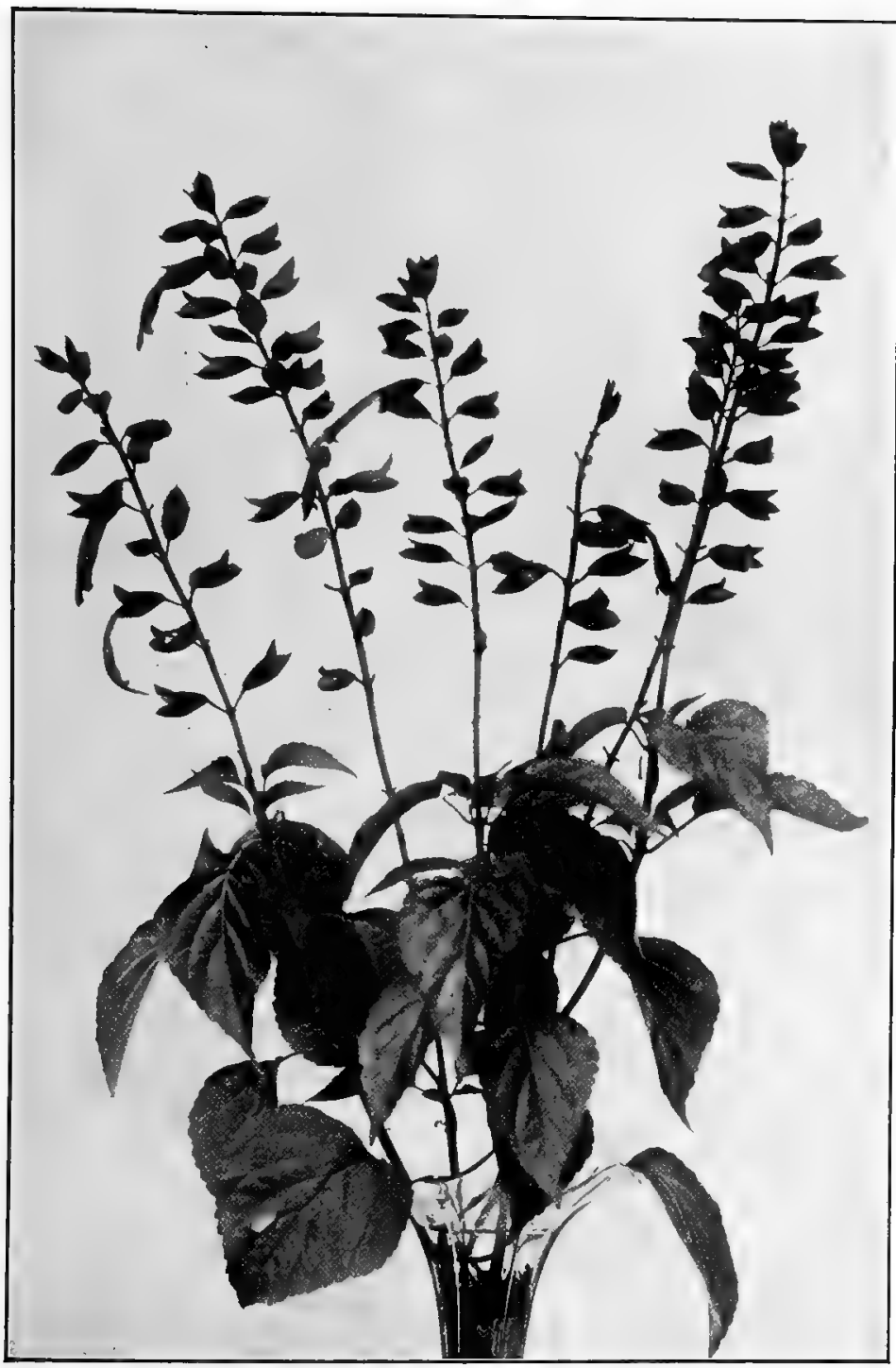

Salvia. Sálvia spléndens 
Corolla.-Deeply two-lipped, narrow in the throat, lower lip threelobed at the apex; narrow middle lobe slightly notched.

Stamens.-Two, ascending under the upper lip of the corolla; filament long, bearing a linear anther at its apex.

Ovary.-Deeply four-parted; style long; stigma two-lobed. Ovary ripens into four akenes.

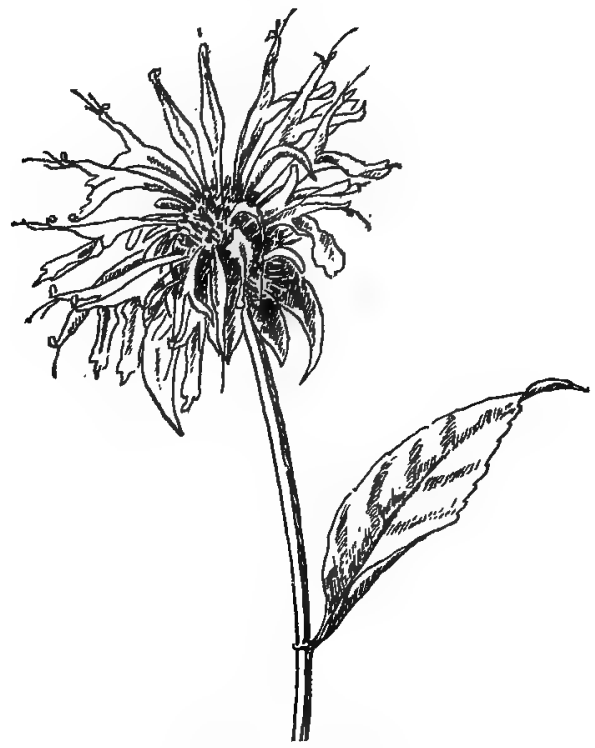

Fragrant Balm. Monárda didyma

Monarda didyma strikes a note of deeper red than most summer flowers. It is rather a coarse herb with large heads of gaping corollas, and of these not many are open at any one time. The plant grows in tufts and can be used effectively in masses. Its native haunt is wildwood tangles along the banks of streams. Its place is in the wild border or in masses against a dark background, and it grows naturally in sunny places as well as in shade.

Wild Bergamot, Monarda fistuldsa, is a plant similar to didyma, but of lower stature and bearing pale-lilac flowers. Abundant in the fields of the Middle West, and often transferred to gardens, where the stems increase in height and the heads in size. 


\section{PHYSOSTEgIA. FALSE DRAGON'S HEAD}

Physostègia virginiàna.

Physostegia, Greek for bladdery covering; referring to the inflated fruiting calyx.

A perennial plant of extensive'habitat, ranging from Quebec south and south-west, through the Mississippi Valley. Somewhat recently introduced into gardens; grows in clumps; flowers all summer.

Stem.-Square, leafy, one to four feet high.

Leaves.-Opposite, oblong, serrate.

Flowers.-Pale rose-purple, crowded upon a simple or a panicled spike.

Calyx. - Bell-shaped, five-lobed, slightly inflated in fruit.

Corolla.-Pale rose-purple, spotted with darker dots, three-fourths of an inch to an inch long, funnel-shaped, slightly swollen, open-throated, twolipped; upper lip inflated, nearly entire; lower lip three-lobed; middle lobe the largest.

Stamens.-Four, in two pairs under the upper lip; outside pair the longer.

Ovary.-Four-lobed; style one; stigma two-lobed.

Fruit.-Four nutlets at the base of the inflated calyx.

Physostegia virginiana is proving itself a good summer-blooming plant. The flowers, of the gaping

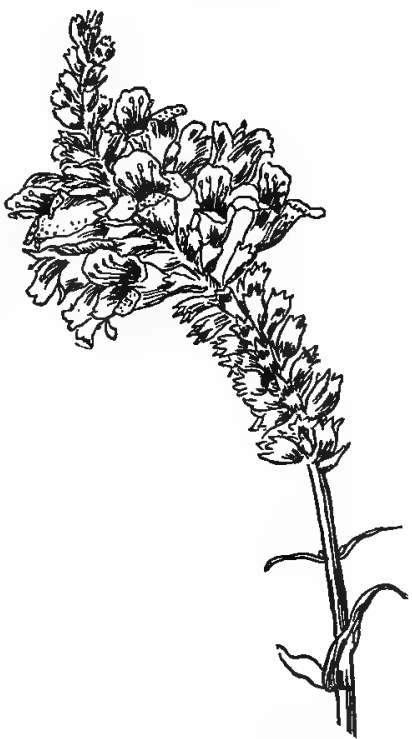

Physostegia. Physostègia virginiana labiate type, are borne in long crowded spikes, and range in color through rosy-pink and lilac to white. A spicate inflorescence may be regarded either as an advantage or an objection to a plant. It certainly lengthens the blooming period, which may be charged to its credit; on the other hand, the buds, the bloom, and the seed vessels are always together-the representatives of the past, present, and future, all the time in evidence. 


\section{GARDEN COLEUS}

\section{Coleus hýbrida.}

Coleus, Greek, sheath; referring to the monadelphous stamens.

A group of bedding plants with brilliantly colored leaves, tender to frost.

Stems.--Square, erect, more or less branching.

Leaves.-Opposite, ovate, sharply and regularly toothed, variously colored with red, yellow, and purple.

Flowers.-Two-lipped, small, borne in a terminal spike-like raceme.

The original of the garden race of Coleus was a plant introduced from Java, called Coleus Blimei, and from this species, more or

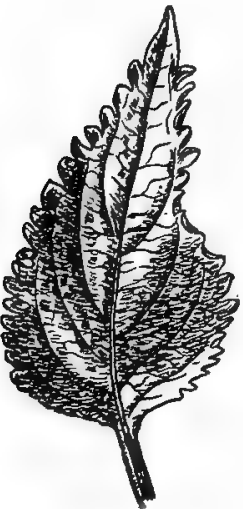

Coleus. Caleus hýbrída

less hybridized with two others, all our garden forms are derived. The variety and brilliancy of the color variations of the leaves are wonderful, and the plants have enjoyed great vogue for beds and borders.

The objections to them lie in the fact that they require a long season, sometimes burn in hot summers, have a weedy habit, and the leaves fall with the first frost; so that they often stand a row of leafless stalks around a flower-bed in which such plants as geranium and vinca are still strong and vigorous.

They are tolerant of the shears, which is one virtue that helps to keep them in place.

Perilla nankinensis is an ornamental foliage plant very similar to Coleus in habit and general appearance. The foliage is dark metallic-bronze, almost black, and is now used considerably for ribbon effects.

Other Labiate in cultivation are:

Rosemary, Rosmarinus, Sea-dew, a half-hardy little shrub, native to the Mediterranean region, which has been prized for ages because of the aromatic fragrance of its leaves. These are 
numerous, linear, with revolute margins. Flowers small, blue, two-lipped, axillary in short racemes. It is difficult to explain the esteem in which Rosemary was held during the Middle Ages, unless it was an inheritance from the Roman times, for it is known that the Romans employed Rosemary in their religious ceremonies and burned it as incense in their temples. Sir Thomas More writes: "As for Rosemarine, I lett it runne all over my garden walls, not onlie because my bees love it, but because it is the herb sacred to remembrance, and therefore to friendship; whence a sprig of it hath a dumb language that maketh it the chosen emblem of our funeral wakes and in our buriall grounds." Ophelia says: "Here's rosemary for you, that's for remembrance."

Sweet Lavender, Lavendula vèra, is a little shrub with narrow, oblong, entire leaves, revolute at the margin; the younger ones often clustered in the axils of the older. The foliage is grayish-green, abundant, and in midsummer surmounted by

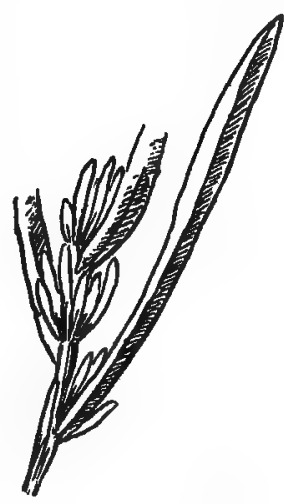

Sweet Lavender. Lavéndula vèra flowery stems bearing many whorls of small, blue flowers; the whole forming a slender interrupted spike four to six inches long. The pleasant aromatic odor of the leaves has long made it a garden favorite. The plant is one of the sweet herbs native to the Mediterranean region; is extensively cultivated in southern Europe for its essential oil, which is used in the manufacture of perfumery, aromatic vinegar, and lavender water.

The generic name, Lavendula, from lavo, to wash, refers to the ancient use of its flowers and leaves in bath perfumery.

Catnip, Népeta catària, is a familiar weed by the roadside and in fence corners. A perennial, with leafy and branching stems two to three feet high, bearing heart-shaped, crenate, gray-green leaves. The flowers are small, purplish, two-lipped, crowded in a dense terminal. The entire plant is pleasantly aromatic, and cats 
are fond of it. Catnip tea once had a place among domestic remedies for children.

Ground Ivy, Gill-over-the-ground, Népeta glechdma, has escaped from cultivation and may be found on roadsides and lawns. It clings to the ground and makes a dense mat, sending out its long, creeping stems to possess

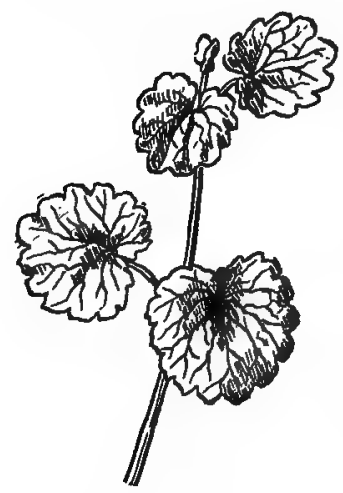

Ground Ivy. Népela Glechòma the land. The leaves are roundish and dentate. The flowers small, blue, two-lipped, in few-flowered axillary whorls. An excellent cover plant, but frequently out of bounds.

Dead-nettle, Làmium maculàtum, a perennial labiate, often used as a border plant, has sparingly escaped to the fields. The leaves are roundish, dentate, frequently marked with a white.spot; the flowers two-lipped, purplish, and borne in the axils of the leaves. Three other species are found as weeds in cultivated grounds: Lamium album, with white flowers, and Lamium purpireum and Lamium amplexicaule, both with small purple flowers.

Hedge-nettle, Stàchys lunàta, an erect tufted plant, stem and leaves covered with thick and silvery-white wool, is frequently used as an edging plant. It comes to us from Europe. 


\section{SOLANÀCEA--NIGHTSHADE FAMILY}

The Nightshade family is, in the main, a family of narcoticpoisonous plants, largely tropical; it has but few genera indigenous to our range; yet it contributes to our cultivation the Potato, Tomato, Egg-plant, Capsicum, and Tobacco, a record of usefulness excelled only by Graminea, the Grass Family.

The plants are herbs with colorless juice and alternate leaves; flowers on the plan of five; five lobes to calyx and corolla; five stamens; ovary two to five-celled and style and stigma one.

Among ornamental plants are Petunia, Salpiglossis, Nicotiana, Browallia, Datura, and the trailing shrub, Matrimony Vine.

\section{PETUNIA}

\section{Petùnia hýbrida.}

Petunia, from Petun, an aboriginal name of tobacco; given to the genus by Jussieu..

A garden race of hybrid annuals, derived principally from two South American species, Petunia nyctaginiflòra and Petunia violàcece. Early summer until late autumn.

Petunia nyctaginiflora was discovered on the banks of the Rio de la Plata in 1823 by Commerson; still found in cultivation.

Stem.-Tall, relatively stout, usually erect, viscid-pubescent.

Leaves.-Rather thick, oblong-oval, sessile or petioled, clammy with hairs.

Flowers.-Dull-white, salver-formed, fragrant at evening.

Calyx.-Viscid-pubescent, five-lobed; lobes acutr

Corolla.-Salver-formed, slightly irregular; border five-lobed; lobes marked with greenish lines running from margin down the tube. 
Tube.-Several times longer than calyx, gradually swelling to the throat, pubescent.

Stamens.-Five inserted on corolla-tube; filaments slender, bearing the anthers at the throat.

Ovary.-Many-ovuled.

Petunia violacea, native to Argentina, smaller than Petunia nyctaginiflora, of neater habit; has been lost to cultivation and appears only in its hybrids.

Stem.-Slender decumbent, viscid-pubescent.

Leaves.-Oval or ovate, sessile or petioled.

Flowers.-Salver-formed, violet-purple or rose-red border, five-lobed; tube short, broad, and somewhat swollen.

Our garden Petunia has a most interesting history, which is admirably given by Prof. L. H. Bailey in his "Survival of the Unlike." He writes: "The modern Petunia is a strange compound of the two original species which were introduced to cultivation less than three-quarters of a century ago. The first Petunia to be discovered was found by Commerson on the shores of the La Plata in South America, and from the dried specimens which he sent home the French botanist, Jussieu, constructed the genus Petunia and named the plant Petunia nyctaginiflora in allusion to the Four-o'clock-like flowers.

"This plant appears to have been introduced into cultivation in 1823. It is a plant of upright habit, thick, sticky leaves and sticky stems, and very long-tubed white flowers which exhale a strong perfume at nightfall. This plant nearly or even wholly pure is not infrequent in old gardens, and fair strains of it can be had in the market.

"This old-fashioned Petunia is a coarse plant and is now but little known.

"The second species of Petunia first flowered in the Glasgow Botanical Garden in July, I83 1 , from seeds sent the fall before from Buenos Ayres by Mr. Tweedie, and in $183 \mathrm{I}$ an excellent colored plate of it appeared in the Bolanical Magazine, under the name Salpiglossis integrifolia. This is a more compact plant 


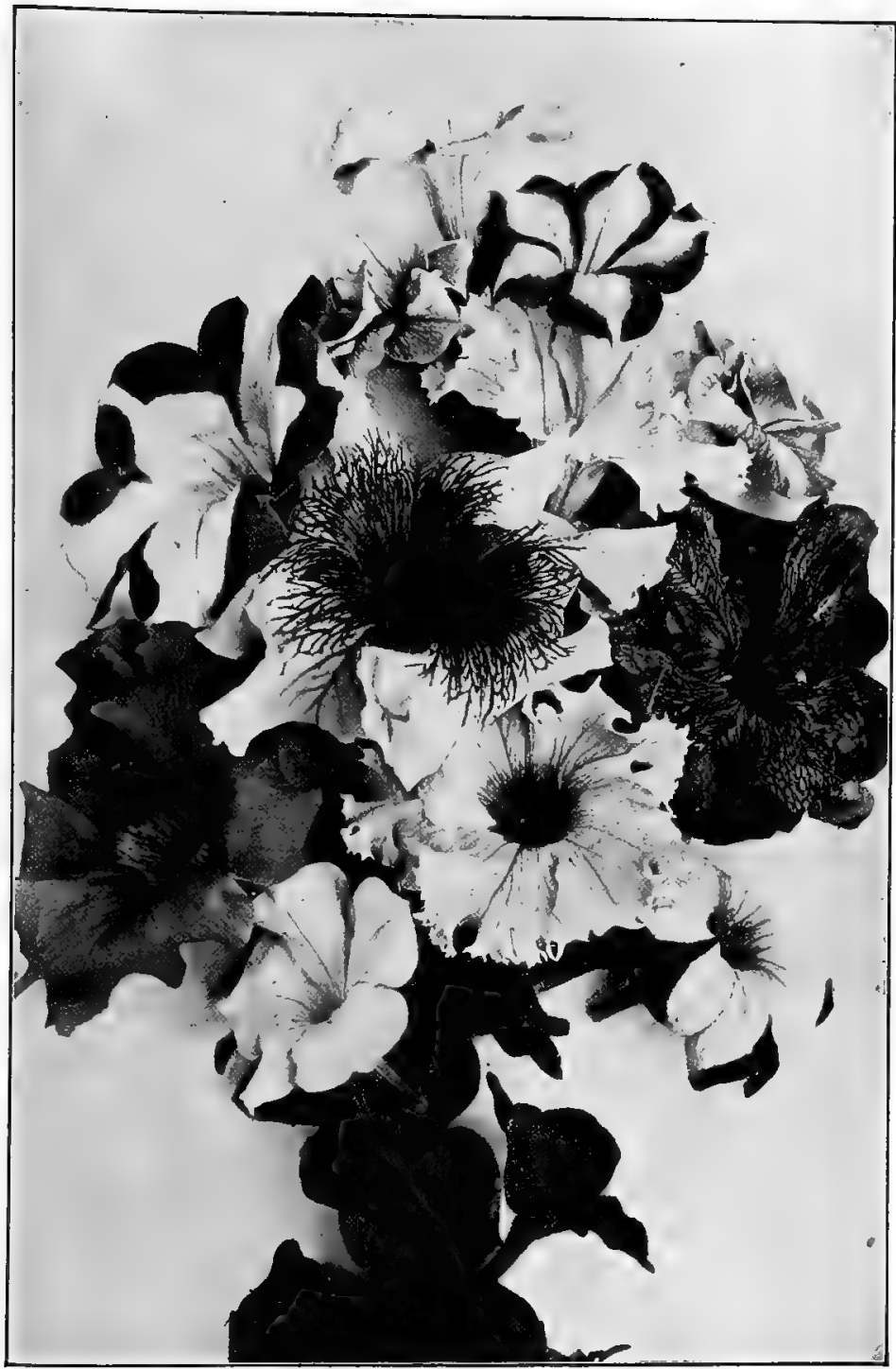

Petunia in variety. Petìnia hýbrida 
than the other, with a decumbent base, narrower leaves, and small red-purple flowers, which have a very broad or ventricose tube scarcely twice longer than the slender calyx lobes. This little plant has been known under a variety of names. Lindley was the first to refer it to the genus Petunia and called it Petunia violacea, the name which it still bears.

"Petunia violacea early hybridized with the older White Petunia, Petunia nyctaginiflora, and as early as 1837 a number of these hybrids-indistinguishable from the common garden forms of the present day-were illustrated in colors in the Botanical Magazine. Sir W. J. Hooker, who described these hybrids, declared that it must be confessed that here, as in many other vegetable productions, the art and skill of the horticulturist had improved nature. Here then our common Petunias started as hybrids, but the most singular part of the history is that the true old Petunia violacea is now lost to cultivation." It could, of course, be recovered from its native land were it worth while.

The Petunia of present cultivation seems to have divided into two fairly distinct classes-one a class of general utility plants, represented by the single mixed Petunias of the garden; the plant rather low and slender and the colors sporting in every combination of the red-purple and white of the original parents. These make beds in sunny sandy places, and grow where other plants will not.

The other class may be considered plants of high degree. They are the result of careful culture and hybridization, attained with difficulty and continued only by unceasing care. They are marvellously variable in size, form, and color. In some of the strains the flower is very broad and open, measuring four or five inches across. There are types with star-like markings radiating from the throat and extending to the margin of the border; there are flowers deeply fringed and ruffled; there are others fully double.

The most noted of the latter forms are the California Giant Petunias which were developed by Mrs. Thomas Gould, of Ventura, California, in I888. They embody the application of intelligence, skill, and patience to a wonderful degree. No two Petunia 
plants of this strain give blossoms of the same kind and no one can know what he has until the plant blooms. Only a small proportion of the seedlings of any double strain will bear double flowers, but the single flowers are often of superior size and color. The reason for this lies in the fact that the seed must be selected from single flowers, as the full doubles do not produce seed. Single flowers carefully pollinated with pollen from double flowers will give seed that

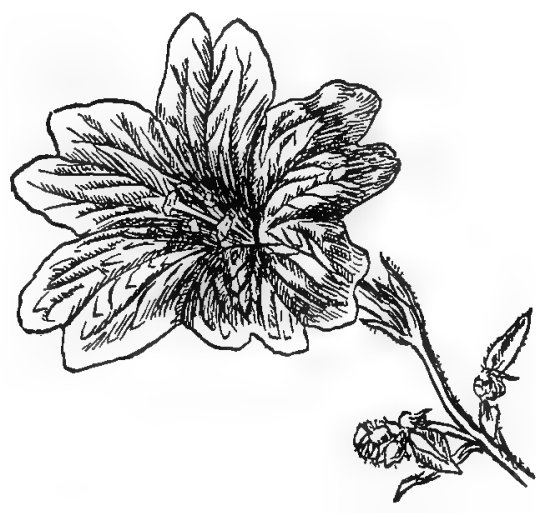

Salpiglossis. Salpiglóssis simiàta will produce an average of twenty-five per cent. doubles. Fancy varieties may be propagated by cuttings, yet so unstable is the strain that the cuttings of double forms do not always come true.

Petunias deserve a place to themselves; they are sure bloomers, will tolerate almost any location, except dense shade or a swamp; if soil is good, large flowers may be expected; if poor, blooms will be smaller, but they will appear, notwithstanding.

\section{SALPIGLOSSIS}

Salpiglóssis sinuàra.

Greek for trumpet-tongued; in reference to the shape of the stigma.

A striking annual; in appearance resembling a petunia, but of taller growth and having an unusual range of color. Chili. Summer and late autumn.

Stem.-Two feet high; branching, sticky, with glandular hairs.

Leaves.-Alternate, various, not abundant on the stems. 
Flowers.-Funnel-shaped, open-throated, two inches across, slightly irregular, five-lobed; each lobe with a notch, and ranging in color from various shades of purple and blue, through reds and yellows, to creamwhite, beautifully pencilled and veined with darker colors.

Calyx.-Tubular, five-cleft, hairy.

Corolla.-Funnel-shaped with slender tube for half its length, then suddenly swelling; lobes five, plicate, emarginate, full of nectar at the base.

Stamens.-Four, in two pairs, inserted on the tube at the point where it begins to enlarge; fifth stamen a sterile filament.

Ovary.-Oblong; style slender; stigma dilated.

Salpiglossis attracts attention anywhere because of the riot of color presented by the bloom. Purple, blue, red, yellow, orange, and cream, in bewildering combinations, and then each flower veined and pencilled with darker lines than the basic color. - In fact, when the plant was first introduced, species were set apart based upon color alone; but these, of course, have been given up.

Salpiglossis is easy of cultivation, blooms in midsummer and on into late autumn. The plants should be grown in masses, as the bare stems make a single individual look weedy.

\section{NICOTIANA}

\section{Nicotìna ald̀ta.}

Named in honor of John Nicot, French Ambassador to Portugal in the sixteenth century, who was instrumental in spreading a knowledge of tobacco.

One of the best garden species of garden Nicotiana, called both alata and affinis in the catalogues. From two to four feet high, bearing long, white, tubular, fragrant flowers which open toward evening and continue through the night, closing after sunrise. Entire plant more or less pubescent. Blooms until winter.

Stem.-Slender, strong, viscid-pubescent, three feet high.

Leaves.-Lance-obovate or ovate-elliptic, the upper one lanceolate, the lower one narrowed into a petiole-like base which is dilated where it joins the stem.

Flowers.-Remote, in a wand-like raceme, white, salver-form, with slender tube three inches long. 
Calyx.-Downy, tubular, slightly swollen, five-angled, five-toothed; teeth slender and pointed.

Corolla.-Salver-shaped; border oblique, five-lobed, white, two inches or more across. Tube three inches long, slender, white or greenish outside, pubescent.

Stamens.-Five inserted on the tube; anthers appearing at the throat. Ovary.-Oblong; style slender; stigma capitate.

Seeds.-Minute.

Nicotiana alata is a deservedly popular plant of easy culture and beautiful bloom. It bears pure-white, star-shaped, tubular flowers whose beauty is not apparent by day, as they are not at their best until the sun is on the wane. By day a blooming plant is a disheartened, dishevelled, unhappy-looking creature; the coming blossoms at midday are greenish-yellow, flaccid, drooping, and immature, but as nightfall approaches, their attitude changes; they become white, stiff, alert, expectant, and pour forth a wealth of fragrance upon the evening air,

from buds that keep Their odor to themselves all day, But when the sunlight dies away Let the delicious secret out To every breeze that roams about.

\section{The individual blossom has}

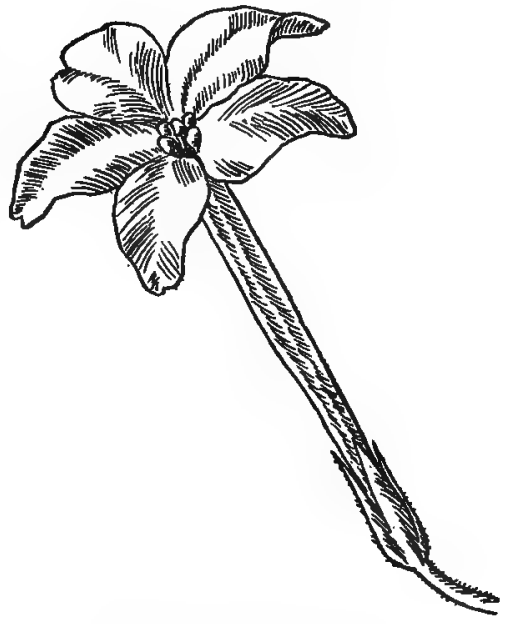

Nicotiana. Nicotiàna alàta the pure-white and something of the poise of Narcissus poeticus. Nicotiana possesses two unexpected qualities. The blooming stalks are admirable as cut flowers; they should be gathered by day and kept in an abundance of fresh water; every bud will open in time, and, curiously enough, will remain open all day if removed from direct sunshine.

The second unexpected virtue is its value as a winter house- 
plant. It must have room and must be fed, but, given these conditions, it blooms all winter and is superb at night.

Of other Nicotianas the Sanderce hybrids are an excellent type of day-blooming flowers in great variety of colors; and Nicotiana sylvéstris gives a good account of itself. A well-grown specimen of Nicotiana tobacum, the common field tobacco, is most satisfactory where a sentinel or pillar-plant is desired.

\section{DATURA. TRUMPET-FLOWER. HORN OF PLENTY}

Datura fastudsa hort. cornucdpia.

Datura, Arabic name of obscure meaning.

The Datura cormucopia has been known in American gardens since 1895, when it was found in South America by an orchid collector of the United States Nursery Company, and by them widely distributed. Annual. Midsummer.

Stem--Two to five feet high.

Leaves.-Ovate-lanceolate, unequal at base, toothed or wavy.

Flowers.-Trumpet-shaped, six to seven inches long, often two or three well-defined trumpets, one within another.

Calyx-Five-lobed.

Corolla.-Funnel-form, strongly plaited in the bud, and with five or more pointed teeth.

Stamens.-Five.

Ovary.-Globular; style slender; stigma two-lobed.

Pod.-Globular, prickly; seeds large and flat.

Botanically the Daturas of the garden are confused, but horticulturally there is very little doubt about them. They are tropical plants that can be successfully treated as annuals. The size of the flower makes them interesting and especially their aptitude in doubling. Sometimes one long tube fits into another until there are three, the inner one being the longer; sometimes the outer trumpet is simply filled with a confused mass of petalage. The Datura naturalized with us is the rank weed known as the Jimson Weed, Datura stramonium. Upon the return of the settlers 


\section{DATURA}

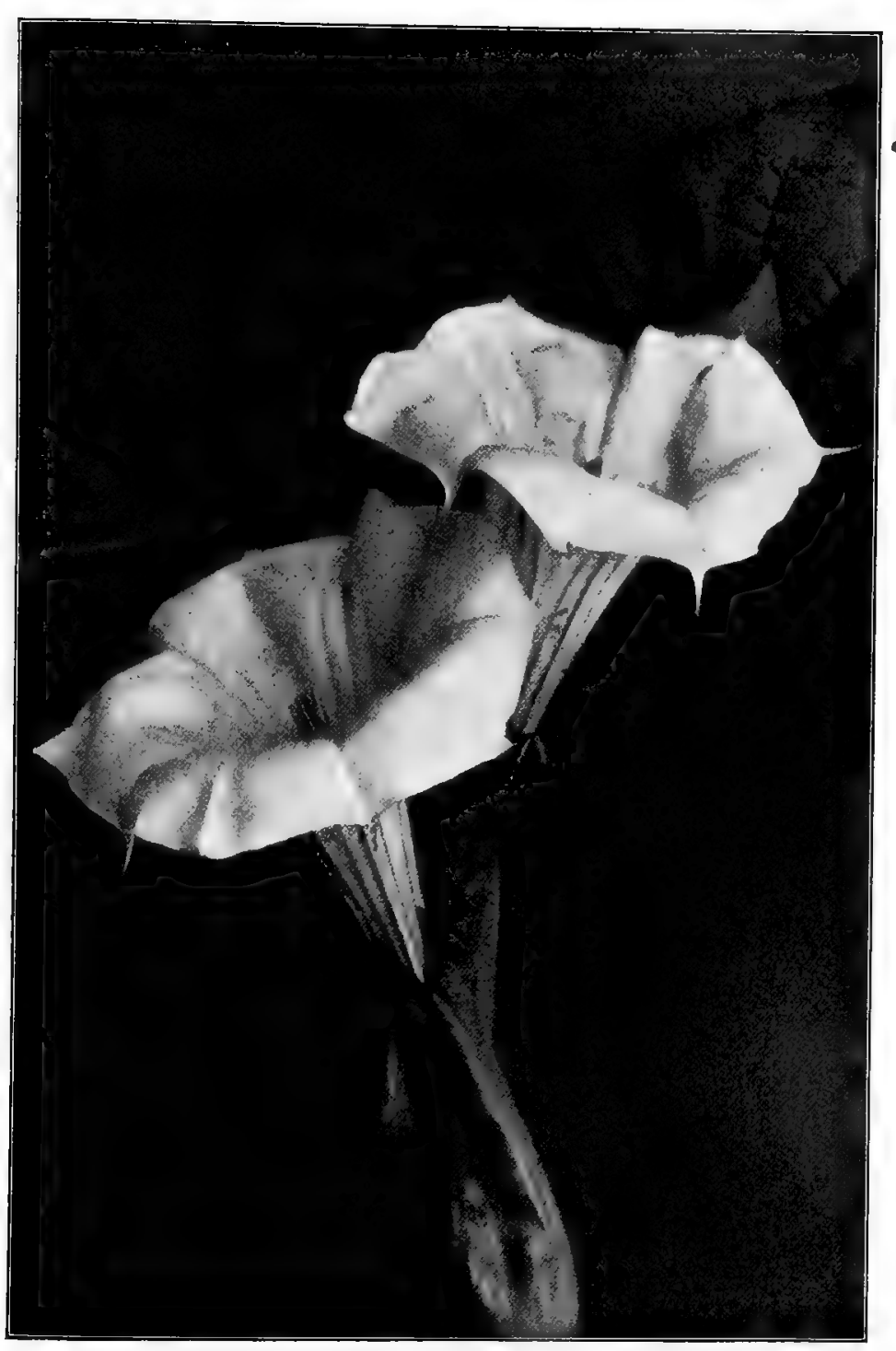

Datura. Datìra fastuòsa var. cornucòpia 
to the deserted foundations of Jamestown, in I609, Captain John Smith reported the presence there of this weed, which doubtless came in ballast, or at least surreptitiously. The plant is un-

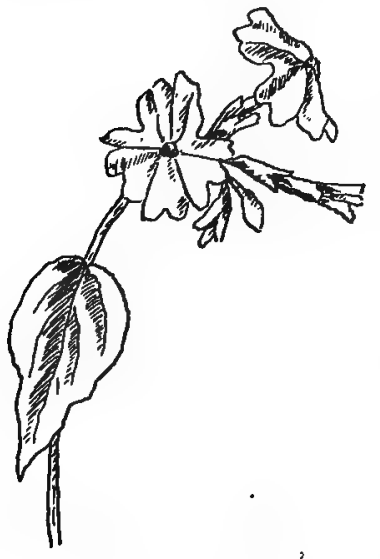

Browallia. Browallia demíssa questionably Asiatic and the books refer its wide distribution to the gypsies, as it has been a favorite medicine of theirs for ages; at least, that indicates one path by which it might have reached its world-wide dissemination.

\section{BROWALLIA}

Browallia demissa. Browállia elata.

Named in honor of Dr. John

Browall, at friend of Linnæus.

An annual South American plant, one to two feet high, blooming abundantly in midsummer.

Stem.-Erect, branching, bushy.

Leaves.-Alternate, usually ovate; margin entire, often variable.

Flowers.-In loose racemose clusters, terminal or axillary, blue with white centre, somewhat irregular.

Calyx.-Tubular, five-toothed.

Corolla.-Salver-shaped; tube an inch long, slightly swollen at the throat; border of five, broad, notched lobes.

Stamens.-Four, in pairs, included within the throat, and inserted on the tube.

Ovary.-Two-celled; style slender; stigma a small, flattened head.

Browallia is a plant of midsummer bloom; its abundant flowers, held up on terminal and axillary stems above the mass of foliage beneath, give a blue shimmer over the bed through all the long, hot days of August.

The individual blossom is slightly irregular, looks as if it had started to be two-lipped, but had thought better of it; the best forms are of a brilliant violet-blue, with a dash of white at centre. 
The plant was named by Linnæus in honor of Dr. John Browall. While the two were friends it was Browallia elata, but after they quarrelled, Linnæus changed it to Browallia demissa, the name it still bears in the books.

\section{MATRIMONY VINE}

Lícium vulgàre.

Lycium, from Lycia, the home of the type.

A somewhat spiny shrub, with long, slender, climbing or trailing branches, often trained upon a wall or upon the side of the house. Western Asia. Summer and autumn.

Stem.-Spiny; branches weak, long, slender, recurved or climbing.

Leaves.-Small, alternate, oblong or obovate, entire, commonly with smaller ones clustered in their axils.

Flowers.-Pale-purple, solitary or clustered in the axils, fading to dull yellow.

Calyx.-Bell-shaped, three to five-lobed, persistent.

Corolla.-Funnel-form, spreading, pale purple aging to yellow, four or five-lobed.

Stamens.-Five, exserted.

Ovary.-Two-celled; style thread-like; stigma capitate.

Fruit.-Oval berry, orange-red.

The Matrimony Vine has neither tendrils nor twining habit, but when trained to supports on a veranda or house wall,

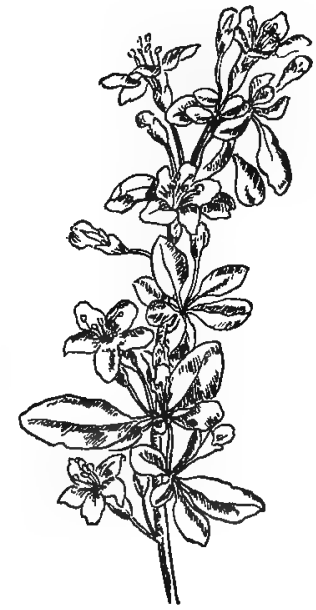

Matrimony Vine. Lýcium vulgàre the effect is good. The common name is suggested by the flowers in the axils of the leaves growing side by side. The fruit is very decorative in autumn.

Lycium chinénse, a recent acquisition of our gardens, is desirable because of its larger scarlet berries. 


\section{BUTTERFLY FLOWERS}

\section{Schizanthus pinnàtus.}

Schizanthus, Greek, split-flower, from the split corolla.

An annual herb with finely cut leaves and terminal open cymes of highly colored flowers with deeply cut petals. Variable, with many horticultural varieties. Chili. May, June.

Siem.-Erect, branching and spreading, two feet high, rather weak. Leaves.-Alternate, once or. twice-pinnate or parted into narrow divisions.

Flowers.-In type violet or lilac.

Calyx.-Deeply five-cleft, the divisions narrow, hairy.

Corolla.-Somewhat two-lipped; border oblique, wide-spreading; the smaller lip three-parted; the larger five-cleft and the lobes cut or notched; the middle lobe of the smaller lip more or less hooded.

Stamens.-Two, exserted; two or three others small and aborted.

Ovary.-Oval, two-celled; style slender.

The Butterfly Flowers are all dainty plants; three species are cultivated, but Schizanthus pinnatus with its variants is the one commonly found in gardens. The lower lip is violet or lilac, the upper lip paler, its middle section with a yellow blotch at base, and spotted with purple or violet. The garden varieties range from pure-white to dark-purple, through violet and rose, with various markings. The character both of foliage and flowers is lightness and delicacy, which should be considered in placing the plant.

\section{TOMATO}

\section{Lycopérsicum esculêntum var. vulgàre.}

Lycopersicum, wolf-peach; probably an allusion to its inferiority compared to the peach.

The common garden Tomato of North America. Probably perennial, but in cultivation treated as an annual. Tender to frost; marked by a peculiar and characteristic odor. 


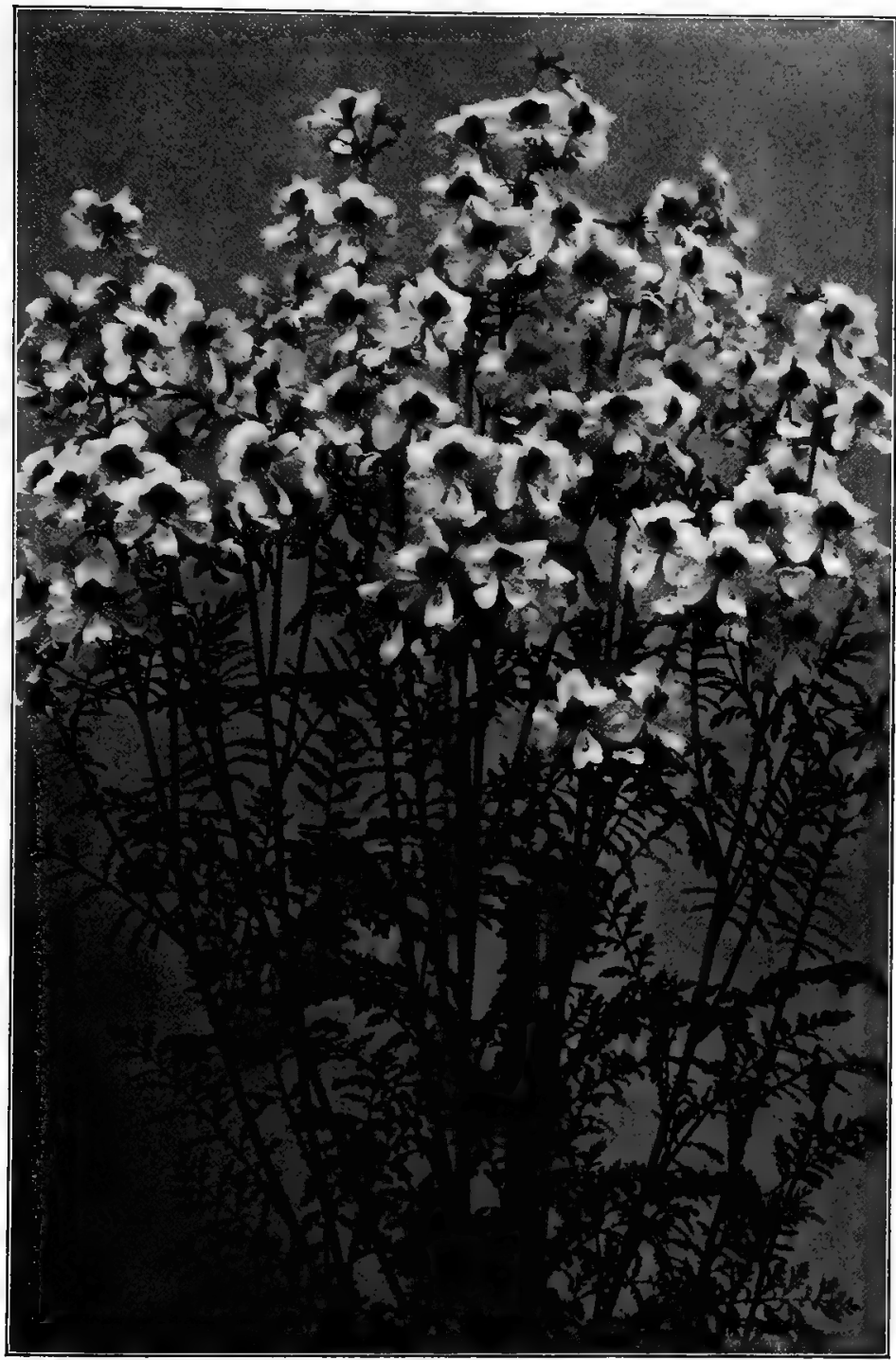

Butterfly Flower. Schizanthus pinnàtus 


\section{NIGHTSHADE FAMILY}

Stem.-Spreading, straggling, hairy, leafy.

Leaves.-Irregularly or interruptedly pinnate, varying in different garden forms. Leaflets of different sizes and shapes, main leaflets more or less notched or lobed.

Flowers.-Yellow, star-like, borne in few-flowered forking racemes, axillary.

Calyx.-Of five to six sepals, persistent in fruit.

Corolla.-Rotate, yellow, border five to six-lobed, plicate-valvate.

Stamens.-Five or six inserted on corolla-tube; filaments short; anthers grown together, tips spreading.

Ovary.-In primitive, two-celled; in present garden forms manycelled. Style short; stigma obscurely three-lobed. Ovules many.

Fruit.-A many-seeded berry-the garden tomato, red or yellow.

The primitive form of our garden Tomato is a plant native to the

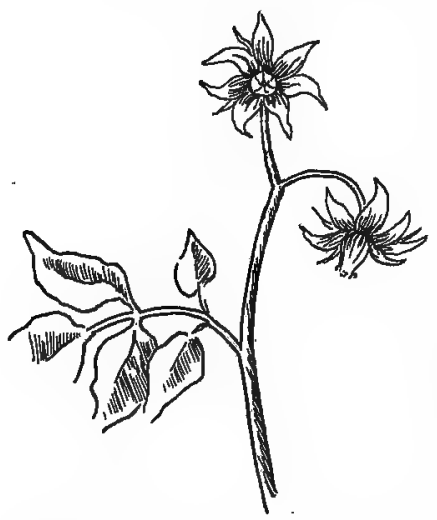

Garden Tomato. Lycopersicum vulgàre western side of South America. It has been under cultivation at least three hundred years; two hundred years ago both red and yellow varieties were known. Notwithstanding this long period, the great development of the Tomato occurred in the last half of the nineteenth century, giving rise to the present garden race. Inasmuch as all the efforts of the gardeners have been directed toward the development and the improvement of the fruit, what changes have occurred in the habit of the plant, in the flower and leaf, have been casual and permitted rather than sought.

Considerable variation in the leaves marks the different members of the garden race, but the flowers have varied little from the primitive. This follows the solanum type; the five or sixpointed yellow star, the corolla-lobes alternating with the green lobes of the calyx. The large anthers grown together make the conical tube in the centre, and out of the aperture at the summit 
protrudes the tiny green style with its green stigmatic head, surrounded by the spreading tips of the anthers. The fragrance of the leaves is marked and characteristic.

\section{POTATO}

Sol̀̀num tuberòsum.

Root.-Produces subterranean stems which bear tubers.

Stem.-Branching, somewhat decumbent.

Leaves.-Pinnatifid, unequally and interruptedly.

Flowers.-Borne in loose panicles, white or pink. .

Calyx.-Five-cleft, hairy.

Corolla.-Rotate, tube short, border with five shallow lobes, more or less gathered or frilled.

Stamens.-Five, set closely at the throat of the corolla; anthers coming together, making a cone.

Ovary.-Two-celled; style short; stigma capitate.

Fruit.-A berry.

If the Potato were not such a common field plant we might sometimes gather its flowers, for in early summer the Potato field is dotted over with clusters of beautiful goldencentred white stars. The story goes that the Potato was rejected with scorn in France, until Louis XV recommended it by wearing amidst his courtiers a bouquet of its flowers.

The economic value of the plant lies in its peculiar habit of developing slender white underground sterns which gradually swell at the free end and produce the tubers with which we are so familiar. The stem nature of these tu-

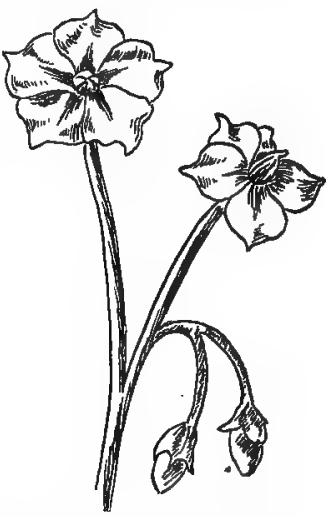

Potato. Sold̀num tuberòsum bers is made evident by the development of eyes or leaf buds. Few plants possess this remarkable power, and the Potato possesses it to the highest degree of any plant known. 
The Potato was developed by the aborigines of South America; the Spaniards met with it first in the neighborhood of Quito, where it was cultivated by the natives and an important article of food among them. It was found elsewhere, was sent first to Spain, then made its way into England, and its tubers are now part of the daily food of a large portion of the human race. These tubers are the only edible part of the plant; the lcaves, fruit, and even the buds which spring from the eyes of the tuber contain solanine, a poisonous substance.

\section{NIGHTSHADE. BLUE BINDWEED}

Solàmum dulcamàra.

Solanum, quieting; in reference to the poisonous character of the genus.

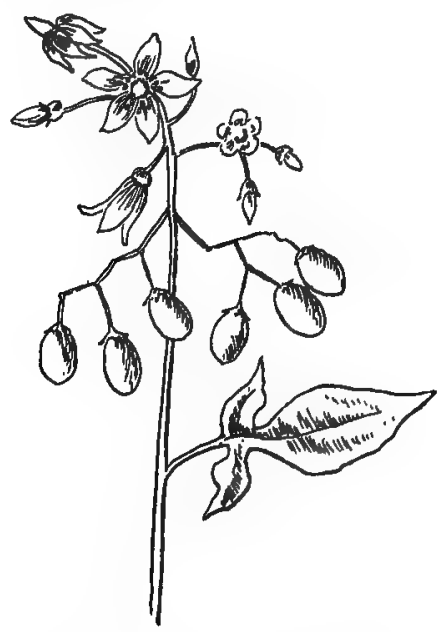

Nightshade. Soldnum dulcamdra

A perennial vine in waste places, moist banks, and around dwellings. Naturalized from Europe. Summer.

Stem.-Climbing and straggling, woody at base.

Leaves.-Ovate or hastate in outline, acute or acuminate, entire, three-lobed or three-parted, with the terminal segment much the largest. 398 
Flowers.-Blue, purple, or white, borne in compound cymes.

Calyx.-Bell-shaped; lobes short, obtuse, persistent at the base of the berry.

Corolla--Rotate, five-lobed; lobes triangular-lanceolate.

Stamens.-Five, inserted on the throat of the corolla; anthers oblong, grown together into a cone and discharging pollen by a terminal opening.

Ovary.-Two-celled; style slender, protruding from the anther cone; stigma small.

Fruit.--Oval or globose berry, red, shining.

This is the errant vine so often found about dwellings, whose pretty blue blossoms and shining red berries are so attractive to children. The berries are so pretty that it seems as if they ought to be good to eat, and children are warned with many repetitions that they are poisonous.

Other species of Solanacece are:

Three species of the Cup-flower, Nierembergia, all excellent for use in hanging baskets and veranda porches. Their name is a tribute to the name and virtues of John E. Nieremberg (I490-I563), a Spanish Jesuit, and first professor of natural history at Madrid. They are perennials from South America, closely allied to the petunia and characterized by the long and very slender tube of the corolla. Possibly Nierembergia gracilis, bearing white flowers with purple centre, is the favorite. This has varied into several garden forms. The two other species are frutéscens and rivulàris.

The Ground Cherry, Phýsalis alkekéngi, sometimes called the Strawberry Tomato, is an old garden plant grown for its brightred inflated calyx, which surrounds the cherry-like fruit. It is perennial, but grown at the north as an annual. The variety Franchêti, called the Chinese Lantern Plant, has a larger and more showy calyx. The species is native from south-eastern Europe to Japan. The flowers are of the solanum type.

Among plants of economic value is the Red Pepper, Cápsicum annuum, native of Chili, cultivated for the large or small, oblong or 
globular, dry berry which is exceedingly pungent and used as a condiment. Leaves ovate, entire; flowers white. Has varied into many garden forms.

Solànum melongèna var. esculentum is the common cultivated species, which produces the fruit known as Egg-plant. It has come to us from India. Several varieties are in cultivation.

Jerusalem Cherry, Solànum pseùdo-cápsicum, is a shrubby house plant from Madeira, cultivated for the ornamental brightred berries which are produced abundantly and which will remain upon the branches of the tiny tree for months. The leaves are oblong and entire, the small white, starry flowers solitary or in small lateral clusters. It has varied into several garden forms. 


\section{SCROPHULARIÀCE/E-FIGWORT FAMILY}

The Figworts are herbs with irregular, mostly two-lipped flowers; stamens two to five, but usually four in two pairs, and inserted on the corolla-tube. The ovary is two-celled, manyseeded, with a single style and a two-lobed stigma. Many of the flowers look like Labiates, but may always be distinguished by the ovary which, in the entire Labiate family; is deeply fourlobed.

\section{SNAPDRAGON. ANTIRRHINUM}

\section{Antirrhinum màjus.}

Antirrhinum, Greek, like a snout; from the shape of the corolla.

Perennial, but usually biennial under cultivation; native to the regions about the Mediterranean. Has escaped from garden's in the Atlantic States. June to September.

Stems. - One to three feet high, branched.

Leaves.-Alternate, oblong or lanceolate, entire, sometimes variegated.

Flowers.- Large, in variety of colors, borne in erect terminal racemes.

Calyx.-Five-parted.

Corolla.-Tubular, saccate at base, closed at the throat by a projecting palate; two-lipped with spreading, irregular lobes.

Stamens.-Four.

Ovary.-Two-celled; style one.

Capsule.-Many-seeded.

The cultivated Snapdragon is an interesting plant that has been improved and petted and coaxed and bullied until it has become virtually one great flowering stalk thickly set with blossoms, whose dropsical bodies and swollen throats have little charm 
separately, but the groups in mass give fine banks of color; reds, yellows, and whites.

The corolla is two-lipped, and the elastic force with which the

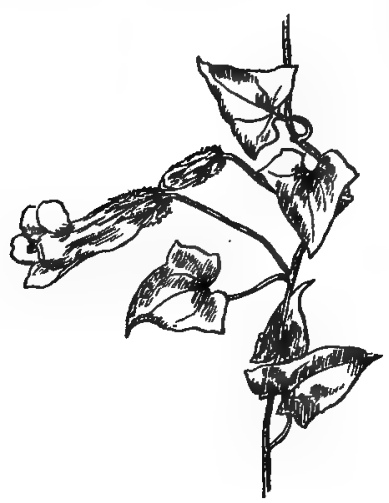

Maurandia. Anlirrhinum maurandioides lower lip closes and fits upon the upper is surprising. The nectar call is to the bee, and the bee responds. She alights on the lower lip, her weight opens the mouth; hidden for a moment she emerges rich in nectar and covered with pollen, only to plunge into the next flower.

Maurandia, Antirrhinum maurandioides, is a vine which climbs by means of its coiling petioles and peduncles; and bears pretty, snapdragon, violet flowers in the axils of the halberd-shaped, three-lobed leaves. Its sprays often sway from window boxes and baskets where it finds a summer home.

\section{TOAD-FLAX. BUTTER-AND-EGGS. RAMSTEAD WEED Linària vulgàris.}

From Limum, flax, which the leaves of some species resemble.

A perennial herb, now regarded as a weed, one to three feet high, with gray-green leaves and yellow flowers in a terminal raceme. Europe.

Flowering-stem.-One to three feet high.

Leaves.-Alternate, numerous, linear, gray-green.

Flowers.-Yellow and orange in a terminal raceme.

Calyx.-Five-parted.

Corolla.-Tubular, spurred, two-lipped, palate nearly closing throat. Stamens.-Four.

Ovary.-Two-celled; capsule opening below the summit by two pores. Seeds.-Many, winged. 


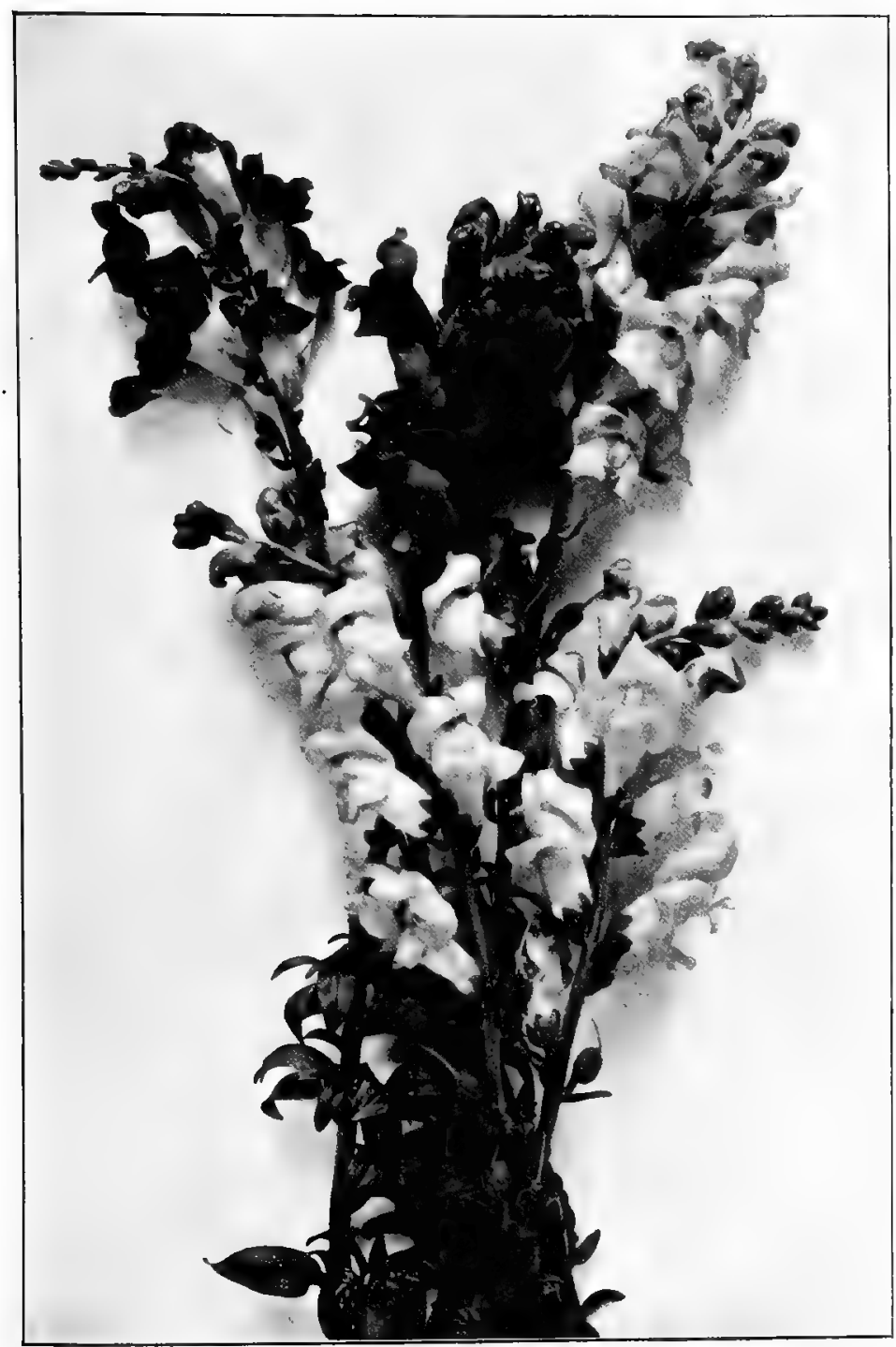

Snapdragon. Antirrhìnum màjus 
A well-known and beautiful outcast from the garden. Doubtless it would have come to us at any rate, but the story goes that Mr. Ramstead, living in the suburbs of Philadelphia, introduced the plant into his garden. No one would have objected had it

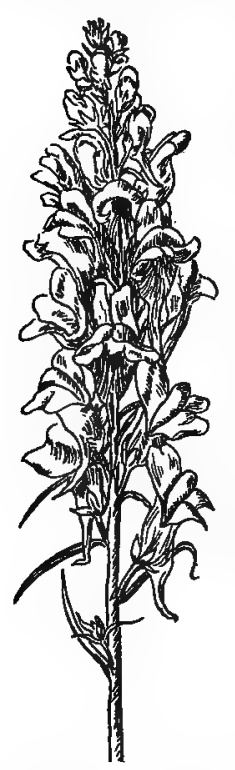

Toad-flax. Linària vulgàris stayed there, but that it would not do; it crawled under the fence and visited his neighbors who were market gardeners, and the outcome of the visits was that the plant received the name of Ramstead Weed. It is better known as Toad-flax and Butter-and-Eggs.

A little plantation of Toad-flax is easily recognized; one sees it as a patch of gray-green by the roadside, which resolves itself into a body of erect stems thickly beset with linear leaves. At the summit of each flowering stem is a spike of beautiful orange and yellow, spurred and two-lipped flowers. The flower flame creeps up the stem slowly so that the blooming period is long extended.

The blossoms appear in two forms: one, the common two-lipped variety, and the other not so common, in which the corolla has five spurs, is regularly five-lobed, and is then said to be in the peloria state. By peloria state is meant the condition in which a plant, that normally produces irregular flowers, produces regular ones. The earliest recorded observation of such a condition was made by Linnæus and upon our wandering Toad-flax. Sometimes there are a few such in a flowering spike; sometimes an entire stem bears only regular five-spurred blossoms. 


\section{BLUE-EYED MARY}

\section{Collinsia vêrna.}

Named in honor of Zaccheus Collins, a Philadelphia botanist; $176_{4}-1831$.

A slender biennial herb with blue and white flowers, in umbel-like clusters, whorled in the axils of the upper leaves. Found in moist soil from Ontario, through New York and Ohio, to Iowa, and southward. April to June.

Siem.-Slender, six to ten inches high.

Leaves.-Ovate; the upper ovate-lanceolate, clasping by the heartshape base, toothed.

Flowers.-Irregular, blue and white, borne on long peduncles, about six in a whorl.

Calyx.-Deeply five-cleft.

Corolla.-Declined; two-lipped; upper lip two-cleft, its lobes partly turned backward. The middle lobe of the lower lip sac-like and enclosing the declined stamens.

Stamens.-Four; fifth stamen gland-like; style single.

Capsule.-Many-seeded.

In northern Ohio the beautiful Collinsia is a flower of May. It is not abundant, indeed, may be considered rare; now and then it is transferred to the garden where, in a moist and sheltered location, it does well. The garden Collinsia is the species bicolor from California which greatly resembles verna, and is in some respects a better plant because the flowers have shorter peduncles.

\section{FOXGLOVE. DIGITALIS}

\section{Digitàlis purpìrea.}

Digitalis, Latin, digitus, a finger; because the flower is something like a thimble in shape.

A biennial, sometimes perennial; native to central Europe; cultivated both for ornament and for medicinal use. June to September.

Flowering-stalk. -Erect, two to five feet high, rising from masses of radical leaves. 


\section{FIGWORT FAMILY}

Radical leaves.-Ovate, crowded; stem leaves alternate, oblong-ovate, rough, downy.

Flowers,-Drooping, tubular, in dense terminal one-sided spikes.

Calyx.-Four-parted, the upper segment the smallest.

Corolla.-A drooping bell about two inches long; more or less inflated tube with short, obscurely lobed border; ranging from purple to white, more or less spotted within; throat bearded.

Stamens.-Four, in two pairs, inserted on the corolla-tube; filaments curved so as to bring the anthers together; mature before the stigma.

Ovary.-Cone-shaped, two-celled; style an inch or more long; stigma two-cleft. brown.

Capsule.-Two-celled, pyramidal; seeds numerous, small, grayish-

The Garden Foxglove is in the main the Common Foxglove of central Europe improved by cultivation and more or less hybridized. The name Foxglove seems so inappropriate that much questioning has arisen concerning its origin. The best explanation is that Foxglove is a corruption of folkglove which, of course, meant fairy glove and referred to the thimble-like shape of the flower. The specific name Digitalis refers to the same characteristic.

A well-grown Foxglove in full flower is a plant of dignity and beauty, admirably adapted for shrubberies and woodland walks, hardy and easily grown. The root is biennial or sometimes perennial, and the first year sends forth large tufted leaves; in the following summer a single, erect, leafy stem arises, bearing at its summit a densely flowering raceme of beautiful drooping bells. In this raceme the flowering impulse moves slowly upward, thus lengthening the blooming period. The position of the bells on the flowering axis is secund, that is, all on one side; sometimes as many as four rows strive to occupy the coign of vantage. This arrangement is more apparent than real, the flowers really originate on all sides of the stem, but the peduncles somehow twist around so that all seem to be on one side. As the fruiting capsules mature the peduncles take their natural position and a fruiting stem has its capsules on every side.

To understand what is doing of a summer day in foxglove-land one needs to watch the bees, whose contented buzzing as they gather the nectar stored in the bottom of each swollen bell, dis- 


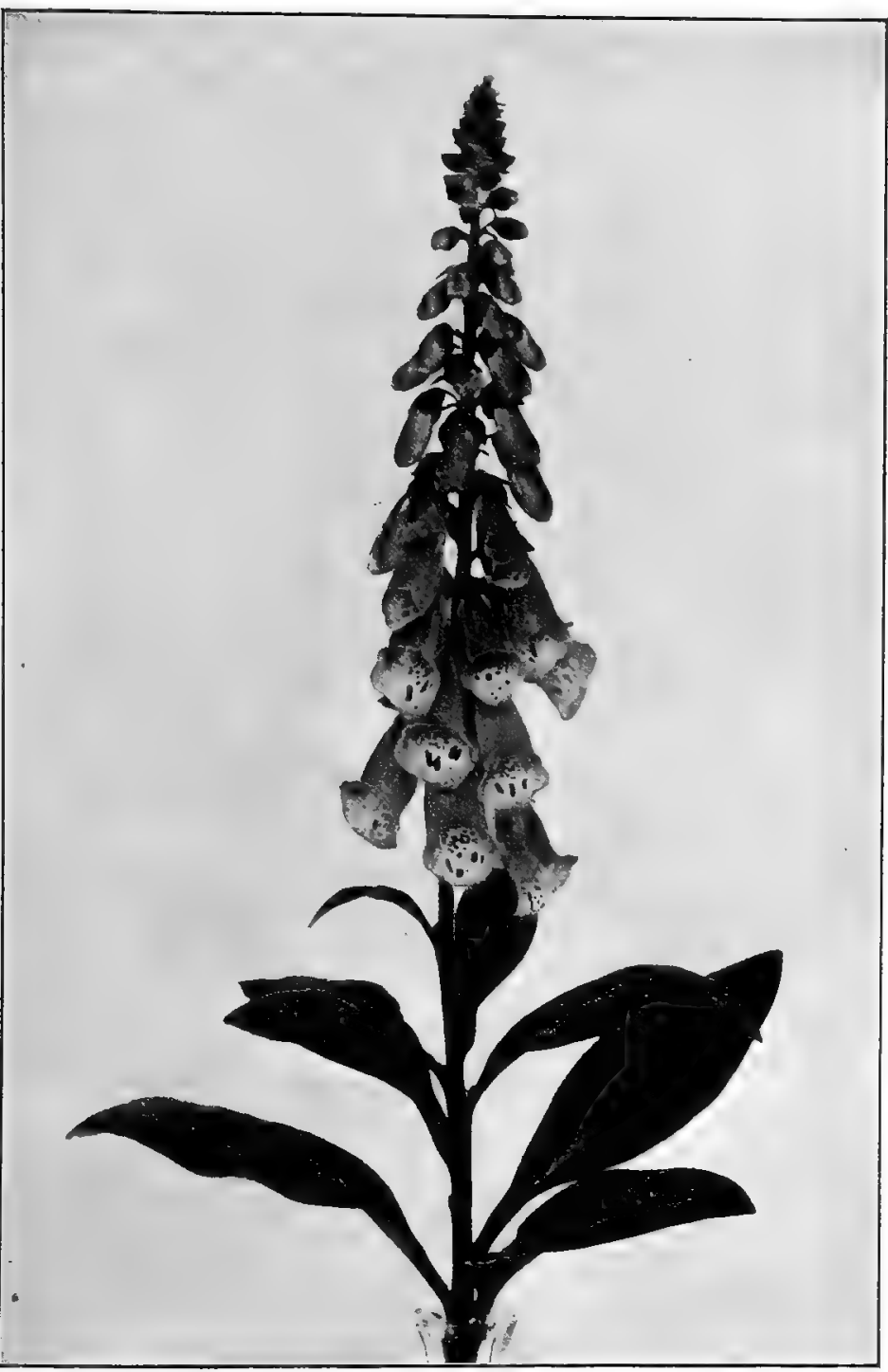

Foxglove. Digitallis purpùrea 
appearing in the flowery depths, out again covered with pollen, in again as they reach the next blossom, shows that they are serving the flower with great satisfaction to themselves. No doubt they think they are attending strictly to their own business; incidentally, they are doing the world's work. The blossom has its own way of making its visitors useful. The bells hang one above another, and we note that the side nearest the stem is longer than the upper side, thus making its central lobe an excellent alighting platform. This is dotted with spots and furnished with long hairs. The filaments of the stamens are curiously curved in order to bring the anthers into one plane; these hug together and the immature stigma is above them. When these anthers mature the pollen is just where the back of the bee rubs it off as she crowds into the flower bell for the nectar secreted by the smooth ridge at the base of the ovary. After the anthers have passed, the stigma matures, becomes two-cleft, and the parts diverge. It then practically occupies the former position of the anthers, and as the blossom con-. tinues to secrete nectar, is able to seize by means of its sticky surfaces some of the pollen which adheres to a bee's back. There are on every stalk flowers in several stages of maturity.

If, however, bees are scarce and the stigma has obtained no pollen the hope of the race is not utterly wrecked, there is one chance left. The corolla clings tight until the stigma has matured, then begins to loosen and in time falls. In so doing the anthers are dragged over the stigma and it may be that some stray home pollen will adhere.

The leaves of Foxglove yield to the materia medica a very important drug called digitalis, whose active principle is digitalin. It is used principally to affect the action of the heart.

Digitalis, as it now appears in our gardens, runs the color range of white, lilac, purple, rose, and yellow; its flowery stalks are superb, and the entire plant is a magnificent specimen of the gardener's art. The structure of the flower has not been broken down. However one monstrous form has been developed which bears a large open flower at the top of the flower spike. There are those who consider this beautiful. 


\section{CHELONE. TURTLE HEAD}

Chelòne oblìqua.

Chelone, Greek, tortoise; referring to the form of the flower.

A native perennial of western and south-western range, growing in wet places. July-September.

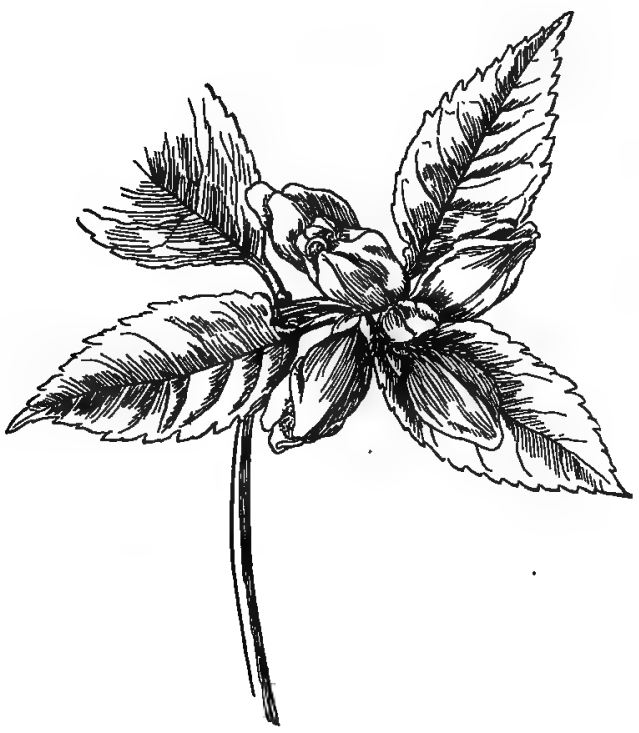

Chelone. Chelòne oblìqua

Stem.-Stout, one to two feet high, growing in clumps, branching.

Leaves.-Opposite, broad lanceolate or oblong, deeply serrate, acute or acuminate.

Flowers.-Deep-rose, sessile, in clusters at the summit of the stem or in the axils of the upper leaves.

Calyx.-Of five distinct, overlapping sepals, deeply five-parted, with bracts at base.

Corolla.-An inch long, tubular, inflated, concave underneath, twolipped; lips only slightly open; upper lip arched, keeled in the middle, notched at apex, protecting the stamens; the lower woolly in the throat and three-lobed at the apex. middle lobe the smallest. 
Stamens and anthers four, white, woolly, in two pairs, inserted on corolla-tube. Sterile filament smaller and shorter than others.

Ovary.-Two-celled; style long, slender, curved; stigma entire.

Seeds.-Winged.

Both the Greek and the English names of this plant emphasize the distinctly reptilian suggestion made by the corolla. The poise of the flower, the keeled upper part, the inflated lip, and the small mouth, all produce a result that, if not strong enough to be a resemblance, is distinctly a suggestion.

The common northern species, Chelone glabra, has the same turtle-headed corolla, but white and delicately flushed with pink at the lips. It bends over many a running stream and sees itself reflected in the water mirror of many a quiet pond.

\section{TORENLA}

\section{Torènia Fournièri.}

Torenia, named in honor of Olaf Toren, a Swedish botanist.

A low, midsummer-blooming annual, with flowers having the poise and color of tricolor violets. Native to Cochin China.

Stem.-Six to twelve inches high, square and slightly winged, bushy. Leaves.-Opposite, cordate-lanceolate, crenate-serrate, an inch and a half long.

Flowers.-Violet-blue, funnel-shaped, somewhat two-lipped, in loose. terminal or axillary few-flowered racemes.

Calyx.-Tubular, angular, five-winged, and five-toothed.

Corolla.-A funnel-shaped tube expanding into a four-lobed border; the upper erect, broad, notched or cut; the lateral and lower spreading.

Stamens.-Four in two pairs; one pair meeting in front of upper lobe; the other at the throat.

Ovary.-Oblong; style long, slender.

Capsule-OOblong; seeds numerous, small.

Although Torenia has been in cultivation over a hundred years, it is by no means as well known as it deserves. A tropical plant and at home a perennial, it must with us be treated as an annual. It is an August bloomer; the flowers on stiff stems have much of the 
poise and all of the color of violet tricolor pansies; indeed in the South the plant is cultivated as a substitute for the pansy. The foliage is dark-green and abundant; the flowers are terminal and axillary. The calyx is angular and winged. The corolla-tube is open and slightly curved, a soft golden tint at base becoming pale-blue as it expands into a broad border. The upper lobe of the border is pale-blue, the lateral lobes dark violet-blue, and the lower middle lobe pale-blue above, dark-violet below, with a dash of yellow in the middle.

Looking directly into the corolla one finds against the glowing golden centre two paleblue stamens which have clasped hands at the mouth of the tube and hold between them the stigma. The flower is beautiful from whatever point of view it is observed. The plant is tolerant of many conditions, will grow in sun or in shade and as its habit is bushy the plants, if set about eight inches apart, will cover the ground. It is best treated in

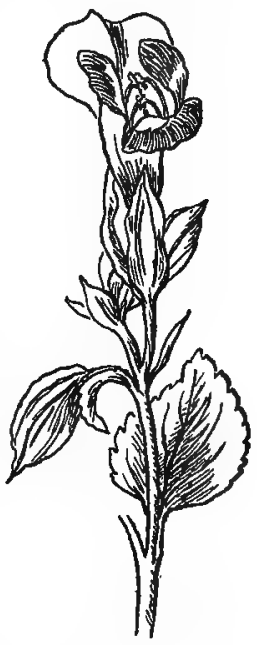

Torenia. Torènia Fournièri masses, as we treat pansies. Varieties, of course, are forming: alba, called White Wings, has pure-white flowers; and grandifldra has very large ones. Did the florists think it worth while, the -plant, doubtless, could be made to vary as much as the pansies.

\section{PENSTEMON. BEARD TONGUE}

Penstèmon digitàlis.

Penstemon, Greek for five stamens, all five being present in this genus, whereas related genera have only four; one of the stamens is commonly sterile.

Penstemon is a North American genus of perennial herbs, containing about one hundred species. The flowers are tubular, often two-lipped, and borne in showy terminal racemes. The stems of a few species are woody at the base. Penstemon digitalis is native to Pennsylvania and the Middle West. 
Stem.-Erect, branched from the base, two to four feet high.

Leaves.-Opposite, ovate to ovate-lanceolate, serrate; the upper sessile and mostly clasping.

Calyx.-Five-toothed.

Corolla.-White, slightly tinged with purple, tubular, abruptly inflated, with open throat, two-lipped; upper lip two-lobed, the lower three-lobed.

Stamens.-Four, declined at the base, ascending above; a fifth, the sterile filament, is bearded.

Ovary.-Oblong; style long and thread-like; stigma entire.

Fruit.--Pointed capsule, many-seeded.

The Garden Penstemons are in the main derivatives or hybrids of several species. Chief of these are: Penstemon barbatus, abundant in Colorado, varying in color from flesh and pale-pink to carmine; Penstemon Hartwégi, or gentianozdes, native to the mountain regions of Mexico, with large dark-purple flowers; Penstemon campanulàtus, also Mexican, rose-purple, long in cultivation; Penstemon cobca, growing on the prairies of Kansas and westward, bearing large blossoms varying in color from reddish-purple to white; Penstemon acuminàtus-carìleus, and Penstemon digitulis.

The native Penstemon of any locality is worthy of a place in the home garden. All the species bear showy flowers, and the plant takes kindly to cultivation. A few are Eastern, but the most beautiful are on the Rocky Mountains and in Mexico, brilliant and glowing beside every mountain trail and in every upland park. The color range runs from white, through all the reds, to purple and violet-blue, and the blossoms under cultivation are likely to increase in size. Yellow appears in some of the wild species, so that it is only a matter of time when it, too, appears in the garden forms. 


\section{PENSTEMON}

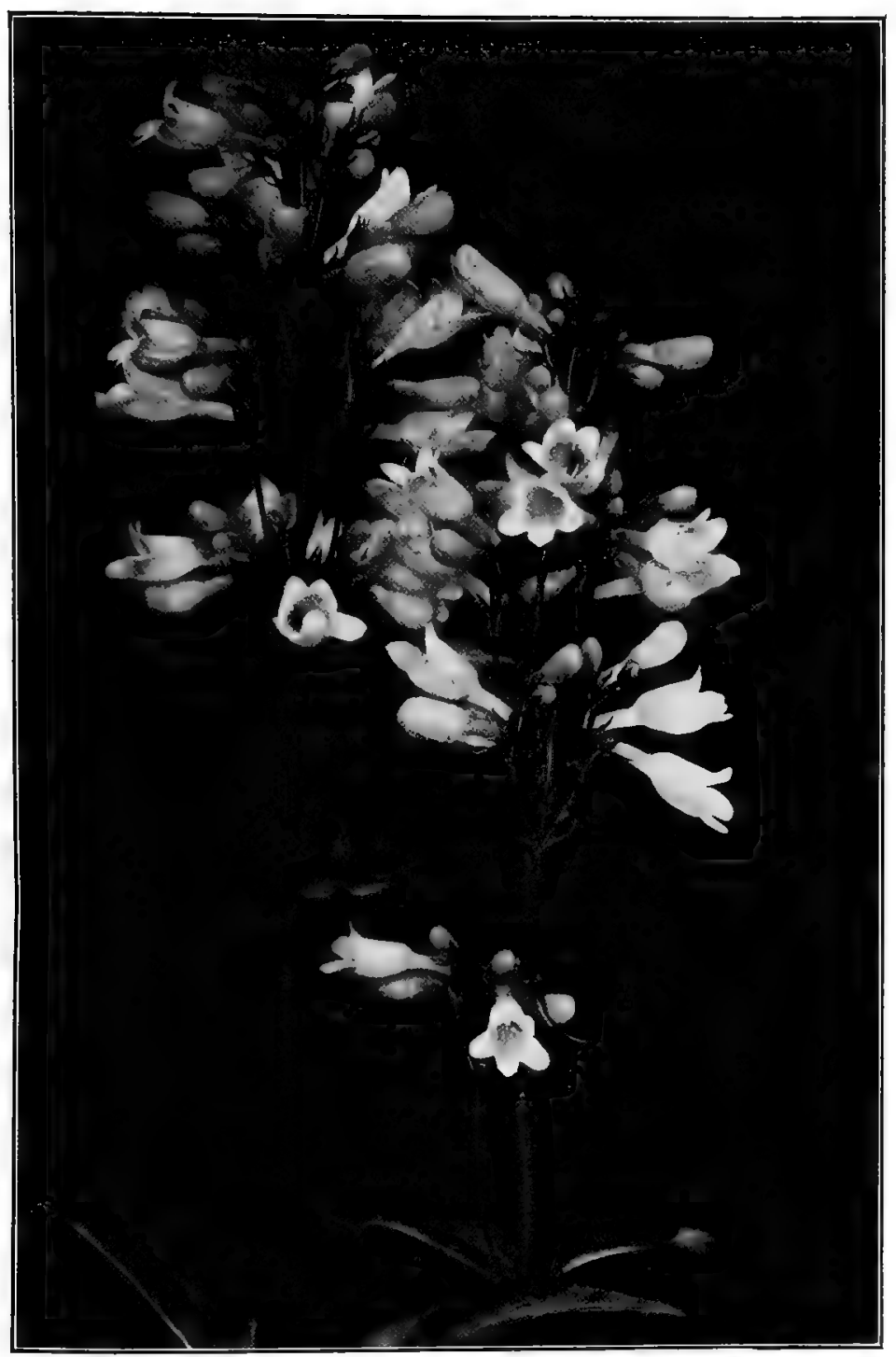

Penstemon. Penstèmon digitàlis 


\section{LONIG-LEAVED VERONICA}

Verónica longifiora.

An excellent representative of the strong-growing and upright Veronicas. Native to wet fields in eastern Europe and western Asia. Several varieties are in cultivation. Perennial. July to September.

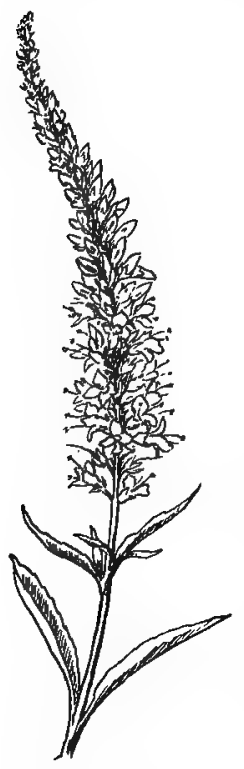

Long-leaved Veronica. Verónica longiflora

Stem.-Upright, leafy, two and a half feet high, usually smooth.

Leaves.-Lanceolate or oblong-acuminate, sharply serrate, acute, lower opposite, upper more or less verticillate, two and a half to four inches long.

Flowers. - Violet, varying in hybrids to blue, borne in erect, dense, bracted, simple or panicled spikes.

Calyx,-Four-parted.

Corolla.-Small, tubular, with four-lobed border, the lowest lobe narrower than the others; deep-lilac or blue.

Stamens.-Two, exserted, one on each side of the upper lobe of the corolla; filaments blue.

Ovary.-Oblong; style thread-like.

Capsule.-Oblong, seeds several.

This European, strong-growing, erect Veronica makes a fine border plant, for the densely flowered racemes give an extended blooming period. In the type the flower color is violet, but in varieties it becomes an intense blue.

Veronica spicata, a very similar species having the same habitat except that it prefers hilly pastures in a sunny location, is also used as a border plant.

When spring is well under way our northern pastures and meadows are full of the dainty flowers of St. Veronica, known as the Speedwells; delicate creeping plants a few inches high, bearing pale-blue or white almost circular blossoms, perhaps an eighth of an inch across, and marked with. dark-blue lines. As they peer out from the green turf, one understands the reason for their ancient name, Bird's-eyes. Veronica peregrina, the Wandering Speedwell, and Veronica serpyllifolia, the Thyme-leaved Speedwell, are two common species. 


\section{RUBIACEA-MADDER FAMILY}

\section{GALIUM. BABY'S BREATH. BEDSTRAW}

Gàlium mollìgo.

Galium, the name of a plant mentioned by Dioscorides as used in curdling milk.

A species of Bedstraw whose delicate and abundant flowers are used to lighten the heaviness of other flowers, in the same way as Gypsophila is used. European. May, June.

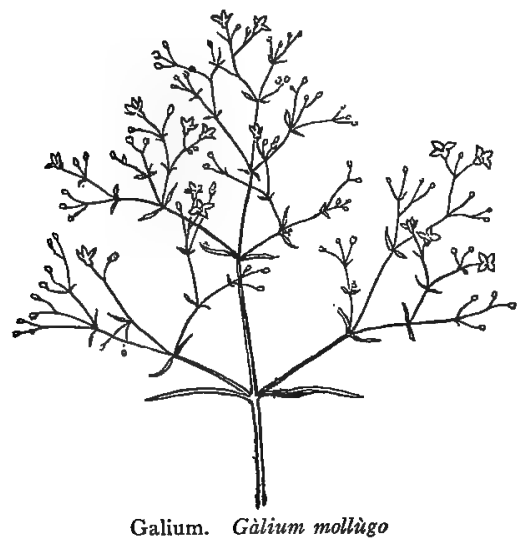

Stem.-One to three feet high, branching.

Leaves.-In whorls of six or eight, obovate to oblong or linear, more or less rough at the edges, always terminated by a little point.

Flowers.-Small, white, four-petioled.

Calyx.-Without teeth, coherent with the ovary. bud.

Corolla.-Small, wheel-shaped, four-lobed; lobes pointed, valvate in

Stamens.-Four, inserted on the tube of the corolla.

Fruit.-Twin, separating into two one-seeded carpels. 


\section{ASPERULA. CROSSWORT}

\section{Asperila.}

Asperula, roughish, referring to the leaves.

Stem.-Square, low but erect.

Leaves and leaf-like stipules form a regular whorl at the joint of the stem, in eights, sixes, or fours.

Flowers.-Tubular, four-parted, honey-bearing, grouped in cymes.

Calyx.-Four-toothed.

Corolla.-Bell-shaped or funnel-formed; border four-lobed.

Stamens.-Four; styles two, somewhat united.

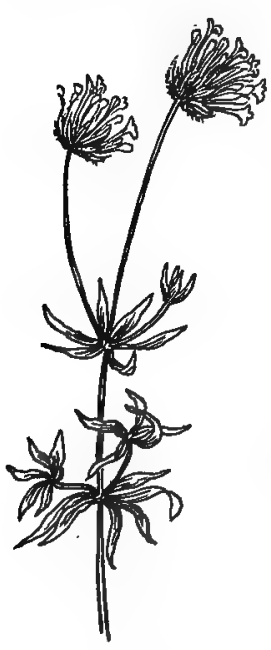

Asperula. Asperita orientàlis

The Asperulas are a group of herbs of low stature and delicate foliage, useful for borders and rockeries in shaded places, but no better than many of our native plants. They bloom from May to July.

The white-flowered, perennial species, odoràta, called Sweet Woodruff, has long been used in Europe as a sweet herb. The dried leaves and flowers have the odor of new-mown hay, a fragrance that lasts for years, so that the plant is packed among clean linen to impart its odor to the clothes. The Germans call it Waldmeister and use it in the concoction of their May wine and summer drinks.

Asperula orientalis is a blue-flowered annual species from Caucasus, whence it was brought into England in 1867 . It is a branching plant about twelve inches high, with lance-shaped, bristly leaves, eight in a whorl. The whorled leaves are characteristic of the Asperulas as well af of the Galiums.

No representatives of the genus are native to the United States, and but one is adventive here, galiotdes, found in New England. 
TRUMPET FLOWER

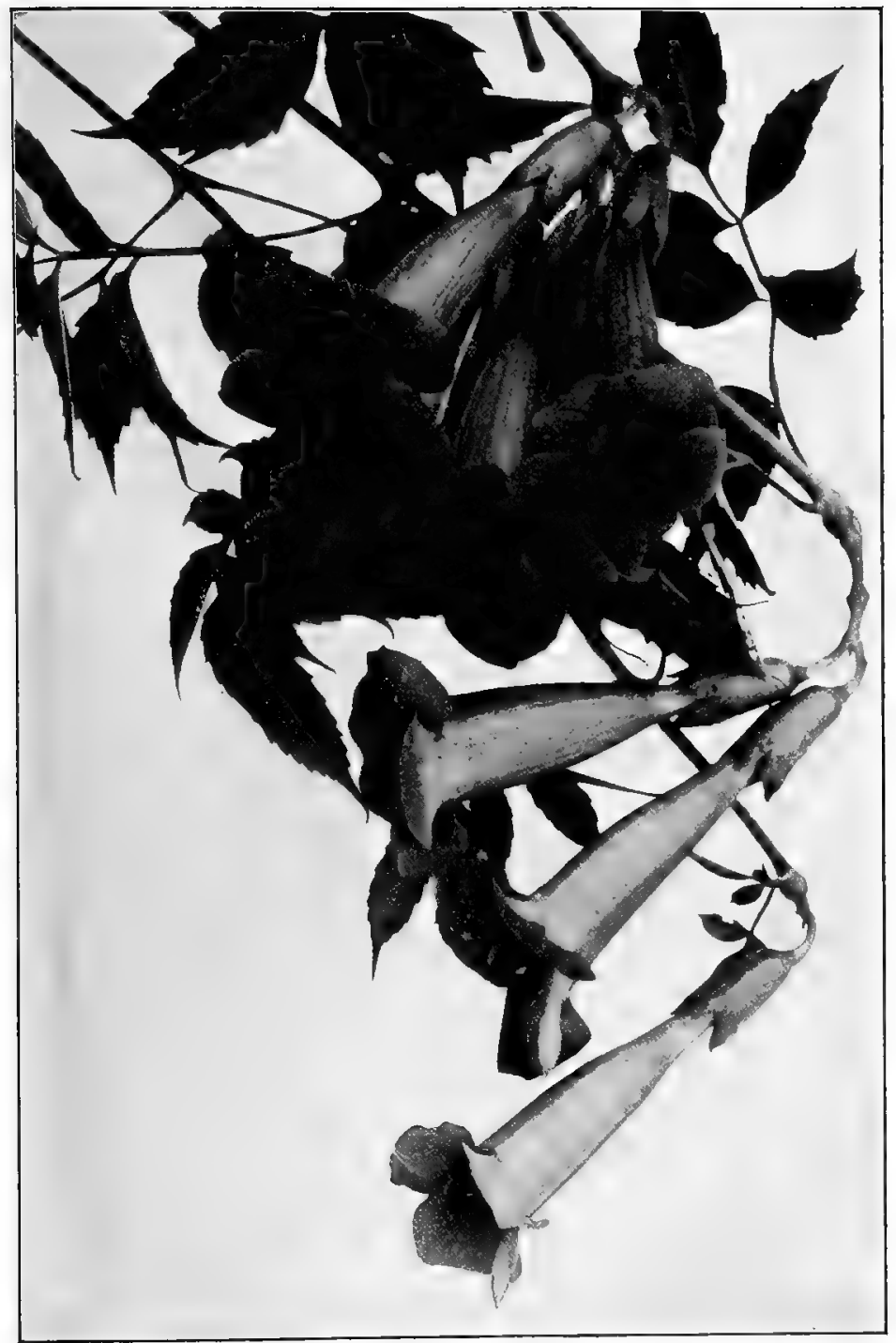

Trumpet Flower. Técoma radìcans 


\section{BIGNONIÀCEAE-BIGNONIA FAMILY}

\section{TRUMPET FLOWER}

Técoma radicans.

Tecoma, an abridgment of the Mexican name Tecomaochitl.

A perennial, ornamental, climbing shrub, native to western and southwestern United States; found in woodlands and fields. July to September.

Siem.-Woody, climbing by aerial rootlets.

Leaves.-Opposite, pinnately compound; leaflets seven to eleven, oval to ovate-lanceolate, bilateral, coarsely toothed, acuminate, about two inches long.

Flowers.-Borne in terminal clusters, orange-red, trumpet-shaped, with open spreading border; three to four inches long and an inch and a half across.

Calyx.-Thick, leathery, slightly curved, pale-yellow, five-toothed.

Corolla.-Trumpet-shaped, border of five rounded lobes, tube veined within, nectar abundant; end of bud five-angled, the lobes of border imbricate in bud.

Stamens.-Four, in two pairs, the fifth stamen aborted; anthers large, versatile.

Ovary.-Oblong; style long, slender; stigma two-lobed.

Capsule.-With flat, winged seeds.

The Trumpet Flower is a general utility vine. It will adorn a fence, cover a porch, climb a post, and supply foliage and flowers to the dead trunk of a tree. It climbs by means of aerial rootlets and the main stem holds fast and tight, but the light spray floats free and the blooming clusters look out to the sunlight. The blossoms are full of nectar and the humming-birds come for it in numbers. 
The entire plant has an interesting one-sided twist. The calyx has it, the corolla shows it, and the leaflets are bilateral, "one half larger than the other." Not the least of its virtues is the length of the flowering season. The terminal corymb begins to open its blossoms in June and it is late September before the end is reached. The plant is hardy, robust, and full-foliaged.

\section{INCARVILLEA}

\section{Incarvíllea Delavàyi.}

Incarvillea, after Incarville, a French Jesuit missionary to China.

Leaves.-Pinnate, a foot long, forming a cluster.

Scape.-One to two feet high, bearing two to twelve large catalpa-like rose-purple flowers, each two to three inches long and fully as wide.

Calyx.-Five-lobed.

Corolla.-Tubular with spreading, five-lobed border; tube yellow inside and out; two upper lobes are smaller than the three lower ones.

Stamens.-Four, inserted on the corolla.

Ovary.-Two-celled; style long; stigma two-lipped.

Seeds.-Winged.

Incarvillea is a plant of generous proportions. Its leaves are large, its flowers are large, and a well-grown plant needs so much room that it can never be a favorite in small gardens. It flourishes in half shade, and, well placed, is effective.

Calampelis, or Eccremocârpus scàper, is an annual climber, native of southern South America; growing about ten feet high. The flowers are somewhat tubular, orange-colored, and borne in racemes. It clings by means of branched tendrils. 


\section{ACANTHÀCEA-ACANTHUS FAMILY}

\section{THUNBERGIA}

Thunbêrgia alàta.

A perennial climber producing abundant yellow and orange flowers. Native of southern Africa. August.

Stem.-Climbing, square, hairy.

Leaves.-Opposite, triangular-ovate, hastate, repand-toothed, rough pubescent, tomentose beneath; petioles winged.

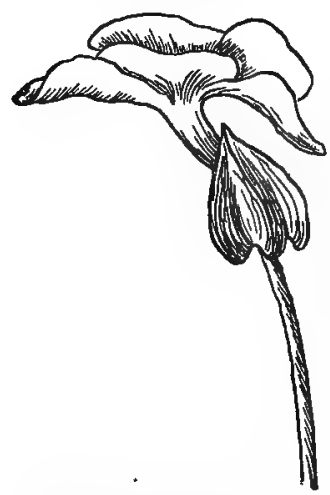

Thunbergia. Thumbérgia alàıa

Flowers.-Buff, yellow, or orange, solitary on axillary peduncles.

Calyx.-Very small, surrounded by two large inflated bracts.

Corolla.-Trumpet-shaped, with a spreading border; tube oblique, enlarged toward the throat; border five-lobed; lobes spreading, two a little smaller than the others. Interior of throat aark-purple, which, as it shows, makes a dark eye.

Stamens.-Four in two pairs, inserted on corolla-tube; anthers curiously fringed.

Ovary.-Two-celled, globular, tipped with a long, flattened beak; style long, slender; stigma two-lobed.

Capsule.-Four-seeded.

Thunbergia alata is one of the plants introduced through the efforts of Thunberg, the great collector of Japanese plants in the first half of the nineteenth century.

The species are mostly tropical plants which flourish with us in the greenhouse; but alata makes a good outdoor vine and is best treated as an annual as it flowers abundantly in late summer. 


\section{BEAR'S BREECH}

Acânthus móllis.

Acanthus, Greek, a thorn or spine; referring to the spiny calyx of some species.

Leaves.-Mostly radical, two feet long; sinuately pinnatifid.

Flowering-stem.-Two, three to four feet high, bearing white or rosy flowers in loose spikes.

Calyx.-Of four unequal segments, two sides being smaller than the others.

Corolla.-Tubular with a single three-lobed lip.

Stamens.-Four, two longer than the others.

Ovary.-Two-celled; style thread-like.

Capsule.-Two-celled, each cell containing two seeds.

Acanthus mollis was introduced into England from Italy nearly four hundred years ago and has been in cultivation there since that time; but the plant is not common in this country and, all in all, is more interesting than beautiful. A single specimen well placed might be valuable, but the foliage needs space and the flowering spikes are inharmonious with softer vegetation. 


\section{CAPRIFOLIÀCE/E-HONEYSUCKLE FAMILY}

\section{HONEYSUCKLE}

\section{Lonícera japbnica.}

Lonicera, in honor of Lonitzer, a German naturalist and physician; I528-I 586.

A favorite climbing vine with variable foliage and fragrant creamwhite, tubular flowers, fading to yellow. Appears in several garden varieties: flexuòsa, chinénsis, Halliàna, and aùreo-reticulàta.

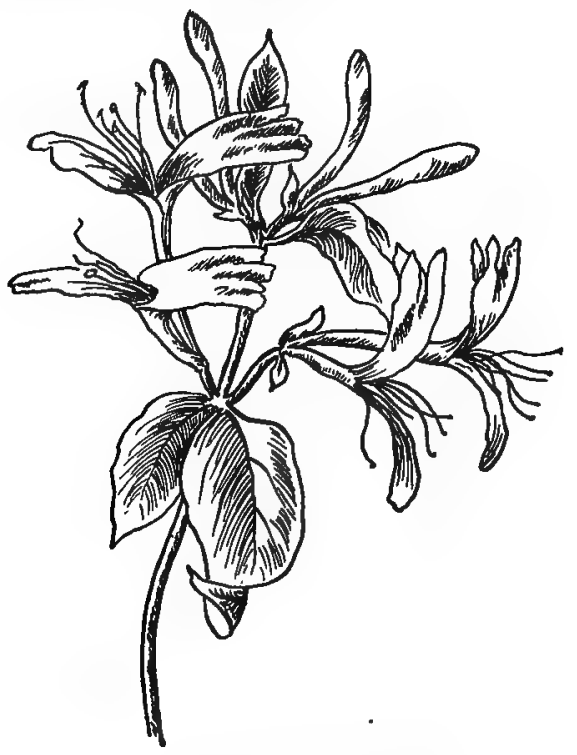

Honeysuckle. Lonicera japónica

Stem.-Long, trailing or climbing.

Leaves,-Opposite, variable, sometimes variegated, half-evergreen; generally ovate and blunt, but sometimes acute, more or less hairy. 
Flowers.-Axillary, in pairs on short pedicels, tubular, cream-white fading to yellow, fragrant.

Calyx.-Five-toothed.

Corolla.-Tubular, one and a half to two inches long, cream-white, sometimes purplish outside; two-lipped, upper lip a long, narrow strap; lower lip broad with a four-toothed border; teeth rounded.

Stamens.-Five, with long thread-like filaments.

Ovary.-Two to three-celled.

Fruit.-A berry.

The Japanese Lonicera is the fragrant white honeysuckle that climbs upon our porches and over our walls. The flowers appear in pairs, at first white, but fade to a dull, pale-yellow before they fall. At the north the leaves just miss of evergreen, in a milder climate they attain it.

Of other climbing species, Woodbine, Lonicera periclymenum, bearing a dense head of very fragrant white, red, or yellow flowers, is a favorite. So is Lonicera caprifolium, which sometimes escapes from cultivation and has been described as an American species. It is, however, native to middle Europe and western Asia.

\section{TRUMPET HONEYSUCKLE}

\section{Lonicera sempérvirens.}

A native climbing Lonicera, long in cultivation, bearing orangescarlet trumpet-like flowers and connate leaves.

Stem.-High-climbing, glabrous, reaching ten to fifteen feet, evergreen southward.

Leaves.-Opposite, oval to oblong, the upper connate; two to three inches long.

Flowers. - Tubular, scarlet or orange-scarlet in peduncled interrupted spikes.

Calyx.-Five-toothed.

Corolla.-Tubular, slightly swollen, one and a half to two inches long; border five-lobed; deep-red without, yellowish within.

Stamens.-Five; style long.

Fruit.-A berry. 


\section{HONEYSUCKLE FAMILY}

Lonicera sempervirens is a beautiful native climber with terminal clusters of lovely red flowers that look like tiny trumpets. Unlike the Japanese Honeysuckle the border is obscurely, if at all, two-lipped; the five lobes are alike. The leaves are opposite and the upper ones grow together, making the stem look as if pushed through a large circular leaf. 


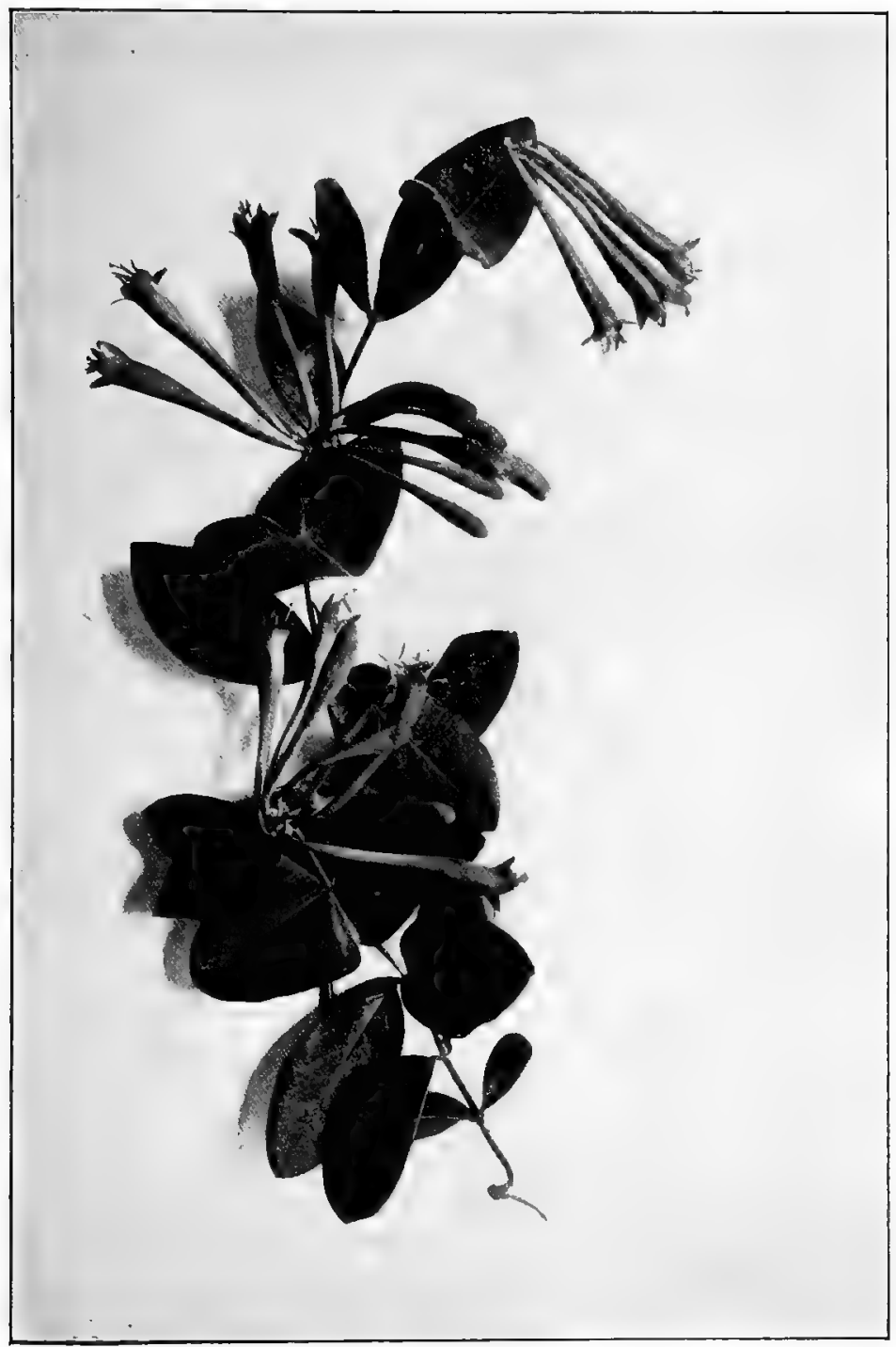

Trumpet Honeysuckle. Lonicera sempérvirens 


\section{VALERIANÀCEA-VALERIAN FAMILY}

\section{COMMON VALERIAN}

Valeriana officinàlis.

Valeriana, a mediæval Latin name of uncertain origin.

The European garden species, producing the medicinal Valerian root; also one of the characteristic plants of old gardens; especially prized for the fragrance of its flowers. Grows in large clumps; and has escaped in New England and the Middle States to roadsides and thickets. Perennial. May, June.

Stem.-Erect, simple below, branching above, two to four feet high. Stem-leaves.-Opposite, pinnately compound; leaflets lanceolate or linear, toothed or notched. Radical leaves larger.'

Flowers.-Numerous, small, whitish, pinkish, or lavender, borne in terminal and axillary cymose-paniculate clusters, fragrant.

Calyx.-Small, the limb of several plumose bristles, like a pappus, which are rolled up inward in flower, but unroll and spread as the seedlike, one-celled fruit matures.

Corolla.-Tubular or trumpet-shaped, small, five-toothed; tube slightly swollen at the base.

Stamens.-Three.

Ovary.-One-celled; style two to three-lobed.

Fruit,-An akene.

Whoever, as a child, roamed in an old garden will remember among the stately perennials that adorned and dignified the broad central walk, clumps of Valerian which held an honored place among the tiger-lilies and the perennial phloxes. At the ground was a clump of finely cut foliage from which rose a number of erect stems, each crowned with a confused and clustered mass of white or pale-lavender, which mass upon inspection proved to be made up of a great many tiny, tubular flowers. The general 


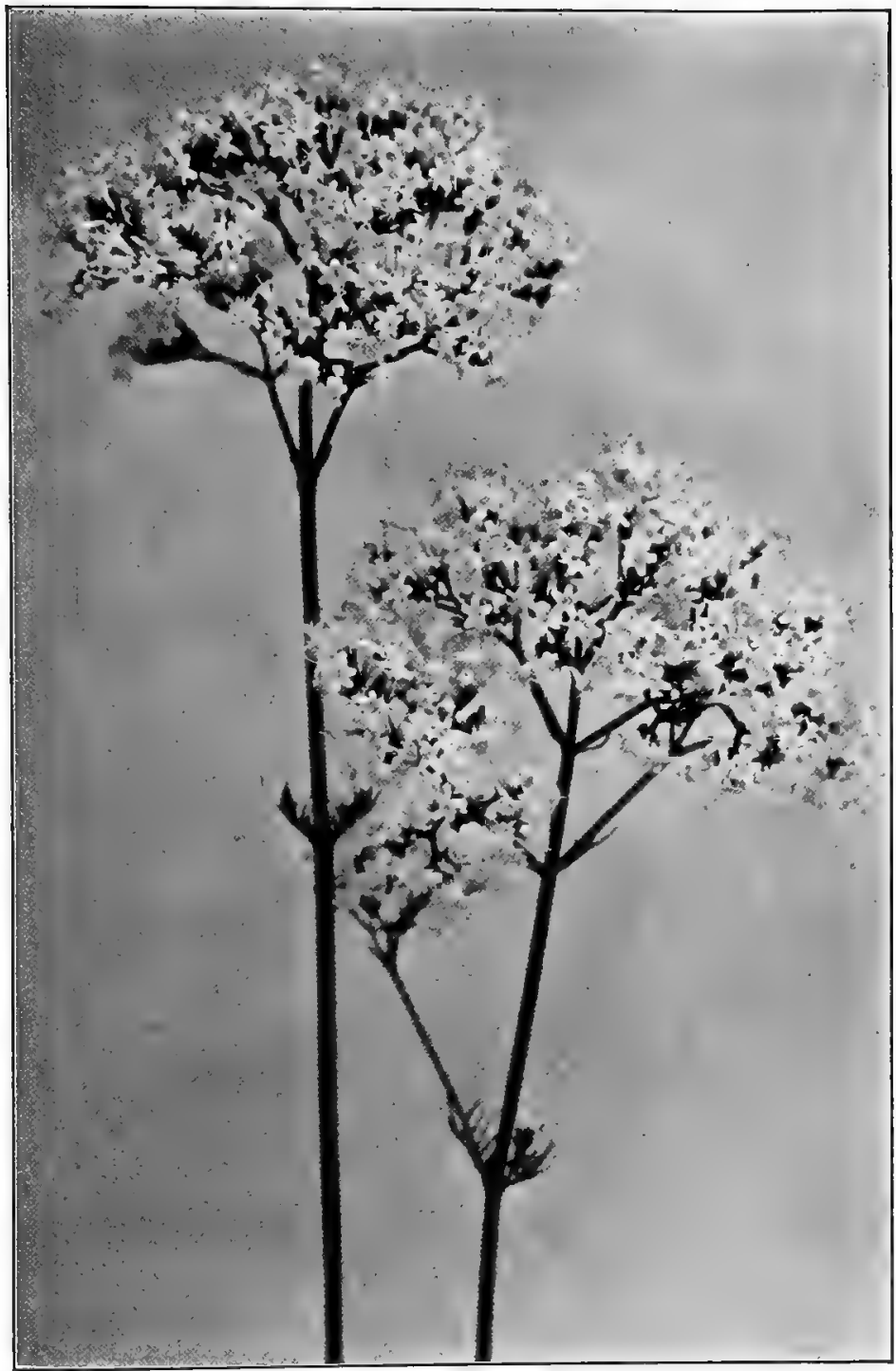

Common Valerian. Valeriàna officinàlis 
effect was pleasing enough, but the chief value of the flower cluster lay in its perfume. No bouquet of June from that garden was really complete, unless a spray or two of Valerian added its fragrance to the general total. For that garden sent forth in its bouquets specimens of many kinds of flowers, rather than many individuals of one kind. Valerian has been neglected in modern gardens, but the flowers are of late beginning to appear in the shops as a filler or background in wreaths of brighter blossoms.

The Valerian of commerce is mostly imported from Europe, though there is no reason why the plant should not be cultivated here. The medicinal property resides in a volatile oil which is abundant in the root.

Red Valerian, Cenanthus ruber, is a compact bushy plant which in summer is covered with many crimson flowers in thick clusters terminating leafy stalks. Foliage gray-green. An attractive border plant. The name Jupiter's Beard serves to emphasize a peculiar development of the calyx of all the Valerians. Before the corolla falls the calyx is represented by a mere thickened margin to the ovary, but as the fruit matures this unrolls and shows itself to be a whorl of feathery appendages. Apparently this is a very large name for a very small thing. 


\section{CUCURBITÀCEA-GOURD FAMILY}

A group of tendril-bearing, climbing or prostrate vines with alternate leaves palmately lobed or veined. The inflorescence is monœcious or diccious. The flowers are either staminate or pistillate or perfect - all three kinds on the same plant or on different plants. The calyx tube adheres to the one to three-celled ovary and the stamens, five or two and a half, commonly united by their tortuous anthers, and sometimes also by their filaments. Stigmas two or three. Limb of calyx and corolla often more or less combined. Fruit fleshy or membranaceous; seeds large and flat. In general cultivation are Pumpkin, Squash, Cucumber, Watermelon, Muskmelon, and Gourd; all in endless varieties. Mostly a tropical or sub-tropical family.

\section{HUBBARD SQUASH}

Cucúrbita pèpo var. máxima.

Stem.-Prostrate, cylindrical, rough, hairy, sparingly branched; tendrils two to three, forked.

Leaves.-Alternate, petiolate, rough, large, orbicular or kidneyshaped, margin more or less sinuate.

Flowers.-Monøcious; large golden cups, three to five inches across, borne in the axils of the leaves, the staminate long-stalked, the pistillate short-stalked.

Calyx.-Hairy, bell-shaped, five-lobed; lobes imbricated.

Corolla.-A golden cup, the body about the same diameter at top and bottom, the border flaring and five-lobed; lobes large, soft and widespreading or drooping.

Stamens.-In staminate flowers, three, arising from the bottom of the flower; the filaments united into a column; the anthers tortuous and combined into an oblong head. In pistillate flowers wanting.

Ovary.-Coherent with the calyx; stigmas three, each two-lobed.

Fruit.-Fleshy, with a firm rind. 
The easiest way to understand the flowers of the Gourd Family is to study the blossoms of the Hubbard Squash or of the Pumpkin. These are so nearly alike that it really does not matter which one is used, but as the Squash is more likely to be in the garden, its flowers are the more available of the two. In these blossoms every characteristic is, as it were, put into capitals. Every part of the

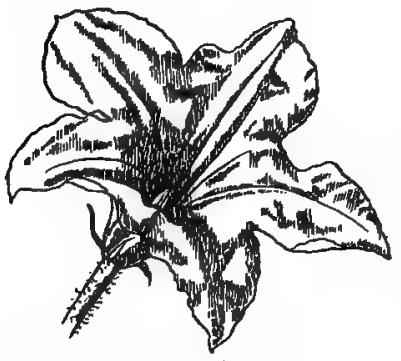

Hubbard Squash. Cucúrbila pèpo var. máxima flower is massive. The calyx is a good-sized cup, upon which the corolla sits. The great vase of the corolla has a spread at the summit of from three to five inches. Its five lobes are veined and frilled after the approved family pattern, and in the bud they come together in the characteristic gourd way.

Each stem bears two kinds of flowers. There arises from the base of one golden cup a golden club an inch and a quarter high, with a short, smooth handle and a long corrugated body. The short handle is made up of three filaments that have grown together, more or less perfectly. At the base there are usually two openings, where the filaments have not entirely united. These openings allow the bees to put their tongues into the hollow beneath, which is stored with nectar. The corrugated body is the anthers - three of them-so perfectly united that it is not easy to tell where one begins and another ends, and the anther cells are long, tortuous, bent, and doubled ridges. This is the staminate flower; it produces pollen, invites the bees, is glorious for a morning, and passes away. The golden heart of the other cup has a different inmate. The way is open down to the depths of the calyx, or hollow receptacle, as later botanists regard it, and from those depths arises a golden column bearing three hammer-headed projections. These are the three two-lobed stigmas. At the base of the column copious nectar exudes and the bees are simply mad to obtain it. 
While the bumblebee has the advantage in the staminate flower, because its tongue is long enough to reach the nectar easily, the honey-bees have their chance in the open chalice of the pistillate flower. Seven bees are often found at one time in a single cup. At the base of the pistillate flower is the tiny green ball that will in time, if all goes well, become a Squash. If cut crosswise its three-celled structure becomes at once apparent. There are more staminate than pistillate blooms, all are solitary, and each appears in the axil of a leaf. One looks at a Squash or a Pumpkin vine with little if any idea of its beauty, yet "with its broad leaves all greenness and its blossoms all gold," the plant may well challenge admiration.

The home of the Pumpkin, Cucurbita pepo, is believed to be America. It has been found growing wild in Mexico, and was under cultivation by the aborigines in Florida, Mexico, and the West Indies when those regions were first visited by Europeans. Dr. Gray believed all except var. maxima, the Hubbard Squash, to be of American origin, but the species and varieties of this genus are hopelessly confused.

The gourd, Cucurbita pèpo var. oviffera is a smaller plant than the type, and produces small, hard, inedible fruit; in shape oval, globular, or oblate, in great variety; and in color simple or blotched or striped. The species is sold in many varieties and under many names.

The Bottle Gourd, Lagenària vulgàris, originally from tropical Africa and Asia, is now generally cultivated because of the varied forms of its fruits, whose smooth, hard shells are often used as drinking cups. The species has varied into many garden forms. 


\section{CUCUMBER}

Circumis sativus.

Cucumis signifies a vessel; alluding to the rind of the fruit, which, when the pulp is removed, forms a cup. Some would derive it from the Celtic cucc, a hollow vessel.

A trailing herbaceous annual, producing the common Cucumber of the market.

Root.-Fibrous and small in proportion to the length and spread of the stem.

Stem.-Trailing, rough, hairy, five to twelve feet long, branched; tendrils simple.

Leaves.-Petioled, alternate, rough, hairy, palmately veined, cordate, three to six inches long, angularly lobed; terminal lobe longest.

Flowers.-Moncecious, yellow, cup-shaped, borne in the axils of the leaves, pistillate flowers solitary, staminate flowers clustered.

Calyx.-Bell-shaped, five-toothed; teeth awl-shaped.

Corolla.-A spreading cup, slightly attached to the calyx; same in both staminate and pistillate blossoms; tube short; lobes five, broad and spreading.

Stamens.-Three; filaments short, somewhat united; anthers curiously bent.

Ovary.-Three-celled, many ovuled; style short; stigmas three, twolobed.

Fruit-Cylindrical, five to ten inches long; when young the surface is besprinkled with tubercles, armed with sharp, rigid bristles, which later fall off; yellow when ripe.

Seeds.-Very numerous, yellowish-white, oblanceolate, flattened; will retain vitality for several years.

The virtues of the Cucumber have been recognized from very early times. Native to the foothills of the Himalayas in northwestern India and cultivated for at least three thousand years, its use has now spread over the civilized world. The plant made its way into Europe and northern Africa through commerce and travel; was early brought to America, and has become one of the most important garden crops about our great cities. The value of the fruit seems to lie in the satisfaction that it gives; it has 
little taste and is mostly water, yet it is and has been persistently sought by the human race.

The plant will grow in rich soil wherever there are three or four months without frost, but it can transmute air and water and carbonic acid into fruit only under the stimulus of considerable, or rather of continuous heat. It requires a warm root-run;

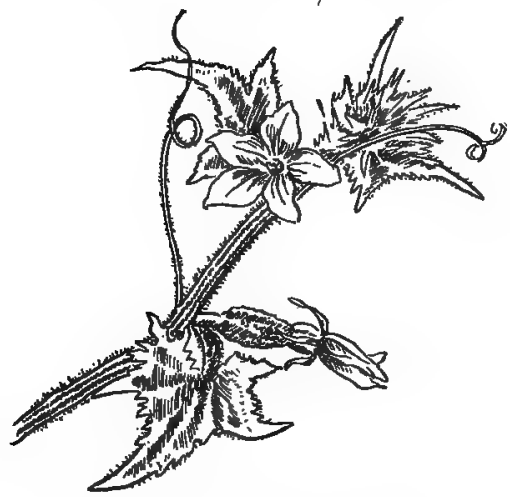

Cucumber, Cùcumis sativus

as soon as the ground cools the vine's work is over. Not all the flowers produce cucumbers; those that grow in clusters never do, they have stamens but no pistils; the pistillate fruit-producing blossoms are solitary.

Cucumis mèlo includes the Muskmelon in all its varieties, which, like the Cucumber, is an Indian plant, but has also been found wild in western Africa, in Guinea, and along the banks of the Niger. It is cultivated by the human race wherever the climate will permit. The rough, hairy, trailing stem grows five to ten feet long, bearing heart-shaped leaves with rounded lobes. The blossoms are polygamo-monœcious; that is, pistillate, staminate, and perfect flowers are found on the same plant. Gardeners say that the melons produced by the perfect flowers have the better flavor. The fruit is globose, cylindrical, or ovate. The seeds have great vitality, which has doubtless aided in the wide-spread dissemination of the plant. 


\section{WATERMELON}

Citrüllus vuigà̃rìs.

Citrullus refers to the color of the pulp, which is sometimes an orange-red, hence citrus color.

Stem.-Prostrate, eight to fifteen feet long; tendrils two to threeforked.

Leaves.-Deeply three to five-lobed, pale or bluish-green.

Flowers.-Monœcious, pale-yellow, borne in the axils of the leaves.

Calyx.-Bell-shaped, five-lobed.

Corolla.-Pale-yellow, a spreading cup, five-lobed.

Stamens.-Three, with short filaments; stigmas three, kidney-shaped.

Fruit.-Usually an oblong spheroid, greenish-brown, mottled or striped; with a firm rind and a juicy, edible core in which the seeds are embedded.

The Watermelon seems to have a social status. In Spain, Italy, and our Southern States it is regarded as the especial luxury of the poor. Murillo paints his beggar boys enjoying the fruit, and our newspapers never tire of ringing the changes upon the negro and the Watermelon.

The wild plant has been discovered in tropical Africa on both sides of the equator. Livingstone reported that he found large districts literally covered with it and that the fruit was eagerly devoured both by the savages and the wild beasts. This was sometimes sweet and sometimes bitter, a characteristic that has followed the cultivated Watermelon throughout all its history. De Candolle says that the ancient Egyptians cultivated the plant and that it is represented in their paintings. $\mathrm{He}$ also gives it to the ancient Hebrews, Arabians, and Berbers, but thinks it came into the Roman world about the beginning of the Christian era and did not reach China until the tenth century.

The Citron of the gardens is a round and solid variety of the species with almost tasteless flesh, which never softens and is often used as a preserve. 


\section{WILD CUCUMBER. BALSAM-APPLE}

\section{Echinocýstis lobàta.}

Echinocystis, from two Greek words, one meaning hedgehog and the other; bladder; referring to the inflated and prickly fruit.

A native annual vine, found in rich low grounds and beside streams, throughout the North. Is cultivated for a quick cover. Summer.

Stem.-Smooth, angular, and grooved, climbing high by means of tendrils; sometimes hairy at the nodes.

Leaves.-Alternate, petioled, palmately five-lobed, three and a half inches long, about the same in width, sometimes broader; deep sinus at base, veins very prominent beneath, margin obscurely serrate; lobes pointed.

Tendrils.- Opposite the leaves, three to four-branched.

Flowers.-Monœcious; the staminate greenish-white, six-pointed stars, in long, slender, compound racemes; the pistillate one or more minute green flowers, consisting of calyx and pistil, in the same leaf axil.

Calyx.-Of staminate flower, bell-like, with six narrow, pointed lobes alternate with the petals.

Petals.-Six, lanceolate; united into an open, spreading, star-like corolla.

Stamens.-In staminate flowers three; anthers more or less united.

Ovary.-Minute, two-celled; stigma broad.

Fruit.-Oval, two inches long, fleshy at first, finally dry, clothed with weak prickles, bursting at the summit, two-celled, four-seeded, the inner part fibrous-netted.

Seeds.-Large, dark, with thick, hard coat.

The Wild Cucumber vine is often seen in cultivation climbing over arbors and on fences. The foliage is not very thick nor the individual leaf very large, but having started on its career the plant grows rapidly, and once established, although an annual, attends to its own sowing so efficiently that there are plenty of seedlings every spring. Amateurs complain that the seeds when sown do not come up quickly, as indeed they do not; they are frequently an entire year in the ground before germination. This, undoubtedly, is due to the strength and thickness of the outer coat of the 
big black seed. Were this nicked, as is done in the case of moonflower seeds, the germination might be more rapid. The

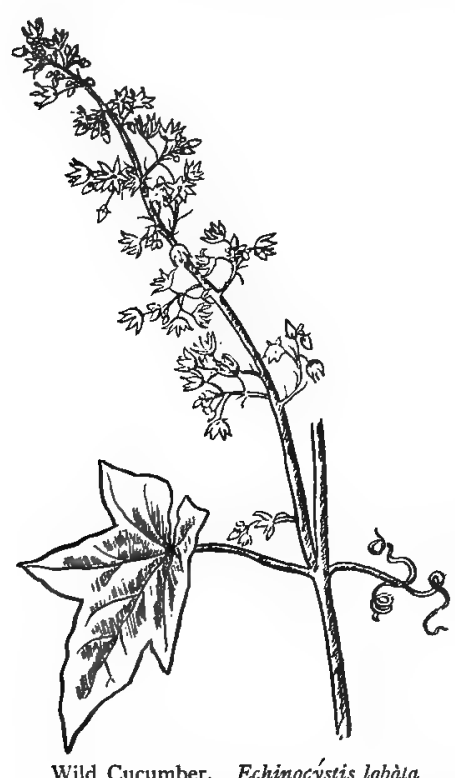

Wild Cucumber. Echinocýstis lobàla inflorescence of the vine is extremely interesting. The flowering racemes are abundant and frequently a foot long; even an ordinary raceme will produce from one hundred and fifty to two hundred staminate flowers. But the puzzle is to find the pistillate flowers which are to produce the fruit. At the base of the long raceme, sometimes on its central stem and sometimes at the axil, is a minute green lump, which may be one and sometimes is several pistillate flowers, so small that only a glass will enable one to separate them, and so inconspicuous that they would never be seen unless sought for. But in time, if all goes well, each unobserved greenling will swell and swell, become prickly and fleshy, and finally produce the hope of the race-four large, dark seeds.

Bryonopsis lacimosa is an annual cucurbit recommended as a good climber. Its leaves are deeply five-lobed; the flower yellow, monœcious, and the fruit pretty green and white spheres about the size of a cherry. Native to Asia, Africa, and Australia. 


\section{CAMPANULÀCEÆ-BELLFLOWER FAMILY}

Herbs with milky juice, alternate leaves, and scattered flowers. The calyx grows fast to the ovary; the corolla is usually a bell, five-lobed; lobes valvate in the bud. Stamens are five, usually free from the corolla. Style one, often hairy toward the summit; stigmas two or more. Fruit a many-seeded capsule. Flowers generally blue and showy. Typical garden Campanulas are Canterbury Bell, Narrow-leaved Bellflower, Rampion-like Bellflower, Harebell, and Platycodon.

\section{CANTERBURY BELLS}

Campánula mèdium.

Campanula, little bell, from the shape of the flower.

One of the most important of the Campanulas; biennial; long in cultivation.

Stem.-Erect, hairy, branching, one to four feet high.

Leaves. - Coarse, sessile, ovate-lanceolate, crenate-dentate.

Flowers.-Large bells, single or double, in leafy racemes, blue, violet, white, rose, or pink.

Calyx.-Five-lobed, with reflexed, leafy appendages.

Corolla.-Large, bell-shaped, inflated, border five-lobed.

Stamens. - Five, borne on the summit of the calyx tube; filaments curved.

Ovary.-Five-celled; style one; stigmas five.

Capsule.-Many-seeded.

Canterbury Bells come into bloom as the peonies are passing, and a well-grown plantation is extremely beautiful. Although the early garden forms were violet-blue and white, the color range now 
includes rose and purple in varying tints. The plant belongs to the biennials that amateurs find so unsatisfactory, since to keep

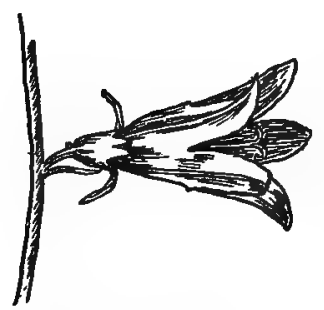

Creeping Bellflower.

Campanula rapunculoìdes. biennials up to the standard requires unceasing vigilance. When one bed is blooming a second must be in preparation, and it is easy to forget. The plant will sometimes bloom the third year, but not often satisfactorily.

The garden varieties now appear in singles, doubles, and semi-doubles, as well as in a curious form known as variety calycanthema, or Cup-and-Saucer. In this the calyx is enlarged and transformed, becoming corolla-like in texture and taking on the color of the true corolla. The doubles are of two types; sometimes one to four perfect bells are formed one within another, or the flower bell is filled with petaloids. Sometimes the bell breaks down and the entire blossom becomes petaloid.

The name Canterbury Bell harks back to the Canterbury Pilgrims who wore on their return from the shrine of St. Thomas à Becket small leaden images of saints as "signs" of their pilgrimage, and whose horses were also decorated with small bells, not only to announce the pilgrimage performed, but as a charm against accidents upon the return journey.

\section{RAMPION-LIKE BELLFLOWER. CREEPING BELLFLOWER}

Campánula rapunculoìdes.

The one Campanula that has become naturalized in this country. Native to central and southern Europe. Perennial. July-September.

Stem.-Erect, two to four feet high.

Stem-leaves.-Ovate-lanceolate, pointed and heart-shaped, the lower leaves long-petioled.

Flowers.-Tubular bells, somewhat drooping, violet-blue, five-lobed, single in the axil of bracts, forming long racemes.

Stamens.-Five; stigmas three-lobed.

Capsule.-Three-celled. 


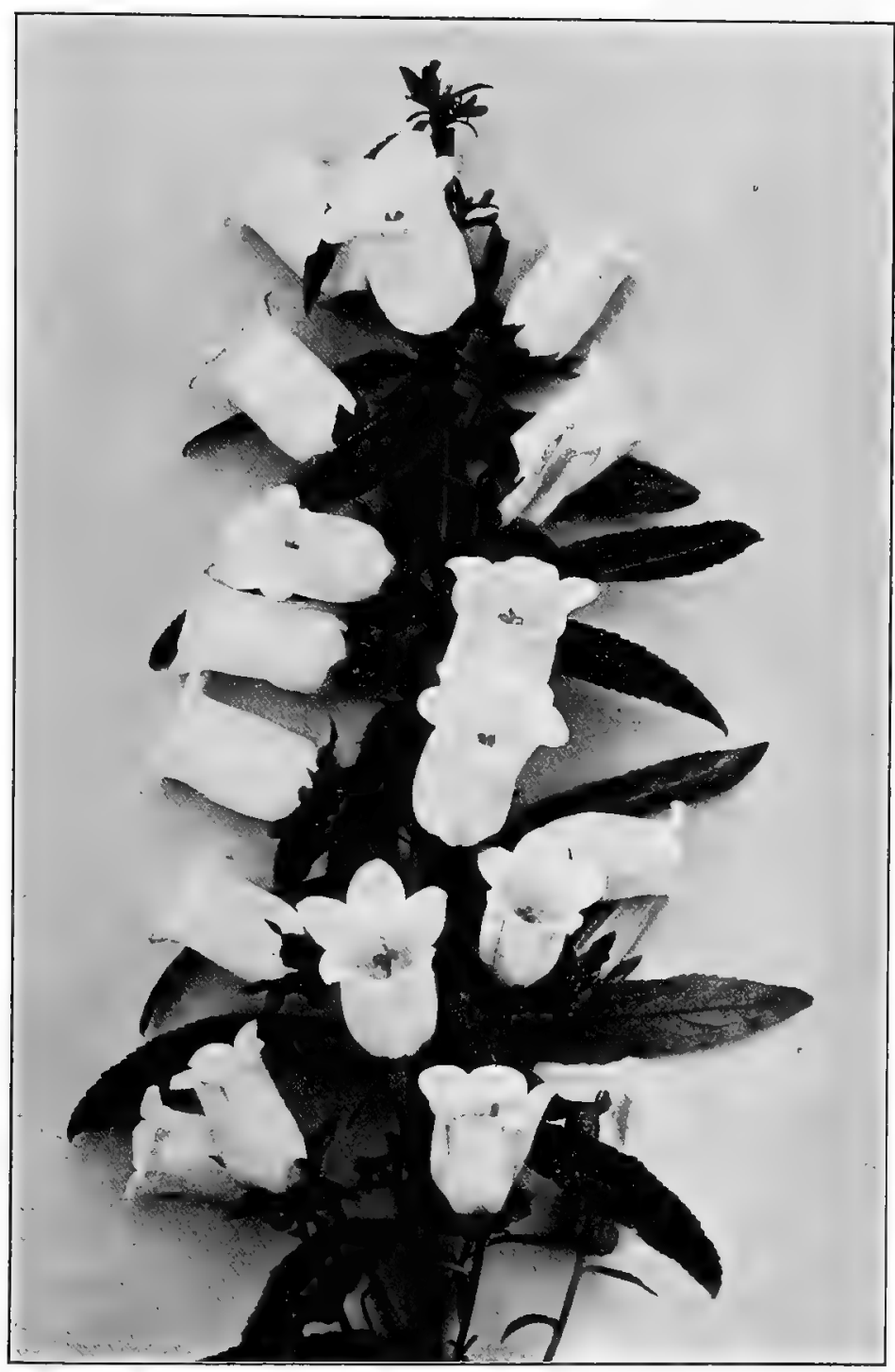

Canterbury Bells. Campánula mèdium 
One of the first Campanulas brought to this country and the only one that may be considered naturalized, as long ago it deserted the garden and went upon the highway. One often meets it along the roadside and in the fields of New England and New York, less often in Pennsylvania and Ohio.

The hardy crown sends up a tuft of erect, rather stout stems each crowned with a leafy raceme of open violet-blue bells. The plant has not much of grace but a good deal of sturdiness.

It is perennial and possesses the power of spreading inveterately by the root.

\section{NARROW-LEAVED BELLFLOWER}

Campanula persicifólia.

Native of southern Europe and long in cultivation, so that its garden forms are extremely variable. Mentioned by Gerard in 1596.

Stem.-Erect, one to three feet high.

Leaves.-Lanceolate, broad or narrow, thick and smooth.

Flowers.-Open or deep bell-shaped, violet-blue in erect racemes.

Calyx.-Five-cleft.

Corolla-Broadly bell-shaped, often two inches across.

Stamens.-Five; filaments broad at base.

Ovary.-Ovoid; stigmas three-lobed.

Capsule.-Three-celled.

A very choice plant which bears many large, cup-shaped flowers ranging upward along tall stems above a tuft of pretty foliage.

Carpathian Bellflower, Campanula carpatica, from the Carpathian Alps, is a tufted plant about six inches high bearing on slender, one-flowered peduncles an abundance of open, bell-shaped flowers, normally blue. The general effect of the blossom is that of Campanula persicifolia, but the plant's size fits it for the border or rockery, especially as it blooms continuously during the summer.

Among additional species offered by the trade are: The Chim- 


\section{NARROW-LEAVED BELLFLOWER}

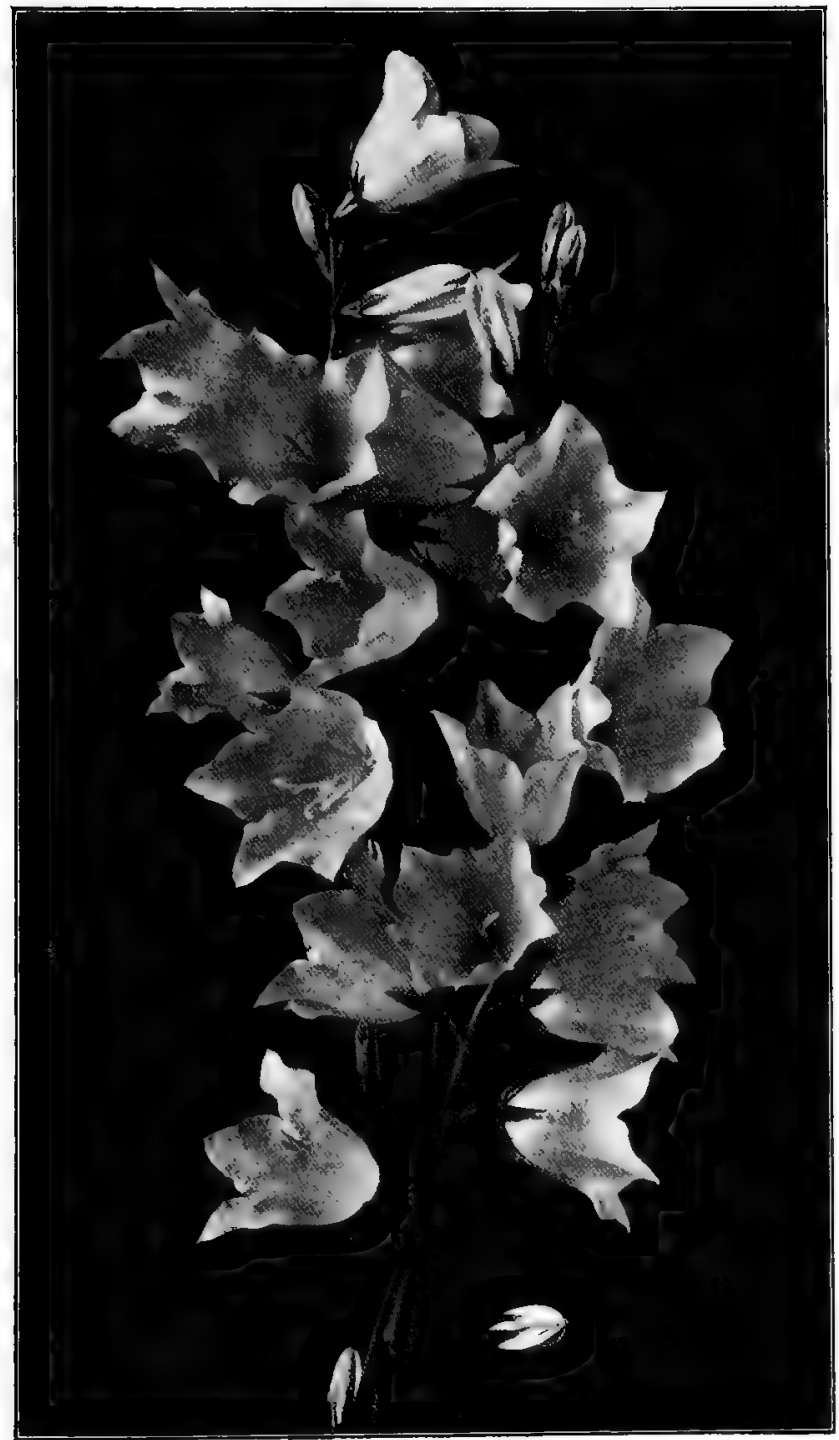

Narrow-leaved Bellflower. Campànula persicifólia 
ney Campanula, Campanula pyramidalis, so named because it was formerly grown in pots to adorn the unused fireplaces in summer; Coventry Bells, Campanula trachelium, an exceedingly robust and hardy perennial, which in a plantation is capable of running out the other Campanulas, and so taking possession not only of their places but of their names; and Campanula glomeràta var. Dahùrica, whose bell-shaped flowers form a roundish head.

An allied genus, Adenóphora, separated from Campanula by minor characters, has blue, nodding flowers produced freely in midsummer in stiff, slender panicles or racemes. Adenophera communis, from western Asia, is perhaps the best of the group.

\section{HAREBELL. BLUEBELLS OF SCOTLAND}

\section{Campánula rotundifólia.}

Stem.-Slender and branching, six to twelve inches high.

Root-leaves.-Orbicular or ovate, cordate, mostly toothed or crenate, long-petioled, early withering-

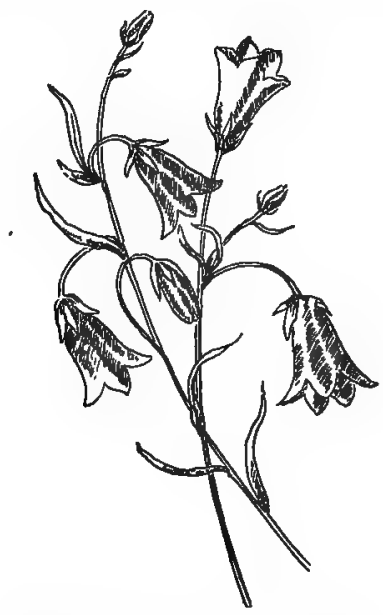

Bluebells of Scotland. Campónula rolundilolia

Strm-leaves.-Linear or lanceolate, entire, smooth. Flowers.-Bright-blue nodding bells. 
Calyx.-With five awl-shaped lobes.

Corolla.-Bright-blue, open bell, five-lobed.

Stamens.-Five; stigmas three-lobed; capsule three-lobed.

Campanula rotundifolia is the Bluebell of literature; a citizen of the world, growing in Europe, America, and Asia. On rocky banks and high ledges it is slender and delicate, its stems swaying in every breath of wind; when transferred to the garden it becomes sturdy and stocky. A curious garden form of the species exists, known as soldanellaftora, with semi-double flowers and the corolla split into strips.

It is extremely variable in height, degree of branching, number and size of flowers, texture of foliage, shape and divergence of caly $x$-lobes-characters which seem to stand in imperfect equilibrium, ready to respond to slight change of environment.

Living as it does in the clefts of rocks, waving its blue bells from inaccessible heights, apparently delicate and yet invincible, it is one of the few flowers that have appealed alike to the hunter, the wanderer, the naturalist, and the poet. One recalls with pleasure Browning's tribute, where he makes Paracelsus say:

I helped a man to die, some few weeks since, Warped even from his go-cart to one endThe living on Princes' smiles, reflected from A mighty herd of favorites. No mean trick He left untried, and truly wellnigh wormed All traces of God's finger out of him:

Then died, grown old. And just an hour before, Having lain long with blank and soulless eyes, He sat up suddenly, and with natural voice Said that in spite of thick air and closed doors God told him it was June; and he knew well, Without such telling, harebells grew in June; And all that kings could ever give or take Would not be precious as those blooms to him. 


\section{PLATYCODON. JAPANESE BELLFLOWER}

Platycòdon grandiflòrum.

Platycodon, Greek, platys, broad, and kodon, bell; referring to the shape of the flower.

A branching, shrub-like perennial bearing several large, open, bell-like flowers from the summit of the stem and branches. Native to northern Asia and Japan. July.

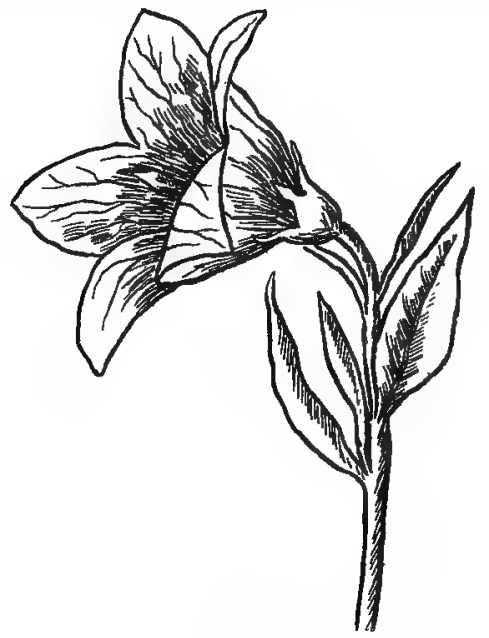

Platycodon, Plalycddon grandiflòrum.

Stem.-Bushy, weak, one to three feet high.

Leaves.-Lanceolate or ovate-lanceolate, glabrous, unequally toothed.

Flowers.-Blue or white, large open bells, inflated in the bud.

Calyx.-Bell-like, five-toothed.

Corolla.-Open bell, violet-blue, pencilled with lines of darker blue, five-lobed; lobes broad, pointed, valvate in bud.

Stamens.-Five; filaments short, dilated at base; anthers long, mature before the stigmas are receptive.

Ovary.-Globose; five-celled; style one; stigmas five.

Capsule.-Five-celled; many-seeded.

The genus Platycodon is closely related to Campanula and contains only the single species grandiflorum, but, though recently 
introduced, this has already developed several garden forms. The flower bell is a larger edition of that of Campanula persicaria, but does not grow in so dense a raceme. The spread of the ordinary blossom is nearly two inches and might easily be more. The corolla lobes are valvate in bud, and before the blooming impulse can force the lobes apart the corolla becomes puffed out into a little balloon. Like all flowers whose stamens die before the stigmas mature, the life of the corolla is extended, for it must live to call the bees for both. That the flowering stems usually need support is an objection, as this always detracts from the grace and dignity of a plant.

A variety called japonicum, with semi-double flowers; that is, with an inner bell whose lobes alternate with the outer, giving the appearance of a ten-pointed star, has been developed in France and is now offered by florists. 


\section{LOBELIÀCEÆ-LOBELIA FAMILY}

Herbs with acrid, milky juice and alternate leaves. The corolla is very irregular, always five-lobed,and sometimes two-lipped; the tube split down on the upper side. The five stamens are united into a

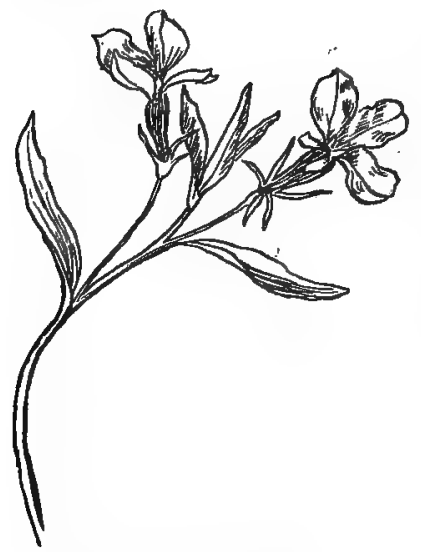

Blue Lobelia. Lobelia erinus tube commonly by their filaments and always by their anthers; from this tube the style and stigma protrude. The calyx-tube adheres to the many-seeded pod.

In cultivation are the many garden forms of Lobelia erinis and two native species, CardinalFlower and Great Lobelia.

\section{BLUE LOBELIA}

Lobèlia erinus.

Lobelia, in honor of Matthias von Lobel, a Flenish botanist and

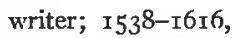

The low, annual, little Lobelia of hanging-baskets and summer gardens; variable, cultivated under many names; flowers abundant, blue, usually white in the throat. Cape of Good Hope.

Stem.-Diffuse, almost trailing, six to twelve inches high.

Leaves.-Alternate, variable, varying from obovate to acute and from crenate to serrate.

Flowers.-Small, on slender pedicels, light-blue with a lighter centre.

Calyx.-Lobes five, awl-like, spreading.

Corolla.-Irregular, with a straight tube split down on the upper side; two-lipped; the upper lip two-lobed, cut between the lobes; the lower spreading and three-cleft. 
Stamens.-Five, united into a tube.

Ovary.-Two-celled; style long; stigma two-lobed.

Capsule.-Many-seeded, opening at the summit.

Lobelia erinus is the low, normally blue-flowered, annual Lobelia, extensively used as an edging plant and as a reliable inmate of window-boxes and hanging-baskets. Its delicate foliage, alert-looking blossoms, and easy culture make it a general favorite.

It varies in habit from a diffuse, half-trailing stem overhanging a box or window to dense upright plants suitable for close edging; sometimes the foliage, always variable in form, becomes variable in color, appearing both in yellow and in bronze.

The blue of the normal blossoms frequently gives place to white, and there are varieties both rose and crimson. In some forms the size of the flower has considerably enlarged.

\section{CARDINAL-FLOWER}

\section{Lobèlia cardinàlis.}

The most showy of our native Lobelias; found in wet or low grounds, beside streams, ditches, and meadow runlets. Range extends from New Brunswick to the Gulf States, west'ward to Kansas and the Northwest Territory. Biennial. July to September.

Stem.-Erect, rarely branched, two to four feet high.

Leaves.-Oblong to lanceolate, slightly toothed, acute at each end, sessile.

Flowers.-With slenderer tube and more deeply cleft lips than most lobelias; brilliant red, rarely rose or white, borne in a long, leafy terminal, rather one-sided raceme.

Calyx.-Five-cleft, with short tube.

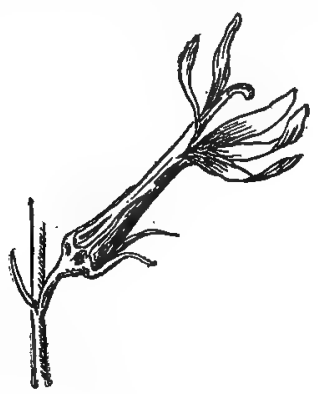

Cardinal-Flower. Lobèliá Cardinàlis

Corolla.-Vivid red; tube long, split down on apparently the upper side, two-lipped; upper lip two-lobed; under lip three-cleit.

Stamens.-Five, red, free from the corolla and united into a tube; anthers purple.

Ovary.-Two-celled; style one.

Capsule.-Many-seeded. 
No other flower of the North kindles such a flame in the thicket as the Cardinal Lobelia. When transferred to the garden it forgets its swampy home, adjures the tangle, takes kindly to drier soil, and when properly cultivated attains a greater height with longer spikes of flame than it ever achieves in the wild.

The blossom is one of slender type for a Lobelia. The corolla tube is long and slender; the corolla lobes are narrow and pointed; the filament tube extends far out beyond the corolla throat; and the slender style bears the stigma considerably beyond the ring of purple anthers.

\section{GREAT LOBELIA. BLUE LOBELIA}

Lobètia syphilitica.

Stem.-Erect, angular, leafy, one to four feet high.

Leaves.-Alternate, oblong-lanceolate, acute or acuminate, unequally serrate.

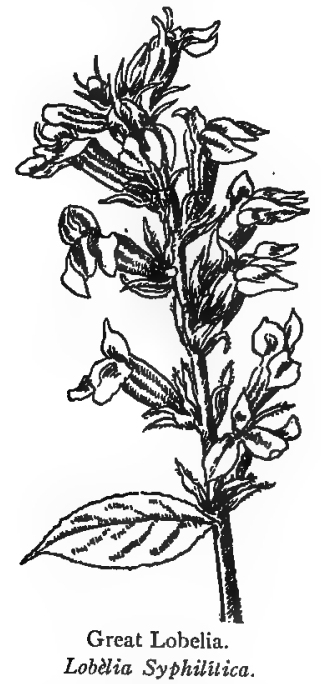

Flowers.-Borne in a long, dense, leafy spike which is six to eighteen inches in length, bright-blue marked with white.

Calyx.-Hairy, tubular, five-cleft, lobes eared at base; reflexed. 448 
Corolla.-Tubular, irregular, cleft nearly to the base on the upper side, two-lipped; the upper lip cleft between the lobes; lower lip threelobed.

Stamens.-Five, united into a tube by their anthers.

Ovary.-Two-celled; style one; stigma two-lobed, fringed.

Capsule.-Opening at the summit; many-seeded.

The Great Blue Lobelia should be in our gardens. It produces a mass of brilliant blue flowers in midsummer; all that it asks in order to do well is good soil, a moist location, and to be let alone. In the wild it will, under favorable circumstances, produce flower spikes over two feet long, and if fed and protected doubtless would -do far better.

In considering the possibilities of our wild flowers, one should remember that what they achieve of stalk and flower is done under the law of competition; they live where they must; they accomplish what they can. But relieved from this struggle for existence and placed in the less strenuous environment of the garden, if the essential conditions are congenial, the plant will improve. 


\section{DIPSACÀCEÆ-TEASEL FAMILY}

\section{SWEET SCABIOUS. MOURNING BRIDE}

Scabiòsa atropurpùrea.

Scabiosa, from scabies, scale; because of its repute as a medicine in skin diseases.

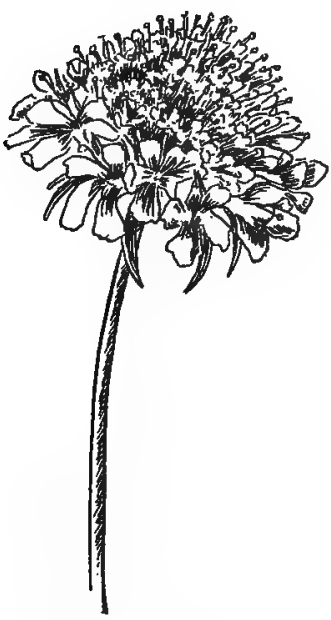

Sweet Scabious. Scabìbsa atropurpirea

A perennial herb from southern Europe; in our gardens an annual. July to September.

Stems.-Branched, two to three feet high.

Stem-leaves.-Pinnately lobed; lobes toothed or cut.

Flower-heads.-On long peduncles; involucre a single row of bracts; florets all tubular; outer row larger than the inner florets. 
Calyx-tube.-Cup-shaped, bristly.

Corolla.-Tubular, oblique, four to five cleft.

Stamens.-Four, inserted on corolla tube.

Style.-Club-shaped and protruding.

Fruit.-Akene, its apex crowned with the persistent calyx-lobes.

Sweet Scabious or Mourning Bride is a garden favorite because of its easy culture, extended period of bloom, and richness of its color range.

Though closely allied to the composites and greatly resembling them, it belongs to a small family known as Dipsacacece, or Teasels. Indeed, Scabiosa, of which we have two native species, and $D i p$ sacus are the only genera of the family growing in this country. The principal distinction between these and the composites lies in the condition of the anthers, which in the composites are united into a tube while in the Teasels they are free.

The flower-head of Sweet Scabious consists of many florets with four-lobed corollas, of which each outer row is larger than the others and increasingly so as they proceed from the centre to the circumference. These corollas are of varying length, with wide, funnel-like mouths, so that their nectar is accessible to shorttongued and long-tongued insects alike; hence the flowers are visited by all the insect tribe who love honey and have wings. The nectar is poured out by the upper part of the ovary and is protected against unwelcome visitors-ants and the like-by the hairy lining of the corolla tube. The florets develop gradually, so that the whole head offers attractions to its insect friends for a considerable time, consequently they return to the same head day after day. The anthers in each floret mature and shed their pollen one at a time; afterward the styles lengthen and the stigmas mature simultaneously with the result that a bee well dusted with pollen could easily fertilize all the florets of a flower-head.

In our gardens the plant is known as Mourning Bride; in Europe, Mournful Widow is the accepted name. It seems that the flowerheads are extensively used in southern Europe for funeral wreaths, whence the name. 


\section{COMPOSITA-COMPOSITE FAMILY}

The great family of Composite, which contains one-tenth of all the species of flowering plants in the world, is marvellously equipped to win in the struggle for life. Its pre-eminence lies in its ability to ripen more seeds to a stem than any other family, and consequently it overcomes its neighbors and possesses the earth by sheer force of numbers. The top of the flower stem is flattened and forms a platform, called the receptacle, upon which the individual flowers are set, often to the number of hundreds These are either tubular or ray flowers, or both.

In the tubular flowers the calyx-tube is so united to the one celled ovary as to be separate only at the summit where the calyx border, technically called a pappus, appears in the form of bristles, awns, scales, teeth, a minute cup, or nothing. The corolla tube is small, slender, five-lobed; the lobes valvate in the bud. The stamens are five; the anthers unite to form a tube surrounding the style, from which it finally protrudes. The style is two-cleft at the apex. The fruit is a seed-like akene, crowned, usually, with the remnants of the calyx-tube which appear so often in the form of white bristles that they are called pappus; Greek for grandfather.

In the ray-flowers the corolla is strap-shaped and the strap often has five minute teeth at the apex. The ray-flowers may be staminate, pistillate, or perfect; the tubular-flowers are usually perfect. The Composite flower-heads appear in three forms; that of which the Sunflower is an example consists of a disk of tubular-flowers and a row of rays about the edge; this is a radiate head. A flowerhead consisting wholly of rays also is radiate, of which the dandelion is an example. A flower-head consisting of tubular-flowers and no rays is called discoid, of which the Eupatoriums and the Greenhouse Stevia are examples. 
About the flower-head are gathered a number of bracts, sometimes leafy, sometimes scarious; frequently several rows, sometimes but one; but in any and every case they make the involucre, and its leaves are termed scales. The bracts and scales, which often grow on the receptacle among the flowers, are called chaff; when these are wanting the receptacle is said to be naked.

The autumn garden is full of Composites; some have been cultivated for hundreds of years, others are recent arrivals. Apparently, the number worthy of cultivation is unlimited and the changes wrought by cultivation very great. The family fitly holds its place as the most efficient type of flowering plants.

\section{COMMON SUNFLOWER. HELIANTHUS}

Helianthus annuns.

Helianthus, Greek, flower of the sun.

The familiar annual Sunflower of the garden, with huge heads and large, roughish leaves; variable; thrives in sunny places.

Stem.-Six to ten feet high, rough, hairy.

Leaves.-Large, usually alternate, petioled, varying in size and character.

Flower-heads.-Huge, four to twelve inches across; involucre of many leafy bracts, imbricated.

Tubular-florets.-Fertile, crowded in concentric circles on the flat, circular disk which is the receptacle; each floret embraced by a persistent bract called chaff.

Ray-florets.-Yellow, in a single row about the edge of the disk; neutral, that is, without stamens or pistil.

Calyx.-Reduced to two awns. .

Corolla.-Tubular, five-lobed.

Stamens.-Five, the anthers making a tube.

Style.-Two-cleft; divisions recurved.

Akenes.-Compressed, angular, wingless, the persistent chaff remaining with the fruit.

The Indian Sun or the golden floure of Peru, is a plant of such stature that in one Sommer, being sowne of a seede in April, it hath risen up to the height 
of fourteen foot in my garden, where one floure was in weight three pound and two ounces, and crosse overthwart the floure by measure sixteen inches broad.

-Gerard.

A careful study of the great flower-head of our Garden Sunflower will make clear the structure of all the composites, since, because of its size, it shows in magnified form all the parts. The tip of the Hower stem flattens out into a disk; this is the receptacle, and every

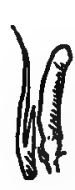

a.

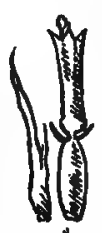

b.

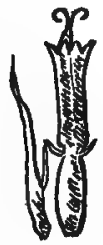

c.

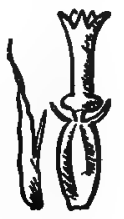

d.

Sunflower Blossoms.

$a$, the bud; $b$, the flower shedding pollen; $c$, the flower with stigma receptive; $d$, the akene maturing.

composite head has one, large or small. Around the outer rim of the circular disk, arranged as close as is convenient, are the large yellow rays; these constitute the chief beauty of the flower; it is they that attract attention. We call them petals, and so they are, but each one represents, in fact is, a separate and individual flower. In the Sunflower this outer circle of florets have lost both pistil and stamens, are corolla purely for show; but the show is worth while, for it is they who call the bees. All the other florets on the disk are small tubular-flowers crowded row on row in concentric circles; count them and you see that they number hundreds.

If you observe closely you will find that by the time the large yellow rays are properly in place the outer row of tubular-florets have opened; also that the flowering impulse proceeds from the outer row toward the centre. The disk-florets of any blossoming head may be seen passing through four regular stages. In the centre are unopened buds; next come open florets, the stamens shedding pollen; then we get florets in which the stamens have 


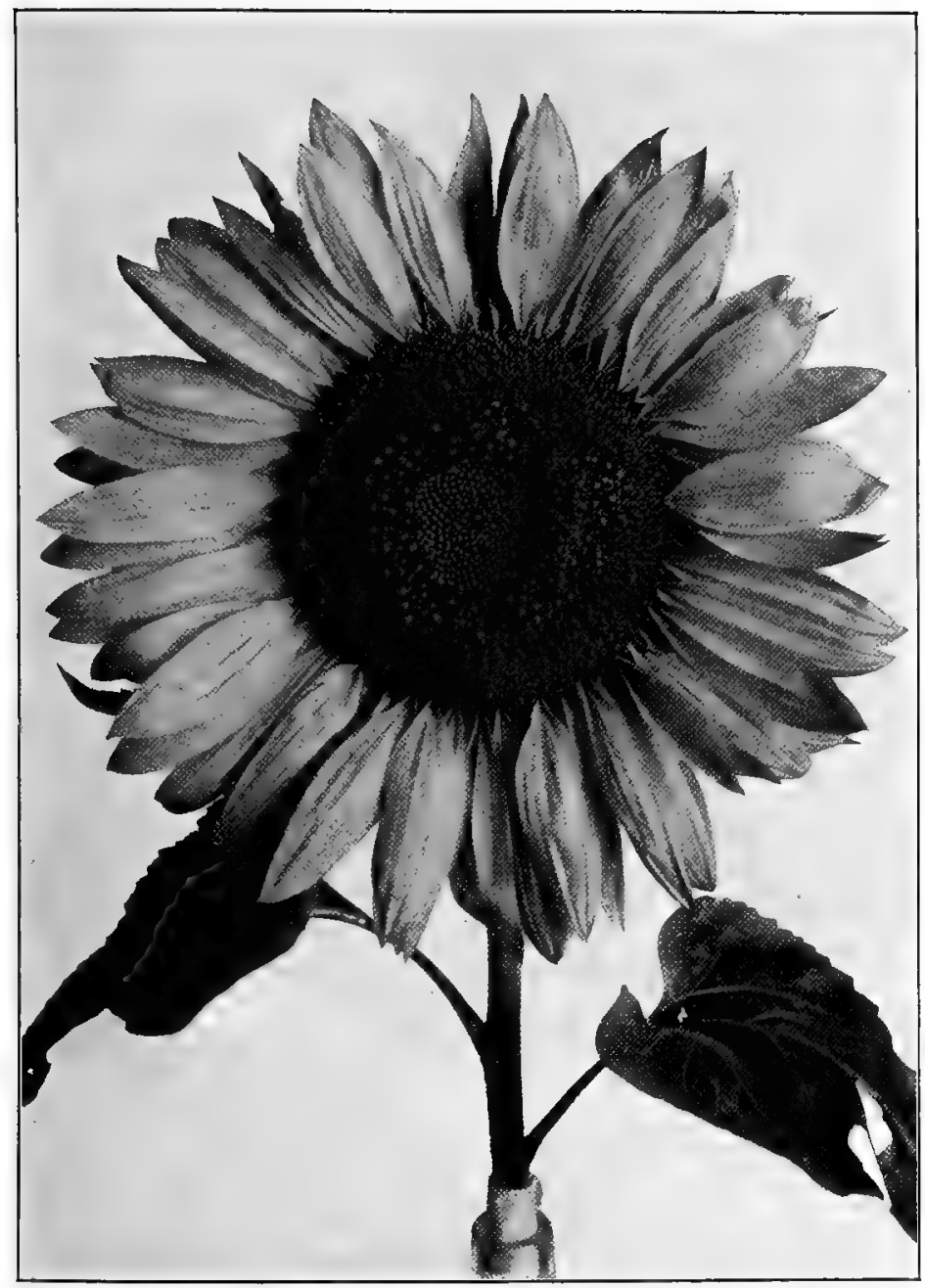

Great Sunflower. Helianthus annuns

Showing the disk-florets in their four stages of development. 
withered while the stigmas have opened, and, being receptive, are loaded with pollen; last of all, next to the rays, are rows of withered florets maturing the fertilized fruits. The flowering impulse is called centripetal; that is, it proceeds from the circumference to the centre. In one respect the florets of the Sunflower are unlike most composites-they still retain obvious traces of a true calyx and consequently are destitute of pappus. The rays stand up bravely to their duty until the very centre florets have opened; then they begin to droop; their work being done, they pass away.

Beneath the receptacle, strengthening and supporting it, are the leafy bracts, row upon row, that make the involucre. All composite heads have this; its office is the protection of the more delicate parts within. As the rays begin to droop, the involucre bracts become active and close as much as possible about the disk to protect the maturing seeds. What seems to be a seed is an akene; that is, a seed-vessel containing a single seed. These are large, brown, shining, each at first with two little ears that are obviously the remains of a calyx.

Moore's famous lines:

As the sunflower turns on her god, when he sets, The same look which she turn'd when he rose,

has been seriously questioned and regarded as a poet's fancy utterly without foundation in fact. But whoever carefully observes the growing plants of the Great Sunflower in his garden will be convinced that at a certain period of their development the growing tips do follow the sun. This is not true of the younger plants; and, obviously, it could not be true of the stem summit when loaded with flower-heads, or even of a single flower-head on its stiff peduncle, but at the time when the leaves of the summit are gathering into a rosette, preparatory to the appearance of the bud, the tips seem to be especially sensitive and they do follow the sunat least mine do; one cannot speak for his neighbors' Sunflowers.

The Great Sunflower has varied into many forms. Californicus is a large, double variety; globdsus has enormous globular heads; 
there is also a dwarf of this variety; the Russian Giant is the form cultivated in Russia for its seeds, which are sold upon the streets as peanuts are sold with us, and eaten raw.

The Sunflower is grown as a commercial crop in southern Europe, in Egypt, and in India. The products are the seeds, the oil that is extracted from them, and the oil-cake that remains. The fibre of the stems is very strong and makes a thread that looks like silk. It is clear that there are commercial possibilities in the plant were it worth while to develop them.

It is well to grow the Sunflower just to renew one's acquaintance with the yellow-birds. On their autumnal migration they seek Sunflower seeds and will visit almost anybody who has them.

Helianthus débilis is the primitive of the common, small, annual Sunflower. The stem branches freely from the base making a bushy plant. The leaves are ovate to triangular, generally cordate, glossy, irregularly toothed or entire, and the flower-heads have a spread of two to three inches. This species is largely grown for cut flowers; in the type the centre is dark. It appears in both single and double forms and does best in a sandy soil.

\section{PERENNIAL SUNFLOWERS. HELIANTHUS}

Heliánthus decapétalus. Heliânthus rígidus. Helianthus leetifiòrus.

The Perennial Sunflowers are in the main either the type or the variation of three North American Helianthi-decapetalus, rigidus, and letiflorus. They appear single, semi-double, and full double. July to October.

Stem.-Vary from two to eight feet, stiff, more or less branching, more or less leafy.

Leaves.-Sessile or short-petioled; in Helianthus rigidus six to twelve inches long, firm, thick, rough-hairy, ovate to broad-lanceolate, entire or slightly toothed, narrowed at the base into a winged petiole; in Helianthus decapetalus three to eight inches long, ovate-lanceolate, sharply serrate, rough above, pubescent beneath; in Helianthus latiflorus four to eight inches long, ovate-lanceolate, rough above and below, more or less serrate. 
Flower-heads.-Radiate, two and a half to four inches across; in type single, developing into semi-double and double forms. The disk in Helianthus rigidus is brown or purplish; in the others yellowish.

Disk-florets.-Fertile, rays neutral.

The garden race of Perennial Sunflowers is derived in the main from three species: Helianthus decapetalus, native to the Alleghany regions and New England as well as the Middle West; Helianthus rigidus, and Helianthus letiflorus, Western forms developed in the Mississippi Valley, accustomed to heat and not unacquainted with drought. All radiate composites under favorable conditions increase the number of their rays, and these native sunflowers have proved particularly amenable in that respect.

Helianthus decapetalus in name apparently records that the heads appear with but ten rays; this is a mistake,- they are frequently numerous even in the type. The plant prefers moist soils; ranges as far north as Quebec and as far south as Kentucky. Under cultivation it has given rise to the horticultural variety multiflorus, whose garden forms differ mainly in the extent of doubling, season of blooming, height and habit of the plant, and size of the flower-head. Among the best of these are: flore-plenus and grandifldrus, both almost completely double; màjor with very large flowers; maximus with a large single flower having pointed rays; Soleil d'Or with quilled florets. These multiflorus varieties are deservedly the most popular of the sunflowers.

Helianthus rigidus, naturally one of the dark-disked species, bears showy heads on long peduncles, and under cultivation has varied chiefly in the direction of doubling, and lengthening the blooming period; many favorite varieties are referred to this primitive: astivàlis, grandiflorus, sémi-plènus, and Miss Mellish.

Helianthus letiflorus is the parent of a very desirable garden variety-semi-plenus-which keeps its half-double form with very little care or attention. It is, of course, well understood that all highly bred varieties, if grown on poor soil or neglected, revert to type.

The landscape gardener who is an artist and has space at his command will often find that he can control results and produce 


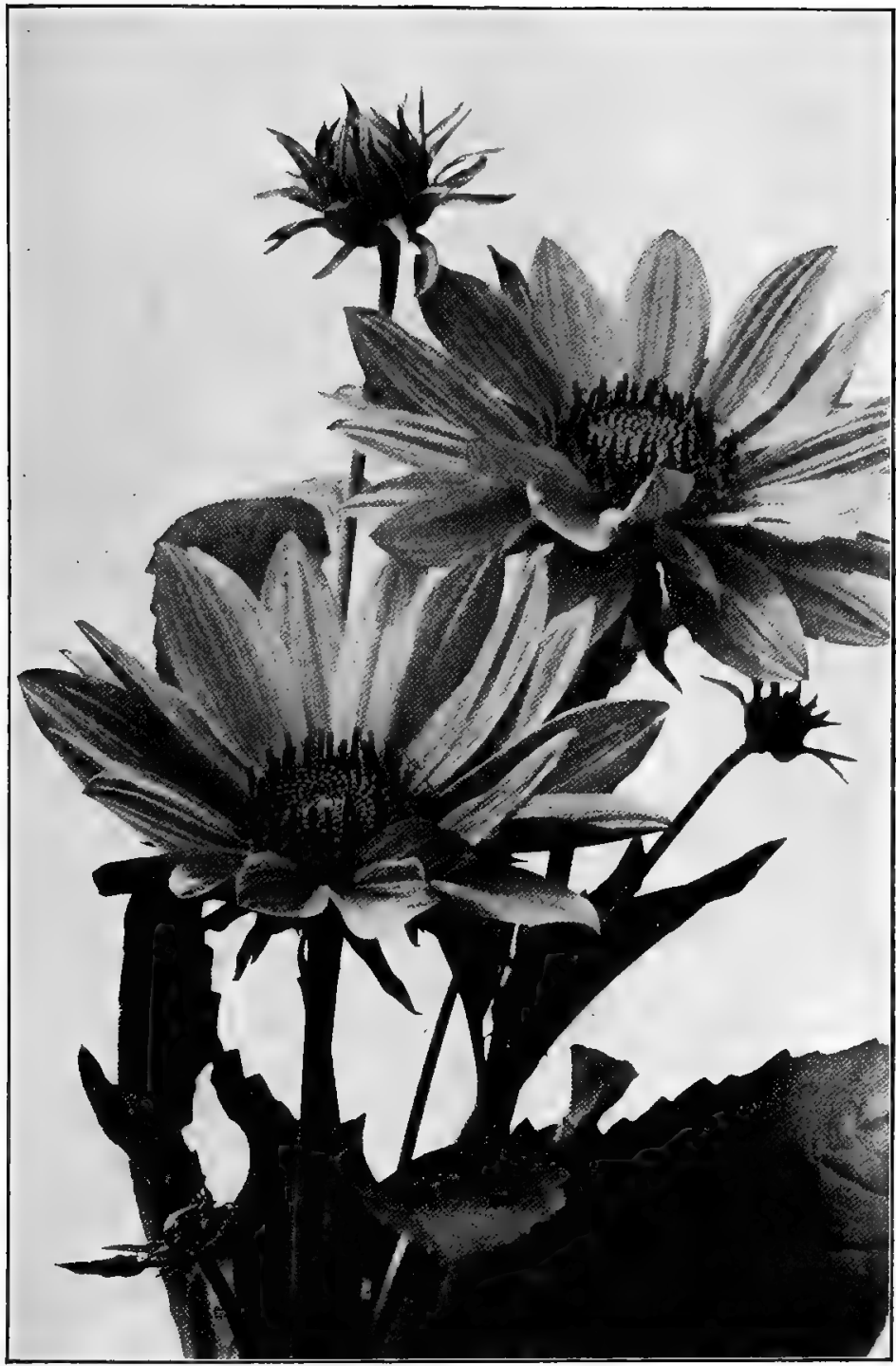

Sunflower. Heliânthus decapétalus. Garden Form. 
desired effects by transferring and massing the Helianthi native to the region rather than by relying upon the petted darlings of the garden. Darlings want to be coddled and that is not always possible.

The Jerusalem Artichoke, Helianthus tuberdsus, by no means an artichoke and having not the remotest connection with Jerusalem, has been grown in the past as a food; the creeping roots producing in autumn a number of irregular tubers which are edible and have the flavor of artichokes. This plant was introduced into England, in $16 \mathrm{r} 7$, from the Farnese gardens at Rome under the name Girasole Articocco, the Sunflower Artichoke. The AngloSaxon genius for changing names is here exemplified, and Girasole soon became Jerusalem and so it has remained. The plant is a trustworthy sunflower; it can be relied upon to do well with little care; it will even increase, its tubers look out for that; sometimes people regard it as a weed. The stem varies from five to twelve feet high, branching above. The leaves, four to eight inches long, are usually ovate, serrate, acuminate, rough. Flower-heads two to three inches across; disk-florets yellow; rays twelve to twenty. It blooms late.

Helianthus orgyàlis is an interesting species from the dry Southwestern plains, eight to ten feet high, having unbranching stems with very many linear, drooping leaves, eight to ten inches long, which give the plant an exceedingly unusual appearance.

\section{HELIOPSIS. OX-EYE}

\section{Heleópsis laèvis.}

Hileopsis, Greek, like the sun.

A beautiful native composite, resembling a wild sunflower, found blooming in sunny thickets during July and August. New York, south and west.

Siem.-One to four feet high, smooth or slightly roughish, often purplish.

Leaves.-Opposite, petioled, ovate or lance-ovate; smooth or roughish, triple ribbed at the base; coarsely serrate, acute or acuminate. 
Flower-heads.-Radiate, terminating the branches, with a spread of two and a half to three inches; rays golden-yellow, fertile; disk-florets yellow.

Involucre.-Of two to three rows of bracts, the inner shorter than the others.

Receptacle.-Convex; chaff yellow-tipped.

Akenes.-Four-sided; pappus either wanting or of two to four minute teeth.

Heliopsis is a great addition to the wild garden. The.flowerheads are three inches across, of a beautiful golden-yellow, and look like wild sunflowers. The distinction between the two lies largely in the shape of the receptacle, the character of the pappus, and the fertility of the ray-floret. In Heliopsis the receptacle is conical, the pappus is either wanting or consists of a few minute teeth, and the ray-florets are fertile. In Helianthus, the sunflower, the ray-florets are neutral; the receptacle flat or convex but never conical, and the pappus of two chaffy scales.

Heliopsis lèvis is advertised under the variety Pitcheriàna, which is, of course, a proper tribute to the one who brought it from the wilds and introduced it into the garden. But any one may gather the seeds in the wild-wood tangle, bring them home, and in due time the lovely creature will smile from the hardy border. The variety scàbra is simply a rougher form of the plant.

\section{HELENIUM. SNEEZE WEED}

Helènium autumnàle.

Ancient Greek name of obscure meaning.

A tall, handsome perennial; one of our finest autumnal composites. Used in park planting.

Stem.-Erect, rough, leafy, two to five feet high.

Leaves.-Alternate, lanceolate, toothed, often decurrent on the stem. $46 \mathrm{r}$ 
Flower-heads.-Radiate, showy, yellow; an inch and a half across, borne in loose corymbs. Rays bright-yellow, fertile, inclined to droop; disk-florets tubular, greenish-yellow, crowded on receptacle

Involucre.-Of a few long, slender, reflexed bracts.

Receptacle.-Globular or conical.

Akenes.-Top-shaped and ribbed.

Pappus.-A few thin scales.

Helenium has been very generally planted in parks along with local forms of Helianthus. It masses well and gives a variety in

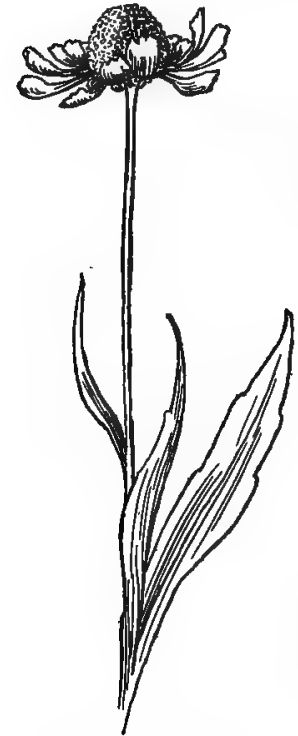

Helenium. Helèrium autumnàle color effects. Although the rays are brightyellow, the disk-florets are greenish-yellow, which affects the tone of the mass. Cultivation has already produced several very beautiful varieties, and more may be expected.

\section{RUDBECKIA. CONE FLOWER}

Rudbeckia laciniàta.

Named in honor of two professorsRudbeck, father and son; predecessors of Linnæus at Upsala.

The typical perennial species which has produced the favorite double form known as Golden Glow. Prefers moist locations; ranges from Canada to Florida, west to Montana and south-west to New Mexico.

Stem.-Two to seven feet high, smooth, branching above.

Leaves.-Alternate; lowest pinnate with five to seven cut or cleft leaflets; uppermost usually three-cleft or undivided.

Flower-heads.--Radiate, on long peduncles, two and a half to three inches across. Rays bright-yellow, several, neutral, somewhat drooping; disk-florets greenish-yellow.

Involucre.--Of two rows of bracts. 
Receptacle.-Oblong and in fruit cylindrical; chaff yellow-tipped.

Pappus.-None or a minute crown-like border.

Akenes.-Four-angled.

Rudbeckia laciniata is one of the tall vigorous composites which brighten the tangle and adorn the roadsides in August. It often stands seven feet high, bearing a loose collection of long peduncled heads, with disks somewhat elongated. The bright-yellow rays droop a little, but the general effect of the flower-head is that of a sunflower.

The garden favorite, Golden Glow, is a full double form of Rudbeckia laciniata which has been cultivated since I896; but whence it came or how it was developed seems to be quite unknown. It was "found" among a collection of plants.

\section{PURPLE CONE FLOWER}

Echinòcea purpìrea.

Echinacea, Greek, hedgehog; referring to the receptacle with its sharp, pointed chaff.

Stem.-Usually smooth, usually two or three feet high, from a thick, black, pungent-tasting root.

Leaves.-Chiefly alternate, three to fiveribbed, veiny, ovate or lanceolate, dentateserrate; lower leaves with long-margined petioles.

Flowers.-Radiate; rays dull rose-purple; rather persistent, long, drooping, pistillate but sterile; disk-florets brownish-purple.

Involucre-Of several rows of bracts, with spreading and pointed tips.

Receptacle-Convex or conical.

Chaff.-Rigid, spiny-tipped, persistent, longer than the disk-florets.

Akenes.-Thick and short, four-sided, with a toothed border for pappus.

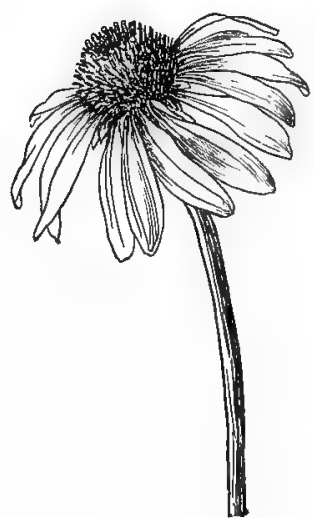

Purple Cone Flower. Echinàcea purpired 


\section{COMPOSITE FAMILY}

The Purple Cone Flower is a coarse, sturdy plant of the type of the familiar Black-eyed Susan or Cone Flower, Rudbeckia hirta, only larger, the rays dull rose-purple and reflexed. The blooming season is long, the flowers effective; but the plant belongs with the stiff, unyielding groups.

\section{LEPACHYS}

\section{Lépachys pinnàta.}

Lepachys, Greek, a thick scale; referring to the thickened upper part of the chaff.

One of our native, perennial composites, now considerably used in park planting.

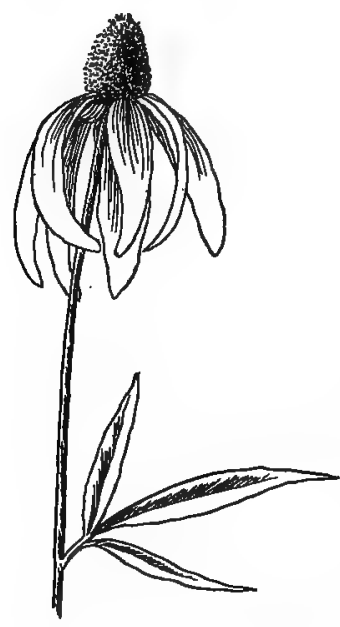

Lepachys. Lếpachys pinndı

Stem.-Slender, hoary, with minute, appressed hairs, three to five feet high.

Leaves. - Alternate, pinnately parted; leaflets three to seven, lanceolate, acute.

Flower-heads.-Radiate, rays bright-yellow or parti-colored, drooping, two inches long; disk-florets reddish-brown, tubular, crowded on the receptacle.

Involucre.-A single row of small, green, spreading bracts.

Receptacle.-Conical or columnar.

Pappus.-None or a short crown.

Akenes.-Flattened laterally, and margined.

Lepachys is one of our Western composites which is proving itself an excellent park plant. The flower-heads are unusual in appearance for the rays look as if poised for flight, ready to wing themselves away at the first opportunity. From the tip of the thimble disk to the last point of its drooping ray the flower-head measures about two and one-half inches. The dark disk-flowers creep up the column, and the great yellow rays wait till the last one opens and then the season is over for that head. 


\section{WHITE TANSY}

Achîllea ptârmica.

A popular, hardy, perennial herb, much used for cut flowers, appearing in gardens principally in its double variety. Naturalized from Europe. Highly prized because of its long blossoming period, extending from June to October.

Roots.-Perennial, by horizontal or creeping rootstocks.

Stem.-One to two feet high, glabrous or slightly pubescent, nearly or quite simple.

Leaves. - Linear or linear-lanceolate, sessile and slightly clasping at base, acute at apex; regularly and closely serrate, sometimes pubescent on the veins beneath.

Flower-heads.-Radiate, white; rays six to twenty; heads in loose corymbs; disk-florets yellow.

Involucre.-Bell-shaped; bracts ovate-oblong, imbricated.

Receptacle.-Chaffy.

Akenes.-Oblong, slightly compressed; pappus none.

The preferred form of Achillea ptarmica

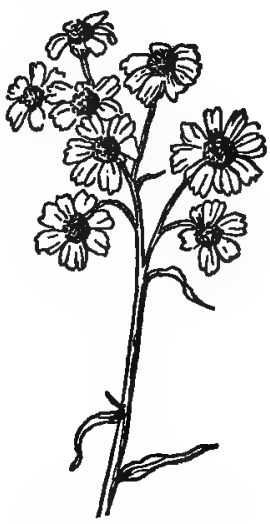

White Tansy. Achillea plármica is the variety known as The Pearl, in which all the tubular flowers have been replaced with rays and each flower-head becomes a little white rosette. Fortunately in this transformation the plant has lost little, if any, of its wild vigor at the same time that it has gained so greatly in beauty.

The familiar Yarrow, Achillea millefolium of the roadside, is a European weed thoroughly naturalized at the North. A variant form with flower-heads of magenta-pink has been transferred to the hardy border; this appears as variety roseum. The typical form was, and perhaps is, still used in that kind of domestic divination of which Scotch and English folk-lore is so full. On Midsummer Eve a bunch of Yarrow under the pillow would bring to the sleeper in dreams the future husband or wife. An old 
rhyme showing this belief is still extant among the common people of England:

Thou pretty herb of Venus tree

Thy true name it is Yarrow;

Now who my dearest friend shall be

Pray tell thou me to-morrow.

\section{DAHLIA}

Déhlia variábilis. Dáhlia rosèa.

Named in honor of Dr. Dahl, a pupil and friend of Linnæus.

Dahlia variabilis is believed to be the primitive form of all the Dahlias in cultivation, with the possible exception of the Cactus Dahlia, Dáhlia juarézii. Found at an elevation of seven thousand feet on the mountains of Mexico. Extremely variable.

Roots. - Tuberous, must be stored in winter and planted.

Stem.-Four to six feet high.

Leaves.-Pinnately compound; the leaflets lobed.

Flower-heads.-Radiate; rays red, yellow, or white; disk-florets yellow. By cultivation the disk-florets are turned into rays producing the well-known double forms.

Involucre.-Of several series of bracts; the outer series leafy, reflexed; inner series more or less scarious, close to the rays.

Receptacle.-Convex, covered with involucral scales.

The horticultural history of the Dahlia is well known. The plant was discovered by Cervantes, the director of the Mexican Botanic Gardens, and by him sent to Spain late in the eighteenth century. From this stock in $\mathrm{r}_{7} 89$ specimens were brought into England, but these all died. In 1800 a consignment of seeds and tubers was sent directly to France from Mexico. The hope then was that the plant would produce an edible tuber; which hope has been disappointed. From this consignment specimens came into England; these were successfully grown and by 1826 the Royal Horticultural Society reported sixty varieties cultivated upon its grounds. There are probably in the present garden race slight 


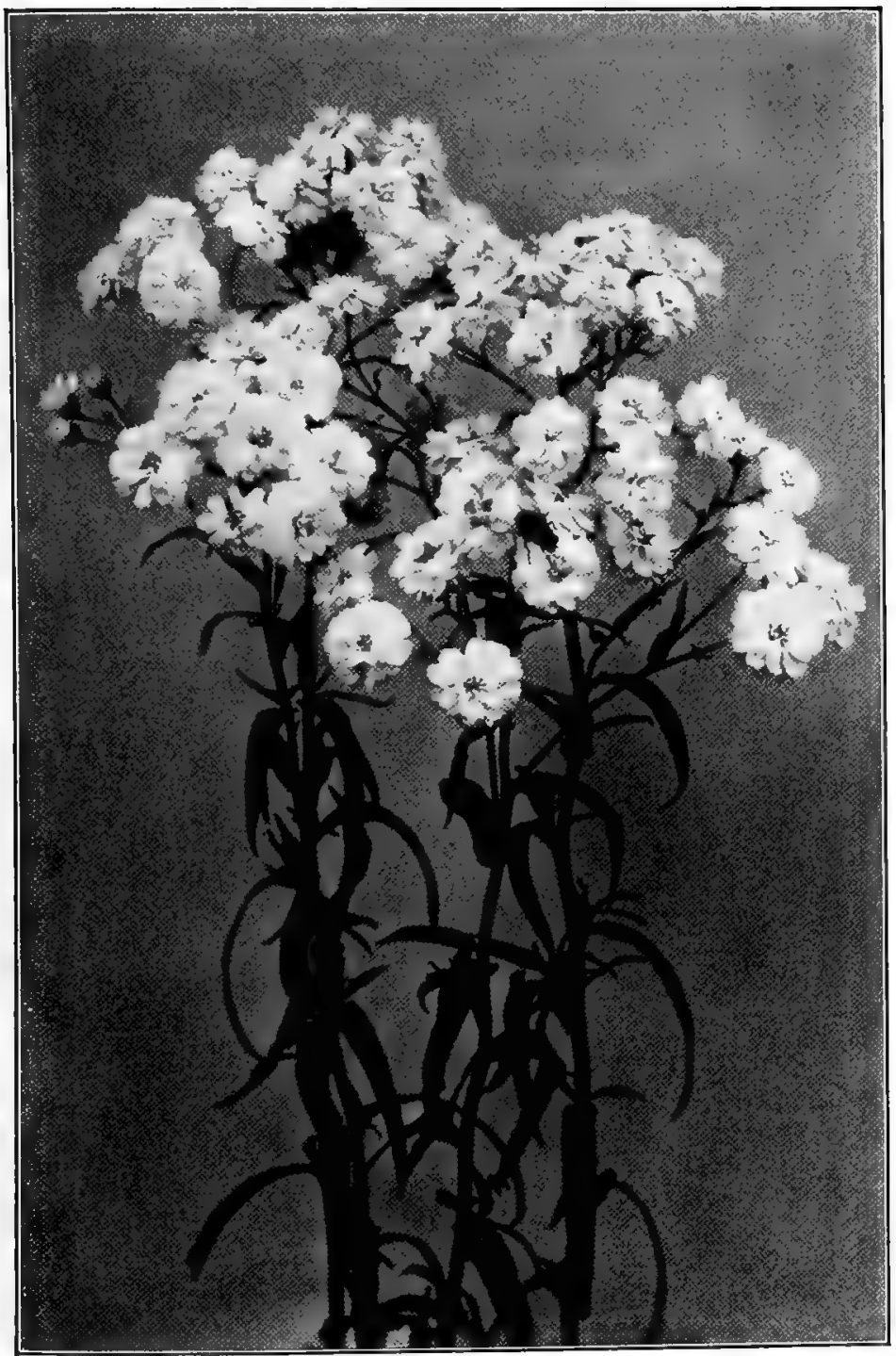

Achillea. Achillea ptârmica var. The Pearl 
strains of other species, but at base the Dahlia of the garden is the modified and variable forms of Dahlia rosea, the first species of the genus introduced into cultivation.

It is evident that from the first the species varied marvellously within clearly defined limits; that the original eight-rayed flower developed double forms with wonderful facility; and that very early two definite groups known as the Show and the Fancy types were established.

This classification still exists; its limits are well understood and its laws observed in all competitions among Dahlia growers. The Show Dahlia is usually of one color, though it does not lose standing if the edges of the ray are darker than the ground.

The Fancy Dahlia is always of two or more colors, striped or with edges lighter than the ground. The Pompon is simply a small brother of the Show or the Fancy Dahlia, having the same colors and the same form with smaller and more abundant bloom. These three groups represented the development of the Dahlia until I88o. They are stiff, formal flowers of surprising regularity and great range of color. The standard of perfection requires that no yellow centre is to be seen. The reaction against this formal flower, this "chub-faced dahlia which carves out of soap, lard, or wax his regular pompons," found expression in the Cactus Dahlia. The origin of this type is virtually unknown. A Dutch dealer got a root from Mexico that produced one plant which is the parent of all the cactus forms. It is not known whether this root was produced by the seed of a wild or of a cultivated form; neither is it known whether any wild single Dahlia of the cactus type has ever been found. The plant was named Dahlia Juarezii in honor of the Mexican president and so appears in all the garden lists. This new Dahlia was named Cactus because of the resemblance in form, but chiefly in color of its blossom to that of the crimson-flowered Cèreus speciosissimus. The name has lost whatever significance it might at first have possessed, for the Cactus Dahlia has acquired all the colors of its race.

The Decorative or Cactus Hybrid group includes all forms that vary from the strictly formal and cactus types. Many are hybrids 


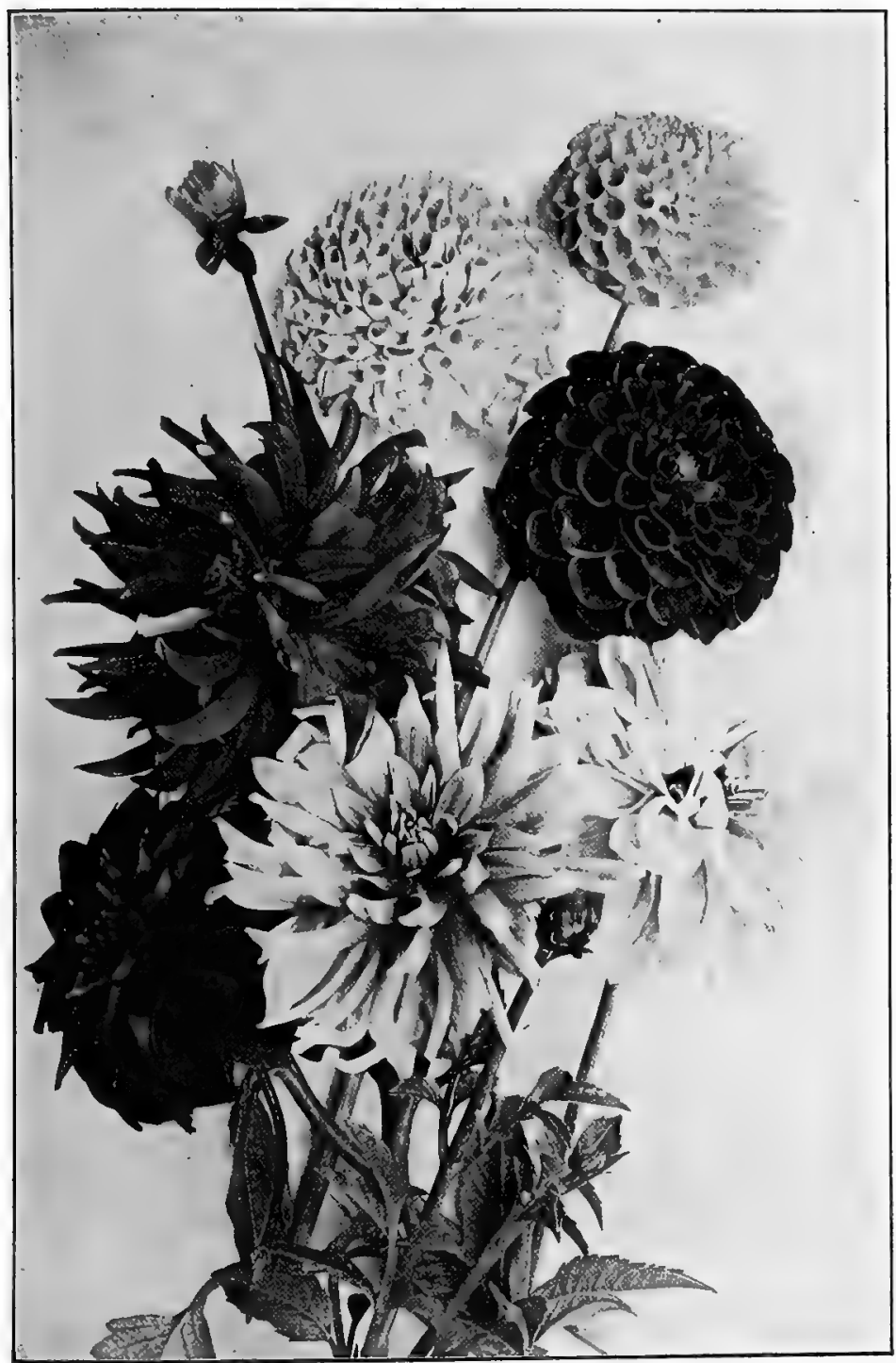

Dahlia in variety. Dáhlia varióbilis 
as the name implies, many are seedlings of the Show Dahlia. In this group are placed the new and hybrid forms, many of them fluffy and touselled.

The single Dahlias in cultivation differ considerably from the wild type. In the primitive form the rays are slender, pointed, and far enough apart to give a star shape to the blossom. The preferred garden form has broader and rounder rays with the spaces between closed; but apart from these differences it well represents the primitive flower as it blooms on the mountain-side in Mexico.

\section{PYRETHRUM}

\section{Chrysânthemum coccinium. Pyrèthrum rosèum.}

The well-known perennial Pyrethrum cultivated in many varieties and often forced for spring flowers. Native of Persia. May, June.

Stem.-Erect, one to three feet high, branching, smooth.

Leaves.-Pinnately cut, the lower leaves petioled, the upper sessile. Flower-heads.-Radiate, terminal, solitary; rays fertile, of various colors, but chiefly shades of red.

Involucre.-Of many close-pressed bracts imbricated in several series, the outer shorter.

Receptacle.-Flat, without chaff.

Akenes.-Ribbed; pappus none.

Pyrethrum in garden literature and language almost always means Pyrethrum roseum, a handsome, summer-blooming, perennial composite with erect stems and finely dissected foliage. The flowers run the range of red to white through pink, carmine, rose, crimson, and lilac. They look like red ox-eye daisies and vary from a single row of rays to double forms like those of asters and chrysanthemums.

The type originated in the mountainous regions of Persia and along the flanks of the Caucasus; has been long in cultivation: is of exceedingly variable nature and docile in the hands of the gardeners, as more than six hundred named varieties have been developed. 
With us they are largely, if not principally, forced in the greenhouses for the spring trade, and as a rule are not cultivated in our gardens. But those who do cultivate them recommend them as hardy and easily grown. They seem better able to withstand our winters than to endure our summers. They must have a cool, moist root-run, and being surface-rooting plants suffer if under the direct rays of our hot summer sun. Doubtless there is a place in every garden where they would flourish, and it is certainly worth while to take the trouble to find it.

\section{SUMMER CHRYSANTHEMUM. KEELED CHRYSANTHEMUM}

Chrysanthemum carinàtum. Chrysainthemum tricolor.

The most brilliant of the annual Chrysanthemums, easily distinguished by the keeled or ridged scales of the involucre and the darkpurple disk.

Stem.-Erect, much-branched, about two feet high.

Leaves. - Cut to the midrib, segments narrow, irregular, and fleshy.

Flower-heads.-Solitary, on stems or branches; rays broad, three to five-lobed, white with a yellow ring at base; have varied into many different forms; diskflorets dark-purple.

Involucre.-With about three rows of ridged or keeled scales and an upper row of scarious scales.

Receptacle.-Slightly convex.

Pappus.-A minute crown.

The Summer Chrysanthemum, or Keeled Chrysanthemum, so named because of the ridges on the involucral scales, is the most brilliant of all the annual chrysanthemums. The primi-

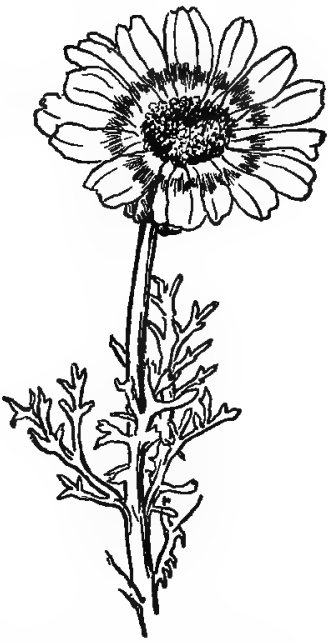

Summer Chrysanthemum. Chrysanihemum tricolor tive of this garden race was brought into England from Morocco in I798. It attracted great attention from the first. Because of 
the variety of color that it displayed-white rays with a yellow zone at base and a dark-purple disk-it received the name Chrysanthemum tricolor.

The garden varieties produced from this wild form are both single and double, but this was to be expected. The unusual

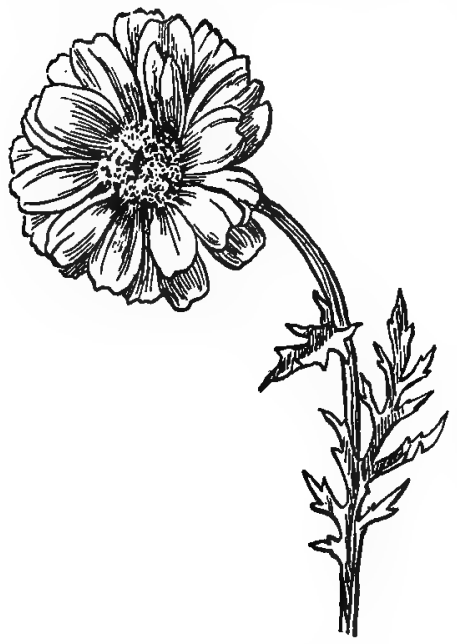

Garland Daisy. Chrysinthemum corondritum achievement has been to add a ring of another color to the original yellow as well as to obtain strains of both red and yellow. Varieties are now offered in the market with a ring of red, maroon, or purple outside the ring of yellow, and in some forms the entire ray is flushed with pink.

The old-fashioned Summer Chrysanthemum, or Garland Daisy, Chrysanthemum coronàrium, or Ánthemis coronària, from the Mediterranean region, also annual, is distinguished by its keeled involucral scales, the upper row of which is scarious. The leaves

are bipinnately parted, somewhat clasping or eared at the base, the segments rather closer together than in carinatum. The rays are bright lemon-yellow, sometimes pale-yellow, almost white. The disk-florets are yellow. Semi-double and full double forms are common and popular. The plant grows three feet high, sometimes more.

Costmary, or Mint Geranium, Chrysanthemum balsamita var. tanacetoides, is a perennial species with sweet-scented leaves and discoid yellow flower-heads in flat-topped clusters. The plant is erroneously known as lavender. It has escaped in a few places from old gardens.

Corn Marigold, Chrysanthemum segetum, "the beautiful pest of 
the corn-fields," is an annual species with golden rays, cultivated and sometimes forced, but really not worthy of the trouble. It is native to Great Britain and the Continent.

Golden Feather, Chrysanthemum prealtum var. aùreum, horticulturally Pyrèthrum aureum, is the low-growing form with yellowish foliage, commonly used for carpet bedding. Sometimes the foliage is very yellow, and so remains throughout the season; it is very likely to become greener as the summer advances, especially if flowers are allowed to form. There is a dwarf variety, aureum crispum, with foliage curled like parsley, and another, glaucum, with dusty white foliage. This

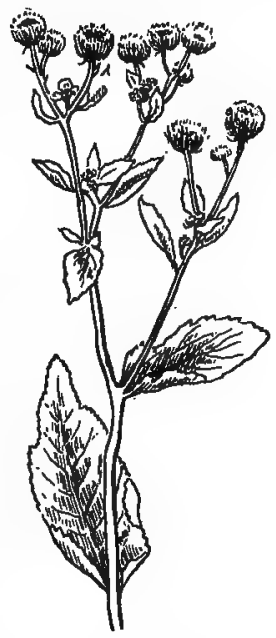
species is not considered by botanical authorities distinct from Feverfew, Chrysanthemum parthènium.

The Marguerite, or Paris Daisy, Chrysanthemum frutesscens, is the well-known perennial greenhouse plant, shrubby at base, branching abundantly at the top. Native to the Canary Islands,

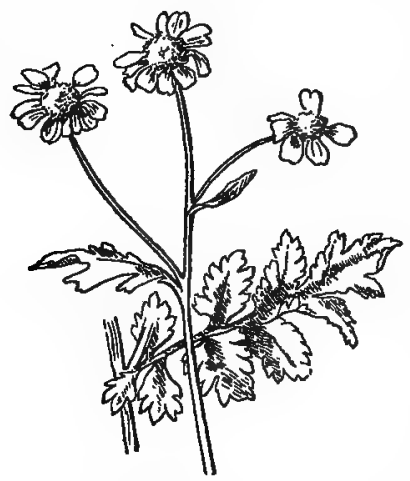

Golden Feather. Chrysánihemum aìreum

it has been the especial care of the French gardeners, and its extensive cultivation has resulted in many varieties. The variety chrysaster has yellow rays and is known as the yellow Marguerite.

Giant Daisy, Chrysanthemum uliginòsum, becomes a stout, erect bush four to five feet high, perennial, but blooming the first year from seed. The blossoms look like particularly fine ox-eye daisies, two to three inches across.

Though native to the swamps 
of Hungary, the plant has thriven under garden conditions and is now deservedly a favorite.

Ox-eye Daisy, or Whiteweed, Chrysanthemum leucanthemum, is the well-known pest of the meadows of New England and the Middle States, detested by farmers but loved by artistic vagrants. The flowers are often gathered for decoration, as they last a long time. The plant came to us from Europe. One of its great centres of distribution was the battle-field of Saratoga and the route of Burgoyne's army, because his horses were fed upon fodder which came from central Germany, and this weed, so tradition says, was in the hay and its seeds sprang up in the track of the army.

The Shasta Daisy, of Mr. Burbank's creation, is a hybrid of leucanthemum, which is modified and improved by strains of German and Japanese daisies.

Hardy Chrysanthemum is the name given to the chrysanthemums blooming in the border in October and November. There have long been in cultivation plants called "Chinese" or Smallflowered Chrysanthemums, and these, now grouped under the "Pompon type," have been greatly improved and are offered in variety by all dealers.

The Hardy Chrysanthemums have been overshadowed by the florists' wonderful flowers, but there are indications that they are coming to their own. It is certainly a mistake to surrender the garden to the first frosts. In northern Ohio it often happens that a killing frost comes in September, followed by weeks of beautiful, warm, summer weather-but the garden is ruined. A little care, some yards of cotton cloth, a few stakes easily moved, and the Nasturtiums, the China Pinks, the Marigolds, and the Pansies would be saved. Indeed, the Gaillardias, Calendulas, and Geraniums make a brave fight on their own account. Sweet Alyssum never surrenders. Petunias do their best. Cosmos, of course, stands. But, at the best, these plants of the summer live a precarious life, and the real foundation for the October garden is, and must be, the Hardy Chrysanthemums. These are essential for massed effects of color, and they give marvellous yellows, yellowbrowns, and pinks. There are also plenty of whites, and it is to 
the whites that one must turn for the peacemaker in the October, as in fact in any, garden.

\section{FEVERFEW \\ Chrysânthemum parthènium.}

Perennial, growing in tufts; early introduced into this country and still in cultivation; in the Eastern States has escaped into waste places. Europe. Summer.

Stem.-One to three feet high, leafy, branching.

Leaves.-Yellow-green, pinnately parted into ovate or oblong segments which are pinnatifid or incised into rounded divisions.

Flower-heads.-Radiate, three-fourths of an inch across, white or cream, borne in loose terminal or axillary cymes; the peduncles leafy or bracted; rays white, few or many; disk-florets white, tipped with paleyellow.

Receptacle.-Slightly convex, naked.

Involucre.-Broad and flat; scales imbricated, margins scarious.

Pappus.-Minute crown, or none.

This is one of the old favorites that grew in pilgrim gardens, and still finds a place in the hardy border. The plant makes bushes three or more feet high and of proportionate breadth. The leaves are

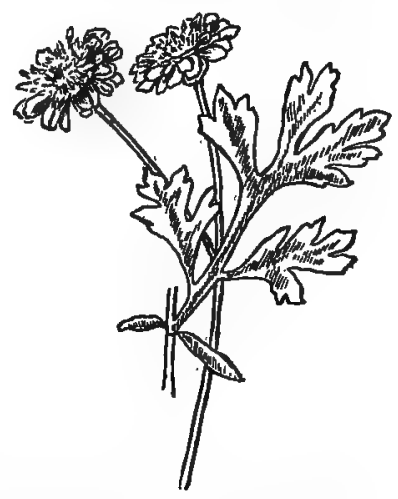

Feverfew. Chrysânthemum parlhenium pinnately divided into coarse divisions, which are cut again into rounded and toothed segments. The flower-heads exercise the unquestioned right of a composite to vary, and while, during all the years of cultivation, they have not enlarged in size materially, many different forms appear. Among these is a half-double with perhaps twenty white rays and a pale-yellow disk; another is a fuill-double, though not very regular; a third has slender tubular rays and small quilled disk-florets; a fourth flat rays and a hemispherical disk of small quilled florets. In all these variations the habit of growth and character of foliage remain unchanged. 


\section{YELLOW CHAMOMILE. GOLDEN MARGUERITE}

\section{Anthemis tinctòria.}

Anthemis, Greek, meaning obscure.

A heavy-scented perennial of abundant bloom, bearing golden-yellow daisy-like flowers; one to two inches across. Europe. Summer.

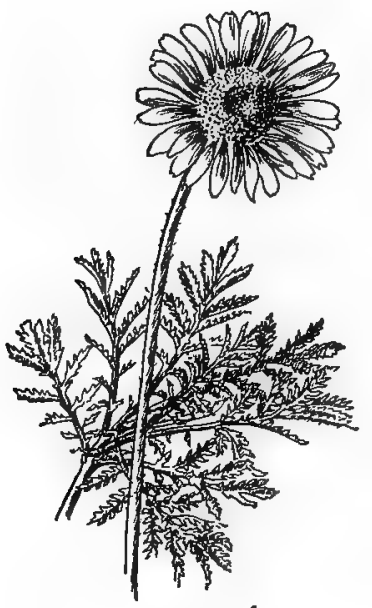

Golden Marguerite. Anthemis tinclòria

Stem.-Erect, angular, two to three feet high, of bushy habit.

Leaves.-Alternate, pinnately divided.

Flower-heads.-Daisy-like, goldenyellow; rays many, fertile; disk yellow.

Involucre.-Hemispherical; b r a cts unequal, small, imbricated.

Receptacle.-Convex, chaffy.

Pappus.-None; akenes oblong.

The Golden Marguerite is a plant a good deal like Pyrethrum, bearing abundantly from midsummer to frost beautiful daisy-like flowers. Of these the disk-florets are on a rounded receptacle and the rays are either brightyellow or pale-yellow; both forms are in cultivation. The variety Kelwayi is the present favorite for cultivation.

The Chamomile of commerce is the flower of Anthemis nobilis, a much-branched, downy-stemmed plant, bearing daisy-like flowerheads with yellow disks and white rays. For medicinal purposes the heads are cut as soon as expanded and carefully dried. A double form is in the garden, and the medicinal form has sometimes escaped from cultivation.

There is an old and still prevalent opinion that this plant thrives better for being trampled upon or kept prostrate. This notion is incidentally alluded to by Shakespeare in "King Henry IV," "For though the camomile, the more it is trodden on the faster it grows-yet youth, the more it is wasted the sooner it wears." 
The Mayweed of our roadsides and waste places is a Chamomile, Anthemis cótula. The flower-heads look like small, white daisies, the leaves are finely cut and the plant is ill-smelling. It possesses that wonderful ability to exist where it is not wanted which makes it a weed, and it crowds close to the wheel tracks at the roadside and takes possession of barnyards and neglected fields. The flower-heads go to sleep at night, the rays turn backward and so put the disk prominently forward, just why is not clear.

The stem branches wonderfully, and in a favorable situation does marvels. A single Mayweed plant growing alone upon the summit of a low heap of clay, by actual measurement, attained a hemisphere two feet in diameter and bore by actual count over six hundred open flower-heads at one time. No plant by the garden walk could compare that morning with the child of the waste land, either in perfection of form or fulfilment of obligation.

\section{GAILLARDIA}

\section{Gaillärdia cristàta. Gaillárdia pulchélla.}

Gaillardia, named in honor of Gaillard de Merentonneau, a French botanist.

The garden race of Gaillardia are hybrids of two species: Gaillardia cristata, a perennial form, and Gaillardia pulchella, an annual plant. Both are native to the Western plains and prairies of North America, from the Northwest Territories to Mexico. May to September.

Stem.-Erect, one to two feet high, hairy.

Leaves.-Gray-green, variable.

Flower-head.-Radiate, terminal on long, slender peduncles, two to three inches across.

Rays.-Neutral, large; broad, yellow, or parti-colored; banded, showing yellow, orange, brownish, crimson, purple, often with a metallic lustre. There are garden forms in which the outer rays are tubular and the disk-florets much enlarged.

Disk-florets.-Yellow, often purple; their corollas slender tubes with five teeth; teeth hairy.

Involucre.-Two or more rows of loose, leafy bracts.

Receptacle.-Convex or globose; fimbrillate.

Akene.-Top-shaped, ribbed, very hairy, crowned with a pappus of six or more long, thin, awned scales. 
The Gaillardias of our gardens are the hybrids and variants of two typical species, native to the warmer parts of the United States. They easily rank among our best garden plants, producing as they do masses of beautiful and effective flowers from midsummer until late autumn. Lovers of the sun, they seem never to find our summers too hot and they also endure considerable cold; one often finds belated blossoms in the Gaillardia bed when other plants are prostrated by the frost.

The cultivated forms are so varied and so confusing that it is practically impossible to distinguish them. If your plant lives over the winter you know it is of the cristata race; if, on the other hand, it dies in the autumn, its dominant strain is pulchella. The most satisfactory plan is to call them Gaillardias and let it go at that.

The color range is red, yellow, and orange, with shades of brown, often brightened with a metallic, purplish tinge; these combina-

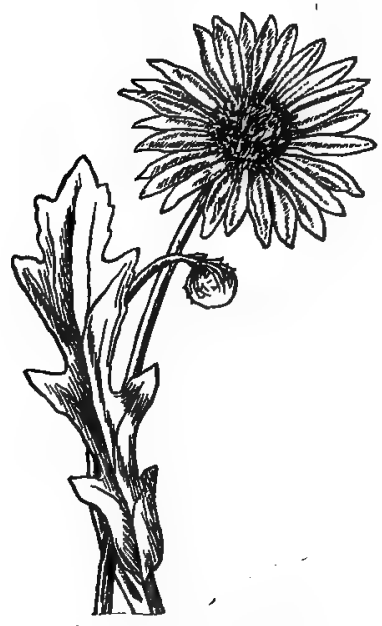

Arctotis. Arclolis grandis tions produce effects of startling brilliancy, each flower-head suggesting a sunburst.

Among Gaillardian virtues is that of being excellent cut flowers; the heads stand up on good self-respecting stems and take water freely.

\section{ARCTOTIS}

Arctòtis grândis.

Arclotis, Greek, bear's ear; alluding to the silky, shaggy akene.

A remarkably handsome annual from south-western Africa, of the daisy type, forming much-branched bushy plants which bear from early summer to late fall beautiful white flowers.

Stem.-Erect, much branched, two to three feet high, hollow, covered with white woolly hairs.

Leaves.-Thick, grayish-green, covered with white woolly hairs above and beneath. 


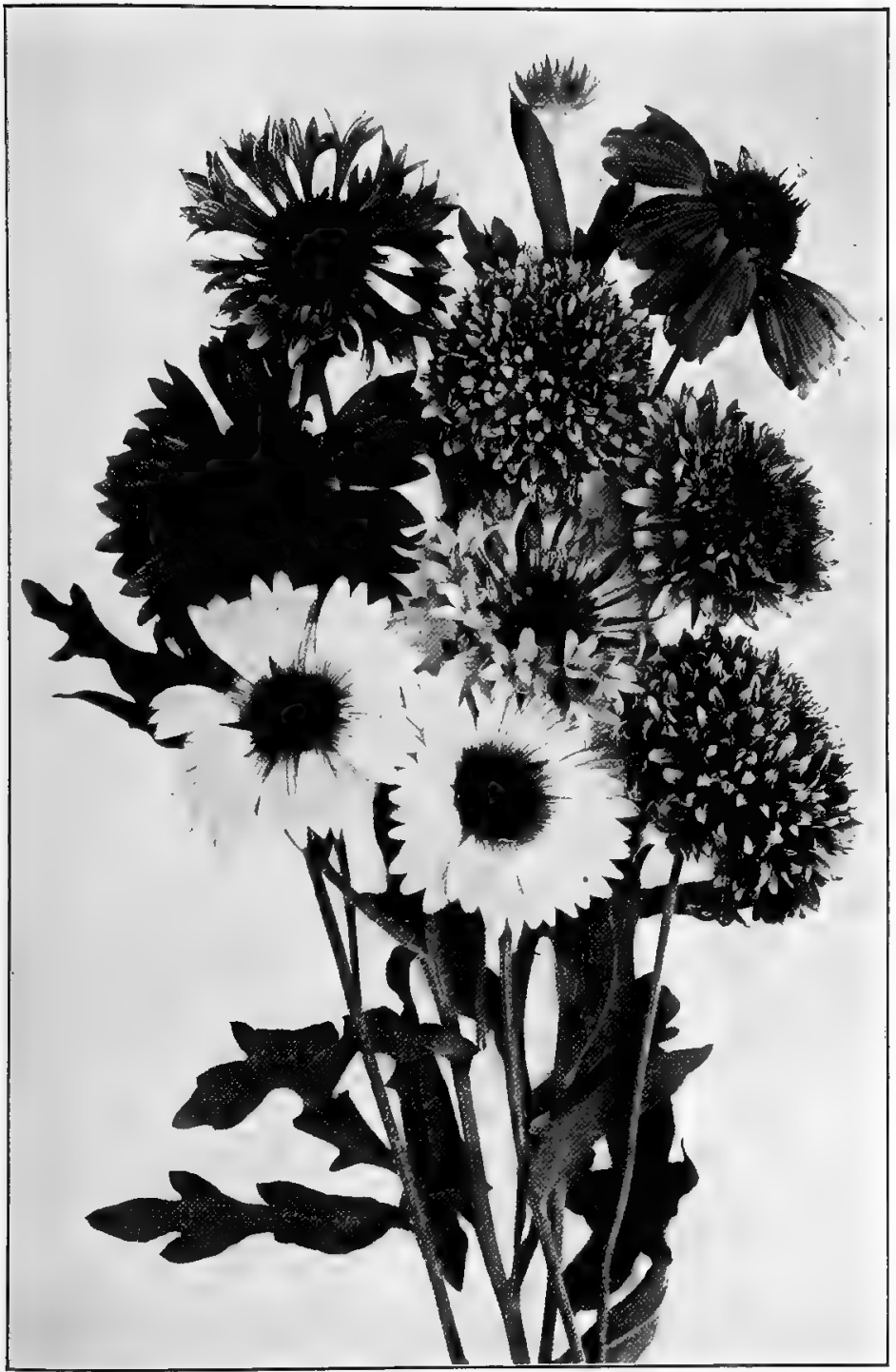

Gaillardia in variety 
Flower-heads.-Radiate, white, with a bluish centre, having a spread of two and a half to three inches; rays many, fertile, white on upper surface, with a dash of yellow at the base, pale lilac-blue beneath; diskflorets blue with white polien.

Involucre.-A flat-bottomed cup of three to four rows of woolly bracts, with free tips, and two or three rows of thin, translucent bracts nearest the rays.

Receptacle.-Flat or slightly convex, honeycombed and fimbriated.

Pappus.-Abundant, of white plumose bristles.

Akenes.-Shaggy, with white bristles.

Arctotis is a remarkably handsome annual from south-western Africa, and a most valluable addition to our list of summer flowers. It belongs to the daisy type of white-rayed composites; its flowerheads on long stems are large and showy, being pure-white on the upper surface, embellished with a yellow zone near the disk; the reverse of the ray is pale lilac-blue. Under the influence of bright sunlight the flower becomes almost flat and the pure-white of the rays contrasts charmingly with the pale-blue disk with its slightly projecting white stamens. The flowers close at night to open the next morning.

\section{MARIGOLD. CALENDULA}

Calêndula officinàlis.

Calendula, Latin calenda, the first day of each month, referring to its continuous flowering in the climate of England.

This Marigold is often grouped among sweet herbs, having been used as a'flavor for soups and meats. Native to the Mediterranean region. Annual. Summer.

Stems.-Erect, branching, one to two feet high.

Leaves.-Alternate, obovate.

Flower-heads.-Radiate, orange to yellow, two inches across; rays in several series, fertile; disk-florets tubular, staminate only, producing no seeds.

Involucre.-Of one or two series of close-growing, pointed bracts.

Receptacle.-Flat.

Akenes.-Curved and without pappus; only the outer circle of rayflorets produces seeds. 
This Marigold of southern Europe has enjoyed great and lasting popularity. It has been dedicated to the Virgin and made prominent at her festivals. It has been an emblem of affection and sympathy, as well as of jealousy and grief. At the same time that it adorned the dress of great ladies, it was esteemed as the "Herb-General of all pottage." The dried florets were supposed to add greatly to the flavor of soups; and syrups and conserves were made of the fresh flowers. All these uses have passed away and the plant now holds its place in the garden because of its real merits as a hardy annual, blooming from midsummer until frost. The flower-heads share with many composites the habit of curving the rays inward at night and so nearly closing the head; within this half-closed head the dewdrops often rest in the morning. This peculiarity has appealed to English poets

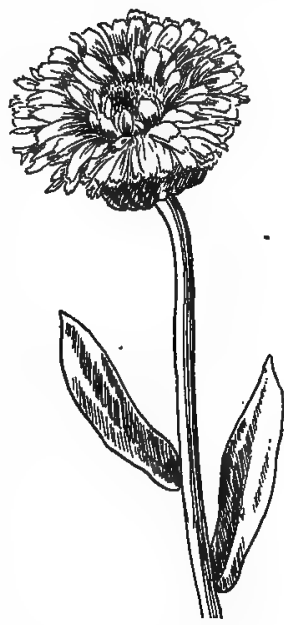

Marigold. Caléndula officinàlis from Shakespeare to Keats and has been the occasion of poetic outbursts which have immortalized the flower.

Hark, hark, the lark at heaven's gate sings

And Phœbus 'gins to rise,

His steeds to water at those springs

On chaliced flowers that lies;

And winking Mary-buds begin

To ope their golden eyes.

- "Cymbeline," Act II, Sc. 3, Shakespeare.

The marigold, that goes to bed wi' th' sun,

And with him rises weeping:

—“Winter's Tale," Act IV, Sc. 3, Stakespeare.

Open fresh your round of starry folds,

Ye ardent marigolds!

Dry up the moisture from your golden lids,

For great Apollo bids

That in these days your praises should be sung. -KFATs. 
Originally single, the flower-head now appears in many forms distinguished by size, color, and degree of doubling; in color it varies from pale-yellow to deep-orange.

\section{AFRICAN MARIGOLD}

Tagètes erécta.

Tagetes, derived from Tages, an Etruscan deity.

An erect annual herb introduced from Mexico, and greatly changed from its primitive form by the French gardeners of the sixteenth century. Midsummer.

Stem.-Erect, more or less branched, two feet high.

Leaves.-Opposite; pinnately divided; segments lanceolate.

Flower-heads.-Solitary at the summit of the stem; yellow or orange; the ray-florets in a single series, normally five, the disk-florets tubular; transformed into rays by cultivation.

Involucre.-One series of bracts more or less grown together.

Receptacle.-Convex, naked; stem swollen and hollow just below.

Akenes.-Oblong, angular; pappus a membranous cup with two awns.

The African Marigold obtained its common name from a misapprehension on the part of the French gardeners as to its native land. By the time the mistake was understood the name was fixed and has continued ever since. The plant is one of the most sturdy, upstanding, and trustworthy of garden creatures. It requires good soil and should not be crowded, as it needs free circulation of air among its stems. In the primitive form the rays were few and the disk-florets tubular, but the skill of the French gardeners soon converted these into rays. There are, however, in most double flower-heads a few florets still tubular, but these are not seen. unless looked for. The gardener's ideal is that there should be none of these. The finer strains now supplied by the florists are wonderfully regular, full-rayed, and vary on the chord of yellow from pale-lemon to deep-orange. A bed of these makes a cloth of gold in the garden, which lasts long, 


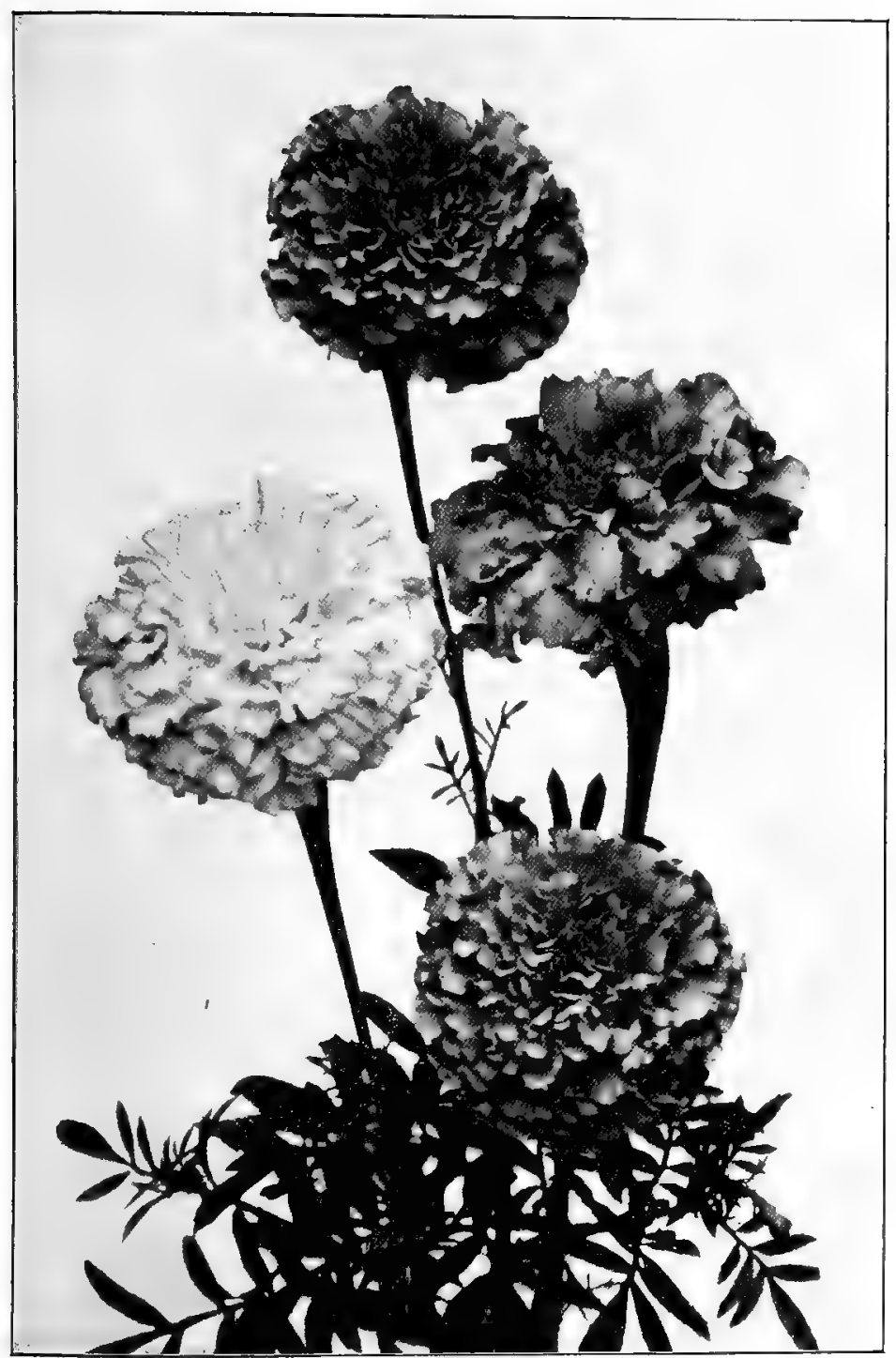

African Marigold. Tagètes erécta 
for, like all the composites, the rays are on duty until the last stigma is fertilized. Marigolds are plants of strong odor.

The French Marigold, Tagetes patula, also from Mexico, came into England from France and so obtained its misleading name. A small plant bearing a small flower, it forms a neat and compact little bush. The flower-heads are small and the color markings are variable, ranging from nearly pure-yellow to nearly pure-red.

Tagetes signàta var. pumila is a dwarf, leafy, bushy form with small bright-yellow five-rayed flower-heads, a favorite for borders.

\section{COREOPSIS}

Coreópsis lanceolàta.

Coreopsis, Greek, like a bug;, referring to the shape of the akenes.

A group of several species native to our Western and South-western States; cultivated for their extremely brilliant yellow, or red and yellow flowers. The two most common in gardens are Coreopsis lanceolata, a perennial, and Coreopsis tinctòria, an annual. Both have been modified and hybridized. Summer.

Stem.-Growing in tufts, one to two feet high.

Leaves.-Lanceolate or oblanceolate; sometimes divided, entire, mostly crowded at the base.

Flower-heads.-Radiate, one and a half to three inches across, on long, slender peduncles; rays yellow, broad; disk-florets yellow.

Involucre.-With two kinds of bracts; the outer narrow and spreading; the inner more or less scarious.

Receptacle.-Slightly convex, chaffy.

Pappus.-Minute or wanting.

Akenes.-Orbicular, winged.

Coreopsis of any species, when, at home, is a weed, wherever that home may be. In cultivation the plant retains many of its weed virtues. Estahlish Coreopsis lanceolata in the garden, not only will it remain, it will enlarge its boundaries and possess the soil. The chief objection to Coreopsis is the extreme difficulty of keeping the flower-heads from going to seed; this is necessary $484^{\prime}$ 
if there is to be a satisfactory production of bloom, and to keep a bed in hand requires continual cutting of heads.

A full bed in bloom is a beautiful sight; the flowers seem some way to embody the joy of living; on their long stems they ride with the wind at the same time that they glow in the sun.

As the seeds begin to ripen the inner circle of bracts hug tight about their treasures, and the heads become coneshaped. When mature the tiny akenes are rounded at the back, flat beneath, winged at the side with two little projections of pappus; altogether their appearance, perhaps, justifies the namelike a bug-Coreopsis. Possibly it is just as well to use the name without thinking what it means.

The name Calliopsis began as a misnomer, but now seems to have become fixed upon

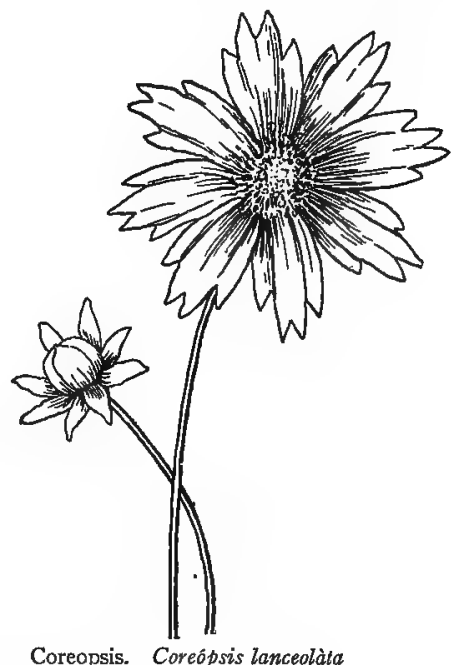
certain garden forms; nevertheless it should be understood that every horticultural calliopsis is a botanical coreopsis.

Coreopsis tinctoria is the annual species most in cultivation. It is tall, the stem branches only at the summit, the leaves are pinnatifid with long, narrow divisions. The flower-heads are radiate, the broad rays brownish-red or partly yellow. A very satisfactory annual. 


\section{CHINA ASTER}

\section{Callistephus chinénsis.}

Callistephus, Greek, from kalliston, most beautiful, and stephane a crown; referring to the double pappus-the "beautiful crown" that surrounds the seeds.

Stems.-Bristly, branched, two feet high.

Leaves.-Oval, coarsely toothed; lower petiolate; upper sessile.

Flower-heads.-Terminal, radiate two to three inches across; rays red, white, blue, or purple; disk-florets yellow, all fertile.

The name China Aster is historically correct. This composite was introduced into Europe in I73I by way of seeds sent to the Jardins des Plantes of Paris, by Father d'Incarville, a Jesuit missionary.

The typical form was a plant two feet high, each stem bearing a terminal flower-head two and a half to three inches in diameter, consisting of a large central disk of yellow tubular florets and a double or triple row of ray-florets, in color rose-lilac, white, or blue. This type reappears whenever the highly bred forms degenerate. Immediately upon the arrival of this new plant, the French gardeners set themselves to the task of turning all the disk-florets into ray-florets. Thev were eminently successful and as this transforming process does not affect the fertility of the florets, Aster seeds are very likely to come true to the parent plant. German, English, and latterly American growers have all co-operated in the development of the Aster, until now there are strains marvellous in beauty of form, at the same time that there has developed a red and a blue color range of exquisite variety and delicacy. So far no yellow has appeared.

In the present garden race there are flower-heads whose rays are incurved, others whose rays curve outward, some which rival the show dahlias in regularity, others whose tubular florets have developed in size and varied in color to produce the quilled forms, still others that suggest chrysanthemums by their tousled beauty. Moreover, the last word is by no means said. The simple stem of 


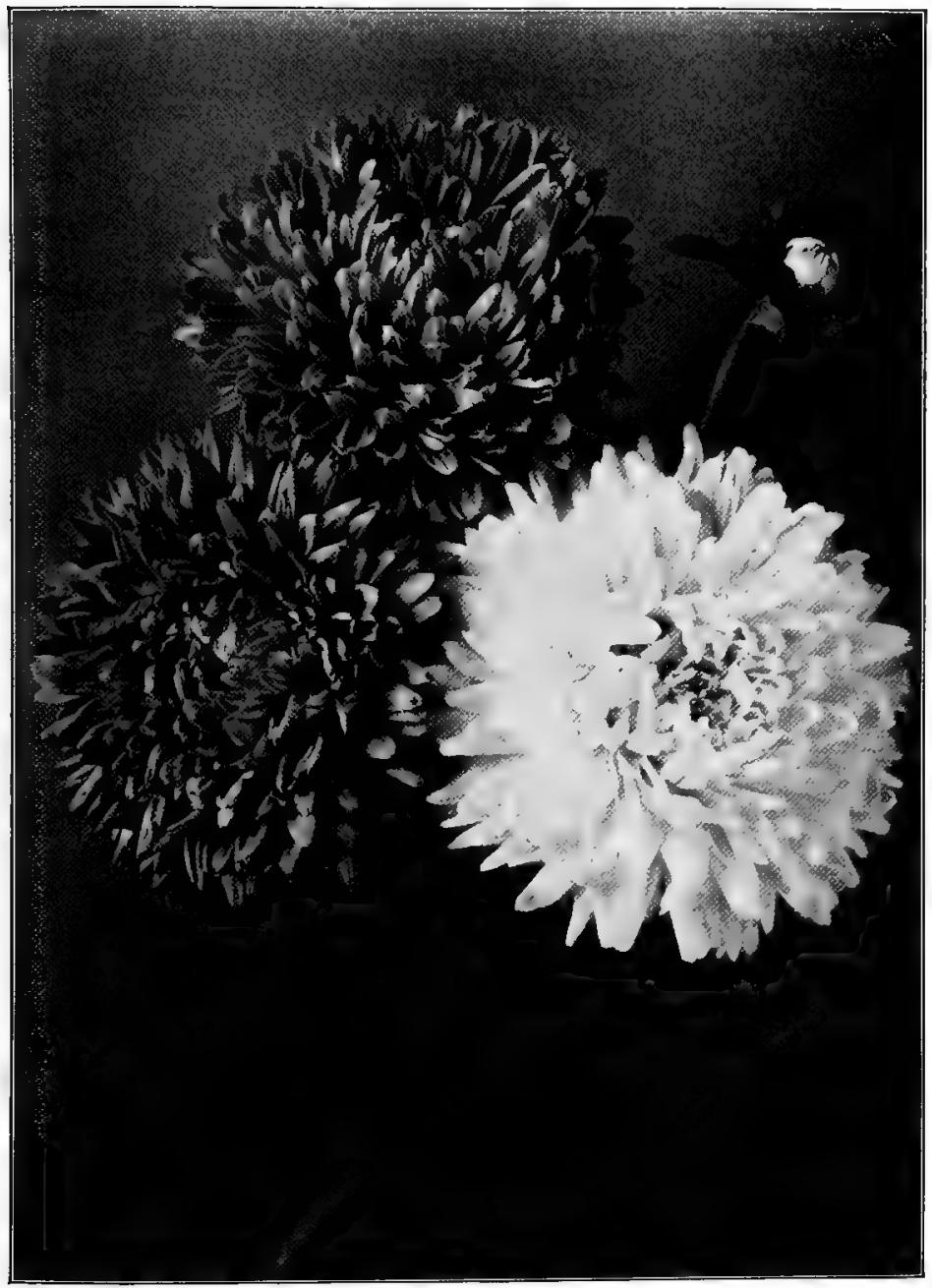

China Aster. Callistephus horténsis 
the type branched long ago and has varied into both dwarf and standard forms.

Botanically, the genus is an endless confusion; horticulturally, the genus is an endless delight. How long the Aster had been cultivated in China before it came into Europe we do not know, but it is probable that it has been a garden plant for ages.

\section{ASTER}

Aster.

Name is Greek for star; referring to the radiate heads of the flowers.

Perennial herbs, with erect branching stems and starry flowers; the species freely hybridizing.

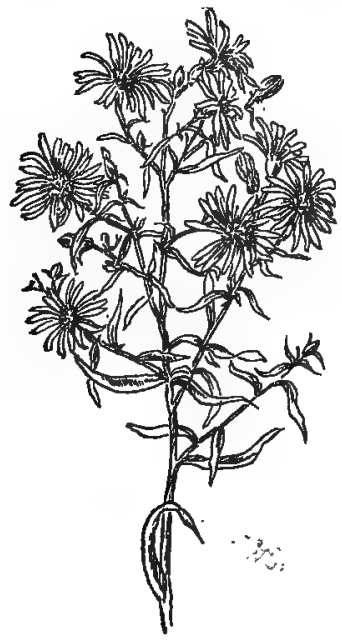

Aster. Aster ericoides

Flower-heads.-Radiate; rays white, purple, lavender, blue, or pink; the diskflorets yellow, often changing to purple.

Involucre-bracts.-More or - less imbricated, usually with leaf-like tips.

Receptacle.-Flat, alveolate.

Pappus.-Simple; of capillary bristles; akenes more or less flattened.

The glories of color, of size, and of petalage, that lie undeveloped in our native Asters, it has not as yet entered into the heart of florist or gardener even to conceive. To do nothing more than transfer them from the hard conditions of the fields, to relieve their fierce struggle for existence, to anticipate their needsatnd to supply their wants, gives them a chance to increase in height, to multiply their stars, to double their rays; in short to indicate what careful cultivation might accomplish. The wealth of the fields has impoverished the garden. One species, Nova Angliae, has been in general cultivation for rather more than a decade 
and is giving an excellent account of itself; but the fields are full of Wild Asters, just as good and, in some respects, better. The White Aster, Aster ericoides, growing along the roadsides of northern Ohio, coming up almost to the wagon track, blooming at the height of four inches to four feet as conditions permit, is one of the most beautiful of native Asters, and, under favorable surroundings, produces an astonishing wealth of bloom and beauty.

\section{BOLTONIA}

\section{Boltònia asteroìdes.}

Named in honor of James Bolton, English botanist of the eighteenth century.

Perennial, bushy-branched, smooth herbs, pale-green with the aspect of Aster. Moist places along streams. Illinois to Missouri. August, September.

Stem. - Three to four feet; in cultivation six to eight.

Leaves.-Lanceolate, entire, thickish.

Flower-heads.--Radiate, an inch or more across; rays many, pistillate, white or pink or pale-purple; disk-florets yellow.

Involucre.-Hemispherical; bracts imbricated in two rows, appressed, with narrow, membranaceous margins.

Receptacle.-Convex or hemispherical.

Akenes.-Flat, obovate or inversely heartshaped, margined with a callous wing; pappus of few or many bristles or two awns or none.

Boltonia is an aster-like plant that has come into general cultivation. Although only two or three feet high in the wild, it can easily reach six and even nine feet.

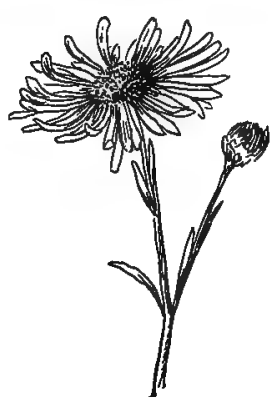

Boltonia. Bollònia asleroìdes By cultivation the flower-heads have enlarged and the rays increased. The plants bloom profusely, stand without staking, and take care of themselves, having once been established. They are often grown for cut flowers. 


\section{TASSEL FLOWER. CACALIA}

Emilia flammea.

Stem.-A bout two feet high.

Leaves.-Obovate and petioled.

Flower-heads.-Discoid; tubular florets orange-red or dull-scarlet, closely packed in an involucre made up of a single row of oblong bracts united at their edges, borne in a loose corymb.

This little flower has long been in cultivation, but there are so many better summer bloomers that it is rarely seen. The

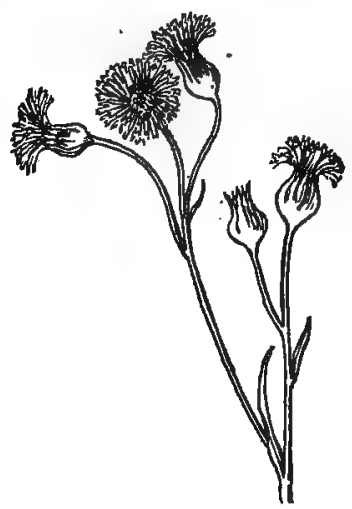

Tassel Flower. Emilia flàmmea

common name is well chosen, for the involucre makes a strong urn-like cup into which the florets are packed fairly to suffocation; the urn considerably smaller at the top than bottom, so that the entire head has a strong resemblance to a tassel. The inflorescence is terminal with a head at the summit of the stem which, of course, limits the growth of the plant. 


\section{ENGLISH DAISY}

Bêllis perénnis.

Bellis, Latin, bellus, pretty.

A dwarf perennial herb, the Daisy of English fields and of English literature; it appears in our market with the early pansies; the commercial forms usually double. April, May.

Leaves.-Clustered, rising directly from a creeping rootstock; oval, obovate with a few rounded teeth.

Flower-heads.-Three-fourths of an inch to an inch across, solitary on hairy scapes, two to three inches high.

Rays.-Fertile, white with crimson tips; disk-florets tubular.

Involucre.-Of one or two rows of green bracts.

Akenes.-Without pappus.

The English Daisy grows but half-heartedly in this country, yet is persistently offered by the gardeners in the spring with the pansies. In western Europe it is at home, and its abundance and beauty seem to have touched the emotions of all the western Europear peoples. There is a caress in all its common names. In Scotland it is Bairnwort, the children's plant; in England the Day's Eye; in France, Marguerite, a pearl. And the English poets from Chaucer to Tennyson have felt its charm and sung its beauty.

Of all the floures in the mede,

Than love I most these floures white and rede,

Soch that men callen daisies in our town.

-Prologue of the "Legend of Good Women," Chaucerr.

When daisies pied and violets blue

And lady-smocks all silver white

And cuckoo buds of yellow hue

Do paint the meadows with delight.

— "Love's Labor's Lost," Act V, Sc. 2, SHakespeare.

Meadows trim with daisies pied.

—"L'Allegro," Mrrton.

Wee, modest, crimson-tipped flower.

—"To a Daisy," Burns. 
Typically, the flower-heads have but a single row of rays, but under cultivation the disk-florets have been converted into rays making the double forms. In some of these variations the original colors have been retained, in others the crimson from

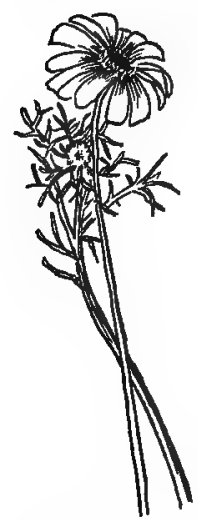
the tips of the rays has spread over the entire surface and become variously intensified. In some forms the rays are flat, in others they have become quilled.

\section{SWAN RIVER DAISY}

Brachỳcome iberidifolia.

Brachycome, Greek, short hair; alluding to the pappus.

A graceful little annual from Australia, suitable for borders. Midsummer.

Stem.- Six to twelve inches, tufted, slender, leafy.

Leaves.-Small, pinnately divided and forked.

Swan River Daisy.

Brachýcome iberi-

Flower-heads.-About an inch across; radiant; rays difolia violet-blue or white in the type; disk-florets either yellow or dark.

Involucre.-Flat; bracts narrow, scarious at tips.

Receptacle.-Naked; pappus short bristles.

The Swan River Daisy would naturally be more of a favorite in England than in this country. It is, however, a most charming, free flowering, summer blooming little composite, which wins hearts whenever it has a chance. Under cultivation its colors vary along the line of violet-blue into blues and lilacs and palepurpies to white. 


\section{ZINNIA}

\section{Zinnia élegans.}

Zinnia, in honor of Johann Gottfried Zinn, professor of botany at Göttingen in $175^{\circ}$.

Hardy annual from Mexico, common in gardens; blooms from midsummer into late autumn.

Stems.-Erect, stiff, hairy, one to two feet high.

Leaves.-Opposite, cordate or elliptic, clasping.

Flower-heads.-Radiate, terminal; rays reflexed; colors various; disk-florets originally yellow, but transformed in the garden race to rays.

Involucre.-Ovate, cylindric, or bell-shaped; scales in several series, broad, rounded, more or less colored.

Receptacle.-Hollow, tubular; chaff takes on the color of rays.

Akenes.-Two kinds, triangular and heart-shaped; laterally compressed, two-toothed at the summit, frequently one-awned from the inner angle.

Zinnia is a plant of surprises; one's Zinnia bed may be a garden of delights or a record of disappointment; it all depends upon the colors which the blossoms assume. No other flower of cultivation takes on such a surprising number of hues, but there is always an element of chance in what a seed may produce. The flower avoids blue, but revels in reds and yellows, and takes on marvellous lurid and bronze effects. Its scarlets and crimsons are worthy to stand before kings, its pinks and salmons are beautiful, its range of yellow is brilliant, but its whites are dull and opaque; and although the Zinnia is capable of the most clear and vivid colors, it is also capable of muddying every red and dulling every yellow, to the disappointment of amateurs and the despair of florists. The plant is said to be unfashionable, the truth is the plant is untrustworthy. In addition, the lack of pleasant odor, and a certain harshness of texture and stiffness of carriage limit its popularity.

The garden form, under neglect, quickly reverts to its first estate; indeed the "rogues," as primitives among highly breds are called, are to be found in most Zinnia beds and should be uprooted. The primitive is a head composed of a single row of broad rays sur- 
rounding a cylindrical receptacle covered with tubular florets which are golden, while the chaff takes on the color of the rays. Given this basis it is easy to see what the gardener's ideal has been. The problem was to transform these tubular florets into rayflorets and to cover the long receptacle with rows and rows of rays evenly overlapping. This has been done, and a highly bred Zinnia is as regular and formal as a show dahlia.

The history of the garden Zinnia is well known. The first double form appeared in 1856 in the nursery of M. Grazau, at Bagneres, France, among a number of plants raised from seed received from the West Indies. This was taken by the famous French grower, Vilmorin, further developed, and placed upon the market in I86o. Through the sixties Zinnias were greatly in vogue, by I880 they had lost caste; to-day they occupy the place that justly belongs to them, alongside of the French and African marigolds and the China asters, admirable for banks of color. There is'a variety which has all its florets tubular, there are also curled and crested forms. All forms are likewise grouped into tall, medium, or dwarf.

\section{cosmos}

\section{Cósmos bìinnàtus.}

Cosmos, from the Greek word, whose root idea is orderliness, hence an ornament or beautiful thing; finally, and usually, the universe because of its orderliness.

Stem.-Annual, glabrous, six to ten feet high.

Leaves.-Oppósite, bipinnately cut; lobes linear, remote, entire.

Flower-heads.-Radiate; rays white, pink, or crimson; disk-florets yellow.

Involucre.-With ovate-lanceolate scales.

Receptacle.-Chaffy; akenes smooth, with a short beak.

Among the garden annuals that have recently come into prominence Cosmos is one of the most interesting. A Mexican plant, it has not yet quite become accustomed to our short seasons, and although it bears cold bravely, it is sometimes overtaken by the 


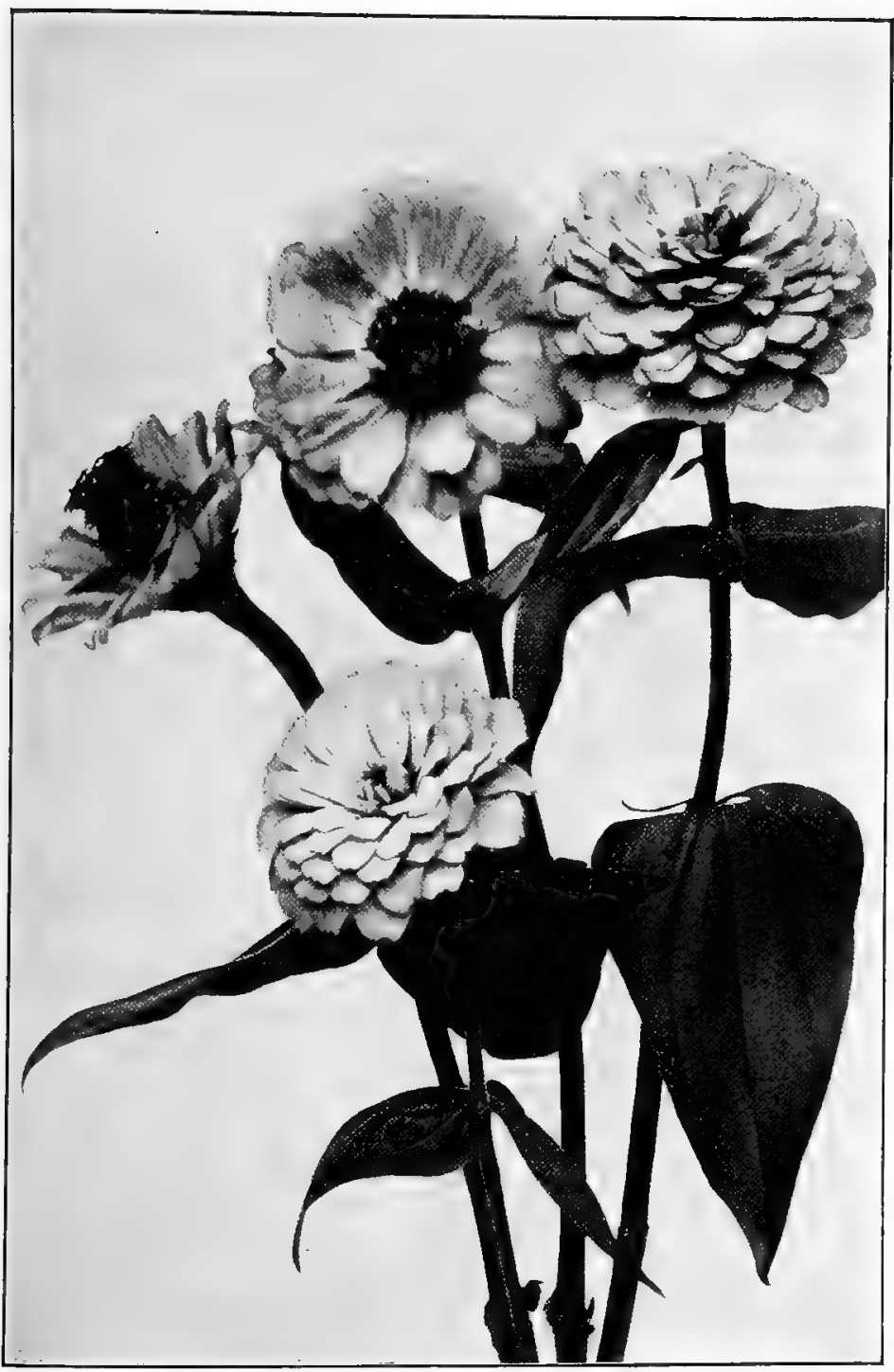

Zinnia. Zinnia êlegans 
snows of November before half its buds have opened. The efforts of the gardeners are turned toward developing plants with a shorter

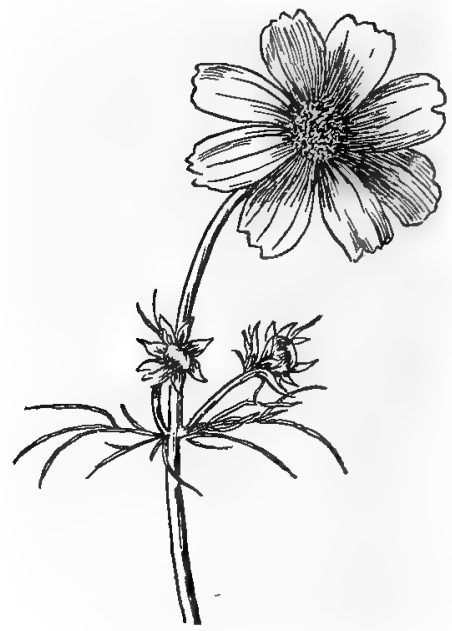

Cosmos. Côsmos bipinnàtus season and lower, better foliaged stems. The primitive flower of Cosmos bipinnatus is stellate; that is, it has open spaces between its rays. These rays in cultivation have broadened and rounded in outline and have overlapped, so that the new forms do not show any vacant spaces between the rays, but present an unbroken face. This same tendency has prevailed in the garden evolution of many other flowers, notably dahlias, coreopsis, and geraniums. Gardeners seem to abhor a space between the petals of a flower as Nature does a vacuum. The size of the primitive flower is about an inch across, but the best varieties are now three inches and even more. The primitive stock was killed by the first frosts, but the race now bears considerable cold. Unquestionably, Cosmos, beautiful as it is, has possibilities of much greater beauty.

\section{GOLDEN-ROD}

Solidàgo.

Name from solidare, to join or make whole; in allusion to reputed healing qualities.

Perennial herbs with wand-like stems, sessile or nearly sessile stemleaves, and yellow flowers.

Flower-heads.-Small, radiate, few to many-flowered; either racemed or clustered. 


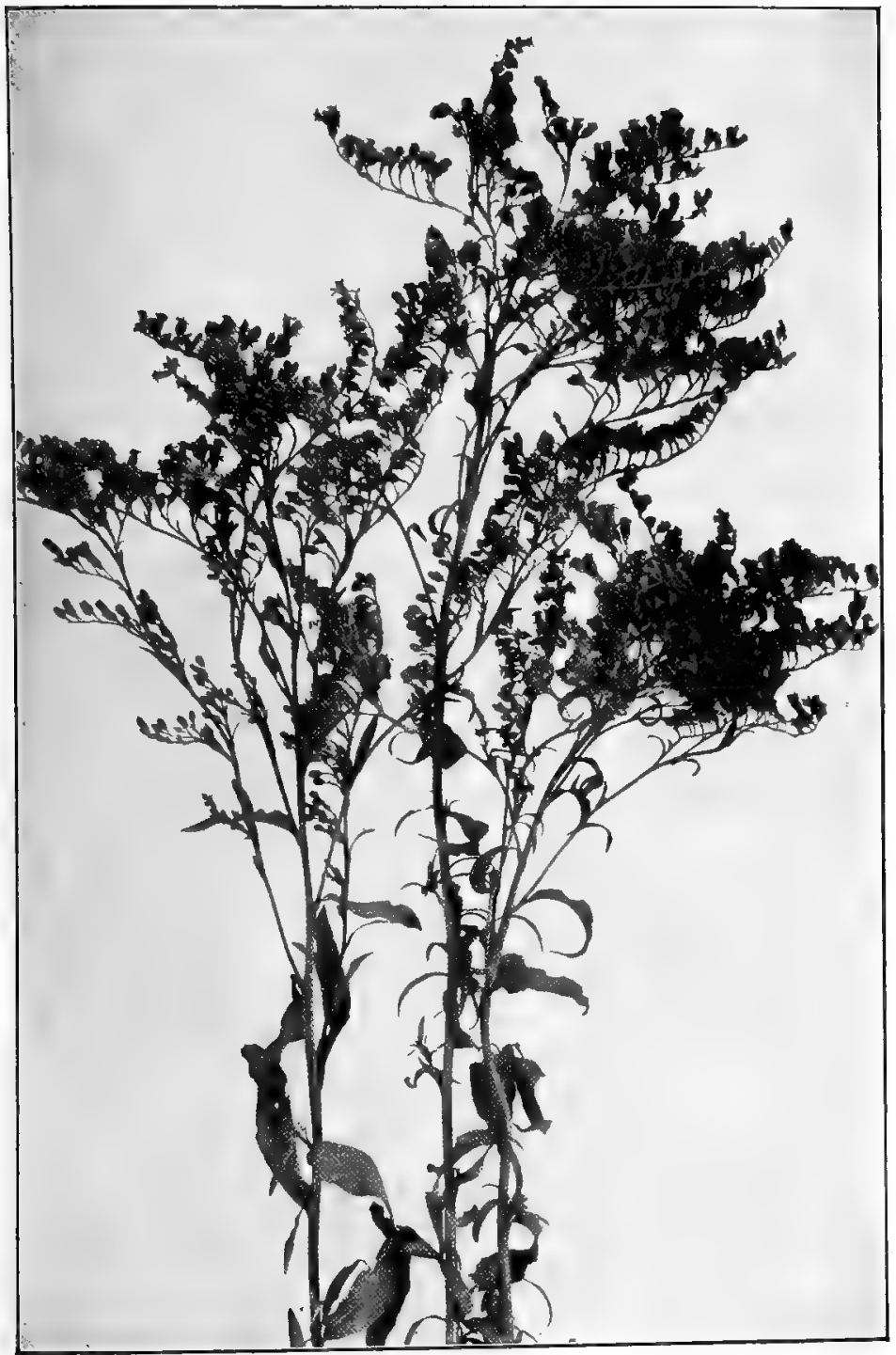

Golden-rod. Solidàgo júncea 
Disk and ray-florets.-Yellow, except in Solidago bicolor, whose rays are cream.

Involucre.-Bracts appressed, destitute of herbaceous tips.

Receptacle.-Small, not chaffy.

Pappus.-Simple, of equal capillary bristles.

Akenes.-Many-ribbed, nearly terete.

The flowers of the Golden-rods are in small radiate heads, each of which is surrounded by an involucre made up of a few more or less appressed scales. The heads are clustered in many ways, sometimes in the axils of the leaves, sometimes they make a panicle of little racemes, sometimes a flat, irregular corymb.

The receptacle bearing the flowers is small, and has no chaff. The pappus is simple, and composed of capillary heads or bristles. The ray-florets are small and pistillate.

Over sixty species of Golden-rods are described in the seventh edition of Gray's "Manual of Botany," and these hybridize so freely that they are often difficult to identify.

Some species, like Solidago canadénsis, are continental in distribution, others appear in a limited area. The following are the familiar species most easily recognized in northern Ohio; they are the ones that a gardener of that region would select to emphasize color effects, relieve dark places, and build up wild tangles:

Solidago juncea, on the shore of Lake Erie, begins to bloom in June; its habitat extends from New Brunswick to Saskatchewan and southward to North Carolina and Missouri.

Solidago nenoralis is the low-growing species in dry, open fields, and may be recognized by the peculiarity of its recurved racemes, all bending in the same direction over an area of several square rods of plants. It begins to bloom in July.

Solidago canadensis is the most beautiful species of the genus; tall, bearing a broadly pyramidal panicle of recurved racemes; it comes into full bloom in September.

Solidago ohioênsis is very abundant in northern Ohio. Its flower-heads are borne in a flat, compound corymb which terminates the simple stem. There is no suggestion of a raceme about the inflorescence. Its best bloom is in September. 
Three smaller and less conspicuous species bloom along the edge of the woods during September and October. One, Solidago bicolor, stands from one to two feet high; a simple, upright stem, with flower-heads clustered in the axils of the upper leaves forming an interrupted spike. The rays are cream-color or nearly white, the disk-florets yellow, so that Two-colored Golden-rod is an appropriate name for it.

Another, Solidago caèsia, in its variety axillàris is abundant. The stem rises two to three feet high, usually simple; leaves thin, long-lanceolate, and in their axils all along the stem are little clusters of bright-yellow flowers making a veritable Golden-rod. At the summit is a little thyrse. This species is said to have given the common name to the genus.

Solidago latifolia will be found blooming in November. The leaves are broadly ovate or oval, strongly serrate, and conspicuously pointed. The heads are in very short axillary clusters. The rays are only three or four, but large for a Grolden-rod, and a beautiful brilliant yellow.

Other species are plentiful, but those mentioned are easily recognized.

\section{CORNFLOWER. BACHELOR'S BUTTON. KAISERBLUME}

Centaurèa cỳanus.

Centaurea, from Chiron, the Centaur; from the legend that Chiron used this plant to heal the wounds of Hercules.

The Cornflower of Europe, largely known in this country as Bachelor's Button, is a favorite annual; grown principally for cut flowers; typically blue, but appearing in many colors. Midsummer.

Stem.-Slender, branching, two to three feet high.

Leaves.-Alternate, linear, acute, grayish with white, woolly hairs.

Flower-heads.-Solitary, on slender stalks; composed of tubular florets only, the outer row large and sterile, apparently taking the place of ray-florets.

Involucre--Globular, hard, compact, of many imbricated scales whose margins are usually fringed. 
Receptacle.-Convex, beset with linear chaff.

Pappus.-Many soft bristles.

Akenes.--Oblong, slightly compressed.

The Centaureas are known as Hard-heads or Knapweeds, due to the compact involucre that surrounds the head of florets. Bachelor's Button is a name shared with several flowers, notably the double buttercup, Ranúnculus acris, and Gomphrèna globòsa, but Cornflower and Kaiserblume are personal. The herb is a weed infesting the wheat fields of central Europe; one often sees on the Continent, as the wind waves sweep over the growing wheat, a mist of blue showing at every depression. The well-known incident of Queen Louise of Prussia, flying with her children before the advancing armies of Napoleon, and upon some delay keeping the little ones good and happy by playing with the blue blossoms of the field, has endeared this flower to the German people. For one of those little boys became the old Kaiser, William I, Emperor of Germany, and in memory of that day the Cornflower was ever his favorite blossom, and to his people it has become the Kaiserblume.

The starry heads fairly twinkle as the wind stirs their long, swaying stems, for the showy outer florets are tiny cornucopias set on a circle around the disk. The inner florets are much smaller, have slender linear lobes, and may be the same color as the outer florets or different; in the type they are usually the same. The five stamens may likewise be the color of the floret; all this re-enforces the prevailing color.

By midsummer the bloom is past and the bed a desolation, but that is true of poppies, sweet-williams, and all the bulbs. It cannot be required of any flower that it should live forever, and if the bed is properly picked the blooming season is lengthened. If it should chance to be undisturbed, in late September there will be a plentiful crop of seedlings, and if undisturbed until the following spring there will be blooming plants in May.

The Mountain Cornflower, Centaurea montana, is a perennial species from Austria. The leaves are cottony; the flower-heads 


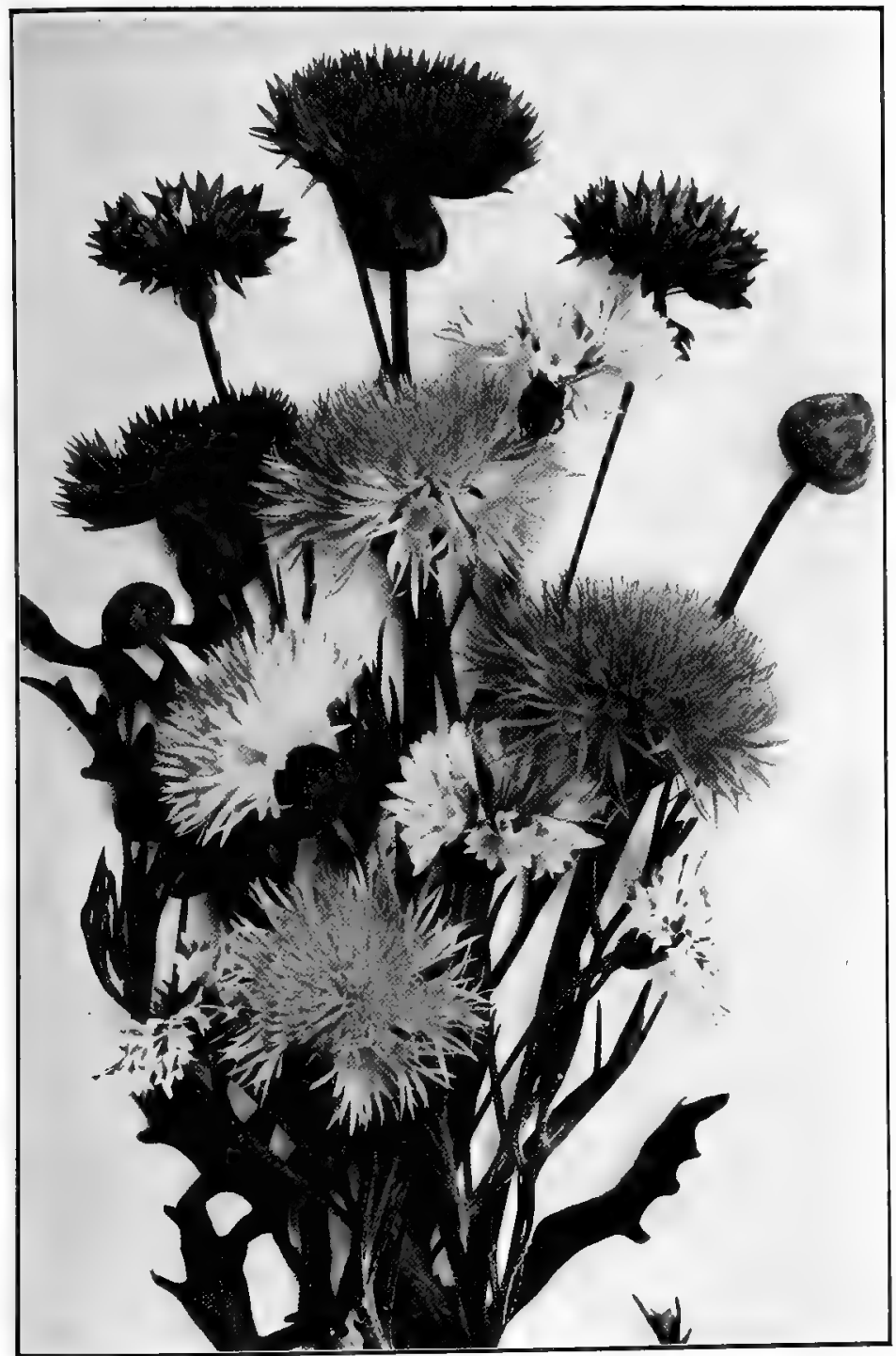

Centaurea in variety 
large; the ray-florets deeply cut into long slender teeth, blue; the disk-florets purple. There are several varieties in cultivation.

Dusty Miller, Centaurea cinerària or candidissima, and Centaurea gymnoscârpa, are two low-growing perennial Knapweeds

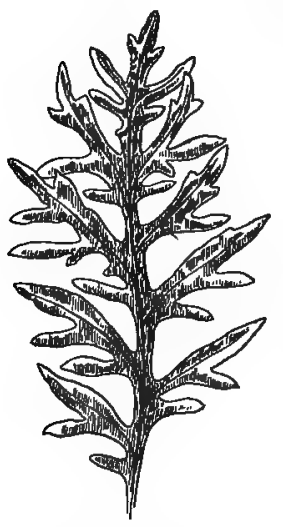

Dusty Miller. Centaurda gymnoscárpa prized for their silvery foliage. The entire plants, stems, and leaves, are covered so thick with soft, white hairs that they look like white velvet, and they are planted to contrast with darker growths in borders and in baskets. Of the two, gymnoscarpa has the finer cut leaves, though they are not always as silvery as candidissima, whose leaves are more broadly cut. They are Italian plants and rejoice in the sunshine. The flower-heads are small, rose-violet or purple, and without garden value.

Stokes' Aster, Stokèsia cyànea, is a most interesting plant in that it has points in common with both asters and centaureas. The marginal row of florets is composed of corollas which have a very short tube at the base, greatly broadened at the apex and cut into long, narrow strips. The centre is filled with tubular florets of the same color or darker than the margin. In cultivation the flowerheads are three to four inches across, and the blossom looks like a centaurea.

\section{SWEET SULTAN}

Centaurèa moschàta.

Hardy annual brought from the Levant into England about three hundred years ago.

Slems.--Erect, two feet high, branching below.

Leaves.--Pinnatifid; lobes dentate. 
Flower-heads.-Solitary on long, slender peduncles; florets all tubular, the outer row becoming large, funnel-shaped with finely fringed margins; the disk-fiorets small with long styles that usually take the color of the outer florets; spread of flower two to three inches.

Involucre.-Globose-ovate; scales large, flat, appressed, dark-green with pale scarious margins; two upper rows wholly scarious.

Pappus.-Many white bristles.

Akenes.-Oblong, slightly compressed.

Sweet Sultan is a royal flower, and properly possesses a royal name. Blood brother to the Bachelor's Button, in it the family characteristics are enlarged, refined, and glorified. Many flowers coarsen as they increase in size, but the larger the Sultan the finer it is. The outer trumpets become veritable cornucopias, an inch and a half long, half an inch across, with edges deeply and delicately fringed. The inner florets enlarge also and send out such a multitude of divided styles, each tipped with the hue of the marginal flowers, that the centre is a glow of exquisite color, over the soft mass of the disk; the result is enchanting. This Hower-head of exquisite beauty is held at the summit

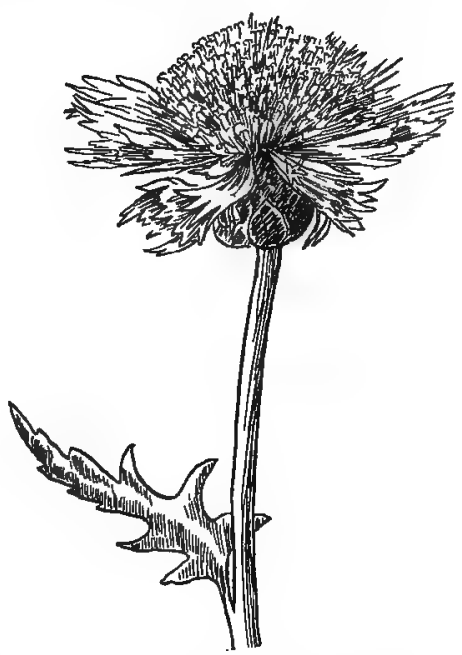

Sweet Sultan. Centaurèa Moschàta of a hard, round ball of an involucre, made up of large, green scales whose pale margins serve to emphasize their form. This involucre holds tight, and well it may, for within is the hope of the future-the seeds of the plant. The color range of the Sultan group runs through rose and lavender and purple and yellow to white. The fragrance of orris-root lingers about the flowers, giving them an added touch of old-time elegance. 
Although the Sweet Sultans are known as Centaurea moschata, the garden race are doubtless hybrids of at least Centaurea moschata and Centaurea suavèolens, both species having been brought into England from the Levant, one in $16{ }_{3} 8$, the other in 1650 . The two species are often regarded as one, but the gardeners of Kew hold them to be separate.

The bloom is easily forced and the flowers are abundant in the shops in the spring. When forced, growers complain of the tendency of the stems to bend and curl, due, doubtless, to the weight of the flower-head, but in the garden no such difficulty appears. The plant grows readily from seed, is perfectly hardy, delights us in midsummer days, and when its course is run, passes away.

Botanically, the genus Centaurea, the Knapweed, is very near Cnidus, the Thistle; the main difference lying in the character of the outer flowers, the shape of the akenes, and the variations in the pappus.

\section{CHICORY. SUCCORY}

Cichòrium intybus.

Cichorium, the Arabic name, coming through the Greek. Succory probably from succerrere, to run, under; referring to the strong taproot.

A perennial plant, native to the Far East, now widely distributed as a weed over Europe and Eastern America. Its bitter tap-root is used as an adulterant of coffee. June to October.

Root.-A deep tap-root.

Stem.-One to three feet high, rigid, angled, and grooved, branching. Lower leaves.-Spreading on the ground, spatulate, deeply cut, narrowed into petioles; upper leaves of stem and branches small, bract-like.

Flowers.-Pale azure-blue, rarely pinkish or white, set close to stem.

Head.-Composed of ray-flowers, tip of each ray five-toothed; surrounded by two rows of involucral bracts, the inner whorl long and the outer whorl short and reflexed. All the florets are rays and all are fertile.

Akenes, -Short with broad summit.

Pappus.-Small, chaffy scales. 
Chicory is a sprawling, awkward, weedy plant whose generally dishevelled appearance is somewhat compensated by the delicate beauty of its blossoms. The leaves cluster at the ground and the flowering stems are long and stiff and bare. The flowers appear singly or in twos, alternate upon the lengthening stems which are about two feet long and have at base a collection of ripening heads, then flowers, then buds. At the end of the season the last flower surmounts the stem and surveys the wreck of summer's glory. The blossom is of exquisite beauty. Every floret is a ray and every ray is fertile and all are blue-pale, tender blue; corolla, stamens, and styles together make up the total of delicate color.

The plant has escaped from cultivation and may now be found "waiting by the way" from the Atlantic coast to the Mississippi. But nowhere does it seem to have struck deeper root and made itself more thoroughly at home than in the vicinity of Boston. In the morning from June till October the waste places of the city are illuminated with the shimmer of divine blue over the green of the grass and weed. Creatures of the morning, by afternoon

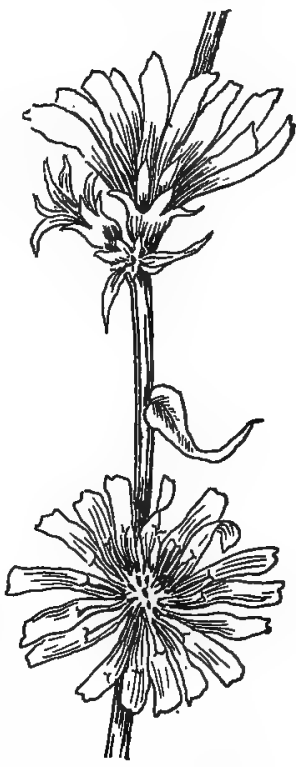

Chicory. Cichorium intybus their fleeting life has passed. A younger and as fair a blossom will appear to-morrow-and the impulse of life moves steadily on.

Chicory is a waif from the Far East, and it still repeats the echo of its Egyptian name, chikourzeh. The strong tap-root which is universally used as an adulterant of coffee gives it a commercial value; and a perverted taste affirms that coffee is better when associated with Chicory. In this connection there is a tale told of Prince Bismarck good enough to be true. The story runs that once, finding himself in a country inn and greatly desiring a cup of 
coffee, he insisted that what he wanted most of all was a decoction of Chicory; in fact that all the Chicory of the establishment was not too much to supply his needs. When the liquid was brought him he directed that it be poured upon the ground; then triumphantly ordered a cup of coffee, reasoning that, as there was no more Chicory in stock, there would be none in his coffee.

The bitter leaves forced and blanched in a warm, dark place are used as a salad by the French, and a very good salad they make.

It is interesting to note how two farmer poets separated by the gulf of two thousand years look at Chicory. Virgil, who was probably color-blind, as we know many of those old Romans were, views it from the agricultural side wholly, for he writes:

The spreading succory chokes the rising field.

Emerson, whose fields no doubt were overrun by the weed, nevertheless having eyes to see, rises above the practical as a poet should, and sings:

The succory to match the sky.

Endive, Cichorium endivia, an old-world species, has large, spreading root-leaves which have long been used as a salad.

\section{AGERATUM}

Ageràtum conyzoìdes.

Ageratum, Greek, not having old age; so named from the absence of the fluffy white pappus usual in composite flowers; not applicable to this flower.

An annual, used considerably as a border plant, bearing corymbed heads of azure-blue flowers. - Native to tropical America, but sparingly naturalized at the South. Summer and autumn.

Stem.-Erect, bushy, one to two feet high, downy.

Leaves.-Opposite, oval or ovate, crenate-serrate.

Flower-heads.-Discoid, blue, half an inch across, the long, divided styles giving a fuzzy appearance to the head. 
Involucre.-Cup-shaped, of two rows of hairy, imbricated bracts.

Receptacle.-Convex, naked.

Akene.-Slender, angled, with a pappus of five to six white, awlshaped bristles.

The Blue Ageratum, which is the form commonly found in gardens, is a native of tropical America. Although blue is the preferred color, the flowers vary to white and rose. The heads are destitute of rays, the tubular flowers are closely crowded, and, as the styles are very long, they give the flower-head a soft, plumy effect.

\section{GOLDEN IMMORTELLE}

Helichrỳsum bracteàtum.

Helichrysum, Greek for sun and gold; referring to the brilliancy of the flower.

One of a group of African and Australian composites, remarkable for their brilliant involucres, which give the effect of rays. The group produce the unfading flowers of commerce, known as Immortelles. Annual. Variable; easily cultivated.

Stem.-Stout, two to three feet high; branched.

Leaves.-Oblong-lanceolate, narrowed to short petioles.

Flower-heads.-Discoid, terminal, solitary; disk-florets yellow, crowded.

Involucre.-Many rows of pointed bracts.

Bracts.-Overlapping; brilliantly colored; normally yellow to orange, but now varying into many colors in the long-cultivated forms. The bracts reflex as the head gets older, and become narrower in the series nearest the disk.

Akenes.-Woolly, crowned with pappus of many plumose bristles.

Among other Immortelles in cultivation are Helipterum Mánglesii, Sun-winged Immortelle, which bears a loose corymb of showy flower-heads, rose or silvery-white; Rhodanthe maculàta, having bell-shaped heads of white, pink, or crimson; Acroclinum, with white or rose heads; and Xeranthemum annuum, a species native to the Mediterranean regions, with flower-heads purple, violet, or white. All are annuals and all of easy cultivation.

The Immortelles are a most unusual and interesting group of 
plants. They are African and Australian, native to dry sands, accustomed to limited moisture. They are as brilliantly colored as marigolds and apparently have as many rays as an aster, andthey do not fade. The secret of the Immortelles is simple enough after one gets the key to the mystery; before that they seem the marvel of the garden; in a certain way they are the marvel of the garden, even after their structure is understood. The silverywhite, or bright-pink, or glowing-yellow, that looks like corolla, and is so indestructible, is not corolla, nor is it even calyx--it is involucre, and corresponds in structure and position to the dullbrown bracts that remain after the seeds of aster or of daisy have ripened and flown away. Nature never gets so far afield as to make corolla of such indestructible stuff. She makes involucre stiff, usually green at first and then brown, but in these wonderful plants from the Antipodes the involucral bracts become the deepest red, the rosiest pink, the most brilliant yellow. It is they who give the flower call to the insect ${ }^{*}$ world.

To make clear: all these flower-heads are composites of the discoid type; that is, they have disk-florets, but no ray-florets; what look like ray-florets are the bracts of the involucre. Bracts in all composites are persistent, normally green, finally brown, but the bracts of this group are brilliantly colored and so they may deceive even the elect, until one tears the head to pieces and then the truth comes out.

If a skilful gardener should take the Immortelle in hand with the aim of lessening the disk and enlarging the bracts, it is very probable that a flower could be produced as regular as a dahlia or as tousled as a chrysanthemum-and indestructible. The only question would be whether it was really worth while.

It is interesting to note that a large export trade in everlasting flowers centres in Cape Colony, South Africa. They are gathered by the Kaffirs chiefly in the Drakenstein Mountains and brought to the country storekeepers, who dry them in long sheds and when dry pack them in cases. The Kaffirs go out in families, the women and children do most of the work; probably the head of the family gets most of the pay. It is not a very easy task to gather them, as often the best specimens grow in most inaccessible places. 


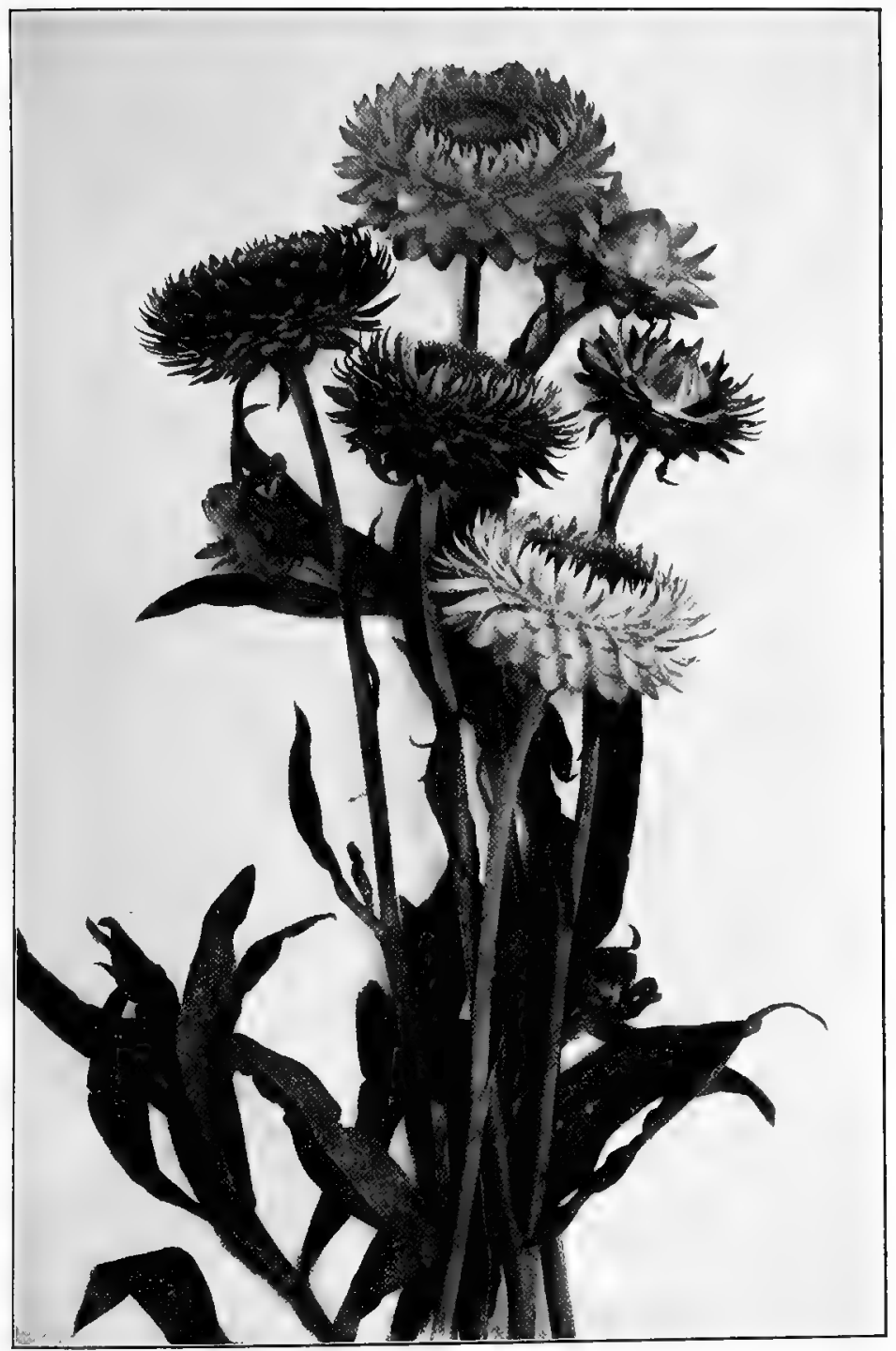

Golden Immortelle. Helichrỳsum bracteàtum 
Helichrysum arenàrium, a perennial species, bearing small, globular heads in compact little corymbs, is extensively cultivated in France and used in the manufacture of memorial wreaths and crosses. The flowers are naturally yellow, but are bleached and dyed in various colors. They are not as beautiful as the Cape flowers.

\section{PEARLY EVERLASTING}

Anáphalis margaritàcea.

Anaphalis, Greek, without known significance.

A beautiful, perennial Everlasting, growing upon dry soil virtually throughout the United States, except on the extreme southern coast. Also found in northern Asia. August, September.

Stem.-Erect, leafy, one to three feet high, floccose, woolly, corymbosely branched at summit.

Leaves.-Alternate, entire, linear-lanceolate, narrowed to a sessile

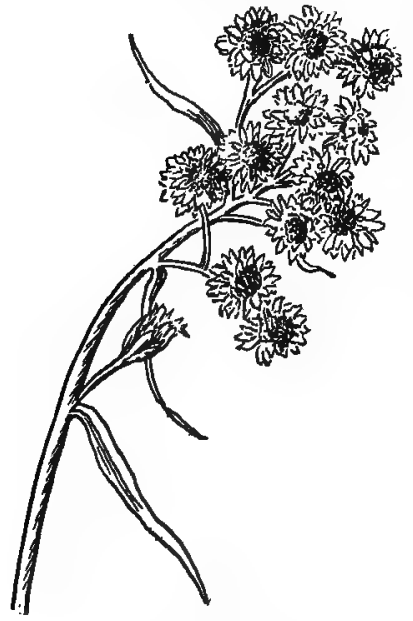

Pearly Everlasting. Anáphalis margarild̀cea base, revolute at margin, green-downy above and woolly beneath; the lowest often spatulate, obtuse.

Flower-heads.-Discoid; of diœcious flowers, many, borne in terminal, compound corymbs.

Pistillate florets. - With tubular fivetoothed corolla; two-cleft style and copious pappus of capillary, separate bristles.

Staminate florets. - With a slender corolla; an undivided style; anthers tailed at the base; pappus not abundant.

Involucre. - Campanulate; bracts ovate-lanceolate, obtuse, pearly-white, imbricated in several series.

Receptacle.-Convex, not chaffy. Pappus.-Several bristles; akenes oblong.

The Pearly Everlasting bears many small flower-heads, each consisting of several rows of persistent white bracts, ranged around a disk crowded with tubular 
florets. This genus is separated from Gnaphàlizm, the Fragrant Everlasting, by the fact that each little flower-head is dicecious; that is, possesses separate pistillate and staminate flowers.

The Sweet Everlasting, Gnaphalium obtusifolium, is the common fragrant Everlasting found upon dry hill-sides and pasture lands throughout the North. It is not cultivated; first, because it is so abundant in the fields, and second, because there are better Everlastings in the garden. The plant is interesting, could be well utilized by the landscape gardener seeking color effects, and its fragrance pervades the air in its chosen home.

\section{WINGED AMMOBIUM}

\section{Ammòbium alàtum.}

Ammobium, Greek, living in the sand.

A perennial, sun-loving plant, native to New South Wales; brought to England in 1823 by Mr. Robert Brown.

Stem.-One to three feet high, cottony, winged, rather weak.

Root-leaves.-Oblong and tapering downward into a petiole. Stem-leaves small and extended down the branches in the form of leafy wings.

Flower-heads.-One-half to one inch across, discoid, solitary, or two or three near together; disk florets tubular, yellow.

Involucre-Several rows of pearly-white bracts, closely surrounding the discoid head; chaffy scales on the receptacle; akenes flattish.

Ammobium alatum is a sprawling plant with gray-green, cottony, winged stems and terminal flowers. The flower-heads

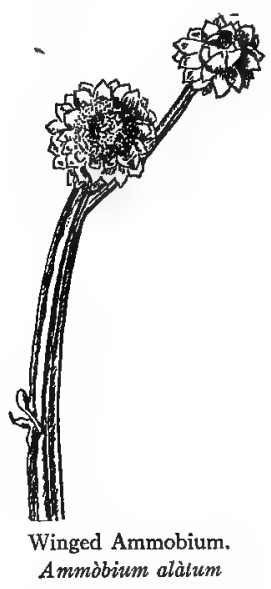
are little white balls with yellow centres, about an inch across, not unlike our native everlastings. Planted in warm but light, sandy soil, with not much water, since moisture is its enemy, it is readily raised from seed. It is more interesting than beautiful. 


\section{TALL GLOBE THISTLE. ECHINOPS}

Echinops exaltàtus.

Echinops, Greek, like a hedgehog; alluding to the spiny, involucral scales.

A tall biennial, of thistle-like aspect, six to seven feet high, wellfoliaged from base to summit and crowned by perfect spheres, two inches in diameter, of disk-florets, steel-blue in color. Summer. Russia.

Stem.--Erect, whitish, woolly, nearly simple, leafy, six to seven feet high.

Leaves.-Alternate, twice or thrice pinnatisect, the lobes and teeth prickly.

Flower-head.-Globular, covered with disk-florets, steel-blue.

Flowers.-Tubular, five-lobed, steel-blue when opening, fading with age.

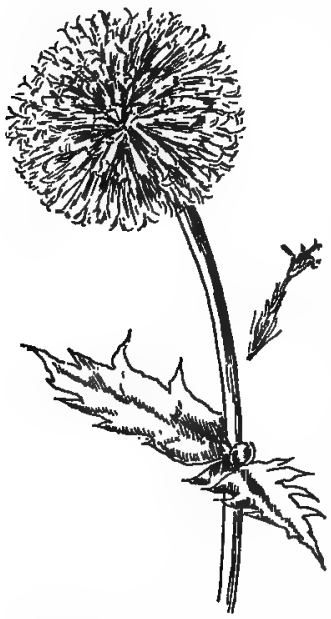

Globe Thistle. Echinops exallàlus

The Tall Globe Thistle is a plant of great dignity, resembling a gigantic gray thistle, but when in bloom its tall stems are surmounted by balls, not thistleheads. So well foliaged are the stems that a group of them might easily make a leafy column to emphasize an entrance, or stand as a sentinel.

The flower-head in full bloom is a sphere. Nature rarely achieves this form in flowers; it is often suggested but rarely attained; in this instance, however, the unusual is accomplished. The head in bud is spherical, the head in full bloom is a sphere, it is only during the period of partial bloom that the exquisite symmetry is disturbed. The florets at the top open first and the blooming impulse proceeds downward; that is, from the centre outward, thus reversing the order of thistle bloom, which is from the circumference inward. The bees swarm about the open flowers in ecstasy; big bees and little bees-all are there and all wild with delight. 
There are several species of Echinops in cultivation; some of these are smaller plants and bear flowers of darker blue, but for height, poise, and dignity, exaltatus easily stands first.

Other Composite in cultivation are:

The Eupatoriums, or Thoroughworts, a genus of stout, weedy, erect perennials, bearing discoid flower-heads in loose corymbs and blooming near the close of summer.

Eupatòrium purpirreum, Joe Pye Weed, becomes a huge plant with a stout, reddish stalk nearly an inch through, crowned at its summit with great masses of bloom, made of many soft, fleecy, magenta-pink florets, bright in the sunshine but dull in the shadow.

The single erect stem bears handsome whorls of dark, pointed, serrate leaves, which feather it from base to summit. The plant loves the swamps, the borders of rivers, and moist, low, alluvial soil.

Eupatorium perfoliàtum, the Boneset of the domestic materia medica, is often the only notable white flower in the

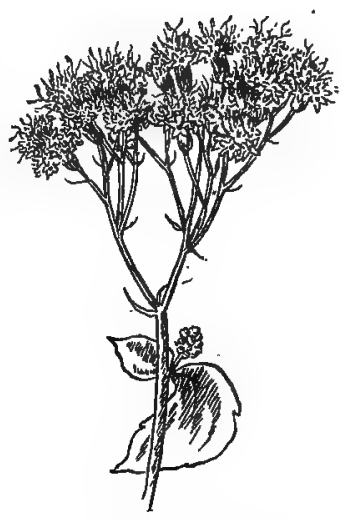

Eupatorium. Eupalòrium ageratoides tangle of gay colors which the low lands encourage in late summer. Its grayish color is more successful, perhaps, in toning down the gay mixture of yellow and purple of the other composites than pure white would be.

The most delicate of all the Eupatoriums is Eupatorium ageratoides, found on the edge of rich woods amid the undergrowth. It bears clear, close corymbs of delicate white flowers, and long petioles; thin dark-green leaves deeply and sharply serrate. This species has been taken up by the florists, cultivated, and sold in the shops. It serves the same purpose as Stevia.

Along with the Eupatoriums, blooming at the same time and under similar conditions, is the Iron Weed, Vernònia noveboracénsis, 
a tall, slender plant of three or four stalks growing together, topped with a large cluster of very brilliant purple flowers. It is the most brilliant purple wild flower of northern Ohio. In height it equals the sunflowers and Joe Pye Weed. The leaves are alternate and scattered.

Blazing Star, Lì̀tris, is a genus of hardy perennials which bēar their rose-red, or purple flowers in wandlike spikes; the petaloid coloring of the involucral bracts increasing the brilliancy of the flowers. 'The most showy species are Liàtris élegans and Liàtris pycnostàchya, both of southern habitat.

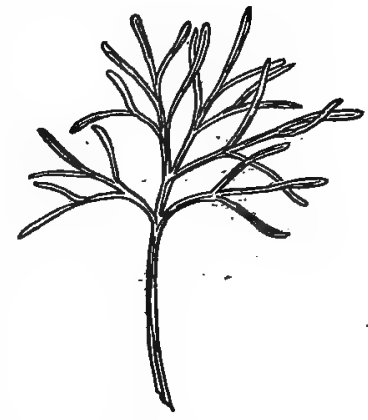

Southernwood. Arlemisia abrótanum

Leopard's Bane, Doronicum, is a genus of hardy composites of which several species are coming into general use, because they bloom in May. The flowers resemble large, yellow, ox-eye daisies and are a brilliant addition to the spring garden.

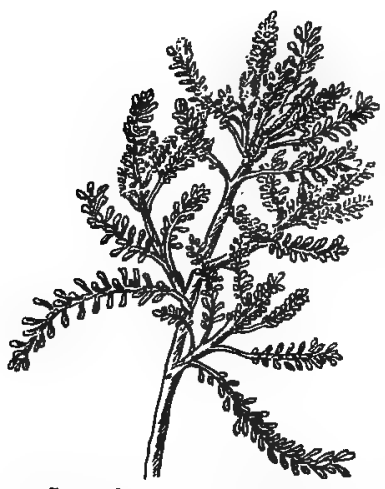

Lavender Cotton. Santolina chamacyparissus

Southernwood, Artemisia abrótanum, is an aromatic, muchbranched, woody-stemmed perennial, bearing many pale, grayishgreen, dissected leaves and small yellowish flower-heads. It is occasionally found in old gardens.

Wormwood, Artemisia absinthium, is closely allied to Southernwood and greatly resembles it. The plant is two to four feet high, the leaves gray, much divided, and intensely bitter. The flowerheads are small and yellowish. An extensive use of the plant is in the manufacture of absinthe, of which it is the principal ingredient. 


\section{LEOPARD'S BANE}

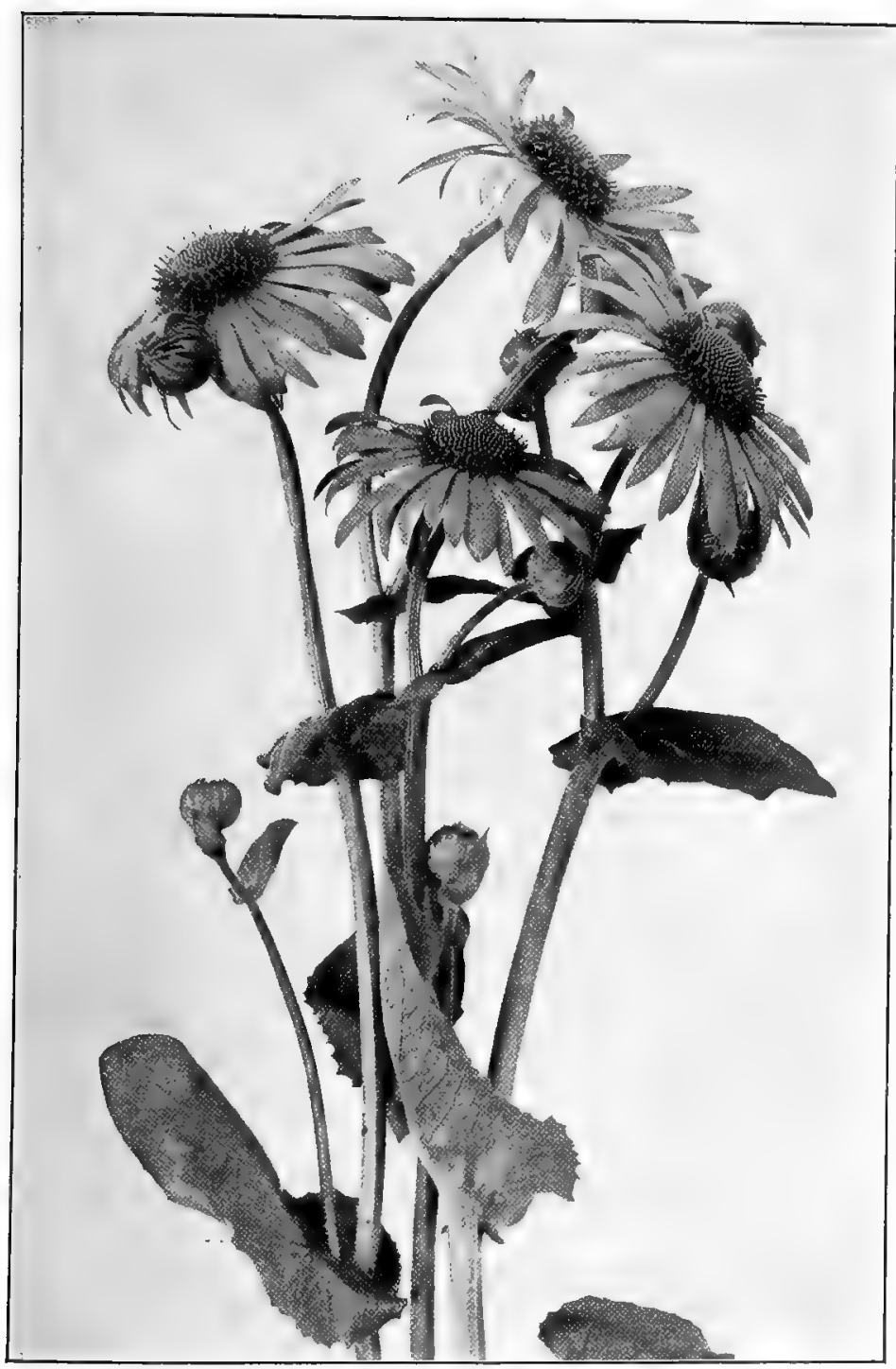

Leopard's Bane. Doronicum 
Tarragon, Artemisia dracunculus, the aromatic plant used for seasoning salads and flavoring vinegar, belongs here.

Lavender Cotton, Santolina chamacyparissus, is a hardy, halfshrubby, much-branched plant about two feet high, with small silvery-gray evergreen leaves, and in the summer many small heads of yellow flowers. Is often used in carpet beds.

Tansy, Tanecètum vulgàre, is an aromatic plant now dwelling principally upon the roadside, consisting apparently of a mass of dark-green feathery foliage that in July becomes a bank of yellow buttons which are discoid flower-heads borne in dense, flat-topped cymes.

Some very curious old English customs are connected with Tansy. The leaves were put into cakes which were eaten at Easter, some say in memory of the bitter herbs eaten by the Jews at the Passover; others deny this and say that people ate Tansy because it was wholesome, after so much salt fish had been consumed during Lent. Certain it is that there was a cake or fritter called Tansie and into it Tansy leaves entered as an essential ingredient.

The list of delicious viands served at the coronation of King James II and his queen includes "Tansie." Tansy tea is still used at the South for colds, but from English cookery the plant has absolutely disappeared. 


\section{SWEET HERBS}

There exists in our modern gardens a group of plants known as Sweet Herbs, which are cultivated solely and expressly for the value that their foliage or seeds possess in giving flavor to food. A study of these throws an interesting light upon a phase of ancient life which, although well-known historically, comes to us with an added emphasis by way of horticulture.

In the first place, we find that the most of these plants grow wild in the regions about the Mediterranean Sea; that is, within the limits of the Roman Empire. Moreover, all were and still are used to give varied flavors to different foods, particularly meat foods. We know that the Greek first, and the Roman afterward, was an epicure; and we also know that the foods of these early days were limited in variety, and that upon the tables of the wealthy meats predominated. The Roman sought varied flavors for the gratification of his palate, and discovering that these wild plants from the hill-sides could render this service, he transferred them into the garden. It is, therefore, probable that Sweet Herbs were among the first plants cultivated in Europe. The cook who felt that a new kind of animal should be created to tempt his master's appetite, did not understand the matter as well as the old Romans; when they had changed the flavor of the meat they had created a new animal as far as food was concerned.

These Sweet Herbs belong, for the most part, to two great natural families: the Mints, Labiate, and the Parsleys, Umbellifere.

The principal Mints in modern use are Sage, Thyme, Savory, Marjoram, Spearmint, and Peppermint. Among the Parsleys are Parsley, Dill, Fennel, and Caraway.

Although these plants belong to families botanically different, all have this character in common: they contain, either in foliage or 
in fruit, an aromatic, volatile oil, soluble in water, which gives the peculiar characteristic flavor of the plant. As the volatilization of this oil is hastened by heat, it is readily given forth in soups, stews, and meat dressings.

The Mints may be known by their square stems, two-lipped corollas, and the four seeds at the bottom of the calyx. The Parsleys are distinguished by their five small petals, the flowers borne in umbels-of which the wild carrot is a typical example-and the flat, dry seeds which usually have tiny oil tubes. The leaves are compound.

All are weedy plants, little, if any, changed from their wild prototypes. This is comprehensible when we recall that they have never been valued either for charm of foliage or beauty of flower; but wholly for the flavor which resided in the essential oil that they naturally produced. Consequently, no early gardener ever thought it worth while to subject them to the discipline of selection. Of late, however, varieties of a few of the best-notably the Sage and the Parsley-are offered by the trade.

Associated with these Sweet Herbs in early gardens were many plants highly valued for their medicinal qualities. Some of these still retain their place among accepted remedies, many have been superseded. The potency ascribed by the old herbalists to these plants is so great that one is filled with wonder that patients ever died, until one examines into the prescriptions, and then one is more astonished that any of them ever recovered.

An old volume on the "Art of Simpling" clearly expounds the ancient Doctrine of Signatures.

It says: "Though Sin and Sattan have plunged mankinde into an Ocean of Infirmities, yet the mercy of God, which is over all His workes maketh herbes for the use of man, and hath not onely stamped upon them a distinct forme, but also given them particular signatures, whereby a man may read even in legible characters the use of them. . . . Viper's Bugloss hath its stalks all to be speckled like a snake or viper, and is a most singular remedy against poyson and the sting of scorpions. 
- . The leaves of Saint John's Wort seem to be pricked or pinked very thick with little holes like the pores of a man's skin. It is a sovereign remedy for any cut in the skin."

Considering the basis upon which many of these medicinal plants were selected, it is surprising, not that so few but that so many have retained their ancient reputation. Dandelion, Horehound, Liquorice, Mandrake, and Marsh Mallow are still to be had among modern remedies.

\section{SAGE}

\section{Sálvia offcinàlis.}

A perennial sub-shrub, about two feet high, cultivated in gardens, but not naturalized in this country. Southern Europe.

Stem.-Woody, one to two feet high.

Leaves.-Grayish-green, thick, oblong, entire, corrugated.

Flowers.-Small, gaping, two-lipped, blue variegated with white and purple, borne on long terminal spikes, in distinct whorls each composed of a few flowers.

Calyx.-Tubular, striated, two-lipped.

Corolla.-Hairy within, upper lip concave; the lower three-lobed.

Stamens.-Two; filament short, at the summit an elongated thread-like body, one end of which bears a one-celled anther.

Ovary.-Deeply four-parted, ripening into four seed-like akenes.

A pleasant odor and certain medicinal qualities have given the Sage a high rank among Sweet Herbs. Although its domestic uses are not so many as

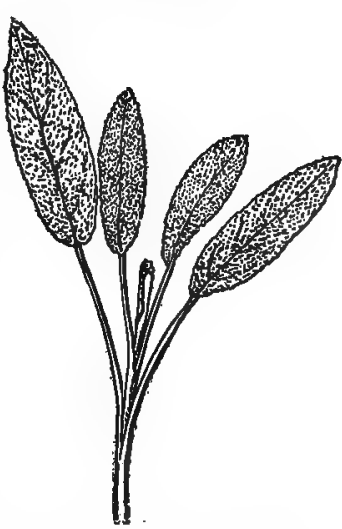

Sage. Sálvia officinàlis formerly, it is still used to impart a peculiar flavor to sausage, to the dressing of roast poultry, and to a certain kind of cheese.

That domestic materia medica in which boneset and catnip hold an honored place also includes the Sage. An infusion of the 
leaves makes an astringent gargle, Sage tea is administered for a nervous headache, and a mixture of Sage and honey is a specific for cankered sore mouth.

Gerard, writing in I596, says: "Sage is good for the head and the brain; it quickens the memory and the senses. The juice of the leaves mixed with honey is good for those who spit blood. No man needs to doubt of the wholesomeness of Sage."

\section{THYME}

Thỳmus vulgàris.

Thymus, classical name of doubtful origin; possibly denotes that the plant was used as an incense in Greek temples.

A low, half-shrubby perennial, with a strong mint-like odor. The leaves and stems yield an oil from which by distillation is obtained the drug Thymol.

Stem.-Erect, base sometimes decumbent, one to two feet high;

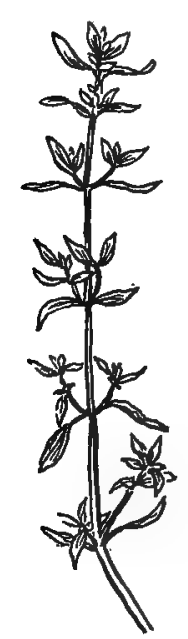

Thyme. Thýmus

vulgdris branches stiff, usually pubescent.

Leaves. - Small, linear to ovate-lanceolate, acute, margins more or less revolute:

Flowers.-Small, two-lipped, lilac or purplish, borne in whorls, forming terminal interrupted spikes.

Calyx.-Five-toothed and two-lipped.

Corolla.-Small, two-lipped; upper lip two-toothed and erect; the lower three-cleft and spreading.

Stamens.-Four, in two pairs, exserted.

Ovary.-Four-parted, ripening into four seed-like akenes.

I know a bank whereon the wild thyme grows.

-SHAKESPEARE.

Sweet Thyme was highly prized by the Romans who used it in many ways for seasoning food. The Greeks never wearied of singing the praises of the honey made from the Thyme that grew on the flanks of Hymettus. Ovid, Virgil, and Pliny all speak of Thyme in connection with bees; no doubt the honey made from its flowers possesses a pungent and aromatic flavor. 
Among the Greeks, Thyme denoted graceful elegance of the Attic style and was besides an emblem of activity. "To smell of Thyme" was, therefore, an expression of praise, applied to those whose style was admirable. In the days of chivalry, when activity was a virtue very highly rated, ladies embroidered knightly scarfs with the figure of a bee hovering about a sprig of Thyme.

The type and its variegated varieties are used as border plants in cultivated grounds; there are also varieties with broad leaves.

Creeping Thyme, Thymus serpylllum, is common in old gardens, and is prized as an evergreen edging and as cover for rockwork and waste places, for the creeping, woody, branching stems form dense cushions. The species has varied into many forms, whose names appear in the catalogues. All are aromatic.

According to Danish tradition, on Midsummer Night at twelve o'clock the king of fairy-land with his retinue disport themselves among the beds of fragrant wild Thyme.

\section{SWEET MARJORAM}

\section{Oríganum majoràna.}

Origanum, Greek from horos, an elevation or hill, and ganos, heauty-the beauty of the hills - a reference to its native habitat.

A perennial herb one to two feet high; hairy, leafy, much branched. Mediterranean region.

Stems.-Many, somewhat woody.

Leaves.-Small, oval, entire, crowded, sprinkled with resinous dots, pale-green.

Flowers.-Two-lipped, small, white or pinkish, in crowded, roundish terminal clusters, surrounded by an involucre.

Seeds.-Very small.

Sweet Marjoram has a pleasing odor and a warm, aromatic, bitterish taste, which makes it highly esteemed as a

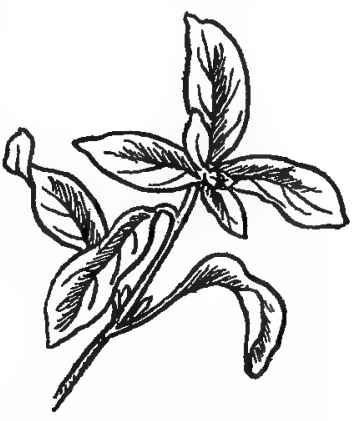

Sweet Marjoram. Oríganum maj̄oràna seasoning for soups, stews, meat pies, and dressings. In our gardens it must be treated as an annual, because it winter-kills. 
The plant seems to have been selected by the Greeks and also by the Romans as a decoration at marriage feasts, when it was woven into wreaths to crown the young married couple. It is mentioned both by Virgil and Pliny.

\section{SUMMER SAVORY}

\section{Saturèia horténsis.}

Satureia, a classical name of obscure meaning.

Annual low herb; native to southern Europe; sparingly run wild.

Stem.-Slender, erect, branching, ten to twelve inches high.

Leaves.-Soft, oblong-linear.

Flowers.-Two-lipped, pink, purplish, or white, small, either clustered in the axils of the leaves or running into panicle spikes at the end of the branches.

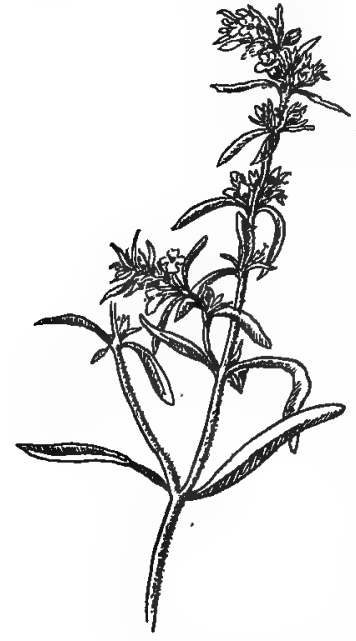

Summer Savory. Salurèia horlénsis

Summer Savory, Satureia hortensis, was once in great repute as a remedy for many ailments; its very presence was considered a safeguard; "keep it dry by you all the year if you love yourself and your ease," was the advice of the ancient herbalists. Moreover, the plant belonged to the satyrs and was the especial property of Mercury. All these mystical values have departed, and to-day Summer Savory is simply a slender-stemmed, weedy plant, extremely aromatic in stem, leaf, and flowers, whose pulverized leaves and stems are found in any dry combination of Sweet Herbs sold in the shops.

There is a perennial evergreen species called Winter Savory Satureia montdna, native to southern Europe which is also used as a seasoning herb, the whole plant being highly aromatic. 


\section{SWEET BASIL \\ Òcimum basîlicum.}

Ocimum, Greek, strong-scented.

An annual of extremely fragrant foliage, long in cultivation.

Stem.-One to two feet high, square, branching, hairy.

Leaves.-O p posite, ovate-oblong, slightly serrate, petiolate; dotted with many, small, translucent oil-glands.

Flowers.-White or bluish, borne in leafy terminal racemes or spikes made up of six-flowered whorls.

Calyx.-Hairy, two-lipped; upper lip orbicular, concave; lower lip four-toothed.

Corolla.-Hairy, two-lipped, one lip four-toothed, teeth rounded; other lip undivided but erose.

Stamens.-Four, declined; lower pair longer; the upper often with a process at their base.

Pistil.-Four-cleft; style arising from between the lobes; stigma two-lobed.

Fruit.-Four akenes.

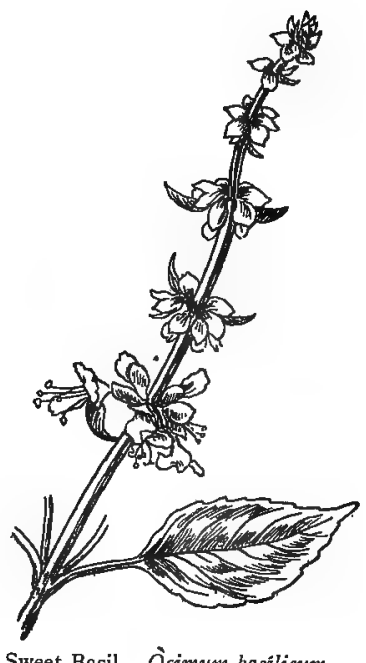

Sweet Basil. Òcimum basilicum

Sweet Basil was formerly used as we use Mignonette, to give a pleasant fragrance to a bouquet; also to flavor soups and occasionally salads. Now, it is rarely seen, either in the flower or the kitchen garden.

\section{PEPPERMINT}

Méntha peperita.

Mentha, Greek, from the name of the nymph fabled to have been changed into mint by Proserpine.

Perennial by runners and rootstocks, growing in wet places, beside running streams. Recognized by the peppery taste of the leaves. Europe, naturalized in America. 
Stem.-Square, one to three feet high.

Leaves.-Two to three inches long, wrinkled, veiny, oblong or lanceolate, sharply serrate, acute, punctate with minute oil-globules.

Flowers.-Small, pale-purple or whitish, forming thick, dense, obtuse spikes, both terminal and lateral. Frequently the lateral overtop the terminal.

Calyx.-Tubular, five-toothed.

Corolla.-Purplish, tubular, border four-cleft.

Stamens.-Four.

Ovary.-Four-parted, developing into four nut-like akenes.

There is no difficulty in recognizing Peppermint, if one chews the leaves, for the intensely pungent, aromatic taste resembling that of pepper is unmistakable, and curiously enough it is accompanied with a peculiar sensation of coldness.

Peppermint ranks as one of the most important plants in the production of essential oils. In the United States it is cultivated in central New York, northern Indiana, and southern Michigan and is regarded as a valuable crop. The plants are cut when just coming into bloom and are cured like hay; they are then taken to the stills where the oil is extracted by distillation with steam. One well-grown acre will produce sixty. pounds of oil. Peppermint oil is used in confectionery, very extensively in medicines, also for the production of menthol and the cordial crême de menthe.

\section{SPEARMINT}

Méntha víridis.

A perennial by leafy stolons, growing in wet places in cultivated districts. Native both to Europe and Asia and naturalized in the United States. Summer.

Stem.-Square, one to two feet high, from creeping rootstocks.

Leaves.-Opposite, sessile, two to three inches long, wrinkled, veiny, oblong or lance-ovate, coarsely serrate, rounded at base, acute.

Flowers.-Small, pale-purple or whitish, clustered in axillary whorls, forming slender, mostly interrupted spikes both terminal and lateral.

Calyx.-Tubular, five-toothed. 
Corolla.-Tubular, border four-cleft, upper lobe broadest.

Stamens.-Four, equal, erect.

Ovary.-Four-parted; developing into four seed-like akenes.

Spearmint has virtues which have long been recognized. The French call it Menthe de Notre Dame, the Italians Erba Santa Maria, and the Germans Frauen Minze. In the Middle Ages it was a charm against the bite of serpents, scorpions, and mad dogs. Its culinary uses were to assist in the making of cheese, to be put with pennyroyal into puddings, and also to be boiled with green peas. That use still survives in England. Spearmint is also cultivated on pep-

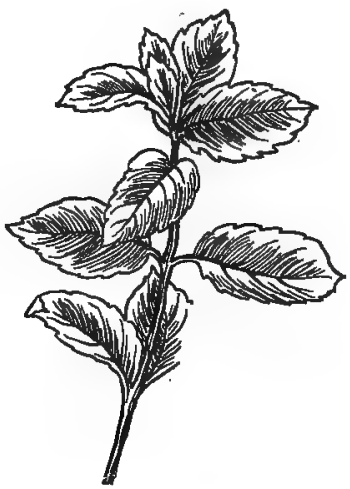

Spearmint. Méntha vîridis permint farms and the plants distilled for their essential oil. This is used chiefly in medicine.

Spearmint is a crop in the vicinity of large cities, where freshly cut sprigs are used in making the "seductive and intoxicating drink known as mint-julep." It is more widely used as an ingredient in mint sauce, the familiar accompaniment of spring lamb.

\section{SWEET FENNEL}

Fceniculum vulgàre.

Foniculum, Latin, from fonum, hay; referring to the odor which suggests that of new-mown hay.

Biennial; foliage and fruit sweet, aromatic, medicinal, and stimulating.

Stem.-Stout, smooth, four to six feet high.

Leaves.-Numerous, three to four times pinnate, spread out into finely cut and almost hair-like segments.

Flowers.-Bright-yellow, in an umbel of ten to twenty rays, without involucre. 


\section{SWEET HERBS}

Calyx.-With limb indistinct.

Petals.-Five, roundish, obovate.

Seed.-Flat on one side and convex on the other, seldom more than one-fourth of an inch long.

Sow fennel, sow sorrow.

-Old Proverb.

There's fennel for you and columbines.

- "Hamlet." Act IV, Sc. 5, Shakespeare.

Christopher. "No, my good Lord."

Count. "Your good Lord! Oh, how this smells of fennel!"

- "The Case Altered," Act II, Sc. 2, BEN Jonson.

We have in Shakespeare's time the plainest evidence that Fennel was the recognized emblem of flattery. If it be true that Ophelia's flowers were all selected for their significance, perhaps it was not by accident that she offers Fennel to her brother-who has just heard the cry: "Laertes shall be king, Laertes king!"

If there was any reason why Fennel should be connected with sorrow that clew is apparently lost, but the proverb remains.

The use of Fennel as a. Sweet Herb still persists in Germany, where it is used to flavor fish sauces and also bread and cakes.

Parkinson says: "Fennel is of great use to trim up and strowe upon fish, as also to boyl or put among fish of divers sorts, cowcumbers pickled and other fruits. The rootes are used with Parsley rootes to be boyled in broths. The seed is much used to put in Pippin pies and divers other such baked fruits, as also into bread to give it the better relish."

It is a good deal of a puzzle how Fennel, which, upon the whole, is rather inert as a drug, ever obtained the tremendous reputation which it enjoyed among the ancients. The plant was believed to be an antidote to all kinds of poisons; to restore sight to the blind and strength to the failing body. That the aromatic seeds should be used to impart a flavor to food is comprehensible; that its pliant stems with strong and delicate leaves lent themselves to the making of wreaths, and so were present at weddings and at funerals, is also clear; but why it was supposed to do so many things that manifestly it could not do is not so clear. 


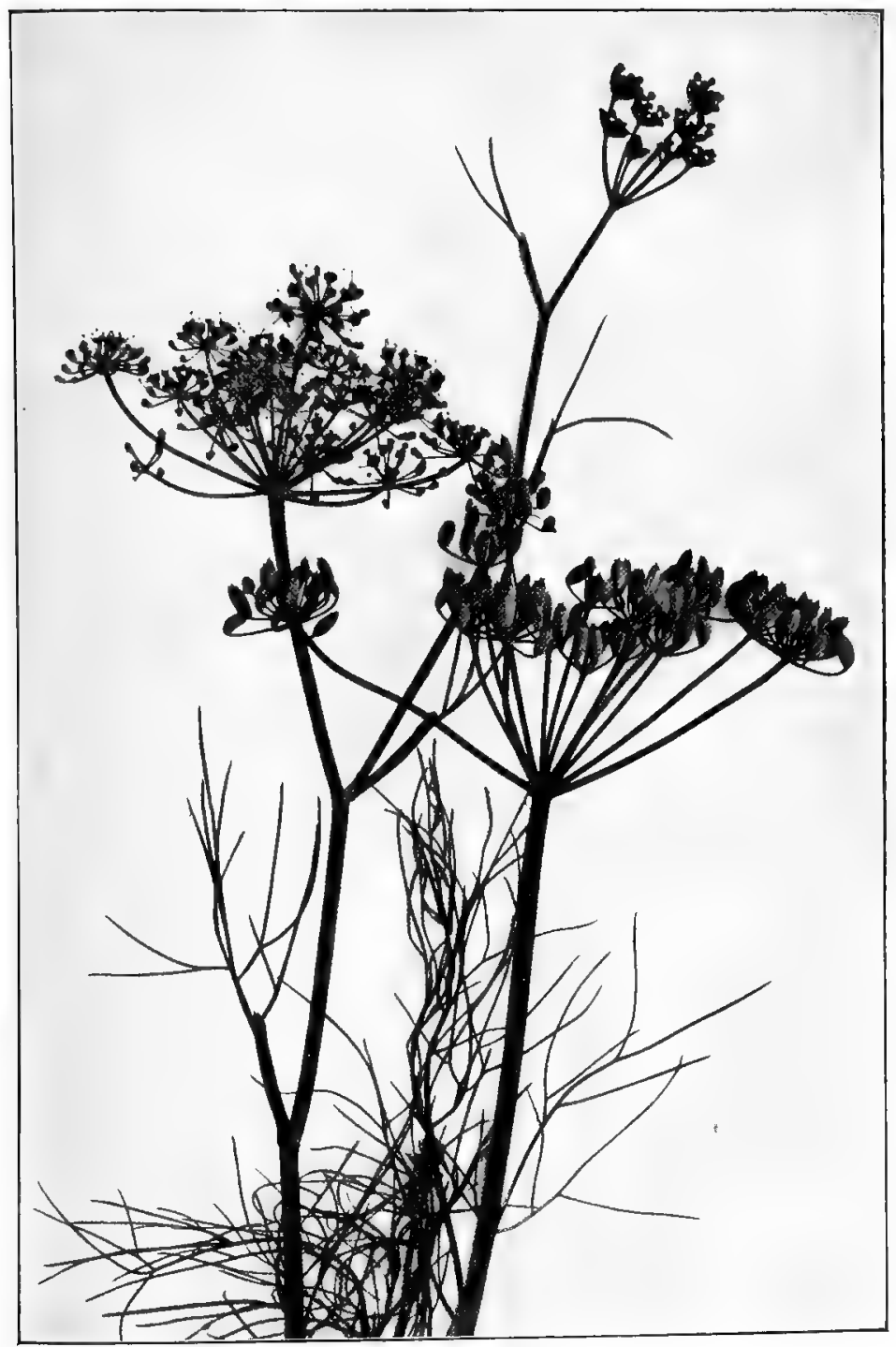

Sweet Fennel. Faniculum vulgàre 
The Greek name for Fennel is Marathon. This fact throws light upon the historic myth that grew up about the swift runner, Pheidippides, he who ran to Sparta to seek aid for Athens against the Persian fleet which threatened the coast. As Herodotus tells the story, after two days and two nights Pheidippides reached Sparta, only to be told that the Spartans could not come until after the full moon. Disappointed and disheartened, he turned back to carry the word to Athens. On his way he met the great god Pan, who promised the Athenians victory and gave him as a pledge of his prophecy a stalk of the Fennel plant. The battle was fought on the Fennel-field, Marathon, and the god's word came true. Statues of the youth always represented him with a stalk of Fennel in his hand. Browning puts the old story in words of wonderful pathos and power in his poem "Pheidippides":

Say Pan saith: Let this foreshowing the place, be the pledge! Gay, the liberal hand held out this herbage I bear-

Fennel-I grasped it atremble with dew-whatever it bode.

Fight I shall with the foremost, wherever this $\dot{F}$ Fennel may grow,

Pound-Pan helping us-Persia to dust and under the deep

Whelm her away forever.

The glory of Fennel has passed from thẹ gardens, and few gardeners even know it by sight. It lives in literature, but no longer lingers beside the garden walk.

\section{DILL}

Anèthum gravèolens.

Anethum, burning, stimulating; referring to the juices of the plant.

An annual or biennial plant of the market garden; much used in the making of pickles; pungent. Summer.

Stems.- Three to four feet high, erect, branching.

Leaves.-Finely dissected, bi or tri-pinnate, glaucus, leaflets threadlike; petioles broad, clasping the stem.

Flowers.-Yellow, borne in large, flat terminal, compound umbels destitute of both involucre and involucels; calyx-teeth obsolete. 
Petals.-Five, yellow, incurved.

Stamens.-Five; stigmatic surface of stigmas large.

Seeds.-Broad-oval, flattened with sharp thread-like dorsal ridges.

Dill is a robust, weedy plant of strong aromatic taste and odor, and in former days had a great reputation not only as a defence against witchcraft, but also as a means of working spells of blackest magic. All its virtues have departed to-day, except the homely one of aiding in the making of a particular brand of cucumber

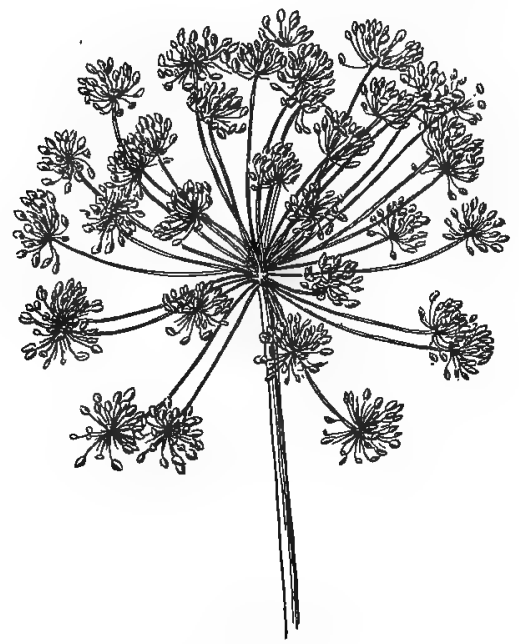

Dill. Al nèthum gravèolens

pickles. It probably descended to this humble office even while its witchcraft reputation was at its height, for three hundred years ago it is recorded that Dill, if "added to pickled cucumbers, gave the cold fruit a pretty spicie taste." Evelyn praises "Gerckens muriated with the seeds of Dill," and Addison writes: "I am always pleased with that particular time of the year which is proper for the pickling of Dill and cucumbers."

The seeds are like caraway seeds in flavor, but not in shape; the stem and leaves resemble those of Fennel, though smaller. 


\section{PARSLEY}

\section{Càrum petroselinum.}

Carum, from the country Caria in western Asia.

The common Parsley of the market, prized for the pleasant flavor of its foliage, used in cookery; occasionally runs wild.

Stem.--Erect, one to three feet.

Leaves.-Pinnately compound; leaflets cleft and cut.

Flowers.-Small, greenish-yellow, borne in compound umbels; calyxteeth small.

Petals.-Five; fruit ovate, ribbed.

We cultivate the Parsley for its leaves, which are in common use as a garnish for meat dishes. Several garden varieties are grown; the one with curled and crumpled leaves is preferred as being more decorative than the others. The cultivated plant is rarely allowed to bloom, but when it does it produces an umbel of small, yellowish flowers, and, later, rather crowded umbels of flat seeds.

An old work on gardening, written about I440, says that Parsley was "much used in all sortes of meates, both boyled, roasted and fryed, stewed, etc., and being green it serveth to lay upon sundry meates. It is also shred and stopped into powdered beefe." The seeds of Parsley were also put into cheese to flavor it, and the anecdote is told that Charlemagne once ate cheese mixed with Parsley seeds at a bishop's palace, and liked it so much that ever after he had two cases of such cheese sent yearly to Aix-laChapelle.

The plant was used among the Greeks as a decoration at funerals and to strew upon graves, hence came the saying, "to be in need of Parsley," signifying to be at death's door. This apparently made it a plant of ill repute, for Plutarch tells the story of a panic created in a Greek force which was marching against the enemy by the soldiers suddenly meeting some mules laden with Parsley which they looked upon as an evil omen.

The seeds are so slow of germination that a Devonshire saying 
records, that the Parsley seed goes to the Devil and back again nine times before it comes up.

Caraway, Carum carui, is grown for its seeds, which are used in flavoring bread and cakes, also in confectionery. It grows a foot or two high, has finely cut, pinnately compound foliage, and small, white flowers in umbels. It occasionally runs wild.

Coriander, Coriandrum sativum is also cultivated for its seeds which are still used by druggists and confectioners, and are perhaps oftenest found in little round pink and white candies. The plant is native to the Mediterranean regions and in general appearance resembles caraway. It may be of interest to note that in the Book of Numbers, XI, 7, Manna is compared to Coriander seed.

Many of the Sweet Herbs of Medieval gardens have passed out of cultivation, modern taste finding them both unpleasant and undesirable. Among such are Elecampane, Good King Henry, Smallage, and Sweet Cicely. Yet they have their place in any garden which seeks to reproduce earlier conditions and represent former tastes. 



\section{GLOSSARY}

Acuminate.-Tapering at the end.

AcUTE.-Sharp pointed.

ADVENTIVE.-Imperfectly naturalized.

AKENE.-A dry, one-seeded indehiscent fruit, with the pericarp fitting closely around the seed.

Alternate (of leaves, etc.).--Not opposite to each other on the axis, but arranged singly at different heights.

ANNUAL. - Of only one year's duration.

ANTHER.-The part of the stamen that produces pollen.

ARIL.-An extra seed covering.

Awn.-A bristle-shaped appendage.

AxIL.-The angle formed by a leaf or branch with the stem.

AXILLARY.-Situated in the axil.

Axrs.-The central line of any organ, or support of a group of organs.

BEAKED.-Ending in a prolonged tip.

BEARDED.-Furnished with long or stiff hairs.

BERRY.-A fruit, whose pericarp is fleshy or pulpy.

BIENNIAL. - Of two years' duration.

BLADE.- The expanded portion of a leaf.

BRACT.-A reduced leaf form situated near or among the flowers.

Bulblets.-Axillary buds which spontaneously detach themselves and fall to the ground and become new plants.

Calyx.-The outer floral envelope; its leaves are called sepals.

Campanulate.-Bell-shaped.

CAUlescent.-Relating to the stem.

CHAFF. - A small thin bract, becoming dry and membranous.

Ciliate.-Marginally fringed with hairs.

Cleistogamous.-Fertilized in the bud without the opening of the flower.

Conduplicate.-Folded together lengthwise.

Connecrive.-The portion of a stamen which connects the two cells of an anther.

Convolute.-Rolled lengthwise.

Cordate.-Heart-shaped.

Corm.- The enlarged fleshy base of a stem, bulb-like but solid.

Corolla. - The inner whorl of the floral envelopes; its leaves are called petals. 
Corymb.-A flat-topped flower cluster.

Corymbose.-Corymb-like.

CRenate.-Dentate with rounded teeth.

Crown.-An inner appendage to a petal, or to the throat of a corolla.

Cyme.-An inflorescence with the central or terminal flowers blooming earliest.

DECUMBENT.-Reclining, with the summit ascending.

DEHISCENT.-Opening regularly by valves or slits, as a capsule or anther.

DENTATE.-Toothed; teeth directed outward.

Diadelphous.-Combined in two sets.

Drœcious.-With two kinds of flowers on separate plants.

Disk.-A development of the receptacle at or around the base of the pistil.

EXSERTED.-Projecting.

EXTRORSE.-Facing outward.

FertiLE.-Capable of producing fruit.

FLORET.-A small flower, usually one of a dense cluster.

Foldrcle.-A single carpel, opening by the ventral suture.

GLABRoUS.-Smooth.

HEAD. - A dense cluster of flowers on a short axis.

HeRB.-A plant with no persistent woody stem above ground.

HyBRID.-A cross-breed of two species.

IMBRICATE.-Overlapping.

INTERNODE.-The portion of stem between two nodes.

INVOLUCRE.-A circle of bracts surrounding a flower cluster or a single Hower.

LANCEOLATE.-Shaped like a lance-head, several times longer than wide and broadest at the base.

LeGUME.-The fruit of the Leguminosa; for example a pea-pod.

LOBE.-Any segment of an organ.

MIDRIB.- The central rib of a leaf.

NODE.-The place on a stem that normally bears a leaf.

Ovary. - The part of the pistil that contains the ovules.

Ovule. - The body that after fertilization becomes the seed.

PANICLE,-A loose, irregularly compound inflorescence.

PAPpUS. - The modified calyx-limb of Compositce.

Peduncle.-A primary flower stalk.

Perennial.-Lasting year after year.

PERfECT (flower), - Having both pistil and stamens.

Periantu.-The floral envelope, consisting of calyx and corolla (when present), whatever their form.

PERICARP. - The matured ovary.

PeTal.-A division of the corolla.

PETALom.-Resembling a petal; used for an abnormal form in double flowers.

Petrole. - The foot-stalk of a leaf.

PIstiL.-The seed-bearing organ of the flower, consisting of ovary, style, and stigma.

PoD.-Any dry dehiscent fruit. 
PoLLEN.-The fertilizing grain contained in the anther.

RACEME.-A number of pediceled flowers on a common axis.

RADICAL.-Proceeding from the root.

RECEPTACLE.-The summit of the stem which bears the organs of a flower. RHIZOME.-A prostrate or subterranean stem, usually rooting at the nodes.

Rоoт.-The underground part of a plant which supplies it with nourishment.

RootsTock.-Same as rhizome.

SCAPE.-A peduncle rising from the ground.

SECUND.-One-sided.

SEED.-The ripened ovule.

SePal.-A division of a calyx.

SEPaloId.-Like a sepal.

SERRATE.-Having sharp teeth pointing forward.

Silique. - The peculiar pod of Cruciferce.

Sinus. - The cleft between two lobes.

Stamen.-One of the pollen-bearing organs of the plant.

STIGMA.-That part of the pistil through which fertilization by the pollen is affected.

STYLE.-Lengthened portion of the pistil connecting the stigma and the ovary.

UMBEL.-An inflorescence in which the pedicels of a cluster spring from the same point.

UTRICLE-A small bladdery one-seeded fruit.

WING.-Any thin expansion bordering or surrounding an organ.

Botanical names, from long-established custom, are pronounced in Englishspeaking countries according to the pronunciation of Latin after the English method, with some few exceptions.

Two accents are used: the grave (') to indicate the long English sound of the vowel; the acute (') to show the shortened or otherwise modified sound. 



\section{INDEX}

ABRONIA, I 26

umbellata, I 26

Acanthacee, 420

Acanthus Family, 420 mollis, $42 \mathrm{I}$

Achillea millefolium, 465 ptarmica, 465

Achyranthes, 123

Aconite, I68

Aconitum napellus, I68

Actinidia, 295

Adam's Needle, 47

Adlumia, 208 cirrhosa, 208

Adonis astivalis, 182 autumnalis, $\mathrm{r} 82$

Spring, I82

vernalis, I82

Egopodium podograria, 330

Ageratum conyzoides, 506

Agrostemna coronaria, 136

Akebia quintata, I 88

Alfalfa, 254

Alleghany Vine, 208

Allium, 5o

$$
\text { cepa, } 5^{\circ}
$$

cernuum, $5^{\circ}$

schœnoprasum, 52

Alstrœmeria, 60

Alternanthera, I 22

Althæa officinalis, 288 .

$$
\text { rosea, } 285
$$

Alum Root, 234

Alyssum maritimum, 2 I4

saxatile, 2 I 5

Sweet, $2 I_{4}$

Yellow, 2I 5

Amarantaceæ, I 18
Amaranth, II8

Family, I 8

Globe, I 8

Red, 118

Amarantus cordatus, I r8

gangeticus, I 8

tricolor, I 18

Amaryllidacea, 60

Amaryllis Family, 60

Ammobium alatum, 5I I

Winged, 5 I $\mathbf{I}$

Ampelopsis quinquefolia, 280

Veitchii, 28I

Amsonia tabernamontana, $35^{\circ}$

Anaphalis margaritacea, 510

Anemone, I74

coronaria, I74

Garden, $\mathrm{r} 74$

hortensis, 174

Japanese, 175

japonica, 174

nemorosa, ${ }^{7} 6$

patens, 176

pennsylvanica, I 76

Poppy, I74

pulsatilla, 176

Rue, $x_{7} 6$

Anemonella thalictroides, I 76

Anethum graveolens, 529

Anthemis cotula, 477

nobilis, 476

tinctoria, 476

Antirrhinum, 401

majus, $40 \mathrm{I}$

maurandioides, 402

Apios tuberosa, $25 \mathrm{I}$

Apocynacex, 347

Aponogetum distachyum, 3 
Aquilegia canadensis, I62

cærula, 165

chrysantha, I66

formosa, $\mathrm{I} 64$

glandulosa, I 66

oxysepala, 166

siberica, I66

Skinneri, I66

vulgaris, I60

Arabis albida, 2 rg

alpina, 2x9

Araceæ, 5

Arachis hypogæa, 255

Arctotis grandis, $47^{8}$

Argemone mexicana, 202 platyceras, 202

Aristolochia macrophylla, I05

Aristolochiaceæ, 105

Armeria vulgaris, 335

Artemisia abrotanum, 5I4 absinthium, 5I4 dracunculus, $5^{16}$

Arum Family, 5

Asclepiaceæ, 35I

Asclepias incarnata, $35^{2}$ tuberosa, 35I

Asparagus, Garden, 53

medeoloides, 54

officinalis, 53

plumosus, 54

Sprengeri, 54

Asperula, 4I6

odorata, 4I6

orientalis, $4 \mathrm{I} 6$

Aster, 488

China, 486

ericoides, 489

Novæ Angliæ, 488

Stokes's, 502

Aubretia deltoidea, 2I9

Avens, Long-plumed, I47

BABY'S BREATE, I4O, 4I5

Bachelor's Button, II9, 499

Balloon Vine, 276

Balm, Bee, 376

Fragrant, 376
Balsam-Apple, 435

Balsam, Garden, 277

Balsaminacer, 277

Banana Family, 97

Baptisia australis, 240

Barbarea vulgaris, 220

Barberry Family, I88

Barrenwort, Large-flowered, I89

Bartonia aurea, 309

Basil, Sweet, $5^{23}$

Bean, Castor, 274

Hyacinth, 250

Kidney, 249

Sacred, I53

Soy, 254

Wild, $25 x$

Beard Tongue, 4II

Bear's Breech, 42I

Bedstraw, $4 \mathbf{I} 5$

Beet, II4

Belamcanda chinensis, 95

Bellfower, Carpathian, 440

Creeping, 438

Family, 437

Japanese, 444

Narrow-leaved, $44^{\circ}$

Rampion-like, $43^{8}$

Bellis perennis, 49I

Berberidaceæ, I88

Bergamot, Wild, 378

Beta vulgaris, II 4

Bethlehem Sage, 327

Bignonia Family, 4I8

Bignoniaceæ, 418

Bindweed, Hedge, 359

Birthwort Family, I05

Bishop's Cap, 233

Bishop's Weed, $35^{\circ}$

Bitter-sweet, Climbing, 269

Blackberry Lily, 95

Blazing Star, 309, $5^{\text {I } 4}$

Bleeding Heart, 203

Bloodroot, I 98

Bluebells, 322

Bluebells of Scotland, 442

Blue-eyed Mary, 405

Bocconia cordata, I 97 
Boltonia asteroides, 489

Boneset, $5^{\text {I } 3}$

Borage Family, 322

Boraginaceæ, 322

Borago officinalis, 325

Boston Ivy, 28I

Bouncing Bet, 139

Boussingaultia, I 77

Brachycome iberidifolia, 492

Brassica alba, 219 campestris, 2I 8 nigra, 219 oleracea, $2 \times 7$

Browallia demissa, 392

Bryonopsis lacimosa, 436

Buckwheat, I IO

Family, Io7

Bulbocodium vernum, $5^{8}$

Butter-and-Eggs, 402

Buttercup, Double, 178

Butterfly Flowers, 394

Butterfly Peà, 239

Butterfly Weed, 35I

Cabbage, Sea, 217

Wild, 2 I 7

Cacalia, 490

Calampelis, 419

Calendula officinalis, 480

California Poppy, 200

Calla Lily, 5

Calliopsis, 485

Callirrhoë involucrata, 294

Callistephus chinensis, 486

Caltha palustris, $I 8_{3}$

Campanula calycanthema, 438

carpatica, $44^{\circ}$

Chimney, 442

medium, 437

persicifolia, $44^{\circ}$

pyramidalis, 442

rapunculoides, 438

rotundifolia, 442

trachelium, 442

Campanulaceæ, 437

Campion, Rose, 136
Candytuft, Bitter, 2I4

Evergreen, 2 I 4

Purple, 213

Canna, 97

Canterbury Bells, 437

Capparidaceæ, 22 I

Caprifoliaceæ, 422

Capsicum annuum, 399

Caraway, 53I

Cardamine, 220

Cardinal-Flower, 447

Cardiospernum halicacabum, 276

Carnation, 132

Carrot, Wild, 328

Carum petroselinum, 530

Caryophyllaceæ, I 28

Caryopteris mastacanthus, 374

Cassia floribunda, 254

Castalia odorata, 150

Castor-Bean, 274

Catchfly, Sweet William, 138

Catnip, 38I

Celandine, 20I

Celastraceæ, 269

Celastrus scandens, 269

Celosia cristata, I 20

Centaurea cineraria, 502

cyanus, 499

gymnoscarpa, 502

montana, 500

moschata, $5 \circ 2$

suaveolens, 504

Centrosema virginianum, 239

Cerastium tomentosum, I4I

Chamomile, Yellow, 476

Cheeses, 292

Cheiranthus cheiri, 219

Chelidonum majus, 20I

Chelone, glabra, 4IO

obliqua, 409

Chenopodiaceæ, II4

Chenopodium botrys, II6

Chickweed, 142

Mouse-ear, I4I

Chicory, $5^{\circ 4}$

China Aster, 486

China Pink, I30 
Chinese Lantern, 399

Chionodoxa luciliæ, 37 sardensis, 37

Chives, $5^{2}$

Christmas Rose, I84

Chrysanthemum aureum, 473

balsamita, 472

carinatum, $47 \mathrm{r}$

coccinium, $47^{\circ}$

coronarium, 472

frutescens, 473

Hardy, 474

Keeled, 47I

leucanthemum, 474

parthenium, 473

segetum, 472

Summer, $47 \mathrm{I}$

tricolor, $47 \mathrm{I}$

uliginosum, 473

Cichorium intybus, 504

Cigar Plant, $3 \mathrm{I} 2$

Cinnamon Vine, 59

Cinquefoil, $I_{4} 6$

Cistaceæ, 298

Citron, 434

Citrullus vulgaris, 434

Clarkia elegans, 320 pulchella, 320

Clematis Davidiana, I 72 Jackmanni, I74

Japanese, I 72

Large-flowered, I74

Leather-leaf, I $7 \mathrm{I}$

paniculata, $\mathbf{I} 72$

viorna, $\mathrm{I} 7 \mathrm{I}$

virginiana, I 70

Wild, I7o

Cleome pungens, $22 \mathrm{I}$

Climbing Bitter-sweet, 269

Climbing Fumitory, 208

Clover, 242

Alsike, 243

Crimson, 244

Hop, 244

Italian, 244

Rabbit Fool, 244

Red, 242
Clover, Sweet, 247

White, 243

Cobœa scandens, 365

Cockscomb, I 20

Colchicum autumnale, $5^{8}$

Coleus hybrida, $3^{80}$ Garden, 380

Collinsia bicolor, 405 verna, 405

Columbine, I60 Colorado, 165

European, I60

Feathered, 179

Golden, 1,66

Red, I62

Siberian, I66

Western, I64

Commelina nudiflora, II

Commelinaceæ, 8

Compositæ, $45^{2}$

Composite Family, 452

Cone Flower, 462

Purple, 463

Convallaria majalis, 55

Convolvulaceæ, 353

Convolvulus, 359

Family, 353

japonica, 360

sepium, 359

tricolor, 360

Copa-de-Oro, 200

Coreopsis, 484

lanceolata, 484

Coriander, 53I

Cornflower, 499

Coronilla varia, 248

Cosmos bipinnatus, 494

Costmary, $47^{2}$

Cotton, 293

Lavender, 5 I6

Tree, 293

Coventry Bells, 442

Cowslip, 183

American, 343

Virginian, 322

Crassulaceæ, 227

Cress, Bitter, 220 
Cress, False Wall, 219

Rock, 2 I9

Water, 220

Winter, 220

Crimson Bells, 233

Crinum, 6o

Crocus, 89

aureus, 89

biflorus, 89

mæsiacus, 89

sativas, 89

Spring, 89

susianus, 89

vernus, 89

versicolor, 89

Crosswort, 4I6

Crowfoot Family, 155

Crown Imperial, 35

Cruciferæ, 2ro

Cucumber, 432

Wild, 435

Cucumis melo, 433 sativus, 432

Cucurbita pepo, 429

Cucurbitaceæ, 429

Cup-flower, 399

Cuphea ignea, 312

Cypress Vine, 358

Cypripedium, I00

DAFFODIL, 62

Hoop-Petticoat, 66

Superb, 46

Trumpet, 62

Van Sion, 66

Dahlia, 466

Juarezii, 466

rosea, 466

variabilis, 466

Daisy, English, 49I

Garland, 472

Ox-eye, 474

Shasta, 474

Swan River, $49^{2}$

Datura fastuosa, $39^{\circ}$

stramonium, 390

Daucus carota, 328
Dead-nettle, 382

Delphinium, 167

Dentaria, 220

Dianthus barbatus, 128 caryophyllus, $x_{32}$

chinensis, I 30

plumarius, 134

Dicentra, 204

canadensis, 204

cucularia, 206

eximia, 206

formosa, 208

spectabilis, 203

Dictamnus albus, 268

Digitalis purpurea, 405

Dill, 528

Dioscorea divaricata, 59

Dioscoreaceæ, 59

Dipsacaceæ, $45^{\circ}$

Dittany, 268

Dodecatheon Meadia, 343

Dogbane, Common, $35^{\circ}$

Family, 347

Dolichos lablab, $25^{\circ}$

Doronicum, $5^{\text {I } 4}$

Draba, 219

Dusty Miller, $5^{\circ 2}$

Dutchman's Pipe, I05

ECHEVERIA, 230

Echinacea purpurea, 463

Echinocystis lobata, 435

Echinops exaltatus, 512

Echium vulgare, 325

Egg Plant, 400

Egyptian Lotus, 153

Emilia flammea, 490

Epilobium angustifolium, 318

Epimedium macranthum, 189

Eremurus robustus, $5^{6}$

Eryngium amethystium, 33I

Eschscholtzia californica, 200

Euonymus radicans, 269

Eupatorium ageratoides, 5 I3

perfoliatum, $5{ }^{13}$

purpureum, 5I 3

Euphorbia corollata, 272 
Euphorbia heterophylla, 274 marginata, 270 pulcherrima, 273

Euphorbiacex, 270

Evening Primrose, 3I4 Family, 3I4

Everlasting, Pearly, 5 Io Sweet, 5 II

FAGOPYRUM ESCULENTUM, IIO False Dragon's Head, 379 False Indigo, Blue, 240 Feather Geranium, I I6 Fennel, Sweet, 525

Feverfew, 475

Figwort Family, 40I

Fire-Weed, 3 I8

Five Finger, 146

Flax, $25^{6}$

Common, 256

Family, 256

Flowering, 257

Perennial, 257

Fleur-de-lis, 79

Flower-of-an-Hour, 290

Fœniculum vulgare, 525

Forget-me-not, 324

Four o'Clock, I25

Family, I25

Foxiglove, 405

Fritillaria imperialis, 35 meleagris, 34

Fuchsia, 3I6

coccinea, 318

macrostemma, 316

triphylla, 318

Fumariace 2,203

Fumitory, Climbing, 208 Family, 203

Funkia, 43

GAILLARDIA, 477 cristata, 477 pulchella, 477

Galanthus Elwesii, 75 nivalis, 74

Galium mollugo, 4I5
Gas Plant, 268

Gaura parviflora, 3I9

Gentian Family, 345

Fringed, 345

Gentiana crinita, 345

Gentianacex, 345

Geraniaceæ, 260

Geranium Family, 260

Garden, 260

maculatum, 26I

Robertianum, 26I

Geum, I47

Gilia tricolor, 368

Gill-over-the-Ground, $38 z$

Gillyflower, 210

Gladiolus, 86

Globe Flower, I77

Globe Thistle, Tall, 51 2

Glory of the Snow, 37

Gnaphalium, 5I I

Godetia, 316

Gold Flower, 296

Golden Feather, 473

Glow, 463

Immortelle, 507

Marguerite, 476

Golden-rod, 495

Gomphrena globosa, II

perennis, I 20

pulchella, I 20

Goober, 255

Goosefoot Family, II4

Gossypium arboreum, 293

herbaceum, 293

Gourd, Bottle, 33 I

Family, 429

Gout Weed, $33^{\circ}$

Grape, Frost, 282

Northern Fox, 283

River-bank, 282

Grape Hyacinth, 38

Great Willow Herb, 3 I8

Ground Cherry, 399

Ivy, 382

Nut, $25 \mathrm{I}$

Gumbo, 291

Gypsophila acutilifolia, I4I 
Gypsophila cerasteroides, I4I paniculata, 140

HAREBELL, 442

Hedge-nettle, 382

Helenium autumnale, 46I

Helianthemum vulgare, 298

Helianthus annuus, 453

debilis, 457

decapetalus, 457

lætiflorus, 457

orgyalis, 460

rigidus, 457

tuberosus, 460

Helichrysum arenarium, 510 bracteatum, 507

Heliopsis lævis, 460

Heliotrope, 326

Heliotropium peruvianum, 326

Helipterum Manglesii, 507

Helleborus niger, 184

Hemerocallis flava, 46 fulva, 45

Hen-and-Chickens, 230

Hepatica acutiloba, I79 triloba, 179

Herb Robert, 26 I

Hesperus matronalis, 216

Heuchera sanguinea, 233

Hibiscus, 288

esculentus, 29I

moscheutos, 288

trionum, 290

Hollyhock, 285

Trailing, 290

Honesty, 215

Honeysuckle Family, 422 Trumpet, 423

Hop, Common, IO3

Japanese, I04

Horn of Plenty, 390

Horseradish, 220

Houseleek, 230

Hubbard Squash, 429

Humulus japonicus, IO4

lupulus, ro3

Huntsman's Cup, 224
Hyacinth, 40

Grape, 38

Roman, 42

Hyacinth Bean, 250

Hyacinthus albulus, 42

candicans, 42

orientalis, 40

Hydrophyllaceæ, 37I

Hypericaceæ, 296

Hypericum moserianum, 296

IBERIS AMARA, 213

sempervirens, $2 \pi 4$

umbellata, $2 \mathrm{I} 4$

Immortelle, Golden, 507

Impatiens balsamina, 277

fulva, 278

pallida, 278

sultani, 278

Incarvillea Delavayi, 4I9

Indian Shot, 97

Ipomcea batatas, $.35^{8}$

bona-nox, $35^{6}$

hybrida, 353

pandurata, 357

quamoclit, $35^{8}$

Iresine Herbstii, I23

Iridaceæ, 79

Iris, 79

- Dwarf, 83

English, 84

Family, 79

German, 80

germanica, 80

Japanese, 84

lævigata, 84

pumila, 83

Spanish, 83

xiphium, 83

xiphoides, 84

Ivy, Boston, 28I

Ground, 382

Japanese, 28I

Ixia, I92

JACOB'S LADDER, $37^{\circ}$

Jerusalem Artichoke, 460 
Jerusalem Cherry, 400 Oak, II6

Jewelweed, 278

Joe Pye Weed, $5^{1} 3$

Jonquil, 72

Joseph's Coat, IIg

KAISERBLUME, 499

Kidney Bean,' 249

Kniphofia aloides, 46

Kochia scoparia, I 16

Kudzu Vine, $25^{2}$

LABIATAE, 375

Lady's Slipper, Ioo

Lagenaria vulgaris, $43 \mathrm{I}$

Lamium album, 382 maculatum, 382 purpureum, 382

Larkspur, I67

Lathyrus latifolius, 238 odoratus, 235

Lavatera trimestris, 294

Lavender, Seá, 334

Sweet, 38I

Lavendula vera, 38 I

Leadwort Family, 334

Leguminosa, 235

Leopard's Bane, 5I4

Lepachys pinnata, 464

Lespedeza Sieboldi, 244

Leucojum vernum, 76

Liatris, $5^{14}$

Liliaceæ, I4

Lilium, I4 auratum, 24 canadense, 27 candidum, I6 concolor, 20 elegans, 20 Harrisii, I8 japonicum, 22 longiflorum, I8 philadelphicum, 20 speciosum, 22 superbum, 27 tigrinum, 26
Lily, 4

Bermuda, 18

Blackberry, 95

Calla, 5

Canada, 27

Checkered, 34

Day, 43, 45

Easter, I8

Gold-banded, 24

Japanese, 22

Lemon, 46

Madonna, I6

Meadow, 27

Plantain, 43

Red, 20

St. Bruno's, $5^{6}$

Showy, 22

Tiger, 26

Toad, $5^{8}$

Torch, 46

Turk's Cap, 27

Upright, 20

Water, I5o

White, 16

Wild Yellow, 27

Wood, 20

Lily of the Nile, 5

Lily of the Valley, 55

Lima Bean, $25^{\circ}$

Linaceæ, 256

Linaria vulgaris, 402

Linum, 256

grandiflorum, 257

perenne, 257

usitatissimum, 256

Live-for-ever, 227

Liverwort, I 79

Loasa Family, 309

Loasaceæ, 309

Lobelia, Blue, 446, 448 cardinalis, 447

erinus, 446

Family, 446

Great, 448

syphiliticus, 448

Lobeliacex, 446

London Pride, I35 
Lonicera caprifolium, 423

Japanese, 423

japonica, 422

periclymenum, 423

sempervirens, 423

Loosestrife Family, 3 IO

Golden, 342

Purple, 3 Io

Swamp, 310

Whorled, 342

Love-in-a-Mist, I86.

Love-in-a-Puff, 276

Love-lies-Bleeding, I I9

Lunaria biennis, 2I 5

Lungwort, Smooth, 322

Lupine, Many-leaved, 246

Lupinus polyphyllus, 246

Lychnis chalcedonica, I35

cœela-rosa, ${ }_{3} 6$

coronaria, $I_{3} 6$

flos-cuculi, 136

githago, $\mathrm{I} 36$

Lycium chinense, 393

vulgare, 393

Lycopersicum esculentum, 394

Lysimachia clethroides, 343

nummularia, 343

quadrifolia, 342

vulgaris, 342

Lythraceæ, 3 IO

Lythrum salicaria, 3 Io

Madder FamiLy, 4I4

Madeira Vine, II 7

Mallow, Common, 292

Family, 285

Marsh, 288

Musk, 292

Poppy, 294

Rose, 288

Swamp Rose, 288

Tree, 293

Malope trifida, 294

Maltese Cross, I35

Malva moschata, 292

rotundifolia, 292

sylvestris, 293
Malvaceæ, 285

Man-of-the-Earth, 357

Marguerite, 473

Golden, 476

Marigold, 480 African, 482

Corn, 472

French, 484

Marsh, 183

Marjoram, Sweet, $52 \mathrm{I}$

Marvel-of-Peru, I25

Matrimony Vine, 393

Matthiola incana, 210

Maurandia, 402

May Pop, 306

Mayweed, 477

Meadow Saffron, 58

Medicago sativa, 254

Melilot, White, 247

Melilotus alba, 247 officinalis, 248

Mentha peperita, 523 viridis, 524

Mentzelia, 309

Mertensia virginica, 322

Mexican Fire Plant, II6

Mignonette, 222

Family, 222

Milkweed Family, 35I

Orange, 35I

Mint Family, 375

Mirabilis jalapa, I25

Mock Cypress, I 16

Monarda didyma, 376 fistulosa, 378

Monlsshood, I68

Montbretia, 96

Moon-flower, 356

Morning-glory, 353

Moss Pink, 364

Mourning Bride, $45^{\circ}$

Mullein Pink, I 36

Muscari botryoides, 38 commosum, 39

Muskmelon, 433

Mustard, Black, 2I9

White, 2 I9 
Myosotis arvensis, 324 palustris, 324

Myrtle, Trailing, 347

NAJADACE 2,3

Narcissus, 6I bulbocodium, 66 Chinese Sacred, 69 incomparabilis, 66 jonquilla, 72 Paper White, 69 poeticus, 68 Poet's, 68 Polyanthus, 69 pseudo-narcissus, 62 tazetta, 69

Nasturtium, 262 armoracia, 220 officinale, 220

Nelumbium, 153 indica, 153 luteum, I 53

Nemophila insignis, $37 \mathrm{I}$

Nepeta cataria, 38I glechoma, $3^{82}$

Nettle Family, IO3

Nicotiana, 388 affinis, 388 alata, 388 Sanderæ, $39 \circ$ tobacum, $39^{\circ}$.

Nierembergia, 399

Nigella damascena, 186 hispania, 187

Nightshade, 398

Nightshade Family, 383

Nyctaginaceæ, I 25

Nymphæa odorata, I 50 tuberosa, $15^{\circ}$

Nymphæaceæ, I50

OCIMUM BASILICUM, 523

Enothera amona, 3 I6

biennis, 3 I4

fruticosa, 3I5

Onagra biennis, 3 I4

Onagraceæ, 3 I4
Onion, Common, 50 Wild, 5o

Ononis rotundifolia, 252

Orange Milkweed, 35I

Orchidaceæ, 100

Orchis Family, I00

Origanum majorana, 52I

Ornithogalum umbellatum, 38

Orpine, Garden, 227 Family, 227

Oswego Tea, 376

Oxalidaceæ, 258

Oxalis acetosella, 258 stricta, $25^{8}$ violacex, 258

Ox Eye, 460

PACHYSANDRA, 275

Pæonia albifolia, ${ }^{156}$ hybrida, I 55 moutans, 156 officinalis, ${ }_{5} 6$

Pansy, 299

Papaver alpinum, 195 nudicaule, 195 orientale, 195 rhœas, 193 somniferum, Igo

Papaveraceæ, I90

Paradisea liliastrum, 56 . Pardanthus sinensis, 95

Parsley, 530

Family, 328

Parsnip, 329

Pasque Flower, I76

Passiflora cærula, 308 incarnata, 306

Passifloraceæ, 306

Passion Flower, 306 Family, 306

Pastinaca sativa, 329

Pea, Butterfly, 239

Cow, 254

Everlasting, 238

Field, 240

Garden, 239

Sweet, 235 
Peanut, 255

Pearl, The, 465

Pelargonum hortorum, 259

Penstemon, 4I I digitalis, 4I I

Peony, I55

Double Red, 158

Moutan, 158

White-flowered, ${ }_{5} 8$

Peppermint, 523

Perilla nankinensis, 380

Periploca græca, $35^{2}$

Periwinkle, 347 Larger, 348 Madagascar, 348

Petunia, 383 hybrida, 383

Phaseolus lunatus, $25^{\circ}$ vulgaris, 249

Pheasant's Eye, I35

Phlox divaricata, 364

Drummondii, 364

'Family, 362 paniculata, 362

Perennial, 362

subulata, 364

Wild, $3^{64}$

Physalis alkekengi, 399

Physostegia virginiana, 379

Pickerel-Weed, I 2

Family, I2

Pie-Plant, II 2

Pink, Bunch, I 28

China, I30

Clove, I 32

Family, I28

- Garden, I34

Grass, I34

Ground, 364

Indian, 130

Moss, 364

Mullein, 136

Scotch, I35

Pipe Vine, I05

Pisum arvense, 240

sativum, 239

Pitcher Plant, 224
Platycodon grandiflorum, 444

Plumbaginaceæ, 334

Plumbago capensis, 336

Poinsettia, 273

Polemoniaceæ, 362

Polemonium cæruleum, 369 reptans, 369

Polianthes tuberosa, 77

Polyanthus, 338

Polygonaceæ, I07

Polygonum, Bushy, I07 cuspidatum, IO7

orientale, rog

sachalinense, 108

Sieboldi, 107

Pondweed, Cape, 3

Family, 3

Pontederia cordata, I2

Pontederiaceæ, I 2

Poppy, Alpine, I95

California, 200

Common, Igo

Corn, 193

Iceland, I94

Matilija, 207

Opium, r9o

Oriental, I95

Plume, I97

Scarlet, 193

Shirley, I94

Portulaca grandiflora, 148

oleracea, 149

Portulacacex, 148

Potamegeton distachyum, 3

Potato, 397

Sweet, $35^{8}$

Potentilla canadensis, 146

Primrose, 340

Chinese, 340

Evening, 3I4

Family, 338

Primula acaulis, 340

japonica, $34^{\circ}$

officinalis, 339

polyanthus, 338

variabilis, 338

Primulaceæ, 338 
Prince's Feather, Iog, IIg

Pueraria Thunbergiana, 252

Pulmonaria saccharata, 326

Purslane Family, I 48

Pyrethrum roseum, 470

Queen ANNE's Lace, 328

RAGGED ROBIN, I36

Ramstead Weed, 402

Ranunculaceæ, 155

Ranunculus acris, 178

Reseda odorata, 222

Rest Harrow, 252

Rheum rhaponicum, II 2

Rhubarb, II 2 palmatum, II 3

Richardia africana, 5

Ricinus communis, 274

Rocket, Dame's, 2I6

Sweet, 216

Yellow, 220

Rockrose Family, 298

Romneya Coulteri, 202

Rosaceæ, I46

Rose Family, I 46

Rosemarinus, 380

Rosemary, 380

Marsh, 335

Rubiaceæ, 4I5

Rudbeclia laciniata, 462

Rue, Common, 266

Family, 266

Rutacex, 266

SACRED BeAN, 153

Saffron, Meadow, 58

Sage, 5 I9

Bethlehem, 326

Scarlet, 375

St. John's-wort Family, 296

Salpiglossis sinuata, 387

Salvia officinalis, $5 \times 9$

patens, 376

splendens, 375

Sanguinaria canadensis, 198
Santolina chamæcyparissus, 5 I 6

Sapindaceæ, 276

Saponaria officinalis, I 39

caucasica, I40

Sarracenia purpurea, 224

Sarraceniaceæ, 224

Satureia hortensis, 522

Savory, Summer, $\mathbf{5 2 2}$

Saxifraga crassifolia, 232 virginiensis, 232

Saxifragaceæ, 232

Saxifrage, Early, 232

Family, 232

Thick-leaved, 232

Scabious, Sweet, $45^{\circ}$

Schizanthus pinnatus, 394

Scilla amcena, 36 autumnalis, 36

bifolia, 36

sibirica, 36

verna, 36

Scitamanaceæ, 97

Scrophulariacex, 401

Sea Holly, 33r

Sea Lavender, 334

Sea Pink, 335

Sedum acre, 228

Showy, 228

spectabile, 228

telephium, 227

ternatum, 228

Sempervirum tectorum, 230

Shooting Star, 343

Silene armeria, $\mathrm{I} 33$

pendula, I33

Silk Vine, 352

Snapdragon, 401

Sneeze Weed, 46r

Snowdrop, Common, 74

Snowflake, Spring, 76

Snow-on-the-Mountain, 270

Soapberry Family, 276

Solanaceæ, 383

Solanum dulcamara, 398

esculentum, 400

pseudo-capsicum, 400

tuberosum, 397 
Solidago, 495

Southernwood, 5I4

Spearmint, 524

Spiderwort, 8

Family, 8

Spinach, II 5

Spinacia oleracea, I I 5

Spiræa, Blue, 374

Spurge Family, 270

Mountain, 275

White-flowering, 272

Squill, Siberian, 36

Stachys lanata, 382

Staff Tree Family, 269

Star of Bethiehem, $3^{8}$

Star Thistle, 33 I

Statice, 334

incana, 335

latifolia, 334

Stellaria graminea, I 45

Holostea, $\mathrm{r}_{44}$

media, I42

Stitchwort, Golden, I45

Stock, 210

Stokesia cyanea, $5 \circ 2$

Stonecrop, 228

Succory, 504

Sundrops, 3 I 5

Sunflower, Common, 453

Perennial, 457

Sweet Alyssum, 214

Basil, 523

Clover, 247

Fennel, 525

Herbs, 517

Marjoram, 52 I

Pea, 235

Potato, $35^{8}$

Scabious, $45^{\circ}$

Sultan, 502

Violet, 302

William, I 28

William Catchfly, I $_{3} 8$

Tanecetum vUlgare, 5 I 6

Tansy, 5 I6

Tarragon, $5^{\text {I } 6}$
Tassel Flower, 490

Tea Family, 295

Oswego, $37^{6}$

Teasel Family, $45^{\circ}$

Tecoma radicans, $4 \mathrm{I} 8$

Tegetes erecta, 482

patula, 484

signata, 484

Telanthera, I 22

Ternstromiaceæ, 295

Tetragonıa, I 16

Thalictrum, I 79 aquilegifolium, I79

dioicum, I79

polyganum, I 79

Thistle, Blue, 33 I

Thrift, 335

Thunbergia alata, 420

Thyme, 520

Creeping, $52 \mathrm{I}$

Sweet, 520

Thymus serpyllum, 52I vulgaris, 520 .

Tiarella, 233

Tiger Flower, 92

Tiger Lily, 26

Tigridia pavonia, 92

Toad-flax, 402

Toad Lily, Japanese, $5^{8}$

Tobacco, 390

Tomato, 394

Torenia Fournieri, 4Io

Touch-me-not Family, 277

Tradescantia virginiana, 8 fluminensis, Io

Tricyrtis hirta, $5^{8}$

Trillium grandiflorum, 52 White, 52

Tritonia crocusmæflora, 96

Trollius asiaticus, I 77 europæus, I77

Tropœolum lobbianum, 264 majus, 262 minus, 262

Trumpet Daffodil, 62

Trumpet Flower, 390, 4I8

Tuberose, 77 
Tulip, 29

Tulipa Gesneriana, 29 suaveolens, 34

Turtle Head, 409

UMBELLIFER 1328

Urticacex, I03

Valerian, Common, 426

Family, 426

Red, 428

Valeriana officinalis 426

Valerianaceæ, 426

Verbena, 372

hybrida, 372

Sand, 126

Verbenaceæ, 372

Vernonia noveboracensis, 5 I 3

Veronica longiflora, $4 \mathrm{r} 4$ spicata, 4I 4

Vervain Family, 372

Vetch, Little, 252

Pea-Like, 252

Vicia cernus, 252 oroboides, 252

Vinca major, 348 minor, 347

Rose, 348 rosea, 348

Vine Family, 280

Viola cornuta, 302 cuculata, 303 odorata, 302 tricolor, 299

Violaceæ, 299

Violet, Bedding, 302

Common Blue, 303

English, 302

Family, 299
Violet, Horned, 302 Sweet, 302

Viper's Bugloss, 325

Virginia Creeper, 280

Virginian Cowslip, 322

Vitaceæ, 280

Vitis vulpina, 282

labrusca, 283

WAKE ROBIN, $5^{2}$

Wallflower, 2I9

Wandering Jew, to

Water-Hawthorn, 3

Water-leaf Family, $37 \mathrm{I}$

Water Lily, White, 150

Giant, 153

Watermelon, 434

White Tansy, 465

Wild Carrot, 328

Wild Cucumber, 435

Wild Potato Vine, 357

Willow Herb, 3I8

Windflower, 176

Wistaria chinensis, 252

Woodbine, 280, 423

Wood Sorrel Family, 258

Woolly Bulb, $5^{8}$

Wormwood, 514

XERANTHEMUM ANNUUM, 507

Yam FamiLy, 59

Yarrow, 465

Yucca filamentosa, 47

glauca, 48

ZEBRINA PENDULA, IO

Zinnia elegans, 493 


\section{BOOKS ON GARDEN \\ F I E L D A N D W O O D}

\section{Our Native Trees and How to Identify Them}

By HARRIET L. KEELER

With 178 full-page plates from photographs, and I62 textdrawings. Crown $8 \mathrm{vo}, \$ 2.00$ net.

The trees described in this volume are those indigenous to the region extending from the Atlantic Ocean to the Rocky Mountains and from Canada to the northern boundaries of the Southern States; together with a few well-known and naturalized foreign trees such as the Horse-Chestnut, Lombardy Poplar, Ailantus, and Sycamore Maple.

"Miss Keeler has made a very commendable addition to the semi-popular treatises on American plants, in a well-written, well-illustrated, and well-printed account of native and naturalized trees. Bits of the best from the poets and prose writers relieve the descriptions, and the folk-lore of a number of trees is well if briefly told."-American Naturalist.

"To such of the general public. as habitually frequent the woods which they love, the book will be most welcome, for it is carefully classified, adequately illustrated, and most readably written."-Boston Budget.

"It condenses into convenient shape a fund of information spread over many volumes of older works, and blends the practical and poetical in a way to delight all readers."

-St. Louis Globe-Democrat. 


\section{BOOKS ON GARDEN \\ F I E L D A N D W O O D}

\section{Our Northern Shrubs}

\section{By HARRIET L. KEELER}

With 205 photographic plates and 35 pen-and-ink drawings. Crown 8 vo, $\$ 2.00$ net.

The volume is prepared not only for the amateur botanist who seeks a more adequate description than the textbooks afford, and not only for the lover of nature who desires a personal acquaintance with the bushes that grow in the fields; but also to serve those who are engaged in the establishment and decoration of city parks, roadways, and boulevards; those who are seeking to beautify country roadsides and railroad stations as well as those who, in the decoration of their own home grounds, would gladly use our native shrubs were their habits and character better understood.

"Simple, clear descriptions that a child can understand, are given of shrubs that find their home in the region extending from the Atlantic to the Mississippi River, and from Canada to the boundaries of our Southern States."-Outlook.

"There are over two hundred plates from photographs, and a number from drawings. The photographs, all of shrubs in flower or fruit, are very beautiful, and so clear as to make identification perfectly simple."-Dial.

"An interesting feature of this book is the sparing but judicious incorporation of quotations from those authors among us who have best interpreted nature."-Churchman. 


\section{BOOKS ON GARDEN \\ F I E L D A N D W O O D}

\section{By Mrs. WILLIAM STARR DANA (FRANCES THEODORA PARSONS)}

\section{HOW TO KNOW THE WILD FLOWERS}

With colored plates and black-and-white drawings. Crown 8vo, $\$ 2.00$ net.

"I am delighted with it . . . it is exactly the kind of work needed for out-door folk who live in the country but know little of systematic botany. It is a wonder no one has written it before."-Hon. THEODORE ROOSEVELT.

"Every flower lover who has spent weary hours puzzling over a botanical key in the effort to name unknown plants, will welcome this satisfactory book which stands ready to lead him to the desired knowledge by a royal road."-The Nation.

\section{HOW TO KNOW THE FERNS}

With I 50 full-page illustrations. Crown $8 \mathrm{vo}$, \$r.50 net.

"This is a notably thorough little volume. The text is not voluminous, and even with its many full-page illustrations the book is small; but brevity, as we are glad to see so many writers on nature learning, is the first of virtues in this field. . . . The author of 'How to Know the Ferns' has mastered her subject and she treats it with authority."-New York Tribune.

"The inspiration that entered into and made "How to Know the Wild Flowers' so deservedly popular has not been lost in 'How to Know the Ferns." "-New York Times.

"From cover to index the book is tastefully and skilfully gotten up . . . the illustrations are abundant and well executed."-The Dial. 


\section{BOOKS ON GARDEN F I E L D A N D W O O D}

\section{By Mrs. WILLIAM STARR DANA (FRANCES THEODORA PARSONS)}

\section{ACCORDING TO SEASON}

Talks about the flowers in the order of their appearance in the woods and fields. With $3^{2}$ full-page illustrations in colors from drawings by Elsie Louise Shaw. \$r.75 net.

"It is a privilege to own such a book, for its artistic charm and its contents well deserve their setting."-The Dial.

"The charm of this book is as pervading and enduring as is the charm of nature."-New York Times.

"Delightful talks upon the beauty of the changing year and the parts contributed to such pleasures by forest, grove, and stream."-The Interior.

\section{By LOUISE SHELTON}

\section{THE SEASONS IN A}

\section{FLOWER GARDEN}

A hand-book of information and instruction for the amateur. Illustrated. \$r.oo net.

"Pleasant and useful, and may be confidently recommended to amateur gardeners."-Nerw York Times.

"A manual admirably adapted in every way to the needs of people who desire to utilize a small garden space to the best possible advantage."-Providence Journal.

\section{CHARLES SCRIBNER'S SONS 153-157 Fifth Avenue, New York}


, 

